CRYING IN THE WILDERNESS: THE OUTLAW AND POET IN BEN HECHT'S MILITANT ZIONISM

A dissertation presented to
the Faculty of the Graduate School
at the University of Missouri-Columbia
In Partial Fulfillment
of the Requirements for the Degree
Doctor of Philosophy
bU by
Dr. Berkley Hudson, Dissertation Supervisor

DECEMBER 2013 
The undersigned, appointed by the dean of the Graduate School, have examined the dissertation entitled

\section{CRYING IN THE WILDERNESS: THE OUTLAW AND POET IN BEN HECHT'S MILITANT ZIONISM}

presented by Julien Gorbach,

a candidate for the degree of doctor of philosophy, and hereby certify that, in their opinion, it is worthy of acceptance.

Professor Berkley Hudson

Professor Dean Mills

Professor Yong Volz

Professor Carla Klausner

Professor Stephen Whitfield 


\section{To Buster and Alley \\ (1999-2013)}

Who taught me so much about innocence and love.

\section{Rest In Peace}

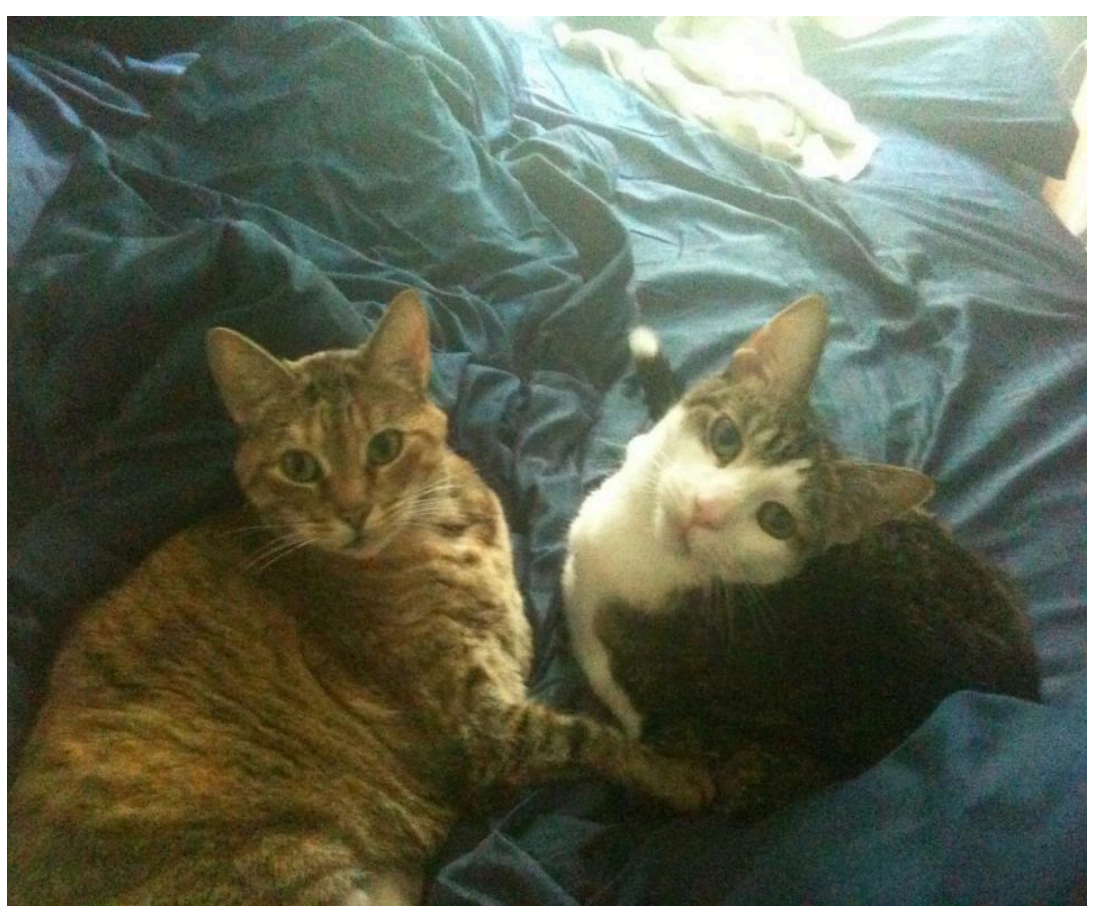




\section{ACKNOWLEDGMENTS}

"Writing, at its best, is a lonely life," Ernest Hemingway once said, but this dissertation would not have been possible without the help of many wonderful people.

I owe a great debt to my newspaper editors, the redoubtable Bill Decker and Dan Campbell, for the guidance and encouragement they provided me when I was a reporter. They taught me the discipline of daily journalism, conscientiousness and even some temperance, and went to bat for me on occasions when targets of my muckraking hollered for my head. Later they wrote the endorsements that launched my career as a scholar.

After nearly a decade in the newsroom, I was welcomed back to academia by the Communication faculty of the University of Louisiana at Lafayette. Drs. T. Michael Maher, Lucian Dinu and Bill Davey mentored me as a novice instructor and urged my pursuit of a doctorate. After the completion of coursework at Mizzou, they welcomed me back as if I had never left, as a Visiting Lecturer of New Media. Dr. Maher was always willing to take a chance with me, while pushing me to achieve further goals.

As a doctoral student I had the honor of studying under brilliant professors at the University of Missouri-Columbia, University of Chicago and Harvard University Summer School. In particular, Betty Winfield, Glenn Leshner, Earnest L. Perry, Abdullahi Ibrahim, John Frymire, Steven Watts and Elaine Lawless at Missouri; Mark Philip Bradley and Paul Mendes-Flohr at Chicago; and Brandeis professor David Engerman opened my eyes to new perspectives and helped me develop the knowledge and skills to become a media historian. 
For all his reputed cynicism, Ben Hecht was a great believer in friendship. I am deeply grateful to lifelong friends who have made me a believer as well: Hannah Mackenna, Dave Scott, John Dale, Dave Twidle, Aaron Schindler, Scott Winder, David Briggs, Dane Melancon, and David and Jessica Wiley Leslie. In Columbia, Yusuf Kalyango, Jeffrey Pe-Aguirre, Seth Graves, John Swain, Terra Stephan and Lekan Oguntoyinbo kept me focused and motivated. Hank Showers, I don't know how I would have made it through the fall of 2010 without your help. During the long slog over the last couple of years in Lafayette, Alfred J. Stahl was a constant supporter and interlocutor regarding all things Hecht. To Bernard Pearce, I owe a deep debt of gratitude for reading passages and helping me hash out the ideas through our endless discussions, day after day, month after month, over his marvelous plates of food.

Dr. Margaret Blanchard used to say that a dissertation committee is like a stagecoach journeying on a long and dusty trail, and that it is therefore crucial to embark with the right combination of people. I was blessed to have five extraordinary fellow travelers with me for the seven years that it took to bring this from inception to completion. They were as honest in their criticism, which I needed and deserved, as they were generous in their praise. For investing so much heart and hard work, far beyond the call of duty, thanks to Drs. Dean Mills, Yong Volz, Carla Klausner and Stephen J. Whitfield.

Thanks to Alison Hinderliter and the staff at the Newberry Library, and to the man who gathered many vital files for me in Chicago, John Montes. Thanks especially to two of the best librarians in the world, Dorothy Carner and Sue Schuermann, who helped me gather and manage that mountain of books. 
Thanks to Buster and Alley for their love, warmth and fluffiness, and to my two young girls, Snowboots and Luna. Thanks to my noble sister Roxane Gorbach — would it be that more people could possess so much goodness-and to my niece and nephew Camille and Cole Vocelka. I am lucky to have such a great family.

And thanks, most of all, to my adviser and mentor Dr. Berkley Hudson, whose gentleness, wisdom, patience and sense of humor ultimately brought out the best in me. And to my parents, Judith and Sherwood Gorbach, who for more than forty years have continued to amaze me with the depth of their love and devotion. 


\section{TABLE OF CONTENTS}

ACKNOWLEDGMENTS........................................... ii

ABSTRACT .....................................................................

INTRODUCTION ......................................................

\section{THE DEVIL'S BARGAIN}

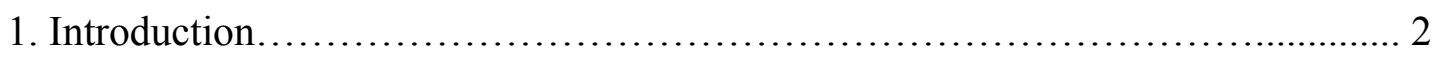

2. The "Chicago School": From Whitechapel and......................................... 13 and the City News to Walter Howey and the Hearst Press

2. Shades of Black: The Stages of Hecht's Cynicism...............................2 28

3. The Journalist \& The Gangster: The Front Page ................................. 47

4. The Journalist \& The Gangster: Scarface ..................................... 64

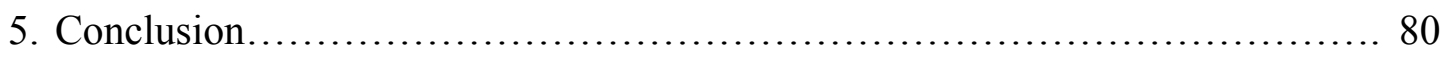

\section{THE EGOISTS}

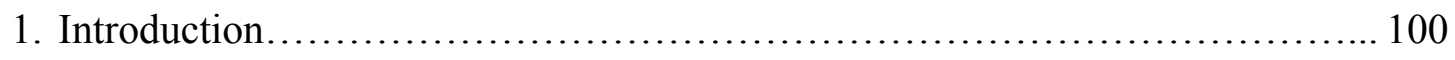

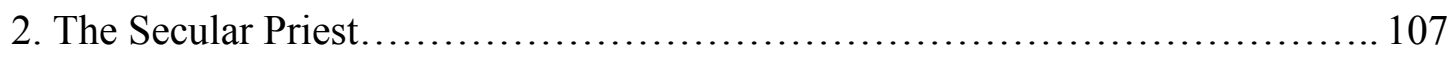

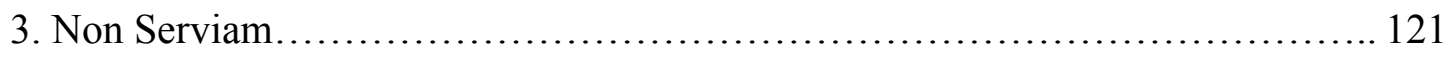

4. Alienation \& Madness: The Jazz Age...................................... 152

5. Alienation \& Madness: Hollywood in the ' 30 s................................. 159

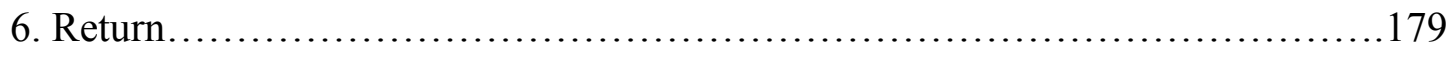

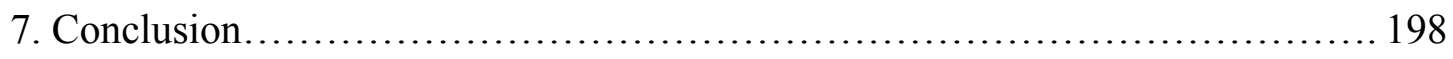




\section{FROM HUMANIST TO PUBLIC ENEMY}

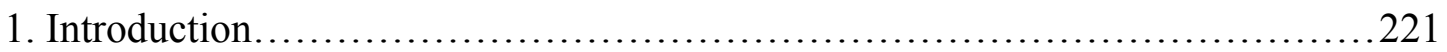

2. Jewish Knights: The Bergson Group..................................... 238

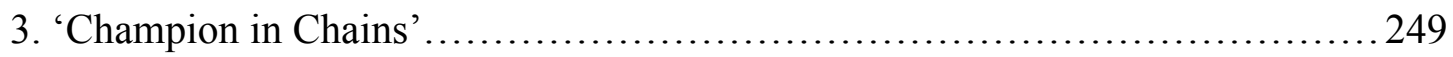

4. Campaign for a Jewish Army................................................ 263

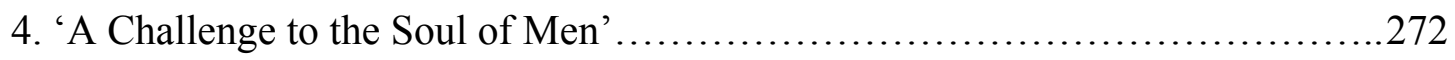

5. 'One of the Greatest Crimes in History'............................................ 293

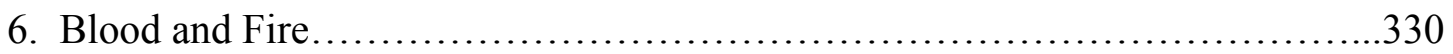

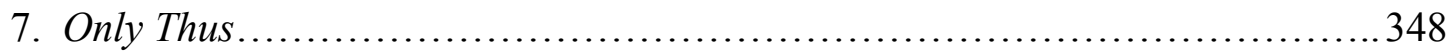

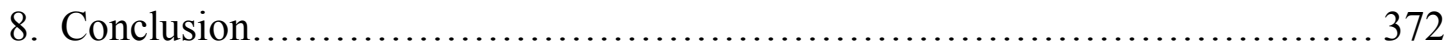

\section{L.A.'S AL CAPONE, MICKEY COHEN}

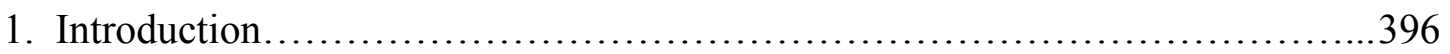

2. 'Some Kind of Strength' .................................................... 408

3. Champion in Chains, Revisited......................................... 428

4. The Old New Journalist......................................................453

5. 'Pure as the Driven Snow' ................................................... 470

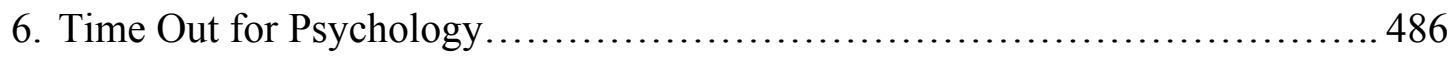

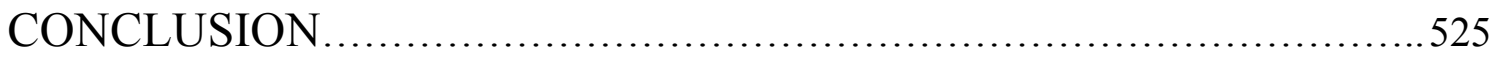

APPENDIX ........................................................ 537

SELECTED BIBLIOGRAPHY .........................................5 578

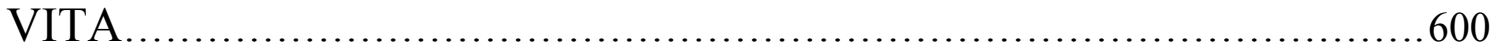




\title{
CRYING IN THE WILDERNESS: THE OUTLAW \\ AND POET IN BEN HECHT'S MILITANT ZIONISM
}

Julien Gorbach

\section{Dr. Berkley Hudson, Dissertation Supervisor}

\begin{abstract}
During the Second World War, the American journalist and screenwriter Ben Hecht had been one of the lone voices to break the silence about the Nazi Holocaust. Then, in 1947, Hecht shocked and outraged people across the world when he called for "terrorism" against his country's closest military ally, Britain, in the fight for a Jewish state. Crying in the Wilderness is an effort to explain, through biography, Hecht's increasingly militant propaganda campaign. This study argues that two friends, one the Jewish gangster Mickey Cohen and the other the Jewish poet Max Bodenheim, provide keys to understanding Hecht's militant rhetoric and its historical relevance. While the Cohen narrative explains the political dimension of Hecht's ideology and the Bodenheim story explains the cultural dimension, both overlap on the issue of ethnicity, the question of Jewish American identity.

Hecht's political response to the genocide and the struggle for a homeland in its aftermath was informed by a cynical worldview that he developed as a crime reporter covering gangland Chicago and the rise of Al Capone. At the same time, his propaganda can be understood as the cultural rebellion of a modernist artist, who was chafing against rules imposed by the "respectable" assimilationist Jews of the New York theater, publishing and newspaper worlds, and against the Jewish moguls of Hollywood. This dissertation weaves the two narratives together: one of Hecht's affinity for the militant outlaw, and the other of his devotion to the uncompromising spirit of the artist-poet.
\end{abstract}




\section{INTRODUCTION}


This time, people said, Ben Hecht has gone too far.

In the spring of 1947, the American journalist turned screenwriter shocked and outraged newspaper readers across the world with a full-page advertisement that openly supported terrorist attacks against his country's closest military ally, Great Britain. The Second World War had cemented America's "special relationship" with the Britain, a partnership expected to be the cornerstone of peace and stability in the postwar world. But since 1939, British Mandate troops had shut the Jews of Europe out of Palestine, effectively clamping Hitler's trap shut during the war years and, in the aftermath, leaving survivors to languish as "Displaced Persons" in the liberated concentration camps. Hecht and the Irgun Zvai Leumi, the faction of Zionist fighters that he championed, believed their guerilla war was the best way to finally smash the blockade, open the gates of Palestine to a mass immigration of Holocaust survivors, and thus clear a path to Jewish statehood.

Hecht's "Letter to the Terrorists of Palestine" explained that so far American support for the Irgun had not been forthcoming because rich and influential American Jews were opposed to the attacks. But speaking for the common man and swearing "on my word as an old reporter," Hecht declared: "Every time you blow up a British arsenal, or wreck a British jail, or send a British railroad train sky high, or let go with your guns and bombs at the British betrayers and invaders of your homeland, the Jews of America make a little holiday in their hearts."

The letter set off a storm of fury that roiled in the international press for months, exposing a deep schism within both Jewish and American life. ${ }^{2}$ It was the culmination of 
an increasingly inflammatory eight-year propaganda campaign that generated debate and conflict at every gradation from the private to the public sphere, from bitter arguments in Jewish homes to dueling newspaper editorials to clashes in the streets outside Hecht's agitprop theatrical pageants. ${ }^{3}$ The story of how Hecht's propaganda emerged from his life experiences, and where his ideas ultimately led him, offers insight not only into American Judaism and the United States' relationship with Israel, but also into the history of American mass media and culture of the twentieth century.

In challenging the right of Britain —or, for that matter, of any outside power— to label as "terrorists" the Jews who fought for their ancestral homeland, Hecht's letter sparked a debate that crystallized two opposing views of what lessons should be drawn from the war. On the one side were the humanists, the mainstream Zionists, who envisioned the Jewish state as a liberal democracy and put faith in diplomacy, multilateralism and international law. On the other side were Hecht and the Irgun, who believed the Jews could rely on, and could be judged by, no one but themselves. The liberals saw the war as a victory of their ideology over fascism. With the birth of the United Nations, the vote for Partition, the Nuremberg trials, the first declaration on human rights and a convention on genocide, the 1940s were formative years for international law, and Jews could point to these achievements as assurances of their basic rights. ${ }^{4}$

But conversely, the Irgun read the war as confirmation that the Jews could not survive by the rules the world made for them. While the mainstream Zionists trusted in the United States and Britain, the Irgun maintained that even the world's great democracies had failed the Jews in their hour of need. Thus while both sides vowed 
"Never Again," they disagreed about how to guarantee that vow. The liberal Zionists believed in the rule of international law, while the Irgun believed in the rule of the gun.

Hecht's letter also staked out a position that would in later decades be associated with "identity politics," by deliberately touching a third rail in discussions among American Jews: the suggestion that a person might be a Jew first and an American second. Since the birth of American Zionism at the end of the $19^{\text {th }}$ century, opponents had leveled the charge of "dual loyalty"- the idea that Zionists could not be counted on as true Americans, because their dream of a future home in the Promised Land weakened their allegiance to their newly adopted home in the United States. By advocating open support for attacks on America's most vital strategic ally in the name of Zionism, Hecht's letter not only stoked suspicions of dual loyalty, for some it actually affirmed they had been well-founded in the first place. ${ }^{5}$

To a large extent, Hecht's attitude had originally developed in reaction to that of the Jewish film executives who were his employers. Since the 1980s, scholars have documented the disturbing degree to which the movie studio chiefs suppressed films that either criticized the Nazis or exposed the persecution of the Jews. ${ }^{6}$ Ben Urwand's recent book, The Collaboration: Hollywood's Pact with Hitler, has drawn a great deal of controversy with its contention that the German Reich was successful in using fear and greed to manipulate Hollywood from afar. ${ }^{7}$ Less contentious, however, is his final chapter, which he devotes to the critical role that Hecht played in this story. "At a time when most American Jews were afraid to rock the boat, when a sizeable number of them were too nervous to even identify themselves as Jews, he chose a different path," Urwand asserts. "He did not run away from his Jewish heritage in a desperate attempt to identify 
himself, whatever the cost, as an American. He understood, rather, that in America he could also be a Jew. ... In this critical period, Ben Hecht's voice was the loudest, most courageous Jewish voice in America. His words changed what it meant to be an American Jew."

\section{GANGSTER, POET, AMERICAN JEW}

Hecht famously said that it was the Nazi persecution and slaughter that had stirred his Jewish consciousness. But he explained in a 1942 essay for Esquire: "The discovery that I was a Jew did not set me to lighting any Friday night candles nor did it alter by a phrase any of my attitudes toward life. These are American attitudes, born in America, nurtured in American schools and developed through service in American journalism, literature, drama and the movies." 9

Crying in the Wilderness traces the origins and evolution of these attitudes through two tales of friendship. The proposition that Mickey Cohen and Max Bodenheim — the former a Jewish gangster, the latter a Jewish poet — represent two respective sides of Hecht reflects the fact that he inhabited two distinct worlds during his early, formative years as a writer. As a young crime reporter, he was immersed in the world of newspapers, trafficking each day in stories of scandal, subterfuge, corruption, murder and hangings_ - "law and order," such as it was in the Windy City during the first decades of the twentieth century. This, in a sense, was Hecht's political world. At the same time, as a young artist who capered about between the garrets of the city's art 
colony along Jackson Park, Hecht was moonlighting as one of the rising stars of the Chicago Literary Renaissance. This was his cultural world. ${ }^{10}$

Hecht's political response to the Nazi genocide and its aftermath was informed by the cynical worldview that he developed as a reporter covering gangland Chicago and the rise of Al Capone. At the same time, his propaganda can also be understood as the cultural rebellion of a modernist artist who had chafed against the rules imposed by the "respectable" Jews of the New York theater, publishing and newspaper worlds, as well as against the Jewish Hollywood movie moguls, all of whom had been his employers.

While the story of his friendship with the gangster Mickey Cohen explains the political dimension of Hecht's belief system, the story of his relationship with the poet Max Bodenheim story explains the cultural dimension. Both narratives overlap on the issue of ethnicity, the question of Jewish American identity. Crying in the Wilderness weaves the two narratives together: one of Hecht's affinity for the militant outlaw, and the other of his devotion to the uncompromising spirit of the artist-poet.

\section{The Mickey Cohen narrative: "reactionary" versus "militancy"}

The newspaper reporters often seemed like gangsters who had accidentally ended up behind a typewriter rather than a tommy gun; they talked and acted as rough as the crooks their assignments forced them to cover ... It is no accident that Ben Hecht, the greatest screenwriter of rapid-fire, flavorful tough talk as well as a major comic playwright, wrote gangster pictures, prison pictures, and newspaper pictures. ${ }^{11}$

Gerald Mast and Bruce Kawin, A Short History of the Movies, 2006

There is no compromise, no equivocation. The way of terror or the way of Zionism, gangsterism or an organized Yishuv ... Whenever and wherever there is a self-governing community of free men, gangsters find no place. If 
gangsters rule - free men are homeless. Take your choice - violence and repression, or constitutional liberties. ... Let us rise up against terror and its agencies, and smite them. The time for words is past. ${ }^{12}$

\section{David Ben-Gurion, Rebirth and the Destiny of Israel, 1959}

In the early aftermath of the war, Hecht managed to interest Mickey Cohen, the flamboyant kingpin of the Los Angeles underworld, in a campaign to help arm the Jewish militants of Palestine. Cohen was wary at first, but when he learned of the bare-knuckled fight that the Irgun had brought to the British, and discovered that America's rich and respectable Jews wanted nothing to do with these "gangsters" and "terrorists," his curiosity blossomed into fascination. ${ }^{13}$

The political rhetoric of the 1940s linked "gangsterism" with "terrorism," and with good reason: The Irgun and its small but highly effective sidekick, the Stern Gang, resorted to extortion and armed robbery to fund their military operations. ${ }^{14}$ The involvement of Cohen and other American underworld figures adds yet another layer to the story of gangsterism and the birth of Israel, raising yet more questions about the distinctions drawn — then and since—-between lawmaker and lawbreaker.

Supporters of Israel have long been loath to acknowledge that Jewish American mobsters like Cohen and Meyer Lansky made any significant contribution to the Zionist cause through their efforts to smuggle arms and materiel to Palestine. For decades, the involvement of such infamous racketeers and killers has been regarded as a blight on the history of the Jewish state, and indeed, Israel's enemies have often pointed to it as proof of the nation's inherently criminal character and lack of legitimacy. Crying in the Wilderness investigates the historical evidence, making the case that the true importance 
of the role played by Jewish American gangsters has remained obscured and unrecognized, despite some attention that it has received in recent years. ${ }^{15}$

When Cohen first became involved with "the Cause" in 1947, the former pro boxer, stick-up artist and mob enforcer seemed to personify the very image of the "tough Jew" that Hecht had introduced to the American public through his propaganda. Nearly a decade had passed since Hecht had first become outraged by the wholesale slaughter of European Jews, as well as by the failure of prominent Jews to stand up for them. From the start, his goal had been to counteract the image of the Jew as weakling and victim. Joining forces with the brilliant young activist Hillel Kook and his small delegation of fellow Irgunists freshly arrived from Palestine, Hecht had generated a flurry of newspaper advertisements, speeches, magazine articles and theatrical pageants to construct the image of the "New Jew" of the Middle East, who was like the Hebrew warrior of ancient times, now resurrected to fight for his people and reclaim their homeland.

Cohen, moreover, was the living embodiment of a whole catalogue of tales that Hecht had been spinning for years, which had come to define him as a writer long before he became involved with Jewish politics. Drawing from his early experiences as a crime reporter, he had effectively invented the gangster movie genre with his Academy-Awardwinning story treatment for the 1927 silent film Underworld. The movie's success sparked the first gangster movie craze in the early 1930s, which Hecht himself had capped with his screenplay for the blockbuster Scarface in $1932 .{ }^{16}$

In the years following their fundraising and arms smuggling activities, Hecht and Cohen remained friends and embarked upon a new partnership, collaborating on a 
biography of the celebrity gangster of Hollywood amid much fanfare, and buzz about an upcoming movie. The final chapter of Crying in the Wilderness recounts what happened as a result. As the story of Hecht's encounter with the reality behind the myth of the "tough Jew" that he himself had created, it suggests a cautionary tale about this romantic image, which Americans have since kept of Israel. ${ }^{17}$

For Hecht, the Shoah (Holocaust) had affirmed, on a global scale, the cynicism about the modern world and its politics that he had developed during those dark early days in Chicago. Hecht essentially saw World War II as a barbarous tribal conflict fought with modern weaponry, and he thought the best way to fight fire was with fire. Like many of his contemporaries, he saw the rise of Nazism as evidence of the ultimate failure of the ideas of the Enlightenment, with its faith in the goodness of man, the power of reason, and the social contract. ${ }^{18}$ His 1944 best-selling polemic against anti-Semitism, Guide for the Bedevilled, begins with an attack against Voltaire: "Jew hatred was the odd hobby of this Prince of Reason ... just as a great detective might practice murder on the side. He was the first witty friend of rational behavior produced by the Christians. Yet this ornament of reason, this glowing brain, had, as a sideline, one of the most bumptious hatreds of the Jew to be found in literature."19

Hecht's political positions reflect this dour view of the legacies of the Enlightenment. As a disciple of H.L. Mencken and a dyed-in-the-wool Chicago newspaperman educated in the newsroom instead of the college classroom, he harbored a defining distrust of politicians, and of governmental solutions to social problems. Although initially a strong supporter of Roosevelt, Hecht came to see the president as a typically duplicitous politician who had refused to do anything to help the Jews, and as a 
consequence became deeply cynical about FDR's liberal vision for the postwar world. ${ }^{20}$

Hecht's views were in many ways paradoxical, and he was never quite an ideal champion of democracy. True, the rise of the police state under Hitler and Stalin had given him a new appreciation of the freedoms he enjoyed in the United States. As Urwand and others have emphasized, he defied the censorship that prominent American Jews had imposed on themselves, and most importantly, shattered the American media's silence about the slaughter of European Jews. Yet his early experiences in the media had left him with little trust in the wisdom of the American public. Loyal to his roots as one of the Little Review's coterie of avant-garde writers, his complaint against the Hollywood moguls was not that they underestimated popular tastes, but that they understood them all too well and pandered to them. Hecht's skepticism about Jefferson's vision of an informed and enlightened public, particularly in an age of mass media, echoes that of Walter Lippmann, and it is worth emphasizing that he sought to assist Hillel Kook and the Irgun with a "propaganda" campaign. ${ }^{21}$

Indeed, as he became increasingly radicalized over the years of the war and its aftermath, there was nothing emphatically democratic about his support for Zionism. Casting aside Chaim Weizmann's “one more dunam” approach to gradually building a Jewish majority on Palestinian land, Hecht instead ascribed to the Irgunist ideology rooted in Zionist Revisionism, favoring military action that would establish a Greater Israel on both sides of the Jordan River by right of conquest. ${ }^{22}$

Given Hecht's lack of faith in the goodness of man, in reason and in democracy, it is tempting to label him "reactionary." Joseph de Maistre, the Sardinian diplomat with whom the term is associated, had responded in disgust to the French Revolution's Reign 
of Terror by embracing the Church and the Divine Right of Kings. ${ }^{23}$ Hecht, too, had a romanticist's mysticism, trumpeting first the valor of the Allied troops, and then the Irgun fighters as if they were the Knights of the Round Table. Yet he was a critic, not a political theorist, and ultimately he had no solutions, no alternatives to the American system to prescribe.

Both his take on the state of world politics and his ambivalence regarding what to do about it are in evidence in a 1957 draft of his Mickey Cohen biography, posthumously published in Scanlan's. Hecht argued that the gangster's activities “represent a certain sanity in a lunacy-whirling world - the sanity of a criminal. ... All other human matters grow complex and indecipherable - what is good, what is noble, what is pious and what is progressive. The criminal alone remains constant. ... As he was in the tribal civilization of thirty thousand years ago, so he is in the civilization of oil interests, hydrogen bombs, the disintegration of human thought into political jabberwock, and the attending prospect of global annihilation."24

By the end of the 1940s, Hecht's closest ally within the Irgun was not the more liberal-minded Hillel Kook, but Menachem Begin, future prime minister of Israel, architect of the settlement policy and founder of the right-wing Likud Party. Because Hecht was a critic and an advocate for the rights of an embattled minority, however, his propaganda should also be understood within the context of American minority struggles and cultural rebellion. Within the latter context, his propaganda cannot be described as "reactionary," or "right wing" or "conservative." Rather, it can be termed "militant," defined as "aggressively active in pursuing a political or social cause, and often favouring extreme, violent, or confrontational methods." Like other militants who would follow in 
later years, Hecht emphasized self-awareness and unity within his minority group, and promoted resisting oppression by any means necessary. ${ }^{25}$

During the 1940s, Hecht played the role in which he felt most comfortable — that of the underdog. As for the role his propaganda would play in shaping perceptions of a Jewish state that would one day be a regional superpower, his legacy is more problematic.

\section{The Max Bodenheim narrative: "crying in the wilderness"}

Whether or not you believe, as has sometimes been suggested ... that it was really Ben Hecht who authored the book of the Apocalypse, not to mention certain of the more astringent passages of the Old Testament, the fact remains that there is something definitely prophetic about the man as of one who had found the tablets of stone in the desert.

Theodore Strauss, The New York Times ${ }^{26}$

I was not the original muckraker; the prophets of the Old Testament were ahead of me.

Lincoln Steffens, The Autobiography of Lincoln Steffens, $1931^{27}$

Hecht had personal reasons for becoming involved with the Irgun that had to with his status as a Hollywood "hack." Despite the fact that he became the top-paid writer during Hollywood's Golden Era in the 1930s, as a man who had long aspired to make his mark in literature, he came to feel unfulfilled as the cynical writer on the studio payroll. When the Jewish executives who were his employers refused to make movies about the Nazi slaughter of their co-religionists in Europe, out of fear of dragging the United States into a "Jewish war," Hecht had an opportunity to play the rebel once again. Moreover, he 
drew a direct link between the cowardly refusal of the movie moguls to stand up and be counted as Jews and their lack of artistic integrity.

The reasons he became so disgruntled and uncomfortable with screenwriting are rooted in the ideas, values and aspirations he developed as an artist during the era of the Chicago Renaissance and the cultural rebellion of early twentieth century Greenwich Village. Just as the story of Hecht's relationship with Mickey Cohen helps explain the politics of his propaganda as he understood them, the story of his relationship with Max Bodenheim explains his propaganda as a critique of American culture, American Jewish culture, and the media.

In the youthful heyday of the Renaissance, Bodenheim and Hecht became known as a kind of bohemian Laurel and Hardy, with the poet's dishevelment and clownish hauteur a perfect complement to the journalist's raffish charm. Bodenheim's histrionics earned him notoriety in New York's tabloid press during the Jazz Age, while he drew a relatively consistent income publishing magazine articles, novels and books of poetry. But just as Hecht's career was taking off at the onset of the Depression, Bodie's headed in a radically different direction. By the time the two bumped into one another on the street a decade later, after years out of touch, Hecht had made it rich in Hollywood, while Bodenheim was a drink-ravaged husk of his former self, sleeping on park benches and peddling poems for drinks. ${ }^{28}$

Hecht offered his old friend a deal: If every week, Bodenheim would send a poem or two pages of writing on any subject, Hecht would cut him a thirty-five dollar check in exchange. Described by Hecht as “one of the most desperate self-portraits I've ever read," the letters from the shattered and destitute Bodenheim read like dispatches of 
despair from the gutters of Lower Manhattan. They touch on the top social, political and cultural topics of the era-Bodenheim, like Hecht, had suddenly become an ardent Zionist—but come from a voice that seems to be crying out from the wilderness. More than a hundred of them are stored in the Hecht Papers archive at the Newberry Library in Chicago. ${ }^{29}$

This dissertation investigates why Hecht made this arrangement and what its connection was to a central concern for both of them: the plight of European Jewish refugees and their bid for a homeland. I argue that Bodenheim was more than just a bygone friend and sympathy case for Hecht. The two shared a past as artists but were fundamentally different in one respect: Bodenheim was congenitally incapable of compromise. He therefore took on symbolic significance as a focal point for Hecht's own unease about being a cog in the Hollywood dream machine.

The title Crying in the Wilderness is meant to suggest that the bitter anger of Bodenheim's letters, and the image of the poet forlornly wandering the streets of the city, are a lurid evocation of the description Lewis Coser offered for Hecht, Bodenheim and their literary contemporaries in Greenwich Village and Chicago as "descendants of the biblical prophets, of those inspired madmen who preached in the wilderness far removed from the institutional pieties of court and synagogue, castigating the men of power for the wickedness of their ways. ${ }^{30}$

The Hecht-Bodenheim story draws attention to four key components of the prophetic narrative. First, there is the moment of inspiration. In the biblical context, this is when the prophet hears the voice of God; in the context evoked by Coser, this is when the artist-writer has flashes of inspiration that are the modern, secular equivalents of 
religious epiphany. Second, there is rebellion or exile, when the protagonist turns away from his people. Third, there is desolation and despair, wherein he begins to feel that he has lost his way and, feeling abandoned, suffers hopelessness, and perhaps even descends into madness. And fourth comes return, which is the effort — at least — of the exile to reconcile with his people. ${ }^{31}$

In the cases of Hecht and Bodenheim, the moments of inspiration and rebellion came in the heady days of the Chicago Renaissance; as the two men became increasingly disillusioned and lost during 1920s and '30s, they went through desolation and despair; and their embrace of Zionism in middle age during the 1940s was their effort at a return to their people. These four narrative themes not only offer a structural basis for this analysis, they also arguably typify the broader experience of American Jewish writers, artists and rebels. Also, we mustn't forget that in common usage, "crying in the wilderness" denotes a warning that goes unheeded, just as Hecht's early warnings about the Nazi genocide of the Jews went unheeded. ${ }^{32}$

\section{BIOGRAPHICAL BACKGROUND OF BEN HECHT}

Ben Hecht was born February 28, 1894 on the Lower East Side, the son of newly arrived Russian immigrants Joseph Hecht and Sarah Swernofski. Frustrated as a cloth cutter for the garment industry, Joseph moved the family to Racine, Wisconsin in 1903 to start a business as designer and manufacturer of women's fashions. Ben's mother ran the storefront. Hecht spent what he described as an idyllic youth in the rural Midwest until 
1910, when he turned down college to move to Chicago, where his uncle landed him a job at the Chicago Journal. ${ }^{33}$

At an age when other young men join fraternities, Hecht found fellowship among the tribe of city newsmen. He at first emulated, and then grew to personify, the mix of cynicism and sentimentality, mischief and unscrupulousness for which Chicago journalism had gained a reputation. The Chicago of Hecht's day was the city of Upton Sinclair's The Jungle, of a newspaper war that turned remarkably bloody, and after 1919, of the Volstead Act and Al Capone. ${ }^{34}$

As he immersed himself in news of crime and scandal, Hecht rose as a leading light of the Chicago Renaissance, "the only cohesive American literary movement to spring from the newsrooms," according to biographer Doug Fetherling. ${ }^{35}$ He contributed regularly to the Margaret Anderson's groundbreaking modernist journal Little Review, and became a disciple of H.L. Mencken, producing a steady stream of short fiction for The Smart Set as well. By 1914 he had joined staff of the Chicago Daily News under editor Henry Justin Smith, who, Hecht would recall, "saw the paper as a daily novel written by a score of Balzacs. ${ }^{36}$ After a brief stint as a foreign correspondent in postwar Germany, he returned to Chicago in 1920 and over the next three years, wrote five novels and a regular column for the News, launched a public relations business, and published The Chicago Literary Times, an underground newspaper covering the arts which has been described as a kind of prototype for the Village Voice. ${ }^{37}$

In pursuit of higher earnings and offered an opportunity to write for Broadway by the publisher Horace Liveright, Hecht finally joined the general migration of Chicago writers to New York City in 1924. He soon found, however, that he cared little for the xxiii 
sophisticates he found in Manhattan, including the literati of the Algonquin Round Table. A November 1926 cable from Algonquin friend Herman Mankiewicz, which would become legendary as the clarion call for American writers to head West, summoned Hecht to Hollywood just as the talking picture was about to be born: "Will you accept three hundred per week to work for Paramount Pictures. All expenses paid. Three hundred is peanuts. Millions are to be grabbed out here and your only competition is idiots. Don't let this get around." 38

By then Hecht's ambitions as a novelist had hit a stall, but in the coming years, he would reach new heights of commercial and popular, if not literary, triumph. The 1928 Broadway debut of The Front Page, his comedic collaboration with fellow newsroom veteran Charlie MacArthur about Chicago newspaper life, was his first bona fide hit, and two years later, he received the Academy Award for Underworld. Over the next forty years he wrote or, more often, collaborated on over seventy screenplays, spinning out blockbusters with a resourcefulness, versatility and speed that at times resembled sorcery.

As mentioned, he justifiably claimed to have introduced the gangster movie genre with Underworld and Scarface (1932). Likewise The Front Page (first adapted for the screen in 1931), Twentieth Century (1934) and Nothing Sacred (1937) have earned him homage as pioneer of the screwball comedy. He is also well remembered for two Hitchcock classics, Spellbound (1945) and Notorious (1946), and for rewriting Gone With the Wind (1939) in one marathon session with producer and friend David Selznick.

Less acknowledged, though, are his sundry contributions to other genres, such as his work as a progenitor of film noir, which, besides Notorious, include the classics Kiss of Death (1947) and Otto Preminger's Where the Sidewalk Ends (1950). To the horror 
genre, he contributed The Thing From Another World (1950), and the now-familiar storyline of the possessed ventriloquist dummy, with The Great Gabbo (1929).

Though Hollywood brought in a lot of cash, it provided little personal fulfillment to this proud graduate of the early twentieth century's avant-garde. Over the course of the next decade, Hecht grew increasingly frustrated with the new mass media industry and its audience, and when black clouds began to form over Europe, he viewed the events on the global scale as a grim reflection of what he had been witnessing firsthand. As he watched the Nazis rise to power, his once jolly cynicism soured into a deep and bitter anger. In 1939, signaling this change of attitude as well as a newfound set of convictions, he scripted the unabashedly political and patriotic Let Freedom Ring, and published the antiNazi Book of Miracles. For the first time he joined a political organization, the prointerventionist Fight for Freedom Committee, for which his most notable contribution was Fun to be Free, a sketch performed at a 1941 Madison Square Garden pageant that drew seventeen thousand people. ${ }^{39}$ Declaring that he "wanted to an honest man again," he also returned to newspaper work, with a column for the new left-wing New York daily $P M$ that assailed Germans, isolationists and, especially, powerful Jews in the American media too timid to speak out against Nazi persecution of their brethren in Europe. ${ }^{40}$

One especially defiant column in April 1941 caught the attention of Hillel Kook, the 25-year-old leader of a small contingent of fiery activists from Palestine, who recruited Hecht to lead the group's propaganda efforts. Kook and his compatriots had come to America to join their ideological mentor, Vladimir Jabotinsky, in a drive to raise a Jewish army that could fight against Hitler. But Jabotinsky died in August 1940, which left Kook's group to chart its own course. ${ }^{41}$ 
Back in 1923, Jabotinsky had founded the Zionist Revisionist movement, which favored an absolute and uncompromising demand for a Jewish state, as opposed to the gradualist push for a "national home" supported by the Zionist mainstream. He was a purely political leader, whereas Kook was the political representative of a group of fighters, the Irgun Zvai Leumi, or National Military Organization, formed to protect and save Jewish lives. Although the Irgun drew most of its ranks from Jabotinsky's youth movement, Betar, the Irgun was of independent origin and was never under Jabotinsky's direct command and control. Nevertheless, Jabotinsky had been the clear leader of this American mission, and he had died right as a series of events precipitated by the start of the Second World War left the Irgun's main organization in Palestine in disarray. As a result, Kook and five comrades now found themselves the "lost battalion" of Jewish defenders in the vast and unfamiliar land of America, just as the Nazi genocide was getting underway. ${ }^{42}$

Kook adopted the alias Peter Bergson to protect his family of prominent rabbinical scholars from being associated with the controversial Irgun. Over the next eight years, the Bergson Group, as they became known, would emerge as more outspoken and aggressive in their advocacy for Jewish rescue than any of the mainstream American Jewish organizations that shunned them as "Jewish fascists." They sustained a media and lobbying campaign that was both innovative and unprecedented in scale in American Jewish history, recruiting many prominent Jews and non-Jews within their first year, including cabinet members, senior members of the War Department, and some one hundred congressmen. By 1943, the Bergsonites had a thirty-two member executive board and a paid staff of forty, and at their peak, they claimed 125,000 active members, 
making them a mass movement in their own right. Journalist and supporter Max Lerner said of Bergson, "He had one of the best natural public relations talents that I had ever seen ... And he had much more as well—a stunningly clear vision of what was happening in the Holocaust and a hard determination to act on it." ${ }^{43}$

Hecht became the driving force of the group's propaganda. He penned the most incendiary of the roughly two hundred full-page advertisements that ran in forty newspapers in fifteen cities, delivered speeches and published articles. ${ }^{44}$ His 1943 pageant publicizing Hitler's Final Solution, We Will Never Die, which featured Edward G. Robinson and numerous other Hollywood celebrities, drew forty thousand people to Madison Square Garden before embarking on a national tour. ${ }^{45}$ In 1946, he followed up with the inflammatory Zionist spectacle $A$ Flag is Born, starring a twenty-two-year-old Marlon Brando.

Under the leadership of David Ben-Gurion in Palestine and Rabbi Stephen Wise in America, the mainstream Zionists actively opposed the Irgun and the Bergson Group. The conflict eventually culminated in a bloody standoff over The Altalena, an Irgun arms ship, in June 1948, in the midst of Israel's War of Independence. Outraged by the deaths of friends and comrades in this exchange of fire between Jews, Hecht washed his hands of the Jewish state, and never set foot in Israel. In 1961, he published Perfidy, a bitter polemic about the Israeli controversy known as the Kastner affair, in which he essentially accused Ben-Gurion and the Zionist leadership of collaborating with the Nazis in the mass murder of Hungarian Jews. ${ }^{46} \mathrm{He}$ devoted most of the last sixteen years of his life to writing memoirs. He died on April 18, 1964 at the age of seventy. 


\section{METHODS AND KEY FINDINGS}

"Ben Hecht was the kind of person to whom legends stuck like lint," begins Fetherling's Five Lives, while MacAdams titled his book, Ben Hecht: The Man Behind the Legend. ${ }^{47}$ These popular biographies acknowledge Hecht's success at becoming a folk hero, one of his own invention.

According to various accounts, Hecht was a child prodigy on the violin who performed solo at Chicago's Orchestra Hall at the age of twelve, and helped build The Seabird, an eighteen-foot sloop that he captained on Lake Michigan with a pirate crew. He spent the summer of his fourteenth year performing as a trapeze artist, in a one-ring traveling circus whose ring-master was the alcoholic, nickel-novel reading son of P.T. Barnum's late partner. ${ }^{48}$

As a sixteen-year-old "picture chaser" for the Journal, Hecht's first job in journalism was to beg, borrow or — mostly—steal newsworthy photos, and this he did with talent and a sense of mission. After Aunt Chasha sewed large pockets into his jacket to conceal burglary tools and the loot, Hecht "clambered up fire escapes, crawled through windows and transoms, posing when detected as everything from a gas meter inspector to an undertaker's assistant," recalled friend and fellow journalist Charles Samuels. ${ }^{49}$ Soon Hecht graduated to reporter and professional hoaxer. Collaborating with photographer Gene Cour, he delivered splashy scoops on police pursuits of riverboat pirates and the Great Chicago Earthquake, which tore a terrific fissure through Lincoln Park.

The only problem with many of these extraordinary tales is that our sole source for them is Hecht. Samuels was a reporter and did come to work as a "legman" for Hecht, 
but Samuels lived in New York, and, in 1910, would only have been eight years old. ${ }^{50}$ And as the stories themselves suggest, the narrator is hardly reliable. Regarding Hecht's journalism, Harry Hansen observed, he "became a romantic reporter, one to whom the meticulous accuracy of a stenographic report was abominable and uninspired. ${ }^{, 51}$ Norman Mailer's assessment was less charitable. "Hecht was never a writer to tell the truth when a concoction could put life in his prose," he complained, frustrated by the falsehoods in Hecht's ghost-written “autobiography" of Marilyn Monroe. ${ }^{52}$

Hecht seems to have followed the suggestion that an editor would later give to David Freeman, a New York Post reporter who tried writing for the movies after he was caught inserting innocuous fabrications into news briefs. The editor's "instructions had been to start with the facts and then add whatever I felt would make the facts tell the truth," Freeman recalled. ${ }^{53}$ But in today's era of persistent scandals in journalism and book publishing, a less lyrical view might be that it is the mark of a true hack to peddle fiction as fact.

The historian, then, has been amply warned to proceed with caution when discussing any "facts" about Hecht's life, and while my research confirmed the essential honesty of a great many of Hecht's claims about his exploits and experiences, one quickly begins to realize how easy it is to fall for a charming fable. For instance, where do we first learn of Mankiewicz's famous cable ("Millions are to be grabbed out here and your only competition is idiots..."), which made Hecht iconic as the Hollywood screenwriter? From Child of the Century, that authoritative source on all things Hecht. ${ }^{54}$ Does it not seem too good to be true? Did the great film critic and Hecht champion Pauline Kael buy it? And if she did, how many others have as well? It is worth keeping in xxix 
mind that before Hollywood so famously beckoned, Hecht reeled in a killing as a Florida real estate huckster.

It is the nature of historical research that available evidence is often fragmentary and woefully incomplete, and we will likely never know the truth behind many of these tales. Where possible, I have tried to sort fact from fiction, to see what alternatives might emerge to the colorful yarns that have been told and re-told and not properly questioned. More important, however, I consider what they tell us, what messages they carry. For it is clear Hecht found stories an effective way to communicate ideas and opinions in vivid, memorable shorthand. We may never know if Mankiewicz's cable was real, but through interpretation, we can nevertheless learn a great deal from such anecdotes about what Hecht thought of journalism and writing for the movies.

Hecht was a writer who started using his experience as the grist for his stories, and ended up transforming his life into myth. While most of his early novels and short stories were roman a clefs, and much of his film work rehashed his fiction, after the 1940s, he devoted the rest of his days to memoirs and biographical treatments of friends. In the penultimate chapter of The Five Lives of Ben Hecht titled "The Champion of Long Ago,” Fetherling explains:

His friendships were important to him because they had replaced the crimes, sensations, intrigues and scandals through which he had lived for so long. With his life quieter, after the excitement of Chicago and the whirligig of Hollywood, he found such vicarious relationships, in which each friend was, in a sense, a collaborator in the myth of Hecht's own past, disappearing. So he began writing his memoirs relatively early in life and never looked back — or rather, seldom looked forward, except to wince at a friend's grave and resume remembering. What made the Memoirist unique in his time was that the process of remembering was in itself a creative act. ${ }^{55}$ 
Hecht thus developed a lore in which friends came to represent archetypes, various selves that together constituted the Janus-headed Ben Hecht. Crying in the Wilderness is an effort to decipher that mythology in order to explain Hecht's propaganda as he himself understood it. While various people, including Carl Sandburg, Sherwood Anderson, H.L. Mencken, Herman Mankiewicz and Charlie MacArthur, all played important symbolic roles, I argue that Cohen and Bodenheim provide the key to understanding Hecht's militant rhetoric and its historical relevance.

In this sense, this dissertation offers an analysis of the propaganda through "intellectual biography," which Carl Rollyson defines as "essentially the history of a mind." One potential pitfall to such an approach is that it can be superfluous, a retelling of the life narrative as the person himself constructed it. However, the core themes that underlie Hecht's propaganda are so diffused throughout his work, and so implied, that an effort to integrate and make sense of them is called for. ${ }^{56}$

An interpretive approach that puts Cohen and Bodenheim in the foreground offers a fresh perspective on Hecht's propaganda because it allows me to draw on rich pockets of archival material. Although a number of quite recent books about Mickey Cohen have now drawn on the drafts and notes of Hecht's unpublished Cohen biography, no study until this one has focused on the relationship between the two men, and on what their friendship meant within the broader context of Hecht's life, work and Jewish activism. By the same token, scant attention has been paid to the letters Bodenheim wrote Hecht in the 1940s, or to Hecht and Bodenheim's collaboration on their own periodical, the Chicago Literary Times. 
The focus on Hecht's unique, personal views on the Jewish politics of the 1940s also offered new lines of inquiry into the vast store of correspondence, financial records, memorandums, speeches, publicity materials and media coverage of the Bergson Group. All of the above materials exist in two archives: The Ben Hecht Papers, 1879-1983, kept at the Newberry Library in Chicago, and the Palestine Statehood Committee Papers, stored at Yale University's Sterling Library.

Archival research yielded other discoveries as well. By-lines during Hecht's era as a reporter were few and far between, but my research for Part I of this study drew from his stories for the Journal and the Daily News collected at the Newberry, and correspondence with Daily News editors, which had not received attention in published research. The materials donated by biographer William MacAdams, which constitute an archive in their own right, include a dozen letters about Hecht from friends and colleagues, and tapes of twenty-two interviews. Since MacAdams' book contains no footnotes or citations of any kind, my review of this material provided an opportunity to set the record straight on several questions about Hecht's life.

The archival research and — just as critical— the process of gathering together many small data points from a variety of primary sources, yielded a number of historical discoveries. Among the most important:

- An extraordinary relationship existed between Chicago's newspapers and the criminal underworld, which underscores that the American media have not only occasionally been guilty of turning a blind eye to crime and corruption, but have themselves been key sources of both at times. Part I points out that most of the gunmen who fought the bootlegging wars of the Capone era received their original training while on the payroll of the circulation departments of the city's dailies, fighting in the bloody newspaper wars that raged from the turn of the century, when William Randolph Hearst first came to town, through the early years of Prohibition. 
During these years, Hecht and other reporters maintained friendships with gangsters or, as in the sensational case of Jake Lingle, were underworld figures themselves. In the 1920s and early ' 30 s, Hecht was just one of several Chicago reporters who popularized the gangster in American culture through a series of hits on Broadway and in the movies. Meanwhile, devious editors like Hearst's Walter Howey maintained blackmail rings to keep local police and city officials under their thumbs.

- The degree to which Peter Bergson, aka Hillel Kook, and his group funded and armed the "terrorists" in Palestine has always been somewhat shrouded in mystery. Drawing on a variety of sources, I argue that Kook used money from Hecht's pageants and newspaper advertisements to pursue a long-term strategy: He invested much of the revenue from A Flag is Born in a provisional Hebrew government based in Paris, which he then leveraged to negotiate the procurement of a major shipment of arms from Franceenough to supply a small army. This was the cargo finally loaded aboard the Altalena in June 1948, but the newly established Israeli government under Ben-Gurion believed - as did the French — that the Irgun would use the arms to stage a coup, which is what led to the bloodshed.

- American Jewish gangsters were likely more important to arms smuggling than has previously been acknowledged, because the mob controlled the East Coast waterfront, blocks from where the Zionists' international operation was headquartered, at Manhattan's Hotel Fourteen. Assistance from Mickey Cohen's East-Coast partners, Murder Incorporated and the Meyer Lansky-Lucky Luciano "Combination," would have been an easy segue from crucial cooperation they had maintained with U.S. Naval Intelligence during the war, whereby they helped to ensure the safety of American shipping. Despite the denials of a key source in The Pledge, Leonard Slater's seminal book on Zionist arms procurement and smuggling, various clues suggest the importance of the mob, such as the fact that Hotel Fourteen was located directly above the Copacabana Club, the most popular nightspot for the underworld and a central place of business.

- Mickey Cohen's famous fundraiser for the Irgun at Slapsy Maxie's nightclub, originally described by Hecht in his memoir Child of the Century and recounted in many recent published histories, did not occur in the summer of 1947 as has been widely reported, but on May 24, 1948. This was less than two weeks after Israel declared independence and was invaded by the armed forces of six Arab nations. 
- Mickey Cohen used his own celebrity and Hecht's vaunted reputation as a screenwriter to generate well over $\$ 100,000$ in "loans" for a movie that never existed. This tale of a charming psychopath who used trust and friendship to perpetrate a massive fraud provides an illuminating coda to the story of Hecht's propaganda campaign.

One potential problem with intellectual biography, Rollyson warns, is that too heavy a reliance on autobiographical writings can inhibit alternative narratives from breaking through. ${ }^{57}$ Hecht's agenda is not the same as that of a reader or biographer who seeks to understand him in the political, social and cultural context of his times. He was an autodidact and an independent thinker, and the primary texts of his contemporariestheir journalism, memoirs and other works - were crucial in helping me put his highly idiosyncratic views into the context of his day.

I incorporated the writings of the political leaders with whom he was linked, namely Jabotinsky, Begin and Bergson, as well as opponents such as Ben-Gurion, Weizmann and Wise. Just as important were the voices of the scholars and intellectuals of the day, like Reinhold Niebuhr, who was also a Bergson supporter, Meyer Levin, Ben Halpern, and propaganda theorists like Harold Lasswell. ${ }^{58}$ In the social-cultural Bodenheim narrative, I incorporated the writings of Hecht's contemporaries to discuss his shared views as well as his differences with comrades in the Chicago Renaissance like Margaret Anderson and Carl Sandburg; mentor H.L. Mencken; the writers of the Algonquin Round Table and Hollywood; and others in the film industry. In discussing how Hecht continued to wrestle with the themes that emerged in his propaganda, I concluded with how these ideas influenced, coincided or clashed with those of writers 
who came to prominence in the 1950 s, particularly the ones he came into direct contact with through The Ben Hecht Show.

Finally, the secondary sources discussed in the appended literature review were vital to putting all of this into the context of history. We may never determine precisely how successful the Bergson campaign was in saving Jews, but we can examine how Hecht understood the events of the Holocaust as they were unfolding, in contrast to other Americans. We are also able to examine the concrete consequences of Hecht's ideology and rhetoric in Palestine, since the historical record of the Irgun's military career is well documented, from its early operations during the 1936 Arab Revolt to its final confrontation over the Altalena in 1948.

\section{FOUR PARTS TO THE STORY}

Crying in the Wilderness proceeds chronologically, beginning with Hecht's early years. Each of the four parts of this tale can stand on its own, but together they constiute an integrated account of Hecht's propaganda.

Part I, “The Devil's Bargain,” traces Hecht's development from Chicago crime reporter to author of a hit comedy about newspapers, The Front Page, and Scarface, his classic movie about Al Capone. This section charts the development of Hecht's ideas about crime and the law, politics and the media. The insolent nihilism that Hecht cultivated as a reporter has been summed up by the phrase "Front Page Journalism," by historians of the Chicago press; likewise, film critics reference the breezy wickedness of Hecht's attitude to explain the allure that movies like Underworld and Scarface had for 
movie fans. Part I explains Hecht as a romanticist, and argues that the bond that he and other Chicago reporters forged with gangsters was a kind of Faustian pact, a devil's bargain, much like the deals struck by Hecht's protagonists in The Front Page, Scarface and other stories.

Part II, "The Egoists," begins with Hecht's ascendance as a representative of the Chicago Renaissance and follows his career up to the outbreak of the Second World War. It explains how the views of fellow bohemians regarding art, culture and society conflicted with the ones that he shared with Bodenheim — views that made the two friends, as Hecht put it, "the best hated men in American literature." ${ }^{, 59}$ Their ideas came to flower in the 1920s, in their poetry and fiction, in the Chicago Literary Times, and finally in a literary feud that they carried on against one another. The ethos they shared determined the fate of their later careers, but with dramatically different consequences for them both. Part II contends that it was this ethos that in large part fueled Hecht's rebellion against Hollywood during the 1940s. Moreover, it argues that as puckish egoists at a time when many cultural rebels piously valued solidarity and socialism, the ways in which the two differed from their contemporaries made them more like authors who came to the fore during the postwar era, which suggests their importance as literary pioneers.

Part III, "From Humanist to Public Enemy," describes Hecht's evolution from a wartime propagandist who appealed to the public's ideals and conscience to an embittered militant pitchman, no longer interested in changing minds, but instead seeking funds for armed struggle from an existing base of support. Hecht's works from the period clearly frame the events of the war and struggle for Palestine in terms of law and order. 
Just as the Allies would hold the Nazis accountable as war criminals at Nuremberg, Hecht and the Irgunists saw Hitler's genocide as one of the great crimes of history. Nevertheless, they also condemned Churchill and Roosevelt as the criminals' accomplices, convinced that the Allies had maintained their blockade of Palestine and refused to launch a rescue program because they cynically viewed Jewish refugees as a threat to Britain's imperial designs on the Middle East. Engaging His Majesty's government in a war of rhetoric, Hecht's challenge to the moral and legal authority of the Allies culminated with his partnership with Mickey Cohen.

Part IV, "L.A.'s Al Capone," picks up with the pair's effort to smuggle arms into Palestine, and then relates Hecht's subsequent attempt to grapple with the ideas and issues raised during the 1940s through drafts of the Cohen biography. Finally, Hecht confronted them in debates with his wife Rose and sister-in-law Minna Emch, a noted psychiatrist. The story of the biography becomes a tale-within-a-tale: The rise and fall of the Jewish Hollywood gangster, his street battles, surreal career as a criminal celebrity and publicity war with Los Angeles Police Department offer yet another lens through which to examine Hecht's beliefs. In relating how this journey ended for both men, Part IV also offers a final assessment of Hecht's cultural significance and political legacy.

\section{CONCLUSION}

The two narratives, cultural and political, reflect the two veins of scholarship about Hecht that have developed up to this point. I have tried to incorporate the insights of both the cultural studies of Hecht and the political ones, to discuss how their 
perspectives complement one another, and also how they converge. I have suggested that Hecht's story helps us understand the late twentieth century cultural rebel, postwar American Jewish identity, our remembrance of the Holocaust and America's relationship with Israel.

Both narratives explain Hecht's propaganda through his experiences as a life-long employee of the media industry. On the one hand, we can look to his disillusionment with screenwriting and his distaste for the Jewish Hollywood movie moguls in order to understand his personal motivations for embracing the Cause in the first place. On the other, we can understand his political ideology by examining the worldview he originally developed as a reporter on the crime beat in Chicago. Ultimately, the cultural story is historically resonant because his unease in Hollywood is emblematic of the tension between the dual roles of artist-rebel versus entertainer that increasingly came to define creative figures in the age of mass media. And in regard to politics, if we understand Hecht's embrace of the "fighting Jew" as a sense of identity that he came to as a direct response to the Holocaust, we have a conception of Jewishness that has been hotly debated, by historians as well as by journalists and pundits in the mass media.

But the question remains, how do these two stories tie together? In the appendix, I note historian Peter Novick's argument that in American collective memory the Holocaust has been useful in moving from an integrationist to a particularist ethos, and in promoting an uncritical view towards Israel. "On a philosophical level," Novick writes, "the Holocaust has been used by conservatives to demonstrate the sinfulness of man. It has provided confirmation of a tragic worldview, revealing the fatuousness of any transformative —or even seriously meliorative— politics. ${ }^{, 60}$ But to point to Hecht as a 
prototype of this view, because he "became a Jew" in 1939 and aligned himself with those who came to represent the right wing of Israeli politics, would be to not only oversimplify but to flatly misrepresent the historical record.

As the scholar Gil Troy emphasizes, Hecht's politics was a morass of contradictions. Even during his most militant phase, Hecht wrote "A Declaration of Faith," in which he contrasted State Department technocrats and contemporary politicians to the original, humanist aspirations of America. He declared that the Bergson Group's American League for a Free Palestine represented the old United States, which "came of age and won renown because it preserved the decent spirit of man.. ${ }^{, 61}$ While this may seem to fly in the face of the tribalistic, law-of-the-jungle perspective that Hecht so often articulated, there is consistency if we consider him as a critic who concluded, "On the whole, I fear I was a churlish liberal." ${ }^{92}$ Thus we may best understand Hecht as a voice of conscience, who challenged Americans and Jews to remember their defining, original ideals and remain true to them.

I have suggested how the Cohen and Bodenheim narratives tell us something about the character and content of mass media, and in turn, about culture and political ideology. But the broader hope is to address what I would argue are two of the most important concerns of our era: the problem of alienation and the threat of annihilation. The story of Hecht's attachment to Bodenheim, a Jewish writer who proved incapable of compromise, sheds light on Hecht's propaganda as a response to the pitfalls of assimilation. Likewise, the story of Hecht's preoccupation with a Jewish outlaw, a "fighting Jew," offers a window into his propaganda as a response to anti-Semitism. To frame it more broadly in terms of American experience, the Bodenheim narrative xxxix 
investigates the sense of alienation Hecht felt in his dealings with the media industry, and with American society more generally, while the Mickey Cohen narrative investigates Hecht's confrontation with the exterior threats of Nazism, genocide and a world at war.

As we have seen with the rise of militancy and terrorism in recent years, alienation today is not just an important Jewish or even American story, but a serious and urgent global phenomenon. And as we progress further into a post-modern world that was ushered in by brownshirts, death camps, aerial bombardments and mushroom clouds, the questions of what created such inhumanity, what permitted it and how best to respond to it grow ever more important.

\footnotetext{
${ }^{1}$ Ben Hecht, "Letter to the Terrorists of Palestine," New York Herald Tribune, May 15, 1947, 17. Chicago Daily News, May 15 1947, 13. Ben Hecht, A Child of the Century (New York: Primus, 1985), 617. Historian Rafael Medoff writes that the advertisement ran once in the Herald Tribune and twice in the New York Post. In his autobiography, Hecht reports that it ran in some fifteen newspapers and was reprinted as a news story in South America and Europe.

${ }^{2}$ For summaries of the response in the press, see Gilad E. Troy, Ben Hecht: From Literary Gadfly to Political Activist (Bachelor of Arts thesis, Harvard University, 1982), 111-115; Doug Fetherling, The Five Lives of Ben Hecht (Toronto: Lester and Orpen, 1977), 134; and Jeffrey Brown Martin, Ben Hecht, Hollywood Screenwriter (Ann Arbor, Mich: UMI Research Press, 1985), 158-159.

${ }^{3}$ Atay Citron describes large street rallies organized by Zionists in Philadelphia to picket Hecht's play, A Flag is Born. Atay Citron, "Ben Hecht's pageant-drama: A Flag is Born," in Staging the Holocaust: The Shoah in Drama and Performance (Cambridge: Cambridge University Press, 1998), 91.

${ }^{4}$ Elizabeth Borgwardt, A New Deal for the World: America's Vision for Human Rights (Cambridge, Mass: Belknap Press of Harvard University Press, 2005), 53-56. Borgwardt observes that "'human rights' was not a new term born of World War II, but during this period it became a shorthand readily understood by educated readers and influential commentators, both in the United States and abroad." She writes that it had previously been used as a variation of "rights of man," and sometimes as a synonym for civil rights, but over the war years it came to apply to "the so-called fundamental freedoms" denied by the totalitarian powers of the day. She traces its use and meaning, and connects it with Roosevelt's New Deal. For a listing of the postwar institutions and tenets of international law that she sees as multilateralist expressions of the New Deal, see page 71 . For her encapsulation of the fundamental philosophical linkages, see pages. 74-75.

${ }^{5}$ William A. Kirk, "Crime and Violence," and Alice E. Holden, "Sympathy Alienated," letters column, New York Herald Tribune, May 18, 1947, 7; Dorothy Thompson, "Do Israeli Ties Conflict with U.S. Citizenship?: America Demands a Single Loyalty," Commentary, March 1950,
} 
210-219. One non-Jewish reader of the Herald Tribune voiced fury at this call "to aid and abet crime and violence in territory administered by a nation friendly to the United States." Another warned that she would cease to feel sympathy for the Zionists unless their appeals were "carried on a higher plane." American columnist Dorothy Thompson, who had been a pioneering opponent of the Nazis and a leading advocate for Jewish rescue, became outraged by the Irgun's violence against Britain. In a 1950 essay for Commentary that linked the Irgun and another militant Zionist faction, the Stern Gang, with Hitler, Thompson warned American Jews against dual loyalty in their support for Israel.

${ }^{6}$ For books on Hollywood's suppression of content, see Neal Gabler, An Empire of Their Own: How the Jews Invented Hollywood, 1st ed (New York: Crown Publishers, 1988); Entertaining America: Jews, Movies, and Broadcasting (New York: Princeton: Jewish Museum, under the auspices of the Jewish Theological Seminary of America; Princeton University Press, 2003); Thomas Patrick Doherty, Hollywood and Hitler, 1933-1939, Film and Culture (New York: Columbia University Press, 2013); Thomas Patrick Doherty, Hollywood's Censor: Joseph I. Breen \& the Production Code Administration (New York: Columbia University Press, 2007); Ben Urwand, The Collaboration: Hollywood's Pact with Hitler (Cambridge, Massachusetts: The Belknap Press of Harvard University Press, 2013); Herman, Felicia, "Hollywood, Nazism, and the Jews, 1933-1941" American Jewish History 89, no. 1 (March 2001): 61-89.

${ }^{7}$ See David Denby, "How Could Harvard Have Published Ben Urwand's 'The Collaboration'?," The New Yorker Blogs, September 23, 2013, http://www.newyorker.com/online/blogs/culture/ 2013/09/how-could-harvard-have-published-ben-urwands-the-collaboration .html; "Harvard University Press Defends Controversial Book on Hollywood and Hitler," ArtsBeat, http://artsbeat. blogs.nytimes.com/2013/09/26/harvard-university-press-defends-controversial-book-onhollywood-and-hitler/; David Denby, "Hitler in Hollywood," The New Yorker, September 16, 2013 http://www.newyorker.com/arts/critics/books /2013/09/16/130916crbobooks_denby; Jennifer Schuessler, "Scholar Asserts That Hollywood Avidly Aided Nazis," The New York Times, June 25, 2013, sec. Books, http://www.nytimes.com/2013/06/26/books/scholar-assertsthat-hollywood-avidly-aided-nazis.html. Like many such controversies, the narrow focus of this one- on the word "collaboration"- does more to obscure than illuminate the truth. As I followed Hecht through the broader story of the media war during the 1930 s and " 40 s, it became clear that Nazis were as canny as they were ruthless, and were indeed successful at preying on prominent Jews in the way that Urwand suggests. Many prominent Jews in Europe were similarly coerced, and the emotional arguments over whether any or all "collaborated" clouds this far more important point.

${ }^{8}$ Urwand, The Collaboration, 244.

${ }^{9}$ Ben Hecht, "Champion on Chains," Esquire, October 1942, 36.

${ }^{10}$ Hecht contrasted the two in Gaily Gaily, when he introduced the latter: "I must move my memory to another world into which I had drifted in my teens, a world unaware of doomed men and 4-11 fires." Hecht, Gaily, Gaily, 1st ed. (Garden City, N.Y: Doubleday, 1963), 162-3.

${ }^{11}$ Gerald Mast, A Short History of the Movies, 9th ed. (New York: Pearson/Longman, 2006).

${ }^{12}$ David Ben-Gurion, Rebirth and Destiny of Israel; (London, Thomas Yoseloff, 1959), 144.

${ }^{13}$ Hecht, Child of the Century,611-613; Michael Mickey Cohen, Mickey Cohen, In My Own Words: The Underworld Autobiography of Michael Mickey Cohen, as Told to John Peer Nugent (Englewood Cliffs, N.J: Prentice-Hall, 1975), 89-93.

${ }^{14}$ See for example Ben Halpern's accusations against the Irgun and the Stern Gang for "terrorism against the Jewish community," as well as for robbery. A December 1948 letter to the New York Times signed by Hannah Arendt, Albert Einstein and other prominent Jews that protested Menachem Begin's visit to America accused the Irgun of persecuting the Jewish community of 
Palestine. "By gangster methods, beatings, window-smashing and wide-spread robberies, the terrorists intimidated the population and exacted a heavy tribute." Mark A. Raider, "Irresponsible, Undisciplined Opposition: Ben Halpern on the Bergson Group and Jewish Terrorism in Pre-State Palestine," American Jewish History 92, No. 3 (September 2004): 325-330; "New Palestine Party Visit of Menachem Begin and Aims of Political Movement Discussed," New York Times, December 4, 1948; Tom Segev, One Palestine, Complete: Jews and Arabs Under the British Mandate, 1st ed. (New York: Metropolitan Books, 2000), 456.

${ }^{15}$ Robert Rockaway offers perhaps the most comprehensive account of the fundraising and smuggling efforts by Cohen, Lansky, Bugsy Siegel and other underworld figures, and has gone to the greatest lengths to sort out fact from fiction. See Robert A. Rockaway, But He Was Good to His Mother: The Lives and Crimes of Jewish Gangsters (Jerusalem; New York: Gefen Pub. House, 2000), 244-252. Rafael Medoff informed me in an email on October 19, 2009, that he is using primary source material on this topic for a forthcoming book. Sources include FBI files and an unpublished autobiography by Bergsonite lobbyist Rabbi Baruch Rabinowitz, See also Hecht, Child of the Century, 610-613; Cohen, In My Own Words, 92-93; and Medoff, Militant Zionism, 151. A seminal book on American arms smuggling for the Jews in Palestine is Leonard Slater's The Pledge (New York: Simon and Schuster, 1970).

${ }^{16}$ The point that Hecht invented the gangster movie genre has been repeated so many times that it is easy to overlook the fact that he was the first to have made the claim, in Child of the Century, 479.

${ }^{17}$ For the purpose of this dissertation, Jack Lule's definition of "myth" will suffice. He explains it as "a sacred societal story that draws from archetypical figures and forms to offer exemplary models for human life." Jack Lule, Daily News, Eternal Stories: The Mythological Role of Journalism (New York: Guilford, 2001), 21-25. Most prominently, Hecht provided American archetypes for the "tough Jew" in his "Champion in Chains" article for Esquire. He also offered Hebrew archetypes there, as well as in A Flag is Born. These works are discussed in Part IV, along with the rest of his propaganda, which was packed with archetypes, and mythmaking. ${ }^{18}$ In this Hecht was in line with many other Jewish writers and intellectuals of his era. Julian Levinson sums up Alfred Kazin's January 1944 essay for the New Republic, plainly: "The senseless murder of the Jews proved that enlightenment ideals have failed. No 'social contract' has managed to protect Jews. The liberal faith in 'essential goodness' must also be rethought." Ludwig Lewisohn explained Nazism as the triumph of Christian Europe's inner pagan, dragging the world into tribal conflict. Donald Weber quotes Arthur Miller as saying that "just as World War II was ending, at the threshold of a hoped for universal peace ... he wasn't sure, looking back, 'whether after peace came, we were launched into a raw politics of race and religion."' According to Mark Shechner, to accept Erich Fromm's account of fascism in Escape from Freedom "as a desperate and infantile attempt to heal the fractured experience of modern manwas to conclude that liberal democracy hadn't a leg to stand on and that fascism, through its appeal to the most infantile layers of the psyche, was certain to sweep the West." Socialist turned neoconservative Max Eastman concluded that "the hereditary nature [of man] is still that of the tribal savage." Shechner quotes Lionel Trilling and Arthur Schlesinger making essentially the same point. Alfred Kazin, "In Every Voice, In Every Ban," The New Republic, 10 January 1944, 44-46; Julian Levinson, Exiles on Main Street: Jewish American Writers and American Literary Culture (Bloomington: Indiana University Press, 2008), 74, 155; Donald Weber, Haunted in the New World: Jewish American Culture from Cahan to The Goldbergs, Jewish literature and culture; (Bloomington: Indiana University Press, 2005), 109; Mark Shechner, After the Revolution: Studies in the Contemporary Jewish American Imagination (Bloomington: Indiana University Press, 1987), 66-67. 
${ }^{19}$ Ben Hecht, A Guide for the Bedevilled (New York: Charles Scribner's Sons, 1944), 20.

${ }^{20}$ Hecht, Child of the Century, 567-573. For an incisive account of Mencken's clash with Roosevelt, see Terry Teachout, The Skeptic: A Life of H.L. Mencken, 1st ed. (New York: HarperCollins, 2002), 1-18.

${ }^{21}$ See for example, in Hecht's Guide for the Bedevilled, 161-221. Walter Lippmann, Public Opinion (New York: Harcourt, Brace and Company, 1922), 3-32.

${ }^{22}$ To be fair, Hecht wanted Israel established as a democracy, but doesn't seem to have given much thought to how this might have worked on territory where Arabs constituted a majority. For Hecht's vision of a Greater Israel that would not kneel "to their new master- the United Nations," see Child of the Century, 597-599, 622. For a summary of Weizmann's "one more dunam" approach, see Walter Laqueur, A History of Zionism (New York: Holt, Rinehart and Winston, 1972), 495.

${ }^{23}$ David Miller, The Blackwell Encyclopaedia of Political Thought, Blackwell reference; (Oxford, UK ; New York, NY, USA: B. Blackwell, 1987), 98. Isaiah Berlin's cogent analysis of Maistre's ideas and their resonance in the modern world, originally broadcast as a speech for the BBC in 1952, is transcribed and edited for print in Freedom and Its Betrayal: Six Enemies of Human Liberty (Princeton, N.J: Princeton University Press, 2002), 131-154. Berlin states, "Although Maistre may have spoken the language of the past, the content of what he had to say is the absolute substance of the anti-democratic talk of our day; in comparison with his progressive contemporaries he is really ultra-modern, born not so much after as before his time."

24 “The Unfinished Life of Mickey Cohen," Scanlan's Vol. 1 No. 1 (March 1970), 70. An excerpt from Ben Hecht's unpublished biography of Mickey Cohen stored with the Ben Hecht Papers, 1879-1983, Newberry Library, hereafter, BHNL. MacAdams Collection.

${ }^{25}$ Oxford English Dictionary Online, "Militant, Adj. And N." Definition A3b: Oxford University Press, http://proxy.mul.missouri.edu:2585/view/. Entry/118418?redirectedFrom=militant\#. As examples, the OED cites references to trade unions (1893), women suffragettes (1914), black militants (1971) and Islamic militants (1992).

${ }^{26}$ Theodore Strauss, "Prophet Without Honor: Ben Hecht, at a Safe Distance, Hurls an Epithet or Two at Hollywood," New York Times, 13 October 1940, Arts and Leisure Section, 126.

${ }^{27}$ Lincoln Steffens and University of Missouri-Columbia, The Autobiography of Lincoln Steffens (New York: Harcourt, Brace and Company, 1931), 357.

${ }^{28}$ Jack B. Moore, Maxwell Bodenheim (New York: Twayne Publishers, 1970); Ben Hecht, "A Poet Out of Yesterday" in 1001 Afternoons in New York (New York: The Viking press, 1941), 61-64; "About Bodenheim" in Letters from Bohemia, 1st ed. (Garden City, N.Y: Doubleday, 1964), 105-132; Child of the Century, 215-218; .

29 "Bodenheim, Maxwell (Bogie), (also poem), ... to Ben and Rose, n.d." Incoming Correspondence, 1914-1979, Box 55, Folder 1081, BHNL; Hecht, Letters from Bohemia, 105132. The letters corroborate Hecht's explanation of their deal.

${ }^{30}$ Coser offered this in attempting to define the term "intellectual" in Men of Ideas, but his conception of the intellectual included literary figures, like Hecht and Bodenheim specifically. The book has chapters on early Greenwich Village, The Little Review and "Intellectuals in the Mass Culture Industry." He discusses Bodenheim in the chapter on Greenwich Village, and Hecht in a section of the mass culture chapter on the movie industry. Lewis A Coser, Men of Ideas; a Sociologist's View (New York: Free Press, 1965), viii, 117, 328.

${ }^{31}$ I suggested these four motifs in a July 2010 letter to Dr. Robert B. Chisholm Jr., author of Handbook on the Prophets: Isaiah, Jeremiah, Lamentations,Ezekiel, Daniel, Minor Prophets, Pbk. ed. (Grand Rapids, Mich: Baker Academic, 2009). In August, he responded: "The four components you mention are all elements of prophetic preaching and/or experience. The prophets 
confront rebellion and warn of exile (or speak of return from it), they are commissioned by Yahweh and hear his voice, they do suffer and sometimes struggle with God's purposes (see especially Jeremiah), and they certainly long for the day when the wayward people will be reconciled to their covenant God (and his righteous remnant, including the prophets). But reconciliation between prophet and people can only come when the people are reconciled to God, because the prophet merely speaks for and represents God."

${ }^{32}$ The phrase comes from Isaiah 40:3, "The voice of him that crieth in the wilderness, Prepare ye the way of the Lord, make straight in the desert a highway for our God." King James Bible, 2nd ed. (Champaign, Ill: Project Gutenberg, 199-?). Chisholm explained, "As for Isaiah 40:3, the imagery there is one of return from exile. A herald (he is not identified as a prophet, though John the Baptizer is later identified as a/the fulfillment of this vision) instructs his audience to prepare the way for the Lord's return to Jerusalem through the wilderness to the east. He will be bringing the exiles with him (vv. 10-11), which is comforting news for abandoned Jerusalem, personified here as a mother who has been robbed of her children. The royal highway is to be built through the wilderness so the king can journey to the city as quickly as possible and without encumbrance." Correspondence with the author, August 3, 2010.

33 "Ben Hecht, 70, Dies at His Home Here," New York Times, 19 April 1964, 1, 84. Hecht, Guide for the Bedevilled, 62-64; Child of the Century, 65, 70; William MacAdams, Ben Hecht: The Man Behind the Legend (New York: Scribner, 1988), 11; Fetherling, Five Lives, 3; Troy, From Literary Gadfly, 1. There is little agreement about whether Hecht was born in 1893 or 1894. MacAdams and the Newberry Library web page biography both report that he was born in 1893 , but Fetherling, Troy and most other biographical sources, perhaps relying on the reports that he was 70 years old at the time of his death, say he was born the following year. Hecht himself is not entirely consistent: In Child of the Century and Gaily Gaily he writes that he was sixteen when he joined the Journal in the summer of 1910, but in Guide for the Bedevilled he says that he was seventeen. William MacAdams's source for Hecht's birth date is a letter from Peter Hecht, Ben's brother, which states that Ben was born February 28, 1893, "as I figure it." However, it is worth noting Peter Hecht's uncertainty: In what appears to be a previous letter, he writes that Ben was born in 1892, "almost five years to my birth in 1897." The 1893 date comes from an undated letter that appears to be a subsequent correction, in which Peter Hecht adds that Ben was born five years and nine months before him. BHNL, MacAdams collection, Folder No. 141, Peter Hecht, p.1 of a 12-page letter; p.1 of a 8-page letter. Both letters are undated. Hecht, Child of the Century, 73; Gaily Gaily, "Greeting," page not numbered; Guide for the Bedevilled, 66.

${ }^{34}$ Sinclair researched The Jungle in 1904. By at least one account, twenty-seven news dealers were killed between 1910 and 1912. Hecht was leaving Chicago just as Capone was on the rise, but he certainly knew the world from which Capone came. Anna Maria Hong and Cynthia Brantley Johnson, introduction to The Jungle (New York: Pocket Books, 2004), IX. Jon Bekken, "Crumbs from the Publishers' Golden Tables: the plight of the Chicago newsboy," Media History 6, No. 1, (2000), 48; Elizabeth Dewey Johns, Chicago's Papers and the News (Unpublished Ph.D. dissertation, University of Chicago, 1942), 2-54; and W.A. Swanberg, Citizen Hearst (New York: Charles Scribner's Sons, 1961), 274. Hecht mentions the newspaper wars in Child on page 151. On Capone, see Child of the Century, 486-487.

${ }^{35}$ Fetherling, Five Lives, 13.

${ }^{36}$ Hecht, Child of the Century, 250.

${ }^{37}$ Fetherling asserts that it "was probably the first underground newspaper in the United States as we understand the term today," in Five Lives, 54.

${ }^{38}$ Hecht, Child of the Century, 466. 
${ }^{39}$ Troy, From Literary Gadfly, 49, citing Joe Schoenfeld, "Seventeen Thousand Turn Out at 'Fun to be Free," Variety 8 October, 1941, 2, 16.

${ }^{40}$ Fetherling, Five Lives, 123.

${ }^{41}$ Yitshaq Ben-Ami, Years of Wrath, Days of Glory: Memoirs from the Irgun, 1st ed. (New York, N.Y: R. Speller, 1982), 241-244, 247-249; Hecht, Child of the Century, 521; telegram from Peter Bergson to Hecht, 28 August, 1941, 12 September, 1941, in "Bergson, Peter, 1941-1952, 1962," Incoming Correspondence, 1914-1979, Box 55, Folder 1069b, BHNL.

${ }^{42}$ In Ben-Ami, Years of Wrath, on being the "lost battalion, 242; on the independence of the Bergson Group, 247-248. For histories of Revisionism, see Lenni Brenner, The Iron Wall: Zionist Revisionism from Jabotinsky to Shamir (London: Zed Books, 1984) and Laqueur's A History of Zionism.

${ }^{43}$ Louis Rapoport, Shake heaven \& earth: Peter Bergson and the struggle to rescue the Jews of Europe (Jerusalem ; New York: Gefen Pub. House, 1999), 45, 84, 86; Monty Noam Penkower, "In Dramatic Dissent: The Bergson Boys," American Jewish History LXX, No. 3 (March 1981), 306.

${ }^{44}$ David Wyman, “The Bergson Group, America, and the Holocaust: A Previously Unpublished Interview with Hillel Kook / Peter Bergson," American Jewish History, 89.1 (2001) n9. David S. Wyman and Rafael Medoff A Race Against Death: Peter Bergson, America, and the Holocaust (New York: The New Press, 2002), 30.

${ }^{45}$ David S Wyman, The Abandonment of the Jews: America and the Holocaust, 1941-1945, 1st ed. (New York: Pantheon Books, 1984), 90-91.

${ }^{46}$ Ben Hecht, Perfidy (New York: Messner, 1961).

${ }^{47}$ Fetherling, Five Lives, 3.

${ }^{48}$ Ibid, 12; Hecht, Child of the Century, 62-63, 70, 76; Brown Martin, Hollywood Screenwriter, 5; MacAdams, Man Behind the Legend, 11-12. Hecht's tales may be truer than they seem.

According to researcher Florice Whyte Kovan, the rooming house, located at 838 Lake Avenue was owned by the Hechts' equestrian landlady, Frances Castello. Her spouse, circus master Dan Castello, a partner of P.T. Barnum, was the first to piggy-back circus cars on trains to the West Coast after the completion of the trans-continental railroad, tithing to Brigham Young in his passage through Utah. His performance for Queen Victoria in London was lauded in a brochure by Charles Dickens. Hecht honored Harry in a story he wrote for the Reader's Digest feature, "The Most Unforgettable Character I Ever Met." His circus and carnival scripts include "Trapeze" starring Burt Lancaster, Tony Curtis and Gina Lollobrigida; "7 Faces of Dr. Lao" (Tony Randall) and "Jumbo" starring Doris Day and Jimmy Durante. In letters to MacAdams, Ben's brother Peter corroborated most of what Hecht states in Child of the Century. Harry "Costello," whose mother owned the boarding house where the Hechts lived, built Ben a fourteen-foot skiff. Costello evidently was a "human fly" - a trained circus performer, he often "walked upside down from ceilings and up theatre proscenium arches." Peter relates that he did take the boys around for a summer as performers in a small traveling circus. In Child of the Century, Hecht writes that Harry's father had been Dan Costello, a partner of P.T. Barnum and famous acrobatic clown. Peter essentially reports this fact as well, though he admits that he has no way of verifying it. Mrs. Costello kept scrapbooks of their circus days, which revealed that she had been the premiere bareback rider. BHNL. MacAdams Collection, Folder No. 141, Letters from Peter Hecht. For Florice Whyte Kovan's information, see "Ben Hecht's Circus Boyhood" on her remarkable Snickersnee Press website devoted to Hecht's life and works: http://benhechtbooks.net/ben_hechts_circus_boyhood. Whyte Kovan publishes books about Hecht.

${ }^{49}$ MacAdams, Man Behind the Legend, 14. 
${ }^{50}$ Wikipedia, s.v. "Charles Samuels," last updated October 4, 2010, http://en.wikipedia.org/wiki/ Charles_Samuels. Picture Snatcher was a 1933 James Cagney film adapted from a story by Danny Ahern (sometimes spelled Ahearn), a pulp writer and gangster who ran with Meyer Lansky and Bugsy Siegel. But did Ahern take the idea from Hecht, or (more likely) did Hecht take the idea from Ahern? Was there ever really such a thing as a picture snatcher, in Chicago or anywhere else? And what do we make of all these connections, between gangsters, newspapers and the movies? See "Picture Snatcher" moviediva.com, revised April 2005. This Web site produced by the film curator at the North Carolina Museum of Art. http://www.moviediva.com/ MD_root/ reviewpages/MDPictureSnatcher.htm. Jay Robert Nash, The Great Pictorial History of World Crime (Wilmette, IL: History, Inc, 2004), 571, 572.

${ }^{51}$ Harry Hansen, "Ben Hecht, Pagliacci of the Fire Escapes" in Midwest Portraits: A Book of Memories and Friendships (New York: Harcourt, Brace and company, 1923), 327.

${ }^{52}$ Norman Mailer, Marilyn, a Biography ([New York: Grosset \& Dunlap, 1973), 18.

${ }^{53}$ David Freeman, "Reporting the News" and "Under the Sun" in A Hollywood Education: Tales of Movie Dreams and Easy Money (New York: Putnam, 1986), 9-19, 268.

${ }^{54}$ Hecht, Child of the Century, 466.

${ }_{55}^{55}$ Fetherling, Five Lives, 168.

${ }^{56}$ Carl E Rollyson, Biography, a User's Guide (Chicago: Ivan R. Dee, 2008), 155-157.

${ }^{57}$ Ibid.

${ }^{58}$ Niebuhr was an active supporter of the Bergson Group, and published a 1942 essay arguing that the liberal humanists were failing to face squarely the Nazi slaughter of the Jews. Rapoport, Shake Heaven and Earth, 112, citing Niebuhr, "Jews After the War," The Nation, 21 February 1942, 214. Ben Halpern spoke on the Bergson Group to the leaders of the Pioneer Women's Organization in 1947. His lecture was transcribed, annotated and published with an introduction by Mark A. Raider in American Jewish History (see note 12), "Irresponsible, Undisciplined Opposition: Ben Halpern on the Bergson Group and Jewish Terrorism in Pre-State Palestine," 313-360.

${ }^{59}$ Hansen, Midwest Portraits, 353. Hansen is quoting a note Hecht sent to Bodenheim.

${ }^{60}$ Novick, Holocaust, 12.

${ }^{61}$ Troy, From Literary Gadfly, 109, citing “A Declaration of Faith” in the Palestine Statehood Committee Papers archive.

${ }^{62}$ Hecht, Child of the Century, 573. 
PART I: THE DEVIL'S BARGAIN 
On May 24, 1948, in the midst of the Arab-Israeli war, Ben Hecht arrived for an Irgun fundraiser at Slapsy Maxie's, the popular Hollywood nightspot, to find the gala attended by some of the most powerful mobsters in the country and hundreds of their underworld associates. Mickey Cohen, who had recently ascended as king of the West Coast rackets, had taken care of the invitations. Hecht was delighted to address "a thousand bookies, ex-prize fighters, gamblers, jockeys, touts and all sorts of lawless and semi-lawless characters; and their womenfolk." He was sure the audience would be receptive to his message. ${ }^{1}$

He spoke about the 1943 Warsaw Ghetto Uprising, when thirty thousand Jews with "pike poles, old guns and bombs made out tin cans" withstood the full might of the Nazi war machine. They held out for twenty days, praying for supplies from the Allies, but no help ever came. Now that the war was over, the survivors of that European slaughter were once again fighting alone, this time in Palestine, in their "desperate hour of rebirth." Would the Jews of America continue to keep their backs turned, or finally reach out and help? ${ }^{2}$

When Hecht finished, Cohen dealt him a stinging blow to the arm. "Make another speech and hit 'em again," Cohen said. Still weak from a recent gall bladder operation, Hecht begged off, so his host pushed Mike Howard, "manager and bodyguard," on to the stage. Hecht later recounted:

"You tell 'em," Mickey ordered grimly. "Tell 'em they're a lot o' cheap crumbs and they gotta give double." Mickey pointed to me and his eyes filmed. "You heard what he said. It's for Jews ready to knock hell out of all the bums in the world who don't like them. Go on-tell 'em."

Mr. Howard roared inarticulately into the microphone. When he had done, Mickey came to the edge of the stage and stood in the 
floodlights. He said nothing. Man by man, the "underworld" stood up and doubled the ante for the Irgun. ${ }^{3}$

Hecht and Cohen had formed a partnership to raise money and smuggle arms and materiel to Palestine during the months when the Irgun's guerilla war against the British ended and the Arab-Israeli War began. This rather public alliance between the two men, who would remain friends thereafter, only seemed to affirm what Hecht had been branded for years: a crass Hollywood mouthpiece for gangsters and terrorists. By late 1947 Hecht had garnered worldwide infamy, and his friendship with the flamboyant L.A. gangster, a Bugsy Siegel protégé-cum-successor whom the FBI had directly linked to seven murders, signaled his embrace of that reputation. ${ }^{4}$

That May, Hecht had shifted decisively from entreating propagandist to enfant terrible with his toast to the killing of British troops in his "Letter to the Terrorists of Palestine" newspaper ad. One Zionist group responded: “There are new playboys in America today. They play with Jewish blood. The thrills of Hollywood are no longer sharp enough." The British press called Hecht a "penthouse warrior," a "remote-control terrorist," "a Nazi at heart," and "a vitriolic Zionist volcano with a touch of the carnival huckster.” Decades later, even Louis Rapoport, the admiring chronicler of the HechtBergson campaign, would criticize Hecht's “tasteless romanticizing of violence." Mike Wallace was among those who concluded, "the act of battle was more important to Ben than the depth of his conviction."5

There were others who felt that such conclusions hardly did justice to Hecht and the cause that he served. The Bergsonites believed Hecht merely became carried away with "bad propaganda" that alienated people and created misunderstandings. ${ }^{6}$ But how else can Hecht's vitriol be understood if not as a callous celebration of violence by a man 
far removed from the battlefield? What was Hecht's coziness with the sociopathic Mickey Cohen if not irresponsible naiveté, and what, in turn, did that say about his judgment in general?

"I don't feel called upon to take this man seriously," remarked Rabbi Stephen Wise, the preeminent elder of American Zionism, in response to Hecht's "letter." Yet ever since late 1942 when, at the behest of the State Department, Wise had sat for months on the news of the Nazis' Final Solution, he himself had been pilloried as hopelessly out of touch and feckless, a liability to his people. To a growing number of American Jews, Hecht's militancy was attuned to realities that respectable humanists like Wise were unable or unwilling to acknowledge. In Child of the Century, Hecht recalls convincing Cohen that the gangster's money and support were needed because America's wealthy Jews wanted nothing to do with the fighting in Palestine; they were "knockin' their own proposition," as Cohen had put it. ${ }^{7}$

And perhaps Hecht was right to imply that his views on the violent world of 1948 resonated with the crowd at Slapsy Maxie's because his convictions were rooted in a coming-of-age on America's streets - as a young crime reporter in Chicago. This story of a young man, "for whom journalism is an initiation into life," reveals the roots that his postwar militant Zionism had in the American experience of the early twentieth century. ${ }^{8}$ But it is also a record of the tough conditions, fierce rivalries and mercenary attitudes that held sway during a formative period for American journalism and mass media, which in large measure shaped the character of our current news industry and mass culture.

"I was a type, it now appears, of some historical significance," Hecht would later write in his 1963 memoir, Gaily Gaily. ${ }^{9}$ Joining the staff of the Journal at the 
impressionable age of sixteen, he had first emulated and then personalized the creed of Chicago newspapermen, a set of beliefs and agreed-upon meanings identifiable as what sociologist Max Weber termed a "style." When Hecht became a foreign correspondent assigned to Germany in the aftermath of World War I, his Chicago sensibility shaped his views of geopolitics and war. Nevertheless, his grim year away changed him, and by the time he returned during the early days of Prohibition and the rise of Al Capone, he had grown circumspect and ambivalent about his old milieu. Over the next decade, he distilled his views of the press and of gangsters in works that made him rich and famous: The Front Page (1928), Underworld (1927) and Scarface (1932.)

Just as Hildy Johnson, Faustian protagonist of The Front Page, is bound to his Mephistophelean editor Walter Burns, the idea of a “devil's bargain" explains Hecht's own proclivities, from his antics as a young reporter to his activism in the 1940s. "Born perversely," Hecht once wrote of himself: a classic, Faustian Romantic, he was drawn to the dark, the forbidden, the dangerous, or the just plain wrong, and he found kinship with rebels and renegades. ${ }^{10}$

The temptation of the Mephistophelean bargain, the proposition that rules are made to be broken, explains not only Hecht's romanticist style of journalism and his fascination with criminals and gangsters, but also his later attraction (as a journalist) to propaganda and political activism, and to an ostracized, outnumbered faction of fighters in Palestine who were willing to resort to ruthless measures in a war for survival. From the start, he had admired his fellow reporters as a tribe of outlaws, a view encouraged by the newspaper industry's adoption in the 1920s of professional standards that marginalized the Chicago brand of journalism. ${ }^{11}$ But, as would later be the case with the 
Irgun and "gangsterism," there was far more to the link between the city's press and outlaws than mere metaphor.

There is a telling scene in The Front Page in which reporters greet a gangster named Diamond Louie. Waving off their unctuous inquiries about plans to knock off a rival, Louie explains he is now retired. "Yeah. That's right. I'm a newspaperman... working for Walter Burns,' he says. 'I'm assistant circulation manager for de nort' side..."12

By the 1930s, various memoirs and press histories related that Chicago's Prohibition-era gangsters had received their training on the payroll of the city's newspapers - as gunmen in bloody circulation wars - before graduating to organized crime with the passage of the Volstead Act. ${ }^{13}$ But perhaps because the epic contest in New York between media titans William Randolph Hearst and Joseph Pulitzer now looms so large in American memory, it has overshadowed the dark chapter in journalism that followed, when Hearst shifted his sights to Chicago.

Determined to gain an edge on the local competition with the launch of the American in 1900, Hearst hired Max Annenberg, a Jewish immigrant from East Prussia and Chicago West-Sider, to organize crews of "sluggers" for strong-arming newsboys into ditching stacks of rival newspapers. The Tribune and Daily News soon rose to the challenge, and what started with knives and brickbat brawls between gangs of neighborhood toughs evolved into shooting sprees that claimed the lives of newsboys and residents alike.

It became a three-way war, as the top dailies fought each other and all sides attacked organized labor. Between 1910, the year Hecht first joined the Journal, and 
1913, twenty-seven newsdealers were killed, according to one oft-cited estimate. ${ }^{14}$ After that, the killings, beatings and abductions continued until bootlegging offered gangs more handsome rewards for this work. And when the gangs did come of age as efficient, corporate enterprises, it was alumni of Chicago's newsrooms, Hecht being one of several, who helped gangsters achieve national celebrity through a raft of best-selling books, Broadway hits and, ultimately, the gangster movie craze.

Despite the carnage of the press' "reign of terror," as one early chronicler called it, police and the newspapers - except for the Chicago Daily Socialist and the Daily World-looked the other way. ${ }^{15}$ But perhaps because the papers were distracted by the fury of competition, this was hardly the only major story they missed. Here was a city crying out for reform. "Chicago is the place to make you appreciate at every turn the absolute opportunity that chaos affords," John Dewey wrote his wife. "Every conceivable thing solicits you; the town seems filled with problems holding out their hands and asking somebody to please solve them-or else dump them in the Lake."16

During the same period when Max Annenberg and his brother Moe first signed on with the American's circulation department, the city's ten dailies ignored fire code violations in the graft-ridden First Ward that routinely had lethal consequences. ${ }^{17}$ Finally, on December 30, 1903, a blaze at the Iroquois Theatre claimed some six hundred lives, mostly children. ${ }^{18}$ Over the next three years, it would take a series of exposés in The Lancet, a British journal, to break arguably the biggest story in the city's history: the disgusting and dangerous conditions of the stockyards, which became the focus of Upton Sinclair's 1906 novel The Jungle. On that news, too, the papers were nowhere to be found. $^{19}$ 
Chicago's newspapermen reflected the character of the city itself. For a reporter who spent days and nights dashing between crime scenes, trolley car and machinery accidents, and the city morgue, Chicago in the throes of its industrial boom was a raw and brutal place. Hecht biographer Doug Fetherling puts it well: "Chicago seemed a prairie Gomorrah where homicide was the logical solution to arguments and chicanery a natural force in the administration of justice. Streets were torn down and new ones erected, gang bosses were murdered to be supplanted by their killers, a dozen railways brought an influx of immigrants never matched by the number of people heading out. ... (Hecht's) rhythms were those of the train wheels, factory whistles, gunfire and later the jazz music of a city which was, just then, exactly what (Carl) Sandburg said it was: hogbutcher, freight-handler, builder of railroads." 20

Or as Hecht would recall, "Trains were wrecked, hotels burned down, factories blew up. A man killed his wife in their Sedgwick Avenue flat, cut off her head and made a tobacco jar of its skull ... The headlines of murder, rape and swindle were ribbons around a Maypole. The Elevated squealed Hosannahs in the sooty air. The city turned like a wheel."21

Journalism historians have offered three different explanations for the frame of mind of the Chicago reporter. While none fully explains the man Hecht would become as an activist and propagandist, each sheds light on the kind of journalist he was when he was young. Most famously, Larzer Ziff wrote that reporters relied on "the twin defenses of cynicism and sentimentality," to perform their jobs within the suffocating conventions of the Victorian-era newspaper industry. "The first kept him from allowing his 
sentimentality to make him vulnerable; the second kept him from allowing his cynicism to cut him off from the human interest that was his stock in trade."22

Norman Howard Sims adds that the Chicagoans shaped an identity as modern urban reporter that retained "a touch of the backwoods journalist, sketch-hoax writer, and the literary artisan" of the $19^{\text {th }}$ century. They adhered to a storytelling tradition of news at a time when there was, by contrast, an increasing emphasis on facts, accuracy and information that became understood as journalistic objectivity. Two diametrically opposed approaches to news, identified by Michael Schudson as the story model and information model, were emerging as the major schools of journalism of the early twentieth century. "By Ben Hecht's era in the 1920s, the opposing scientific-factual style had triumphed," wrote Sims, "making Hecht an outcast and an eccentric."23

Adding yet another take on the Chicago reporter, Matthew Ehrlich argues in Journalism in the Movies that The Front Page is the first to deal with competing myths that have traditionally been at the center of Hollywood films: the official hero versus the outlaw hero. The renegade journalist of The Front Page is an outlaw hero, "akin to the wanderers and loners of American popular culture. He (or she, but most often he) holds no particular hope for society's betterment. He views the world and especially the institutions of government as inherently corrupt. Resolutely independent, he shuns convention and obligation and scorns officially sanctioned truth and morality. In contrast, the 'Greek citizen' or 'official' journalist is a dedicated public servant."24

These perspectives offered by Ziff, Sims and Ehrlich are like pieces of a puzzle that, when fitted together, provide a more direct explanation for why Hecht the reporter would one day become a militant propagandist allied with "terrorists" and gangsters. 
Each illustrates that Hecht was a romanticist who grappled with the political and cultural developments of the twentieth century, who constructed a worldview that he conveyed in The Front Page and Scarface, arguably his first mature works. Hecht's peers appreciated that he upheld the Romantic tradition, but our everyday understanding of the "romantic" as a sentimental dreamer clouds the word's very different connotations as a term for a literary movement and philosophy. ${ }^{25}$

The Romantics of the late eighteenth and early nineteenth centuries were products of their times and yet were in rebellion against them. They sought salvation in sensuality, love, art and science - in all things available to a modern world in which God and king were dead. As prototypical modern souls, the Romantics were eager to break free from the remnants of social and moral constraints that had been imposed in the name of the Lord. But as rebels and malcontents, they felt the fruit was already rotting on the vine, with the vaunted Age of Reason giving way to an age of shabby pretensions, and uncertain of a way forward, they cast their gazes backwards, yearning for things lost on the road to progress. Any bid for transcendence in this godless, unheroic new era seemed bound to end badly, whether for a Dr. Faust or for a Dr. Frankenstein, both of whom strove to recover the past; every blind quest grew so desperate it turned grotesque, hurling the Romantic into chaos, despair, and madness. The Romantic started as a lover and dreamer, but his or her path often led to violent destruction: The Romantic protagonist tended to be one who was good ... and then turned bad.

Dictionaries of literary terms and encyclopedias explain that the Romantic Movement "rejected the earlier philosophy of the Enlightenment, which stressed that logic and reason were the best response humans had in the face of cruelty, stupidity, 
superstition, and barbarism." Instead, Romanticism "asserts the unique nature of the individual, the privileged status of imagination and fancy ... the rejection of civilized corruption, and a desire to return to natural primitivism and escape the spiritual destruction of urban life." Characteristics include: "a turning in upon the self and a heightened examination of human personality and its moods; ... a preoccupation with the genius, the hero, and the exceptional figure in general; ... an emphasis upon imagination as a gateway to transcendent experience and spiritual truth; ... and a predilection for the exotic, the remote, the mysterious, the weird, the occult, the monstrous, the diseased, and even the satanic." 26

Within the context of early twentieth century journalism, romanticists like Hecht were unenthusiastic about the information model for newspapers, which represented an ideal, rooted in the Enlightenment and enshrined by the Constitution, of a press that functioned to inform and engage the citizenry. The story model, on the other hand, suited them, because they regarded the government and public with equal disdain. "We were tattered Tories with no more social consciousness than the mooing calves in the Stock Yards," Hecht would recall. "With all the black deeds going on around us, frequently under our noses, we could not imagine a better world.,27

Contemptuous of a crooked city hall and the "law and order" it imposed, Hecht saw outlaws and street toughs as representative of the "natural primitivism": age-old characters who were honest in their own way, and relative innocents compared to the politicians. When the Great War intruded upon the parochial concerns of Chicago newspapermen, Hecht, like other romanticists of his generation, understood the unprecedented bloodshed of a modern, mechanized conflict as the universal failure of 
Enlightenment philosophies and the "civilization" they had spawned. Nazism and World War II would later represent an entirely predictable progression of this moral collapse.

Pessimistic that there was any point in exposing the breakdowns in the machinery of government or the root causes of society's ills, the romanticist literary artisans of the Chicago crime beat were far more interested in the psychology of the individual. Hecht was particularly fascinated by the criminal sociopath, the charming and sympathetic Dr. Jekyll-type who, with his gift for keeping those around him guessing, turned out to be the ideal antihero for the neo-Romantic tale. Drawing this motif of the doppelganger - the Romantic hero stalked by his sinister twin — evidently became a habit of mind for Hecht: Not only were there two sides to the journalist Hildy Johnston, the protagonist of The Front Page, and to the gangster Tony Camonte, protagonist of Scarface, but journalistJohnson is the precise inverse of gangster-Camonte.

Both are egoists who rise by way of a Mephistophelean pact, but while Hildy's "wickedness" is really his goodness- - his boyishness, free-spiritedness and rakish charm - the sociopathic Camonte is another story. "All of time he smile on top," his own mother must explain to her daughter, Cesca, "but what he thinks ... Oh, he's got lotsa tricks! ... He's a-no good!" Later in the film, she adds: "I tell you. I tell you lots of times. He hurt you. He hurt you. He hurt everybody.",28 


\section{THE "CHICAGO SCHOOL": FROM WHITECHAPEL AND THE CITY NEWS TO WALTER HOWEY AND THE HEARST PRESS}

Journalists! Peeking through keyholes! Running after fire engines like a lot of coach dogs! Waking people up in the middle of the night to ask them what they think of Mussolini. Stealing pictures off old ladies of their daughters that get raped in Oak Park. A lot of lousy, daffy buttinskis swilling around with holes in their pants, borrowing nickels from office boys! And for what? So a million hired girls and motormen's wives will know what's going on. ... I don't need anybody to tell me about newspapers. I've been a newspaperman for fifteen years. A cross between a bootlegger and a whore. And if you want to know something, you'll all end up on the copy desk_-gray-headed, humpbacked slobs, dodging garnishees when you're ninety. ${ }^{29}$

\section{Hildy Johnson in The Front Page}

The things we'll do for our papers! We lie, we cheat, we swindle and steal. We break into houses. We almost commit murder for a story. We're a bunch of lice. $^{30}$

Herald and Examiner reporter Sam

Blair, as quoted in Gall and Honey, by Edward Doherty

There is a rich body of lore about "the Front Page era" of Chicago newspapers, tales reworked over and again in the memoirs of the veterans. Originally swapped in downtown barrooms and greasy spoons, this jumble of yarns, spun by conspicuously unreliable narrators, offer tribute to mischief in the name of journalism. ${ }^{31}$ As sources of history, they are a tangle, but though the facts may vary from one account to another, the essential story they tell remains consistent.

By the time Hecht first contributed his own memoir in 1954, he was well practiced at the alchemy that transformed reporter's notes into hit novels and movies. Yet while Child of the Century has been criticized as one of "the less serious books (that) ... shamelessly fictionalize events," in fairness, there is a basis of truth to Hecht's newspaper tales. $^{32}$ Though they seem fantastic, they explain the traditions of Chicago journalism 
through a kind of narrative shorthand. The idea that newspapers paid young men to break into homes and steal photographs, for example, may seem hard to believe, but Theodore Dreiser cites it as a common practice in his memoir Newspaper Days. Vincent Starrett, who like Hecht, started his career this way, describes his own adventures in detail. ${ }^{33}$

Hecht's claim that his promotion to reporter afforded the opportunity for a shortlived, madcap career as a hoaxer recalls yet another dubious journalistic sport, one that Chicago reporters adopted and made peculiarly their own. The hoax had been a tradition of the nineteenth century: a rash of them had appeared with the advent of New York's penny press in the 1830 s, and by mid-century, variations of the "tall tale" were a popular staple of Western newspapers. Mark Twain and Edgar Allen Poe perfected hoaxing as an art, while in more modern times, Orson Welles would leave an indelible mark on mass media history with his War of the Worlds broadcast.

But the Chicago hoax went beyond being a mere genial prank: it became one more ploy in the reporter's bag of tricks, put to use in the bare-knuckle fight for scoops. In the 1890s, Finley Peter Dunne of The Herald and Charles Dillingham of the Times brought it into play against the Tribune's Frank Vanderlip, their competitor on the hotel beat. The hapless Vanderlip could not understand how his rivals kept grabbing exclusives with famous and exotic personages who stopped in town overnight and then vanished without a trace. Unable to keep pace, Vanderlip was fired for incompetence, without ever realizing that these extraordinary hotel guests had never come or did not exist. In Chicago, "the hoax took a twist," explains Sims. "It became invisible... an unrecognizable deceit."34 
Chicago newspapermen were delinquents and misfits, "part detectives, thieves and con-men who enjoyed prying into the lives and business of others, and a few had the touch of a poet," observed Klatt. Hecht's compatriots included an undertaker's assistant, an aspiring opera singer, a former strongman in the circus, a failed priest, an ex-fighter, a tramp and a crackpot mystic embittered by gonorrhea. "I became a journalist after I had failed at nearly everything else," wrote Starrett. ${ }^{35}$

Oddball quirks, rivalries and devious tactics were all part of what became the persona of the modern urban reporter. This identity, which had coalesced by the time Hecht joined the Journal in 1910, had its origins in two local institutions of the late nineteenth century, at a time when, as Schudson has observed, journalists were developing a self-awareness of their profession, and were "as eager to the mythologize (it) ... as the public was to read of their adventures." ${ }^{, 36}$

One of the two was Chicago's wire service, the City News Bureau, which functioned as a journalism school before actual schools were established. The other was a fraternity of literary-minded police reporters called the Whitechapel Club, which took its name from the London slum where Jack the Ripper had committed his murders. Hecht evoked both institutions, and their legacies, in his memoirs. As Sims noted, Hecht "told wonderful stories about his life as a reporter. Unbelievable stories, as a matter of fact, but their authenticity is not the point. Rather, the image Hecht sought to portray, how he remembered himself as a reporter in the past, is the issue. Although the Whitechapel Club was long gone in physical fact, its spirit survived in Hecht."37

Home to boisterous rebels and a morbid, bizarre brand of bohemianism, the Whitechapel Club originally convened in the backroom of Kloster's saloon, established 
in the summer of 1889 by journalists who found the Press Club of Chicago too stodgy and expensive. It was a place of refuge at the end of a shift, sometimes late in the night, an alternative to the seamy downtown taverns, where reporters could discuss their jobs, social issues, and their shared literary ambitions. It served as a forum, wrote Alfred Lawrence Lorenz, "in which they could define themselves as journalists by agreeing on what journalists were, how they should approach their work, and on a set of professional values - in short, what it meant to be a journalist." Although the Whitechapel Club existed for only five years, it became legend, influencing generations of journalists to follow. ${ }^{38}$

Most legendary was the club's decor. A thick oak door with ornate wrought-iron scrollwork opened to a room dominated by a horseshoe-shaped bar. Each place was set with a churchwarden's pipe and a tobacco-filled bowl that had once been the brainpan of a skull. The sawed-off lower portion of these skulls served as shades for the club's gas lighting fixtures. Brightly colored glass globes implanted in the eyeholes cast weird, eerie hues. Dr. John C. Spray, a Whitechapel member and a superintendent of a hospital for the insane, had donated the skulls, which he had used in a study to discover cranial differences between the sane and the mentally ill. Adornments along the walls included a twelve-foot snakeskin, skeletons, blades, revolvers and bullets that had slain famous criminals. The pride of the club, though, was the smaller room upstairs, which was fitted with a coffin-shaped bar studded with large brass railheads imprinted with the number of each member. As Lorenz notes, "The decorations served as symbols of the often-dark world the members covered and the mocking posture they assumed toward it.",39 
Within this setting, members played poker - though playing for money was strictly forbidden — shared their writing, and hosted guest speakers whom they subjected to unsparing heckling that they called "sharpshooting." This jousting sharpened the edge of their characteristic skepticism: trusting in facts and experience, the Whitechapelers were determined to expose the ugly realities that belied a Victorian faith in social "progress." They were rebels who remained clean-shaven to distance themselves from a bewhiskered older generation, who took aim at religion, tradition and morality. Columnist and playwright George Ade described them as "harum-scarum irresponsibles who scorned the conventions and shared an abiding enthusiasm for alcoholic liquors."

Nonetheless, they were intellectuals with ideas ahead of their time. They were not "in any sense reformers, or actuated by the smug and forbidding spirit which too often inspires that species," wrote Brand Whitlock. "They were, indeed, wisely otherwise, and they were, I think, wholly right minded in their attitude toward what are called public questions, and of these they had a deep and perspicacious understanding."40

The gallows humor reflected an important element of the Whitechapel style. "The police beat was, for most reporters of the 1890 s, an initiation into the realities of city life," noted Sims. "Not only did they have to deal with the killings, suicides and executions of the world of crime, reporters also had to live with the day-by-day pressure of journalistic competition." The humorist Opie Read recalled that fellow members sought to produce "photographic exposures of contemporary existence," whereas he himself wanted his journalism to be more like painting. Whitechapel became a wellspring of the naturalist school that emerged from journalism as a seminal movement in American literature. A hard-bitten, unique literary society, the club contributed to an 
enduring myth of "men who insisted on talking to one another about the hypocrisy of the social system even while they were being paid to explain it away,” noted Ziff, “...who read everything they could get their hands on and fanned one another's literary aspirations as they sat about in the city room on a rainy night." ${ }^{, 41}$

This spirit of Whitechapel did survive in Hecht-he shared their macabre sensibility, and emulated their unique literary bohemianism—-but there was a key difference between him and these predecessors. As naturalists, newspaper novelists of the 1890s focused on details deemed worthwhile because they were unprintable in the daily press, but they sometimes failed to invoke the deeper issues at hand. As Ziff points out, most "were unable to lose (their superficiality) when they turned to fiction or sociology. And having survived the twin perils of cynicism and sentimentalism, they were sunk on the reef of realism as its own excuse for being. ${ }^{, 42}$ Hecht, on the other hand, saw realism as a style, albeit one with thematic implications. He proved a productive and popular storyteller largely because he was so adept at weaving Romantic themes and plot variations, which he often cloaked within the trappings of gritty, naturalistic settings.

The City News Bureau helped to forge another integral element of the Chicago style: the tradition of the scoop, which as Martin Mayer explained in Making News, "has been cultivated more jealously and single-mindedly in Chicago than anywhere else." A venerable local institution for more than a century, the City News established itself in the 1890s as a training ground for cub reporters, known for "its iron discipline, its hard-nosed insistence on accuracy and, most of all, its legendary tightfistedness. ${ }^{.43}$ In the days before journalism schools, the bureau instilled a code in its graduates and thus by osmosis, in the whole Chicago press. It was a code shaped by the dictates of free market competition 
rather than by a sense of civic mission. Speed and accuracy meant survival in a crowded newspaper field. Yet ironically, the same bottom line that compelled a swarm of young men to get their facts straight also honed their talents for deception and misdirection in the contest for scoops, creating the cutthroat culture portrayed in The Front Page.

The City News developed a rather schizophrenic attitude towards the truth. A news service could ill afford mistakes or fabrications, which had potential to damage the reputations of client newspapers, or worse, open the door to libel suits. Accuracy thus became the watchword that bureau editors branded on the minds of their young charges. At the same time, how reporters got their news was another matter entirely; the papers counted on the City News to be on top of every breaking story. The bureau stretched its budget to the limit to underwrite twenty-four hour vigils, streetcar fare, "leg men" and, most famously, a pneumatic tube system put into use in 1893, which shot dispatches to newsrooms at thirty to seventy miles an hour through an underground labyrinth of pipes. Every reporter knew that the proven ability to produce scoops would be his ticket to his first newspaper job, an end to the grueling hours and pauper's wages of the City News. ${ }^{44}$ "'Get the news! Get the news!'- that was the great cry in the city editorial room," recalled Theodore Dreiser, who was struck by the "pagan or unmoral character" of newspaper work. 'Don't worry much over how you get it, but get it, and don't come back without it! Don't fall down! Don't let other newspapers skin us-that is, if you value your job! ... While a city editor might readily forgive any form of trickery he would never forgive failure. Cheat and win and you were all right; be honest and lose and you were fired. To appear wise when you were ignorant, dull when you were not, disinterested when you were interested, brutal or severe when you might be just the 
reverse - these were the essential tricks of the trade. ... And I ... soon encountered other newspaper men who were as shrewd and wily as ferrets, who had apparently but one motive in life: to trim their fellow newspaper men in the matter of news, or the public which provided the news." 45

Tales of scooping are legion. Reporters were known to toss false tips that sent the competition on wild goose chases. Collier's celebrated Harry Romanoff of the Herald \& Examiner as Chicago's greatest telephone reporter because of his talent at impersonations. Once calling a barroom where a murder had occurred, Romanoff identified himself as Sgt. Donohue of the coroner's office. "That's funny," said the voice on the other end. "So is this." Stepping things up a notch, City News alum and Her-Ex editor Frank Carson staged a collision of two circulation trucks in front a police station, a diversion that enabled his operatives to steal the diary of the alluring murderess Ruth Randall out of the evidence room. ${ }^{46}$

Courtroom scoops involved feats of ingenuity and acrobatics. According to one account, City News staffer George Wright enlisted the aid of a courthouse janitor to bring a 20-foot plank into the ceiling crawlspace above the Loeb-Leopold grand jury proceedings. Wright then drilled a hole and used a stethoscope to listen in, confounding investigators for days while he continued his coverage. When the jury convened in the famous 1897 case of human remains found in a vat at a sausage factory, Fred A. Smith lowered himself into a courthouse air duct by rope. Hecht's friend Wallace Smith of the American hung upside down from the eaves of the courthouse roof, fifty feet above the ground, to peer through the windows of the jury room. ${ }^{47}$ 
Sometimes reporters planted evidence. "If it occurred to us that a janitor's missing mother-in-law might have been lured into the janitor's furnace, and the clues did not fit that attractive hypothesis," wrote Starrett, "we helped the story to headlines by discovering incinerated bones that somehow the police had missed." ${ }^{48}$

Journalism historians have generally contended that by the 1890 s, all the elements of "objectivity" had come together. Over the next century, it would become the ideal, or what one media critic in 1996 denounced as "the false god" of the profession. A key element is supposed to be detachment: a textbook from 1911 instructs reporters to "keep yourself out of the story," while one from 2012 explains that journalists "are neutral observers, not advocates or participants. ${ }^{, 49}$ Such admonishments must have struck Front Page era newspapermen as a joke, if not as a complete surprise. When Chicago crime reporters were not breaking into places or pulling a con, they were busy deputizing themselves with the local law enforcement.

"Murder mysteries fascinated readers, and the reporters, not the police, would solve them," wrote John J. McPhaul in Deadlines and Monkeyshines: The Fabled World of Chicago Journalism. Hearst veteran George Murray argued that the phenomenon of reporter-as-super-sleuth should not be surprising, since newspapers had far more money and resources for certain investigations than police departments did. Among the most famous newspaper gumshoes was Buddy McHugh, portrayed in The Front Page as "Buddy McCue." When police hit a dead end interrogating a slow-witted suspect about the fatal beating of a widow, it was McHugh who broke the impasse, asking simply, "Did she scream when you hit her, Eddie?" To elicit the confession of child killer Thomas 
Richard Fitzgerald, Romanoff presented Fitzgerald with a newly purchased doll that he claimed belonged to the victim. ${ }^{50}$

In the 1890s, the sheriff's department swore in reporters as deputies and allowed them to make their own news by raiding the gambling dens of Michael McDonald, a Democratic Party boss and the publisher of the Chicago Globe. Papers supplied badges that reporters would flash to pass themselves off as detectives or assistant coroners. By the mid-1920s, the police provided press cards inscribed with a note from the chief of police, instructing that journalists be extended all courtesies. But Carson, who was always ready to push things further, invented "muscle journalism," manufacturing phony badges, warrants and other documents, and installing wiretaps. On one occasion, he recruited a bruiser from the Circulation Department to pose as a detective in order to “arrest” a killer in Adams, Wisconsin. ${ }^{51}$

If the City News was the trade school where journalists learned such arts of manipulation, it was Carson's mentor and boss, Walter Howey, who reigned as master. Managing editor for the Herald \& Examiner, Howey would become immortalized as the Machiavellian genius Walter Burns, the Mephistopheles of The Front Page. Time would describe him as "a profane romanticist, ruthless but not cruel, unscrupulous but endowed with a private code of ethics. He was the sort of newsman who managed to have Hell break loose under his feet, expected similar miracles from his underlings, rewarded them generously." When a staffer named Edward Doherty produced one "sob story" too many, Howey advised, “This isn't that kind of story, Eddie, it's straight news. And don't try to break my heart. It isn't that kind of heart.",52 
Howey's career became the grist for much of the lore about the Front Page era. A man whose mild-mannered appearance belied his ferocity as competitor and power broker, he lost an eye when, according to Hecht, he had passed out one evening while drunk at his desk and planted his face down on a spindle. Howey himself boasted that he lost it in the circulation wars. More plausibly, the injury occurred when some chemicals had exploded during one of his experiments to invent the news-related devices for which he secured several patents, including one for Soundphoto, a system for transmitting images through the phone lines. ${ }^{53}$

Many of the tales about Howey concerned his feats as a journalistic prodigy, but Howey soon found that his investigative talents were far more useful to newspapers for the purposes of extortion than for journalism. This realization came at the start of his career as editor, when his boss at the Inter-Ocean, George Hinman, had him dig up dirt on power company magnate Samuel Insull and Mayor Fred Busse, who opposed the paper's ownership of an electric light plant. What followed, Time later reported, was two months of "burglary, bribery and tireless sleuthing." 54

By the time Howey assumed the helm of the Herald \& Examiner, he had amassed an extensive collection of files. The paper's sole support of mayoral candidate William Hale Thompson proved another winning card. Charlie MacArthur, Hecht's co-writer of The Front Page and a former reporter under Howey for Her-Ex, claimed the police were always at the beck and call of the paper to prevent rival newspapers from taking photographs at crime scenes or bring perpetrators for "interrogation" at a hotel nearby Hearst headquarters. "The other papers howled with rage, but what could they do?" said 
MacArthur, when interviewed for Howey's obituary. "Walter had the resignations of half a dozen city officials in his desk to be used at his convenience."

Murray explained his editor's view of the staff's investigations: "Howey knew that such exposés would do no good, as far as reform is concerned. He was under no illusions about the intelligence of the ordinary citizen, or his capacity to remember from one day to the next which politicians are gypping him and how they are going about it.... Howey did not operate his paper by any code of ethics dreamed up at journalism school in an ivory tower full of idealistic professors. He ran it on the same basis as other businesses in the community operated." ${ }^{, 56}$

While the character of the Chicago news business had taken shape by the 1890s, the arrival of Hearst in 1900 - a first step in his national strategy to become presidenttook things to a new level. That June, Hearst challenged business manager Solomon Carvalho to establish a Chicago paper in time for the Democratic National Convention in Kansas City, just thirty days away.

"It's a tough town," Carvalho had admonished. "We'll have to shoot our way in." “Take all the ammunition you need," Hearst replied. ${ }^{57}$

His executives and their rivals would soon take those words literally. Carvalho first deployed the same tactics that had worked so well in New York: He dropped calling cards on all the best editors and writers in the city and lured them in with salary hikes. He also offered the American for one penny, while the Tribune and the Daily News sold for three. The paper retained a network of tipsters that covered the train stations, hotels, hospitals and police precincts across the city. When lurid layout, shocking headlines, scoops and sensationalized copy were deemed insufficient, editors 
exhorted leg men and rewrite men to concoct fiction. If a rival paper offered a better piece of fantasy — as in the case of one account that featured firemen saving lives by forming a human ladder - the reporter was shown the door. The American burned through twenty-seven city editors in its first thirty-seven months. One reason for such furious turnover was that Hearst was using Chicago as a testing ground for talent, and would send the best editors on elsewhere. ${ }^{58}$

These efforts represented a good start, but in a city that already had nine daily newspapers, more was needed. The rough handling of newsboys was nothing new; brawls had been a common feature, for example, of the Hearst-Pulitzer contest in New York. Carvalho, however, counted on the shrewd and dangerous Max Annenberg as circulation manager to win his war. Attired in his signature flaming red sweater with soft cap pulled down over his brow, Annenberg organized crews of goons, many of them broken-down prize fighters, to secure the loyalty of news vendors district by district using all necessary means of persuasion. In 1902, he was joined by his more sophisticated brother Moses, who would go on to pursue a lifelong career in newspaper publishing and rackets, the latter with his racetrack wire, the Nationwide News Service. ${ }^{59}$

Though the Daily News and the Tribune did not capitulate, the violence rarely became lethal until 1910, when the Tribune poured a million dollars into a circulation drive, dropped its price to a penny and, taking a page from Hearst's playbook, poached the Annenberg brothers. They also armed their crews with revolvers. Hearst's lead executive Andrew Lawrence matched the stakes, and soon gunmen were stalking each other in black circulation trucks, pouring out for firefights in the streets. The Inter-Ocean published an editorial demanding indictments, but otherwise news of the bloodshed was 
suppressed, or falsified as labor troubles, by all papers except the Daily Socialist and the unionized Daily World. ${ }^{60}$

The hostilities peaked in 1912. In May, the Daily Socialist reported the beating and kidnapping of a newsdriver. In June, thugs shot a street conductor and then fired wildly through the crowded trolley. In July, an assailant blasted into the roof of a streetcar when he found passengers were not reading the American. Two weeks later, a gang riddled the Wellington Avenue elevated station to intimidate a newsdealer. Circulation crews were spotted wearing special police stars. Attempts to indict Max Annenberg and others ended in acquittal. "Bloody newspapers and bodies were a gruesome but not uncommon sight in the Chicago River," observed crime historian Rose Keefe. $^{61}$

The war began to sputter out by 1913, but incidents of violence continued for years as the circulation departments graduated some of the city's most notorious killers, including the infamous Gentelman brothers, labor racketeer Maurice "Mossy" Enright, another of Prohibition's “dean of Chicago gunmen” Walter Stevens, "Big Tim” Murphy, Frank McErlane, who was described by the Illinois Crime Survey as "the most brutal gunman to ever pull a trigger in Chicago," and James Ragen, who together with another slugger, Mickey McBride, would run childhood friend Moses Annenberg's Nationwide News Service in the 1930 s. ${ }^{62}$

Most prominent among the alumni was Dean 'Deannie" O'Banion, a reigning bootlegger and friend of Hecht and MacArthur who worked for Hearst until at least 1920. In 1925, O’Banion was killed in his flower shop by the Johnny Torrio-Al Capone mob, an event that Hecht depicted in both Underworld and Scarface. "After their honorable 
discharge from the newspaper wars, all these gunmen and their many pupils opened shop on their own account, having acquired valuable lessons in typical corporation methods," wrote Ferdinand Lundberg in Imperial Hearst, his scathing 1936 biography. ${ }^{63}$

Though the circulation war was over, the Front Page era was still in full steam by the onset of the 1920s, a decade that would deliver an unprecedented drumbeat of carnage and bloody spectacle. In 1918, Hearst merged his morning Herald with the newly acquired Examiner and put Howey in charge, to create the paper that would earn a reputation as the most aggressive of the interwar period. "Nobody moved even to the water cooler except at a dead run," reporter Bob Casey said about the Hearst building, which became known as the Madhouse on Madison Street. "The city editor yelled at his copy readers, the copy readers yelled at the copy boys, and the copy boys yelled at each other. Each story, from a triple murder to a purse snatching in the ghetto, was a big story and greeted with quivering excitement by everyone who had anything to do with it." Columnist Arthur James Pegler observed, "A Hearst paper is like a screaming woman running down the street with her throat cut." ${ }^{, 64}$

Discussions about the Front Page era continued for decades afterwards, but writing in 1970s, Sims argued the debate had gone askew by focusing on the antics: "picture stealing, impersonation of police officers, side-door con artist tricks, the use of literary devices. These discussions are supposedly about the 'ethics' of reporters. But the important questions are about sensibilities. A reporter's outlook on the world, his sensibilities, the way he interprets and creates the world in his reports, the form his reports take - those are the revealing questions. Ethics is subsumed within responsibility., 


\section{SHADES OF BLACK: THE STAGES OF HECHT'S CYNICISM}

Some of us guys have more brains on our shoes than we have under our hats.

City News Bureau reporter Willis O'Rourke at the scene of the St. Valentine's Day Massacre ${ }^{66}$

An iconic label for the generation that came of age in the 1920s was a phrase from a passing remark that was caught by the American expatriate writer Gertrude Stein. She had heard the patron of a garage, angered by a failure to repair her car, lash out at his mechanic, complaining that the employee's whole generation was a useless crop that had been "lost" to the war. "That's what you all are," Stein later snapped at Ernest Hemingway as she recounted the incident. "All of you young people who served in the war. You are a lost generation. ${ }^{, 67}$ It was Hemingway who had read something deeper into what was otherwise just middle-aged griping: The tumult and trauma of the new century had not only buried many sentimental notions of the old world, it had left its progeny shattered, dazed and haunted. Hemingway popularized Stein's phrase by using it as the epigraph of The Sun Also Rises, a novel that captured his own shellshocked malaise, as did his other early works, including A Farewell to Arms and In Our Time. But though Hemingway and his cohort of expatriate artists would be the ones best remembered for the phrase, it applies just as well to the generation as a whole, and especially to Hecht, MacArthur and their fellow crime reporters in Chicago.

Both Hecht and MacArthur would see the carnage in Europe first-hand, but in the years leading up to the conflict, even those who were to remain at home got a strong taste of what the war would bring. Hecht recalls reporter Larry Malm, who never took off an overcoat and muffler even on hot summer days. During coverage of the Iroquois Theatre 
fire, he had found himself buried in charred corpses, and thereafter could never escape the chill in his bones. Starrett wrote that the first time he was dispatched to steal a photo from a crime scene, he crawled through a window and found himself ankle-deep in blood, alongside the body of decapitated woman. In St. Louis, Dreiser had rushed to a road pileup where a truck had poured boiling oil over a crowd of people. Gruesome episodes such as these fill the memoirs and anecdotal histories of the Chicago press; Hecht offers a long litany of them in Child, which reads like a newspaperman's version of Bob Dylan's “A Hard Rain's A-Gonna Fall," written for the pre-atomic age. ${ }^{68}$

Like Hemingway, these reporters maintained the stoicism that was then expected of gentlemen. MacArthur served not only in the Great War but in the preceding hunt for Pancho Villa in Mexico and World War II—an ulcer kept him out of Korea—and despite his best efforts to pretend otherwise, he carried the scars. In his 1957 biography Charlie, Hecht wrote that during a heavy shelling of the trenches, MacArthur dove for cover to land head first in an enemy latrine. "Smothered by enemy crap, with shells blasting all around, I got an optimistic feeling," Hecht's friend had recounted. "I said to myself 'MacArthur, this is the lowest point of your life. From here on everything has to be an improvement. ${ }^{, 69}$

Such jokes, however, could never fully hide the pain. "This teller of the exuberant anecdote who could talk the night away left behind chiefly a memory of reticence," Hecht explained. "None of the thousand friends, including the women who loved himexcept one — knew him deeply. Of our forty years of friendship I can remember hundreds of things he did, but nothing he felt. He never told me.,70 
When Hecht traveled to Germany in December 1918 as foreign correspondent for the Chicago Daily News, he bore witness to the devastation and bloody aftermath of the war. His memoirs trace his own path to disillusionment, from the feigned worldweariness that he first adopted as a young reporter back in America to the horror and disgust that would later mark his soul. In stories first published in Playboy that were then compiled, with other material, in Gaily Gaily, "Hecht projects himself as a wide-eyed, impressionable youth for whom journalism is an initiation to life, particularly the darker underside of abnormal and, in many cases, criminal behavior," noted Robert Schmuhl. Looking back at the things he saw during his year in Germany, Hecht wrote, "They remind me of the darkest fact I have learned in my life - that the decency and sanity of the human race is a small mask.",71

Hecht's journey from youth to maturity, an emotional development that started in Chicago and continued into Europe, established motifs that would repeat themselves in his life as well as his work. Altogether, they told of an initial stage of gay, posturing cynicism that was broken by the realization that the corruption and darkness he had seen all around him had infected the people he most trusted — his fellow journalists — and perhaps even himself. What followed had been the more searing disillusionment that had come for his whole generation with the war. In the aftermath, he was left to struggle with the question of whether, in the face of the kind of cruelty and injustice he had witnessed in Germany, one could in good conscience remain a journalist-bystander or whether he had an obligation to intervene; it was a dilemma that hinged not so much on journalistic ethics as on Hecht's view of politics as inherently demeaning and soul-destroying. His friend and mentor H.L. Mencken had been the one to advise him that the "leader of every 
cause was a scoundrel." As the years passed, however, he grew uncomfortable with such tidy, implacable cynicism. ${ }^{72}$

When he started as a crime reporter, his own youthful sense of invulnerability insulated him against the death and violence that he saw on a daily basis. He was present at some seventeen hangings, but as with the rest of his coverage he was there as spectator. Not yet ready to process the tragedy of such events emotionally, he focused on their absurdities and ironies. A closeted homosexual condemned for killing his wife agreed to confess only if he could be supplied a woman's vanity case. The man walked to the scaffold painted in rouge and lipstick, and in his death rattle, the long, final note that rang from the depths of his throat was his true voice - a high-pitched feminine wail. Hecht's lead: "Fred Ludwig lived as a cowardly man but he died a brave woman." At another hanging, Hecht and MacArthur schemed to pump a syringe full of adrenaline into the condemned man just after his corpse was pulled from the rope. They believed that this would induce a resurrection, and thus give them a national exclusive on a marvel. ${ }^{73}$

Hecht and his compatriots knew nothing about public policy and weren't much interested, but that mattered little, because in the Chicago of 1910, ward politics were simply crime, and the papers covered them as such. "Election day emptied the Press Room," Hecht recalls in Gaily Gaily. "Even the cardplayers disappeared. All reporters, regardless of their wiliness, had to take their legs to cover the town's voting centers; not to see who got elected, but how many people were slugged, stabbed and shot during the hours in which free men voted." In these contests, the incumbent had the advantage of a war chest and a compliant police force, and even if he were somehow outmaneuvered 
during the voting, he could usually perpetrate some fraud when the ballots were counted. $^{74}$

The "finest political plum" was the First Ward, which had a split personality that made it the most lucrative and powerful territory of the city. Its southern portion was the Levee, a tenderloin of whorehouses, gambling dens, barrelhouses, burlesque theaters, peep shows, Turkish baths, voodoo doctors and dope dispensaries. Adjoining this to the north was the Loop, the downtown business district that was Chicago's commercial engine. For decades, the First Ward was the domain of two aldermen, "Bathhouse" John Coughlin and "Hinky Dink" Mike Kenna. ${ }^{75}$

Hecht remembers that a few days before each election, every derelict and degenerate of the ward would swarm to the Levee's fleabag hotels. Packed six to a room, these lucky delegates were treated to their fill of free booze, hop and prostitutes until it came time to cast ballots, when they would gratefully reel and stagger forth to vote multiple times in different precincts under different names. If the opposition challenged the results, officials would find the names in the guest registries of the flophouses. The day after the election, each voter was paid for his service, and provided a bonus based on the number of votes he cast. Such strategies were evidently so effective that the rule of Bathhouse and Hinky Dink endured for more than fifty years, from Coughlin's first election to council in 1892 until Kenna's death in $1946 .^{76}$

The most conspicuous symbol of turn-of-the-century Chicago's moral character was the aldermen's annual fundraiser, the First Ward Ball, also known as the Gangsters' Ball, which Hecht makes a centerpiece of Underworld. "The guest list included nearly every criminal in town with the price of a shave, and nearly every whore from 
Englewood to Evanston who had access to a ball gown," Hecht wrote. "Pickpockets, pimps, porch climbers, jack rollers, sluggers, heisters and gunmen I had seen before court judges were on display socially in the Coliseum; and the judges with them. The judges, police officials, bigwigs from the city hall and state capitol and every variety of the political genus were intermingled with the agents of crime and vice."

This public display of decadence and corruption, which foreshadowed Mickey Cohen's fundraiser at Slapsie Maxie's, became more brazen each year. Spectacles like the grand march, in which Coughlin and Kenna linked arms with madams to lead a parade around the center floor, increasingly drew public ire. After dynamite exploded just before the ball of 1908, and Coughlin's thugs assaulted a newspaper cartoonist and a photographer, the reformers mobilized and put an end to the party. ${ }^{78}$

In 1910 a vice commission appointed by Mayor Fred Busse issued a bombshell report, estimating that there were over one thousand brothels in the Levee, run by nearly two thousand pimps and madams and employing four thousand prostitutes. This generated a gross annual income of some $\$ 60$ million (equivalent to $\$ 1.2$ billion today), with $\$ 30$ million in profits. The difference between the gross and profits wasn't the result of salaries paid to bouncers, cooks, piano players and whores, but the sums paid for "protection," claimed first and foremost by the aldermen, and then distributed throughout the justice system, police, and city and state government. "The city's courts, police and politicians had been taking bribes for a generation by the time Al Capone began to buy the protection he needed to do business in Chicago and elsewhere," notes historian Michael Lesy in Murder City. "By 1929, the parasite that had once been the Levee had begun to consume the city that had once been its host.",79 
The Coughlin-Kenna system of graft harnessed hard power as well as wealth. Headquartered at Kenna's saloon, Workingman's Exchange, the aldermen oversaw “an army of city jobs," held veto power over all building, zoning and licensing in their district, and took sizable cuts of public contracts and traction franchises, exercising direct control over everything from the utility trusts and high finance of the Loop to the tamale stands and filthy cribs of the Levee. Hecht theorized that the "good-citizen majority" remained oblivious because they saw their rogue politicians as a harmless cast of colorful vaudevillians who brought entertainment to their constituents' dull lives. And though headlines may have howled in ostentatious outrage, the attitude of Hecht and other rank and file newspapermen was actually much the same as their readers. ${ }^{80}$

There was a common belief, shared by politicians, the public and the press alike, that stamping out vice was impossible and not good for business, and that instead it should be tightly relegated to certain districts so it did not wind up at respectable doorsteps. This view suited the romanticist journalist, to whom the stern-faced reformers seemed as guilty of Victorian hypocrisy as the grafters. As a youth, Hecht's own idea of "reform" was to try to make an honest woman out of one of the prostitutes who introduced him to the joys of sex, crusades that invariably ended in disappointment. ${ }^{81}$ As for the true radicals of society, Emma Goldman, Eugene Debs, Mother Jones, Bill Haywood and the like "were looked upon as windy bores, except when they spoke too well. Then they were either run out of town or clapped into jail. ... Oddly, we young ones who lived on crumbs were ready to defend the feast with our lives-which we were never called on to do. But we showed our metal (sic) in derision.... We who watched the 
show from our newspaper front seats stood pat against the would-be emancipators of the poor as if we were millionaires all.",82

Since the political sphere was good for some amusement, but actual reform was ultimately hopeless to the point of being tiresome, the truly serious subject of study for the crime reporter became the nature of the individual—namely, the criminal. "We were not ... only scorekeepers of the dead, injured and abused. We were psychologists," Hecht remembered. "We had a great interest in the psychology of everything that came close to us. We sat in saloons, analyzing our fellow humans as people now analyze prime ministers." 83

Just as he had tried to uplift prostitutes and once rented a room for ten weeks before realizing he was living in a brothel, young Hecht was often taken in by protestations of innocence and vows of repentance that came from death row. In Child, he recounts the case of brothers Ignace and Manow, caught for killing a farmer in a robbery. At the trial Ignace begs the judge to spare his brother. Hecht finds this makes a great story, but on the execution day, when Ignace sees the noose, a cry rises from his throat: “Hang Manow!” This comes as no surprise to Hecht's more seasoned colleagues. "You'll find that is the easiest thing people can do," remarks Sherman Duffy, Hecht's mentor at the Journal. "Change into swine.,"84

Such lessons in life may not have been cheery, but they could not overcome Hecht's youthful exuberance. Amidst all the wickedness, Hecht saw the journalist as just a traveler, like Orpheus in the underworld. "There was, I am sure, neither wordliness nor cunning enough among the lot of us to run a candy store," he wrote. "But we had a vantage point. We were not inside the routines of human greed or social pretenses.... 
There was a feast all around us. We attended it as scavengers. ... Politicians were crooks. The leaders of causes were scoundrels. Morality was a farce full of murders, rapes and love nests. Swindlers ran the world and the Devil sang everywhere. These discoveries filled me with great joy." ${ }^{, 85}$

There came a point right before the war, however, when Hecht discovered that his notion of the journalist's enduring innocence was just one more illusion of youth. And then his mood began to darken, and genuine cynicism set in.

"The Negress" chapter in Gaily Gaily is another of Hecht's apocryphal anecdotes, based in part upon the real-life execution of Grover Cleveland Redding in 1921, and as with those other narratives it both illustrates and explains the evolution of his beliefs. He tells of falling for Dido De Long, a beautiful black nightclub singer who has given her heart to the leader of a "Back-to-Africa" movement in Chicago. At the end of the story, Hecht sees Dido painted and trussed "like an erotic caricature of herself," offering herself to any official who might help obtain a pardon for her true love, "Prince Ephraim," who killed two policemen when a political rally turned violent, and now awaits execution. Hecht's entreaties to let him write of Dido's cause fall on deaf ears, since the aspirations of African-Americans were not considered newsworthy. ${ }^{86}$

Journal editor Eddie Mahoney laughs that this woman who had dreamt of becoming an African queen has uselessly slept her way through half the capitol. Hecht recalled: "I almost hated Mr. Mahoney. I had never before known anything wrong in the world of myself. Crime, murder, suicide, swindle, and perversion were my daily pickings. But they were outside my world, a storm that blew and rattled wildly beyond its snug windows. Now the storm was inside the windows, the wrong was around me. I had 
discovered the fact that injustice existed, and that everybody I knew was somehow part of it." If Hecht had struck a devil's bargain the moment that he had first become a journalist, it was not until now that he had realized it. ${ }^{87}$

A tale in Child titled "The Death of Henry Spencer" catalogues all the discoveries he had made by the eve of war in August 1914. Newly hired as a staffer for the Daily News, he is sent to the idyllic small town of Wheaton, Illinois to cover the hanging of Spencer, condemned for bedding and wedding a wealthy widow and then beating her head to a pulp with a hammer. On the night before the execution, Spencer professes to have found God, impressing Hecht with his aura of total calm. Hecht interprets this conversion as an example of an individual's capacity for change, but reporter Wallace Smith just scoffs. "Nothing can change a man," Smith says. "It's all fake. You are what you are. And you can only pretend to be something else. Henry's a rat and will die a rat." The sheriff, up for re-election, has built a scaffold the size of the Coliseum and handed out tickets to every political worker in the county, contracting his brother-in-law for the construction at three times the cost. In the evening, the sheriff's pretty seventeenyear-old daughter greases the noose under pale moonlight. The reporters amuse themselves by placing bets on how far Spencer will get up the scaffold stairs before slipping. When an editor asks Hecht for a short article that omits the gruesome details, Hecht cynically fires back, "Will try to make hanging as cheerful and optimistic as possible." At dawn, Spencer makes his way up the scaffold without incident, but after delivering a long homily about finding God, loses himself completely, and swears to his innocence while crying out piteously for mercy. 
The dawn, however, has brought more news than the death of Henry Spencer. It is August 15, and reports have arrived that the First World War has begun. "That night is gone," wrote Hecht. "And none like it was ever to be in my time again. For on this August, 1914, night, an innocence was departing from the world. ... When I look back on that hour, I see more than Henry Spencer dying in the sunlight on the end of a rope, with his immortal soul damned and Hell in his blackening face. A civilization hangs in the Wheaton stockade." 88

Big city reporters could see for themselves that massive changes were already underway, but the war to be fought far off in Europe had yet to unfold, and it would be years before Hecht could appreciate what it wrought. Civilization may have just dropped from the gibbet, but Hecht was twenty years old in 1914, and only beginning to awaken to himself as an iconoclast. For assistance years later in this self-discovery, Hecht credits Mencken, who ignited the fire in him for social criticism as well as for the spinning of plots. According to Hecht, the two first met in person at the Republican National Convention in 1920, by which time they had already exchanged letters. In one early missive to Mencken, Hecht said he complained "'that I had no program in me, nothing to tout. I just had a skepticism that was born of nothing.' Mencken replied: 'Go ahead anyhow. That will be a start for a novel."

By the summer of 1914, Hecht had become a member of the salon based around Margaret Anderson's groundbreaking new literary journal, The Little Review. He spent the war years rising as a star of both the local press and an historic literary movement, the Chicago Renaissance. In the South Side bohemian community near Jackson Park, Hecht forged friendships with other young talents who were on their way to national 
recognition, including Sherwood Anderson, Carl Sandburg and Max Bodenheim. On November 28, 1915, he married Marie Armstrong, who had worked as a reporter for the Journal for a short stint just before he left. Their child, Edwina, or "Scotty," was born in November $1916 .^{90}$

Reporters who had outgrown their usefulness for daily crime stories were either kicked upstairs to management or shipped overseas as foreign correspondents, and in the final days of 1918, the Daily News assigned Hecht to Europe. Nevertheless, it seems, in retrospect, a curious decision to have sent a journalist who had never demonstrated any interest in politics, even on the local level, to cover the intrigues, maneuvering and Byzantine affairs that would shape the postwar world. In Child, Hecht looks back at the experience not only as the final evolution of his cynicism, but as an explanation for why he was able to prophesize the Nazi Holocaust at a time when just about all other American writers remained either unaware or uninterested - a role that, arguably more than any other, earned him a place in history.

It is reasonable to question whether in his memoirs, Hecht is guilty of reading history backwards, of giving himself credit, with the benefit of hindsight, for canny insights into the future that no one else seemed to have. Yet just as Hecht actually did predict the German genocide in a story published in June 1939, his correspondence and published articles from 1919 corroborate his memoir. "Among his reports home he made the prediction that Germany would be at war (again) in 20 years," recalled Peter Hecht in a 1976 letter to biographer William MacAdams. "This, nobody believed." ${ }^{\text {91 }}$ It is true that if Hecht had indeed been convinced of what the future would bring, he could have sounded a public warning in Erik Dorn, his 1921 novel based in part upon his 
experiences in Germany. But the record nevertheless makes clear that, unlike most of his peers in the press, Hecht understood the game of intrigue that was afoot.

Such insight, however, would come to him only after he had spent a sufficient amount of time overseas. Chicago had prepared him well in some ways for what he was to find there, but had left him unprepared in other ways. "All the inhumanity that I note today as history, I saw in Germany in 1918 to 1920 , except that I saw it then with a youthful delight for the preposterous," he recalled in Child. "... I had no notion that the humorless and macabre atmosphere was to become the air of the world. ... And I reported them with the enthusiasm I had brought in Chicago to four-eleven fires, basement stabbings, love-nest suicides and all the other hi-de-ho doings outside the norm of living.".92

Certainly Daily News managing editor Charles H. Dennis regarded Hecht as unprepared. In a letter forwarded to the correspondent from foreign news chief Edgar Price Bell at the end of January, Dennis made clear that he disagreed with the decision to send Hecht to Berlin in the first place, complained about the time it was taking Hecht to arrive, and worried about expenses. Days later, Hecht responded that he had already submitted eight stories while en route. "I do not understand how it was expected of me to reach Berlin from New York much quicker than I did," he continued, "and in view of that fact I do not understand the office's despair at my general uselessness. ${ }^{, 93}$

The editor thought Hecht too superficial a thinker for the adult business of international affairs. In a February 7 letter that critiqued Hecht's interview with new Weimar Chancellor Philipp Scheidemann, Dennis took him to task for describing the chancellor's surroundings in lush detail, and then passing over Scheidemann's aims and 
programs for a new Germany. "Was not there meat in the coconut?" Dennis asked. "Was not this what you went to see him for?" He also chided Hecht for calling Scheidemann an "affable combination of Bismark and Hinky Dink": "This is playing leapfrog in the presence of a corpse or whistling in church.” According to Child, Bell was so infuriated with the story that he demanded Hecht's removal. ${ }^{94}$

But Hecht was no longer the rube who had once been fooled by the cries of innocence or repentance from convicted killers on death row. Indeed, while the foreign press corps and their editors back in the States hung on every word from official sources, Hecht knew a con when he saw one. ${ }^{95}$ He understood Scheidemann and his colleagues as many historians later would — as pawns in a cynical game. ${ }^{96}$ Behind the scenes, the nation's militarists had set up the Weimar socialists to take the blame for the disastrous outcome of the war, while portraying Germany as weak and wounded, ready prey for the Red Menace of Russia, which strengthened Germany's hand in the Paris peace negotiations.

"What with trying to convince the world that Germany is starving, trying to regain a toehold on the vanishing colonies and trying to persuade German workingmen that Germany is a socialist state, while endeavoring to reassure the outside world that it is not, the present Ebert-Scheidemann government faces difficulties," Hecht reported in the Daily News on February 15. In Child, Hecht recalled, "My knowledge was skimpy, my political insights almost nonexistent and my sources of information limited at the time to drug addicts, nymphomaniacs and a waiter. But the Lie about Russia was as obvious to spot as a sheiss house in a fog." To his astonishment, not only did the priggish foreign correspondents fall for this lie, but Bell and Dennis believed it, too. ${ }^{97}$ 
As a newspaperman, Hecht nevertheless still found himself susceptible to a great story, even one that happened not to be true. His front page article for March 13 startled readers with the revelation that Germany had not in the end suffered military defeat, but according to General Max von Hoffmann, chief of staff of the eastern front, had lost as a result of the Russian surrender, which had erased the battle lines that divided the troops and allowed the vaunted German army to become "rotten with Bolshevism." And yet days earlier, Hecht had witnessed events that would make him wonder what was really at play. $^{98}$

Trailing a small band of doomed Spartacan rebels through barbed wire and rubble of the Alexanderplatz neighborhood, he had witnessed the final skirmishes that had stamped out the communist revolt known as the January uprising. On March 11, he had joined a good-natured, well-dressed crowd to watch the army march the rounded-up Spartacans towards Moabit Prison. When the prisoners, handcuffed together and herded "like two-legged cattle," approached the gates, a hurdy-gurdy cut its rollicking tunes, and the crowd drew silent. Now that the rebels were within earshot, their pleas for mercy could be heard. "Most of them resembled workers in any group to be seen leaving a factory in Chicago at 6 o'clock on a spring day," he reported. "I counted four women. I noticed that six of them were lame and were being dragged along by their upright comrades chained to their wrists."

Another ten minutes of silence passed after the last entered the gates. Hecht tried to ask a guard what was happening, but was pushed aside. "Suddenly, as I was turning to leave, I heard the sputter of machine guns," he wrote. "They were shooting behind the walls of Moabit. The shooting continued. Above the sound of the guns came the cries of 
men. I could not distinguish the words. The cries changed to howling. The machine guns continued. I waited till both the howling and the sputtering were over." A white-faced guard turned and told him that all two hundred and twenty had been cut down. ${ }^{99}$

It was not until the revolt in Munich a month later that Hecht came to understand the grander game, and discover how von Hoffmann's tale had been "part of the machinery of the Lie." According to a remarkable story he tells in Child, he agreed to offer a well-known Bolshevik agent in Berlin a lift to Munich in an airplane requisitioned with Daily News funds for transport around Germany. Shortly thereafter, the head of Anti-Bolshevik League also asked to come along. During the flight, Hecht was shocked to find these two enemies sitting calmly together in the cabin of his bomber, playing poker over a suitcase.

The situation grew even stranger as the plane came in for a landing. Right in front of the pistol-packing anti-Bolsheviks, the Bolshevik agent asked Hecht to carry his suitcase through customs. It contained a million gold marks, money that would be used to bribe the military garrison in Munich to stand down when the revolutionaries overtook the city. Without a word of protest from the anti-Bolsheviks, who would only have had to draw their guns to end the whole plot, Hecht carried the suitcase through security.

Hecht soon found out why the anti-Bolsheviks had been happy to let their enemies use the money. When the time came, the German army crushed the Munich revolt in a matter of days. The revolutionaries had meanwhile served an important purpose, because the headlines they produced scared the world into thinking the Russian threat was real. Hecht wrote the episode "left me with a permanent cynicism toward history" and that "the cynicism of this action was beyond anything I had yet seen in the 
world. It said — go hire killers to kill my own people. When the time comes we will kill those killers. And out of all this killing we will win a point. We will convince people that the lie we are telling is the truth." 100

The Germany Hecht encountered was not altogether devoid of hope, however, for along with so many dark actors, he also found some he considered genuine heroes. One was Count Russworm von Gleichen, who had first opened Hecht's eyes to von Hoffman and the bigger "Lie." Another was Hugo Haase. At the national assembly to draft a new constitution, Haase spoke out against the crimes and deceptions and delivered a brave, impassioned plea for German liberty. These men were defeated in 1919, but to Hecht their conduct was testament to the old adage that war brings out the best and the worst in people: In the face of such inhumanity, they had shown the finest humanity. As he concluded his story of Haase in Child, Hecht realized that he had neglected to mention one small fact: Haase was a Jew. ${ }^{101}$

The lessons that Hecht took from Germany would emerge as themes he replayed in his fiction over the next thirty years, and they explain, again in narrative shorthand, his own reasons for shifting from writer to activist when the Nazis rose to power. He wrote them, for example, into the plot and the beginning pages of Alfred Hitchcock's 1940 film Foreign Correspondent.

Dedicated "to those forthright ones who early saw the clouds of war while many of us at home were seeing rainbows," the story opens in the office of the New York Morning Globe's senior editor. The editor tosses down a cable from Europe in disgust. ““According to a high official, it is believed...' Bah! Foreign correspondent! I could get more news out of Europe looking in a crystal ball," he rails. "I don't want any more 
economists, sages or oracles bombinating over our cables! I want a reporter, somebody who doesn't know the difference between an 'ism' and a kangaroo. A good, honest crime reporter. That's the what The Globe needs. That's what Europe needs. There's a crime hatching on that bedeviled continent!"102

The crime is the rise of Hitler and the double-dealing diplomacy that positioned him to conquer Europe with a series of lightning strikes. In Foreign Correspondent, the discovery of this European crime story becomes a call to action. As in Hecht's 1937 play To Quito and Back, characters inspired by von Gleichen and Haase intervene to convince a world-weary reporter to drop his dime-store cynicism in the face of momentous events and embrace a cause, just as Hecht himself would do 1940.

In an essay titled “The Hidden History in Ben Hecht's Suitcase,” Ron Rosenbaum explains

with his invaluable Chicago newspaperman's instinctual ability to smell a rat, Hecht was soon onto the story that most of the international press was missing: the devious maneuvering by the German General Staff to retain its weapons and its power in German politics. Scheming which gave rise to, among other things, the "Stab in the Back" myth, one of the Big Lies Hitler rode to power.

By maneuvering the hapless socialist government, which had been left holding the bag when the Kaiser fled, into responsibility for signing the onerous armistice (and later, peace treaty) terms with the Allies, the German Army set itself up to claim forever after that it was not really defeated, but only "stabbed in the back" by the treacherous civilian authorities, the "November Criminals," as Hitler called them (after the November 1918 armistice).

The other aspect of the game the German Army generals were playing - the other rat Hecht smelled - was the way the army seemed to him to be tolerating, if not encouraging, local outbreaks of Red-led revolutionaries, the better to convince the Allies that Germany still needed a well-armed military force to suppress and prevent Bolshevik revolutions from sweeping the nation. ${ }^{103}$ 
The politics that Hecht had encountered in Europe were not fundamentally different in nature from the politics of Chicago. So what was different? Before the war, he had seen clever subterfuge, as well as brutal violence. But he had never seen such apocalyptic horror, the kinds of scenes that were destined to mark the rest of the twentieth century. Like the Ford Model T, the tin can and cheap newspapers, the Industrial Revolution was now mass producing murder. By the time Hecht was writing Gaily Gaily in the early ' 60 s, he preferred to stay with his memories of the old days of pre-war Chicago, "when the stakes were smaller and the Halloween battles for power more fun to watch. ... I am aware that the political stakes have changed, that human survival is now the name of the game. But I see no alteration in politicians." In Child, he recalled, "I was a youth of twenty-four when I entered Germany. When I emerged from it my young cynicism had lost much of its grin." 104

The Chicago that he returned to was not the same, either. During his absence the Volstead Act had passed, and the bootlegging wars were now getting underway. The world war was over, but the world had changed for good. 


\section{THE JOURNALIST AND THE GANGSTER: THE FRONT PAGE}

Some little typewriter, eh? I'm gonna to write my name all over this town with it...in capital letters!

Tony Camonte, brandishing a machine gun in Scarface $e^{105}$

Beginning in April 1924, an odd-looking clock face appeared each day on the front page of the Chicago Tribune. The clock had three hands, or "Hands of Death": One was labeled "Autos" and tracked the fatal accidents occurring now that cars were massproduced. The other two were labeled "Moonshine" and "Guns."

The city had a murder rate twenty-four percent above the urban national average. Other cities had higher rates, but Chicago was the biggest city in America second to New York, which had a rate thirty-one percent below the national average. A 1926 Senate investigation into the links between criminals and government officials, called for by local civic leaders, had the ironic effect of raising Chicago's profile as crime capital. New York was known for bright lights, intellectuals and artists. Chicago became known for murder. $^{106}$

It wasn't just the statistics or a Senate investigation, however, that earned the city its reputation. It was also the work of the city's press, which had a talent for sensationalizing and glamorizing crime. In this final stage of the Front Page era, Chicagoans created the style of lurid, crime-driven news that was dubbed "Jazz Journalism" and best exemplified by America's first tabloids. In 1919, it was Tribune owner Joseph Medill Patterson who launched the Daily News in New York, while in 1924, Hearst sent Howey to establish its competitor, the Daily Mirror. A Chicago photographer with a hidden camera snapped the iconic tabloid image of Ruth Snyder 
jolted to death in the electric chair. Chicago's newspapermen wrote the hit crime dramas of the stage and screen of the late 1920s and early ' 30 s, and the city was the site of the three legendary Grand Guignols of the Jazz Age: the Leopold-Loeb murder of Bobby Franks, the Beulah Annan and Belva Gaertner killings made famous on the Broadway stage in Chicago, and the St. Valentine's Day Massacre. ${ }^{107}$

At the same time, the close partnerships between gangsters and the press that had first been forged in the circulation wars now deepened during this period. "Chicago mobsters enjoyed having newspeople around them like pets," observed local press historian Wayne Klatt, who noted that the papers treated the mob killings in the LoopDion O’Banion on November 10, 1924, Early "Hymie" Weiss on October 11, 1926, and Tony Lobardo on September 7, 1928 — as isolated instances, not as part of a pattern. The gangsters fed underworld tidbits to Her-Ex reporter Peggy Doyle and chummed around with sportswriters like boxing columnist Vern Whaley. Journalists were happy to take handouts, and gangsters were always good for a meal. Capone invited them to his table at the Club Metropole. The gangs were such good copy that they rarely became the targets of outrage. While the papers crusaded for years against Mayor William Hale Thompson's corruption, Thompson fired back in 1931 with a pamphlet stating that, according to the newsboy union president, the Tribune's Max Annenberg had appealed to Capone to intercede in a labor dispute. Publisher and editor Robert McCormick had allegedly told Capone at the meeting, "You know you are famous like Babe Ruth. We can't help printing things about you, but I will see that the Tribune gives you a fair deal."108

Such sensationalism and unscrupulousness were an old story, but the emergence of mass communication was radically changing American life by the early 1920s, raising 
questions and heightening concerns, and Jazz Journalism prompted calls to establish firm standards of ethics and professionalism for the press, an effort that would eventually stamp out the hellfire of the Chicago style of journalism. A January 1922 article in the Atlantic gave voice to the rising tide of condemnation. "What makes yellow journalism really dangerous," wrote author Frederick L. Allen, "is not so much its appetite for scandal as its continual distortion of the news in the interest of undiluted entertainment. $" 109$

In response to this and a flurry of similar attacks, Hecht's supervisor at the Daily News, Charles H. Dennis, joined four other editors at the Blackstone Hotel in February 1922 to found the American Society of Newspaper Editors. After drafting a code that called for "truthfulness, impartiality, fair play and decency," the society spent the next decade embroiled in a vociferous debate over whether enforcement should be given the same authority that one finds in licensed professions like law and medicine. ${ }^{110}$

Pursuing a different tack, in 1921 McCormick donated funds to Northwestern University to found the Medill School of Journalism. When critics had originally suggested that journalism schools would create class distinctions in the newspaper world, Joseph Pulitzer, who had endowed Columbia in 1904, said this was exactly the point: to separate the fit from the unfit. "We need a class feeling among journalists—one based not upon money, but upon morals, education and character."111

Hecht returned from Germany in early 1920 with a new awareness about journalism and his place in it. He also had a huge pile of debt. He would no longer work as a reporter, but over the next four years would launch a public relations firm; produce a column of daily sketches; publish six novels, several plays and a collection of short 
stories; and edit and publish The Chicago Literary Times, a prototype of the alternative weekly newspaper. Within the next ten years, he would use the skills and knowledge he obtained as a reporter - his understanding of public tastes, the tricks he learned as sketchhoax literary artisan — to acquire wealth and a modicum of fame. His various incarnations in the 1920s, as public relations impresario, columnist, novelist, Broadway playwright and Hollywood screenwriter, reflected the historic changes that were then occurring with the advent of mass media and the early evolution of American mass culture.

In Erik Dorn, The Front Page and other works, he would investigate the media and reflect many of the major concerns voiced by critics and scholars of the day. But Hecht was unique in that he effectively combined insights into media with skills as a practitioner. Just as this earned him fortunes in public relations, theater and film during the 1920s, it would one day enable his pursuit of loftier aspirations as a professional propagandist, one who was happy to produce materials for the U.S. War Department and State Department, but who preferred to stick to the more personally significant work he did pro bono.

By 1920 , he and his family had adopted a lifestyle far beyond their means. To put himself back in the black upon return to Chicago, Hecht became a partner in a public relations start-up, soon hiring on his fellow foreign correspondent, Richard Little. ${ }^{112}$ According to his recollection in Child, he organized events and campaigns and wrote copy for interests that "came clamoring to our office, which, after the first month, consumed an entire floor in the Francis Willard Building." This was to be the first of Hecht's two lucrative forays into the field, just as it developed out of the propaganda campaigns of what the New York Times had called "the first press agents' war." The U.S. 
and British propaganda bureaus had, from the start of the conflict, tapped the finances and expertise of Chicago-based military contractors, and these private-public partnerships were instrumental in the burgeoning of "publicity" in the postwar era. ${ }^{113}$

While moonlighting in public relations, Hecht began his "One Thousand and One Afternoons" column in June 1921. He had envisioned the column as a feat of storytelling, a high-wire act, just as Scheherazade's one thousand and one Arabian tales had beenthough the sultan's wife had performed for her life, while Hecht was just doing it to prove that he could. Every day for more than a year, he produced a different tale about the city. In the fall of 1922, bookstore proprietors Pascal Covici and William McGee published a collection of sixty-four of the columns in book form, interleaving them with expressionistic illustrations in black ink by the artist Herman Rosse. In the book's preface, Daily News editor Henry Justin Smith explained Hecht's "Big Idea- the idea that just under the edge of the news as commonly understood, the news often flatly and unimaginatively told lay life; ... He was going to be its interpreter. His was to be the lens throwing city life into new colors."114

Each story, each slice of life, was a shard in the kaleidoscope of modern city life. A great financier finds himself distracted on a rainy day by thoughts about his own insignificance; solitary souls wander through the mists of a downtown that "is like the exposed mechanism of some monstrous clock"; a poor widow spends so lavishly on her husband's funeral that she loses her children; a Mr. Prokofieff directs a chaotic, circuslike modernist opera; hundreds of fishermen sit all afternoon along the Municipal Pier, staring across Lake Michigan at oblivion. There are portraits, ironic yarns, and mood pieces painted in brush strokes: "A dark afternoon with summer thunder in the sky. The 
fan-shaped skyscrapers spread a checkerboard of window lights through the gloom." As Smith noted, "Comedies, dialogues, homilies, one-act tragedies, storiettes, sepia panels, word-etchings, satires, tone-poems, fugues, bourreess - something different every day." $" 115$

Hecht reached to determine the limits of what reporting could offer the storyteller. His column harkened back to the daily columns of George Ade and Eugene Field in the Chicago newspapers of the 1890 s, which may have been the first signed columns to appear in any American paper, and the Mr. Dooley stories of Finley Peter Dunne. These were varieties of the newspaper "sketch," a broad category of newswriting that encompassed any report based on personal observations. Hecht's style most resembled the relatively unmannered realism of "Stories of the Streets and of the Town," Ade's column, which grew directly out of reporting experience. ${ }^{116}$

But in the end, Hecht did find the limits of shoeleather, at least for himself. In the final column of his collection, "the newspaper reporter" opens his notepad at night to find that the "secret of the city" he had thought he held in his mind during the day has now slipped away from him. The next day the reporter tries to ferret out the secret by interviewing people who lie on the grass in Grant Park, staring up at the clouds, but upon return home, finds the secret has eluded him once more. ${ }^{117}$

While ASNE may have been insisting upon objectivity as a standard of professionalism, "One Thousand and One Afternoons" reflected a growing acknowledgment of the subjective nature of journalism. Newspapers were adopting more nuanced ideas about objectivity, distancing themselves from the "naïve empiricism" once understood as realism in the 1890s. Like the debut of the political column at this time, the 
more frequent use of bylines and the emergence of "interpretive reporting" in the form of news summaries and analysis, Hecht's column suggested that facts and events require interpretation and that every report contains a point of view. ${ }^{118}$

A leading voice of this new skepticism about objectivity was Henry Luce, who worked as a leg man for Hecht on the column (much to Hecht's dissatisfaction), and within two years, co-founded Time, a news weekly full of summaries and analysis. "Show me a man who thinks he's objective," Luce had said, “and I'll show you a man who's deceiving himself."119

These doubts about objectivity, the call to police journalism and the birth of an industry of experts who massage data and carefully calibrate messages coincided with growing pessimism about the notion of a public that was capable of reason and informed decision-making. In Public Opinion (1922), Walter Lippmann "had begun to knock the 'public' off the perch that the rhetoric of democracy had built for it," wrote Schudson. A spate of writing about "crowds" and crowd behavior had begun to appear in the late nineteenth century and gained popular attention by the early 1920s, with such works as Everett Dean Martin's The Behavior of Crowds (1921). Mencken, virtually unmatched in his astringency, ridiculed the American middle-class as the "Booboisie," (boob-wahZEE); dismissed democracy as an "incomparably idiotic" fraud in which political "bugaboos" preyed upon the fears and imbecilities of the mob; and maintained that the modest duty of the writer lay in "stirring up the animals." Lippmann wrote that voters "arrive in the middle of the third act and will leave before the last curtain, having stayed just long enough to decide who is the hero and who is the villain."120 
Collectively, though, the new attitudes about the press and the public were symptomatic of something deeper at work. They reflected a profound new skepticism about the power of reason and the knowability of truth, a pervasive lack of confidence and sense of distrust that was a legacy of the war. Hecht's search for realism had only affirmed his subjectivity. He had gone off as a reporter seeking facts and found "that the city was nothing more nor less than a vast, broken mirror giving him back garbled images of himself." $" 121$

His first novel, Erik Dorn, which hit the bookstands in the fall of 1921, offered a perspective that was diametrically the inverse of what he provided each day in his column. As the story begins, Dorn is Hecht as he imagines himself six years in the future: no longer a reporter or columnist, now a thirty-four-year-old editor for a newspaper. $\mathrm{He}$ has become jaded to the human drama that plays out across the city each day, all the writhing turmoil and tragedy captured in newsprint and churned out "sausage fashion" in a half million newspapers a day. Whatever secrets the city holds have been revealed, and he is weary of them all. Walking the streets and scanning the reams of copy that cross his desk, he sees the tumult of human activity like the patterns on an ant hill. His eyes trace these geometries, but they are meaningless. Newspapers, with their editorial bromides and shrill sensationalism, hold up a carnival mirror to this carnival of life, delivering "a caricature of absurdity itself." Dorn, meanwhile, is captive to the mocking laughter in his own head, his own devastating irony. ${ }^{122}$

"The book as a whole is as beautiful and disturbing as a live thing," wrote a reviewer for Vanity Fair. "It remains to consider how far Erik Dorn is a brilliantly colored caricature of a generation of disillusionists, a generation which, though still 
young, can find no reason for its continued existence but that the blood is warm and quick in its veins.” Dorn voiced his generation's pessimism, echoing Lippmann's denunciations of the public that same year, lamenting that people "want black and white so they can all mass on the white side and make faces at all the evil-doers who prefer the black. They don't want facts, diagnosis, theories, interpretations, reports."123

At the same time, in the character of Dorn, Hecht gave form to the anxieties of a new era about cold corporate efficiency. In an introduction to the 1963 reprint of Erik Dorn, Nelson Algren credited Hecht with anticipating the themes of alienation and of conformity — the latter personified by the "organization man" — that permeated American literature after the Second World War. "I'm like men will all be years later," Dorn says, “when their emotions are finally absorbed by the ingenious surfaces they've surrounded themselves with, and life lies forever buried behind the inventions of engineers, scientists and business men." ${ }^{\prime 24}$ In the early 1920 s, this was efficiency in the manufacture of everything from tin cans and Ford automobiles to machine guns and bootleg whiskey. It was an efficiency that Hecht and other Chicago newsmen would soon associate with a fresh breed of gangsters and, in particular, with the cold-blooded Al Capone.

This editor's cold detachment is not objectivity_-far from it. Algren suggests that Dorn's cynicism is merely "a hideout from the winds of passion" that blow within him. Biographer Doug Fetherling argues, on the other hand, that Dorn is a man with more talent, intellect and promise than he knows what to do with, and thus ultimately finds himself dissatisfied and disillusioned. ${ }^{125}$ He feels things, even falls in love, but ultimately can't help mocking his own folly. In short, while Hecht's daily experiment in realism with his column had led to a deeper sense of subjectivity, his newspaperman Erik Dorn is 
his original Romantic egoist, the first of many to follow: a malcontent who is brilliant, coldly efficient, but driven by a mad hidden passion.

With his explosion of output over the next few years, Hecht seemed determined to prove himself a storyteller who could match the Scheherazade of legend. His ability to spin tales at a furious rate had been in evidence since at least as early as 1917, when, thanks in part to Mencken, who fed him plotlines, he had produced some twenty short stories for the Smart Set in a year and a half, contributing as many as eight stories to a single issue. In Child, he claims that he dictated The Florentine Dagger in thirty-six hours to win a wager: He bet that he could write a novel within two days that would receive favorable reviews and sell twenty thousand copies. In years to come, Hecht's ability to produce popular stories in every genre at remarkable speed made him the most sought after screenwriter in Hollywood, where he said that of the more than sixty movies he wrote, over half were written in two weeks or less. ${ }^{126}$

Over the longer term, Hecht's extraordinary output came to be regarded as evidence of his shallowness and dissolute talent. Dorn, which was arguably the best of his novels, has on occasion been dismissed as an overwritten and plotless mess. And what some admired as Hecht's aptitude for inverting themes and weaving plot variations- $\mathrm{a}$ gift that helps account for his productivity—others saw as his endless re-hashing of the same old tired material, from Erik Dorn to Child of the Century. Such dismissals, however, ignore both the many dimensions of his works and the excellence of a considerable number of them, particularly of his best films, and books like $A$ Book of Miracles, Child of the Century and Gaily Gaily. Regardless, Hecht's technique of 
flipping and twisting the tropes of Romantic literature offers a key to understanding his works, respectively and holistically, and to understanding the writer himself.

Dorn had indeed drawn heavily from biography, and like his fictional protagonist, Hecht was leaving his wife for another woman. He had originally met Rose Caylor, a studious, pretty young blonde, just before he departed for Germany with Marie, when Rose was a City News reporter. By the time he returned, she was working at the Daily News. He finally moved with Rose to New York City in 1924, and they married in 1926, once he had obtained a divorce from Marie. A Jewish woman whose parents had also emigrated from Eastern Europe, Rose had been active in politics since childhood, when she had grown disillusioned with socialism. Hecht would credit her with his own turn towards politics in 1939. For the rest of their lives, she would be his muse, confidant, collaborator, editor and, on occasion, fierce interlocutor. ${ }^{127}$

"We were all fools to have left Chicago," Hecht would later lament, and in the event he left reluctantly, the last of the Renaissance writers to make the migration to New York. There Hecht joined a literary society comprising newspaper veterans and magazine writers from the East Coast and elsewhere, including Gene Fowler, Damon Runyon, Dorothy Parker, Herman Mankiewicz, Samson Raphaelson and George S. Kaufman. Other former reporters from Chicago included sportswriter Ring Lardner, a friend of F. Scott Fitzgerald's who gained acclaim for his short stories, Tribune staffer Maurine Watkins, who wrote Chicago, which premiered in 1926, and Bartlett Cormack, author of the 1927 Broadway play The Racket. In addition to critical essays, stories and novels, these writers made a significant contribution to theater at a time when Broadway was producing some 225 plays a year. ${ }^{128}$ 
Pauline Kael wrote that they were "ambivalently nostalgic about their youth as reporters, journalists, critics or playwrights, and they glorified the hard-drinking, cynical newspaperman." For many of this group, newspapers had offered both a paycheck and training as writers and storytellers. But quite a few in the press, at the time and since, saw them as a crowd of daydreamers and partiers, who had little commitment to the true mission of journalism in a democratic society. "A lot of the 'reporters' in the 1920s weren’t reporters at all,” wrote John Justin Smith, nephew of Hecht's editor, in 1974. “They were poets, for heaven's sake. Or playwrights or novelists...They could dance the Charleston, but never heard of investigative reporting.,"129

They nevertheless lampooned and dissected the press on stage and in popular literature, during what has been called "the Golden Age of press criticism." It was, moreover, a Golden Age of distaste and suspicion of the press. While ASNE struggled to establish a code of ethics only to find it unenforceable, Upton Sinclair's The Brass Check topped a considerable literature of radical critiques that denounced the press as captive to big business. While Lippmann and Dewey disagreed about what could be done to save a democracy from the destructive impacts of urbanization and industrialization, neither held out hope that journalism could come to the rescue. ${ }^{130}$

Meanwhile, scholars at the University of Chicago were laying the groundwork for the study of mass communication as an academic discipline. Harold Lasswell published the seminal Propaganda Technique in the World War in 1927, the same year he joined the faculty, while another Dewey disciple, Robert Park, helped to lay the foundation of the field in social science. ${ }^{131}$ 
By 1926 the activities of Hecht and MacArthur were expressive of their own puckish cynicism about the press. On the payroll of Morrill Goddard's Sunday supplement for Hearst, MacArthur wrote features about the end of the world, spies from Mars, and the accomplishments of fleas. In this capacity, according to Hecht, MacArthur tried to peddle rejuvenating cream by advertising two lovely young sisters as nonagenarians who had achieved eternal youth. ${ }^{132}$

Hecht meanwhile raked in enormous sums in a notorious South Florida real estate scam, his second venture in publicity. In Child, he claims to have planted news stories across the nation about chests of pirate treasure discovered in Key Largo, inciting a frenzied grab for lots of what was, at the time, a mosquito-infested dump site. Whether this particular shenanigan actually occurred-we know from at least one other account that Hecht did strike a bonanza in Florida — again, the underlying point is clear. He had learned to use the tricks of the Chicago newspaper trade, namely the hoax, not just to earn a scoop, but also to draw real dividends. ${ }^{133}$

Hecht and MacArthur would soon find another way to profit from Chicago-style subterfuge: by presenting it on stage as farce. They had spent time together as young reporters, but after they met on a New York City street one day when they were both in their thirties, their friendship became a way to hold on to the past. "We were both obsessed with our youthful years," Hecht recalled. “...We remained newspaper reporters and continued to keep our hats on before the boss, drop ashes on the floor and disdain all practical people." Fresh from writing the treatment for Underworld, Hecht spent the summer of 1927 compiling memories of Chicago with MacArthur and weaving them into the script of The Front Page. ${ }^{134}$ 
The play, which opened at the Times Square Theatre on August 14, 1928, ran for 276 performances at a time when one hundred was considered successful. Bawdy, raw, and described the New York Times as "unfailing entertainment," it was Hecht's biggest hit to date and the work he would be most remembered for. Canonized by theater critics and scholars as "the best American comedy ever written," it also rose from among the many contemporaneous appraisals of the press to become the best-known portrayal and critique of journalism. $^{135}$

The action takes place in the pressroom of the Cook County Criminal Courts Building, where reporters are awaiting the execution of Earl Williams, a young radical accused of killing a black police officer. The mayor and Sheriff Hartman are hoping to capitalize on the hanging in an election year in which they are running on a tough-oncrime platform. Herald and Examiner managing editor Walter Burns is determined to have star reporter Hildy Johnson cover the story, but runs into a problem: Johnson has announced that he is getting married, leaving the news business for good, and taking an advertising job in New York City. He has just dropped by the pressroom to bid his farewells, when suddenly Williams breaks loose. With a blockbuster story breaking right before his eyes, all of Johnson's impulses start to fire, and he finds himself facing "an emergency of spirit." 136

The Front Page impressed audiences with its gritty, naturalistic portrayal of Chicago journalism; Tennessee Williams would famously praise it as the play that "took the corsets off the American theater." Photographs of the actual pressroom show that it closely resembled the sets of various productions of the play. The action itself is based on two real events. The first was “Terrible" Tommy O'Connor's escape from the Cook 
County jail, with a gun that may have been smuggled to him in a pork chop sandwich, four days before his execution in December 1921, a major story in the city for weeks. The second was a practical joke Howey was said to have played on MacArthur when the latter fled to New York to marry fellow staffer Carol Frink: Howey gave MacArthur a pocketwatch as a farewell gift, and then arranged to have MacArthur detained on charges of theft when the train stopped in Gary, Indiana. This episode provided the final punchline of the play, delivered by Burns: "The son of a bitch stole my watch!",137 The characters of The Front Page, with few exceptions, were actual and indentifiable people, including the gangster Diamond Louie and the police officer Woodenshoes Eichhorn. Reporters, including McCue, Bensinger, Murphy and Schwartz were all recognizable by their names, lines and idiosynchrasies. Delighted by the casting of the original production, Hecht remarked, "You would have thought you were in Chicago 1917, looking at the real beauties of the Criminal Courts pressroom.” The real Hilding Johnson was known for his sartorial elegance and merciless scooping, such as the time he pieced together a murder verdict by rummaging through the jury ballots in a wastebasket, and then tampered with them so the competition would get the story wrong. ${ }^{138}$

In truth, though, the Hildy of the play was likely based more on how Hecht and MacArthur preferred to remember themselves. The basic dilemma that Hildy confronts had already appeared in Hecht's novels: “There, the Hechtian man, artist or newsman, is caught between his drive for self-actualization and the demands of the world around him," wrote Jeffrey Brown Martin, "between his work and his home, between his soaring 
spirit and possibilities and the encroachments of age and the encroachments of a bourgeois civilization that always threatens him."139

Once again the style of Hecht's work is realism, but the heart and soul is pure Romanticism. Certainly the opening description of Hildy is suggestive of a Faustian figure, introducing him as "a vanishing type — the lusty, hoodlumesque, half-drunken caballero that was the newspaperman of our youth. Schools of journalism and the advertising business have nearly extirpated the species." But the introduction of Walter Burns as a modern, corporate Mephistopheles is explicit: "Beneath a dapper and very citizen-like exterior lurks a hobgoblin, perhaps the Devil himself. But if Mr. Burns is the Devil he is a very naif one. He is a Devil with neither point nor purpose to him—an undignified Devil hatched for a bourgeois Halloween." ${ }^{\prime 40}$

Driving the point home, Walter is jocularly portrayed casting a spell on Hildy (“D'Artagnan never gave Richelieu an ear more startled or more innocent"), convincing him that his story will kick "over the whole City Hall like an applecart." Minutes later, Hildy starts "coming out of the ether: 'You just bitched up my whole life! That's what you've done!"' When the newsmen later find themselves handcuffed and facing criminal charges, Walter tells Hildy not to worry. Arching his eyebrows, he explains, "something seems to watch over the Examiner"- "an unseen power.","14

The play struck a nerve with defenders of the press. New York Times attorney George Gordon Battle blasted it in an editorial: "Managing editors are not all conscienceless and cruel. The standards of all newspaper men are not those of the gutter." When the film version appeared in 1931 along with other movies that showed newspapers in a harsh light, like Five Star Final and The Finger Points, newspaper editor 
Stanley Walker warned young prospective reporters against depictions of the reporter who "writes best on twelve Scotch high-balls" and "insults everybody in earshot." Indeed, the image the play created of newsmen as cynical, hard-drinking scoundrels would live on long after the actual era it portrayed had ended, enduring in public memory as "a slick piece of work about very crude people who through constant traffic with corruption, had become ninety-nine percent corrupt themselves." ${ }^{\prime 142}$

Yet there was clearly more to the story. In an epilogue included in the third printing of the script in 1928, the authors offer "an apology." They had meant to write a play that "would reflect our intellectual disdain of and superiority to the Newspaper." But instead, they ended up producing "a Valentine thrown into the past." Walter and Hildy do manage to get their scoop, and in the process, save Earl Williams from execution and expose the sinister scheme of mayor and sheriff. The press comes out victor in the end, even if "triumph results from a series of comic, cosmic accidents." As Matthew Ehrlich observed, "Hecht and MacArthur — and the seasoned Broadway pros Harris and Kaufman — managed not to stack the deck one way or another. If the play asks not only whether Hildy will leave journalism but also whether he should leave journalism, it very carefully leaves the second question unanswered."143 


\section{THE JOURNALIST AND THE GANGSTER: SCARFACE}

There's a new crew coming in. ... They're gonna be shooting each other like rabbits from now till hell freezes for the control of the booze business. It's gonna be like war. Get that in the lead. WAR...GANG...WAR.

$$
\text { A managing editor in Scarface }{ }^{144}
$$

We live in a depraved and bloodthirsty age, Tony.

$$
\begin{aligned}
& \text { A novelist speaking to Tony } \\
& \text { Camonte in Hecht's script of } \\
& \text { Scarface }
\end{aligned}
$$

Scarface with Paul Muni was recently barred from Germany when it was discovered that there was an uncommonly close resemblance between some of the gangsters in the picture and certain high Nazi officials.

Filmfront, January 28, $1935^{146}$

While scoring a hit with The Front Page, Hecht simultaneously used the knowledge acquired as crime reporter to launch the gangster movie craze, with his sixtyeight-page treatment for Underworld. Films about street gangs dated at least as far back as D.W. Griffith's fifteen-minute one-reeler The Musketeers of Pig Alley, and other contemporaneous titles, which have not survived, focused on the notorious Black Hand, a precursor to the mafia. But Underworld is "unanimously regarded by film historians as the first gangster movie with modern credentials." Though it opened with modest hopes, it met with massive box office success, and Hecht would receive an Oscar for Best Original Story at the first Academy Award ceremony, on May 16, 1929. "Here's to crime," wrote a reviewer for Motion Picture Classic. "Ever since Underworld came through with flying colors, most every producer including its particular sponsor, Paramount, has been trying to duplicate it." ${ }^{, 147}$ 
The movie had struck a chord because Hecht understood America's fascination with the soul of the racketeer. His own Menckenesque contempt for hypocritical "Puritan" morality had put him at the center of a revolution in morals and manners underway in the 1920s. In Walter Winchell's gossip column and elsewhere, readers were following the love lives of gangsters as closely as their murders and deaths. ${ }^{148}$

"My movies were usually successful because I had a sense of what the public liked," Hecht explained in his unpublished biography of Mickey Cohen. "I found this out as a newspaperman. It liked hotheaded villains who didn't give a damn for the Commandments or the conventions." When friend Herman Mankiewicz advised that in the movies, the villain could have as much sex as he wanted, but that heroes and heroines must be virgins, Hecht recalled: "An idea came to me. The thing to do was to skip the heroes and heroines, to write a movie containing only villains and bawds. I would not have to tell any lies then."149

As a former crime reporter, he also understood the public's fascination with violence. For a Columbia University oral history project on popular arts, Hecht recalled the pitch he had made to producer Howard Hughes for Scarface. He had told Hughes that he was not fond of Armitage Trail's novel, and would devise his own story instead. When the producer had asked what the plot would be, Hecht said he replied:

"I haven't got any plot, but there have been several gangster pictures made, and I will double the casualty list of any picture to date, and we'll have twice as good a picture. The Secret Six killed off about eight people. I will kill off twenty, and we'll have the audience right in our hands."

I killed off anybody I could. I killed as many people as I could shoot down. I shot 'em down because I knew audiences loved that. I always liked to do violent action pictures, because I knew audiences adored disaster, sudden death, explosions, much more than they did ideas, points of view or intelligence of any kind. And the reason I did 

good pictures was that I stuck to doing things that had no thought in
them.

The current and former journalists shaping Chicago's image as crime capital of the Jazz Age developed their own mythology of violence and glamor. In the 1930s, former City News reporter Loren Carroll wrote that the newspapers had embroidered their depiction of Richard Loeb and Nathan Leopold as brilliant, fabulously wealthy party boys who plotted the perfect crime for the thrill of it. The education of the two young men had in fact been ordinary, Carroll argued, their wealth merely above average, and their intelligence mediocre at best. ${ }^{151}$

Maurine Dallas Watkins gained an insider's knowledge of Front Page journalism when she wrote about crime from a "feminine perspective" for the Tribune for six months in 1924. She showed plenty of flair in covering the trials of rich murderess Belva Gaertner and beautiful Beulah Annan, "whose pursuit of wine, men, and jazz music was interrupted by her glibness with the trigger finger.” But Watkins' Broadway hit Chicago was a scathing satire of the trials and the general sensationalism of crime in the press. ${ }^{152}$

Underworld's release in 1927 coincided with a Broadway season that delivered a wave of successful "fast-talking, liquor-and-crime melodramas," including Chicago and Cormack's The Racket. It would also mark the rise of two Jewish actors who would be instrumental in Hecht's propaganda campaign during the 1940s. One of the best of the plays was Four Walls, in which a young star of the Yiddish Theater named Meshilem Meier Weisenfruend played Lower East Side gangster Benny Horowitz. Weisenfruend would change his stage name to Paul Muni and star as Tony Camonte in Scarface, the movie that made him famous. ${ }^{153}$ 
His cousin, fellow Yiddish-speaking Lower East Sider Emanuel Goldenberg, played the lead that season in The Racket under the stage name Edward G. Robinson, before he achieved celebrity in MGM's Little Caesar (1931), the first hit movie of the sound era and the first of a trilogy_including Public Enemy and Scarface — that established the gangster movie as a major genre of film. ${ }^{154}$ In 1943 , both men would star in We Will Never Die, Hecht's propaganda pageant meant to raise awareness of the Nazis’ Final Solution.

In books and the press of the late 1920s and early '30s, Capone also rose to fame. Journalists who had spent years covering crime stories wrote them up for the pulps or turned them into histories, like Walter Noble Burns' The One-Way Ride: The Red Trail of Chicago Gangland from Prohibition to Jake Lingle, and biographies, like John Bright's Hizzoner Big Bill Thompson and Fred Pasley's Capone: The Biography of a Self-Made Man. A smiling portrait of Capone on the March 1930 cover of Time magazine marked his celebrity status. At a Cubs game, Chicagoans booed President Herbert Hoover, but gave a great cheer for their reigning mobster. ${ }^{155}$

“Americans marveled at Capone's wealth and power, built on an empire of prostitution, gambling, racketeering and bootlegging," wrote David E. Ruth in Inventing the Public Enemy. "In press conferences, interviews with reporters and a highly theatrical social life, Capone worked as hard as any movie star to create a favorable public image." But it had been the ruthless, calculated efficiency of the 1929 St. Valentine's Day Massacre that had propelled him to national notoriety. Members of his South Side gang dressed as police officers had lured seven of George "Bugs" Moran's rival outfit into a Lincoln Park garage with promises of premium whiskey at a bargain price. When ordered 
to press their faces up against a wall, Moran's people thought they had been pinched and obediently complied. Capone's hit squad then coolly cut them to pieces with Thompson sub-machine guns. ${ }^{156}$

In film, a string of crime and gangster movies had chased Underworld's success over the next two years, including a kind of sequel made by its director Josef von Sternberg, The Drag Net, along with The City Gone Wild, Dressed to Kill, Forbidden Faces and Romances of the Underworld. Moviemakers stumbled, however, in their first efforts at the gangster film in sound, such as Broadway and another foray by Sternberg, Thunderbolt, both released in 1929. By now, audiences had grown too sophisticated for the crime story as Romantic fable. They wanted something that corresponded with the realities they were reading about in the newspaper. ${ }^{157}$

They got it from Darryl F. Zanuck, who in January 1931 was appointed chief executive in charge of all productions for Warner Brothers and its new acquisition, First National. A Reader's Digest report that 486 gangsters were killed on Chicago's streets in 1929 sent Zanuck hunting for Chicago tales. He was not interested, however, in the flock of writers who had made hits for Broadway and then found work in Hollywood adapting each other's work for screen. "Zanuck was more interested in journalists than in playwrights," explained Carlos Clarens in Crime Movies. "He was not after canned theater like the movie version of The Racket or fancy stuff like that of Broadway. He was prepared to take a chance on properties that were not backed by Broadway prestige, and he began buying stories that seemed good material." $" 158$

He snatched a Chicago novel syndicated in eighty-two newspapers, Little Caesar, by W.R. Burnett, an unpublished collection of short stories titled Beer and Blood by 
Bright, and A Handful of Clouds, an unproduced play by Rowland Brown, a screenwriter with one credit to his name. With these, Zanuck turned out three smash hits by the end of that year: Doorway to Hell from Brown's play, Little Caesar, and Public Enemy, adapted from Bright's stories. “Zanuck’s gambit had paid off,” Clarens noted. “The Warners' motto proclaimed 'Snatched from Today's Headlines,' and the new vogue was auspiciously launched." 159

This early period of talk also saw the launch of the newspaper film, another genre inspired by Hecht — in this case, by The Front Page — which likewise focused on corruption. The portrayals of the press in the first wave of newspaper movies were notably negative, prompting journalism professor John Dewry to complain to colleagues that the movies made "the reporter more nearly resemble a gangster than even a moderately well-off business or professional man." 160

The fusion of the journalist and gangster was not just the stuff of cinematic fiction, however: Its reality became national news with the gangland execution of Alfred "Jake" Lingle on June 9, 1930, in one of the most publicized cases of the Prohibition era. Lingle was a Tribune police reporter, shot through the neck and skull as he was walking down the stairs to the open platform of the Illinois Central Station. This murder of a journalist in broad daylight in the middle of a busy downtown street, the eleventh Chicago gang killing in ten days, sparked outrage across the country. The Tribune, the Hearst papers and the City Press Club offered rewards, and Capone himself, never one to miss an opportunity for good publicity, said he had assigned fifty men to hunt down the culprit. $^{161}$ 
But public indignation soon curdled into cynicism as details about Lingle emerged. His mouth still clutching a burning cigar, Lingle had been found wearing a diamond-studded belt buckle said to have been a gift from Capone, and carrying fourteen hundred dollars in one-hundred-dollar bills. His lavish summer home and downtown suite at the Stevens Hotel were further evidence of his true occupation-trading inside information about the city and police to the underworld.

The story seemed made for Hollywood, and true to their motto, Warner Brothers snatched it for the screen with The Finger Points, which premiered the following March. It is the tale of Breckenridge Lee, a Southern rube who begins with idealistic notions of the press, gets entrapped and ultimately becomes corrupted by crime. "An alleged reporter who was in the service of everything but truth, Lingle represented the ultimate corruption of the printed word by municipal government, law enforcement, and gangsters," wrote film historian Jennifer Smyth. ${ }^{162}$

In retrospect, 1931 looms as the year of the gangster film-while none were blockbusters as we understand the term today, they generated the most attention and discussion. The debut performances of Clark Gable, James Cagney and Robinson, all playing violent criminals, were cinematic sensations. On the heels of this success, independent producer Howard Hughes was determined to make the gangster film to end all gangster films, surpassing all others "in cost, scope, authenticity, and, needless to say, violence."163

In choosing to do a thinly disguised biopic of Capone, Hughes also picked the grandest subject. His crucial production decision was to hire as principal writers Hecht, Burnett and Pasley, the Capone biographer and fellow Chicago Daily News veteran. 
Hecht, who did not trust Hughes, insisted on payment of one thousand dollars at the end of every workday, and completed his draft in about eleven days in January 1931. Hughes was a maverick, known to spend exorbitantly on his films, with little care for the time and money it required. This scared Hollywood, who feared he would break the uneasy truce the studios had maintained with the censors, and indeed the censorship battles waged over Scarface were historic. Seldom has the violence of a film been such a target. ${ }^{164}$ Of three events in the 1920s that left a permanent imprint upon American consciousness, Clarens argued, the arrival of sound in motion pictures had deeper repercussions than either Prohibition or the onset of the Depression. Those unique events will remain in public memory, he reasoned, "but when pictures started to talk and sing and make noises, they altered forever the way we perceive reality, even the way we imagine ourselves to be." Hecht would one day tout the gritty "truth" he brought to the treatment of his silent film Underworld, and he blamed Sternberg for adding sentimental touches. But the film itself harkened back to a more innocent time, and compared to Scarface, it illustrates not just the contrast between silent versus sound movies, but between the days of ward bosses and thugs versus the modern era of crime syndicates, and between a world as yet untouched by world war versus one that was shaped by it. ${ }^{165}$ Sternberg, who would go on to make the Paramount-Ufa coproduction The Blue Angel, was Hollywood's ambassador of German Expressionism, and he shot Underworld, to Hecht's chagrin, entirely in Paramount's studios. This was the Chicago of the auteur's imagination, simply "a great city in the dead of night." The realism that Dreiser, the White Chapelers and others had brought to corruption and violence was missing. Clarens 
contends that "Hecht had been betrayed, not by Sternberg as he thought, but by silence." 166

But Jonathon Munby has argued that the arty mis-en-scene of silent-era gangster films reflected a nativist reaction to masses of poor immigrants who had flooded American cities, "part of a general middle-class moral crusade to both redeem and stigmatize the ethnic ghetto." The movies, he suggests, were a projection of a policy of containment anchored in Prohibition. But after the crash of 1929, the bootlegging gangster of the movies broke free from the old restraints, establishing a new connection with the speakeasy crowds of urban moviegoers. "When the gangster eventually spoke, he relocated the desires of his community in a specific body politic. ... A space of cultural containment was turned into something more rebellious." ${ }^{167}$

Chicago was a city of extreme wealth and poverty, fantastic energy and growth, disorder and lawlessness. Commentators linked the city's aggressive capitalism with its underworld, and with the rise of a new breed of entrepreneur. In pulp stories and popular biographies of Capone, Big Jim Colosimo’s reign under the sponsorship of Hinky Dink and Bathhouse John was told as a rags-to-riches Horatio Alger story. "His career was built on traditional crimes, limited to a long-standing old vice district, rooted in a villagelike community, and supported by patrons reminiscent of a colorful but fading past," explained David E. Ruth in Inventing the Public Enemy. ${ }^{168}$

Colosimo's execution and replacement by John Torrio was portrayed as an old order pushed aside when Prohibition transformed urban crime into big business. Torrio is the efficient manager, the refined businessman, yet his hold on power is nevertheless short-lived. The various accounts of how Capone usurps Torrio suggest that to be king of 
the underworld, business acumen is not enough: masculinity_-brawn coupled with fearlessness - are also part of the right stuff. The stories of how Capone knocks out his North Side rivals, however, tell us that guts and toughness must be tempered by the cool rationality of the businessman. Dion O'Banion and Hymie Weiss were bold and smart, but fatally hotheaded. In the end, they both fail to "play it smart": Caught up in their own passion and bluster, they commit the mistakes that are their undoing. ${ }^{169}$

Scarface was the dark side of Erik Dorn's organization-man efficiency. In his biography of Cohen, Hecht explained:

A new type of industrialist entered American business - the illegal booze maker, and a new type of salesman hit Chicago. They hit it with brass knuckles and Tommy guns in a selling campaign that makes even our present day television commercials seem tame. Rival salesmen operating foolishly for other bosses than Capone were massacred. Customers, café owners and saloon proprietors inclined to shop around for alky products were pistol-whipped and left comatose in their wrecked premises. And the voters of Chicago grinned and drank. Their contempt for the Prohibition law was deeper than their penchant for law and order. ${ }^{170}$

Pasley saw Capone as a "self-made man," a heroic figure, like Henry Ford, Charles Lindbergh or Douglass Fairbanks. "If he had only been honest, what a hero he would have made for a Horatio Alger tale," said one city official whom Pasley quoted. In a scene in Scarface that mimics The Great Gatsby, Camonte piles shirts upon his bed to impress his blonde-headed moll, Poppy. Camonte is a post-crash "a parody of the American Dream...a psychopathic Horatio Alger...a reproach to both the principles of the market place and the reigning values of American life," wrote Richard Pells. ${ }^{171}$

He was echoing Robert Warshow's “The Gangster as Tragic Hero,” which famously asserted: “The gangster is the 'no' to that great American 'yes' which is stamped so large over our official culture." A creature of the city, the gangster must rise 
and fall alone, "one must emerge from the crowd or else one is nothing." The audience cheers for the gangster's brutal rise and then cheers for the punishment that comes as a consequence. The gangster, as Romantic antihero, is ultimately doomed: "The final meaning of the city is anonymity and death."

In their cold-blooded lethality, the talkie-era gangster also appeared as a Frankenstein created by the Great War. Capone claimed that the scars on the left side of his face were wounds from fighting on the Western Front. Pasley believed Capone's service in Europe introduced him to the machine gun and gave him the upper hand in the bootlegging wars. Zanuck, a veteran himself, wove the war into his films, particularly as the issue that divides brothers Tom and Mike Powers in The Public Enemy.

But no film was more packed with war imagery than Scarface. After the slaying of the Big Jim Colosimo character, "Costillo," a city editor presents a dummy of the front page to his managing editor, who tells him it's rotten. “GANG WAR - That's what I want," the managing editor insists. "Costillo's the last of the old-fashioned gang leaders. ... There's a new crew coming in. ... They're gonna be shooting each other like rabbits from now till hell freezes for the control of the booze business. It's gonna be like war. Get that in the lead. WAR...GANG...WAR." One striking emblem of corporate and military power combined is Camonte's custom-made swivel desk chair, with its tall bullet-proof back made entirely of a plate of solid steel.

The most salient and iconic image of the entire film is the downtown flat Camonte converts into an urban fortress, replete with its own armory and steel window shutters fitted with slots for guns, where Camonte will make his last stand. Gangster chronicler Walter Noble Burns was also a historian of the Wild West, and he had portrayed the pre- 
war gangster, Colosimo, as natural inheritor of the Western outlaw tradition. Yet he could not avoid linking the cold efficiency of Capone's generation with the deadlier Western front of the more recent past. "Rather than agents of national continuity, the modern gangster was a product of a war which had fractured an understanding of a unified and progressive past,” wrote Smyth. “...The war and the government have taught (Capone) 'the fine art of murder', and have provided him with the tools and strategy of fighting another war."173

The postwar imagery characteristic of expressionism might be described as the darkest bits of the Romantic tale - the rampage of Frankenstein's monster, the curse of the ghostly ship in the "Rime of the Ancient Mariner"- distilled and then snapped off from the tale's beginnings, thus reflecting the fracture and dislocation that were the impacts of the war. Hecht's own imaginings were consistently expressionistic, from Erik Dorn's marooned soul to the demonic ventriloquist mannequin in his short story "The Rival Dummy.”

While Sternberg may have been the great Hollywood pioneer of this German style of filmmaking, it would take the advent of sound, and the American director Howard Hawks, to finally capture Hecht's unique blending of realism with Romanticism's architectonics and the phantasmagoria of expressionism. In departure from the somewhat stiff, unimaginative filming of Little Caesar and The Public Enemy, "Hawks went for violent chiaroscuro, tight grouping within the frame, and fluid, stalking camera movement," wrote Clarens. Munby suggests that in the way Scarface shows the world through Tony Camonte's distorted subjectivity to affect "a heightened realism," one might call it an attempt at "documentary expressionism."," 
Certainly Hawks appreciated Capone-Camonte as the "psychopathic Horatio Alger" of an expressionistic tale. He remembered that what first attracted him to Capone's legend was an notorious tale about him hosting a banquet for fellow mobsters at which he bludgeoned the guests of honor with a baseball bat. Capone's mood continued to darken as he spoke, until at last he concluded his address by bludgeoning the three guests of honor with a baseball bat. The Camonte of Scarface is a crazed Romantic egoist, narcissistic enough to stare up at a T.J. Eckleburg-like neon billboard for a travel agency and believe that the words "THE WORLD IS YOURS" are meant solely for $\operatorname{him}^{175}$

When Hawks convinced Hecht to work on the script of another gangster film by suggesting that this one would be different - the story of the Borgias set down in Chicago-Hawks was likely thinking of the image of domestic bliss that Capone was so proud of presenting to the media with his family. Within this context, the incestuous connection between Camonte and his sister Cesca, written into Hecht's script as a retelling of Lucrezia Borgia's alleged romance with her brother Cesare, is another representation of the perversion of the American dream, like Camonte's tossing of the shirts onto his bed. ${ }^{176}$

The Hays Office of censorship was determined to suppress the film's suggestions of incest, and little of the Borgia theme in Hecht's script survived in the final cut. Just enough remains to sketch the contours that lead to Tony's final downfall: his jealousy over his sister that leads him to kill her lover Rinaldo, after which he retreats to his fortress, where he soon finds that the police have him surrounded. 
"The finale will be grandly operatic," Clarens observed. The Camonte siblings reunite "like desperate, guilty lovers" in a suicidal bid to fend off the invading army of law enforcement. Cesca, who had come to avenge Rinaldo but cannot bring herself to kill her brother, now becomes his moll: "I'm like you," she says as she loads his guns, "You're not afraid, are you?" Her hysterical laughter, rising amidst this "Liebestod of searchlights and gunfire" is bluntly cut short by a bullet that ricochets off one of Tony's much-vaunted steel shutters, a symbol to him of his invulnerability. As she falls, he is suddenly lost. ${ }^{177}$

The room, trembling from explosions, fills with tear gas. He staggers through the smoke - "a mad, disheveled creature"—and then outside, where he makes one final desperate run, only to be shot down in the gutter. As the last of his life runs out of him, flashing neon illuminates his grimy face. The camera tilts upward to show, through Camonte's final gaze, the Cook's Tours sign: "THE WORLD IS YOURS."178

The tragedy of Camonte, critic Robin Wood pointed out, is his "terrible innocence," or savagery, which is apparent at every turn. As a businessman, Camonte wants a secretary, but the thug he chooses for the job fears the telephone, wants to smash or shoot it, and can only grunt and curse into to its mouthpiece. Camonte tries to take in a play at the theater with his capos, but he must leave to carry out a hit in the middle of an act, and receives a hopelessly garbled report of how the story ends from his lackey Angelo. Camonte goes fishing with a group of sophisticates in Florida, but when he struggles to reel in his line, Angelo ruins things again by blowing the fish apart with a pistol. ${ }^{179}$ 
In these and other scenes, "we are made to feel the frightening discrepancy between the achievements of civilization and the actual level of culture attained by the individuals who are its by-products," Wood observed. It is Camonte's innocence, his lack of awareness, that permits him to kill and ransack, or murder his sister's husband in a jealous rage. The savage, primitive gangster stands as a reminder of humankind's true nature, and of the Enlightenment's failure to produce a modern, civilized world. ${ }^{180}$

Tony Camonte's “terrible innocence” is an inversion of Hilding Johnson's Huck Finn-like innocence, just as the gangster's incestuous family life and twisted American Dream is an inversion of Johnson's dream of a future in New York with his new bride. In Camonte, what seems good, or at least charming or amusing, is really bad, whereas Johnson's “wickedness” is really his goodness. As opposites, a yin and a yang, Hecht's gangster and reporter are twinned. Their duality, in turn, reflects the dual natures at war within each of them respectively, Camonte's paradoxical "terrible innocence" and Johnson's “lusty, hoodlumesque” yet childlike nature.

Hecht found such contradictions in character and moral ambiguity to be the very stuff that made stories interesting. The perversities of human nature and their consequences were what drove him as a writer, which is why he set out to write a film containing “only villains and bawds.” As Jeffrey Brown Martin pointed out, "What Hecht manages to do in his best work...is to make the audience sympathetic to a protagonist who is essentially an unsympathetic individual. He does this in part by making him the best person in the universe of the work." He rebelled against the studio's insistence upon two-dimensional good guys and bad guys, later remarking that he spent more time in Hollywood arguing than writing. ${ }^{181}$ 
Hecht's impulses as a storyteller carried over into the way he conducted his life. He loved picture-stealing, hoaxing and double-crossing, indeed the whole bad-boy, rulebreaking ethos of Chicago newspapers. He loved it even more when ASNE, university professors and others condemned this kind of journalism and worked to eradicate it. $\mathrm{He}$ grew attracted to criminals and gangsters because he saw them as fundamentally more innocent and honest than the lying, thieving politicians who sponsored them, and because he saw himself as a kind of journalistic and artistic renegade—a "pencil outlaw," as he once put it. By 1940, he was ultimately drawn to political activism, perhaps because this was something he had forbidden himself; certainly it was shunned by rule-abiding journalists. ${ }^{182}$ 


\section{CONCLUSION}

Just as Zanuck's gangster movies were hitting screens across America, a new hood arrived in Chicago whose readiness with a machine gun would soon attract attention. Assigned by Capone's outfit to protect a Jewish gambling joint on the North Shore, Mickey Cohen opened fire on three intruders before they even made it through the plate glass door, killing two of them. Cohen would later claim that after the North Side mob sprung him from jail, he was summoned to meet the boss himself at the downtown Lexington Hotel. ${ }^{183}$

Born in 1913, Meyer Harris Cohen received his first training as hustler and thug hawking newspapers on the streets of Boyle Heights, a mixed neighborhood to the east of downtown Los Angeles. Caught heisting a candy factory when he was seven years old, his brother enrolled him in a strict Hebrew school, but the rabbi sent him home after he "got into a beef" with another boy. At nine he was arrested for operating a still behind the family store — and for assaulting the police who were examining it.

As a newsboy, Cohen fought his way to the top corners of downtown Los Angeles, then hired out his fists for a brisk trade in protection. Two years after he won the local flyweight newsboy title, he headed East to box professionally. He also became involved in the rackets, in New York City, Cleveland, and then Chicago. ${ }^{184}$

As Cohen tells it, Capone immediately took a liking to him. If the meeting actually did take place, perhaps he impressed or amused the underworld king, or perhaps both. With his broken nose and a conspicuous scar under his right eye, the five-footthree-inch gunman had attracted notice because he looked like a miniature version of the boss. The fact that Cohen also chose to dress like Capone added to the effect. This turned 
out to work in his favor. "I soon found there were lots of older guys willing to teach me about how to grow up and be good at a particular piece of work I wanted to get to know about," he later recalled. ${ }^{185}$

When Hecht met Cohen in June 1947, the Jewish gangster could not have failed to remind Hecht of Capone, as well as of his own celluloid creation, Tony Camonte. Hecht would devote much of his later life to investigating his feeling of connection to gangsters, in writing Cohen's biography, his memoirs, and other works. Moreover, his friendship with Cohen would come to represent his own embrace of the Irgun, and the tenets of Zionist Revisionism that had spawned it. Theirs was a movement branded as "gangsterism," and defined, from the start, by a belief that at times the devil's bargain was the only means by which Jews could survive in a hostile world. This readiness to deal with the devil was unacceptable to the mainstream Zionists, who saw themselves as champions of the liberal ideals of the Enlightenment and regarded the Revisionists as fascists.

The massive and immediate responses to Hecht's militant propaganda indicate that his arguments had deep resonance with the American public. It is of secondary importance whether we see him as the creator of frames that the American press now uses to discuss Israel, or whether his propaganda simply reflects those frames that were in use when debates about Israel were first contested in the public sphere-debates over Israel's right to exist, its means of defending itself, and its accountability under international law.

The purpose here has simply been to show that ideas have strange bedfellows. In Hecht's case, his beliefs derived not from Zionism itself, nor from the Jewish religion, 
nor even from American Jewish culture. Rather, his creed grew out of the attitudes and practices of Chicago newspapermen during the Front Page era. I have tried to show how these reporters lived and what they thought, so that their story can be understood as an important chapter of the American experience. Their role in shaping modern media, the deep roots their story has in the nation's social and cultural past, helps explain why Hecht's ideas continue to have a hold on the American psyche today. Understanding his worldview allows for a more a critical appraisal of the rhetoric and politics it fostered, an appreciation of its underlying insights and value, but also of its fallacies and hazards.

\footnotetext{
${ }^{1}$ Ben Hecht, $A$ Child of the Century, 612. For the date of the event, which is discussed in Part IV, see "Witness Tags Cohen as Debt Welsher," Los Angeles Times, June 8, 1951, 1,4. The journalist Dean Jennings also cites May 24, 1948 as the date. Dean Jennings, "Mickey Cohen: The Private Life of a Hood, Conclusion," The Saturday Evening Post, October 11, 1958, 118.

2 "Speeches: Delivered at Slapsie Maxie's (sic) - financed by Mickey Cohen," in "Works, 19081983” Box 27, Folder 683.

${ }^{3}$ Hecht, Child, 612.

4 "Memorandum for Mr. Ladd. Information Furnished by Informants and Developed in Connection with the Crime Survey Program." Federal Bureau of Investigation, "Meyer Harris Cohen," file 62-HQ-89947, p. 88.

5 "There are new playboys in America..." advertisement of Habonim, an American Zionist organization supporting the Haganah, quoted in R.M. MacColl, "Hecht's Holiday-Britain Protests," Daily Express, 20 May, 1947, 1. The British press called Hecht... Associated Press, "British Press Brands Hecht As 'Public Villain No. 1,'” The Free Lance-Star of Fredericksburg, Virginia, May 31, 1957, 1-2. http://news.google.com/newspapers?nid=1298\&dat=19470531\&id= ZKQwAAAAIBAJ\&sjid=1ooDAAAAIBAJ\&pg=2349,5724745. Even Louis Rapoport... Louis Rapoport, Shake Heaven \& Earth: Peter Bergson and the Struggle to Rescue the Jews of Europe (New York: Gefen Pub. House, 1999), 203. Mike Wallace was among those... quoted in Troy, From Literary Gadfly, 121, 158. Troy quotes from an October 1, 1963 episode of "Personal Close-up," which Wallace produced daily for CBS Radio. Though Troy cites the Newberry Library archive, the transcript or audio is no longer listed in the finding aid.

${ }^{6}$ Rapoport, Shake Heaven, 203.

7 "I don't feel called upon..." "Hecht—-terrorist at a distance says Zionist chief," Daily Express, May 22, 1947, 1. "Knockin' their own proposition..." Hecht, Child, 610.

${ }^{8}$ Robert Schmuhl, "History, Fantasy, Memory: Ben Hecht and a Chicago Hanging," Illinois Historical Journal 83 (Autumn 1990): 155.

${ }^{9}$ Hecht, Gaily, Gaily, 183. Six of the nine stories in this volume were originally published in Playboy, after Hecht first submitted "The Fairy" in the summer of 1961. He tightened and polished some of the stories significantly for the book. See Schmuhl, 154-155. Fetherling, Five Lives, 172-173.

${ }^{10}$ The phrase "born perversely," attributed to Hecht, comes from Harry Hansen, Midwest Portraits: a Book of Memories and Friendships (New York: Harcourt, Brace and company,
} 
1923), 320. Hansen quotes it from his copy of a paragraph that Hecht wrote about himself, originally requested by another critic or editor.

${ }^{11}$ Norman Howard Sims, The Chicago Style of Journalism (PhD dissertation, University of Illinois at Urbana-Champaign, 1979), 24, 261-266; Bruce J. Evensen, “Journalism's Struggle over Ethics and Professionalism During America's Jazz Age," Journalism History 16, no. 3-4 (Autumn-Winter 1989): 54-63.

${ }^{12}$ Ben Hecht and Charles MacArthur, The Front Page (New York: Covici-Friede, 1928), 28. Near the end of Act II editor Walter Burns barks over the phone: "Duffy! Send down word to Butch McGuirk I want ten huskies from the circulation department to lam right over here..."

${ }^{13}$ For the earliest and most detailed accounts, see Ferdinand Lundberg, Imperial Hearst; a Social Biography, (New York: The Modern Library, 1936) 151-164, 391; Elizabeth Dewey Johns, Chicago's Papers and the News (Unpublished Ph.D. dissertation, University of Chicago, 1942), 2-54; and Wayne Andrews, "Quite a Croquet Game" and "Cold-Blooded Murderers," in Battle for Chicago (New York: Harcourt, 1946), 232-241, and 262, 285-286. See also W. A. Swanberg, "The .38 Caliber Circulation Drive" in Citizen Hearst, a Biography of William Randolph Hearst (New York: Scribner, 1961), 270-271, 274; and Stephen Longstreet, Chicago, 1860-1919 (New York: McKay, 1973) 240, 454-456. For accounts of the newspaper war in memoirs, see Burton Rascoe, Before I Forget, First edition. (Garden City, N.Y: Doubleday, Doran \& Company, Inc, 1937), 268-276; George Murray, The Madhouse on Madison Street (Chicago: Follett Pub. Co, 1965) 41-54; and Vincent Starrett, Born in a Bookshop: Chapters from the Chicago Renascence, 1st ed. (Norman: University of Oklahoma Press, 1965) 78. Describing the growth of protection rackets after the end of the circulation war, Rascoe explains in detail how "out of the Hearst publishers hiring the Annenbergs and their gunmen and sluggers to cripple competition in the newspaper sales, grew the worst reign of lawlessness in Chicago that any city has ever known" (p. 271). For a subsequent look back from a Chicago paper, see Steve Mills, "Vending Violence in a '.38-Caliber Circulation Drive,"' Chicago Tribune, June 8, 1997. Tribune editor James Keeley provided a detailed description of the circulation war to a Senate committee at hearings in Chicago on Jul 26, 1911. See "Election of William Lorimer, Senator from Illinois, hearings 9 vols." Senate document No. 484, Committee on Privileges and Elections, 62nd Congress, $2^{\text {nd }}$ session, April 12, 1912, S2054-6, 2072-4.

${ }^{14}$ Andrews, Battle for Chicago, 232. The casualty figure comes from the 1921 testimony of Chicago Tribune publisher Robert Rutherford "The Colonel" McCormick, when his paper was sued by the Journal of Commerce for obstructing newsstand sales. Max Annenberg also gave vivid testimony. See Journal of Commerce Publishing Company vs. The Tribune Company et al., Transcript of Record, United States Court of Appeals, Seventh District, October term, 1921. No. 3116, 75, 557, 892-893, 728-729, 730, 703. As noted, the Daily Socialist and Daily World offer the only immediate accounts of the violence. None of their articles include a grand total of the deaths. John Cooney has pointed out that McCormick's figure refers to newboys: There is no estimate for the number of street soldiers killed. John Cooney, The Annenbergs (New York: Simon and Schuster, 1982), 37. After the scandal that erupted over the murder of Tribune reporter Jake Lingle, McCormick denied that his paper had been involved in the circulation war. Andrews, 285. On Jake Lingle, see above, p. 68, and footnote \#159.

15 "Reign of terror..." Lundberg, Imperial Hearst, 154.

${ }^{16}$ The Cambridge Companion to Dewey (Cambridge ; New York: Cambridge University Press, 2010) 26. Quoted in Matthew C. Ehrlich's chapter on The Front Page in Journalism in the Movies (Urbana: University of Illinois Press, 2004), 24.

${ }^{17}$ Matthew Ehrlich, Journalism in the Movies, 22; Wayne Klatt, Chicago Journalism: a History (Jefferson, N.C: McFarland \& Co, 2009), 77. With the launch of Hearst's Chicago Morning American on May 2, 1902, there were ten dailies in town. When the full-blown war erupted in 1910 , there were eight papers. By the time it was over, there were only six. 
${ }^{18}$ There is compelling evidence that as a boy, Hecht was very nearly caught in that catastrophic fire. His brother Peter Hecht wrote to biographer William MacAdams that their mother had taken her two boys to see the performance. However, she refused to pay the full price for three tickets, since she planned to keep Peter on her lap, and instead, they went to the McVickers Theater to see Busy Izzy. After their father arrived at the Iroquois to collect them, he spent a frantic afternoon and evening searching for them among the burned corpses. Surviving documents offer some support for Peter Hecht's story: Matinee performances of Busy Izzy were indeed appearing in Chicago theaters at the time: theater programs for them can be found in the Chicago Public Library. Letter from Peter Hecht to Stephen Fuller (aka William MacAdams), pp. 7-8 of an undated 8-page letter, Folder No. 141, MacAdams Collection, BHNL. For Busy Izzy theater programs from the period, see the digital Chicago Theater Collection-Historic Programs at the Chicago Public Library: http://digital.chipublib.org/cdm4/ browse.php?CISOROOT $=\% 2$ FCPB01\&CISOSTART $=61,1281 \&$ CISOSORT $=t i t l e \% 7 \mathrm{Cr}$ ${ }^{19}$ Klatt, Chicago Journalism, 72-74, 83.

${ }^{20}$ Doug Fetherling, The Five Lives of Ben Hecht (Toronto: Lester and Orpen, 1977) 21.

${ }^{21}$ Hecht, Child, 156.

${ }^{22}$ Larzer Ziff, The American 1890s; Life and Times of a Lost Generation (New York: Viking Press, 1968), 152.

${ }^{23}$ Sims, The Chicago Style of Journalism, 24, 29-33, 41. Michael Schudson has argued that two distinct models of journalism had emerged by the early twentieth century. Joseph Pulitzer's World and William Randolph Hearst's Journal exemplified "the story model," which put a premium on storytelling and entertainment, and traded in sensationalism. By contrast, the New York Times exemplified "the information model," which stressed facts and objectivity, and sought respectability and credibility. As discussed later in Part I, by the time Hecht and fellow Chicago press veteran Charlie MacArthur were writing The Front Page, the information model was setting the standard, and the play would celebrate a wicked, disreputable Chicago style thereafter referred to as "Front Page journalism." Michael Schudson, "Stories and Information: Two Journalisms in the 1890s," in Discovering the News: a Social History of American Newspapers (New York: Basic Books, 1978), 88-120.

${ }^{24}$ Ehrlich, Journalism in the Movies. On mythmaking about journalism in the movies: 5-7; on the "outlaw hero" versus the "official" journalist-hero: 8-9. "The Front Page crystallized the outlaw vision of the press while expressing ambivalence toward it": 13.

${ }^{25}$ Gil Troy, in his 1982 thesis on Hecht, wrote: "Expressionism, Decadence, Symbolism, Dadaism, Radicalism, Bohemianism and the other 'isms' that shaped Hecht and his times were basically reactive. They negated what existed without offering alternatives. Many seemed to be motivated by some idyllic past rather than a visible future. In the absence of an affirmative vision they often degenerated into litanies of cynical, superficial and meaningless negation." Troy was an undergraduate when he wrote this, but a remarkably precocious one, and his comments are emblematic of the fact that Romanticism is the forest that those who have studied Hecht have lost from the trees. It's true that Hecht lived through a time when there was an eruption of literary experimentation and that he dabbled in many different styles, but critics have been unfair when they have insinuated that he was rootless and rudderless. Expressionism, Decadence, Symbolism, Dadaism, Radicalism, Bohemianisms and other "isms" may have been reactive, but they also all owed a debt to the original Romantic Movement. To the extent that he experimented, he was expressing himself as a romanticist. As for whether these styles "negated without offering alternatives," the same can be said of Romanticism itself, which can be understood as a loose constellation of principles rooted in basic truths nevertheless. Troy, From Literary Gadfly, 23-24. 26 "Rejected the earlier philosophy of the Enlightenment..." "Literary Terms and Definitions," the website of Dr. L. Kip Wheeler, http://web.cn.edu/kwheeler/lit_terms_R.html; “... asserts the unique nature..." Wheeler, "Literary Terms and Definitions"; "a turning in upon the self..." 
Encyclopedia Britannica Online, s.v. "Romanticism," accessed October 1, 2013, http://www. britannica.com/EBchecked/topic/508675/Romanticism. See also Chris Baldick and Oxford University Press, The Oxford Dictionary of Literary Terms, 3rd ed, (Oxford ; New York: Oxford University Press, 2008), http://proxy.mul.missouri.edu:3443/views/ENTRY.html?entry=t56.e131 \&srn=1\&ssid=228167676\#FIRSTHIT; J. A. Cuddon, The Penguin Dictionary of Literary Terms and Literary Theory, 3rd ed (London: Penguin, 1992); The Routledge Dictionary of Literary Terms, (London; New York: Routledge, 2006).

${ }^{27}$ Hecht, Gaily Gaily, 186.

${ }^{28}$ Scarface, the Shame of the Nation, directed by Howard Hawks (1932; Universal City, CA: Universal Cinema Classics, 2007), DVD. The bound screenplay credited to Hecht and stored at the Newberry Library does not include these lines: Evidently they were added in a subsequent rewrite or during production. Regardless, while Scarface cannot be said to be a nuanced portrait of a sociopath, the whole point of Tony Camonte's relationship with his sister Cesca, and for that matter, of the Borgias-family theme, is to suggest the dual nature of the protagonist. The 1983 Brian De Palma-Oliver Stone remake makes the point even more obvious: In that version, Tony seals his own doom through an act of conscience, when he refuses to carry out a hit because it would also involve killing the target's wife and children in the process. Hecht, "Scarface/dialogue-continuity by Ben Hecht" (1932?), Newberry Library Special Collections $4^{\text {th }}$ Floor, Case folio PS3515.E18 S32.

${ }^{29}$ Hecht and MacArthur, The Front Page, 40-41.

${ }^{30}$ Taken from Klatt, Chicago Journalism, 116. Eddie Doherty, Gall and Honey; the Story of a Newspaperman (New York: Sheed \& Ward, 1941), 44-46.

31 "Most of my material came by word of mouth, and was checked for dates and details against old files and various newspapers," explained George Murray in his brief acknowledgments. "It would be impossible to name all the storytellers, but Harry Romanoff, John Dienhart, and Edward (Dynamite) Sokol cannot be overlooked." Murray's Madhouse is typical of these memoirs: In Dateline Chicago, William T. Moore introduces an anecdote by debating with himself about whom he should credit as the original storyteller, Walter Howey or his protégé, Frank Carson. Murray, Madhouse, vi. William T. Moore, Dateline Chicago: a Veteran Newsman Recalls Its Heyday, 1st ed. (New York: Taplinger Pub. Co, 1973) 116.

${ }^{32}$ Klatt, Chicago Journalism, 1. Hecht's flair for self-invention is evident at least as early as 1922, when he did the publicity for his first book, Erik Dorn. An interview with the New York Morning Telegraph seems to corroborate his accounts in Child of the Century of early careers as a violinist, trapeze artist and newspaper picture thief, except that he told the Telegraph that he had played the violin while standing on his head, shipped himself back by freight from his circus adventures, and later talked his way out of being shot at sunrise while a foreign correspondent in Berlin. Roy L. McCardell, "Ben Hecht—Literary Huck Finn," Morning Telegraph, April 30, $1922,1$.

${ }^{33}$ Starrett, Born in a Bookshop, 75, 79-80. Theodore Dreiser, Newspaper Days, 7th ed. (New York: H. Liveright, 1931), 153-154. Starrett also started as a picture chaser, for Inter-Ocean in 1906. One of the early newspaper films was Picture Snatcher, starring James Cagney. Picture Snatcher, directed by Lloyd Bacon (1933, Burbank, CA: Warner Home Video, 2008), DVD.

${ }^{34}$ Sims, The Chicago Style of Journalism, 34-39; “... an unrecognizable deceit,” ibid, 39.

${ }^{35}$ Klatt, Chicago Journalism, 4. Starrett, Born in a Bookshop, 73.

${ }^{36}$ Schudson, Discovering the News, 69.

${ }^{37}$ Sims, The Chicago Style of Journalism, 260.

${ }^{38}$ Ibid, 216-217, 219. Alfred Lawrence Lorenz "The Whitechapel Club: Defining Chicago's Newspapermen in the 1890s," American Journalism 15, no. 1 (1998): 83-102. Richard DigbyJunger, "The Chicago Press Club: The Scoop Behind the Front Page," Chicago History 27, no. 3 (Winter 1998-99): 42-53. 
${ }^{39}$ Sims, The Chicago Style of Journalism, 220-221; Lorenz, "The Whitechapel Club," 85-86. There are some minor discrepancies between these accounts: According to Sims, the club was first formed in 1887, not in the summer of 1889. Lorenz describes a pane of stained glass at the transom with a skull and crossed bones and the legend: "I, too, have lived in Arcady." Sims relates that in later years, there was a ceremonial goblet in the upstairs bar-the skull of a wellknown prostitute who had worked the docks, engraved with the inscription, "I, too was born in Arcadia." Lorenz drew from a "Whitechapel Nights," a 36-part series by Hecht's former supervisor at the Daily News Charles H. Dennis, who was not a member himself, but was city editor at the Morning News when the club started.

40 "...not in any sense reformers..." clean-shaven rebels, "sharpshooting," Lorenz, "The Whitechapel Club," 87, 93; “...harum-scarum irresponsibles...” Sims, The Chicago Style of Journalism, 223.

41 "Not only did they have to deal..." on Opie Read and the Whitechapel style, Sims, The Chicago Style of Journalism, 217, 242-246; “....men who insisted," Ziff, The American 1890s, 165.

${ }^{42}$ Ziff, The American 1890s, 164-165.

${ }^{43}$ Martin Mayer, Making News, 1st ed (Garden City, N.Y: Doubleday, 1987), 46; “....its iron discipline..." A. A. Dornfeld, Behind the Front Page: The Story of the City News Bureau of Chicago (Chicago, Ill: Academy Chicago, 1983), xiii.

${ }^{44}$ On the commercial imperative of accuracy... Dornfeld, Behind the Front Page, 51-52, 69-71; on the twentieth-century challenges, pneumatic tubes and leg men... A.A. Dornfield, Behind the Front Page, 27-28, 55-61, 74, 89, 90. Tribune writer Bill Granger vividly recalled that decades later, when he was a copy boy at the Daily News, violent summer thunderstorms would flood the tube system with river water that would then gush into the city room, creating a soggy, chaotic mess. The City News Bureau finally stopped using the tubes in 1961. Bill Granger, "Sitting on a Big Story at the Daily News," Chicago Tribune, April 16, 1992.

http://articles.chicagotribune.com/1992-04-16/features/9202030927_1_chicago-tunnel-tubechicago-river

${ }^{45}$ Drieser, Newspaper Days, 148, 152-153.

${ }^{46}$ Sending rival reporters on wild goose chases... A.A. Dornfeld, Behind the Front Page, 39; Harry Romanoff's impersonations, A.A. Dornfield, Behind the Front Page, 119-120; Frank Carson's staged collision and the Ruth Randall diary, Murray, Madhouse, 189 and Klatt, Chicago Journalism, 125; for background on the Ruth Randall story, see Ben Hecht, The Front Page: From Theater to Reality, ed. and with an introduction by George W. Hilton (Hanover, NH: Smith \& Kraus, 2002), footnote \#170, 153-155.

${ }^{47}$ Trial eavesdropping, at Loeb-Leopold trial, Dornfeld, Behind the Front Page, 137; and Fred A. Smith, Klatt, Chicago Journalism, 68, 131-132.

${ }^{48}$ Starrett. Born in a Bookshop, 101.

${ }^{49}$ What one media critic... David T. Z. Mindich, Just the Facts: How "Objectivity" Came to Define American Journalism (New York: New York University Press, 1998). 1; a textbook from 1911... Mindich, Just the Facts, 116; “...neutral observers, not participants...," Fred Fedler, Reporting for the Media, 8th ed. (New York: Oxford University Press, 2005), 66. The media critic Mindich quotes in Jon Katz, "No News Is Good News." Hotwired, October 27, 1996. http://www.hotwired.com/

${ }^{50}$ John J. McPhaul, Deadlines \& Monkeyshines: The Fabled World of Chicago Journalism (Englewood Cliffs, N.J: Prentice-Hall, 1962), 19; the phenomenon of the super-sleuth should not be surprising..., Murray, 105; Buddy McHugh's career and reputation, Dornfeld, Behind the Front Page, 133-134; inspiration for Buddy McCue in Hilton, From Theater to Reality, 43 and footnote \#9, 58-59; Romanoff and the doll... Hilton, From Theater to Reality, footnote \#169, 152-153. 
${ }^{51}$ The sheriff's department swore in deputies... Dreiser, Newspaper Days, 77-78; Frank Carson, the "muscle journalist," arrest in Wisconsin... May Mann, Going Hollywood column, The Ogden Standard-Examiner (Ogden, Utah), December 5, 1940, 9; "Muscle Journalist," (obituary) Time, March 31, 1941, 40; Murray, Madhouse, 194-201; by the mid-1920s, police provided... Klatt, Chicago Journalism, 119. According to Mann's "Going Hollywood" column, Carson "kidnapped people, tapped wires... burglarized houses for evidence armed with phony warrants, strong-armed his way through impassable barriers by means of fake police badges, and generally practiced the type of headline-smashing journalism alongside of which Hecht and MacArthur's 'Front Page' seems like a vehicle for Donald Duck." True or not, Klatt, Murray and others have relayed this information as history. Theodore Dreiser's first reporting job was with the Globe, owned by Michael Cassius McDonald, who established a gambling syndicate and kept the Democratic Party machine well-oiled with graft. For the sake of a good story, reporters Finley Peter Dunne and George Weber, got themselves sworn in as deputy sheriffs to raid McDonad's gambling joints. Since the Globe existed to maintain and protect McDonald's position, Dreiser and other reporters were deployed to retaliate against the assets of the rival Republicans. Dreiser's target was the mock auction shops downtown, which operated with police collusion.

52 “...profane romanticist...” "Hearst's Howey,” Time, June 17, 1935, 36; “... it isn't that kind of heart..." Doherty, Gall and Honey, 65. Another Howey line was, "When a Hearst paper gets sick, they call me in, and I make it sicker."

${ }^{53}$ Ben Hecht, Charlie: The Improbable Life and Times of Charles MacArthur, 1st ed. (New York: Harper, 1957) 49-50; Klatt, Chicago Journalism, 112. Hecht was supposed to have said you could always tell which eye was glass because it was the warmer one. Pauline Kael, The Citizen Kane Book, 19. The 1935 article in Time cited above describes a hand-held device with an electric eye on one side and a speaker on the other side. Once a photo was scanned by the eye, the device could be screwed on to a telephone receiver to transmit electronic signals for a printout: In other words, Howey invented the fax machine.

${ }^{54}$ Klatt, Chicago Journalism, 88; “... burglary, bribery and tireless sleuthing," "Hearst's Howey," Time.

55 "Walter C. Howey, Boston Editor, 72," New York Times, March 22, 1954. Hecht also describes Howey's blackmail in Charlie, 50.

${ }_{57}^{56}$ Murray, Madhouse, 178.

${ }^{57}$ Ibid, 3.

${ }^{58}$ Chris Ogden, Legacy: a Biography of Moses and Walter Annenberg, 1st ed. (Boston: Little, Brown, 1999), 44-45; Lundberg, Imperial Hearst, 140; a network of tipsters... Klatt, Chicago Journalism, 79. According to McPhaul, "Figuratively, a Journal man would take a trolley to a crime scene and two Hearst men would pass him en route in a taxi." Deadlines \& Monkeyshines, 113.

${ }^{59}$ Chicago has nine dailies in $1900 \ldots$ Klatt, Chicago Journalism, 77, 83; the rough handling of newsboys was nothing new... Joyce Milton, The Yellow Kids: Foreign Correspondents in the Heyday of Yellow Journalism, 1st ed. (New York: Harper \& Row, 1989), 43. Mickey Cohen's battles as a West-Coast newsboy are discussed at the end Part I and in more detail in Part IV. An article on May 6, 1912 in the Daily Socialist noted Max Annenberg's "flaming red sweater" and "soft cap" pulled low over his brow, quoted in Lundberg, Imperial Hearst, 158-159.

${ }^{60}$ Andrews, Battle for Chicago, 232-241; Lundberg, Imperial Hearst, 149-162; Murray, Madhouse, 41-54; Ogden, Legacy, 41-56.

${ }^{61}$ Rose Keefe, Guns and Roses: The Untold Story of Dean O'Banion, Chicago's Big Shot Before Al Capone (Cumberland House Publishing, 2003), 77.

${ }^{62}$ Wayne, Battle for Chicago, 234, 238-9; Lundberg, Imperial Hearst, 153-154; Ogden, Legacy, 49; Cooney, The Annenbergs, 36. Max Annenberg testified that at the height of the circulation wars, the papers had a total altogether of about sixty thugs on their payrolls. Both Enright and 
Stevens were referred to in the press as "dean of Chicago gunmen," "Moss Enright Slain in Labor War, Tim Murphy Held for Quiz," Chicago Tribune, February 4, 1920, 1; "Chicago Gangster Defies Tradition, Dies of Pneumonia," Decatur Evening Herald, February 16, 1931, 1. “...the most brutal gunman ever to pull a trigger...," quoted in Keefe, Guns and Roses, 118. In Child of the Century, Hecht recounts being confronted in the middle of the night by two of Al Capone's hoods about his script for Scarface. Hecht assures them, "I don't even know Al," and then warms them up by telling them it's about some of the gangsters he knew from years back. "I also knew Mossy Enright and Pete Gentleman," he says. Hecht, Child, 486-487. "Big Tim" Murphy became successful as a bookmaker with then-partner Mont Tennes before establishing one of the city's most powerful Irish American gangs after 1910. After likely killing Enright in 1920 he became one of the leading Irish gangleaders during the Capone era, but was shot and killed on June 26, 1928 , perhaps by associates of Enright's.

${ }^{63}$ Lundberg, Imperial Hearst, 162-163. Lundberg relates that O'Banion worked as "chief circulation agent" from 1917 to 1922, whereas Keefe, in Guns and Roses, has him working as circulation agent from 1910 to 1920. Both Hecht and MacArthur considered O'Banion a friend, and told many fond tales about him. Hecht continued to find him a favorite subject throughout his life. Starting in 1959 and up until weeks before Hecht died, he was writing a Runyonesque musical with O'Banion as the hero, Chicago Days. O'Banion's friends "Hymie" Weiss and George "Bugs" Moran succeeded him as leaders of the North Side Gang, which survived as the leading rival to Capone during Prohibition. Weiss, whose real name was Henry Earl J. Wojciechowski, fell to Capone's bullets in 1926. Moran was then targeted in the Saint Valentine's Day Massacre, which he narrowly eluded. Another friend of O'Banion was the Jewish gangster Nails Morton. For examples of anecdotes about O'Banion, see Ben Hecht, Charlie: The Improbable Life and Times of Charles MacArthur, 1st ed. (New York: Harper, 1957), 12-13, 20, 76. Herald-Examiner reporter Edward Dean Sullivan related a tale that would become legend of the motorcycle chaperone and gallant, life-saving protection that "circulation slugger" O'Banion provided for coverage of a July 1919 race riot. Edward Dean Sullivan, Rattling the Cup on Chicago Crime (Freeport, N.Y: Books for Libraries Press, 1971) 1-7. 64 "Nobody moved..." Robert J. Casey, Bob Casey's Grand Slam (Indianapolis: Bobbs-Merril, 1962), 22; "...a screaming woman running down the street with her throat cut..." quoted in Hecht, Child, 144.

${ }^{65}$ Sims, The Chicago Style of Journalism, 264-265.

${ }^{66}$ Dornfeld, Behind the Front Page, 139.

${ }^{67}$ Ernest Hemingway, A Moveable Feast: The Restored Edition, 1st Scribner hardcover ed. (New York, NY: Scribner, 2009), 61.

${ }^{68}$ Larry Malm, see Hecht, Child of the Century, 137; Gaily Gaily, 74, The Chicago Literary Times 1: 17 (1 November, 1923): 8. Starrett, Born in a Bookshop, 78-9. Dreiser, Newspaper Days, 156-9. Hecht's litany, Child of the Century, 150-6. For more biographical information on Larry Malm, see Hilton, From Theater to Reality, footnote \#44, 78-9.

${ }^{69}$ Hecht, Charlie, 3, 19. MacArthur served with the Rainbow Division, a coalition of National Guard units that was the first deployed and saw some of the heaviest fighting of any American force during the war. According to longtime friend and fellow reporter Gene Fowler, he served as a colonel in the chemical warfare division during World War II. Gene Fowler, Skyline; $a$ Reporter's Reminiscence of the 1920s (New York: Viking Press, 1961), 37.

${ }^{70}$ Gene Fowler, Skyline, 5.

${ }^{71}$ Robert Schmuhl, "History, Fantasy, Memory," 155. Hecht, Child of the Century, 269.

${ }^{72}$ Hecht, Child of the Century, 537. In another passage, Hecht wrote: "As I grew older I fell away from Mencken. The pessimism at the bottom of his thinking was not in my nature. ... No pessimism was ever more thorough and serene than Mencken's. ... It was the pessimism of a surgeon with a steady hand who could not be seduced into admiring the disease he was 
attending — humanity. There came a time when Menckenian sanity deserted me. ... I was unable to stay reasonable and to view unreason with contempt alone. Compassion came to me, compassion even for the stupid, the hypocritical and the ugly." Child of the Century, 177-178.

${ }^{73}$ On his own youthful sense of invulnerability, ibid, 111-114. Seventeen hangings, ibid, 152. Playboy published the Fred Ludwig story, "The Fairy," and "Clara," which included the resurrection anecdote, in 1962. Both appeared in Gaily Gaily a year later. Ben Hecht, "The Fairy," Playboy, November 1962, 88, 90, 184-187. "Clara," Playboy, March 1962, 57, 88, 122124. Gaily Gaily, 1-13, 34-49.

${ }^{74}$ Hecht, Gaily Gaily, 209, 211.

${ }^{75}$ Arthur J. Bilek, The First Vice Lord: Big Jim Colosimo and the Ladies of the Levee (Cumberland House Publishing, 2008), 4453.

${ }^{76}$ Hecht, Gaily Gaily, 211. On the span of Bathhouse John's and Hinky Dink's rule of the First Ward, Bilek, The First Vice Lord, 268. See also Robert G. Spinney, City of Big Shoulders: a History of Chicago (DeKalb: Northern Illinois University Press, 2000), 151. "Era of 'Hinky Dink' and 'Bathhouse John," Electronic Encyclopedia of Chicago, 2005 Chicago Historical Society. http://www.encyclopedia.chicagohistory.org/pages/2408.html

${ }^{77}$ Hecht, Gaily Gaily, 212.

${ }^{78}$ Bilek provides a rich and well-documented account of the so-called Gangster Ball's rise and fall. See "First Ward Ball, 1896-1908," in The First Vice Lord, 67-77. Spinney, City of Big Shoulders, 156. In Gaily Gaily, Hecht claims that he attended some of these balls and wrote about them for the newspapers, but since by all accounts they were shut down in 1908, this would not have been possible.

${ }^{79}$ Michael Lesy, Murder City: The Bloody History of Chicago in the Twenties, 1 st ed. (New York: W.W. Norton \& Co, 2007), 306-7. Lloyd Wendt, Lords of the Levee; the Story of Bathhouse John and Hinky Dink, 1st ed. (Indianapolis, New York: Bobbs-Merrill Company, 1943). 294.

${ }^{80}$ On the Coughlin-Kenna system, Bilek, The First Vice Lord, 48-9. Hecht theorizing on the political consciousness of the citizenry, Gaily Gaily, 213-4.

${ }^{81}$ There was a common belief..., see for example Bilek, The First Vice Lord, 52. For examples of Hecht's efforts at "reform," see "Tale of the Murderer and Two Odalisques," in Child, 198-202 and "Clara," in Gaily Gaily, 34-49.

${ }^{82}$ Hecht, Gaily Gaily 185, 186.

${ }^{83}$ Ibid, 186-7.

${ }^{84}$ Renting a room in a brothel, Hecht, Child of the Century, 136-140; brothers Ignace and Manow, Child of the Century,146-7.

${ }^{85}$ Ibid, 142.

86 "The Negress" in Gaily Gaily, 17-33, originally appeared under the title "Queen Dido" in Playboy 9: 5 (May 1962): 55, 78, 134, 136, 138-140. "A Nigger Who Was Hanged," Ben Hecht, Broken Necks; Containing More "1001 Afternoons" (Chicago: P. Covici, 1926), 61-6. Robert Schmuhl's excellent study for the Illinois Historical Journal, "History, Fantasy, Memory: Ben Hecht and a Chicago Hanging," examines the real background of the story and how it evolved as Hecht told and re-told it over the decades, providing a case of how reality and fantasy, experience and imagination fused in the writer's hands. Although the local news of the early 1920s rarely carried bylines, Hecht likely covered the so-called "Abyssinian Affair" for the Daily News, and then started fictionalizing the events beginning with "A Nigger Who Was Hanged" in 1926. According to Schmuhl: "Contemporary accounts and historical studies report that on June 20, 1920, Grover Cleveland Redding, who called himself 'The Grand Exalted Mysterious Ruler of the Star Order of Ethiopia and Princes of Abyssinia,' rode horseback while leading a parade and demonstration on the city's South Side that culminated in the burning of two American flags. Violence broke out as the flags were being set on fire, leaving two men fatally shot and several 
other people injured." Redding confessed to one of the killings, and he and another member of the Abyssinian movement, Oscar McGavick, were convicted in the affair and sentenced to hang on June 24, 1921. Redding's career coincided with the return to Africa movement that Marcus Garvey began to promote in New York City between 1916 and 1920.

${ }^{87}$ Hecht, Gaily Gaily, 31-2.

88 "The Death of Henry Spencer" and "God Loses a Guest" in Hecht, Child of the Century, 255267. According to MacAdams, Hecht was hired at the Daily News in August 1914 to replace Harry Hansen, who was sent to Europe to cover the outbreak of the war. MacAdams does not cite a source for this information, but Hansen did indeed sail for France that July, according to a 1977 letter from his wife, Ruth McLernon Hansen. Some rare Journal articles that carry Hecht's byline, on file at the Newberry Library, also help narrow down when Hecht took his job at the Daily News: The latest Journal story is dated December 29, 1913. Regarding Hansen's departure date for Europe, see William Roba, "Harry Hansen's Literary Career," University of Iowa Libraries, Special Collections. http://www.lib.uiowa.edu/spec-coll/bai/roba.htm "Newspaper Articles, Chicago Daily Journal, 1912-1913," Works, Box 14, Folder 383a, BHNL.

${ }^{89}$ On meeting Mencken at the Republican National Convention, Hecht, Child of the Century, 178-9. On Hecht's letter to Mencken, Hansen, Midwest Portraits, 315. Hecht met Mencken in person three years after publishing his first short story in Smart Set, "The Unlovely Sin," in 1917. 90 "Divorces Ben Hecht: Wife Gets Decree in Chicago on Grounds of Desertion," New York Times, February 28, 1926; MacAdams, The Man Behind the Legend, 57. Gil Troy, From Literary Gadfly, 3. "Inventory of Ben Hecht Papers, Biography of Ben Hecht," BHNL website. http://mms.newberry.org/html/hecht.html These sources differ on the year of the marriage: MacAdams reports that it took place on November 28, 1915, the same year cited in the Newberry Library's biography on its finding-aid web page. Marie Armstrong Hecht told the New York Times that they were married in November 1916, which would have been the same month their daughter was born. Perhaps relying on this article in the Times, Troy gives 1916 as the year of the marriage. I am checking with Cook County's Vital Records office to ascertain the correct date.

${ }^{91}$ Letter from Peter Hecht to Stephen Fuller (aka William MacAdams), p. 6 of an undated 8-page letter, Folder No. 141, MacAdams Collection, BHNL.

${ }^{92}$ Hecht, Child of the Century, 269.

${ }^{93}$ Letter to Edgar Price Bell from Charles H. Dennis, January 27, 1919, "Dennis, C.H., 1919," Incoming Correspondence, Box 56, Folder 1183, BHNL. Letter from Hecht to Charles H. Dennis, February 1, 1919, Berlin, 1919, Subject Files, BHNL. Clearly Dennis and Hecht did not have an ideal working relationship. Dennis' letter to Bell begins, "I am sorry that Mr. Hecht has such difficulty in arriving anywhere," and continues in the same tone-indeed fretting about his general uselessness.

${ }^{94}$ Letter from Dennis, February 7, 1919, “Dennis, C.H., 1919,” pp. 1-2. Hecht, Child of the Century, 285.

${ }^{95}$ In 1920, Walter Lippmann and Charles Mertz undertook a careful examination of coverage and events to determine why American foreign correspondents had utterly failed to anticipate the Russian Revolution. They concluded that it was because of the press's overreliance on official sources. Walter Lippmann and Charles Merz, "A Test of the News," a special supplement to The New Republic, August 4, 1920, 1-41.

${ }^{96}$ See for example Richard J. Evans, The Coming of the Third Reich, 1st American ed. (New York: The Penguin Press, 2004), 73-76. Exploiting the threat of bolshevism becomes rolled in with the stories of the "November criminals" and the "stabbed in the back" legend circulated by German militarists and, within a few years, by the Nazis.

${ }^{97}$ Hecht, "All Berlin's Dreams of Utopia Shattered," Chicago Daily News, February 15, 1919, 2; Child of the Century, 275. Hecht recalled that he was snubbed by the foreign press, with their "high-class journalism." He was told by a British reporter named Rennick that he had been 
dropped from the Berlin Foreign Correspondents' Club. He had not been aware of the existence of such a club, but the news nevertheless depressed him. Child of the Century, 286-7.

${ }^{98}$ Ben Hecht, "Lenin Beat Germany, Says Commander Who Signed Russ Peace/Army Became 'Rotten With Bolshevism,' Gen. Hoffmann Declares," Chicago Daily News, March 13, 1919, 1.

${ }^{99}$ Ben Hecht, "Watches Reds Snipe Troops From Roofs," Chicago Daily News, March 11, 1919, 1; "Spartacan Captives 'Fell Like Dominoes," Chicago Daily News, March 15, 1919, 1. Hecht recounted the "White Terror" in Guide for the Bedevilled and Child of the Century. He recalled that at the bar of Adlon Hotel, he came upon a German guard slugging back one shot of brandy after another. After the guard explained that for three hours, he had manned a machine gun at Moabit Prison, mowing down three hundred men, women and children, Hecht had rushed out and climbed a tree with binoculars to witness the murder of the last of the two thousand prisoners. In Child, Hecht also recounted the Sparticist uprising that had sparked this crackdown. His companion that day at Alexanderplatz, the seasoned war correspondent Dick Little, had remarked that it was the strangest "battle" he had ever seen. Nine hundred rebels had summarily surrendered to the army with hardly a shot fired. According to historian Richard Evans: "Once the attempted coup had been defeated by a general strike, the Red Army was put down by Free Corps units, backed by mainstream Social Democrats and supported by the regular army, in what amounted in effect to a regional civil war. Well over a thousand members of the Red Army were slaughtered, most of them prisoners 'shot while trying to escape." Hecht, Guide for the Bedevilled, 72-4; Child of the Century, 290-1; Evans, The Coming of the Third Reich, 74-5. ${ }^{100}$ Hecht, "Concerning a Suitcase," in Child of the Century, 295-9. Hecht uses the tale of the reporter who smuggles the suitcase through customs in order to fund a revolution at least twice in his fiction. See Erik Dorn, a Novel, (Chicago: University of Chicago Press, 1963), 319-331; Ben Hecht, To Quito and Back (New York: Covici, Friede, 1937), 17-32. When he had compiled evidence and reported that Gen. von Hoffman's story about the German surrender had been a lie, Dennis had spiked the stories, and wired: "Your surmises both wild dangerous to President Wilson's work for just peace. Confine yourself solid political facts." Hecht wired back: "All my information solid not surmise." Child of the Century, 282.

${ }^{101}$ Hecht, Child of the Century, 289, 292-5.

${ }^{102}$ Foreign Correspondent, draft manuscript ("Release Dialogue Continuity,") Property of Walter Wanger Productions, August 3, 1940, Reel 1-A pp. 1-5, Works, Box 9, Folder 272A, BHNL. Hecht's politically charged contribution to this script is particularly significant given the censorship of Hollywood films at the time, and it has received little to no attention from scholars. See page 62 of "Hollywood's Jewish Question," in J. Hoberman and Jeffrey Shandler's Entertaining America, and my discussion of Urwand et al, pp. 3-4 and endnote \#8. Hoberman and Shandler report that producer Walter Wanger abandoned an adaptation Vincent Sheean's Personal History after the Hays Office warned that its "pro-Jewish" content was inflammatory. But in fact, the story was instead transformed into Foreign Correspondent, which still conveyed an anti-Nazi message. Clearly there is evidence that Hecht wrote these five pages, as they are stored in the Newberry archive with a note in the finding aid: "Purchase, Society of Collectors, 2008." According to MacAdams, Hecht was the one who originally rewrote the script, though he went uncredited. His draft had focused on the Nazis' "intrigue in Europe." Wanger wanted a revision that focused entirely on the intrigue storyline, but Hecht was already committed to another project with director Howard Hawks. He was, however, tapped by Wagner and Hitchcock for an ending when the film was being shot. The opening scene in particular is vintage Hecht. MacAdams, Man Behind the Legend, 208. Pauline Kael cites the script as a graphic example of Hollywood's contempt for writers, noting that Wanger put twenty seven writers to work in groups in succession on Personal History. The Citizen Kane Book: Raising Kane, 1st ed. (Boston: Little, Brown, 1971), 27. 
${ }^{103}$ Ron Rosenbaum, The Secret Parts of Fortune: Three Decades of Intense Investigations and Edgy Enthusiasms, 1st ed. (New York: Random House, 2000), 653-7. Although Hecht never specifically refers to a "Big Lie" or "stabbed in the back," he does capitalize the "L" in the "Lie" spread about the threat of Bolshevism. See Child, 275, 280. Hecht was not the only one to articulate this interwar conspiracy theory about the Germans. See also Michael Sayers and Albert E. Kahn, The Plot Against the Peace; a Warning to the Nation! (New York: Dial press, 1945). ${ }^{104}$ Hecht, Gaily Gaily, 210; Child of the Century, 270.

${ }^{105}$ Hecht, "Scarface/dialogue-continuity by Ben Hecht," 78. J.E. Smyth uses this epigraph on her study of early gangster films, but offers a different version, perhaps because she is drawing from a draft of a script that she discovered in her archival research. Her version of the quote is: "Sounds like a typewriter, eh? I'm goin' to write my name all over Chicago with this, in capital letters." J.E. Smyth, "Revisioning Modern American History in the Age of Scarface (1932)," Historical Journal of Film, Radio and Television 24: 4 (2004), 535-563.

${ }^{106}$ Lesy, Murder City, 303-4.

${ }^{107}$ On Ruth Snyder, the Daily Mirror and the New York Daily News... Klatt, Chicago Journalism, 4, 125.

${ }^{108}$ Ibid, 137-140. Mayor Thompson, McCormick and Capone... Lundberg, Imperial Hearst, 390. Newspapers crusaded against Thompson, Hecht, Gaily Gaily, 213. Thompson considered a tool of the Capone mob... Hilton, From Theater to Reality, 3.

${ }^{109}$ Frederick L. Allen, "Newspapers and the Truth," Atlantic Monthly January 1922, 44-54, quoted in Bruce J. Evensen, “Journalism's Struggle over Ethics and Professionalism During America's Jazz Age, 54.

${ }^{110}$ Evensen, "Struggle over Ethics and Professionalism," 54-63.

${ }^{111}$ Klatt, Journalism History, 115.

112 "By the spring of 1921, "he had been divorced from our staff for some weeks," wrote Daily News editor Henry Justin Smith, "and had married an overdressed, blatant creature called Publicity." See Smith's Preface, written July 1, 1922 in Ben Hecht, A Thousand and One Afternoons in Chicago (New York: Covici Friede, 1927). A Chinese Fair in June" in "News of Chicago Society," Chicago Tribune, May 8, 1920, 2. Hecht, Child of the Century, 321-3. Hecht writes that he partnered with Atlanta entrepreneur Grady Rutledge to do publicity drives for J.P. Morgan's China Famine Fund, Herbert Hoover's Near East Relief Fund, and a project to spread the Baptist faith called "The Northern Baptist Drive," which was able raise \$25 million in the Midwest. According to researcher Florice Whyte Kovan, Hecht also helped organized anti-Ku Klux Klan campaigns as a partner in the firm. The campaigns were underwritten by the National Unity League. Having established the drive in Chicago, Hecht and Rutledge expanded it to Milwaukee on October 21, 1922, where they announced a plan to expose Klan members. See "Some Notes on Ben Hecht's Civil Rights Work, the Klan and Related Projects" on Snickersnee Press and BenHechtBooks.net website, http://benhechtbooks.net/ben hecht human rights.

${ }^{113}$ Electric power tycoon Samuel Insull, for example, began advising the American branch of the British propaganda office in 1914, and contributed a quarter of a million dollars for slanted war stories to appear in newspapers. After the war, Insull's Illinois Publicity Utility Information Committee borrowed the propaganda machinery he had used during the war to churn out a massive volume of promotional material, a trend soon copied by utilities across the country. Schudson, Discovering the News, 142-3. "The Press Agents' War," New York Times, September 9, 1914.

${ }^{114}$ Henry Justin Smith, Preface to One Thousand and One Afternoons in Chicago. The pages to the Preface are not numbered.

${ }^{115}$ Hecht, One Thousand and One Afternoons, Henry Justin Smith's Preface, "Fog Patterns," 27; "The Sybarite," 60-3; "Waterfront Fancies," 68-71; "Fantastic Lollypops," 97-100; "Pandora's Box," 273; "Ripples," 265-8. 
${ }^{116}$ On "the sketch," see Sims, 31-4, 41. Hecht's columns most closely resembled Ade's... Fetherling, Five Lives, 29-30. For a good overview of the late nineteenth century Chicago columnists, see Larzer Ziff, The American 1890s, 157-161.

${ }^{117}$ Hecht, "Grass Figures," in One Thousand and One Afternoons in Chicago, 285-9.

${ }^{118}$ For cogent analyses of the evolution of "objectivity" during the 1920 s, see Schudson, "Objectivity Becomes Ideology: Journalism After World War I," in Discovering the News, 121159; James Carey: a Critical Reader (Minneapolis: University of Minnesota Press, 1997), 137$141,162-3,192-4$.

${ }^{119}$ Schudson, Discovering the News, 149.

${ }^{120}$ Ibid, 122-8. Mencken on the nature of the mob and the machinations of politicians... H. L. Mencken, Notes on Democracy (New York: Knopf, 1926), 15-23. 55; on democracy as "an incomparably idiotic" fraud, 209, 211. He uses his signature phrase "stirring up the animals," for example, in H. L. Mencken, My Life as Author and Editor, 1st ed. (New York: Knopf, 1993), 1081-2. Walter Lippmann, The Phantom Public (New York: Harcourt, Brace, 1925), 65.

${ }^{121}$ Hecht, One Thousand One Afternoons in Chicago, 285. On the new lack of confidence in the knowability of the truth, see David Hollinger, "The Knower and the Artificer," American Quarterly 39, no. 1 Special Issue: Modernist Culture in America (Spring 1987): 37-55. On how the knowability of truth ties to journalistic "objectivity," see Carey, The James Carey Critical Reader, 162-4.

122 “...absurdity itself...” Hecht, Erik Dorn, 19.

123 "Erik Dorn," Vanity Fair, November 1921 in "Vol. 1: Reviews, 1921-1928," Scrapbooks, Box 103, BHNL. Hecht, Erik Dorn, 380.

${ }^{124}$ Hecht, Erik Dorn, xiii, 9.

${ }^{125}$ Ibid, viii. Fetherling, Five Lives, 35-40.

${ }^{126}$ Thanks in part to Mencken, who fed him plotlines... Abe C. Ravitz, "Ballyhoo, Gargoyles, \& Firecrackers: Ben Hecht's Aesthetic Calliope," The Journal of Popular Culture 1, no. 1 (June 1, 1967): 38. He claims that he dictated The Florentine Dagger... In a 1931 newspaper profile, Hecht said that he had wagered \$1,000 to another man's \$2,000, that he had dictated The Florentine Dagger in nineteen hours with the aid of two stenographers, and that it had sold 15,000 copies. See Ruth Seinfel, “Author of 'A Jew in Love' Longed for Lost Unpopularity, but Now That He Has It He Confesses Remorse," New York Post, 1931, “A Jew in Love, n.d., 19301932," Publicity, Box 79, Folder 2411, BHNL. Horace Liveright told MacAdams that the novel in fact took two months to write, and was based on Sardou's play La Tosca. MacAdams, The Man Behind the Legend, 67. ... he said that of the more than sixty movies he wrote... Child, 467. According to Tribune reporter and book reviewer Fanny Butcher, Charles MacArthur's older brother Alfred had offered a \$2,500 wager that no one could write a successful book in one sitting, and Hecht took him up on it. Hecht told Butcher the two stenographers helped write the book, because at every twist he would ask them who they thought the murderer was, and would then would change the plot to keep it unpredictable. Fanny Butcher, Many Lives--One Love, 1st ed. (New York: Harper \& Row, 1972), 67.

127 "Divorces Ben Hecht: Wife Gets Decree in Chicago on Grounds of Desertion," New York Times, February 28, 1926. In the article, Marie said Hecht deserted her when he left Chicago for New York City on February 15, 1924. Hecht later wrote that he was awaiting the divorce so that he could re-marry, in Charlie, 129. On meeting Rose, falling in love, and her influence... Child, $350-4$.

128 "We were all fools..." Hecht, Charlie, 69. On New York's society of newspaper veterans and literary crowd, see Ehrlich, Journalism in the Movies, 27; Child, 384-6, 390-6; and in greater depth, Charlie, 73-112.

${ }^{129}$ Kael, The Citizen Kane Book, 25. "A lot of the 'reporters' in the 1920s..." Sims, The Chicago Style of Journalism, 266. 
130 "The Golden Age of press criticism," Robert W. McChesney and Ben Scott, introduction to Upton Sinclair, The Brass Check: A Study of American Journalism (University of Illinois Press, 2002). Michael Schudson, "What Journalism Knows about Journalism but Doesn't Know about 'Public,", in The Idea of Public Journalism, ed. Theodore L. Glasser (New York: Guilford, 1999), 124, cited in Ehrlich, Journalism in the Movies, 29.

${ }^{131}$ On the origins of mass communication research, propaganda studies and "the Chicago School"... Jesse Delia, "Communication Research: A History," in Handbook of Communication Science, eds. Charles R. Berger and Steven H. Chaffee (Beverly Hills: Sage publications, 1987), 20-98. For a clear, straightfoward explanation of ideas, see Stanley J. Baran and Dennis K. Davis, "The Rise of Media Theory in the Age of Propaganda," in Mass Communication Theory: Foundations, Ferment, and Future, 2nd ed. (Australia ; Belmont, CA: Wadsworth, 2000). For a cogent discussion of this history and how it has been misrepresented, see J. Michael Sproule, "Progressive Propaganda Critics and the Magic Bullet Myth," Critical Studies in Mass Communication 6, no. 3 (September 1, 1989): 225-246; and "The Chicago School and the History of Mass Communication Research," The James Carey Critical Reader, 14-33. Laswell joined the faculty of the University of Chicago in 1927... Encyclopedia of World Biography, 2nd ed (Farmington Hills: Cengage Gale, 2011), http://ezproxy.umsl.edu/login?url=http://find.galegroup.com/gvrl/infomark.do?type=aboutBook\& prodId $=$ GVRL\&eisbn $=9781414462790 \&$ userGroupName $=$ morenetumsl\&version $=1.0$.

${ }^{132}$ Hecht, Charlie, 82-4.

${ }^{133}$ Hecht, Child, 446-465. Journalist Alva Johnston essentially confirms Hecht's tale in one of a series of articles about South Florida, and in his biography of architect Addison Mizner, that he published before $A$ Child of the Century had appeared. Referring to Hecht's pamphlets, Johnston writes, "It is impossible even now to read his prose without feeling an urge to rush South and invest a couple of hundred thousand dollars in the tidal swamp that was once the town's Millionaire's Row." Alva Johnston, The Legendary Mizners, 1st pbk. ed (New York: Farrar, Straus \& Giroux, 1986, first published 1953), 297. Alva Johnson, "The Palm Beach Architect," The New Yorker, December 13, 1952, 43-4. Hecht's charade about buried treasure gave him an opportunity to have fun with a favorite subject - pirates. But over the succeeding decades, a wave of treasure hunters would find hundreds of millions of dollars worth of gold "pieces of eight" in sunken Spanish galleons off the Florida Keys.

134 "We were both obsessed with our youthful years..." Hecht, Child of the Century, 391. At a 1980 Newberry Library dinner, MacArthur's wife Helen Hayes gave a speech about "Ben and Charlie" in which she said: "Ben was never comfortable in the adult world. He spent his whole life trying to hang on to youth, its mindset, its wonderment, its carefree fizz." Robert Schmuhl, "Sorting Out Ben Hecht," Chicago Tribune, March 31, 2002, http://articles.chicagotribune.com /2002-03-31/entertainment/0203290370_1 ben-hecht-joseph-epstein-carl-sandburg. Hecht spent the summer of 1927... Sidney E. Zion, "The Scoop from Helen Hayes," New York Times, November 16, 1986, sec. 2. p. 1. According to Hayes, Hecht and MacArthur wrote the play in the summer of 1927 at the Rockland Female Institute, a girls' school that they rented out in South Nyack, New York. Sidney E. Zion, "Playwrights' Widows Remember first 'Front Page," New York Times, May 12, 1969, 52. Rose Hecht recalled that they wrote most of the script in 1927 at the Hechts' apartment on Beekman Place, which is located in midtown on Manhattan's East Side, and that it took nearly a year to write. During the same 1969 interview, Hayes recalled that Charlie had proposed to her when she ran out to meet him on the fire escape during the first act of the opening performance, by which time it had become it clear that "the boys" had produced a hit. They were married three days later. In Child, p. 391 Hecht writes of collaborating on the play at the girls school in Nyack. In Charlie p. 134, he refers to working on the play at Beekman Place. ${ }^{135} 276$ performances... Robert Schmuhl, "The Front Page Turns 75," on Poynter.org, August 6, 2003. http://www.poynter.org/uncategorized/14410/the-front-page-turns-75/ "Unfailing 
entertainment..." J. Brooks Atkinson, "The Play," New York Times, August 15, 1928, 28. "The best American comedy every written..." was the judgment of English theater critic Kenneth Tynan, quoted in Hilton, From Theater to Reality, 1, from Barry Norman, "Michael Blakemore: Setting in Motion a Dazzling Machine," Times (London), June 17, 1972, 11. According to producer Jed Harris, the ovation in Chicago at the end of Act 1, "sounded like the roar of a herd of wild animals panicked by fire at the zoo." From Jed Harris, A Dance on the High Wire: Recollections of a Time and a Temperament (New York: Crown Publishers, 1979), 119. Quoted in Hilton, From Theater to Reality, 21.

136 "an emergency of spirit..." Fetherling, Five Lives, 69.

${ }^{137}$ Helen Hayes recalled that Tennessee Williams had once told her: "Your Charlie and Ben Hecht made it possible for me to write my plays. They paved the way for me. They took the corsets off American theater." Carol Lawson, "Theater Hall of Fame Gets 10 New Members," New York Times, May 10, 1983. Tommy O'Connor's pork chop sandwich... “"Terrible' Tommy: The Mobster That Got Away-Part 2," in Examiner.com, August 5, 2011. www.examiner.com/ article/terrible-tommy-the-mobster-that-got-away-part-2 Photographs of the actual pressroom... Fetherling, Five Lives, 69. On Carol Frink...Hilton, From Theater to Reality, 2 and footnote \#109, 111-2. In Sidney Zion's 1969 New York Times story (see endnote \#133 above), Rose Hecht said that she in fact preceded Carol Frink as the first female reporter for the Herald-Examiner, but quit when Walter Howey told her at one point to wear a Western Union delivery girl uniform. MacArthur and Frink were finally divorced on June 26, 1926.

${ }^{138}$ Hilton's exhaustively researched From Theater to Reality explains the connections between the actual characters and events and those represented in the play. "...looking at the real beauties of the Criminal Courts pressroom..." Hecht, Charlie, 139. On the real Hilding Johnson, and the jury ballot, wastebasket trick... Dornfeld, Behind the Front Page, 110-111.

${ }_{139}$ Brown Martin, Ben Hecht, Hollywood Screenwriter, 47.

140 “... vanishing type..." Hecht and MacArthur, The Front Page, 31. "Beneath a dapper..." The Front Page, 129.

141 "D'Artagnan never gave Richelieu...” ibid, 132. “...coming out of the ether...” ibid, 150. "Something seems to watch over the Examiner..." 176, 179.

142 "Managing editors are not all conscienceless and cruel..." George Gordon Battle, "Stage Profanity Under Fire," New York Times, September 9, 1928, sec. 10, p. 2, quoted in Ehrlich, Journalism in the Movies, 38. When the film version appeared in 1931 along with other movies that... Stephen Vaughn and Bruce Evensen, "Democracy's Guardians: Hollywood's Portrait of Reporters," Journalism Quarterly 68, no. 4 (Winter 1991): 832. Newspaper editor Stanley Walker warned young prospective reporters... Stanley Walker, City Editor (New York: Frederick A. Stokes, 1934), 37, quoted in Ehrlich, Journalism in the Movies, 3. “... a slick piece of work about very crude people..." Fetherling, Five Lives, 81.

${ }^{143}$ For the text of the epilogue, see Hilton, From Theater to Reality, 187-88. "...triumph results from a series of comic, cosmic accidents..." Ehrlich, Journalism in the Movies, 32-4.

${ }^{144}$ Hecht, "Scarface/dialogue-continuity," 6.

${ }^{145}$ Ibid, 251.

${ }^{146}$ Filmfront 1, no. 3 (January 28, 1935). Quoted in MacAdams, The Man Behind the Legend, 301-302.

${ }^{147}$ Ben Hecht, Underworld: An Original Story of Chicago ([Chicago: Hecht, 1927) 68 leaves. Films about street gangs... "the first gangster movie with modern credentials..." Carlos Clarens, Crime Movies: From Griffith to The Godfather and Beyond, 1st ed. (New York: Norton, 1980), 15, 31-2. “...here's to crime..." Eugene Rosow, Born to Lose: The Gangster Film in America (New York: Oxford University Press, 1978), 124, quoting Motion Picture Classic, August, 1928, 52. 
${ }^{148}$ Rosow, Born to Lose, 117, 118. It was Frederick Lewis Allen who most famously referred to the changes taking place in the 1920s as "a revolution in morals and manners." Frederick Lewis Allen, Only Yesterday: An Informal History of the 1920's, 1st Perennial classics ed (New York: Perennial Classics, 2000). For discussions of how the gangster film reflected these changes, see Jonathan Munby, Public Enemies, Public Heroes: Screening the Gangster from Little Caesar to Touch of Evil (Chicago: University of Chicago Press, 1999); and David E. Ruth, Inventing the Public Enemy: The Gangster in American Culture, 1918-1934 (Chicago: University of Chicago Press, 1996).

149 "My movies were usually successful..." Hecht, "The Unfinished Life of Mickey Cohen," Scanlan's, 74. "An idea came to me..." Hecht, Child of the Century, 479.

150 "Popular Arts Project: The Reminiscences of Ben Hecht," Oral History Research Office, Columbia University, 1959, p. 736; filed as "Oral History, Transcript, Columbia University, 1959," Miscellaneous, 1885-1974, Box 133, Folder 3006, BHNL.

${ }^{151}$ Dornfeld, Behind the Front Page, 138. Klatt, Chicago Journalism, 130-1.

${ }^{152}$ Douglas Perry, The Girls of Murder City: Fame, Lust, and the Beautiful Killers Who Inspired Chicago (New York: Viking, 2010); Louise Kiernan, "Murder She Wrote," Chicago Tribune, July 16, 1997, sec. 2, pp. 1, 7. Kiernan's 1997 article quoted longtime American Play Company president Sheldon Abend as saying that Watkins later turned down offers to adapt her story because she felt remorse about her coverage, as her stories may have played a hand in the women's acquittals. But according to Perry, Abend was thus propagating a myth. There is no evidence Watkins ever expressed such feelings of guilt, and as her coverage itself reflects, "she did everything she could to see Beulah and Belva convicted, sometimes pushing the bounds of journalistic integrity in an effort to achieve her desired result." Perry suggests, alternatively, that Watkins may not have wanted any further liberties taken with her one great work, after seeing the film adaption in 1927 and the 1942 version, Roxie Hart, which Hecht had a hand in writing. Nevertheless, Watkins might have loved what Bob Fosse ultimately did with her material after her death in 1969, because his now legendary 1975 musical stayed true to the original spirit of her play. Whether or not there is any evidence to corroborate Abend's claim, it is possible that Perry has overlooked one crucial aspect of sensationalism in assessing Watkins' coverage: As Hecht later noted, journalists have made a practice of loudly moralizing about the "vileness" of a criminal while lingering on every beguiling detail about the individual (see Part Four of this study.) On Watkins' original play and the myth about her remorse, see Perry, 230-9, 265-6.

${ }^{153}$ Clarens, Crime Movies, 42; Rosow, Born to Lose, 124.

${ }^{154}$ Rosow, Born to Lose, 124.

155 J.E. Smyth, "Revisioning Modern American History in the Age of Scarface," 531, 551; chapter five, "The Invention in the Flesh: Al Capone in Chicago," in Ruth, Inventing the Public Enemy, 118-143. A smiling portrait... ibid, 118. Time, March 24, 1930. At a Cubs game... Tere Tereba, Mickey Cohen: The Life and Crimes of L.A. 's Notorious Mobster (Toronto: ECW Press, 2012), 24.

156 “Americans marveled at Capone's wealth and power..." Ruth, Inventing the Public Enemy, 119. The ruthless, calculated efficiency of the St. Valentine's Day massacre had launched him into fame... ibid, 118, 125-131. Walter Noble Burns worked for the Tribune. Bright and Pasley had been reporters for the Chicago Daily News. An early history was Rattling the Cup on Chicago Crime, written by Her-Ex reporter Edward Dean Sullivan just a few weeks after the St. Valentine's Day Massacre. In 1930 he published another, Chicago Surrenders.

${ }^{157}$ Clarens, Crime Movies, 34-38, 43-47.

${ }^{158}$ Ibid, 51-3.

${ }^{159}$ Ibid, 53.

${ }^{160}$ The portrayals of the press in the first wave of newspaper movies... Stephen Vaughn and Bruce Evensen, “Democracy's Guardians: Hollywood's Portrait of Reporters, 1930-1945,” 832. 
“...the reporter more nearly resemble a gangster..." John E. Dewry, "Presidential Address: The Journalist's Inferiority Complex," Journalism Quarterly 8 (1931): 14.

${ }^{161}$ Klatt, Chicago Journalism, 151-3; Hilton, From Theater to Reality, 68, footnote \#26; Dornfeld, Behind the Front Page, 139-140; Murray, Madhouse on Madison Street, 360-4; McPhaul, Deadlines \& Monkeyshines, 261-277; Edward Dean Sullivan, Chicago Surrenders (New York: The Vanguard Press, 1930) 3-28, 78-120. John Boettiger, a Tribune reporter who took the $\$ 1,400$ in cash found on Lingle back to his superiors to help avoid a scandal, soon thereafter wrote a book about the case. John Boettiger, Jake Lingle; or, Chicago on the Spot (New York: E.P. Dutton \& Co., Inc, 1931).

162 J.E. Smyth, "Revisioning Modern American History in the Age of Scarface," 541.

${ }^{163}$ Clarens, Crime Movies, 82-3.

${ }^{164}$ On demanding a thousand dollars each day... Hecht, Child of the Century, 486; "Oral History, Transcript, Columbia University, 1959," 736. Howard Hawks corroborated Hecht's story about the arrangement and said the script was written in eleven days. MacAdams, The Man Behind the Legend, 123-125; Hawks interview with Peter Bogdanovich in Jim Hillier and Peter Wollen, eds., Howard Hawks: American Artist (British Film Institute, 1997), 52. On Hughes breaking the truce with censors and Hecht writing the script in January 1931... Clarens, Crime Movies, 83, 84. Seldom has a film been so targeted for violence... Gronstad, Asbjorn, "Mean Streets: Death and Disfiguration in Hawks' Scarface," Nordic Journal of English Studies 2, no. 2 (2003): 389-390. Burnett, Walter Noble Burns and Pasley all worked on the script, contributing their knowledge of Capone and recent underworld history. By all accounts, however, it was Hecht who really put the story together and produced a viable screenplay. John Lee Mahin, whom Hecht had met one day on the train to Nyack and who became one of the writers in Hecht's script-writing "factory," polished the script, as did Seton I. Miller. See Smyth, "Revisioning Modern American History in the Age of Scarface," 554; interviews with Hawks and Mahin in MacAdams, The Man Behind the Legend, 144-5; and notes in the margins about Mahin from Rose Hecht, on p. 2 of an undated letter from Charlie MacArthur, "MacArthur, Charles (Charlie), n.d., 1917-1951," Incoming Correspondence, Box 59, Folder 1431, BHNL. According to MacAdams, and to Hawks biographer Todd McCarthy, Mahin was "a Harvard graduate and former reporter who had just quit his job as an advertising copywriter on the strength of Hecht's promise to add him to his writing stable at two hundred dollars a week and find him a job in Hollywood." For more on the role of each writer and Hecht's contribution, see the McCarthy biography. Todd McCarthy, Howard Hawks: The Grey Fox of Hollywood, 1st ed. (New York: Grove Press, 1997), 130-131. ${ }^{165}$ Clarens, Crime Movies, 40. Hecht touted its gritty "truth," and blamed Sternberg for adding sentimental touches... Child of the Century, 479-480.

${ }^{166}$ Clarens, Crime Movies, 32, 34, 42.

${ }^{167}$ Munby, Public Enemies, Public Heroes, 4-5.

${ }^{168}$ Ruth, Reinventing the Public Enemy, 123-4.

${ }^{169}$ Ibid, 125-131.

${ }^{170}$ Hecht, "The Unfinished Life of Mickey Cohen," Scanlan's, 71.

${ }^{171}$ Pasley saw Capone as a "self-made man," Smyth, "Revisioning Modern American History in the Age of Scarface," 552. In a scene that mimics The Great Gatsby... Marilyn Roberts, "Scarface, The Great Gatsby and the American Dream," Literature/Film Quarterly 34: 1(2006): 73. “... a psychopathic Horatio Alger...” Munby, Public Enemies, Public Heroes, 15, quoting Richard H. Pells, Radical Visions and American Dreams: Culture and Social Thought in the Depression Years (Middletown, Conn: Wesleyan University Press, 1984), 271-2.

172 Robert Warshow, "The Gangster as Tragic Hero," in The Immediate Experience; Movies, Comics, Theatre \& Otheraspects of Popular Culture, Atheneum Paperbacks, 159 (New York: Atheneum, 1971) 85-88. 
${ }^{173}$ Smyth, "Revisioning Modern American History in the Age of Scarface, 551, 553, 538, 547, 558.

${ }^{174}$ Clarens, Crime Movies, 91. Munby, Public Enemies, Public Heroes, 56. On Sternberg and Expressionism, see "Paramount and the Emergence of the Hollywood Studio System," in filmreference.com. http://www.filmreference.com/encyclopedia/Independent-Film-RoadMovies/Paramount-PARAMOUNT-AND-THE-EMERGENCE-OF-THE-HOLLYWOODSTUDIO-SYSTEM.html

${ }^{175}$ What first attracted Hawks to the Capone legend... Clarens, Crime Movies, 85, 88-89. On Scarface and the Gatsby imagery, see E.R. Hagemann, "Scarface: The Art of Hollywood, Not 'The Shame of a Nation'," The Journal of Popular Culture 18, no. 1 (June 1, 1984): 33; Roberts, "Scarface, The Great Gatsby and the American Dream." Clarens recounts a version of the anecdote that has Capone bashing a single guest of honor, but the legend is rooted in the May 7 , 1929 murders of three Capone gunmen: Albert Anselmi, John Scalise and Joseph "Hop Toad" Guinta. Capone biographer Jonathan Eig explains that because their badly beaten bodies were discovered in a back alley, Walter Noble Burns took literary license in his 1931 book The OneWay Ride, imagining a banquet at which they had first been drugged before being killed. Then in 1975's The Legacy of Al Capone, George Murray described a banquet scene in which Capone suddenly brandished a pair of wooden clubs. However, the story of the baseball was obviously circulating by the early ' 30 s, when columnist Howard Vincent O'Brien asked Capone if it was true. A depiction of the incident also turned up in the 1958 film Party Girl, as well as in the 1987 movie starring Robert De Niro as Capone, The Untouchables. Jonathan Eig, Get Capone: The Secret Plot That Captured America's Most Wanted Gangster, 1st Simon \& Schuster hardcover ed (New York: Simon \& Schuster, 2010), 223-225, 315-316.

${ }^{176}$ Bogdanovich interview in Howard Hawks, American Artist, 52. Hawks said: "When I asked Ben Hecht to write it, he said, 'Oh, we don't want to do a gangster picture.' And I said, 'Well this is a little different. I would like to do the Capone family as if they were the Borgias set down in Chicago.' And he said, 'We'll start tomorrow.' We took eleven days to write the story and dialogue. We were influenced a good deal by the incestuous elements in the story of the Borgias. We made the brother-sister relationship clearly incestuous. But the censors misunderstood our intention and objected to it because they thought the relationship between them was too beautiful to be attributed to a gangster."

${ }^{177}$ Clarens, Crime Movies, 85, 88-9; Robin Wood, "Scarface," in Gangster Film Reader eds. Alain Silver and James Ursini (Pompton Plains, N.J: Limelight Editions, 2007), 25.

${ }^{178}$ Hecht, "Scarface/dialogue-continuity by Ben Hecht," 147-8.

${ }^{179}$ Ibid, 52-4, 90, 124; In trying to explain the play himself, Camonte says: "There's a minister and a soldier fella and this girl, unnerstan'? This Sadie — she's a been-(he searches for a word)...what you call it...disillusion. (he smiles, happy at his verbal accomplishment.)" Ibid, 87. "...terrible innocence..." Wood, "Scarface," 24.

${ }^{180}$ Wood, Scarface, 20, 22, 24.

${ }^{181}$ Brown Martin, Hollywood Screenwriter, 55. Hecht spent more time in Hollywood arguing than writing... Child of the Century, 473.

${ }^{182}$ Letter in reply to Minna Emch dated July 5, 1958, in "Hecht, Ben - to Emch, Minna and Arnold (Noldi), n.d., 1953-1958," Family Correspondence, 1915-1976, Box 71, Folder 2234, BHNL.

${ }^{183}$ Michael Mickey Cohen, Mickey Cohen, in My Own Words: The Underworld Autobiography of Michael Mickey Cohen, as Told to John Peer Nugent (Englewood Cliffs, N.J: Prentice-Hall, 1975), 20.

${ }^{184}$ Ibid, 1-8; “(Other Writers) Cohen, Mickey - Mickey Cohen, Own Story, n.d.,” unnumbered pages, Works, 1908-1983, Box 51, Folder 976, BHNL.

${ }^{185}$ Cohen, In My Own Words, 21, 22. 


\section{PART II: THE EGOISTS}




\section{Dear Ben and Rose:}

Thanks very much for the weekly cheque which came this morning. My typewriter rent is now months in arrears and I may lose the machine, but perhaps that will not matter too much since my creations seem to be tacitly rubber-stamped for rejection before they reach the editorial offices. The boys and girls just can't resist the momentum of habit, I suppose... With unrivaled courage and pertinacity, the British government has concentrated five heavy cruisers and an entire division of soldiers to prevent 1500 unarmed, yearning, bedraggled, scarred Jewish refugees from entering Palestine. On our side of the fence, the Mead Investigation drearily nibbles at the fringes of corruption, graft and gorging indulged in by munitions manufacturers and other industrialists while American men were dying and suffering on the battle fronts. As I view the world of reality surrounded by high walls, it seems a bad, corny, utterly unprincipled American dream beneath coats of whitewash and gilding so palpably ridiculous and fraudulent that one wonders why the culprits still bother to wield the paint brushes!

Fond regards to both of you and best wishes to your daughter from a very pessimistic

$$
\text { Bogie }^{1}
$$

Thus reported Maxwell Bodenheim in one of his epistolary dispatches from a life on the margins in 1947. In these weekly installments to Hecht, the poet telescoped his daily desperation, or erupted with the same white-hot fervor of holy wrath that had once made people take notice. But people had long stopped noticing. His manuscripts were never to be published again, the last of his books being Selected Poems, an anthology of old verse issued in 1946. Now he was fighting eviction from his flat in Brooklyn and caring for his sick wife, battles that he was about to lose. ${ }^{2}$

Within a few years he would hit bottom, peddling his poems for twenty-five cents at the Village Vanguard or Minetta Tavern, his rank smell pushing customers away as he shambled from table to table, a corpse-eyed toothless scarecrow in dirty pants held up with twine, swollen ankles rising out of laceless shoes. Some believed the poems were 
worth the quarter, but others bought them solely for the autograph, "for they saw not a besotted bum," explained Greenwich Village chronicler Ross Wetzsteon, "but a defiant spirit, debonair even in his degradation, the poet praised by Pound, the novelist pursued by smut-hounds, the notorious roué of a thousand amours, iconoclast, renegade, scourge of the Philistines, 'unwashed archpriest of Bohemia,' Poet Laureate of Greenwich Village-Maxwell Bodenheim." ${ }^{3}$

Twenty years earlier, Bodenheim had been considered one of the finest poets of his generation, in a class with T.S. Eliot, William Carlos Williams and Conrad Aiken. He and Hecht had been twin spirits, counted among the most promising voices of a groundbreaking movement in American letters. Luminaries of the Chicago Renaissance and, soon thereafter, the New York literary scene of the Jazz Age, the two rode the crest of modernism, but the wave, which broke on the shoals of the Depression, cast their lives in very different directions.

In the 1920s, Hecht reinvented himself as a novelist and playwright before achieving fame and fortune as a Hollywood screenwriter. Bodenheim became legend as "a wild-looking Lothario who was relentlessly pursued by women," and earned a national reputation for his poetry and incisive commentary. His essays appeared regularly in Poetry magazine, The New Republic, the Dial, the Nation, Harper's, Bookman and the Yale Review, and he produced nine books of poems and thirteen novels. But after the crash of 1929, the money and attention evaporated, and during the 1930s, his life fell apart. What followed was a long descent into what Hecht called "some private hell.".

When a gaunt and shattered Bodenheim had emerged by chance out of the winter rain on $47^{\text {th }}$ Street in 1941 , Hecht had not seen his old friend in more than a decade. They 
ducked into a neighborhood bar, where Hecht pored over a decade's worth of unpublished poems packed into a beat-up briefcase that Bodenheim carried everywhere. When the rain turned into a heavy snowfall, Hecht brought the poet back to the warm shelter of his home in Nyack, hoping his guest would stay the night. But a woozy Bodenheim insisted on returning to his dying wife, and left before for dinner, his overcoat pockets stuffed with socks, shorts, ties, shoes and pajamas ransacked from Hecht's closets. $^{5}$

The sight of this old friend's condition prompted Hecht to make an offer. In exchange for a poem or two pages of prose on any topic every week, he would send Bodenheim a thirty-dollar check. Hecht kept up this bargain for several years, and each week the poet's submissions arrived, accompanied by a letter acknowledging receipt of the money or gently noting that it had not yet arrived. "These letters...contain one of the most desperate self-portraits I've ever read," Hecht wrote. "The portrait of an unwanted talent; penniless, almost rotted away with liquor and calamities— but still as proud and articulate as any prime minister."

Hecht had known many artist-rebels in his youth, but Bodenheim had always been different, because Bodenheim had been the most like him. ${ }^{7}$ The youngest two among the art and literature disciples who would be remembered as the vanguard of the Chicago Renaissance, they had once been more than close friends; they were alter egos with shared sensibilities that distinguished them from the rest of their tribe. They grabbed the limelight in the tinseled, cynical era that followed the Great War by savaging their fellow literati in their weekly magazine, The Chicago Literary Times. And then, having declared war on everyone and everything else, they declared war on each other. Staging a well- 
publicized feud that played off their reputation as a team, Hecht caricatured the poet's flamboyant, caustic egoism in his 1926 novel Count Bruga, while Bodenheim, most adept with the counterpunch, lampooned Hecht as a vain and shallow sellout in his 1931 novel Duke Herring.

Now such memories took on a new significance. Bodenheim was forgotten and penniless, while Hecht had become one of the highest paid writers on the planet. Yet Hecht had been loudly proclaiming that he felt rudderless and hollow as a mass media entertainer, and as he, too, found himself adrift, the poet's old charge of sellout seemed to stick. Both men were casting about for a port of call. Bodenheim needed some way to fit in, somewhere to belong. Hecht needed a sense of meaning and purpose in his life. Both sought something that reminded them of who they had been when they were young, back when they had believed in art and literature, and in themselves.

The rising emergency for Europe's Jews thus had an unique effect on Hecht, for the more riled he became by the disturbing developments at home and abroad, the more he began to regain the sense of conviction that he once felt in the confidence of youth. In fact, for a while anyway, he was to discover a truer iconoclasm, a more clear-eyed and authentic banner for his rebelliousness that he had been seeking all along. Over the months and years ahead, the causes of militant Zionism and rescuing Jews from the Nazis would allow him to appreciate his Jewish heritage as a source of self-discovery and renewal. As he later explained of his propaganda, "I did all these things partly out of my own needs. ${ }^{\prime 8}$ In turn, his activities stirred Bodenheim, whose letters suggest that he found in Judaism at least some solace and reassurance - though not, ultimately, a path to redemption. 
Hecht's seven-year campaign would become as much an encounter and confrontation with American Jewish writers, actors, publishers and studio executives as with politicians and the public. Yet although he was in rebellion against Hollywood in particular and against "the culture industry" more generally, he nevertheless depended upon the studios for a paycheck. The resulting unease about himself as a sellout was a feud raging within him that echoed his old feud with Bodenheim. During these years of the war and its aftermath, the poet's plight took on a special significance, which Hecht would continue to write about and wrestle with for the rest of his life. ${ }^{9}$

One reason that American literature remained vital well into the twentieth century was that it retained a strong spirit of dissent. As Sacvan Bercovitch observed, "American writers have tended to see themselves as outcasts and isolates, prophets crying in the wilderness." This has likewise been a natural role for writers of Jewish heritage, because of the Jewish experience with anarchism and socialism in Hecht's day, but more fundamentally, because of the tradition of the Hebrew prophets, which is rooted in Jewish history and scripture. But while the pattern for American Jewish and gentile writers alike has been to burst upon the scene as impassioned iconoclasts, only to later find themselves bewildered, lost and alone, the Jewish tradition offers an alternative to an otherwise predictably tragic ending. ${ }^{10}$

Again and again American culture of the early twentieth century saw the appearance of "the secular priest," the young soul who finds divine inspiration in modernistic art, in the utopian dream of socialism, in the world of show biz, or in the wonder and mystery of the modern city. ${ }^{11}$ But this embrace of the secular is also a turning 
away, a departure from family and religious tradition. It is expressed in Joyce's much celebrated credo of non serviam, when in Portrait of the Artist as a Young Man, Stephen Dedalus tells Cranly, "I will not serve that in which I no longer believe whether it call itself my home my fatherland or my church." ${ }^{, 2}$ The determination to accept the consequences of this decision, however lonely, desolate and painful, stands as the final measure of one's faith and devotion to the modern dream.

But the heart of the drama is to be found in the fact that this seeker, this pilgrim, is never able to actually arrive anywhere. Instead, the American artist, every bit as much as the Jewish immigrant parvenu, is caught betwixt and between, in Matthew Arnold's formulation, "lost between two worlds, one dead, the other powerless to be born." This, then, is the story of the "alienation," which for American Jews has historical roots in the immigrant experience. When alienation joined with a religious-like fervor to produce such incarnations as, for example, the "daemonic" Al Jolson performing in The Jazz Singer, the modern artist became the image not just of the isolate or outcast, but also of the madman. ${ }^{13}$

Hecht and Bodenheim both followed this three-stage progression. Their commitment to non serviam and self-liberation, which harkened back to the Romantic tradition, had meant rebellion not only against the strictures of Victorianism, but also against those of their own bohemian tribe who embraced humanistic political causes. By the 1930s, however, they had both hit dead ends. Hecht's artistic and personal journey started to look like a flight to nowhere, an ultimately unfulfilling mission that left him casting about for new directions. Bodenheim's rebellion was so defining that, whether by 
choice or temperament, it left him no other way to be: By the time he reached middle age, his embrace of wine and poetry was not so romantic anymore, nor was it sustainable.

Finally, in Jewish tradition there is the theme of return and rebirth. For the Jewish people as a whole, this drama played out on the world's stage with the birth of Israel in the wake of the Holocaust. For the Jew as American rebel, however, the denouement was murkier. Perhaps some achieved a kind of return. For many other characters, however, in fiction and in life, return became a final forlorn dream, but one that tells us something intimate about each individual. 


\section{THE SECULAR PRIEST}

I demand that life be inspired every moment.

$$
\text { Margaret Anderson }{ }^{14}
$$

Margaret Anderson had an unearthly quality. Tall, blonde and blue-eyed, her stunning beauty, regal poise and elegant fashions gave her the aura of a Scandinavian ice goddess, or an angel. She drew stares as if she was a cover girl or a famous beauty of the stage. She expected things to go her way, was treated accordingly, and accomplished things that people said were impossible while making them look easy. ${ }^{15}$

Her idea to launch The Little Review came after she found herself depressed one day, and awoke in the night with the sudden realization that her life lacked inspiration. She concluded that editing a magazine packed with brilliant voices would fill the vacuum inside of her, and resolving to commence with the project without delay, fell back into a sound asleep. At twenty-one years old, Anderson would produce one of the most remarkable and important journals of American literature, introducing the public to many of the literary geniuses of her generation.

In "gasps, gaps and gestures," she had explained her idea to Dewitt C. Wing, an agricultural journalist and editor of the Breeder's Gazette, as they dined together in the white and gold room of the Annex to Chicago's Fine Arts Building. He offered a portion of his salary to pay for printing and office rent. "Dick understood the code and could supply all the words I never had time to stop for," she recalled. "When I hurriedly told him I was going to publish the best art magazine in the world, he saw the idea perfectly." She had no idea what kind of magazine it would be or what it would contain, but she knew it was going to be important. ${ }^{16}$ 
She also knew that she would be building a temple - a temple of art. In the debut March 1914 issue, she announced:

If you've ever read poetry with a feeling that it was your religion, your very life; if you've ever come suddenly upon the whiteness of Venus in a dim, deep room, if you've ever felt music replacing your shabby soul with a new one of shining gold; if, in the early morning, you've watched a bird with great white wings fly from the edge of the sea straight up into the rose-colored sun-if these things have happened to you and continue to happen till your left speechless with the wonder of it all, then you'll understand our hope to bring them near to the common experience of the people who read us. ${ }^{17}$

Anderson's The Little Review, humble, stitched together, nevertheless heralded Chicago's arrival as an American vanguard of literature and art. By 1917, the city's explosion of talent would prompt Mencken to pronounce in the Sunday Tribune: "Find me a writer who is indubitably American and has something new and interesting to say, and who says it with an air, and nine times out of ten...he has some sort of connection with that abattoir by the lake - that he was bred there or got his start there, or passed through there during the days when he was tender." 18

Critic Burton Rascoe suggested that the golden era known as the Chicago Renaissance started with the 1909 launch of Friday Literary Review, an eight-page book supplement of the Chicago Evening Post which, under the far-sighted editorial leadership of Francis Hackett, fostered literary culture and promoted local talent. In 1912 Harriet Monroe founded Poetry magazine with Ezra Pound as foreign correspondent, which published T.S. Eliot's first great work, "The Love Song of J. Alfred Prufrock" when Eliot was still an unknown poet, and became an early outlet for the experimental verse of Hart Crane, Wallace Stevens, William Carlos Williams, Amy Lowell, D.H. Lawrence and others. That same year Maurice Browne established The Little Theater, pioneering a new 
movement of small-scale, semi-professional productions that was gaining popularity, which helped to complete the city's emerging bohemian scene. ${ }^{19}$

Yet as Bernard Duffey wrote in his incisive account of the Renaissance, "More than either Poetry or the Friday Review, the first limited by its concentration on verse, the second to what could be smuggled into a book reviewer's columns, the Little Review embraced the whole of the Renaissance. Margaret set no limits on the magazine." Assembled according to no principle other than her inspiration and printed on wood pulp, rag or glossy paper depending on what she could afford at the time, the journal first championed anarchism and socialism before devoting itself to the aesthetic cause of imagism with Pound's defection from Poetry to become foreign editor in 1917. It published W.B. Yeats, Djuna Barnes and Gertrude Stein, the early stories of Sherwood Anderson and the first notable vignettes and stories of Ernest Hemingway. But its greatest and boldest contribution was its serialization of James Joyce's Ulysses in twentythree installments from 1918 to 1920, until the Society for the Suppression of Vice charged it with obscenity. ${ }^{20}$

"It was Art," Hecht would recall wistfully. "I have met many things in my life that were Art, but they were always Art plus something else—Art plus fame, money, vanity, success, politics, complexes, etc. The Little Review was, nakedly and innocently, Art."21

This Art represented a new consciousness, a new way of looking at and thinking about the world. There is a common recognition that America experienced a cultural revolution early at some point early in the twentieth century. A popular impression has been that it happened amidst the giddy madness of the Jazz Age, when a tumult of diversions, lifestyles and new ideas—-from miniature golf and dance marathons to 
speakeasies and the Smart Set—knocked aside quaint old conventions that had existed before the War and forever changed American life. But historians have long argued that the real upheaval had in fact begun before the war actually started, with a transformative burst of creative thought and activity between 1912 and 1917 that Henry F. May called "the Innocent Rebellion." 22

In New York's Greenwich Village and Chicago's Jackson Park art colony, an avant-garde of artists, intellectuals and agitators attacked fundamental Victorian notions of culture, basic morality, and even truth. "This movement, often called the Liberation, was mystical rather than naturalist, passionate about art but not amoral, iconoclastic but full of hope and even, on its own terms, reform," argued May. Above all, it turned into a revolt against the Victorian self-assurance and self-righteousness that kept women, immigrants and the poor in their place. ${ }^{23}$

But ultimately the First World War, as spectacle of modern civilization tearing itself apart, shattered this self-confidence and started to knock down barricades. As the old social order appeared to collapse, new alliances across the crumbling dividing lines seemed possible. But by the 1920s, many dreams of a changed society led either to failure or to unintended consequences. This left unanswered questions of what a new, modern era of equality would look like, and what would be necessary to achieve it. ${ }^{24}$

Hecht, with his journalistic skill for simplicity, put it concretely:

If you did not believe in God, in the importance of marriage, in the United States Government, in the sanity of politicians, in the necessity of education or in the wisdom of your elders, you automatically believed in art. You did not automatically plunge into the worlds of painting, music and literature. You plunged out of worlds, out of family worlds, business worlds, greed and ambition worlds. You did not necessarily stay out of them forever. ... But as long as you 
"believed in art" you remained orphaned from the smothering arms of society. ${ }^{25}$

By the 1890s, the city Sandburg called the "Hog Butcher for the world" had made great strides establishing institutions of high culture: the University of Chicago, with Thorstein Veblen and John Dewey on the faculty, the Auditorium concert hall designed by "father of skyscrapers" Henry Louis Sullivan, and most spectacularly, the World's Columbian Exposition of 1893. Chicago drew writers and artists from small towns across the Midwest, educated them, and thereby gave them things to smash. ${ }^{26}$

The Renaissance arose literally out of the ruins of the Columbian Exposition. By the spring of 1913, Theodore Dreiser, Sherwood Anderson, Margaret Anderson, Vincent Starrett, Harriet Monroe and Eunice Tietjens (assistant editor at Poetry) had joined a circle that gathered for soirees at the studios Floyd Dell, Hackett's young successor as editor of the Friday Literary Review, and Dell's wife, Margery. The couple rented adjoining flats in the Jackson Park art colony at the east end of $57^{\text {th }}$ Street and Stony Island Avenue. This was a South Side neighborhood of single-story frames originally constructed for the world's fair as souvenir stands and temporary restaurants-Currey's place was a converted retail storeroom—which were remodeled into apartments attractive to bohemians because of their cheap rent and proximity to the university. It was at the Dells' gatherings that Margaret Anderson announced her plan to start a magazine and discussed possible titles. ${ }^{27}$

Hecht became acquainted with the group through Margery after she was hired as a reporter for the Daily News in the fall of 1913. By now her marriage to Floyd was dissolving as a result of his infidelities, and he left for New York City to become editor of The Masses. Hecht, who was already rising in the newspaper world, had been reading 
Poetry since its inception and was working at short tales and poems influenced by the imagist style fostered by Pound. He was also collaborating on half a dozen short plays produced at Jane Addams's Hull House with Kenneth Sawyer Goodman, an aspiring dramatist and Princeton graduate, the most successful of their later works being The Wonder Hat. At some point in early 1914, Margery, who reverted back to her maiden name Currey, invited him over to the studio, where he found the community that would foster his ambitions as an artist. It "was another world into which I had drifted in my teens," he recalled, "a world unaware of doomed men and 4-11 fires.."28

Of all the early contributors to The Little Review, young Hecht was Margaret's favorite. She was charmed by his talk, and while she rebuffed his advances - she was a lesbian — he pushed his disappointment aside because of the support and opportunities she offered, and because he came to see her purity, devotion and — most of all—results, as a kind of genius. In 1915, The Little Review became the first outlet for his creative work, before it started showing up in the Smart Set and elsewhere. When, by 1918, he tired of churning out formulaic fiction for Mencken, he returned to contribute some of the best of his early stories, and continued to publish in The Little Review for the next four years. $^{29}$

Playwright and theater producer Lawrence Langner remembered meeting Hecht at the time. "He expressed his intention of devoting his life entirely to pure literature, as evidenced by certain coruscating stories he had contributed to The Little Review," Langner wrote. "These, he said, would win him immortality, though he would undoubtedly die penniless in an attic. Years later I pondered over the evanescent nature 
of human intentions, as he informed me, with considerable bitterness, that he was then the highest-paid writer in Hollywood."30

By the summer of 1914, Hecht had fallen in with another habitué of Margery Currey's studio, Bodenheim. Of the young bards now appearing at Harriet Monroe's Poetry office, "this usually silent figure was perhaps the most unpromising and forlorn," she later wrote. "He was always looked hunted and haunted, as if half-starved and halfill.” But her attitude soon changed when she read Bodenheim's verse. Langner remembered that the poet's arrival on the scene sparked a feud between the little magazines. "We have just discovered a new poet," Margaret had told him breathlessly, "probably one of the greatest in America, and now Harriet is trying to print one of his poems in Poetry Magazine so as to claim credit for his discovery before we publish him in The Little Review." Years later in New York, at a party given by Bodenheim's publisher Horace Liveright, Langner had heard a loud crash in the hall at two in the morning and had inquired timidly what it was. "That," said Liveright with chagrin, "is Maxwell Bodenheim falling downstairs." 31

Strutting about bohemia like an odd rooster, Bodenheim was shabby but generally clean, often draped in a U.S. army overcoat in wintertimes. He smoked a four-foot-long, malodorous Polynesian pipe decorated with a baby blue ribbon around its stem, and was always ready with a lashing remark, a mocking grin as if privy to a private joke known only to himself, and florid, ornate phrases that many women found beguiling, if also incomprehensible. "Your face is an incense bowl from which a single name arises," was one typical line. "Your hair is a tortured midnight," was another. He was tall, lanky and handsome, with baby blue eyes that matched the color of his pipe, and despite what some 
have written in recent decades, he was a gifted if uneven writer, capable of producing fine poetry and compelling essays. Despite his eccentricities, which could be worn as a badge of honor in ever-tolerant bohemia, he looked destined for a brilliant future. "But beneath the surface there lurked a man of acute inner tensions, wracked with selfdefeating conflicts," observed Allen Churchill in The Improper Bohemians. "I have a malady of the soul," Bodenheim had begun declaring in Chicago. It was a line he would often find occasion to repeat thereafter. ${ }^{32}$

Bodenheim's mother came from a family of émigrés from Alsace, France who had risen to wealth and prominence in Memphis. Max had grown up under the shadow of their success, and in the ignominy of his father's failures. Born May 26, 1892, he was raised in Hermanville, Mississippi, until his family moved to Chicago in 1900. The town had been founded by his maternal uncle, M.B. Herman, who started a booming drugs, dry goods and grocery business, buying property and opening shops from Jackson to Natchez that he supplied along the Illinois Central Railroad. Already rich from this enterprise, Uncle Herman had then gone on to medical school, eventually establishing himself as an eminent Memphis surgeon.

Max's father, Solomon Bodenheimer, was another story entirely. Also an émigré from Alsace, he had tried and failed with his own shop in Hermanville, before drifting through stints as traveling whiskey salesman, sales clerk and other jobs, all invariably ending in defeat. His shortcomings as breadwinner were not lost on his domineering wife, who meanwhile saw her brothers and sisters thrive, leading to a home life wracked by bitter quarrels and instability. Bodenheim became a rebellious boy, expelled from Hyde 
Park High School for reasons unknown. In 1909 he ran away from home and joined the army. ${ }^{33}$

Hecht reports that Bodenheim was jailed for hitting a lieutenant in the head with his musket after the officer had ridiculed him as a Jew. Biographer Jack B. Moore, however, who drew much of his information from Bodenheim's first wife Minna Schein, discounts this as just one of the stories Bodenheim told to cover up what really happened. According to Moore, Bodenheim had tried to desert only to be recaptured, and then panicked and swallowed lye. He spent the remainder of his duty at Fort Leavenworth. As a result of the lye incident, his teeth began to rot and his taste buds were destroyed, so that for the rest of his life he dumped bottles of Tabasco and Worcester sauce on everything he ate to give it some taste. ${ }^{34}$ After a year or two of wandering around the South and Southwest, Bodenheim returned to Chicago in 1912, where he worked at telephone line maintenance and at other jobs before his literary career got underway.

By the winter of 1915, Hecht was congregating at a Cass Street boarding house packed with young bohemians, where Sherwood Anderson rented a third-floor room. Anderson had nicknamed the place, where he reigned as dean, Little Children of Arts, a joking reference to a nearby Catholic school. He too was a runaway who had landed in bohemia, but of a unique variety. Originally from Ohio, Anderson had owned a manufacturing firm in Elyria, but the business had fallen apart, and one morning he walked out of his office onto the road that led out of town, leaving his wife and three young children behind. His own accounts of what happened over the next four days would always be vague; apparently he became lost in a spell and suffered amnesia. Finally he showed up dazed, disheveled and incoherent at a Cleveland drug store and was 
taken to a hospital. The incident put an end to his marriage and marked the start of a new life and career. ${ }^{35}$

Now thirty-nine years old, Anderson was being hailed as Chicago's "great unpublished author" by Floyd Dell for the manuscript that he had been writing in his Elyria attic, Windy McPherson's Son, and he was well along with two more novels, Marching Men and Winesburg, Ohio. At a younger age he had worked in advertising in Chicago, and this he had now resumed, writing copy for Taylor-Critchfield-Clague while enjoying his seniority over the young penniless artists. Good-looking and exuding a suave self-confidence, "Swatty" came across to Hecht as a shrewd salesman of the lies he told about himself. Hecht was won over by his charm, but only to a degree. "I stopped thinking of him as a barber or swami," Hecht recalled in Child. "He became a gypsy full of larceny and guitar music." But as Irving Howe argued in his biography of Anderson, the elder writer undoubtedly concealed a deep sense of insecurity that he experienced upon finding himself among urchins half his age who could talk all night about authors he had never heard of. ${ }^{36}$

Anderson nevertheless seemed to see his new life in bohemia as a second chance at childhood, and he embraced his newfound sense of innocence and wonder. When girlfriend Tennessee Mitchell brought him to the opera, he remarked that while the music had made no strong impression upon him, he found the costumes marvelous. He often lit candles to the gods of inspiration when he read at gatherings or sat down to write at his big table. In the first issue of The Little Review, he trumpeted the "new note" entering into the world, which owed nothing to what had come before. "If we are a crude and 
child-like people," he would later assert, "how can our literature hope to escape the influence of that fact? Why indeed should we want to escape?"37

By 1915 Hecht had also befriended Carl Sandburg, when the latter was working for Day-Book, a magazine that championed the common man. In his mid-thirties and hailing from Galesburg, Illinois, Sandburg had been at different times a hobo, a journalist, and a committed activist employed by Wisconsin's Socialist Party. Hecht managed to convince his boss at the Daily News, Henry Justin Smith, to hire his new friend, and while the editors found Sandburg infuriating, Hecht and the other reporters were amused by his starry-eyed radicalism and obliviousness of deadlines. ${ }^{38}$

In March 1914, Sandburg's "Chicago Poems" started to appear in Poetry. Packed with gritty, resonant imagery of industrial-era Chicago, they described fog creeping like cat feet and "Black ships that heave and lunge/And move like mastodons/Arising from lethargic sleep." The poems gave voice to the downtrodden, exploited and luckless: "Mamie" told the story of a girl who escapes her small town only to become abused and used up as a streetwalker. The poems soon earned Sandburg several champions, including Dreiser and, in turn, Mencken, and Edgar Lee Masters, whose Spoon River Anthology garnered significant attention after its publication in 1915. Harriet Monroe lobbied for Sandburg vociferously, arranging for him to win the 1914 Poetry contest. ${ }^{39}$

Bodenheim's career was also rapidly on the ascent. He had been exchanging poems and letters with Alfred Kreymborg, editor of the poetry magazine Others, and at some point probably in late 1914 traveled out to New York for a stay. Arriving with an old portmanteau in one arm and the other in a sling, he had struck his host as "the queerest among the queer." The injury, Bodenheim explained, had occurred when he fell 
off a streetcar before entraining for the journey_- "another of life's little jokes," he had quipped, with the weariness of an old man. "Bogie's poems, mature to the last degree, were frankly admired in the crowd," Kreymborg recalled, "and the poverty-stricken misanthrope, who hated nothing on earth as he hated Chicago and the Poetry crowd - the first of an endless series of antipathies — sunned himself in this admiration."

Tales of Bodenheim's effronteries and outrages in Chicago had not yet followed him East, though they soon would. One characteristic story, which would be told and retold in various versions, was that when the Great War started, Bodenheim let it be known the army was after him for draft dodging. His plight had attracted the sympathies of wealthy radicals, who took him into hiding and catered to his every whim. As if born for the role, Bogie was soon doling out demands like a pasha. But when newspaper friends made inquiries on his behalf, they discovered that the military had never considered him suitable for service. Informed of this at last, his hosts descended in a fury and tossed him out. As he stared back thoughtfully at his duped supporters, Bodenheim fluttered his eyelids and remarked, "The anger of fools is my favorite crown."41

In New York the supposedly injured Bogie accepted the ministrations of Kreymborg's wife "with the bored air of a visiting potentate." William Carlos Williams, who also opened his home to Bodenheim during the month-long visit, remembered that his guest had arrived with a fake sling in order to avoid assisting with any chores. Bogie's stay was no small inconvenience to Williams' wife Florence, who had two young children to care for. When the poet left after a week, Williams expressed his pleasure at having had his company. "Yes,” mused Bodenheim, "I think you have profited by my visit." 42 
With his cackling wit, rakish flair and literary airs, "the queerest among the queer" managed to amuse the likes of Marcel Duchamp, Malcolm Cowley and Conrad Aiken. He drank at the Hell Hole with Eugene O'Neill, whom he would later profile for the New Yorker, and Dorothy Day, composing a long poem with them. As one of the revolving cast of editors for Others, he discovered Hart Crane, who related excitedly to his mother in 1917 that "Bodenheim is at the top of American poetry today." When Others folded, Williams, who also served as editor, told Amy Lowell that the periodical had been valuable because it "held the future of such a man as Bodenheim in its palms, even if only for a short while." ${ }^{43}$

In 1920 the New York Times spotlighted the publication of Bodenheim's second book of poetry, Advice. Critic Herbert S. Gorman announced: "He is a phoenix of strange origin who must have risen from the ashes of some bird...bursting upon one from the blue with absolutely no antecedents, no formative guides to point back at. ... Mr. Bodenheim is a wizard of phrases. He is a master of the elusive word. ... He peers behind phrases, finding strange lumber there and building up his airy structures with a decisive gesture. 'Advice' is indubitably one of the most important books of the year." With the publications of Masters' Spoon River, Sandburg's Chicago Poems and Anderson's Winesburg stories, the Renaissance reached its apex between 1915 and 1916. Poetry, The Little Review and the Little Theater had all hit their stride. Hecht, who married Marie Armstrong in 1915, was furiously churning out short stories while continuing to write plays with Goodman. He also partnered with Bodenheim, with whom he wrote Dregs, The Master Poisoner and other plays produced by the Players Workshop, a little theater on $57^{\text {th }}$ Street. ${ }^{45}$ 
Sherwood Anderson and Sandburg would soon soar to fame and literary glory. Anderson's Windy McPherson's Son garnered a few exuberant reviews but poor sales in 1916, while his subsequent novel and book of poems both flopped. But his luck changed in the spring of 1919, when publisher Ben Huebsch took a risk with Winesburg, Ohio. It became a sensation, and the following year, Poor White scored another major success. Sandburg earned a Pulitzer Prize for Corn Huskers in 1917, and would eventually win two more; his American Songbag, printed in 1927, has endured as a seminal compilation of folksongs, while his multivolume biography of Abraham Lincoln is regarded as a masterpiece. $^{46}$

Reading back over The Master Poisoner in the final days of his life, Hecht found it astonishing. The plot and dialogue were both unintelligible. "Yet the printed phrases seemed to spin and leap with some mysterious excitement," he wrote. "Youth in love with words. The embrace may have been a little disorderly, but I have found few things better to love-since then." ${ }^{, 47}$ 


\section{NON SERVIAM}

He fell and was hurled with his rebellious angels into hell. What his sin was we cannot say. Theologians consider it the sin of pride, the sinful thought

conceived in an instant: non serviam: I will not serve. That instant was his ruin.

\section{A preacher's sermon in Portrait of the Artist as a Young Man, by James Joyce $^{48}$}

A process of assortment took place: the Dells and the Cooks left Chicago for New York, while the Hechts and the Bodenheims with their Art-for-Art's sake dictum remained in Chicago for another decade or so, to wait till Greenwich Village was scared by the anti-Red hysteria and lulled by Coolidge Prosperity into a drink-and-sex era, with politics excluded.

\section{Albert Parry, Garretts and Pretenders $^{49}$}

While assembling the third issue of The Little Review in May 1914, Margaret Anderson heard Emma Goldman lecture, and "had just time to turn anarchist before the presses closed." As a result, she lost her funding from Wing, and from thereon the poised and gentle lover of art and poetry would draw such notoriety as seditious firebrand that in 1930 she would title her memoir My Thirty Years' War. By the time Wobbly poet Joe Hill was executed by firing squad for the murder of a shopkeeper in November 1915, Anderson had embraced socialism, and was now calling The Little Review a magazine of “Art and Revolution.” In her December editorial, she wondered why the five thousand Chicagoans who marched at Hill's funeral on Thanksgiving Day had not rallied before he was shot. "Incidentally,” she added, “why didn't some one shoot the governor of Utah before he could shoot Joe Hill?" For that matter, she suggested, they could now beat up a local police squad on behalf of Chicago's garment strikers, set fire to some of the factories, or sabotage the shops. "For God's sake," she demanded, "why doesn't some one start the revolution?",50 
Goldman had at first pegged the young diva as just another frivolous, bourgeois bohemian, but was impressed to discover Anderson so admirably broke that she possessed not a stick of furniture. Lacking the income for rent, in May of 1915 Anderson invested in wooden boards and built a tent camp north of the city on the shore of Lake Michigan. Hecht and Bodenheim would trek out and tack poems to her tent flaps. On a visit that summer, Goldman now found that her hostess' liberation from the trappings of bourgeois materialism had gone a bit too far, and remained miserably planted on a kitchen chair in a heavy black gown, savagely slapping at the mosquitoes on her neck as her face grew redder by the minute. "I have a nice cool comfortable hotel room in Chicago," Goldman complained, "and I let Margaret drag me away for the week end." In the fall police burned down the encampment while news photographers snapped photos. By then Anderson had moved to a nearby house, but she was arrested for chopping down a neighbor's evergreen for a Christmas tree. ${ }^{51}$

Though based in Greenwich Village, Emma Goldman also became a fixture in Chicago. In lectures promoted by Ben Reitman, her eccentric ex-lover and press agent, "Red Emma" drew as much public and police attention for her advocacy of "free love" as for her anarchism. Reitman, a pioneering physician in the treatment and prevention of venereal diseases, was an imposing man with untidy black hair who usually wore a tie and black slouch hat, carried a cane, and according to Anderson, "wasn't so bad if you could hastily drop all your ideas as to how human beings should look and act." At a time when the city became host to some fifty thousand homeless men, Reitman crowned himself King of the Hobos. ${ }^{52}$ 
Chicago had a long history of labor unrest, from the city's emergence as an industrial hub after the post-Civil War Depression of 1873-1879 to the Haymarket bombing and riot of 1886 . In the early twentieth century, it naturally became headquarters for the Industrial Workers of the World, better known as the IWWs or Wobblies, and drew the most prominent political agitators and advocates of the day. One was the hulking, one-eyed Big Bill Haywood, an itinerant miner, cowboy and Wobblies founding member who was put on trial for a bombing murder in 1907. Others included fellow Wobbly founder Eugene Debs, prosecuted for leading 80,000 unionists in the Pullman Strike of 1894, and Clarence Darrow, a one-time attorney for the railroads, who switched sides to successfully defend both Debs and Haywood before taking up other causes. $^{53}$

On a surface level, the Renaissance writers and Chicago's activists had achieved a degree of harmony by 1915. But Haywood, a battle-scarred veteran of the barricades and leading organizer, did find Margaret Anderson frivolous, and expressed annoyance that her editorial had so cavalierly dismissed the struggle and sacrifice of those on the picket lines. As Irving Howe observed of the Renaissance writers, "absent was the social rebelliousness and guilt that was to rake American intellectual life in the 1930s. There were, to be sure, such socialists as Floyd Dell, but when Sinclair Lewis called Dell a faun on the barricades he was rather close to the truth. Most of the Chicago writers who cared about socialism at all thought of it merely as the terminus of a joyous and visible democratic expansion." 54

Anderson and many of the other Renaissance writers would soon relocate to New York City, where by 1913, Art and Revolution had mingled and fell in love at Mabel 
Dodge's Greenwich Village parties — an affair that would prove both torrid and volatile. ${ }^{55}$ "I was going to dynamite New York, and nothing would stop me," Dodge recalled in her memoir, referring to her sponsorship of the incendiary Armory Show art exhibition, if not also to the drama that was later to follow. On any given evening at her elegant Fifth Avenue apartment, Emma Goldman and Margaret Sanger might be engaging in spirited debate with Alfred Stieglitz, Lincoln Steffens and Randolph Bourne, while Bill Haywood briefed Max Eastman and Walter Lippmann on the latest news of a strike. Free love, the eight-hour workday, psychoanalysis, cubism, birth control, and women's suffrage were a few of the topics hotly argued and discussed: "Oh, how we were all intertwined!" Dodge wrote. $^{56}$

The electric energy of her salon came not just from her talent for hosting such a diverse and extraordinary group, but also from Greenwich Village itself, which stood at the confluence of many different crosscurrents in American life. By the end of the nineteenth century, a fluid downtown mix of foreign- and native-born, rich and poor, emancipated men and unescorted "new women" had begun to coalesce as a vibrant bohemian milieu. Some were drawn to the openness and cosmopolitanism that offered a sense of adventure, a taste of things forbidden by Victorian moral strictures. Others flocked there for the intellectual and cultural education they had not received in college, a schooling that was particularly well provided for on the proximate Lower East Side. ${ }^{57}$

Historian Christine Stansell described the bohemians' encounter with the frenetic Jewish ghetto south of Houston Street:

Intellectually, some of the talk was almost certainly over their heads, turning upon fine points of revolutionary dogma, European literature, or Continental philosophy. Much of it was also linguistically incomprehensible, since conversations tended toward Yiddish, French, 
German, or Russian. But by its very nature, bohemia invited the adoption of a transnational identity, one that piqued people's interest in one another.

...Politics and art mingled in discussions over endless glasses of tea. Socialist, anarchist and Zionist controversies reverberated through the lecture halls, saloons, and tenements, the preoccupations of a "modern-minded European working class for whom Yiddish was its primary medium of expression." The grave and precise debate, both aesthetic and political, was remarkable even for the United States, where traditions of autodidactic learning were strong among workers. Feuds raged between the main political camps - say, Zionists versus socialists - but quarrels also flared up over the nature of realism or the quality of a production at a Yiddish theater. ${ }^{58}$

New York's bohemia brought together those who had been outsiders- the Wobblies, women dissatisfied with their "separate sphere" in Victorian society, and strays from small Midwestern towns. It put them at the forefront of national dialogues, forged alliances that had never existed before, and created new dynamics of intimacy based on equality. By 1910 the scene had consolidated in Greenwich Village, which now became a destination for seekers, eccentrics and aspiring artists from across the country. Arrivistes from Harvard and Columbia like Walter Lippmann, John Reed and Max Eastman talked of "vital contact," the notion that while overeducation and privilege had dulled them, they could recover their vitality by mixing with the salt of the earth. ${ }^{59}$

At Mabel Dodge's posh brownstone apartment, Villagers converged for almost weekly parties that were each dedicated to a theme, such as Sex and Antagonism, or Evenings of Art and Unrest. Dodge, a wealthy socialite of thirty-three when she arrived from Europe at the end of 1912, was not one for commitment to anything, including the radical causes she espoused. To her critics she was "nothing but a dilettante of radicalism, mixing champagne and dynamite, confusing feelings and thought, regarding insurrection as entertainment." But intuitively Dodge understood better than many of her more erudite 
guests that all the multifarious groups and ideas were intrinsically linked. "Looking back at it now," she famously observed, "it seems as though everywhere, in that year of 1913, barriers went down and people reached each other who had never been in touch before; and there were all sorts of new ways to communicate, as well as new communications. The new spirit was abroad and swept us all together." ${ }^{, 60}$

The Armory Show, for which Dodge served as the vice president, one of its financial backers, and most ardent publicist, jolted exhibition goers and newspaper readers as a shrewdly orchestrated piece of theater that featured some thirteen hundred works, presenting European developments in painting since the 1870s. Recognized as the most important exhibit of the twentieth century, it exploded upon American consciousness, introducing the nation to Picasso, Matisse, Van Gogh, Cezanne and Kadinsky. The most famous, and infamous, was Marcel Duchamp's Nude Descending on a Staircase. Flabbergasted and outraged by such departures from tradition, the press heaped on the ridicule. When the show closed after a month in mid-March 1913, having previously stopped in Chicago, the Times spluttered, "It should be borne in mind that this movement is surely part of the general movement, discernable to all the world, to disrupt, degrade, if not destroy, not only art but literature and society too...the Cubists and the Futurists are cousins to anarchists in politics." ${ }^{, 61}$

The warning could not have been more timely, for Dodge was already helping to seal the bond between radical art and politics and draw the Village crowd into the streets. A turning point for New York's intelligentsia had already come before her arrival in the winter of 1912, with a textile mill strike in Lawrence, Massachusetts. When the Wobblies decided to transport the workers' families to the protection of supporters in New York 
and Boston, violent efforts by the police to block them at the Lawrence train station drew the attention and sympathy of the press, particularly the family magazines of New York such as Harper's, Collier's and the American. ${ }^{62}$

Haywood, who had been instrumental in the effort, was impressed by the results of enlisting the capitalist press, and overcame his distaste for society gatherings to appear regularly at Dodge's parties. At her Dangerous Characters evening, "a great battered hulk of a man, with one eye gone and an eminent look to him" now in repose on her chaise longue, seemed "like a large, soft, overripe Buddha." Walter Lippmann tried to quiz him on Wobbly policies, but only seemed to depress him and got nowhere. ${ }^{63}$

A strike by silk workers in nearby Paterson, New Jersey that spring at last provided the opportunity for action. When Haywood groused that the newspapers were determined to keep New York workers in the dark about the strike, Dodge found herself suggesting that they stage a reenactment in the city. A voice chimed in from the back of the room. "That's a great idea. I'll go over to Paterson first thing in the morning. We'll make a pageant of the strike!" The speaker was John Reed, and there began the famous romance of Greenwich Village's heyday.

Reed was a Harvard man, dashing adventurer, and crusading journalist for The Masses. Dodge soon fell in love. While Reed covered Paterson with a rolling, spicy account that ginned up more enthusiasm for the cause, Dodge led meetings at Margaret Sanger's apartment and recruited Villagers. Reed wrote scripted the pageant, rehearsing with the strikers revolutionary chants to the tune of "Harvard, Old Harvard," as he, a former cheerleader, directed by megaphone. On June 7, fifteen hundred strikers marched 
up Fifth Avenue from the Village to Madison Square Garden, where fifteen thousand spectators cheered and cried as the players reenacted clashes with police. ${ }^{64}$

Now the spirit of activism had taken hold in the city. For ten days in late February 1914, a young spirited radical named Frank Tannenbaum led six hundred homeless and unemployed men to the doors of churches for food and shelter. This led to a bloody battle with police in which 190 were arrested, including Tannenbaum. Over the days of rioting that followed, the Villagers found themselves on the front lines. As suffragist and writer Mary Heaton Vorse recalled, "That winter was sort of a welding process...In Lawrence we had, after all, been only spectators... Now we were on the inside, part of the movement, with responsibility for these men." 65

But the dream of unity proved short-lived: In retaliation for the deaths of workers in Ludlow, Colorado, and the violence of February, Emma Goldman's companion Alexander Berkman, who previously served fourteen years for attempting to assassinate steel magnate Henry Clay Frick, planned an attentat, a bombing of the Rockefeller estate. In June, the bomb accidentally exploded in the tenement building of an immigrant neighborhood, killing four. Goldman, who was sensitive to the damage done to the activists' ties with the bohemian community, was doubly disgusted by the mess Berkman had made of her magazine Mother Earth, which, in her absence, he had filled with chilling calls for violence. What had started with inspiring dialogue about a new society had ended in, as Goldman put it, with "prattle about force and dynamite.",66

Dodge's enthusiasm for the cause had flagged when her relationship to Reed fell apart and he had left for Mexico to cover the hunt for Pancho Villa. Sent next to report the war in Europe, he then traveled to Russia for the crucial days of the Revolution. There 
he caught the scoop of a lifetime, which he captured in The Ten Days That Shook the World. But before dying of typhus, he also bore witness to early days of Soviet totalitarianism, leaving generations to speculate as to whether, at the very end, he had reconsidered his devotion to communism. The vision of "anarchists and socialists...united with painters and poets, by two Villagers who were falling in love,...the quintessential Village link of politics, art and sex" was over now. As May observed, "Literary rebellion and the political left, although they were to come together again, never met in such a free and unforced union." Subsequent generations would look back at this union as an experiment that had somehow gone awry. ${ }^{67}$

With the United States entrance into war came a reactionary backlash that precipitated a fierce crackdown on the Innocent Rebellion. Government agents were now more numerous than Emma Goldman's followers at her speeches, and just as the post office was poised to ban Mother Earth under the same Espionage and Sedition Acts that had shut down The Masses, a U.S. marshal arrested her and Berkman for conspiring against the draft. In an impassioned defense, she compared her radical critique of the United States to a man's open-eyed love for a woman, faults and all. She was sentenced to two years in jail, but though Justice Louis Brandeis freed her and Berkman pending appeal, this was rejected by the Supreme Court in 1918. When she was released in late 1919 after serving twenty months, Attorney General Alexander Mitchell Palmer signed a warrant for her rearrest under the law authorizing the deportation of alien anarchists. The New York Times led the call to eject her, and on the freezing morning of December 21, she and 245 others were shipped out on "the Red Ark" from New York harbor. Although 
initially defiant, she spent the remaining twenty years of her life mostly lonely and lost, in her own haunting words, "nowhere at home." 68

When Margaret Anderson moved from Chicago to New York in 1917 after a winter in San Francisco, she had trouble finding a place among the East Coast bohemians, and finances, never steady, became an increasing strain. In 1920, she and her lover and co-editor Jane Heap were booked on criminal charges of distributing obscenity through the mails for the publication of Ulysses. Failing to obtain representation from the American Civil Liberties Union, they turned at last to attorney John Quinn, who harbored a deep dislike for women in general and lesbians in particular.

Though a few years earlier their trial would have been a cause celebre, the alliance between the literary and political worlds was long over now. The press took little interest in their case, and New York's literary critics, who had never been warm to the book, were mute. Quinn, who in truth concurred with censorship, instructed his clients to remain silent, and then offered a defense that both insulted them and undermined their cause. The editors, however, were determined to be heard. At a pre-trial hearing, Heap stood up in defiance of Quinn, and much to his annoyance, voiced protest with a lyricism that ensured her words would not soon be forgotten: "Girls lean back everywhere, showing lace and silk stockings, wear low-cut sleeveless blouses, breathless bathing suits; men think thoughts and have emotions about these things everywhere-seldom as delicately and imaginatively as Mr. Bloom—and no one is corrupted." 69

In 1922, Anderson joined the ex-patriot community in Paris, having concluded that America would neither tolerate nor support her idealism. "I wasn't born a fighter," she wrote in her memoir. "I was born with a gentle nature, a flexible character. ... I 
shouldn't have been forced to fight constantly and ferociously. The causes I have fought for have invariably been causes that should been gained by a delicate suggestion." ${ }^{, 70}$

The crackdown had been just one element of the sweeping changes that had come with the war. The rebels had known change was imminent, but imbued with the same sunny optimism and confidence as the Victorians, they had been no better prepared for the dark days ahead. When Americans faced the war themselves, it looked not only like a funeral pyre of the old culture; there was the suggestion that this was the true face of the culture they had inherited from Europe. "Is it not a possibility," asked Frank H. Simonds in The New Republic, "that what is taking place marks quite as complete a bankruptcy of ideas, systems, society, as did the French Revolution?" Beyond even that, the atrocities could appear a vivid repudiation of belief in the basic decency of human nature. The rebels now could feel vindicated in many of their attacks on the smugness of Victorian society. But there was no joy in such vindication. ${ }^{71}$

By the time the London Nation reprinted Mencken's grand proclamation that Chicago was "The Literary Capital of the United States," in 1920, most of the principal players of the Renaissance were gone. Dreiser, Dell, Sherwood Anderson, and Margaret Anderson had all moved away, while radicals Eugene Debs and Bill Haywood were sentenced to jail time in 1918.

That left Hecht and Bodenheim to bask in the limelight of what Dale Kramer called "a new age of cynical glitter" that followed. The two savants held court at the Round Table of Schlogl's, which offered exotic lunchtime fare at equally exotic prices and became the center of the new scene. Other regulars of this stag club-women and their escorts dined in a dilapidated upstairs room-included newspaper columnists 
Richard Henry Little and Keith Preston, artist and journalist Wallace Smith, editor Henry Justin Smith, publishers and booksellers Pascal Covici and Billy McGee, physician and medical editor Morris Fishbein, author and literary sage Vincent Starrett, critic Burton Rascoe, and Harry Hansen, whose 1923 book Midwestern Portraits focused on Round Table personalities. Of the original Renaissance writers, Sherwood Anderson, Dreiser and Masters would occasionally drop in. Other visitors included Vincent Sheean, Ludwig Lewisohn, Louis Untermeyer, Sinclair Lewis and Charles MacArthur. ${ }^{72}$

"As a matter of fact, the Renaissance became a one-man affair, centering around Hecht," observed the editor, translator and Lost-Generation memoirist Samuel Putnam. “It was Hecht who dominated the 'Daily News School,' the gathering-place of which was Schlogl's Restaurant, with dignified, scholarly Hansen, then literary critic on the News, as matter of ceremonies...There was good conversation, and it helped to preserve the illusion that Chicago was still the 'capital' it had once been; but it did not require much inspection to discover that this was far from being the case." Hecht would later quip: "Would that our writing had been as fine as our lunches!",73

The nighttime hotspot was the Dill Pickle, a kind vaudeville venue, burlesque club, and carnival freakshow rolled into one. Bordering the northside bohemian community known as Towertown that had sprung up just before the war, what had started as an informal discussion group for the soapbox radicals of "Bughouse Square" had moved to nearby 18 Tooker Alley by $1917 .{ }^{74}$ It offered all-night jazz from the Chicago bands of the early '20s; Little Theater productions of Ibsen and Strindberg starring strippers with stage names like Angela d'Amore and Lucrezia Borgia; and speakers of every stripe, all of whom had to endure the murderous heckling of the Pickle's crowd. 
Mixed with a lecture on a woman's right to live her own life or a heated debate between University of Chicago scientists on the unheard-of topic of atomic energy, "any sensationalist figure of the moment - paroled convict, unwed mother, reformed vegetarian or three-headed guinea pig was apt to appear." A "professor," now graduated to Sirfressor, would rail against socialism, while Triphammer Johnson, a colossal Norwegian with walrus mustaches, expounded upon Nietzsche and Kierkegaard with the thunder of a Viking. All acts were aggressively promoted by founders Ben Reitman and Jack Jones, the latter a former Wobbly whose mangled hand was rumored to have been the result of a nitroglycerin accident while safe cracking, or from a botched sabotage operation during a strike. "I give them the high brow stuff until the crowd begins to grow thin, and then I turn on the sex faucet," Jones had told Sherwood Anderson, referring to the club's notorious "sex lectures."75

The Pickle's all-inclusiveness stretched well beyond the bounds of Mabel Dodge's salon, creating a postwar scene of a different character altogether. It evolved into a speakeasy supplied by Bugs Moran's gin, where hookers blew in from North Clark Street to become paramours of newspapermen and Wobblies. "A world less like Greenwich Village or Saint Germaine would be hard to imagine," observed Kenneth Rexroth in 1977. "In Paris...now that intellectuals are coming back and mixing with the hustlers in cafés...there is a kind of ragamuffin bohemia of petty crooks, carnival performers, models and prostitutes, and bad, penniless artists and unprinted poets, which greatly resembles Chicago in the Twenties."76

While the Dil Pickle did not rely on Hecht, his regular appearances certainly were good for business. The Picklers welcomed Dregs, his gritty one-act about a derelict, 
whereas many in the audience at the Players Workshop had stormed out after the opening line, which contained vulgar oaths of "Jesus Christ" and "son of a bitch." On another evening, Hecht and Bodenheim packed the house for a literary debate, and then announced the topic: "Resolved, that people who attend literary debates are imbeciles." On this they immediately concurred, declared the debate over, and then fled out the back with the ticket sales. ${ }^{77}$

The story sums up their attitude in general.

"Around 1920 the audience-change began," Hecht later recalled. "Philistines started turning into aesthetes by the train load. The desire to be peculiar and original was always a part of the artist's ego. It began to become part of the audience's." He attributed this to the ferocious pace of urbanization and industrialization, which made people feel small and insignificant. "Blotted out by the roars and menaces of progress, thrust into anonymity by mob-glutted cities and stuck away in the filing cabinet rash of sky scrapers...they shopped for personality among the artists who had continued to flourish under the labels of con men and fakers. Our castaway citizens couldn't join the artists...but they could admire the incomprehensible paintings, applaud the headacheinducing symphonies, and even read the incoherent poetry erupting from the art world."78

Discovering this world now overrun by boobs and charlatans, Hecht and Bodenheim had at last found their ideal target. Harpooning "the American Intellectual Establishment" must have appeared, at least intuitively, a deeper and truer rebellion than the anarchist and socialist adventures of the pre-war set, for after all, the prophets of old had directed their challenge not at the pharaohs, Philistines, and sundry other idolaters, but at the Chosen People, who were in breach of their covenant with the Divine. In 1922, 
Hecht summoned Bodenheim back from the Village to Chicago: "After seven years you and I are still the best hated men in American literature. Why not pool our persecution mania? ...I shall be here Monday at 4 with a bottle of gin." 79

The platform for their assault was to be the Chicago Literary Times, a biweekly riot of absurd, quixotic headlines and snarky commentary printed on tabloid-sized pages of bright pink, yellow and green, evocatively illustrated by Stanislaus Szukalski, Herman Bosse, Wallace Smith and George Grosz. Launched on March 1, 1923 with Hecht as editor and Bodenheim hired on a month later as associate editor, this "gazette devoted to the Sacred Ballyhoo" mocked the pretensions of arts and letters, taking aim at any and all targets of opportunity. Pascal Covici provided the financing, erroneously believing that it would promote his bookselling and publishing concerns. By the time it folded on June 1, 1924, the Times had a circulation of between fifteen and seventeen thousand. Three months after its launch, a New York Times editorial headlined "Startling the Radicals" observed: "Shocking the bourgeois has become too stale and tame a sport for Chicago. The game of advanced radicals in that city is now to horrify the radicals of the East. ...(Hecht and Bodenheim) set themselves up as the real Goths and Vandals of the liberal movement, and have no patience with those 'radical journals' of New York that keep up 'an unceasing caterwauling for justice, heroism, sanity, and beauty of the soul."»80

A favorite practice was to stalk multiple and diverse quarries at once, sometimes in juxtaposed left- and right-hand columns, other times altogether in just one. The front page of the premiere issue featured attacks on both Chicago and New York. The left-side column denounced the "reeking, cinder ridden...the chewing gum center of the world, the bleating, slant-headed rendezvous of half-witted newspapers, sociopaths and pants 
makers," while the polemic on the right headlined "Concerning the Natl. Cemetery of Arts and Letters" lamented the depressing state of Gotham's magazines. "They seem to be suffering from the lack of a good drink or a good physic," Hecht inveighed. "They are continually talking about Art as if it were their dead grandmother." ${ }^{81}$ Two months later, he bashed the lowbrow idiocy of radio broadcasts, and in an adjacent item, derided the pitiful amateurishness of highbrow little magazines. Bodenheim scoffed at the hack writer who every once in a while "sets up a sixteen by fourteen target and calls it Bohemia," only to then ridicule those deluded downtown posers who "have made the word 'Bohemia' to erase the smallness that pervades them during the lulls in their 'artistic' labors." 82

The literary giants of the day were, with a few notable exceptions, hauled into court and sentenced without mercy. Bodenheim described Eliot's "The Waste Land" as "Intellect engaging in a drunken commotion, and Erudition prattling with the husky candor of a vagrant in the back-room of a saloon.” A review of F. Scott Fitzgerald's play "The Vegetable" asserts that the author is "a ringleader among the class of garrulously obvious writers... accomplishes the old trick of swatting hypocrisies and fondling them at the same time." One Bodenheim column offered a round robin of invective, complaining that the current writers had all become respectable tradespeople who peddled polished and lifeless formulas: "You can be certain that Carl Sandburg will use a bragging slang to persuade people that they are not small and defeated-' 'what the hell, it'll all come out in the wash' - , that Sherwood Anderson will turn his kindly eye upon the fact that people desire each other's bodies, that D.H. Lawrence will sputter ferociously about the carnal 
misery of life, ... that T.S. Eliot and Ezra Pound will run to six languages and certain dry and mirthless tactics to entertain their tired minds..."

The pair of gadflies received the reaction they had hoped for. Anderson wrote to a friend that Hecht's "smartiness" would destroy what little talent he might have had. In a July editorial, Hecht noted the complaints pouring in that the publication only seemed to be interested in irritating people. He responded that however wrongheaded the Times may be, such individuals should be grateful for a periodical that challenged their ideas. Each issue was packed with sound and fury, as if the sole objective was to shock readers by dismissing all literature as a grand farce. Headlines were written in a pseudo-news style suggestive of today's Onion, like one above a column excoriating critics that announced, "Bodenheim Runs Amuck; 4 Dead, And 3 Wounded."

Yet despite the madcap format and tone, the Times served as a forum for Hecht and Bodenheim's genuine views and criticism. They celebrated Yiddish theater, vaudeville and Charlie Chaplin. Hecht championed Ulysses, albeit by attacking its critics: "We are reminded of the fact that literature is often like a mirror. If an ass looks in, one can hardly expect an apostle to look out." And Bodenheim mourned the closing of the Little Review and departure of its editors to Europe. In the same column, he objected to the decision to award the 1922 Pulitzer Prize for poetry to Edna St. Vincent Millay, passing over such writers as William Carlos Wiliams and Conrad Aiken. Other items weren't really essays at all, but short narrative sketches, like an allegorical lament to the loss of the old, pre-war bohemia, or a quick study of tired, disappointed straphangers returning home from Coney Island on a Sunday evening to face another week of drudgery. ${ }^{85}$ 
Most important, the pair articulated their own aesthetic, social and political

worldview — their creed of individualism. Two weeks before an editorial that denounced bolshevism for replacing Christianity as a new magnet for mindless zealotry, Hecht had asserted:

Institutions are and always will be a menace to the individual. The battle between rival institutions - between conservatism and radicalism - is an eternally amateur circus....That the progress of man, exciting phrase, does not lie in the substitution of one set of mob notions for another at least a hundred successful "revolutions" have long ago proved. The individual is the only authentic enemy of institutions. And the individual, raised to his highest point - becomes an artist—is the only "hope" for the eventual sanity of existence. ${ }^{86}$

Hecht and Bodenheim had been formulating this code, which was essentially a reassertion of Romanticism, since their emergence on the literary scene. With the failure of the Innocent Rebellion and the more cosmic collapse of the war, their ideas seemed borne out by events. Yet the true Renaissance pioneer of apolitical individualism, Sherwood Anderson, was a man Hecht could not wholly embrace. When Hecht gave Anderson an early copy of Dorn, his old comrade simply cast the book aside. With the friendship turning sour, Hecht described Anderson in the Times as a slick con man with "the mellow garrulity of a small-town barber." Gazing back in the early '60s, Hecht would recall, "In later years I understood the superiority that Sherwood flaunted over us. We were all buzzing with ego...but none of us was full of the magic of self-love." He added, "The only outsiders (Anderson) could love were the characters his pencil created. And these were not outsiders, they were all Sherwoods. He crooned over them and sang like a poet of their big and little troubles." ${ }^{97}$

According to Hecht, Anderson proposed that as a lark, they cease being friends and assume the roles of enemies in print—although it may have been Hecht who actually 
proposed the idea, after Anderson had reacted coldly to Dorn. In one letter, Anderson praised Hecht as a talented writer, but also took the opportunity to cut him down. "I've always thought Henry Mencken was so nuts on the Puritans...because maybe he's afraid that at bottom he's one himself and I'll begin to think that about you and the boobs if you don't quit being so sure everyone in the world but yourself and a few of your special friends are boobs," he wrote. “...Just for a kind of vacation consider...that you aren’t as specialized a thing as you think. ... The bluff you throw about being so full of energy and being so smart and fast don't bluff me. I've got your number on that because you are so very like myself." 88

Such words may well have cut deep, for at the time Hecht was struggling, with marginal success, to master the one form of writing that counted most to him and his cohort - the novel. In fairness, this was a period of feverish, almost frantic stylistic experimentation. Hecht was particularly influenced by the self-conscious Romanticism of European Decadence and the ornate, crystalline imagery of Symbolism—by the rococo wordplay of Joris-Karl Huysmans, the depictions of inner torment in Arthur Symons, the eerie tales of Arthur Machen and Oscar Wilde, and the polemics of Edgar Saltus and James B. Huneker. Harry Hansen, who upon their first meeting had found Hecht absorbed in Sir Richard Burton's translation of The Arabian Nights, characterized his fiction as "a fondness for realism, naturalism and iconoclasm; a leaning towards sex psychology and neuropathic and psychopathic studies; a love for glittering phrases...; a dominant preoccupation with the mind and especially psychiatrics." ${ }^{, 89}$

Though Erik Dorn and his other early works received a good deal of praise, even Rascoe, one of Hecht's most stalwart champions, pointed out a characteristic flaw. 
Gargoyles, a stab at social realism loosely patterned after Robert Herrick's Memoirs of an American Citizen and Dreiser's Financier, was too watered down with exposition, failing to reveal character through action and dialogue. Others faulted Hecht's constant recycling of material. In a review for The Dial titled "Arriviste and Aristocrat" that called Dorn "one of the noisiest books ever written," Gilbert Seldes noted that tellingly, Hecht's admirers often likened his prose to a mechanical marvel. "The rhythm of life, as simple and unpredictable as the pulse beat, has escaped Mr. Hecht entirely. For the most part it has been lost in a torrent of words. ${ }^{.90}$

The harshest judge of all, however, turned out to be Time. A considerable number of the novelists and poets Hecht and Bodenheim regularly pummeled in their gazette have since been canonized, but within a few years Erik Dorn, Gargoyles and Humpty Dumpty ceased to appear as reprints, and were soon altogether forgotten. And though Hecht always said that he wrote for the movies only to finance his literary endeavors, by the early '30s he had given up on the novel altogether. The exceptions were a lighthearted toss-off, I Hate Actors!, published in 1944, and The Sensualists, released by a small press in 1960 and a poor seller, which was attacked for its cleverness and thin characterizations as his first novels had been, nearly forty years earlier.

He would achieve far greater results with his short stories, published in collections starting with the tightly constructed tales of Broken Necks in 1926, continuing with diverse innovations in styles and themes from the '30s with Champions of Far Away and Actor's Blood, and through to Gaily, Gaily, in 1963. Arguably his single best book of fiction, and certainly his most extraordinary, was the sequence of seven novellas comprising the 1939 Book of Miracles. In the memoirs that he wrote after 1950, his prose 
achieved measure and readability that his work as a young man had lacked. But when it came to novels, from the start he had possessed too keen a bead on the critics and public to be unaware of his lack of traction, despite all of his bluff about speed and energy. By the time he had completed Humpty Dumpty in 1924, he was tiring of such efforts and abandoned them in favor of self-conscious exercises in profit-making and selfpromotion. $^{91}$

The epitome of his literary stunts was Fantazius Mallare, published by CoviciMcGee in a limited run of two thousand copies that sold for $\$ 12.50$ apiece, just as Boni \& Liveright was issuing Gargoyles in September 1922. It was intended as bait for the Society for the Suppression of Vice and packed with sadomasochistic sex, though the action is too abstract and indecipherable to be deemed pornographic by today's standards. The plot, which quickly dissolves into a morass of superheated prose, involves Mallare, a Svengali-like sculptor who seeks to unshackle himself from conventional morality, turns satanic, and spirals into madness. In the story's climax, Mallare is driven over the brink when his gypsy love slave Rita takes revenge upon him by copulating with his hunchbacked golem servant. To ensure the book caught the censors' attention, it included a savage preface "Dedicated to my enemies," and six phantasmagoric illustrations by Wallace Smith in which erect phalluses poke out from nightmarish grotesques. ${ }^{92}$

Hecht's original plan had been to retain Clarence Darrow, rally the literati, and achieve new heights of fame while striking a victory for free expression. But he was fired from the Daily News for the tract, and when no one but Mencken appeared to testify at the trial in February 1924, he and Smith pleaded nolo contendere and were fined a thousand dollars. Now finding himself all but alone in Chicago, he prepared to leave with 
Rose to New York. In a June farewell column for the Chicago Literary Times titled "My Last Park Bench," he confessed that with the passing of years, he no longer felt the wonder of the city and poetry of its streets inside of him anymore. ${ }^{93}$

While shifting gears to write plays for Broadway, he churned out Kingdom of Evil, an uninspired sequel to Mallare, and the successful potboiler Florentine Dagger. In his final novelistic effort of the decade he turned - as if having exhausted all other targets - upon Bodenheim. The parody of Count Bruga was perhaps inspired by the phenomenon of "Emperor Norton," the favorite lunatic of late nineteenth century San Francisco newspapers, who dressed in a fanciful military outfit with golden epaulets and issued imperial proclamations from the city streets. Bodenheim is portrayed as Jules Ganz, a poet who originally entered New York hailed as a great talent but soon managed to alienate and infuriate everyone he came into contact with. Inevitably hounded from the city, Ganz now has returned flush with cash from a rummy game, and having reinvented himself as the royal Count Hippolyt Bruga, invites the newspapers to announce his arrival. Confronted in his room at the Ritz by reporters who have discerned his real identity, he insists that he is an aristocrat who found it necessary to venture into the world as a drunken and buffoonish vagabond poet in order to develop his genius. The reporters decide to humor him, and in victory the count returns to his garret—above a factory for snake oil that is advertised as a love potion. ${ }^{94}$

While written as light comedy, the work rendered Bodenheim as a man hiding beneath layer upon layer of disguise, posturing and self-delusion. A darker story along similar lines that he related many years later recalls a dinner party during the early days of the Renaissance, at which Bodenheim, finding himself no longer the center of 
attention, began to chew on a wineglass. "Good God!" someone shouted, "you'll kill yourself swallowing that glass. You're a poet, not a circus freak.” Bodenheim had replied, in his typically aloof tone, "Every poet is both." 95

Deeply wounded by the book, Bodenheim retorted in 1931 with his novel Duke Herring, which was undermined by bitterness. It echoes Anderson's suggestion that Hecht was beneath it all a boob. The author of a "thousand-and-one-poses," Duke Arturo Herring "wanted to be an affluent, luxurious, commercial panderer, tossing off flashy bilge with tongue in his cheek, and also an unruly, brilliant, slashing intellect in more serious talk and creations...he wanted to be supreme in both camps, commercial and artistic, without pledging allegiance to either one." A Babbitt at heart, Herring lives in constant fear of "deserting the respectable safeguards and emoluments of his life."96

Though he makes every effort to cheat on his wife, Herring has nowhere to go at night but home or the brothel. He finally finds a mistress and abandons his marriage, only to find himself trapped with a woman who reflects his own vapid cynicism. As for the quality of his work, "His favorite boast was that he intended to accumulate a million dollars in the following year, and though his goal had eluded him so far, he did amass thousands of dollars annually through the sale of meretricious short stories, shallowly clever plays with short runs, and epileptic novels, whose malicious brilliance always held one eye cocked toward the adding machine." 97

Bodenheim could, at least, claim that he had never been a panderer. While the Chicago Literary Times had turned out to be one of many profitable enterprises for Hecht, it became yet another blind alley for the poet. By 1924 Bodenheim had published five collections of poems and two novels, Blackguard and Crazy Man, as well as 
numerous essays and reviews, but his novels did not sell well, and the money from his poetry was trifling. He now had his wife Minna and four-year-old son Solbert to support. Hecht was paying him about twenty dollars a week, and for this Bodenheim put in disciplined work, cutting down on drinking, pairing his budget, and producing columns that were witty and consistent. The paper dominated his energies, as he wrote or acquired work from friends to fill about half of it, and at first he had been optimistic that it would grow to generate a more liveable income. But Hecht's wife Marie argued that room and board should account for his salary, which led to increasing friction between the two friends. By the spring Hecht was no longer paying him, and when the paper folded in June a despairing Bodenheim was left at loose ends. ${ }^{98}$

When he had traveled to England in 1920, T.S. Eliot had written his mother: "There is an odd American Jew here named Bodenheim; rather pathetic, although foolish. He is a vagrant poet and man of letters at home, and thought he could pick up work just as easily here. ... I told him of my history here, and left him to consider whether an American Jew, of only a common school education and no university degree, with no money, no connections, and no polish or experience, could make a living in London."99

Minna, who maintained her love for him throughout their lives, had been selfsacrificing and supportive in the early years of their romance, but after the birth of their son, increasingly found that Bodenheim was unable to handle his responsibilities as either father or husband. She grew frustrated by his lack of commitment to anything but art, angered, for example, by his refusal of a popular magazine's generous offer for tales of Village antics on the grounds that such work would be literary prostitution. With his venture at the Times ending in fiasco, she had come to the realization that he could only 
drag her and Solbert down into his own abyss. "Somewhere in his early years," wrote Moore, "in that time of rebellion and shame, Bodenheim became an engine for destruction whose blades cut sharper within than without."100

In "Jewish Writers in America," a 1922 essay for the Menorah Journal in which Bodenheim observed that each great American iconoclast spawned generations of inferior imitators, he criticized the recent call for a Wild Whitmanesque literature that would “express America." America was not one thing but many things of different shades and colors, he said, and critics such as Paul Rosenfeld, Waldo Frank and Louis Untermeyer were calling for something bland and meaningless by comparison. Far from demonstrating the genius of their common heritage, these critics "are exhibiting a surface Jewish tendency — an ability at mimicry and masquerade - a tendency acquired by the Jew of the past for protective reasons." The true genius of Judaism, rather, was a "penetrating tolerance" and flexibility of mind learned by outcasts who, for centuries in which persecution had alternated with indifference, had gazed at others from a distance. Jews knew how to blend in, but they had learned more by being bystanders. ${ }^{101}$

These critics and other writers, such as Ludwig Lewisohn, Michael Gold and Samuel Roth, refused to remain aloof, Bodenheim continued; they were preoccupied with American rawness and passion, and disdained the "ivory tower" of self-detatchment. But "the exceptional Jew, who actively reveals the hidden elements of his race, is essentially an aristocrat — an intense individualist who distrusts the lusty mediocrities inherent in democracy and yearns for the distinctive power that life has sought to withhold from him." Such a writer was Ben Hecht, "a combination of street urchin and skeptical 
intellectual" whose first novel Erik Dorn had produced an uproar of fearful denunciation and periodic praise. Bodenheim nevertheless faulted Hecht for thus far possessing little interest in Judaism, for until such a man of talent shows interest in "the problems and potentialities of his race...it will be absurd to claim that Jewish writers in this country form a unit. They may fuse together in the future but at present they are sadly scattered."

Twenty years later, when Hecht wrote about anti-Semitism in the midst of the Second World War, he would recall that moving to New York City in 1924 had been like arriving in a foreign country full of Jews who were not like his aunts and uncles, but rather "non-Jewish Jews" like himself. These were "writers, publishers, theatrical producers, journalists, wits, actors and mighty drinkers whose only synagogue was Broadway." He confessed that he had been the least Jewish among them, full as he was "of no-man's land iconoclasms." Yet somehow he had found himself drawn to Henry Street on the Lower East Side. ${ }^{102}$

He remembered that he and Rose had been apartment hunting in a taxi with MacArthur, who at $25^{\text {th }}$ Street jumped out, refusing to penetrate any further into the wilds of downtown. As the cab proceeded, Hecht gazed at shabby neighborhoods that brought back memories of his family and of an old rhyme about life going by "gayly gayly" along the river bank of the ghetto. "I looked out of the cab window and saw sidewalks crawling with infants, push carts hung with ties, alarm clocks and bananas, old gentlemen in linen frock coats smoothing their whiskers, mothers screaming out of windows, little boys and girls playing hide-and-go-seek in refuse barrels," he wrote. "In the midst of all this stood a house to let." He and Rose had stayed there for seven months, but being unemployed he had withdrawn into himself, and missed this opportunity for what not so long before had 
been called vital contact. Driven out at last by the smells that came with summer, he joined the crowd "uptown," who regarded this sojourn as a bout of eccentricity. ${ }^{103}$

Several of Hecht and Bodenheim's uptown friends and acquaintances had once been guests in Mabel Dodge's salon, but the fact that she never mentioned their Jewish heritage in her memoirs suggests that the "Jewish question" was not a common topic of discussion. When John Reed brought her to see the conditions of the Lower East Side, she had annoyed and embarrassed him by insisting they do the tour in her chauffeurdriven limousine. But although the Jewish immigrant neighborhood was a world far apart from the Village, its history followed a closely parallel trajectory. During the years in which, as Dodge had said, all the barriers went down and people who had never been in touch were reaching out and finding new ways to communicate, Zionist leaders were creating the concepts and vocabulary that would form the popular lexicon of American ethnicity. And while art and socialism were forging their famous bond in the Village, a catastrophic fire in a downtown Jewish factory and ensuing union pressure would push through historic reforms in American working conditions. ${ }^{104}$

Most of the roughly 2.5 million Jews who emigrated to the United States between 1880 and 1924 came from the Pale of Settlement, a vast East European ghetto. For a people driven by the thousands from Russian cities, facing slaughter in pogroms or conscription into the army, and shut out from commerce, employment and education, the revolutionary ideology of Marxism had represented a means of struggle against tyranny as well as a pathway to modern secular society, one that would allow them to shed the stigma of Judaism and join with others in the new global collective of the proletariat. On the Lower East Side, where an immigrant often found work in ceaseless, exhausting 
shifts at a textile sweatshop, "the union became the secular equivalent of the Beth Hamidrosh, the house of prayer and learning in the shetl, where he could fraternize with his fellow townsmen," explained Henry L. Feingold. With the union hall as synagogue, the labor organizer assumed the role of rabbi, and socialism arose as a new faith. ${ }^{105}$

Less than two years before the strike in Lawrence would stir consciousness in the Village, prominent Boston attorney Louis Brandeis was called in to mediate "the Great Revolt" of some sixty thousand unionized cloakmakers. The March 1911 fire at the Triangle Shirtwaist Factory that claimed the lives of 146 female employees spurred the International Ladies' Garment Workers Union's drive for pioneering workplace safety and child labor laws, as well as a Factory Investigating Commission that led the way with reform. Meanwhile, Brandeis' experience negotiating the "Protocols of Peace" led to his own awakening as a Jewish American. ${ }^{106}$

Three years before everyone became so intertwined at Dodge's apartment, Israel Zangwill's “The Melting Pot" had opened on Broadway, offering its assimilationist vision of Americans from all backgrounds shedding their ancient loyalties to form a unified nation. An English Zionist, Zangwill had recently founded a splinter group that called for establishing a Jewish homeland, not in Palestine, but wherever it turned out to be possible. But by the time alliances in Greenwich Village were splintering in 1915, the Zionist philosophy scholar Horace Kallen had repudiated the melting pot ideal in a twopart article for The Nation. Instead he advocated "cultural pluralism," the notion that each American should hold fast to his or her distinct heritage while participating in a democratic society in which tolerance and diversity would be a source of strength. Brandeis, who had been recruited as president of the Federation of American Zionists in 
1914, applied Kallen's reasoning to dispel fear that the "dual loyalty" of Zionism would call Jewish American patriotism into question, and with the force of this argument coupled with his skill as leader and organizer, built a movement of 176,000 members within three years. ${ }^{107}$

During the 1920s, cultural pluralism came to reflect an attitude particularly characteristic of first-generation Americans like Hecht and Bodenheim, and unwittingly they were a conspicuous group by the time Hecht encountered them in New York. As he would remark, "It had been normal to look on one Jew, myself, and consider him unJewish. But it was difficult to look at a swarm of Jews and accept them as similarly unJewish." His observations of the "Non-Jewish Jew" anticipated a 1958 essay by Isaac Deutscher that traced this long-standing attitude back to such rationalist Jews as Spinoza, Marx and Freud. By the '20s, such individuals increasingly recognized with pride traits of their heritage, namely a record of struggle against oppression, yet refused to regard these as uniquely Jewish qualities, or see themselves as exemplary of these qualities because they were Jews. Their attitude was nevertheless wholly distinct from the assimilationist abandonment of identity that Zangwill had espoused in "The Melting Pot." 108

Cultural pluralism represented a conflicted ethos, the weaknesses of which became more apparent over time as economic and social conditions changed. As historian John Higham noted, it suffered from a "chronic indistinctness" in the tension between embracing one's heritage on the one hand, while on the other, joining a diverse society in the spirit of cosmopolitanism. The precise relationship between the two poles of attraction had never been adequately investigated by vocal proponents like Kallen, 
Brandeis and Greenwich Village intellectual Randolph Bourne. The magazine that explored the question most deeply had published Bodenheim's essay on Jewish writers, the Menorah Journal, launched in 1916, which was the organ of the Menorah Society, a national organization that Kallen had helped to establish. ${ }^{109}$

"My colleagues had discarded their Jewishness out of the belief that as Jews they could line up only for a snubbing," Hecht later concluded. "As Americans or, more particularly, as egoists and talents, they could step forth as superiors and even as snobs." It was in those years that Hecht had begun to notice with pride that New York's Jews ran most of the theaters and publishing houses, composed and sang many of the popular songs, and wrote a sizeable portion of the plays and poems. They were also some of the most productive newspaper reporters and columnists. Above all, Hecht was taken by the comedians, "a great Jewish cast of clowns and troubadours." In their clubs and hotel rooms, he joined in their wisecracking as if they were cousins, these talents who had risen up from the tenements. Among them were three who were to remain lifelong friendsGroucho and Harpo Marx and Fanny Brice—as well as Jack Benny, Milton Berle, George Burns, Eddie Cantor, George Jessel, and Al Jolson. ${ }^{110}$

Jolson's 1927 Warner Brothers movie The Jazz Singer was the first major release to introduce sound — a milestone in Hecht's life because the advent of the talkie had created the lucrative new demand for writers in Hollywood. An iconic expression of cultural pluralism, The Jazz Singer was the tale of a Jewish cantor's son who finds himself torn between his roots on the Lower East Side and the bright lights of show business. In the souvenir program to the musical, author Samson Raphaelson explained that his inspiration had come from witnessing the electrifying spectacle of Jolson 
performing ragtime. Of the man Gilbert Seldes called "the daemonic" Al Jolson, Raphaelson wrote:

I hear Jazz, and I am given a vision of cathedrals and temples collapsing and, silhouetted against the setting sun, a solitary figure, a lost soul, dancing grotesquely in the ruins. ... Thus do I see the jazz singer.

Jazz is prayer. It is too passionate to be anything else. It is prayer distorted, sick, unconscious of its destination. The singer of jazz is what Matthew Arnold said of the Jew, "lost between two worlds, one dead, the other powerless to be born." In this, my first play, I have tried to crystallize the ironic truth that one of the Americas of 1927-the one which packs to overflowing our cabarets, musical reviews, and dance halls - is praying with a fervor as intense as that of the America which goes sedately to church and synagogue. The jazz American is different from the dancing dervish, from the Zulu medicine man, from the negro evangelist only in that he doesn't know he is praying. ${ }^{111}$ 


\section{ALIENATION AND MADNESS: THE JAZZ AGE}

Greenwich Village is the Coney Island of the soul.

$$
\text { Maxwell Bodenheim }{ }^{112}
$$

In the '20s landlords milked the Village's popularity by subdividing the row houses into "artist studios." A new subway stop at Sheridan Square increased the traffic, and moderns who had stayed grew adept at marketing their bohemian reputations. “Thrillagers” patronized Dick Dickerman's Pirate Lair or the Nut Club, with its “topsyturvy decorations." One bar featured a jail-cell theme, with waiters in striped convict suits serving drinks, while in another offering the ambience of a country fair, farm-boys wearing overalls danced with the crowd as others circled in old-fashioned bicycles. "From the granite chateaus of upper Fifth Avenue and the well-guarded arm chairs of Brownsville, Wisconsin, they flock to the gaudy sensualities and avarices of a fraudulent Latin Quarter and drop their dollars in the slots," cracked Bodenheim in the Times. The Village's arty mystique and allure of sexual freedom made it "a hunting grove for the love-sick bourgeois" observed another critic. Uptown women cruised in to find lovers who were poets or painters, sugar daddies set up their paramours in studios with bathtubs large enough to make gin, and carloads of baggy-knickerbockered and bobbed-haired flappers trooped to the neighborhood "speaks" in pursuit of erotic adventure. ${ }^{113}$

Among the many eccentrics was a slinky nineteen-year-old brunette named Aimee Cortez. The unofficially elected "Mayoress of the Village" was famous for dancing a striptease with a stuffed gorilla—a specially ordered duplicate of one from the red lights of Montmartre - before leading the last man she pointed at off to bed. 
According to My Life and Loves in Greenwich Village, allegedly Bodenheim's posthumous memoir but actually penned by publisher-pornographer Samuel Roth, "She never extended her favors to sterile, uncreative men, and the idea of sleeping with a banker or shopkeeper would have been as abhorrent to her as engaging in an affair with a daughter of Lesbos." 114

By 1925 Bodehenheim was caught in a spiral: broke, estranged from his wife, and shunned by his former friends and colleagues. But his luck changed when John Sumner's Society for the Suppression of Vice attacked Replenishing Jessica, his new novel about a rebellious young woman to whom "the simple feat of keeping her legs crossed was a structural impossibility." Publicity from the trial, which ended in acquittals, solidified the author's reputation as a downtown Don Juan, and when the book finally hit the shelves in 1928, it became a bestseller. Even this turnaround, however, was tinged with bitterness: Bodenheim saw no royalties because Boni \& Liveright had purchased it outright for a thousand dollars, and while he was shipped away on a publicity tour during the trial, Horace Liveright denounced the novel on the stand as trash that he had been forced to publish under contract. ${ }^{115}$

What should have been the poet's moment of fame and glory would instead provide an absurd and tragic final chapter to Jazz-Age Village legend. The trouble started when Bodenheim fell in with Robert Clairmont, a college student working as a soda jerk in Pittsburgh when in early 1925, attorneys notified him that he had inherited half the fortune of magnate Sellers McKee Chandler. Clairmont had met Chandler five years earlier when he had been a lifeguard at an athletic club, and had taught the old man to swim. With the $\$ 350,000$ from the will now in the bank, he enrolled in Columbia's 
School of Journalism and invested in stocks. The market was booming, and right away his fortune grew exponentially. ${ }^{116}$

In New York, Clairmont summoned Pittsburgh friend Tom Boggs, a fellow poet who would also earn a modicum of critical recognition. They moved into a grand apartment at 142 West Fourth Street previously inhabited by the daughter of President Wilson, established arrangements with local bootleggers, and invited Villagers to a party that had no end. Word spread as the young Adonis whom the city would come to know as "the millionaire playboy" led crowds of revelers through the streets to nightspots where he was happy to pick up any cheque handed to him. While the money and booze poured out, new cash from investments poured in.

It was not long, however, before the apartment began to resemble Grand Central Station, with people coming and going all day and night. They wrecked and liberated books, stole sheets and pillows, and burned holes in the carpets and furniture. Wearied and disenchanted, Clairmont began to avoid his own home. Finally, while he was off on a trip, a thirty-four-year-old illustrator named Hans Stengel invited Villagers over for what was to be an epic bash. Amid the festivities, Stengel vanished shortly after midnight. Hours later he was found hanging in the bathroom from his belt: the affair had been the artist's suicide party. Clairmont was evicted after that. ${ }^{117}$

He and Boggs now joined with Bodenheim and a fourth poet to form the Greta Garbo Social Club, a group dedicated to the mission of "systematically seducing all unvirtuous innocents who bobbed like so many ripe apples in the liberated Village barrel." In Bruga, Hecht had mocked Bodenheim as a bizarre lech who scared women away by "leering, prancing" and "pawing their evening gowns." Many others have 
described his womanizing as sadistically cruel. Perhaps the best that can be said is that since he was antagonistic to everyone and, underneath all the posturing, never seemed to have much respect for himself, he had no idea how to treat his lovers any better. In Moore's view, “Bodenheim's New York career gathered to it gratuitous and grotesque fragments of futile destruction as others acted out an expressionistic parody of his life." 118

By the summer of 1928 , his popularity was at its apex. Now that reviewers were paying attention, they found the craftsmanship of his novels so flawed they hardly knew where to begin. But even as sales soared with Replenishing Jessica, he scored a second bestseller with Georgia May, his newest release about the decline and death of a Memphis prostitute. Some began calling him King of New York; one photo from the time shows him "flanked by scantily clad showgirls, holding his best-selling novel out like a trophy." Genuine triumph, however, seems to have been impossible for him. ${ }^{119}$

One of the many enamored with him that July was eighteen-year-old New York University student Gladys Loeb. When he jilted her and, for good measure, criticized her poetry as worthless tripe, she tried to commit suicide by sticking in her head in a gas stove, only to be saved just in time by her landlady. Less than two weeks later, twentyfour-year-old Virginia Drew left Bodenheim's theater district hotel room at 3 a.m. and drowned herself in the Hudson River.

Virginia Drew had sought a mentor, and in the spirit of honesty, he had promptly notified her that her work was "sentimental slush." Vowing to "force him in time to acknowledge me as a good writer," she left to meet him on the night of her death with manuscripts for novels and a book of poems. After her body washed up and Bodenheim was seen leaving for Grand Central with luggage and his typewriter, he became front- 
page news and the target of a nationwide search. Detectives who broke down his door discovered Quintillions, Robert Clairmont's book of poetry, bearing the inscription: “To Maxwell Bodenheim, roué of the first order, a dangerous rival in affairs of the heart."120

The press had remarked that the case had become as strange as his fiction, but he had never concocted anything as bizarre as the episodes that ensued. Perhaps in competition for the headlines, Gladys Loeb had now decided to run away, and her irate and desperate father tracked Bodenheim to Provincetown, arriving at his shack with reporters in tow. Confronted about Virginia Drew, Bodenheim swore that when she burst in on him in the night talking of suicide, he had done his best to dissuade her, and thought he had succeeded. "I argued with her until I was black in the face," he insisted, explaining that he had parted with her only after she promised to make the best of things. ${ }^{121}$

Within hours, Glady Loeb showed up on a bus from Boston. She agreed to return to the city only if the poet came along. Bodenheim agreed at first, but everything went awry just as they set out, when he banged his head on the taxi door, the cab blew a connecting rod, and another car smashed into its rear. The calm now shattered, the girl's father and the poet had it out.

"You're an irresponsible bum," the father said.

"I am a genius," replied the roué. "You do not understand me; you are too obtuse. $^{122}$

SCRIVENING MAGNET OF MISSING MAIDS the papers hooted. PURSUED PASH POET. Bodenheim's Summer of Love had yet to end. According to Churchill, young women's suicides in Paris and London followed when news of the Drew-Loeb 
drama went international. In late August, Dorothy Dear, another inamorata who had been corresponding with Bodenheim, was killed on her way to meet him in one of the worst subway disasters of the city's history. Scattered across the burnt and bloody tracks reporters for the tabloids found the great lover's letters, which their papers were happy to publish. "Walk on cobwebs stretched between the horns of the moon," he had urged her. $^{123}$

That previous February Aimee Cortez, Mayoress of New York and dance partner of the stuffed gorilla, took a page from Loeb by stuffing her head in her gas oven with a photograph of Bodenheim clutched to her chest. She turned out not to be so lucky as Loeb: her landlady found her too late. Few believed that she had ever carried on an affair with Bodenheim, but later, local speculation was that she simply wanted to hitch her wagon to the poet's falling star, and seal her name to Village legend. ${ }^{124}$

With the crash of 1929, Robert Clairmont lost eight hundred thousand dollars. He spent a last thousand on a farewell finale for the Greta Garbo Social Club, and then moved into the Municipal Lodging House, one of the great city homeless shelters of the Depression, where he found work in the stock room. There he was discovered a year later by W.C. Handy, a jazz musician he had once given four thousand dollars to play Carnegie Hall, who now returned the favor by playing free for the lodgers. Bodenheim used the last real money he would ever see on a final trip to Europe. In Paris Ezra Pound invited him to the Restaurant de l'Odeon, where he was honored with a special luncheon. In his archives is a menu with the date "May 1930" written across it along with a note: "Sworn and attested to in a moment of heavenly sobriety by Maxwell Bodenheim. We the undersigned certify Max Bodenheim was chaste, sober, and industrious, and 2 hours 
in the company of undersigned without inebriety and completely loving company-Ford Maddox Ford, Riva Putnam, Olga Rudge, Ezra Pound."125 


\section{ALIENATION AND MADNESS: HOLLYWOOD IN THE 1930s}

Samuel Goldwyn, Louis B. Mayer, the Warner Brothers, the Schenk Brothers, Adolph Zukor, Harry Cohn, Irving Thalberg, Carl Laemmle, Jesse Lasky, B.P. Schulberg and their mishpoochas were conducting a Semitic renaissance, sans rabbis and the Talmud. The fact that they were flinging at the world the ancient Greek credo that deluding the mind of the public with tommyrot was better medicine than torturing it with truth (Plato) cut no ice about who was running the renaissance - Greeks or Hebrews. And the first wave of geniuses from Broadway, London, Paris and Berlin was already on hand issuing dinner invitations (black tie), collecting weekly bags of gold and denouncing Hollywood, much as in these pages.

\section{Ben Hecht, in Charlie ${ }^{126}$}

While the rest of the country was plummeting into the Depression, Hecht had reached what he called "the new El Dorado." Hollywood, which asked of writers merely their hearts and souls as the price of admission, would drive the likes of F. Scott Fitzgerald to a "crack-up.” But there was a bright side. Ensconced during those early years on the Youngworth Ranch, a "wooden castle" and turkey farm overlooking MGM's backlots in Culver City, Hecht's guests for a typical night of drinking might include the movie star Jean Harlow, soon-to-be princess of Austria Nora Gregor, director Howard Hawks, Harpo Marx, Dashiell Hammett, composer George Antheil, MacArthur, and other fellow writers. ${ }^{127}$

“The sun shone," Hecht wrote. "The dinner parties looked like stage sets. International beauties sat in candle-lit café nooks, holding hands with undersized magnates. Novelists, poets and playwrights staggered bibulously in and out of swimming pools. Floperoo actors and actresses from New York, ex-waitresses, elevator girls, light o' loves, high school graduates with the right-size boobies all met their Good Fairy and were given seats on the royal bandwagon. And out of the hotel suites, brothels and 
casinos came a noise of life undaunted such as not been heard since the Forty-niners drank themselves to death looking for nuggets." ${ }^{\prime 28}$

On the Hollywood payroll one joined the most accomplished writers and artists of a generation. In the heyday of the studio system, writers were paid more money than they had ever seen to become workers on a factory line. Here perfectionism was anathema, and anyway, an author could expect the writing conferences and other machinations of film production to perversely salvage his or her worst ideas while shearing off the best. "Your writing stinks," observed MacArthur, "but you meet the people you want to be in a room with." With fat rolls of cash, studio bosses summoned the highest class of talent if only for the sense of culture it gave them, and for the feeling of superiority that came from telling such people what to do. ${ }^{129}$

In Raising Kane, Pauline Kael treats Hecht as representative of a famous literary migration, a quest for better pay and new opportunities in an era of dramatic technological, economic and cultural change. To this end, she explains the significance of Herman Mankiewicz's 1926 cable:

The bait that brought the writers in was the money, but those writers who, like Mankiewicz, helped set the traps had their own reason: conviviality. Mankiewicz's small joke: “Don't let this get around" came from a man who lived for talk, a man who saw moviemaking as too crazy, too profitable and too easy not to share with one's friends. By the early thirties, the writers who lived in Hollywood or commuted there included not only Mankiewicz and Hecht but George S. Kaufman and Marc Connelly, Nathanael West and his brother-in-law S.J. Perelman, and Preston Sturges, Dorothy Parker, Arthur Kober, Alice Duer Miller, John O'Hara, Donald Ogden Stewart, Samson Raphaelson (the New York Times reporter who wrote the play The Jazz Singer), Gene Fowler, and Nunnally Johnson, and such already famous playwrights as Phillip Barry, S.N. Behrman, Maxwell Anderson, Robert E. Sherwood and Sidney Howard. Scott Fitzgerald had already been there for his first stretch, in 1927, along with Edwin Justus Mayer, and by 1932 William Faulkner began coming and going, 
and from time to time Ring Lardner and Moss Hart would turn up. In earlier periods, American writers made a living on newspapers and magazines; in the ' $40 \mathrm{~s}$ and ' $50 \mathrm{~s}$, they went into the academies (or once they got to college, never left). But in the late '20s and ' 30 s they went to Hollywood. ${ }^{130}$

Between Hecht and MacArthur's Broadway hit The Front Page in 1928 and their Astoria experiment in independent filmmaking in 1934, Hecht provided the stories or scripts for twenty films, while doing the script doctoring - some of which involved complete rewrites - for at least another thirteen. While also collaborating with Charles Lederer, Gene Fowler and director Howard Hawks, he developed a writing factory, farming out work to Bartlett Cormack, John Lee Mahin and Johnny Weaver. Successful in every genre, his own plots included the 1929 horror pictures The Unholy Night and The Great Gabbo, the Marx Brothers comedy Monkey Business, the gangster-comedy Roadhouse Nights, and Scarface. ${ }^{131}$ His 1933 film for Jolson Hallelujah, I'm a Bum!, adapted from a story by Floyd Dell, reflected his own insulation from the Depression as the lighthearted tale of a carefree "mayor" of hobos too in love with life to be tied down to a job. According to Hawks, their collaboration that same year based on a biography of Pancho Villa, Viva Villa!, could have been one of their best works together. But after the film was shot in Mexico, actor Lee Tracy got drunk and urinated on the Chapultepec Cadets during their Independence Day parade, and then the interference of MGM studio head Louis B. Mayer wrecked the film. ${ }^{132}$

Hecht also published his second short story collection in 1931, A Champion of Far Away, and continued to write for Broadway. Reviewers bashed his effort with Fowler, The Great Magoo, when it premiered in December 1932, but they hailed as genius Twentieth Century, his Broadway follow-up with MacArthur to The Front Page, 
when it appeared weeks later. Later described by Pauline Kael as "a first-rate hardboiled farce about theatrical personalities," Hawks' film adaptation featured what Andrew Sarris called one of the era's "maddest and most savage confrontations between the sexes." Such critics would look back at the screwball comedies of the '30s as the wittiest, fiercest, most sophisticated works to have ever hit the screen, and Twentieth Century was the first. Hecht kept going with Nothing Sacred in 1937, while in 1940 Hawks would deliver the most inspired screen version of The Front Page, recasting Hildy Johnson as a fast-talking dame reporter played by Rosalind Russell in His Girl Friday. ${ }^{133}$

Within a year, Hecht, MacArthur and Hawks were collaborating on another comedy for the stage, Jumbo, a story of two rival circus families based on Hecht's idea of combining the most spectacular type of theater - the circus - with history's most spectacular plot—Romeo and Juliet. Produced by Billy Rose at the old Hippodrome, the musical drama would involve "two acts and eleven scenes with tightrope walkers who worked over an open lion pit, clowns, ... bareback riders, ax throwers and trained bears." According to one review, it was "a sane and exciting compound of opera, animal show, folk drama, harlequinade, carnival, circus, extravaganza and spectacle."134

The blackest mark on Hecht in those years was his latest novel—ironically, the only piece of work he produced that, given the standards of the time, could have established his literary bona fides. Published in 1931, A Jew in Love was another dissection of a monstrous egoist, this one of the Don-Juan variety. A vulture both in appearance and character, publisher Jo Bashere was a composite of two Jews who made their profits in the arts: Jed Harris, Broadway producer of The Front Page and Twentieth Century, and Horace Liveright. The plot consists of Boshere juggling three women with a 
cruelty that, in the words of one critic, "oscillates between a provocative masochism and relieving sadism." Boshere ships his wife off on ocean liners and torments his mistress while haranguing a third lover, the blond dancer Tillie Marmon, who ultimately proves to be his undoing. When a fourth woman rejects his advances, he destroys her placid marriage just for sport, by pitting wife and husband against one another. ${ }^{135}$

Publisher Pascal Covici primed his staff for A Jew in Love, announcing it as the best thing Hecht had ever written. But the firm's co-owner Donald Friede recalled that shortly after he and three colleagues dove eagerly into its pages, they suddenly stopped and stared at one another as if on cue, realizing, in the instant, that none of them liked it. By then, however, the gears of publishing were already in motion, and with the firm's aggressive publicity, the book sold nearly fifty thousand copies, an extraordinary figure at the time and far beyond what any of Hecht's other novels had sold. ${ }^{136}$

"A Jew in Love is positively nauseating at times," wrote Bob Stafford of the Akron Times. "It is rare that I experience a feeling of revulsion at a book. There were times when I did in this case. And I am not the least squeamish." Some suggested it was obvious from the deep bitterness that the author was settling a personal score. Others were impressed by the sheer brute force of Hecht's prose, observing, for example, that his "almost explosive combinations of words and images has been toned down somewhat, but his style still hammers at the readers with a succession of verbal shocks." Just as often, however, they denounced his novels in general as "disgusting, noisome and thoroughly boresome," and the most esteemed newspapers dismissed all of the hullabaloo as another cheap stab at publicity. "Ben Hecht is a man of great talent," observed the New York Times. "The talent, however, has never been able to attach itself to ends, and it is 
continually spending itself in mockery.” A critic for The Wisconsin State Journal lamented, "I can enjoy his ironic humor, condone his lewdness; it is his sneering hatred of humanity that puts me in a jangle of resentment every time I read one of his books." ${ }^{137}$ While most newspapers either ignored Hecht's treatment of Judaism or dismissed it as incidental, the Newark News pointed to it as an example of Jewish anti-Semitism, while the Buffalo Evening News asserted that if any gentile had "let loose such a volley of invective," Jews would have every reason to feel themselves victims of bigotry. Outrage from some quarters of the American Jewish community showered down like an avalanche. Typical was Rabbi Louis I. Newman of New York City, who called the book an "atrocious malignment of the Jew... an offense against good taste in general, and a careless, sensational effort to promote sales in the bookshops and stores." The book was banned in Canada, Boston and Springfield, Massachusetts. Informed that the largest bookstore in Detroit refused to sell it on the grounds that it constituted "an unnecessary offensive attack upon the Jewish race," Hecht responded tersely: "The Jewish race will survive."138

Passages of the book speak for themselves. The novel begins: "The Jews now and then hatch a face which for Jewishness surpasses the caricature of the entire anti-Semitic press. These Jew faces in which race leers and burns like some biologic disease are rather shocking to a mongrelized world. People dislike being reminded of their origins. They shudder...at the sight of anyone who looks too much like a fish, a chimpanzee or a Jew." While Hecht quickly explains that Jo Boshere does not quite look like this, he has burned into the reader's mind an image of a protagonist taken straight from the hate literature of 
his day. As Leslie Fiedler later pointed out, Boshere "is portrayed by Hecht as the caricature of the anti-Semite come to life." ${ }^{, 139}$

There is a hall-of-mirrors quality to the novel. Hecht flays Boshere as a selfhating Jew himself, who cannot shed his Jewishness no matter how eager he is to do so. Boshere disdains his sister's Zionism as “raising nickels for a lot of God damn stinking Jews in Palestine," and claims that it is they who are "ashamed of being Jews," while he has grown beyond both shame and Judaism. Hecht parodies another non-Jewish Jew modeled on George Jessel: "Lean, overgroomed, reeking with expensive perfumes, slobbering when he laughed and showing a set of heavy white teeth, Solomon was of the tribe of Jews who dominate the night life of Broadway, who stamp their legendary sophistication as a trademark on American entertainment." Fiedler acknowledges there is implicitly "a self-criticism of the Jewish intellectual that cuts much deeper than personal satire," but one that is so ill-construed and poorly articulated that it degenerates into incoherence. ${ }^{140}$

Whenever Hecht elaborates, he digs a deeper hole. Of Broadway writers, he rails:

Those Jews, decadent, humanless, with minds as sharp and strident as banjos offer through their perversities the last blatant sob of Jewish culture...Their songs quiver with self-pity, are full of the unscrupulous wailings of the ancient Jew grief tricked out in Negro, Russian and Oriental rhythms, and pounded home with the rabbinical slobber of an atonement prayer...Their wit, sterile with disillusion, cackling, derisive, full of epithet, proclaims them clowns and from behind their clownish front they sell Jewish tears at a fancy profit, weep into the coffee cups and wine glasses of the Gentiles and label the performance Broadway. ${ }^{141}$

Fiedler called Hecht's novel, which was published the same year as Duke Herring, "a work of inspired self-hatred: a portrait of the Jewish author as his own worst (Jewish) enemy.” In suggestion of Hecht's unconscious angst, Fiedler noted that 
Boshere's blond shikse stands as "an image of a world which all of his assaults and betrayals cannot make his own." On the other hand, biographer Doug Fetherling, argued that A Jew in Love "is a cynical book to no good purpose, redolent of the self-hatred he felt not as a Jew, but as a hostage of show business, as an outsider from Chicago and all that implied." The two interpretations, however, are not mutually exclusive. ${ }^{142}$

Hecht told New York Post reporter Ruth Seinfel that he was grateful to have recovered his old notoriety as the bad boy of literature — he really couldn't be happy without it. He advised young writers to stay on the losing side of every fight, or they would end up like his friends, Carl Sandburg, Sherwood Anderson, and even Bodenheim, who recently "got kudos from all the critics" for Georgie May. "When I talk to them now they sound like all the things we used to fight against in the old days," he said. ${ }^{143}$ But to these friends it must have seemed that Hecht was "the sell-out," for while he now ascended to wealth and privilege as a lord in Philistine movieland, the vogue of the Don Juan had ended for most people with the crash of 1929. In the place of Jazz-Age egoism, the collapse of the markets, joblessness and poverty had ignited a new radicalism.

As in the old days, both Hecht and his contemporaries saw themselves as rebels, but this time too he remained apart in his staunch egoism. Hecht also had much in common with his Jewish contemporaries_-ironically—in his very rebellion against heritage, but here again, it was his creed of individualism that set him apart. The Depression ended the salad days of the "non-Jewish Jew" of Broadway, and the golden era of cultural pluralism was over for everyone.

At the Menorah Journal, a new schism reflected the changing times. A year after Bodenheim's commentary had appeared in its pages, a young prodigy named Elliot 
Cohen started a column in the sardonic style of Mencken that celebrated the diversity of Jewish Americans by observing them in all walks of life, as gangsters, baseball players or eccentrics. When Cohen became managing editor in 1925, he assumed a Mencken-like role as sage and cultivator of talent, recruiting writers such as Felix Morrow, Herbert Solow, Tess Slesinger, Anita Brenner, and Lionel Trilling. After Black Tuesday, Cohen, Morrow, Solow and others abandoned the tenets of cultural pluralism for communism, ultimately splitting with the board of the Menorah Society over a series of articles by Solow that denounced Zionism as bourgeois and imperialist. ${ }^{144}$

This split represented a turning point: a rejection of the Journal's ambivalent Jewish pride for the purer universalism of Marx. It also marked the emergence of the New York Intellectuals, a loose confederation chronicled and discussed in countless books and essays, that included Fiedler, Howe, Sidney Hook, Irving Kristol, Daniel Bell, Nathan Glazer, and Partisan Review founders William Phillips and Philip Rahv. These individuals characteristically drew inspiration from the Russian Revolution, and for the Jews who accounted for most of the group, Marxism tended to represent a new faith, just as it once had for the parents and grandparents who had been among the luftmensch of the Pale or the radicals of the Lower East Side. ${ }^{145}$

Little love would ever be lost between these writers and Hecht, who belonged to a different generation and viewpoint altogether. He would later dismiss the radicalism of the '30s as group therapy for intellectuals, since none of its firebrands ever led proletarian masses in revolt, nor did they topple any tyrants such as the Russian czar or Chang Kaishek. While Hecht tended to steer clear of the fights between his Hollywood writer friends over the issue, he later noted that his own "non-communism" never had anything 
to do with fear of the Soviets or Marxist theory: "It was founded on the simple personal fact that in a Communist state I would be jailed or shot for speaking my mind. I could understand almost anybody espousing Communism except a writing man or a man of active intelligence."146

The new collectivist uprising of the ' 30 s echoed the activism at the culmination of the Innocent Rebellion, and it would suffer a similar fate. Indeed, in 1931 Cohen's group joined under the leadership of Theodore Dreiser with several of Hecht's old friends and associates from the early days of Greenwich Village and the Renaissance-Floyd Dell, Sherwood Anderson, Alfred Kreymbourg, Lincoln Steffens, Waldo Frank and others - to form an activist vanguard that was an adjunct of the Communist Party. Over the next three years, however, their drift towards Leon Trotsky put them on a collision course with the Party, which took its direction from Stalin. In late March 1934, an editorial titled "Unintelligent Fanaticism" in the New Masses attacked Dreiser, Anderson and other writers, along with "the erstwhile Menorah Journal group - these loop-de-loopers from Zionism to 'internationalism."'147

As in the days of 1915, the new radicalism collapsed in profound disillusionment, precipitated yet again by the onset of a world war. Lofty principles grew entangled with petty bickering that drained the creative energies of Cohen's disciples, as they became sucked into an internecine conflict between the Trotskyites and Stalinists. Event after event that followed—Stalin's show trials, his non-aggression pact with Hitler and the crucial role that the two great capitalist-imperialist powers, U.S. and Britain, played in defeating fascism, all seemed to repudiate the ideals of the communist movement, shattering its faith and spirit. This time around the disillusionment cut to the core, and the 
psychic effect on American writers would be more permanent, part of a sweeping shift from integrationism to egocentrism that emerged after the Second World War. It was a shift that Hecht and Bodenheim, as the "best hated men in American literature," had once foreshadowed in the early 1920s.

In 1930 Bodenheim published his last two books of the Jazz Age, the novel Naked on Roller Skates, and a well-received book of poetry, Bringing Jazz! Two years later he tried to follow the migration to Hollywood, staying with friends while he attempted to peddle his novels to the industry through an intermediary who posed as his secretary. His efforts got him nowhere, and Hecht, who was not amused by Duke Herring, offered no help. Bodenheim published four more novels over the first half of the decade, but his work was no longer selling, and these would be his last. ${ }^{148}$

Always responsive to literary trends, in New York he had struck a new pose as the proletarian poet. While his two major works of the period generally followed the conventions of the radical Depression-era novel, scholars of the genre like Walter Rideout have never counted them as such, perhaps because they are more accurately stories of disaffected radicals. ${ }^{149}$ In Run, Sheep, Run (1932), protagonist George Romaine starts out as a communist, but finds himself unable to connect to either the intellectuals and agitators who are his fellow travelers, or to the workers whenever he deals with them as a group. The writers he knows lose themselves in theory or are shallow and insincere in the first place, while the workers tend to resent him. At the end of their shifts they battle violently among themselves, but they obediently take punishment each day while they are on the clock. Run, Sheep, Run finally builds to a crescendo not with the strike 
that is typical of the genre, but with a vast, apocalyptic riot suggestive of Nathanael West's Day of the Locust published seven years later.

Written in the darkest years of the Depression, his 1934 novel Slow Vision is an intensely bleak portrait of people lost in dazed despair, of a society bewildered and bled dry by forces of corruption that strike blindly and with impunity. "There's something wrong with this world all right, but I can't put my finger on it," says the book's hero, Ray Bailey. 'I don't believe in what those dirty Reds say...but something must be wrong when a fellow can't get a decent wage, can't tell when he's going to be fired, can't look forward to any promise of happiness. Something is rotten somewhere." The book telescopes Bodenheim's own sense of despair of those years. "Slow Vision was Bodenheim's last published novel, and one of his most powerful," wrote Moore. "His unremitting and relentless pursuit of Depression neurasthenia effectively reproduces one aspect of the times...he projects in a technically straightforward manner a harsh, grainy newsreel of psychological, familial and communal breakdown."

When this novel also failed, in late March of 1935 Bodenheim generated some press by leading five placarded members of the Writer's Union to the New York City Department of Welfare office, where he complained that his provision of fourteen dollars a month for rent and five dollars every other week for food was insufficient. Later when he brought this protest to City Hall, the newspapers derided his lack of a shave, dirtiness, and rumpled clothes. In a sad echo of both Count Bruga and the career of Emperor Norton, they ridiculed him as the "mayor" of New York City. He was later hired by the Federal Writers' Project, which was established that same year, and in 1939 married Grace Finan, whose previous husband had worked with him there. But in 1940 he was 
fired for falsely signing an affidavit that stated he was not a member of the Communist Party. Whatever ties he once had to the movement had never been strong, and were virtually non-existent by the time of the inquiry. As Hecht noted, "The truth is that Bogie was the sort of Communist who would have been booted out of Moscow, overnight.",151

At the 140,000-square-foot Astoria studio in Queens, a marble staircase led up to the grand old office originally built for Paramount Pictures founder Adolph Zukor. It was here in 1934 that Hecht and MacArthur installed their producer for a new four-picture deal: a pinhead named Bippo they had discovered on a visit to Coney Island. They seated Bippo behind a desk, and gave him a business suit to replace his old grass skirt. "Poor Bippo's head lolled and he drooled a bit," Hecht recalled, "but he was always happy to listen to visitors come with plots, inventions and promotion schemes to sell.",152

The recruitment of Bippo summed up Hecht and MacArthur's attitude towards the studio bosses, who in return, handed the two friends enough rope to hang themselves. The offer of at least a million dollars to make their own movies at Astoria, a vast and once lavish outpost for East Coast film production that Paramount abandoned in 1932, represented the most significant opportunity for independent filmmakers since the early 1920s. As a dream come true for Hollywood writers, it was a great privilege but also a responsibility: a first chance to prove that there was a truer and better way to create movies than the corporate compartmentalization of the studio system. ${ }^{153}$

"Neither Charlie nor I had ever spent an hour on a movie set," Hecht boasted. "We knew nothing of casts, budgets, schedules, booms, gobos, unions, scenery, cutting, lighting. Worse, we had barely seen a dozen movies in our lives." They were, 
nevertheless, undaunted, certain in the knowledge that they were armed with "the great Secret about movies": that 90 percent of a film's success lay in the script. The rest was up to a handful of competent technicians. All that meddlesome producers and directors contributed was bombast and pretension, which ran up costs and time with the "charging chariots and toppling temples," "clash of extras in togas or tin hats," Mars landings, fist fights, lingering close ups and "panoramas showing the littleness of man and the bigness of the director." 154

An opportunity to strike a blow against corporate schlock while scoring a victory for Art, Astoria also represented a shot at personal redemption. Hecht admitted that it wasn't just money and conviviality that drew the talented to Hollywood, it was also weakness - greed, laziness, and fear. The incentives were perverse: an individual could brag of never having written something so lowly as a successful script - it was never a discredit to Fitzgerald or Faulkner-while commercial success marked a writer as a literary whore, and scripts of good quality promised neither recognition nor money. Furthermore, Hecht found the work degrading. "Writing cheaply, writing falsely, writing with 'less' than you have, is a painful thing," he wrote. "To betray belief is to feel sinful, guilty — and taste bad. Nor is movie writing easier than good writing."

In an essay for Commentary, Joseph Epstein noted that for Hecht, the split between serious art and commercial work had first become an issue when he had moved from Chicago to New York with old debts and a new wife. Having already produced six novels, he gave up trying to score a best-seller and turned to Broadway.

The issue can be formulated simply enough: was Ben Hecht a sell-out? The term sell-out has a dishonorable history. It originated in the enclosed, always at least slightly paranoid, world of American Communism, where any divergence from the party line sent from 
Moscow was felt to constitute a desertion, or selling-out, of true principles. Transferred to the realm of art, the term meant betrayal of one's talent for either money or popular success. The assumption was that buyers were everywhere: Hollywood and Henry Luce, the critic Edmund Wilson famously remarked in the 1930s, were the two great enemies of talent in our time.

The notion inevitably lent a strong note of inner drama to artistic careers. Anyone who wrote for the movies, or Broadway, or the news magazines... or later television, had to consider the possibility that he was selling out. It was of course also and always a selfcongratulatory possibility, implying that one had something high and fine and serious in oneself to sell...But the line between what passed for selling out and what for artistic purity began in time to blur. ${ }^{156}$

Hecht and MacArthur festooned their new offices with thirty-foot banners that proclaimed their mission while simultaneously poking fun at the industry and themselves, bearing slogans like "Better Than Metro Isn't Good Enough" and "When in Doubt Cut to the Chase." The next order of business, when it came to stepping into the role of director, was to urgently call someone who knew what the hell he was doing and beg for assistance. Hawks recalled Hecht saying over the phone, "For God's sake, will you come back here for a week and help us? We don't know a God damn thing about it." Hawks came in for a visit, told them what he would do, and left. His advice may have included hiring Arthur Rosson, who had an excellent record as an assistant director, to handle business and financial issues. On the suggestion of MGM producer David Selznick they hired cameraman Lee Garmes, who essentially relieved them of the role of director, and avant garde cinematographer Slavko Vorkapich, whose major contribution was a striking two-minute montage at the beginning of their first film. ${ }^{157}$

Of the four films that Hecht and MacArthur made at Astoria, two of them, Crime Without Passion and The Scoundrel, received mostly favorable reviews and were modestly profitable. The other two, Once in a Blue Moon and Soak the Rich, were 
pilloried by the critics and considered disasters by Paramount, which almost refused to release them at all. Film historians like Richard Kozarski, who offered a thorough and unsparing account of the Astoria project in Hollywood on the Hudson, have suggested that it did more harm than good to the cause of independent filmmaking in the era. ${ }^{158}$

Crime Without Passion begins with the Vorkapich sequence, opening with a title card that reads: "Beyond man's dreams lurk the furies - the three sisters of Evil who live in wait for those who live dangerously and without Gods." Each of the harpies then emerges from a pool of blood that has dropped from a crime of passion, and the camera follows them as they soar high above the streets of New York. Cackling maniacally, they swoop down to crash through skyscraper windows into scenes of misbegotten romance, as they lead the audience to the film's protagonist, Lee Gentry. Played by Claude Rains, the attorney is another of Hecht's egoists, who in the arrogance of believing he is too clever for the law, winds up in the electric chair. In the first scene he stares out his office window at the people below. "Fascinating, those insects," he says... The film, which stuck to a budget of only $\$ 180,000$ thanks to Garmes, received extraordinary attention and praise from reviewers. Among them was Richard Watts Jr., who noted the effect of "a completely integrated production, which seemed to bring a planned economy to the motion picture." Ultimately, however, he found this to be only "a self-conscious stunt, without feeling or dramatic warmth."159

Once in a Blue Moon, which was based on a story by Hecht's wife Rose, is about a Broadway clown who loses his circus troupe in the turmoil of the Russian Revolution. Wandering the countryside, he stumbles upon a family of fleeing aristocrats, who hide as members of his traveling show. Hecht's daughter Marie Armstrong plays the aristocratic 
daughter the clown falls in love with. Paramount shelved the film for a year, after which it popped up randomly at children's matinees and grind houses. It featured a score by George Antheil that ran almost continuously, but was marred by sound problems, and Hecht said the script "was a dud." Although the reviews were overwhelmingly harsh, this appraisal was not unanimous. "There is hope yet for cinema to achieve its destiny as an art form while lives the pioneering spirit that produced this curious fantasy for childrenand adults." Wrote Frank Nugent of the New York Times. ${ }^{160}$

The Scoundrel was an adaptation of $A$ Jew in Love, but with all the references to Judaism removed, except for one, when a rival in love refers to the publisher as "a Don Jew-an." The most successful of the Astoria films and one of the better efforts of Hecht's entire movie career, it illustrates the strengths of his screenplays over his novels. The constraints of screenwriting forced him to stick to dialogue and action, and strip away the exposition that bogged down his books. And many of the qualities of his novels cited as weaknesses - the clockwork precision that critics like Seldes complained was too mechanical, the iciness of many of his characters - somehow became virtues in the swift, breezy language of film.

The picture is elevated by the multi-talented Noel Coward, chillingly convincing as Anthony Mallare, the debonair snake who promises an ingénue that he "always rattles eight times" before he strikes. One quickly gets a sense for why Hecht's critics paid so much attention to his epigrams. When an assistant asks whether their company's interest is in radical or conservative books, Mallare hisses, “Our firm doesn't care about the battles, it only wants the spoils." Lionel Stander stands in as the acid-tongued Bodenheim character, Rothenstein, though he seems more of a Colombo-like, wisecracking detective 
than a poet. Clearly his comments are meant for the author himself: When Mallare says, "I call anyone clever enough to see through me a friend," Rothenstein fires back, "And anyone who doesn't, a sweetheart."161

While Hecht and his egoists had contempt for the masses, the feeling was apparently mutual. The critic Andre Sennwald reported on the response of one girl seated in the row behind him "who assumed the responsibility for representing the American film public and applied the scalpel of sarcasm to almost every line of the work. In a deafening stage whisper she disliked Noel Coward, Ben Hecht, Charles MacArthur, and the picture. 'Dear Noel' she hissed...'Isn't he too clever?'” Journalists who visited the set invariably commented on the careless brattiness of Astoria's two geniuses, who were often lost in backgammon games, slumping languidly in chairs, or missing altogether. But as Vogue's Marya Mannes observed, "the carpenters, the electricians, and the camera men move in an audible frenzy. And the actors do their scenes over and over and over again, like bad but patient scholars."

In Child of the Century, Hecht credits Garmes' amazing technical expertise and command of filmmaking: "I would sit by silent and full of admiration as Lee and his magicians prepared the set for my 'direction.' My job seemed little more than putting a frame on a finished canvas." But as Kozarski pointed out, Hecht was just admitting what everyone else already knew. Ultimately awarded screen credit as co-director, it was Garmes who marked and lit the scenes, framed the angles, and coached the actors. He kept Astoria under budget and on schedule, with innovations in efficiency and costcutting such as his decision to scale down scenery, fashion it into separate pieces, and set 
these on wheels for rapid changes. Time noted that Garmes might have been more essential to the successes at Astoria than either Hecht or MacArthur. ${ }^{163}$

By the time production had started on their final movie, rumors were flying that Paramount had called Hecht and MacArthur into conference and warned them to halt the backgammon and hijinks. Starring Mary "Mimi” Taylor, a fashion model with whom Hecht was having an affair, Soak the Rich was meant to be a lighthearted, wisecracking parody of campus radicalism- "A few years ago it was the fashion to be Don Juans. Today ideas have taken the place of drink and revolt is the latest form of necking." But by now Garmes, Rosson, and other important members of the Astoria crew had left for other work. The staff that remained seemed weighted down by the dragging effects of the Depression. And two days after production began, Hecht's mother was killed in a car accident on Wilshire Boulevard. The film lacked vitality, and it was obvious. The New York Sun concluded, "The Messrs. Hecht and MacArthur prove again, in their Soak the Rich, that their gift for writing dialogue and situation is perhaps the most brilliant of all the movie scenarists. They prove, too, in this new film, that they have little talent for directing or producing." In the summer of 1936 the Hollywood Reporter ranked the box office performance of all 221 features released thus far that year, and Soak the Rich was at the very bottom. ${ }^{164}$

It is tempting to interpret Hecht and MacArthur's Astoria experiment as damning proof against the proposition that in moviemaking, the writer, not the auteur, is the true "author" of the film. But Astoria was never a fair testing ground for the argument, which in any case, has long been forgotten. Since "the boys," as Hecht and MacArthur were called by the press, knew absolutely nothing about directing, the notion that they 
understood "the great Secret of movies" had been altogether unreal in the first place. Rather, Astoria failed because of hubris, or chutzpah, as Hecht might have preferred, which is both ironic and fitting, since the pair's best films were about mad egoists. "Was this to be 'the boys' art now that they were freed from the dead hands of the Mongolian idiots who ruled Hollywood?" complained Alfred Hayes in New Theatre. "We may remember years and years ago...that Hecht himself once showed signs of being an artist. But that was another country, and besides the wench is dead." ${ }^{, 165}$ 


\section{RETURN}

It has always been the privilege of the Jew to take the measure of the godless and the inhuman... They have a little blindly made us the symbol of the thing they are seeking to overthrow...For do they kill us all, silence us all, and burn all our books, the teachings we have helped give the world will still remain to confront and confound them to the day of their doom.

\section{Ben Hecht, "Four Rabbis Speak" in 1001 Afternoons in New York ${ }^{166}$}

Astoria did not turn out to be a new start for independent filmmaking or for Hecht. Having agreed to be compensated through profit-sharing, he and MacArthur had earned little during their first year of the project, so they had to return to Hollywood even before the premier of The Scoundrel to write Barbary Coast for producer Samuel Goldwyn. Hawks, who directed it, called it "a lousy picture, a contrived thing done more or less to order." Unlike Viva Villa! Hecht could not blame its failure on studio interference, and to the extent that the largely autobiographical play that he wrote next, To Quito and Back, reflected his state of mind in 1936, he could not altogether blame Hollywood for his overall sense of unease. His problems lay deeper. ${ }^{167}$

Hecht had been a serial adulterer for years, but his affair with Mimi Taylor was becoming serious. As items about the couple began to appear in newspapers, they traveled to Quito, Ecuador, and their trip became the premise of his new script. His experiences as a war correspondent in Germany also figured into the story, likely because Hitler's prominence in the news triggered these memories. While To Quito and Back is yet another story of an egoist, Alex Sterns is not a Don Juan, but an empty and bewildered middle-aged man. ${ }^{168}$

The play begins with the familiar suitcase full of cash that will be used to fund a revolution, which Sterns good naturedly carries past authorities. His friend Zamiano, the 
guerilla leader, talks like one of Hecht's gangsters: "If anybody touch or get fresh—you shoot. I come right away. Understand?" Like Camonte, Zamiano isn't familiar with the word "disillusioned," but understands what it means. Sterns is fond of Zamiano, but is unable to buy into the revolution, and instead dismisses all political beliefs with glib epigrams that he swaps with Frazer, a "hear-all, see-all, do-nothing Newspaper Ned," who once stood by and watched thousands massacred at Moabit Prison in Germany. ${ }^{169}$ As they and fellow sophisticates watch Zamiano's revolution get underway, Frazer recalls his days as a young reporter in Chicago, when radicalism meant a May Day picnic in the park. Now communism is the new religion, laments Sterns, while fascism is communism without the high-minded words, communism minus a soul. Democracy is quaint, but relies on the People, a mindless mob always ready to be led around like a herd of sheep. Such banter continues, while meanwhile Sterns begins to realize that, having betrayed yet another woman in his life, he can't seem to believe in love anymore, either: "Yes, what I've done has filled me full of distrust. My betrayal of her has taught me not to believe....in others, or myself.",170

With his affair now falling apart, he becomes disgusted most of all by the numb paralysis of his own cynicism, his inability to "get used to the idea of words and actions going together." The repartee of his friends becomes increasingly intolerable: "There's quite a tribe of us at large in the world. Fair-minded citizens who understand the cries of the underdog...We hover on the sidelines of all passionate events, and entertain ourselves with discussion...We're always on the right side of discussions but never on any side of the barricades." Finally, he decides that instead of returning to a life on a treadmill in America, he would rather join Zamiano in hopeless resistance to a fascist 
counterrevolution. At least dying for a cause might mean something to the poor of Ecuador who will have to face such oppressors again in the future. In a farewell to Lola, he explains: "In a world too loud with false gods there is nothing left to serve except the least false of them."171

Hecht finally ended his affair with Mimi, patched things up with Rose and returned to New York to participate in the play's production. He told the Times that he might be through with pictures for good: "Once in my pristine youth, I wrote books with some mental content. Now I am going back...(to) see if it's any fun to be a writer again.” But he was soon to find the Theater Guild every bit as meddlesome as the studios. It's unlikely that as early as 1936 he had consciously rendered a portrait of appeasement and isolationism, but in the summer of 1937 he wrote Rose that the "Guild keeps having meetings about the dangers of the play." When "a poor milk soppy looking goon named Maurice Wertheim" suggested that "some of the anti-fascism be cut down because it could outrage Hitler and kill a lot of Jews" he flew into a rage. The Guild watered it down a great deal anyway, and with the notorious appeasement to Hitler of the Munich Agreement still a year in the future, critics like the Partisan Review's Mary McCarthy and the Times' Brooks Atkinson saw no connection to the developments in Europe. ${ }^{172}$

Hecht had been paying attention to the plight of German Jews at least since July 31, 1935, when he wrote a guest column on the subject for Walter Winchell, six weeks before Hitler introduced the Nuremberg Laws in the Reichstag and during a summer in which the anti-Semitic street violence had become far more virulent. In the column Hecht noted that when the insular, religious life of the Jewish ghetto began to dissolve early in the nineteenth century, it had been in Germany that Jews first became world citizens. 
This was unfortunate, he said, for the Germans had the worst inferiority complex in Europe. It was the current tragedy of the Jews to now be driven back into the ghetto, as Germany's desire to rid itself of its own sense of inadequacy forced a sophisticated, metropolitan people to relive a past existence that they had long ago outgrown. ${ }^{173}$ Apparently Hecht believed in 1935, as many did, that the current persecution represented just another ugly spate in the long continuum of German anti-Semitism, and that it would ebb again, as it always had in the past. He suggested it would ultimately turn out worse for the persecutors than for the persecuted: "I have a feeling that this Jew consciousness is rather good for the seemingly assimilated Jew. There is a certain strength in shaking hands, however briefly, with so valorous a historic sire as the Jew." The light, even snarky tone of the piece now seems jarring in hindsight, and it clearly marks a midway point between the self-hatred of A Jew in Love and Hecht's transformation "into a Jew" in 1939. But what is most salient in the column is what remained consistent all along: a pronounced distaste for assimilation and cosmopolitanism, which Hecht associated with craven conformity and social climbing. Such traits offended him as the proud individualist who celebrated difference and originality.

Despite his statement that he might be leaving Hollywood for good, he continued to be a prolific screenwriter through the final years of the '30s, scripting the 1937 screwball comedy Nothing Sacred, a savagely funny satire of the idiocy of the People, the Goldwyn Follies, Gunga Din, Wuthering Heights and Lady of the Tropics, as well as the storylines for John Ford's Hurricane and Stagecoach, the Marx Brothers'At the Circus, Angels With Dirty Faces, Some Like It Hot and It's a Wonderful World. Hecht became 
the fix-it guy producers would call in whenever they had an emergency. Most famous was his down-to-the-wire rewrite for David Selznick of the last nine reels of Gone With the Wind. By the end of the decade, however, Hecht was a changed man.

Early November 1938 saw Hitler's annexation of Czechoslovakia under the Munich Agreement, and Kristallnacht, or "night of broken glass," a massive pogrom in which the SA paramilitary ransacked Jewish homes, businesses, schools, hospitals and synagogues across Germany, killing 91 and arresting some thirty thousand, many of whom were sent to concentration camps. ${ }^{174}$ By now Hecht was completing $A$ Book of Miracles, a collection of seven novellas that he and most critics agreed was the best fiction he ever wrote, although very few people ever read it. The collection included "The Little Candle," his uncanny prophecy that at the Fuehrer's command, "a great International Pogrom" would slaughter over half a million Jews across Europe, leaving the Jews who survived to be hunted down and murdered:

For when we opened our newspapers we found that the cloud we had watched so long and, in a way, so aloofly, had grown suddenly black and dreadful and immense. It filled all the pages of the journals. The world had made it seem but a single face overnight and this face thrust itself into our breakfast hour, ugly and hellish. Like a monster evoked out of the smoking pages of our history, it confronted us, exultant and with the ancient howl of massacre on its lips. ${ }^{175}$

Many reviewers were moved by the story when $A$ Book of Miracles appeared in June 1939, although a few remarked that it seemed farfetched. Hecht's publisher tried to get him "to reduce the dreadful prophecy in 'The Little Candle' to a neat book-keeper's figure of fifty thousand dead," but he refused. Associated Press critic John Selby praised it as "one of the bravest stories the public will see in a long time, and one of the truest," but nevertheless sounded a note of incredulity: "Mr. Hecht imagines that Europe actually 
decided to kill off the Jews — not many of them but all of them." In a sense, such comments were in line with the remarks he had always received from critics, who were often put off by a contempt for humanity that seemed to mar all of his work. Only someone with so grim a view of the human soul could have imagined that people could be capable of such a thing. ${ }^{176}$

From late 1938 onward, Hecht acted as though he was sure of what was about to happen and willing to do whatever he could to help stop it. This spirit of activism was altogether new in a man of forty-four who had stood on the sidelines during the years of the Innocent Rebellion and the resurgent radicalism of the early 1930s, the cynical journalist who had held all politics in contempt, and more lately, the happily oblivious Hollywood playboy just come off a "two-year party" at Astoria during the very darkest period of the Depression. In his film work, his changed attitude was first evident in Let Freedom Ring, released in late February 1939. A Western about a young man who enlists workers and the local newspaper to battle a cattle baron, it was a parable for anti-Nazi, anti-fascist struggles such as the war against Franco, but with jingoistic overtones. Soon thereafter, Rose arranged for him to write a column for P.M., Ralph Ingersoll's startup daily newspaper, which could serve as a platform for his views.

Ingersoll could only pay $\$ 75$ a week for "1001 Afternoons in New York," and the job meant passing up a seven-thousand-dollar-a-week contract with MGM. But Hecht later said he was "grateful for a forum larger than (his) dinner table." As columnist, he championed interventionism and took powerful American Jews to task for kowtowing to the isolationists. He relayed the case of Hymie Weinberg, a man who had thousands in the bank but pretended to be a beggar "who couldn’t possibly be expected to help 
anybody." It was a shame that Hymie had died of malnutrition, Hecht remarked, because with a little training he could have become another isolationist congressman or senator. In other columns, Hecht compared Vichy head of state Philippe Petain to a pelican who drowned in the sea because he lacked the strength and heart to flap his wings; blasted the Hearst newspapers for discouraging American assistance to Britain; and likened isolationist Senator Burton Wheeler to a crackpot who preached that the earth was flat, predicting that in future years, Wheeler would remain just as defiantly unrepentant. ${ }^{177}$ In the spirit of the column of his Chicago days, Hecht captured slices of life in "the addle-headed city of New York - the teeming and invincible citadel of ball games, slum dramas, night life, (and) soap-box revolutions." He wrote of having drinks with Sherwood Anderson, whom he had not seen since the early 1920s. Anderson died just a few days after the reunion, while on a cruise headed for South America ${ }^{178}$ Hecht also related his chance encounter on the street with Bodenheim after fifteen years of estrangement, on the occasion when he agreed to pay his friend thirty dollars a week for a poem or two pages of prose.

Though Hecht would later offer far less flattering descriptions of how the poet had appeared on that day, in the column he recalled that in youth Bodenheim had been "a mathematician of words" who "arranged them into acrobatic patterns of cabalistic tenderness." In the corner of a midtown saloon, Hecht had pored over years' worth of unpublished work: a record of the calamities and despair wrought by the Depression, but utterly devoid of self-pity. "They were full of love of others," Hecht explained. "They sang of shop girls and laborers and of human gropings for justice. They cried out the immemorial pain of the underdog, and they cast a light."179 
Hecht's column represented not just a return to younger days in Chicago, but also a return to his Jewish roots. "How Do You Do" offered an epitaph for the great Yiddish author and playwright Sholem Aleichem. "It was out of battered and tattered hearts that he wrung his great laughter," Hecht explained, quoting from his tombstone: "Here lies a Jew, plain as an old vest,/Who suffered like the devil but wrote comedy the best." Hecht told of how Harpo Marx made a snobbish, anti-Semitic doorman the butt of a slapstick routine by sending him chasing all over the street after a handful of scattered fake jewelry. Groucho praised Hecht's own ridicule of the Nazis with a brief note: "That's what we need — a little more belligerency professor and not quite so much cringing."180

One of Hecht's most important columns, which appeared January 16, 1941, attacked former ambassador to Britain Joseph Kennedy's clandestine meetings, in which he had warned important Jews of Hollywood and New York not to produce anti-Nazi movies and literature. Such propaganda would not only escalate tensions with Germany, Kennedy had advised, but would also make fellow Americans resentful that they were being dragged into "a Jewish war.", 181

Kennedy had made national news two months earlier, on November 10, 1940, when Boston Daily Globe reporter Louis Lyons printed off-the-record remarks he had made at the Ritz-Carlton. Still ambassador at the time, Kennedy had declared that Britain — having just sustained the German Luftwaffe's unprecedented bombardment in the Battle of Britain and now enduring the punishment of the Blitz-was doomed, and “democracy is all done.” As for America, “I'm willing to spend all I've got to keep us out of the war," Kennedy had told his three journalist companions before departing. "There's no sense in our getting in. We'll just be holding the bag."182 
A week later he delivered "a thundering three-hour monologue" at a luncheon at the Warner brothers' studio. A former movie executive, Kennedy had been expected to talk about the impediments of exporting movies to Europe during wartime. Instead, he warned that just as Britain's Jews were being blamed for the war overseas, American and Hollywood Jews would be blamed for whatever suffering the United States incurred should it too join the fight. "He apparently threw the fear of God into many of our producers and executives," wrote Douglas Fairbanks Jr. to President Roosevelt the following day, "by telling them that they should stop making anti-Nazi pictures or using the film medium to promote or show sympathy to the cause of the 'democracies' versus the 'dictators.' ... He continued to underline the fact that the film business was using it power to influence the public dangerously and that we all, and the Jews in particular, would be in jeopardy, if they continued to abuse that power."183

The speech was never reported in the newspapers - until Hecht wrote his column in mid-January. Taking aim at Kennedy's core argument, Hecht noted that people never ran out of reasons for hating Jews. Not so long ago Hollywood Jews were decried as radical Bolsheviks; now they were accused of being capitalist imperialists intent upon bringing the boot down on the working man. "All this is confusing enough to people studying what is known as the Jewish question from the outside," Hecht added. "Studied from the inside it grows a little nightmarish." 184

In Child of the Century Hecht wrote that when he "turned into a Jew in 1939" he also became an American, and insofar as he became an ardent interventionist, this was true. In 1940 he joined the advocacy group Fight for Freedom, Inc., for which he and MacArthur wrote the stridently patriotic one-act play Fun to Be Free. But while Hecht 
expressed confidence that the United States and its allies would defeat Nazi Germany, he was not optimistic about the fate of Europe's Jews. Moreover, he was deeply disturbed by the silence of the American media when it came to the ongoing butchery, and it rankled him that the isolationists muzzled powerful Jews by playing on their fears of appearing un-American. As for the Jews themselves, he was angered to see that even in this time of crisis, social status still counted for so much, that the rich and powerful of Hollywood, like the Jazz-Age Jews of Broadway, "had discarded their Jewishness out of the belief that as Jews they could line up only for a snubbing."

It had been the very success of Jews within American culture during Hecht's lifetime that had raised "the Jewish question" he referenced. Historian Stephen Whitfield has noted that in the decades that saw the emergence of mass entertainment, "no minority group was better poised to seize both artistic and business opportunities." As immigrants or first-generation Americans, Hecht and his contemporaries had a yearning to establish themselves in American society that the Anglo Saxon inheritors of wealth and power lacked. At the same time, compared to other minority groups, they also benefited from the relative tolerance of Americans: Their status as outsiders had its advantages in show business and the arts, and unlike African Americans or Asians, Jews could also pass, finding a degree of acceptance within the mainstream. Simultaneously outsiders and insiders, they straddled a boundary line. The sociologist Georg Simmel explained this with the concept of "The Stranger" (der Fremde): a person who is a stranger from within, "he who is far, is actually near." The role of being both insider and outsider was one Hecht had been playing all his life, not only as an American Jew, but also as a journalist, artist and member of the Hollywood elite. ${ }^{186}$ 
The immigrant experience of the Lower East Side, and the piecework of the garment industry in particular, had also provided Jews with unique preparation for the burgeoning of mass culture. Starting out as clothing entrepreneurs, future studio heads of Hollywood had acquired an appreciation for popular tastes, trends, and changing fashions. Fiedler noted that the evolution from the garment to the movie industry "began by blurring away class distinctions in dress and ended by blotting out class distinctions in dreams." ${ }^{" 187}$ It was no coincidence that people so familiar with mass production, distribution and exhibition would introduce the star and studio systems. Nor is it surprising that Hecht, a Lower-East-Sider himself whose parents manufactured and sold women's fashions, had created a writing factory as soon as he had established himself in California. The common background that he shared with the studio bosses may also explain some of his bitterness as their employee: His father, after all, had fled the sweatshops of the ghetto to become his own boss in the Midwest.

In the years that saw the explosion of nickelodeons, the Lower East Side had the highest concentration of them anywhere in the United States. When the New York City Police Department padlocked their doors on Christmas Eve of 1908, on the grounds that they were unsafe and unsanitary, ex-garment worker William Fox and former newsboy Marcus Leow led the proprietors' effort to have them reopened. Another Jewish immigrant, Carl Laemmle, would successfully challenge a monopoly on film production and lead the initial exodus to Southern California in 1912. The teens and '20s saw the beginning of the Hollywood film industry and the studio system, with six major Jewish entrepreneurs dominating the field—Fox, Loew, and Adolph Zukor, who had all been both garment workers and film exhibitors, ex-garment worker Samuel Goldwyn, and 
exhibitors Laemmle and Louis B. Mayer. With the advent of talk, they were joined by the Warner brothers, Irving Thalberg and David O. Selznick. ${ }^{188}$

During the 1920s, the rise of these "moguls," as they soon came to be called, prompted the first phase of the Jewish question, characterized by a nativist xenophobia that was a backlash to the sudden and dramatic changes of the era. After the Fatty Arbuckle trial and a series of additional scandals early in the decade, the moguls preempted government censorship by recruiting U.S. Postmaster General Will Hays, who created an alliance with the Catholic Church to establish the Motion Picture Production Code in 1930.

As Hecht noted in his column on Kennedy, the second phase of the Jewish question during the run up to the Second World War was shaped by isolationism. As early as 1933, Hays blocked an anti-Hitler feature that was to be written by Mankiewicz, The Mad Dog of Europe. Hays's successor from 1934 through the late '40s was lay Catholic and former Variety reporter Joseph I. Breen, who wrote to a friend the year he was appointed head of the Hollywood Production Code Administration that the Jews were "probably the scum of the earth." For the remainder of the decade, he became the major roadblock to movies about the Nazis and Europe's Jews.

Paul Muni, Edward G. Robinson and Ernst Lubitsch, who were to become leading participants in Hecht's 1943 pageant for Jewish rescue, were all affected by Breen in one way or another. Breen was particularly suspicious of the Hollywood Anti-Nazi League (HANL), to which Muni and Lubitsch belonged, because its sympathy for the Republicans in the war against Franco suggested that it was a communist front organization. The only studio heads openly supportive of the HANL were Harry and Jack 
Warner, who in November 1938 - the same month that Kristallnacht occurred and Nazi filmmaker Leni Riefenstahl visited Hollywood — announced that they would be producing a new feature titled Confessions of a Nazi Spy, starring Edward G. Robinson. The Warners released the film on April 28, 1939, having ignored a protest from the German consul and a warning from Breen himself. Picketers rallied at some of the showings, and there were isolated incidences of violence. At one screening in Milwaukee, Nazi sympathizers set fire to the theater. ${ }^{189}$

In June of 1938, Breen rejected a script based on Vincent Sheean's memoir Personal History, the story of a foreign correspondent in Hitler's Germany that was to end with the hero rescuing several Jews and marrying a Jewish woman. After Britain went to war, producer Walter Wanger handed the script to Hitchcock and had it stripped of all direct references to fascism and Jews. Breen approved Foreign Correspondent, despite its interventionist message, which was particularly strong in the introduction that Hecht had provided. The movie appeared in theaters in 1940, along with a handful of other anti-Nazi pictures, including Charlie Chaplin's The Great Dictator and a Three Stooges' short You Nazi Spy! Late that year, Joseph Kennedy, a former RKO executive, held the closed meetings in which he bluntly warned Hollywood producers to stop making anti-Nazi films. ${ }^{190}$

Hecht wrote that the Nobel Prizewinning French philosopher Henri Bergson had an excellent answer to Kennedy. The Vichy government had granted Bergson a special exemption so that he would not have to register as a Jew and thus surrender all of his civil rights. In response, the eighty-year-old philosopher had struggled from his deathbed and joined the line at the Paris bureau of racial records. He had died a week later. ${ }^{191}$ 
Hecht did not couch his arguments in terms of the "the melting pot" versus "cultural pluralism," but in the 1940 became one of the first to articulate the more aggressive attitudes we nowadays associate with "identity politics." He may have been altogether unfamiliar with the work of Kallen and Bourne, but he nevertheless was on intimate terms with cultural pluralism, inasmuch as the phrase reflected the attitude of his generation. He had been rebelling against it since at least as early as A Jew in Love, though it had taken him a decade to switch valence, from rejecting his heritage to embracing it.

If his mind had conflated Israel Zangwill's vision of a melting-pot America with Kallen's vision of a nation that celebrated its diversity, that was because Hecht had seen too many Jews of his generation simply shrug off their Jewishness. Now, in light of the new onslaught against Jews abroad and at home, that kind of dismissiveness was starting to look a lot like cowardice. He took aim at it in an April 15, 1941 column titled "My Tribe is Called Israel," that also articulated his own, new credo. ${ }^{192}$ It was this brief manifesto that caught the attention of the young Palestinian Zionist Peter Bergson, and launched the new phase of Hecht's life as propagandist for a movement.

The column had been prompted by "a barrage of strangely nervous and sadly sensitive letters" he had received as one of the only newspapermen to openly address the Jewish question. Replying to one common objection, he said that he understood very well that Judaism was not a "race," but such distinctions hardly mattered to the Nazis and their collaborators. Furthermore, he knew that most Jews were hardly Jews at all but citizens of the world, who rarely spoke or even thought about Judaism. He himself had lived as a successful example of this type. Nevertheless, he argued: 
It is the pathetic notion of my critics that the best way to combat this gibbering but powerful attack on the Jews is to stand, anthropology books and citizenship papers in hand, and prove by chapter readings and government stamps that there are no Jews. The thing to do, they say, is to prove by our deeds and words as well as by our great worldliness that we are Americans - fine patriotic Americans first and Jews afterward, if at all. ...(But) it is back on all the radios of Europe and on an alarming portion of them in the U.S.A. And you won't get very far in your rebuttals by quibbling, Talmudic fashion, as to whether or not you are a Jew...I suggest, too, that you stop wasting your angers on me. I am not attacking you. I am only asking you to fight. ${ }^{193}$

Throughout the '30s Hecht had been more or less unconsciously folding his critiques of Jewish American culture into his satire of mass media, but after the Joseph Kennedy controversy, the connection became explicit. Up until then, he had been writing fiction in the vein of the Hollywood novel, that new literature of alienation and angst in the age of mass culture spawned by the migration of writers to Hollywood, which included such works as Day of the Locust, The Last Tycoon, What Makes Sammy Run? And I Should Have Stayed Home. Hecht's own contributions to this genre, which came mainly in the form of short fiction, added up to something significant as a sum total, but have been overlooked because they were spread out over so many years and through so many different volumes of his work. In addition to his zany 1944 murder mystery I Hate Actors!, they included stories from The Champion From Far Away, and Actor's Blood, as well as the 1943 story, "Concerning a Woman of Sin."194

Two of the best tales appeared in A Book of Miracles. In "The Missing Idol," a frenetic producer named Mr. Kolisher-whose genius is that he knows and understands nothing, and in knowing nothing, understands the People perfectly_-becomes inspired to make the most spectacular big-budget passion play of all time. He commissions dozens of screenwriters, biblical savants and university scholars, buys five hundred camels and one 
hundred dromedaries, and proceeds to reconstruct ancient Jerusalem. In fact, the thing is so good that God himself grows interested, and wants to lend a helping hand in the production. The Lord scoops up the great movie star playing Jesus from the middle of the crucifixion scene, and endows him with a small touch of divine aura. But by a cruel, unforeseen twist of fate, the star can now no longer be captured by a Hollywood movie camera, his career is finished, and he ends up forgotten and bitter. ${ }^{195}$

"The Missing Idol" is essentially a parable for the relationship between art and mass media. It's a subject Hecht also considers in "The Heavenly Choir": Can the new mass medium of commercial radio bring the beauty of art to the masses? Is this not "the long-awaited liaison between Beauty and the Beast"? No, Hecht concludes, for when the two lie together, "it was not the beast that underwent any marked alterations, but, as always, Beauty. For Beauty lying down with the Beast too often grows a bit cockeyed and contemptible herself." 196

When Hollywood remained silent about the Nazi massacre of Jews, Hecht's critique developed from there. In writing Guide for the Bedevilled during the darkest days of the war, he imagined himself pitching a movie to the studio heads that "had nothing to do with Jews so they need not wince in advance." Instead, it would put "a new villain on the screen...a new gangster...a new Public Enemy Number One": humanity itself. The story would focus on Ignatz Philip Semmelweis, a Hungarian physician who discovered that when doctors failed to wash their hands before performing medical procedures, they spread infection and disease. Semmelweis' breakthrough could have saved millions of lives, but out of sheer human blindness and callous stupidity, he was ignored. Hecht imagined that in conference a producer would insist that the story be changed so that 
Semmelweis was the villain and the People were the hero. And indeed producer Herbert J. Yates at Republic turned the idea down in July 1946, just as Hecht had predicted. ${ }^{197}$ Hecht noted that in much of what had been written about Hollywood, there was a major lie of omission, which was that it was "an empire of toy-making, invented by Jews, dominated by Jews, and made to flourish like unto the land of Solomon — by Jews, and a few embattled Irishmen." He added that when he had been young, the stage was full of Jewish comics and dramas, the magazines "were full of Potashes and Perlmutters," and many popular songs were sung with Jewish inflections: "Don't do dot dance, I tell you, Sadie." Yet "whereupon the two great media of mass entertainment appear-the movies and the radio, both dominated by Jews—and the Jew vanishes." 198

Nearly a decade later Commentary writer Henry Popkin would build on Hecht's thesis, citing in his essay, "The Vanishing Jew of Our Popular Culture: The Little Man Who Is No Longer There," dozens of examples of recognizably Jewish characters who had disappeared from broadcasting and the movies. He credited Hecht's Guide for the Bedevilled for one of the rare discussions of this during the 1940s. While Popkin neglected to mention that the other Jews missing from the airwaves and movie screens were the victims of the Nazi genocide, of the missing Jewish characters he wrote: "The source of this phenomenon, as of so many others in Jewish life today, is Hitler. When Hitler forced Americans to take anti-Semitism seriously, it was apparently felt that the most eloquent reply that could be made was a dead silence: the American answer to the banishment of Jews from public life in Germany was the banishment of Jewish figures from the popular arts—in the United States."199 
Hecht, however, was observing all of this from within the movie industry, and he had a different point to make, both about the character of American mass entertainment and about his powerful Jewish contemporaries in Hollywood. He recalled that when he first came to Hollywood, the Jewish studio executives reminded him not of the smooth sophisticates he had known in New York during the 1920s, but of his immigrant aunts and uncles. He had initially assumed that they were crude and simple Philistines, but in this he had been quite wrong. In fact, he had found himself in the midst of a great historic current of Jewish genius that dated back thousands of years. Hollywood represented the destiny of a people long pushed to the margins of commerce, "forced to create a world out of their limbo.",200

Jews were accustomed to serving tyrants, but in America the "tyrant," in Hecht's view, was the People. And so years before coming to Hollywood, this "ancient tribe of king-serving and luxury-bringing Jews" had reached to take possession of theaters and amusement parks. "These were naturally theirs," Hecht argued, "for were they not long trained and adept in the business of catering to their masters?” But while such servility may seem the mark of a humble soul, it was really just a mask worn out of necessity. "Under the mask there has remained the gift for loving oneself above one's master," Hecht continued. "In this fact lies the paradox of a servile Hollywood run by the world's most startling collection of egoists."

With this now explained, he drew the link between what he saw as the cowardice of movie moguls who were afraid to stand up for their fellow Jews in Europe, and the absence of artistic integrity in Hollywood. "That the great Jews of Hollywood bow to the dictates of Jew haters is only part of their cowardice," he wrote. "It is also the mark of 
consistency. For the Jew haters are part of the Public, and the servility of Hollywood makes no distinctions in its master." 201

It was the reasoning of a man not only outraged by the inhumanity of Nazism and the spinelessness of fellow Jews, but also personally saddened by the disappearance of a world he had once known. He was far away now from the days of the Jackson Park art colony and young Greenwich Village, from a world where people held readings by candlelight and built temples to Art. Hecht had seen Art poached by the poseurs, mountebanks and tourist boobs of the 1920s, before it had been devoured by radio and the movies. By the time television had arrived in the early 1950s, Hecht would write:

Despite the popularity of concerts, exhibitions, ballets and printed matter - or, perhaps, because of it - the artist is a vanishing figure and the arts are becoming a branch of the Advertising Business. Never was the public so 'artistic' and never was there so little mystery and magic entering the world.

There are, in fact, no arts. There are only entertainments. Our talents, like our waterfalls, have all been harnessed to make life pleasanter for the Public. The iconoclastic or anti-public artist exists no more than an anti-public traction company.

In Russia all individualism in art has been forbidden by law and is punishable as crime. There are no such laws in the U.S.A. Here our individualism has dried up and blown away by itself. ...

My announcing the death of American art may be premature. It may be that I am not in touch with its underground. Somewhere beyond my ken possibly there are still candlelit rendezvous in the big and little towns where youth gathers to kick the hell out of syntax and sanity. But I doubt it. Such American revolters as I know in these days are a twofaced lot. They revolt on week ends. The other five days are full of box-office dreams. ${ }^{202}$ 


\section{CONCLUSION}

Hecht may have been noting the conformity or spiritual bankruptcy of the early 1950s, but certainly in the post-war era, individualism — if not actually individualitywas on the upswing. This was as true for average Americans who had returned from the war to settle in the suburbs and pursue the American Dream as it was for the nation's cultural elite. "Jewish intellectual life in America since the 1930s has been a mass exodus from the ghettos of revolutionism to the condos of individualism," wrote Mark Shechner in 1987. By the time he made this observation, however, the idea of the late twentieth century as an era of extreme individualism had already become a commonplace, having first been popularized by Thomas Wolfe in his 1976 essay for New York Magazine about “the 'Me' Decade," and delineated by Christopher Lasch in his seminal study, The Culture of Narcissism. ${ }^{203}$

Shechner's point about the collapse of socialism may explain a transformation within American intellectual life for Jews as well as for gentiles, but there were broader factors transforming the culture as a whole. The shared traumas of the Depression and World War II had imposed an unprecedented degree of national unity, but in the end, had also provided the manufacturing muscle and relative wealth that enabled America to emerge from the war as a superpower. The way was now open for the individualistic "pursuit of happiness" that was, after all, the nation's original promise to its citizens. Another driving factor of change had been the advent of mass media: again, during the 1930s and war years a homogenizing influence, but as Hecht had perceived, a technological and market-driven phenomenon and therefore intrinsically a self-oriented one in the first place. 
The country had seen this movie before: in the shift from the collectivist aspirations of the avant-garde artists and the radicals of the Innocent Rebellion to the Don Juanism of the Jazz Age. The first time this shift had occurred had been a kind of dress rehearsal for the second, a point that the cultural historian Michael Kammen has helped put into context by drawing a distinction between the more rudimentary "popular culture" of pre-World War II industrialized America, with its Coney Island and nickelodeons, and the "mass culture" of America the postwar superpower, with its Disney World theme parks, multiplexes and televisions. ${ }^{204}$ It was the point Hecht was making when he suggested that there are no arts anymore, only entertainments. In the postwar era, there was more public admiration for the individual artist, the rebel, the iconoclast than ever before, as culture had become democratized through the mass media and mass market. But Beauty had lain with the beastly masses, and Beauty would never be the same.

Though both Hecht and Bodenheim are virtually forgotten as literary figures now, they had anticipated this overall trend of the twentieth century, and had understood their own era's narcissism with more clarity than many of their far more celebrated contemporaries. Their writings touted, dissected and vilified this narcissism with wit and acumen. Indeed, in no better way did they augur the often amusingly fraught and imperfect egoism of post-war artist-entertainers than in their own personas. Shades of Hecht and Bodenheim are on display, for example, in the "bad boy" Jewishness of Lenny Bruce, in the self-absorption of Woody Allen, and in the shared traits of an otherwise richly diverse cast of Jewish American writers that would come to include Saul Bellow, Norman Mailer, Philip Roth and Allen Ginsberg. ${ }^{205}$ 
Not only had Hecht and Bodenheim also embarked upon a quest for self-liberation and self-fulfillment, but as a consequence, they had faced the same internal and external crises. In grappling with popular and commercial success, they displayed the characteristic qualities of artists in the age of mass media - vanity, promiscuity, even cruelty, but also vulnerability and, in the case of Bodenheim, self-destructiveness. Moreover, their relationship was uniquely charged by that "strong note of inner drama" that became endemic to artistic careers, particularly as the line between art and entertainment began to blur: that concern over being a sell-out. ${ }^{206}$

What is perhaps most tragic about Bodenheim is that his novels and poems add up to a significant body of work, one that reveals a writer of extraordinary versatility, honesty, and emotional power. One of his more recent advocates, the journalist Jason Boog, has argued that his books from the ' 30 s have been ignored by scholars and forgotten about because “Americans don't like to dwell on failure." While there is a degree of truth to this, his novels tended to be terribly uneven; the prose was sometimes clumsy, and he had a habit of meandering from narrative action and dialogue into subjective exposition. As Philip A. Greasley notes, “Bodenheim's notoriety has outlived that of his works. His literary flaws-looseness of structure, lack of control, and repetitiousness - make a resurgence of his literary reputation unlikely. But each of his novels is a clear portrayal as well as an indictment of newly urban America."207

He appears to have been the victim of his own self-fulfilling prophecy of defeat. In a revealing scene from his first autobiographical novel, Blackguard, protagonist Carl Felman returns home after being fired from his job as a telephone lineman. When his father warns him not to be a "poor schlemiel" all his life, Carl turns in a rage, reminding 
the old man that his own twenty years as traveling salesman and general store manager had added up to nothing but failure. "You recommend a treacherous wine," Carl yells. “...Perhaps I've inherited nothing from you save your curious inability at making money.,208

But Hecht wasn't interested in psychologizing about his friend, and as for the quality of the work, Hecht saw Bodenheim as Bodenheim saw himself, as a poet, not a novelist. He described Bodenheim's books as "hack work with flashes of tenderness, wit and truth in them, and some verbal fireworks in every chapter," In their tenure together at the Times, Hecht had seen Bodenheim generate prose of consistent quality, and while in his company, though always aware of his friend's buffoonery, had observed a slashing wit that put even Mencken to shame. ${ }^{209}$ Hecht was convinced of his friend's innate talent, and always saw the sincerity, sensitivity and depth come through in the writing. Moreover, despite Hecht's preoccupation with cold, egoistic characters who found themselves their own best company, his friendships were important to him, and in the 1940s, he was saddened to see an old companion plummet so helplessly. For these reasons, and perhaps most of all, because of Hecht's recognition of his own flaws, what ultimately mattered to him was not what the world did or did not owe his friend, but rather what Bodenheim seemed to symbolize.

In youth, Bodenheim had been good theater. In print as in life, he seemed always to be switching and combining the roles of ragged Baudelarian poet, caustic jester, and fiery rebel who held no interest in adjusting to society. But over the years that he drifted, sometimes living in cheap rooms and often homeless, it became increasingly obvious that being a misfit had never been a matter of choice - that he was not unwilling but unable to 
fit in. As Hecht watched a friend fall apart and the talent that he had so admired drain away, he could not forget the young man he had once known. Bodenheim illustrated that the rebel poet and tragic outcast could be two sides of the same coin, which is what made him a uniquely representative and resonant symbol of the artist in Hecht's mind. He was, as Hecht said of Bruga, "a stranger to life." 210

During the 1940s, Bodenheim also gained a new respect and admiration for Judaism, and this at least brought him some consolation. In one of his letters he wrote:

Frankly, I was never a particularly keen Jewish nationalist in the past, and the fact of my Jewish blood was a matter causing me neither shame (n)or pride - a scarcely noticed, mildly accepted equation. But now, I am beginning to realize that Jewish blood symbolizes innate challenge, defiance, plaintively beset but enormous pride, and a somber breadth of imagination. I have not rushed to the opposite extreme of sublimation. I am simply compelled to recognize the whip-scarred heritage that sets us apart from other people, the heritage we are so prone to forget when we are surrounded by a surface amiability that does not single us out... ${ }^{211}$

Bodenheim could not, however, see a pathway of return to a Promised Land. He was too lost in the wilderness by then. In a room off the Bowery on the early morning of February 7, 1954, a disturbed twenty-five-year-old dishwasher named Harold Weinberg shot Bodenheim to death and fatally stabbed the poet's third wife, Ruth Fagin. Hecht announced that he was going to pay for the funeral, although it is not clear that he did. In a letter explaining the death to his young daughter, he wrote: "Bogie was my friend and he lived in a sort of doll world surrounded by word-toys - and he never looked up from playing until someone came along to stab, shoot and murder him. He was a young man who lived on top of verbal steeples and walked on sidewalks not visible to other citizens. He was the only poet I ever knew who lived only in the land of poetry and recognized words as the only riches there were."212 
${ }^{1}$ Letter from Bodenheim, undated, "Bodenheim, Maxwell (Bogie), ... to Ben and Rose, ca. 19401950s," Incoming Correspondence, Box 55, Folder 1078, BHNL.

2 Jack B. Moore, Maxwell Bodenheim, 158, 160-1, 168.

${ }^{3}$ Ibid, 168; Ross Wetzsteon, Republic of Dreams: Greenwich Village: The American Bohemia, 1910-1960 (New York: Simon \& Schuster, 2002) 380-1.

${ }^{4}$ Ravitz, "Ballyhoo, Gargoyles \& Firecrackers," 39; Hecht, Child of the Century, 216.

${ }^{5}$ Hecht relates this encounter several times. See Child of the Century, 215-8; "A Poet out of Yesterday," in Ben Hecht, 1001 Afternoons in New York (New York: Viking Press, 1941), 61-4; "About Bodenheim," in Ben Hecht, Letters from Bohemia, 122-4.

${ }^{6}$ Hecht, Letters from Bohemia, 123-4. Just about every letter from Bodenheim from this period in Hecht's archive refers to their arrangement - either to thank him for a recent check or to prod him for another payment. See Incoming Correspondence, folders Box 55, Folders 1078-1082, BHNL. ${ }^{7}$ Albert Parry, in his classic 1933 history of American bohemianism, asserts: "Hecht and Bodenheim were the most colorful characters of Chicago's bohemia of 1913-1923. There were, of course, greater names in the circle. There were Carl Sandburg, Sherwood Anderson, Edgar Lee Masters, and others. „, But Hecht and Bodenheim provided action, scandal, amours. They were the unlaced souls of the group, the starters of clubs and journals, the noisy bearers of flags." Albert Parry, Garretts and Pretenders: a History of Bohemianism in America (New York: Covici, Friede, 1933), 191.

${ }^{8}$ Hecht, Child of the Century, 109.

${ }^{9}$ Horkheimer and Adorno coined the term "culture industry" in a famous essay published in 1944. See "The Culture Industry: Enlightenment as Mass Deception," in Max Horkheimer and Theodor W. Adorno, Dialectic of Enlightenment: Philosophical Fragments (Stanford, Calif: Stanford University Press, 2002).

${ }^{10}$ Sacvan Bercovitch, The American Jeremiad (Madison: University of Wisconsin Press, 1978), 180. American literature and Jewish writers and a language of dissent... Julian Levinson, The Daemonic in the American Theatre Main Street: Jewish American Writers and American Literary Culture (Bloomington: Indiana University Press, 2008) 4-6. On the pattern of bursting upon the scene as impassioned iconoclasts... Alfred Kazin, On Native Grounds: An Interpretation of Modern American Prose Literature (New York: Harcourt, Brace \& World, 1942).

${ }^{11}$ Examples abound. See discussions of The Jazz Singer in Hoberman et al, Entertaining America, 76-80; and in Donald Weber, Haunted, 56-61; Weber on David Schearl of Henry Roth's novel, Call It Sleep, 80-81, 86-94; and Feingold's description of unionizing and socialism as the new religion in Zion in America, 161. Alfred Kazin describes the reading room of the New York Public Library as a house of worship in Shechner, After the Revolution, 47.

${ }^{12}$ James Joyce, A Portrait of the Artist as a Young Man, Centennial ed. (New York: Viking Press, 1982), 247.

${ }^{13}$ Gilbert Seldes, "The Daemonic in the American Theatre," in The Seven Lively Arts (New York: Harper \& brothers, 1924), 191-200. In a striking preface to the film souvenir program, Samson Raphaelson, author of the short story and play from which the movie was taken, describes the confusion of secular and religious fervor, desolation and madness, that he saw in jazz, and in Jolson. Reprinted in Hoberman et al, Entertaining America, 77-78, 82.

${ }^{14}$ Margaret C. Anderson, My Thirty Years' War; an Autobiography (Westport, Conn: Greenwood Press, 1971), 35.

${ }^{15}$ Dale Kramer, Chicago Renaissance; the Literary Life in the Midwest, 1900-1930, 1st ed. (New York: Appleton-Century, 1966), 244-5. Fanny Butcher recalled Anderson from small bookshop in the Fine Arts Building, where Francis Fisher Browne published his conservative literary 
magazine, The Dial: “That shop's showpiece for a while was an objet d'art, a salesgirl, as beautiful as a dream come true, one of her admirers confided to me, with the graces of Marie Antoinette and the dedication of a missionary. Her name was Margaret Anderson. She was to go down in literary history."

${ }^{16}$ Anderson, My Thirty Years' War, 35-6, 40-1.

${ }^{17}$ Margaret Anderson, “Announcement," The Little Review 1, no. 1 (March 1914): 2. On building a temple for art, My Thirty Years' War, 46-7.

${ }^{18}$ Henry L. Mencken, "Civilized Chicago," Chicago Tribune, October 28, 1917, 5. Three years later, on April 17, 1920, Mencken followed up with an essay in the London Nation that - as its title reflects - proclaimed Chicago "The Literary Capital of the United States." Hugh Dalziel Duncan, The Rise of Chicago as a Literary Center from 1885 to 1920; a Sociological Essay in American Culture (Totowa, N. J: Bedminster Press, 1964), viii. Hecht said that Mencken's dubbing of Chicago the literary capital "was one of his best jokes - a slap at the complacency of New York." See Fanny Butcher, Many Lives, 407.

${ }^{19}$ Rascoe, Before I Forget, 318-321; "A History of the Magazine," at poetryfoundation.org, http://www.poetryfoundation.org/poetrymagazine/history; Constance D'Arcy Mackay, The Little Theatre in the United States (New York: H. Holt and Company, 1917), 103.

${ }^{20}$ Bernard I. Duffey, The Chicago Renaissance in American Letters, 2nd ed. (East Lansing: Michigan State University Press, 1956), 189-193. See also a brief history of the journal provided by The Modernist Journals Project, which has made all issues of the Little Review available online. http://www.modjourn.org/render.php?view=mjp_object\&id=LittleReviewCollection. ${ }^{21}$ Hecht, Child of the Century, 233.

${ }^{22}$ Henry Farnham May, The End of American Innocence: A Study of the First Years of Our Own Time, 1912-1917 (New York: Columbia University Press, 1992). May makes this argument, which has become seminal to studies of the history of twentieth century American cultural rebellion, in his introduction, xxiii-xxviii.

${ }^{23}$ Ibid, 215-216.

${ }^{24}$ Regarding the social implications and the consequences of the Liberation, see Christine Stansell, American Moderns: Bohemian New York and the Creation of a New Century, 1st ed (New York: Metropolitan Books, 2000).

${ }^{25}$ Hecht, Child of the Century, 220.

${ }^{26}$ Carl Sandburg, "Chicago," in Carl Sandburg, Chicago Poems (New York: H. Holt and Company, 1916). Originally published in Poetry 3, no. 6 (March 1914). Establishing great institutions and giving them things to smash... May, The End American Innocence, 102-3, 106.

${ }^{27}$ On developing out of the ruins of the Columbian Exposition, see Susan O'Connor Davis, Chicago's historic Hyde Park (Chicago: University of Chicago Press, 2013), 122-3. On Currey's studio as the converted retail storeroom where he met the fellow members of the Renaissance... Sherwood Anderson, Sherwood Anderson's Memoirs, First ed. (New York: Harcourt, Brace and Company, 1942), 248. Irving Howe, Sherwood Anderson (Stanford, CA: Stanford University Press, 1968), 64. On the scene that had developed at Floyd Dell's and Margery Currey's studios, and finding a title for the magazine... Margaret Anderson, My Thirty Years' War, 36-42; Kramer, Chicago Renaissance; The Literary Life in the Midwest, 1900-1930, 232-7. Starrett, in Born in a Book Shop, also recounts the evening everyone tried to come up with a title, and notes Hecht had been invited but for some reason was unable to attend, p. 174-5. Currey's name is sometimes given as "Curry" or "Currie" in different accounts and Hecht spells her first name "Marjy" in Child of the Century. However, in issues of the Little Review, it is spelled Margery Currey. See for example The Little Review 2, no. 8 (November 1915).

${ }^{28}$ Hecht, Child of the Century, 174-5; both Starrett and Hecht were colleagues with Currey at the Chicago Daily News; Hecht, Child of the Century, 221-3. “... a world unaware of doomed men and 4-11 fires..." Gaily Gaily, 162-170. 
${ }^{29}$ Letter to Rose Hecht from Margaret Anderson, April 20, 1964, "Anderson, Margaret to Rose, 1959-1964," Incoming Correspondence, Box 55, Folder 1037. Upon Hecht's Death, Margaret Anderson wrote to Rose: "Ben was always my favorite of all the first contributors to the Little Review, and the only one who kept up a correspondence with me." In 1918, Hecht grew tired of writing formulaic prose for Mencken... MacAdams, The Man Behind the Legend, 43.

${ }^{30}$ Lawrence Langner, The Magic Curtain: The Story of a Life in Two Fields, Theatre and Invention, by the Founder of the Theatre Guild, 1st ed. (New York: Dutton, 1951) 85-6.

31 "...this unusually silent figure..." Harriet Monroe, "Comment, Maxwell Bodenheim," Poetry 25 (March 1925): 320-327. Langner remembered... The Magic Curtain, 86. On Hecht as a habitué of Margery Currey's studio, see also p. 81.

${ }^{32}$ Ben Hecht, Count Bruga (New York: Boni \& Liveright, 1926), 12; Child of the Century, 221-4; Gaily Gaily, 167-9, 180; Letters from Bohemia, 111, 114; Margaret Anderson, My Thirty Years' War, 59; Sherwood Anderson, Memoirs, 199. Jack B. Moore, Maxwell Bodenheim, 19. Hecht also describes a corncob with a "sewer-smelling" tobacco called "nigger weed"; Sherwood Anderson describes the same pipe, while Margaret Anderson mentions the odor. "If Ben Hecht was the most prominent of the Covici-McGee (Bookshop) habitués, Bodenheim was the most spectacular," recalled former Tribune reporter and critic Fanny Butcher in 1972. "He was the original hippie in our town. His never-washed blond hair was long, his clothes bizarre, and he ostentatiously smoked what he said was opium in a pipe with a bowl the size of a thimble. He also smelled - of a mixture of whatever he smoked, an allergy to soap and water, and potently of Maxwell Bodenheim." Butcher, Many Lives, 67. Allen Churchill, The Improper Bohemians: a Re-creation of Greenwich Village in Its Heyday, 1st ed. (New York: Dutton, 1959), 307. Although in Child, Hecht recalls meeting Bodenheim at Sherwood Anderson's Cass Street flat in the spring of 1913, Anderson did not move there until the fall of the following year. See Walter B. Rideout, Sherwood Anderson a Writer in America (Madison: University of Wisconsin Press, 2006), 191. According to Harry Hansen in Midwest Portraits, the two met at the office of the Little Review, 322.

${ }^{33}$ Jack B. Moore, Maxwell Bodenheim, 13-6. In his endnotes, Moore explains that in addition to the help that he was provided here by Bodenheim's first wife, Minna Schein: "Floyd Dell was one of several to mention to me Bodenheim's self-destructive tendencies. Dell has never published on Bodenheim, but wrote me several letters" (p. 173). Two more important sources on Bodenheim, which time and resources did not permit me to consult, are the collection of his papers archived at Columbia University and a 1957 doctoral dissertation: Edward T. DeVoe, "A Soul in Gaudy Tatters," (PhD diss., Pennsylvania State University, 1957). The finding aid for his papers can be found at: http://findingaids.cul.columbia.edu/ead/nnc-rb/ldpd_9025181/summary Recent studies of Bodenheim attest to the fact that interest in his life and work still exists. See Jason Boog, "People's Libraries," Los Angeles Review of Books, November 12, 2011. https://lareviewofbooks.org/essay/peoples-libraries John Strausbaugh, The Village: 400 Years of Beats and Bohemians, Radicals and Rogues: a History of Greenwich Village (New York, NY: Ecco, an imprint of HarperCollinsPublishers, 2013). Strausbaugh's passage on Bodenheim appears on the website The Chiseler: Forgotten Authors, Neglected Stars and Lost Languages Rediscovered: http://chiseler.org/post/38071308208/maxwell-bodenheim

${ }^{34}$ Moore, Maxwell Bodenheim, 13-16. Hecht, Letters from Bohemia, 111.

${ }^{35}$ Hecht, Child of the Century, 225-228; Gaily Gaily, 167; "About Sherwood Anderson," in Letters from Bohemia, 88-99; Hansen, Midwest Porttraits, 109-180; Rideout, A Writer in America, 154-161, 191-2; Kramer, Chicago Renaissance, 167-173, 288-9. Howe, Sherwood Anderson, 46-9, 64-8.

${ }^{36}$ On Anderson's progress as "the great unpublished author"... Kramer, Chicago Renaissance, 240-3, 288-293. "I stopped thinking of him as a barber or swami..." Hecht, Child of the Century, 226. Howe, Sherwood Anderson, 64-8. 
${ }^{37}$ Howe, Sherwood Anderson, 68. "If we are a crude and childlike people..." In May, p. 250, originally from Sherwood Anderson, “An Apology for Crudity," Dial, November 8, 1917, reprinted in Alfred Kazin and Charles Shapiro, Stature of Theodore Dreiser (Bloomington, Ind., 1955), p. 81.

${ }^{38}$ On Sandburg's background... Hansen, Midwest Portraits, 30-44; Kramer, Chicago Renaissance, 52-60, 182-4, 243, 263; Duffey. The Chicago Renaissance in American Letters, 209-215. On Sandburg's relationship with the Chicago Daily News... Kramer, 312; Duffey, 221. Hecht, Child of the Century, 243-255.

${ }^{39}$ Kramer, Chicago Renaissance, 278, 283-5. Sandburg, "Mamie" and "Docks," in Chicago Poems, 35, 160.

${ }^{40}$ Alfred Kreymborg, Troubadour, an American Autobiography, American Century Series, S-22 (New York: Sagamore Press, 1957) 251-2.

${ }^{41}$ Hecht, Count Bruga, 15-18; Letters from Bohemia, 117-118. In the Bruga version, he posts a typed not that reads: "I WILL BE REVENGED."

${ }^{42}$ Kreymborg, Troubadour, 251-2, 265-6. William Carlos Williams, Imaginations (New York: New Directions Pub. Corp, 1971). Kreymborg and his wife finally had to kick him out.

${ }^{43}$ Jack B. Moore, Maxwell Bodenheim, 21-5, citing Ezra Pound, The Letters of Ezra Pound, 1907-1941, 1st ed. (New York: Harcourt, Brace, 1950); William Troy, "The Story of the Little Magazines," BOOKMAN 70 (1930): 659; William Carlos Williams, The Selected Letters of William Carlos Williams (New York: New Directions Pub. Corp., 1984); Hart Crane, The Letters of Hart Crane, 1916-1932 (New York: Hermitage House, 1952); and Arthur and Barabara Gelb, O'Neill, 1st ed. (New York: Harper, 1960), 361.

${ }^{44}$ Herbert S. Gorman, "Poets of Today and Yesterday," New York Times, December 26, 1920, 48.

${ }^{45}$ Kramer, Chicago Renaissance, 309. Duffey, The Chicago Renaissance in American Letters, 241. Mackay, The Little Theatre in the United States, 113, 114 117. Hecht's An Idyll of the Shops, The Home Coming, The Wonder Hat and The Hero of Santa Maria, all of which he co-wrote with Kenneth Sawyer Goodman, were performed at the Little Theater in 1916, as was his controversial play Dregs. The following year the theater produced a play he co-wrote with Bodenheim, Mrs. Margaret Calhoun. The Hull House Players performed Hecht and Goodman's The Poem of David.

${ }^{46}$ Kramer, Chicago Renaissance, 302-9, 353-4; Duffey, The Chicago Renaissance in American Letters, 219-222.

${ }^{47}$ Hecht, Letters from Bohemia, 113.

${ }^{48}$ James Joyce, A Portrait of the Artist as a Young Man (New York: B.W. Huebsch, Inc., 1916), 134.

49 Albert Parry, Garretts and Pretenders, 190-1.

50 “Just time to turn anarchist before..." Margaret Anderson, My Thirty Years' War, 54.

Anderson, "Toward Revolution," The Little Review 2, no. 9 (December 1919): 5.

${ }^{51}$ Margaret Anderson, My Thirty Years' War, 54-6, 69-70, 74, 80-3, 85-92, 99-102; Lawrence Langner, The Magic Curtain, 84-5; Kramer, Chicago Renaissance, 254-262.

${ }^{52}$ Margaret Anderson, My Thirty Years' War, 70; Franklin Rosemont, The Rise \& Fall of the Dil Pickle: Jazz-Age Chicago's Wildest \& Most Outrageously Creative Hobohemian Nightspot, Bughouse Square series; Variation: Bughouse Square series. (Chicago: Charles H. Kerr Pub., 2004), 21; Kramer, Chicago Renaissance, 9-11. According to author Sam Dolgoff: "Reitman was a distinguished physician, specializing in venereal and allied diseases. He taught pathology and bacteriology, public health and hygiene in reputable Chicago medical schools and nurses schools. He was one of the pioneers in the movement for the prevention and treatment of venereal diseases." Excerpt from Fragments: A Memoir, Personal Recollections Drawn from a Lifetime of Struggle in the Cause of Anarchism (London: Refract Editions, 1986), in Rosemont, 60. 
${ }^{53}$ Rosemont, Rise \& Fall of the Dil Pickle, 10, 12; Kramer, Chicago Renaissance, 10-11. On the background of Chicago as a center for labor struggles... Paul Avrich, The Haymarket Tragedy (Princeton, N.J: Princeton University Press, 1984), 15-8. On Haywood and Darrow, see Bruce Watson, Bread and Roses: Mills, Migrants, and the Struggle for the American Dream (New York: Viking, 2005).

${ }^{54}$ Kramer, Chicago Renaissance, 255-6. Howe, Sherwood Anderson, 69.

${ }^{55}$ Albert Parry noted: "In New York, in the same early 1910s, the Greenwich Villagers also quoted the Bible, but it was in support of their Socialist views. The contemporary intellectuals of New York waved their banners of revolt in politics; they were acutely conscious of social problems. For New York's tempo was more tearing and grinding than Chicago's; it made no favorite of native sons but exploited all...The intellectual youngsters who came there to create art for art's sake soon developed an interest in Socialism, especially since New York was a natural port of first call for all the newest currents of European thought floating to America." Garretts and Pretenders, 190.

56 "I was going to dynamite New York..." Mabel Dodge Luhan, Movers and Shakers: Volume Three of Intimate Memories (New York: Harcourt, 1936), 36. Altogether, the quotes used here can only be found in her unabridged multi-volume autobiography. On any given evening.... Ross Wetzsteon, Republic of Dreams, 15; Lois Palken Rudnick, Mabel Dodge Luhan New Woman, New Worlds, 1st ed. (Albuquerque: University of New Mexico Press, 1984), 62. "Oh, how we were all intertwined!” Mabel Dodge Luhan, Movers and Shakers, 261. Quoted in Wetzsteon, 15; Stansell, American Moderns, 298.

${ }^{57}$ See "Bohemian Beginnings in the 1890s" in Stansell, American Moderns, 11-16 and the rest of the chapter.

${ }^{58}$ Ibid, 22. Albert Parry describes Jewish bohemianism of the Lower East Side and explains its fascination for a burgeoning Greenwich Village in "The Yiddish Note," in Garretts and Pretenders, 79-88.

${ }^{59}$ Ibid, 8, and "Journeys to Bohemia," 40-1, 61, as well as the rest of the chapter.

${ }^{60}$ Wetzsteon, Republic of Dreams, 15-26. “...nothing but a dilettante of radicalism...” Republic of Dreams, 25. "Looking back at it now..." Mabel Dodge Luhan, Movers and Shakers, 39.

${ }^{61}$ On Dodge's role in producing the Armory show, see "Mabel Doge: Hostess to Bohemia," in Archives and Public History Digital, http://gvh.aphdigital.org/exhibits/show/mabeldodge/ enablingbohemia; Wetzsteon, Republic of Dreams, 28-9; Rudnick, New Woman, New Worlds, 6671. "It should be borne in mind..." "Cubists of All Sorts," New York Times, March 16, 1913.

${ }^{62}$ Stansell, American Moderns, 180-3.

${ }^{63}$ Luhan, Intimate Memories: Movers and Shakers, 89, 187.

${ }^{64}$ Wetzsteon, Republic of Dreams, 36-9; Stansell, American Moderns, 11-12, 183-4.

${ }^{65}$ Stansell, American Moderns, 112-114. “...that winter was a kind of welding process...” Mary Heaton Vorse, A Footnote to Folly: Reminiscences of Mary Heaton Vorse, Signal Lives (New York: Arno Press, 1980), 61.

${ }^{66}$ Stansell, American Moderns, 115-117. “...prattle about force and dynamite...” Emma Goldman, Living My Life, Vol. 2 (New York: Dover Publications, 1970), 538.

${ }^{67}$ On Mabel Dodge and John Reed, Wetzsteon, Republic of Dreams, 41-3; Stansell, American Moderns, 196-7. “...the quintessential Village link...” Wetzsteon, Republic of Dreams, 39. "Literary rebellion and the political Left..." May, The End of American Innocence, 392.

${ }^{68}$ Emma Goldman, Nowhere at Home: Letters from Exile of Emma Goldman and Alexander Berkman (New York: Schocken Books, 1975). Wetzsteon, Republic of Dreams. 220-1, 315-317; Stansell, American Moderns, 323-6.

${ }^{69}$ Stansell, American Moderns, 327-8. "Girls lean back..." Martha Craven Nussbaum, Upheavals of Thought: The Intelligence of Emotions (Cambridge, UK ; New York: Cambridge University Press, 2001), 688. 
${ }^{70}$ Margaret Anderson, My Thirty Years' War, 123.

${ }^{71}$ Is it not a possibility..." Frank H. Simonds, "1914-The End of an Era," The New Republic, January 2, 1915, 12-13. May, The End of American Innocence, 361-2.

${ }^{72}$ See Hansen's introduction, "Of an Ancient Tavern on a Well-Traveled Highway," in Midwest Portraits, 3-12; Kramer, Chicago Renaissance, 331-4; Duffey, The Chicago Renaissance in American Letters, 246-8.

73 "...the Renaissance became a one-man affair..." Excerpt from Samuel Putnam, Paris Was Our Mistress: Memoirs of a Lost and Found Generation (New York: Viking Press, 1947), in Rosemont, The Rise \& Fall of the Dil Pickle, 138-9. "Would that our writing..." Hecht, Child of the Century, 345.

${ }^{74}$ Bordering the northside... Rosemont, The Rise \& Fall of the Dil Pickle, 23-4.

${ }^{75}$ All-night jazz and Little Theater productions of Ibsen and Strindberg starring strippers...

Excerpt from Kenneth Rexroth, An Autobiographical Novel (Weybridge, Surrey, UK: Whittet Books, 1977), in ibid, 93, 95. Speakers of every stripe subjected to a murderous heckling, "....any sensationalist figure..." Ben Reitman, "Life and Death of the Dil Pickle," Chicago Tribune, August 2, 1937, 20-1, in ibid, 63, 64. On the then unheard-of topic of atomic energy... "Yellow Kid" Weill, The Autobiography of America's Master Swindler (Chicago: Ziff-Davis, 1948), in ibid, 111. The anti-Socialist Sirfressor (F.M. Wilkesbarr, aka Malfew Seklew), from George Murray's column for the Chicago American, May 27, 1960 and March 25, 1959 in ibid, 116. Triphammer Johnson in Rexroth excerpt, ibid, 98. Jack Jones...nitroglycerine... "and then I turn on the sex faucet..." from Sherwood Anderson, Memoirs, 270.

${ }^{76}$ Rexroth, in ibid, 94, 95.

${ }^{77}$ On the reaction to Dregs, Starrett, Born in a Bookshop, 198-9. On the literary debate... Parry, Garretts and Pretenders, 191.

${ }_{78}^{78}$ Hecht, Gaily Gaily, 124-5.

${ }^{79}$ This note from Hecht to Bodenheim is quoted by Harry Hansen in Midwest Portraits, 353. 80 "....gazette devoted to the Sacred Ballyhoo..." see Hecht, "Our First Issue: Salutation On the Saxophone," Chicago Literary Times 1, no. 1, 23 March 1923, 1. Erroneously believing that it would promote his bookselling and publishing concerns... Hecht, Child of the Century, 338-9; in Midwest Portraits, pp. 354-5, Hansen recounts that Hecht wanted to launch the magazine with sandwich board men and a parade of brass bands and a half-mile of floats, so at the very least, it was meant to generate publicity for itself and for Hecht. Achieved a circulation of between 15,000 and 17,000... Ravitz, "Ballyhoo, Gargoyles \& Firecrackers," 40-1. "Shocking the bourgeois has become too stale and tame..." "Startling the Radicals," New York Times, July 29, 1923, Sec. 2, p. 4. Ravitz remarked of a full-page illustration in the premiere issue: "The ultimate in this literary caricature was Hecht's vision as a derby-hatted cane-waving barker at a side-show carnival endeavoring to lure the parading customers into the big tent to see the scribbling freaks, much of whom were cartooned."

${ }^{81}$ Hecht, "Our First Issue" and "Concerning the Natl. Cemetery of Arts and Letters," March 23, $1923,1$.

${ }^{82}$ Hecht, "Semi-Idiot Broadcasting Programs Doom Radio as Charm for Civilized Homes," "Surveying Bumper High-Brow Crop of Little Magazines," May 1, 1923, 1; Bodenheim, "Peeping Tom in Verbal Dressing Rooms of Bohemia," May 15 1923, 2.

${ }^{83}$ Hecht, "The Waste Land," March 1, 1923; On Fitzgerald... ibid; Bodenheim, "Again the Bozarts Seem on The Way to the Bow-wows," July 15, 1923, 6.

84 "Bodenheim Runs Amuck; 4 Dead, and 3 Wounded," July 1, 1923, 1.

${ }^{85}$ They celebrated Yiddish theater, vaudeville and Charlie Chaplin... Obeisance to the Wrinkled Thalia of Yiddish Theater," July 1, 1923, 5; Bodenheim, "Vodvil Vignettes," June 15, 1923, 8; Hecht, "Charlie Chaplin's Greatest Picture; A Future Review," July 15, 1923, 3; Hecht championed Ulysses... "Editorial Notes," March 15, 1923, 1; Bodenheim mourned the closing... 
"New York Letter Closeups of the Literary Suburbs," June 15, 1923, 5; ... an allegorical lament to lost bohemia... Hecht, "High-Hat Complex Corrupts Circus of the Days Gone By," May 15, 1923, 1, 5; ... disappointed straphangers returning home from Coney Island... Bodenheim, "Coney Island Notes, July 15, 1923, 7.

${ }^{86}$ Hecht, "Editorial Notes," July 15, 1923, 4.

${ }^{87}$ Hecht, "Adante Con Amore Face to Face With Artist Anderson," April 15, 1923, 1. Letters from Bohemia, 92. Though a kind of champion of egotism, Hecht sympathized far more with the fragile, damaged egoist. On the same page of the Chicago Literary Times, he muses of Bodenheim: "His egoism is inferior to Anderson's. Hallucinations of grandeur and persecution, fits of despondent self pity, periods of manic excitement intrude frequently upon the poet's astonishing insight and almost magical clarity. The distinguishing feature of Bodenheim's poetry and prose is an unwavering originality..." It's worth noting that Anderson's first novel had been a fictionalized retelling of his own flight from a business and marriage that had fallen to pieces, but he had tacked on an unconvincing, storybook ending. His great achievement in Winesburg, Ohio was to create characters who were not marionettes or fantasized versions of himself, but independent souls who came alive on the page. He later concluded that whatever contentment he had found came not from fleeing or rebelling against conventional society, but from a love of craft: "The real reward, I fancy, lies just in the work itself, nowhere else." In Erik Dorn, Hecht's protagonist says of the Sherwood-Anderson character, Warren Lockwood, "This fellow's content to write. I'm not. He's found his way of saying what's in him, getting rid of his energies and love. I haven't." See Duffey, The Chicago Renaissance in American Letters, 197-208; Erik Dorn, 218.

${ }^{88}$ MacAdams, The Man Behind the Legend, 61-2. The location of this letter, which MacAdams quotes in its entirety, is a mystery. It is not with Hecht's papers, nor printed in Letters from Bohemia, nor compiled in the Letters of Sherwood Anderson, ed. Howard Mumford Jones in association with Walter Rideout, 1st ed., reprinted (New York: Kraus Reprint Co, 1969). MacAdams cannot now remember where he found it. Anderson's cold reaction to Erik Dorn... According to biographer Walter Rideout, Anderson found Hecht's first novel too flashy. See $A$ Writer in America, 437. In one letter, Anderson wrote: "The smartiness will perhaps defeat Ben. It may have already." Letters of Sherwood Anderson, 119. For Hecht's claim that being enemies was Anderson's idea, see "A Pair of Windows," Chicago Literary Times, March 1, 1923, 2, and Child of the Century, 230. In the Chicago Literary Times version, Hecht retorts: "I don't have to make any artificial pacts to ensure a supply of enemies." In Hecht's 1954 version of the story, Anderson suggests that they become "real enemies." Although it would be uncharacteristic of Hecht to twist the truth about such a thing, he did carry on literary feuds-while remaining warm friends in reality - with Burton Rascoe, and of course with Bodenheim, though that was a genuine falling out. Hecht would remember Anderson as a cruel, womanizing egomaniac, but Anderson's own memoirs recall Hecht as a warm and kind person at heart, who nevertheless loved to trade insults for the fun of it. ("Abuse was meat and drink to him.") See Sherwood Anderson, Memoirs, $252,254$.

${ }^{89}$ On Hecht's literary influences, see Hansen, Midwest Portraits, 310-320; on discovering him reading Arabian Nights... Midwest Portraits, 306; “... a fondness for realism...” Midwest Portraits, 310.

${ }^{90}$ Burton Rascoe, “An American Epithetician,” The Bookman, October 1921, 164-5. Gilbert Seldes, “Arriviste and Aristocrat," The Dial 71, no. 5 (November 1921): 597-600. Dorn was, however, hailed by many as the debut of an important new voice. "When Ben Hecht gets himself well in hand," wrote a critic for the New York Times, "America will have another great realistic writer of novels." In the New Republic, Francis Hackett argued that the novel put to bed the idea that clever men are also brittle. Dorn has "the same glassy sharpness of line" as his short stories in the Little Review, "the same bitterness and mockery...the same moonlit inhospitality." But rather than a firework that fizzles out in a rain of sparks, it "whizzes with cold and elaborate ardor 
through the full length of 409 pages." Russell Gore in the Detroit News wrote that a novel with a style "so darkly beautiful and so irritatingly clever as Mr. Hecht's divides readers into opposing camps." New York Times, October 9, 1921, 12, 18. Francis Hackett, New Republic, August 31, 1921. Russell Gore, Detroit News, September 21, 1921.

${ }^{91}$ For a thorough bibliography and filmography, see MacAdams, 299-357. In The Five Lives of Ben Hecht, Doug Fetherling set out to correct the record on Hecht's literary reputation, and largely succeeds with a vivid perceptive survey of Hecht's books.

92 T.K. Hedrik, "Ben's Most Hechtic Book," Arts Monthly, October 22, 1922, "Fantazius Mallare" in Publicitiy, Box ,Ravitz, "Ballyhoo, Gargoyles \& Firecrackers," 39. Ben Hecht and Covici-McGee Co, Fantazius Mallare: a Mysterious Oath (Chicago: Covici-McGee, 1922) 11 18.

93 "Hecht Fined for Mailing Obscene Book in Chicago," Bridgeport Telegram (Bridgeport, Conn.), May 2, 1924, 10. Hecht, Child of the Century, 180. Hecht, "My Last Park Bench," Chicago Literary Times, June 1, 1924, 16. His last column for the Daily News was published on October 10, 1922. The earliest mention of Hecht being fired from the Daily News that I could find was in Fetherling's biography, Five Lives, 54. It is also mentioned in the biography provided on the Newberry Library web page for Hecht's papers. http://mms.newberry.org/html/hecht.html Hecht joined the Committee for the Suppression of Irresponsible Censorship, and contributed to a compilation of essays by Dorothy Parker, Alexander Woollcott and others. Hecht, "Literature in the Bastinado," in ed. George P. Putnam, Nonsenseorship: Sundry Observations Concerning Prohibitions, Inhibitions and Illegalities (New York, 1922).

${ }^{94}$ Hecht, Count Bruga, 1-28.

${ }^{95}$ Hecht, Letters from Bohemia, 118-120.

${ }^{96}$ Maxwell Bodenheim, Duke Herring (New York: H. Liveright, inc, 1931), 35, 150.

${ }^{97}$ Bodenheim, Duke Herring, 119.

${ }^{98}$ Jack B. Moore, Maxwell Bodenheim, 88-92. Moore provides a bibliography of Bodenheim's novels, books of poetry and published articles, and offers excellent summary and analysis of his works. For the bibliography, see 183-184. The summaries and analyses are included as independent sections in each chapter.

${ }^{99}$ T. S. Eliot, The Letters of T.S. Eliot, Rev. ed., vol. 2, 1898-1922 (New Haven: Yale University Press, 2011), 476. On the trip to England, see also Jack B. Moore, Maxwell Bodenheim, 55-56.

${ }^{100}$ Moore, Maxwell Bodenheim, 26-28, 89-92, 156-158. “....in that time of rebellion and shame..." Maxwell Bodenheim, 92.

${ }^{101}$ Bodenheim, Maxwell, "Jewish Writers in America," Menorah Journal 8, no. 2 (April 1922): 74-78.

${ }^{102}$ Hecht, Guide for the Bedevilled, 77, 158.

${ }^{103}$ Ibid, 159-160.

${ }^{104}$ The fact that she never mentioned their Jewish heritage in her memoirs suggests that the Jewish question... Harold Cruse, The Crisis of the Negro Intellectual (New York: Morrow, 1967). Cruse uses the Jewish question as an example of the Villagers' attitudes towards topics of ethnicity and minority rights. Insisting they do the tour in her chauffer-drive limousine... Wetzsteon, Republic of Dreams, 41.

${ }^{105}$ Henry L. Feingold, Zion in America: The Jewish Experience from Colonial Times to the Present (New York: Hippocrene Books, 1974). On immigration... 120; on conditions for the immigrant... 159-161; on "the sweating system" and working conditions... 162; on radicalization in Eastern Europe and unionization in America... 166-168. “...the union hall became the secular equivalent of the Beth Hamidrosh..." Zion in America, 161. On conditions in the Eastern European Pale of Settlement and radicalization, see also Walter Laqueur, A History of Zionism (New York: Holt, Rinehart and Winston, 1972), 56-70. 
${ }^{106}$ Richard A. Greenwald, The Triangle fire, the protocols of peace, and industrial democracy in progressive era New York, Labor in crisis; Variation: Labor in crisis. (Philadelphia: Temple University Press, 2005), 57-60; "Triangle Shirtwaist Fire" in Jewish Women: A Comprehensive Historical Encyclopedia on the Jewish Women's Archive website. http://jwa.org/encyclopedia /article/triangle-shirtwaist-fire On Brandeis' awakening... Melvin I. Urofsky, American Zionism from Herzl to the Holocaust, 1st ed. (Garden City, N.Y: Anchor Press, 1975), 124-125.

${ }^{107}$ Israel Zangwill, The Melting-pot, Drama in Four Acts (New York: The Macmillan company, 1913). An English Zionist, Zangwill had recently founded... Urofsky, American Zionism, 28. Horace M Kallen, "Democracy Versus the Melting Pot, Part One" Nation, February 18, 1915, 191-194; and "Part Two," February 25, 217-220. On Brandeis using Horace Kallen's cultural pluralism to argue for Zionism... Urofsky, American Zionism, 128-131; on building a movement of 176,000 members... American Zionism, 145.

${ }^{108}$ Hecht, Child of the Century, 380. Alan M. Wald, The New York Intellectuals: The Rise and Decline of the anti-Stalinist Left from the 1930s to the 1980s (Chapel Hill: University of North Carolina Press, 1987), 27-28.

${ }^{109}$ Cultural pluralism reflected a conflicted ethos... Wald, The New York Intellectuals, 29, referencing John Higham, Send These to Me: Immigrants in Urban America, Rev. ed. (Baltimore: Johns Hopkins University Press, 1984), 196. The magazine that explored the question most deeply, the Menorah Journal... Wald, 30.

${ }^{110}$ Hecht, Child of the Century, 381-382.

${ }^{111}$ Gilbert Seldes, "The Daemonic in the American Theatre," The Dial (September 1923), 303308. For a reproduction of the souvenir program for the Jazz Singer, see J. Hoberman and Jeffrey Shandler, Entertaining America, 81-83.

112 Jack B. Moore, Maxwell Bodenheim, 160.

${ }^{113}$ Subdividing row houses and a new subway stop at Sheridan Square... Albert Parry, Garretts and Pretenders, 325; Christine Stansell, American Moderns, 334. "Thrillagers patronized Dick Dickerman's Pirate Lair... Roy Kotynek, American Cultural Rebels: Avant-garde and Bohemian Artists, Writers and Musicians from the 1850s Through the 1960s (Jefferson, N.C: McFarland \& Co, 2008), 132. "From the granite chateaus of upper Fifth Avenue... Maxwell Bodenheim, "Soulful Flirtation Between 'Beauty And the Beast," Chicago Literary Times. May 15, 1923, 4. “...a hunting grove for the love-sick bourgeois..." Albert Parry, Garretts and Pretenders, 327.

${ }^{114}$ See also endnote 124 below. Maxwell Bodenheim, My Life and Loves in Greenwich Village (New York: Bridgehead Books, 1954), 73; Allen Churchill, Improper Bohemians, 296-297.

115 "Bodenheim Cleared of Charges on Book," New York Times, March 21, 1928; David Dempsey, "No Way to Run a Publishing House," a review of Horace Liveright:Publisher of the Twenties, New York Times, May 31, 1970; Churchill, The Improper Bohemians, 255, 310; Jack B. Moore, Maxwell Bodenheim, 89-93. Moore drew on "personal interviews with his wife, with one of his publishers, and with some of his intimates who prefer anonymity." Hecht's harsh portrayal of an amoral, womanizing publisher in the 1935 film The Scoundrel was said to be based on Liveright.

116 “A Prodigal Boom-Time Bohemian,” New York Times, August 20, 1933; "Lavish Spender Portrayed in Book," New York Times, July 3, 1933. Bodenheim's adventures with Robert Clairmont, and the latter's spectacular rise and fall, are told in Tom Boggs, Millionaire playboy: a delirious and true extravaganza of inheriting a fortune and squandering it (New York: The Vanguard Press, 1933); Albert Parry, "Playboys Escaping," in Garretts and Pretenders, 316-328; and Allen Churchill, The Improper Bohemians, 298-306, 312, 314, 319, 330. According to Boggs, he inherited a half million dollars. Boggs' hard-to-find, first-hand account is a lost gem.

${ }^{117}$ Allen Churchill, The Improper Bohemians. 
118 “...bobbed like so many ripe apples...” Moore, Maxwell Bodenheim, 93-94. “... leering and prancing...” Hecht, Count Bruga, 12, 13. “... an expressionistic parody of his own life...” Moore, Maxwell Bodenheim, 109.

${ }^{119}$ Now that reviewers were paying attention... See for example "Hell's Kitchen," a review of Ninth Avenue in the New York Times, December 12, 1926; "An Underworld Story," a review of Georgie May in the New York Times, June 10, 1928; and "Poet and Novelist," a review The King of Spain and Other Poems and Georgie May in The Saturday Review of Literature, August 18, 1928, 52. “...flanked by scantily clad showgirls..." Jason Boog, "A Man's Life: Sad Men," in Wabash Magazine, December 15, 2009. http://www.wabash.edu/magazine/index.cfm?news id=7593 Of Georgie May, the Times wrote: "Bodenheim slugs the reader most to death with sullen clubs of sentences." Many critics continued to laud his books of poetry but, like The Saturday Review's William Rose Benét, felt "Bodenheim as a novelist is another matter. When his manner is adapted to prose one realizes that the impact of his peculiar images and metaphors is often far greater in the stringent speed of verse than on the balder page of prose." Gorman, who had praised him so highly in the Times, concluded: "Mr. Bodenheim is, first of all, an original and valuable poet. He is much more the poet than he is the novelist, for it is in his novels, particularly the last two, 'Replenishing Jessica' and 'Ninth Avenue,' that his half-reluctant desire to meet the popular impulse is to be discerned." Herbert Gorman, "Sui Generis," a review of Ninth Avenue in The Saturday Review of Literature, June 18, 1927, 912.

120 "Bodenheim Vanishes as Girl Takes Life," New York Times, July 21, 1928, 1, 9.

121 "Keeps Missing Girl From Bodenheim," New York Times, July 22, 1928, 1, 9.

122 "Bodenheim Coming Back From Cape Cod," New York Times, July 23, 1928; "Bodenheim Hiding, Doctor Back in City," New York Times, July 24, 1928.

123 "Scrivening Magnet of Missing Maids," “...walk on cobwebs between the horns of the moon..." quoted in "Matters Unannounced, the Poet, 1954," New York Daily News, September 16, 1998; "Inquiry Opens Today Into Subway Wreck: Death List Now 16," New York Times, August 22, 1928, 1, 2.

124 "Village 'Mayoress' Dies by Gas in Room," New York Times, February 14, 1928; Allen Churchill, The Improper Bohemians, 316-317. Such rumors may in fact have been started decades later in 1959, when Village chronicler Allen Churchill got his dates wrong. Aimee Cortez, whose real name was Amelia Klein, had killed herself the previous February, not February 1929 as Churchill reports. According to the Times, her title of Mayoress was the result of an "election" by students in her neighborhood of the city.

125 "Lavish Spender Portrayed in Book," New York Times, July 3, 1933; "Village Bohemian Now It's Laureate," New York Times, July 11, 1935; “Tom Boggs, 47, Dies, Poet and Editor," New York Times, November 18, 1952. Bodenheim used the last real money he would ever see... Jack B. Moore, Maxwell Bodenheim, 138-139.

${ }^{126}$ Hecht, Charlie, 164.

${ }^{127}$ On the Youngworth Ranch... MacAdams, The Man Behind the Legend, 123; Todd McCarthy, Howard Hawks: The Grey Fox of Hollywood, 130. Both biographers interviewed Mahin, who said to MacAdams of the 75-acre ranch: "They paid twelve hundred dollars a month for it, which at the time was godawful rent"; Hecht said he was put up at the ranch and given a salary of two hundred and fifty a week in Charlie, 179. Mahin apparently described it to MacAdams as an avocado farm, but Hecht said there two hundred and fifty turkeys running around the place, in Charlie, 174. "...a wooden castle..." in Charlie. Guests for a typical night... "Drinking Bout," in Charlie, 178-183.

${ }^{128}$ Hecht, Charlie, 163-164.

129 "Your writing stinks..." ibid, 158. Of hiring superior talent... In Charlie, Hecht explained: "The boss liked a superior writer to turn out his kindergarten truck - for a number of reasons, some of them mystic. It was a foolish waste of money, like hiring a cabinetmaker to put up a 
picket fence. But there was a certain pleasure in it for the boss. The higher the class of talent he could tell what to do and how to do it, the more giddily cultured he could feel himself. A good four-fifths of Hollywood's bosses were money-grabbing nitwits whom movie-making enabled to masquerade as Intellects and Creative Spirits. The boss who hired Dostoevsky to write like Horatio Alger somehow became Feodor's superior." Ibid, 157-158. On the spiritual toll for writers of talent, Hecht quotes from F. Scott Fitzgerald's memo of anguished protest to a producer who had tossed out all of Fitzgerald's dialogue on a script: "How could you do this to me? ... How can you throw me away in this fashion?" To which Hecht concludes: "Signatureand crack-up." Ibid, 161.

${ }^{130}$ Pauline Kael, Raising Kane, 9-10.

${ }^{131}$ For Hecht's screen work and credits during these years, see MacAdams, Man Behind the Legend, 116-124,132-133, 144-160. Interviews and letters suggest that people were referring to Hecht's "script writing factory" at least as early as the 1940s, but the first published reference to it appears to have been in Doug Fetherling's 1977 biography: "At length his benchmark became so much in demand that he created a factory of anonymous younger writers to block out and draft scripts which he then revised and signed. The members of this assembly line, who were called into action only when needed for a specific job, did not necessarily know one another's identity, a fact that distinguished them from the gallery of disciples and apprentices employed by artists as far back as Michelangelo's time and revived for iconoclastic effect by Andy Warhol." Fetherling, Five Lives, 142. According to MacAdams, who calculated that Hecht received screen credits on sixty-five films and worked on a total of 146, Hecht started his writing factory in the early ' $30 \mathrm{~s}$ with Scarface, subcontracting to writers who included Bart Cormack, Johnny Weaver, Gene Markey, old friends Wallace Smith and Gene Fowler, and new friend Charles Lederer.

MacAdams suggested: "In his movie days, Hecht managed to re-create the boisterous atmosphere of a Chicago newsroom." Hecht himself disliked that Hollywood operated as a factory, and though he wrote of the joys of screenwriting collaboration in Child of the Century (p. 281), it is unlikely that he would have been comfortable claiming credit for a "writing factory." On recreating the newsroom, see interview with MacAdams in Ron Grossman, "Reporter, Film Writer, Spellbinder," Chicago Tribune, June 12, 1990. For Hecht's initial "factory" and director Henry Hathaway and producer David Selznick's references to one in the 1940s, see Man Behind the Legend, 245.

${ }^{132}$ MacAdams, Man Behind the Legend, 158. MacAdams interviewed Hawks.

${ }^{133}$ Pauline Kael, 5001 Nights at the Movies: a Guide from A to Z, 1st ed (New York: Holt, Rinehart and Winston, 1982), 796. Andrew Sarris, "The Sex Comedy Without Sex," American Film 3 (March 1978), 8, 14.

${ }^{134}$ Percy Hammond, "The Colossus of Rose," review of Jumbo, New York Herald-Tribune, November 18, 1935, 10. MacAdams, The Man Behind the Legend, 163-165.

135 "Books on Our Table," New York Evening Post, 26 January 1931. See “A Jew in Love, n.d., 1930-1932), Publicity, 1920-1979, Box 79, Folder 2411, BHNL.

${ }^{136}$ Donald Friede, The Mechanical Angel, His Adventures and Enterprises in the Glittering 1920's, 1st ed. (New York: A.A. Knopf, 1948), 116-119.

137 "A Jew in Love is positively nauseating at times..." Bob Stafford, "Book Notes and Comment," Akron Times, February 8, 1931. Some suggested it was obvious from the deep bitterness... "Ben Hecht's Novel Brutal Study Of A Book Publisher," Baltimore Evening Sun, January 24, 1931. "... almost explosive combinations of words and images..." "Ben Hecht Dissects Mind of an Egoist,” Star Bulletin (Honolulu, HI), January 31, 1931. “...disgusting noisome and thoroughly boresome..." Milwaukee Journal, January 31, 1931. "I can enjoy his ironic humor..." Adelin Hohfield, “About Books," Wisconsin State Journal, February 15, 1931. These reviews can be found in "Ben Hecht is a man of great talent..." New York Times, January 25, 1931. “A Jew in Love,” n.d., 1930-1932), Publicity, 1920-1979, Box 79, Folder 2411, BHNL. 
${ }^{138}$ An example of Jewish anti-Semitism... Newark News, February 21, 1931. “...let loose such a volley of invective...” Buffalo Evening News, February 7, 1931. Typical was Rabbi Louis I.

Newman... Name of newspaper not discernable from the copy of the article on file, Wilmington Delaware, February 25, 1931. The book was banned... News (Dayton, OH), April 3, 1931.

${ }^{139}$ Ben Hecht, A Jew in Love (New York: Covici, Friede, 1931), 3. "...the caricature of the antiSemite brought to life..." Leslie A. Fiedler, "The Jew in the American Novel," in The Collected Essays of Leslie Fiedler, Vol. 2 (New York: Stein and Day, 1971), 82.

140 “...raising nickels for a lot God damn..." Hecht, A Jew in Love, 142. "Lean, overgroomed, reeking of expensive perfumes..." A Jew in Love, 217. "... a self-criticism of the Jewish intellectual..." Fiedler, "The Jew in the American Novel," 82.

${ }^{141}$ Hecht, A Jew in Love, 217.

142 "... inspired self-hatred..." Fiedler, "The Jew in the American Novel," 81. "an image of a world which all of his assaults..." ibid, 82. “... a cynical book to no good purpose..." Fetherling, Five Lives, 118.

${ }^{143}$ Ruth Seinfeld, "Author of A Jew in Love Longed for Lost Unpopularity, But Now That He Has It He Confesses Remorse," New York Evening Post, 1931. Date deleted from copy of article on file. “A Jew in Love, n.d., 1930-1932), Publicity, 1920-1979, Box 79, Folder 2411, BHNL.

${ }^{144}$ Alan Wald, The New York Intellectuals, 31-45; Mark Krupnick, "The Menorah Journal Group and the Origins of Jewish-American Radicalism," Studies in American Jewish Literature 5, no. 2 (Winter 1979): 56-67. Wald concludes, "When the depression began, Cohen's Menorah group abandoned the cultural pluralist perspective; it appeared insufficient from the vantage point of their intense radicalization after the stock market crash."

${ }^{145}$ In addition to Wald's book, another excellent introduction to the New York Intellectuals is Alan Rosenberg, Nathan Glazer, Daniel Bell, Irving Kristol, Irving Howe, Arguing the World, written and directed by Joseph Dorman (New York: First Run Features, 2005), DVD. Because I was most interested in Hecht in relation to this group within the context of American Jewish literature, I also drew on Mark Shechner's After the Revolution, Julian Levinson's Exiles on Main Street and Donald Weber, Haunted in the New World: Jewish American Culture from Cahan to The Goldbergs, Jewish Literature and Culture (Bloomington: Indiana University Press, 2005). ${ }^{146}$ Hecht, Child of the Century, 360-362, 365.

${ }^{147}$ At the vanguard of Jewish intellectual life in the 1930s, joined with several of Hecht's old contemporaries from Chicago... Wald, The New York Intellectuals, 56-57, 58, 62-63. An editorial denouncing Upton Sinclair, Theodore Dreiser, Sherwood Anderson and “...the loop-de-loopers from Zionism to 'internationalism'..." Wald is quoting Editorial, "Unintelligent Fascism," New Masses 10, no. 13 (27 March 1934): 6.

${ }_{148}$ Jack B. Moore, Maxwell Bodenheim, 125-139, 156-157.

${ }^{149}$ Ibid, 142, 159.

${ }^{150}$ Maxwell Bodenheim, Slow Vision (New York: The Macaulay Company, 1934), 122. Jack B. Moore, Maxwell Bodenheim, 154.

151 "Bodenheim Asks Relief; Author, With Escort of 5 Pickets, Applies at Welfare Bureau," New York Times, March 5, 1935. "Bodenheim Dropped in WPA Red Inquiry," New York Times, August 2, 1940. Jack B. Moore, Maxwell Bodenheim, 157-159. Jerre Mangione, The Dream and the Deal: The Federal Writers' Project, 1935-1943, 1st ed. (Boston, [Mass.]: Little, Brown, 1972), 37, 160, 252. Jason Boog, "People's Libraries," Los Angeles Review of Books. Hecht, Letters from Bohemia, 110. According Mangione, who drew from the remembrances of Bodenheim's fellow workers on the Federal Writer's Project: “Although strongly given to tippling, Maxwell Bodenheim, the Greenwich Village Bohemian turned Communist, who was probably the New York City project's best-known author, faithfully executed his assignments in a tiny and meticulous handwriting. ... So well did Bodenheim complete his assignments that he was promoted to the position of supervisor." However, Bodenheim quickly slid downhill after he 
was unofficially allowed to work from home. Required to report once a week for duty, he would arrive at the office entrance half-drunk, refuse to enter, and then retreat across the street to a bar, where colleagues would have to fetch him and drag him in. See Mangione, 180.

${ }^{152}$ At the 140,000 square-foot Astoria studio in Queens, a marble staircase... Richard Koszarski and ebrary, Inc, Hollywood on the Hudson: Film and Television in New York from Griffith to Sarnoff (New Brunswick, N.J: Rutgers University Press, 2008), 28, 29. Bippo... Hecht, Charlie, 191. Composer George Antheil recalled that when he first came to the studio to negotiate his salary, Hecht and MacArthur had said all money matters were handled by their "executive producer": "I advanced to the desk, where a little pinhead gentleman in a high wing-collar was writing. I looked at what he was writing. He was doodling. He looked up, and then jumped right over the desk at me! He always jumped right over the desk at visitors, jabbering incoherently. Otherwise he was harmless." From Koszarski, p. 291, quoting George Antheil, Bad Boy of Music (Garden City, N.Y: Doubleday, Doran \& Company, inc, 1945), 271.

${ }^{153}$ On the troubled history of Astoria, Paramount's great white elephant, see Koszarski, Hollywood on the Hudson, 12, 22, 26-32, 57, 158-159, 179, 203, 225-227. On the million-dollar offer... Hecht, Charlie, 183. A truer and better way than the corporate compartmentalization of the studio system... MacAdams, The Man Behind the Legend, 169.

${ }^{154}$ Hecht, "A Movie Secret," in Charlie, 183-187.

${ }^{155}$ Ibid, 158-159.

${ }^{156}$ Joseph Epstein, “The Great Hack Genius,” Commentary (December 1990): 40-48. It was actually in the mid-1940s when Wilson wrote that a decade earlier, writers had fallen easy prey "to the great enemies of literary talent in our time: Hollywood and Henry Luce." From Edmund Wilson, "Thoughts on Being Bibliographed," in Classics and Commercials: a Literary Chronicle of the Forties (New York: Vintage Books, 1950), 105-108. Wilson had originally written the essay for the Princeton University Library Chronicle 5, no. 2 (February 1944).

${ }^{157}$ Hecht, Charlie, 190. "For God's sake, will you come back here..." Hawks interview with MacAdams, The Man Behind the Legend, 169-170. Arthur Rosson, David Selznick, Lee Garmes and Slavko Vorkapich... Koszarski, Hollywood on the Hudson, 286. Richard and Diane Koszarski interviewed Lee Garmes in 1976.

${ }^{158}$ Koszarski, Hollywood on the Hudson, 284-285.

${ }^{159}$ First two scenes of Hecht and MacArthur, Crime Without Passion, starring Claude Rains, Margo and Whitney Bourne (New York: Hecht-MacArthur Productions, 1934), DVD. “...a completely integrated production..." Richard Watts. Jr. "Crime Without Passion," New York Herald-Tribune, September 9, 1934. Quoted in Koszarski, 289.

${ }^{160}$ Hecht, Charlie, 189. Frank Nugent, "It Happens: 'Once in a Blue Moon,"' New York Times, February 16, 1936.

${ }^{161}$ Hecht and MacArthur, The Scoundrel, starring Noel Coward and Julie Haydon (New York: Hecht-MacArthur Productions, 1935), DVD.

162 Andre Sennwald, "Upon Merely Being Clever," New York Times, May 5, 1935. Koszarski, Hollywood on the Hudson, 288-289, 291-294. Marya Mannes, "Vogue's Spotlight, Vogue, November 15, 1934, 60-61. Quoted in Koszarski, 291-292.

${ }^{163}$ Hecht, Child of the Century, 483-484. Koszarski, 293-294, quoting “The Scoundrel," Time, May 13, 1935.

${ }^{164}$ Frank S. Nugent, "Thunder Over Astoria," New York Times, October 27, 1935. Koszarski, 295-297. "Soak the Rich," New York Sun, February 7, 1936, and "Hits and Flops of '36," Hollywood Reporter, July 13, 1936, 1, quoted in Koszarski.

${ }^{165}$ Alfred Hayes, "The Pair from Paramount," New Theatre, March 1936, 15. Quoted in Koszarski, 285.

${ }^{166}$ Hecht, "Four Rabbis Speak," in 1001 Afternoons in New York, 67. 
${ }^{167}$ Koszarski, 295. "a lousy picture...” MacAdams, The Man Behind the Legend, 177-178. MacAdams interview with Howard Hawks.

${ }^{168}$ On his affair with Mary "Mimi” Taylor, see "Ben Hecht Acts in Play He Didn't Write," Pittsburgh Press, September 1, 1936, 18. http://news.google.com/newspapers?nid=1144\&dat= $19360901 \& \mathrm{id}=$ uyUbAAAAIBAJ\&sjid=30sEAAAAIBAJ\&pg=2728,2613280. On Hecht taking Taylor to Quito, Ecuador, see MacAdams, 188-189. Hecht had been a serial adulterer for years... Hawks told MacAdams that during the autumn, 1933 shooting of Viva Villa in Mexico, Hecht had registered at a hotel with a girlfriend and learned that Rose was coming for a surprise visit.

Hawks was amused whenever Hecht got into "a real bind" like this. "He was a Romeo but he was in love with Rose and liked her jealousy," Hawks said. "He was a pretty devious guy with a lot of different sides to him. It's as though other women were appealing to what his imaginative mind would work out and Rose appealed to what he was. Rose checked him on everything, she took care of him, otherwise he would've gone to California without any clothes if she didn't pack them. With other women he wasn't trying to make anything that was lasting. Ben had to adore Rose, she was not a nagging person at all. He was a genius in his way and she treated him as one." MacAdams, 157-158.

${ }^{169}$ Hecht, To Quito and Back, "If anybody touch or get fresh..." 22; Zamiiano isn't familiar with the word "disillusioned"... 142; a "hear-all, see-all, do-nothing Newspaper Ned," and Moabit prison... 181 .

${ }^{170}$ Ibid, radicalism meant a May Day picnic... 56; communism minus a soul... 145; democracy is quaint, but relies on the People... 140, 142-143; "Yes, what I've done has filled me full of distrust..." 69.

${ }^{171}$ Inability to "get used to the idea of words and action going together..." 148; "There's quite a tribe of us in the world..." 58-59. On deciding to join the hopeless resistance, see Act Two, Scene Two, 154-175. "In a world too loud with false gods..." 185.

172 “...to see if it's any fun to be a writer again..." Bosley Crowther, "Home is the Hunter, Home from the Hills," New York Times, September 19, 1937. The "Guild keeps have meetings about the dangers of the play..." Letter from Ben to Rose, n.d., 1937 in "Hecht, Ben - to Rose, 1937," Family Correspondence, 1915-1976, Box 72, Folder 2250, BHNL.

${ }^{173}$ Hecht, as guest contributor to Walter Winchell, On Broadway, The Daily Mirrorr, July 31, 1935. "Walter Winchell On Broadway, (Ben Hecht as guest columnist, The Daily Mirror), 1935," Works, 1908-1983, Box 31, Folder 790, BHNL.

${ }^{174}$ Martin Gilbert, Kristallnacht: Prelude to Destruction, 1st ed. (New York: HarperCollins, 2006) 13; "World War II: Before the War," The Atlantic, June 19, 2011. http://www.theatlantic. com/infocus/2011/06/world-war-ii-before-the-war/100089/ Though most historians have focused on the events of November 9 and 10, it was in fact a four-day pogrom that started on November 7 with rioting in Kassel, a city in north central Germany. James M. Deem, Kristallnacht: The Nazi Terror That Began the Holocaust, The Holocaust Through Primary Sources (Berkeley Heights, NJ: Enslow Publishers, 2012), 10.

${ }^{175}$ Ben Hecht, A Book of Miracles (New York: Viking, 1937), 25.

${ }^{176}$ Hecht, "Preface to Shylock," p. 3, in "Shylock, My Brother, 1964," Works, 1908-1983, Box 24, Folder 635, BHNL. John Selby, "Book of Miracles," The Literary Guidepost, a column syndicated through the Associated Press, The Billings Gazette (Billings, MT), June 18, 1939, 4. ${ }^{177}$ Hecht, Child of the Century, 520; Leonard Lyons, "Hecht's 'Manhattan Montage,"” The Saturday Review, November 22, 1941, 8. Hecht, "The Fable of Hymie Weinberg," in 1001 Afternoons in New York, 33-36; Petain... "Good-by to an Old Man," 45-48; Senator Wheeler... "A Handful of Don Quixotes," 131-135; the Hearst press... "A Red Herring Comes to Bat," 196199.

${ }^{178}$ Hecht, "Afternoon of an Author, in 1001 Afternoons in New York, 16-17; "Go, ScholarGypsy!" in 1001 Afternoons in New York, 37-40. He wrote: "I never knew whether he was going 
to found a new religion or end up in jail for seduction. But he was too shrewd for either fate. ... It was Sherwood Anderson who reinvented the American soul-dead since David Harum. He found it in the milking shed, the hardware store, the village meeting hall, in the factory noon-hour, and on the front porch and touring in his tin lizzie." The final lines of Hecht's column were:

"Sherwood is off to find something that vanished out of the world he knew and wrote about. It disappeared out of the West and East and even out of the South, where he went looking for it a few years ago. It was the America he knew - that moody, whimsical, and inarticulate hero of the pre-radio, pre-movie hinterlands. Something scotched him. And Sherwood, his great biographer, is off for strange lands, where he can forget that his hero is dead."

179 "A Poet Out of Yesterday," in ibid, 61-64.

180 "How Do You Do?" in ibid, 49-52; "Don Harpo de la Mancha," 99-102. Note from Groucho, August 29, 1941, "Marx, Groucho, 1941," Incoming Correspondence, 1914-1979, Box 60, Folder 1452, BHNL.

${ }^{181}$ Hecht, "A Diplomat Spikes a Cannon," 1001 Afternoons in New York, 25-28.

182 David Nasaw, The Patriarch: The Remarkable Life and Turbulent Times of Joseph P. Kennedy (New York: Penguin Press, 2012), 497-510. Kennedy hardly had the temperament to be a diplomat. Rather than acting as the Roosevelt administration's representative in London, he had pursued his own crusade for negotiations with Hitler ever since arriving in England in 1938. Returning to the United States under a cloud in late October 1940, Kennedy ever afterwards maintained that he had been targeted by "a number of Jewish publishers and writers" who were advocating war. When Kennedy formally submitted his resignation on December 1, 1940, the president did not censure the ambassador for the remarks he had made in Boston and Hollywood that November: It would take some time to find a replacement for him, and Roosevelt was still hoping for Kennedy's support on a plan to arm Britain. On December 16 Kennedy met with Breckinridge Long, the special assistant secretary of state, who was keeping the immigration of Jewish refugees well below quota (see Part Three), with the justification that some of the asylumseekers might be Nazi spies. In a diary entry that evening, Kennedy wrote that Long was facing pressure from Supreme Court Justice Felix Frankfurter, Washington Post publisher Eugene Meyer, and other powerful Jews who had conspired to receive special treatment for their people. "A greater fraud and well-engineered scheme was never perpetrated on the American public than that a thousand refugees have been taken into the United States," Kennedy wrote a friend in Boston. "Not one of them, I know, had ever been investigated by the F.B.I., and yet I don't suppose any newspaper in the United States would print the truth for fear of losing advertisersand then we boast of freedom of the press. Nuts, I say." Within a week after Hecht's column ran on January 16, 1941, a speech by Kennedy over the radio and contemptuous, evasive testimony before Congress on Roosevelt's proposed Lend-Lease policy would end Kennedy's political career for good.

${ }^{183}$ Ibid, 501-502.

${ }^{184}$ Hecht, “A Diplomat Spikes a Cannon," 1001 Afternoons in New York, 497-510.

${ }^{185}$ Hecht, Child of the Century, 381, 517-518. Souvenir program in "Fun to Be Free, 1941, 1944," Publicity, 1920-1979, Box 79, Folder 2396, BHNL.

${ }^{186}$ Stephen J. Whitfield, In Search of American Jewish Culture (Hanover, NH: Brandeis University Press/University Press of New England, 1999), 48-49, 52. Paul R. Mendes-Flohr, Divided Passions: Jewish Intellectuals and the Experience of Modernity, Culture of Jewish Modernity (Detroit: Wayne State University Press, 1991), 14-15, 31, 33. Georg Simmel, "The Stranger," in The Sociology of Georg Simmel, Kurt H. Wolff, trans. and ed. (New York: The Free Press, 1950), 403-408.

${ }^{187}$ Stephen Whitfield, In Search of American Jewish Culture, 52, quoting Leslie Fiedler, "What Shining Phantom: Writers and the Movies," in The Collected Essays of Leslie Fiedler, Vol. 2, 447. 
${ }^{188}$ J. Hoberman and Jeffrey Shandler, "Nickelodeon Nation," in Entertaining America, 14-22.

189 "Hollywood's Jewish Question" in ibid, 47-66, 73-75. See also Neal Gabler, An Empire of Their Own: How the Jews Invented Hollywood; Thomas Patrick Doherty, Hollywood and Hitler, 1933-1939: and Ben Urwand, The Collaboration: Hollywood's Pact with Hitler. Doherty's and Urwand's recent books have yielded a great deal of new information about the interactions between the Jewish executives of the American movie industry and Nazi Germany. Though it's clear that Hecht was not privy to these communications, it is just as clear that he was a keen observer of their effects. He did not know, for example, that Hollywood had stopped trying to make films about the Nazi persecution of the Jews after The Mad Dog of Europe had been blocked in 1933, or that after The House of Rothschild the following year, the studio heads had decided to stop putting Jews in any films at all. But as discussed, in 1944 he wrote about the disappearance of Jews from American mass entertainment. Urwand, The Collaboration,

${ }^{190}$ J. Hoberman and Jeffrey Shandler, "Hollywood's Jewish Question," in Entertaining America, 62. See also my previous discussion of Hecht's role in the adaptation of Personal History into Foreign Correspondent in Part One, pp. 43-44 and endnote \#101.

${ }^{191}$ Hecht, "The Diplomat Spikes a Cannon," in 1001 Afternoons in Chicago, 27-28.

${ }^{192}$ Hecht, "My Tribe is Called Israel," in ibid,164-167.

${ }^{193}$ Ibid, 166.

${ }^{194}$ Hecht, I Hate Actors! (New York: Crown publishers, 1944); The Champion From Far Away (New York: Covici, Friede, 1931); Actor's Blood (New York: Covici, Friede, 1936); "Concerning a Woman of Sin," Parts One and Two, in Collier's, March 27, 1943, 11, 30-38, and April 3, 2430. On the Hollywood writers of the era and the genre of "the Hollywood novel," see Tom Dardis, Some Time in the Sun: The Hollywood Years of F. Scott Fitzgerald, William Faulkner, Nathanael West, Aldous Huxley and James Agee (New York: Scribner, 1976); Bruce L. Chipman, Into America's Dream-dump: a Postmodern Study of the Hollywood Novel (Lanham, Md: University Press of America, 1999); Carolyn Penelope See, The Hollywood Novel: An Historical and Critical Study (Ann Arbor: University Microfilms, 1976).

${ }^{195}$ Hecht, "The Missing Idol," in A Book of Miracles, 55-112. For an excellent summary and appraisal of the book, see Fred T. Marsh, "Miracles by Hecht," New York Times, June 18, 1939. ${ }^{196}$ From "The Heavenly Choir," in A Book of Miracles, 324.

${ }^{197}$ Hecht, Guide for the Bedevilled, 161-199. On Yates turning the story down... MacAdams, The Man Behind the Legend, 231-232.

${ }^{198}$ Hecht, Guide for the Bedevilled, 202-203, 207-210,

${ }^{199}$ Henry Popkin, "The Vanishing Jew of Our Popular Culture: The Little Man Who is No Longer There," Commentary 14, no. 1 (July 1952): 46-55. Excerpt in Entertaining America, 136-143.

${ }^{200}$ Hecht, Guide for the Bedevilled, 216-219.

${ }^{201}$ Ibid.

${ }^{202}$ Hecht, Child of the Century, 219.

${ }^{203}$ Mark Shechner, After the Revolution, 7. Thomas Wolfe, "The 'Me' Decade and the Third Awakening," New York Magazine, August 23, 26-40. Christopher Lasch, The Culture of Narcissism: American Life in an Age of Diminishing Expectations, 1st ed (New York: Norton, 1978). For more recent attention to this idea, see Kurt Anderson, "The Downside of Liberty," New York Times, July 3, 2012.

${ }^{204}$ Michael G. Kammen, American Culture, American Tastes: Social Change and The 20th Century, 1st ed. (New York: Alfred A. Knopf: 1999), 71-72. Stephen Whitfield provides helpful clarification in his review of Kammen's book. See Journal of Interdisciplinary History 31, no. 4 (Spring 2001): 665-666.

${ }^{205}$ See J. Hoberman, "Flaunting It: The Rise and Fall of Hollywood's 'Nice' Jewish (Bad) Boys," in Entertaining America, 220-243.

206 “...strong note of inner drama...” Joseph Epstein, “The Great Hack Genius,” 43. 
${ }^{207}$ Jason Boog, “A Man’s Life: Sad Men.” "Maxwell Bodenheim," in Dictionary of Midwestern Literature, Philip A. Greasley, ed. (Bloomington: Indiana University Press, 2001), 73-74.

${ }^{208}$ Maxwell Bodenheim et al., Blackguard (Chicago: Covici-McGee, 1923), 91-92.

209 “...hack work with flashes of tenderness, wit and truth in them..." Hecht, Letters from

Bohemia, 122. A slashing wit that would put even Mencken to shame... Letters from Bohemia, 112.

${ }^{210}$ Hecht, Count Bruga, 293. Hecht wrote: "But the poet in Hippolyt (Bodenheim) was a stranger to life. Neither coaxing nor obeisance could lure him into social existence."

${ }^{211}$ Letter from Bodenheim, March 19, no year provided, "Bodenheim, Maxwell (Bogie), ... to Ben and Rose, ca. 1940-1950s," Incoming Correspondence, Box 55, Folder 1078, BHNL.

${ }^{212}$ International News Service, "“Scar-Face' Hunted in Novelist Killing," Los Angeles HeraldExpress, February 8, 1954, 1, 3, 12. "Indicted in Poet's Slaying," New York Times, March 3, 1954. Jack B. Moore, Maxwell Bodenheim, 172-173. "Bogie was my friend..." Leonard Lyons, "Hecht Flooded By Calls," The Evening Standard (Uniontown, Penn.), The Lyons Den, February 24, 1954, 11. 


\section{Part III: From Humanist to}

Public Enemy, 1938-1947 
The American press reacted with outrage to Kristallnacht, the giant German pogrom of November 1938. Nearly a thousand editorials ran in metropolitan and smalltown newspapers, and first-hand accounts of the brutal violence appeared on front pages for over three weeks. But the Nazis themselves still had no plan for the Jews: their systematic extermination did not start until the invasions of Poland and the Soviet Union, and the Final Solution to the Jewish Question was still years away. Though Americans understood November's bloodshed as a portent of things to come, the attitude of a nation just recovering from nearly ten years of Depression was neatly summed up by the isolationist credo: America First. ${ }^{1}$

For the first time, the newspapers linked Germany's treatment of its Jewish citizens to Nazi foreign policy, with one analyst for the Saturday Evening Post going as far as to observe, "hatred of the Jews is the mortar which binds together into one house all the bricks of Hitler's other hatreds." The public outcry prodded President Roosevelt to recall Ambassador Hugh Robert Wilson for consultation, and the president joined the choir in expressing his shock: "I myself could scarcely believe that such things could occur in a twentieth century civilization."2

But as Deborah Lipstadt has observed, the press "still had difficulty grasping that one of the primary motives for Kristallnacht had been to destroy organized Jewish life and to make the Reich Judenrein." The confiscation of Jewish valuables and property was read as a German grab for "easy loot," while even as American attention flagged, new laws expelled Jews from schools, cabarets, theaters, sports facilities, fairs, city districts, museums and university libraries; stripped them of their driver's licenses; and prohibited them from all health-related professions. ${ }^{3}$ 
Gallup polls and the coverage of the day reveal that Americans overwhelmingly opposed opening the gates of immigration to Jewish refugees. In early December Time deferred to the "most statesmanly Jewish pundit in U.S." Walter Lippmann, whose "sober and broad-gauge view of the situation" was that the admission of a half-million German Jews would not solve Europe's “surplus population” problem. The Poles were already beginning to clamor for entry into the United States as well—where would it end? Lippmann offered that there was enough free space in Africa to dump Europe's excess humanity for years. The Christian Science Monitor urged Americans to pray for the Jews. Six months later, when first Cuba and then the United States refused to admit roughly nine hundred refugees aboard the St. Louis, dooming them to a return to Europe, the attitude of the press remained much the same. ${ }^{4}$

So Americans were not altogether in the dark about what was happening overseas, but there was an impassive tone to the coverage of June 1939 that contrasted sharply with the sense of alarm Hecht telegraphed in A Book of Miracles, which hit the bookstores that same month. "The Little Candle" predicted the imminent genocide, and also described the Final Solution as it was plotted three years later, at the Wannsee Conference of January 1942: “This great International Pogrom had taken place under the auspices of the four Nazi-fascist governments and was the flower of a long and careful series of conferences among thinkers of the countries involved.... The extirpating of Jews had been carefully planned." Hecht had noted the fanatic urgency of the killers, and the zeal for efficiency - the most salient characteristics, as it would turn out, of the psychology of Wannsee. ${ }^{5}$ 
But more significant than these predictions, "The Little Candle" gave readers a vivid look at the horror that was at the world's doorstep, in a narrative so charged that it calls to mind the eyewitness accounts and survivor memoirs of later years:

We learned that overnight some five hundred thousand Jews had been murdered in Germany, Italy, Rumania and Poland. Another million or so had been driven into forests, deserts and mountains. Thousands lay wounded and dying everywhere. More thousands, having seen their loved ones butchered and decapitated under their eyes, had taken leave of their senses and were howling like animals behind the barbed wire of concentration camps into which they had been clubbed. ${ }^{6}$

As a snapshot in time, that summer of 1939—at the cusp of the mechanized war that has dwarfed all others in history—is crowded with stark juxtapositions: there were dramatic differences, if not necessarily in the way the various parties saw the future, then in what they were prepared to do in the face of it. It was a moment that was as telling as it was decisive, for it revealed both the character of Hecht's soon-to-be allies and opponents, and the ideological lines that would divide them during the war and the battle for Palestine that followed in its wake.

Back in February, Zionist leaders Chaim Weizmann and David Ben-Gurion discovered that they had lost all negotiating power over the fate of Palestine, as Britain, now girding for battle with Germany, became eager to diffuse Arab unrest throughout North Africa and the Middle East. The British promised Palestine wholly to the Arabs, legalistically drawing to a close the commitments made by the Balfour Declaration, their pledge of 1917 to help establish a national home for the Jews. In May, as Nazi terror engulfed Austria and Czechoslovakia, Prime Minister Neville Chamberlain's government announced the White Paper, limiting Jewish immigration to Palestine to seventy-five thousand over the next five years. ${ }^{7}$ 
"A more evil, foolish and short-sighted policy could not be imagined," BenGurion railed. Weizmann, the architect of the Balfour Declaration and heretofore a devout believer in Britain's benevolence, called it a "death sentence." Now crushed and frazzled, he spoke to the Zionist congress in Geneva that August of "a darkness all around us," but still grasped for hope: "There are some things which cannot fail to pass, things without which the world cannot be imagined." Many of the delegates departed Geneva to face their deaths, for less than a week afterwards, Germany invaded Poland. ${ }^{8}$

Earlier in the decade, Ben-Gurion had talked of millions immigrating to Palestine, but he had envisioned this as a process that would take over fifty years, and now faced with an overwhelming catastrophe, his outlook became coldly pragmatic. "I was not wellversed on matters of saving the Jews of Nazi-occupied Europe, even though I was chairman of the Jewish Agency," he conceded years later. "The heart of my activity was enlisting Jewry in the demand to establish a Jewish state." He famously vowed, "We shall fight with Great Britain in this war as if there were no White Paper. And we shall fight the White Paper as if there were no war." But it would be inaccurate to say that, particularly in the pre-war era, the Zionists devoted themselves to rescue; indeed, they focused emphatically on "selectivity"-importing the strongest and fittest who could best contribute to building a new state. ${ }^{9}$

Far more engaged in saving the Jews through illegal immigration was the contingent that, impressed with Hecht's columns in $P M$, would ask him in the spring of 1941 to generate publicity for their cause. Peter Bergson and his colleagues were representatives of the Revisionist faction of Zionists whom Ben-Gurion and the mainstream denounced as fascists. In 1936, Revisionism's founder Vladimir Jabotinsky 
had proposed a plan to "evacuate" a million and a half Jews to Palestine, and a year later, the Irgun Tsvai Leumi, or National Military Organization, dispatched Yitshaq Ben-Ami to coordinate illegal immigration from Vienna, Poland and Prague. Known in Hebrew as Aliyah Bet or Ha'apalah, these Irgun operations from 1937 to 1940 saved somewhere between nine thousand and twenty-four thousand lives. In his memoir, Ben-Ami asserted that the World Zionist Organization, "though it had worldwide Jewish financial resources at its disposal," managed to smuggle only 6,200 Jews to Palestine between 1934 and mid1940, while the Irgunists moved about twice that many. Although these specific figures are difficult to verify, the two movements made no secret of their respective philosophies; the mainstream Zionists dismissed Jabotinsky's schemes of evacuation as fantasy and, both for ideological reasons and because they were unprepared for the extraordinary catastrophe that was about to occur, pursued immigration in this era with nowhere near as much urgency. ${ }^{10}$

The number of lives saved through the smuggling was minuscule compared to the six million that would be lost, and in any case, the British merely deducted an estimated number of these refugees from the White Paper limit of seventy-five thousand. But the story of illegal immigration nevertheless points to a perverse logic at work during those years. The official Nazi policy was to expel the Jews from Europe, so while America and Britain blocked escape routes, the allegedly fascist Irgunists coordinated their rescue efforts with none other than Adolf Eichmann, assigned by the SS to establish the Central Office for Jewish Emigration in 1938. The Revisionists had also developed a close partnership with the anti-Semitic government of Poland, which was likewise eager to expel its Jewish population, the largest of Europe. According to Ben-Ami, the Irgun's 
efforts to purchase ships that could have transported up to ten thousand refugees per voyage were thwarted by Weizmann, who in the spring of 1939 advised Robert Rothschild and other Jewish leaders of France, "When you soup with the devil, you've got to have a long spoon."11

In America, Zionist and non-Zionist Jewish leaders advised their communities to close their doors to the Revisionists. In February 1940, United Palestine Appeal's Executive Director Henry Montor circulated a letter that stated: "Selectivity is an inescapable factor in dealing with the problem of immigration...many of those who have been brought into Palestine by the Revisionists have been prostitutes and criminals." Echoing another common complaint, that Ben-Ami and company were cruelly casting the refugees to sea in squalid "death ships," the Emergency Committee for Zionist Affairs chaired by Rabbi Stephen Wise issued a twenty-six-page booklet that declared: "The conditions on their boats are revolting... They resemble concentration camps in that passengers are hung to the mast and were refused food in retaliation for criticism or complaints." 12

It might begin to appear obvious just who distinguished themselves as heroes and who did not during that critical period, but this is hardly the whole story, and the truth is not so simple. The finger-pointing over what could or should have been done to save Europe's Jews has carried on for over sixty years, and to a significant extent, has shaped the contours of the debates over Israel today. In the midst of one particularly venomous round of argument in the pages of Commentary during the early 1980s that involved former partisans and American Jewish scholars, Irving Howe observed, "How various schools of thought responded to the Holocaust and the events leading to it is a question 
both complex and painful. It needs to be treated sensitively, without polemical coarseness. There are enough failures and mistakes to go around." ${ }^{, 13}$ Indeed, polemics have long distracted from a more holistic assessment of both the wisdom and the errors of each side. If anything is to be learned from this pivotal moment of history about the world that it left behind, it is necessary to acknowledge that no group had a monopoly on truth and sagacity.

Yitshaq Ben-Ami's son has objected to attempts over the years to define his father, Hecht and their colleagues within the narrow terms of right-vs.-left politics, and to the frequent denunciations of them as "fascists," "right-wing extremists," and "terrorists." "I knew these men and women," said Jeremy Ben-Ami, who served as a senior adviser to the Clinton administration and founded J Street, the leading liberal lobby group on American policy towards Israel. "And I read up on what they did in the 1930s and 1940s. Those descriptions were not even close to the truth." He noted that the letterhead of the group's advertisements in American newspapers “reads like a Who's Who of liberal intellectuals and activists." Growing up during the 1970s and '80s, Jeremy Ben-Ami listened to the ex-Revisionists discuss Israel-related controversies in his living room, and found that "some of them leaned to the right, some leaned to the left, and others came down the middle." ${ }^{\prime 14}$

Here was another tribe for Hecht, like the pirates and circus performers of childhood, like the Chicago journalists and artists, like the Don Juans of New York and Hollywood, and like the gangsters. And like the others, this tribe had a code. But Revisionism, the cause Hecht took up in the 1940s that would change his life and legacy, is challenging to evaluate for several reasons, not the least of which is that, like other 
movements in Jewish history, it splintered into a multitude of competing factions. Although the disciples Jabotinsky groomed in his youth group Betar adored their leader, fundamental ideological disagreements developed between the "father" and his more radical and militaristic "children." The Irgun itself was an independently formed and operated fighting organization, and disputes arose over both direction and leadership between Peter Bergson, who led the six-member delegation in America that partnered with Hecht, and Menachem Begin, who in 1944 became commander on the ground in Palestine. The Irgun in turn was less radical than the splinter group known as the Stern Gang, which, under the leadership of Avraham Stern, parted company at the outbreak of the war, when Irgun commander David Raziel called for a unilateral halt to all attacks against Britain.

There were also tensions within the respective groups — between Peter Bergson and Hecht, for example - as well as conflicts within the breasts of each of the leaders themselves. Jabotinsky, like Zionism's founder Theodor Herzl, was a humanist whose beliefs were deeply rooted in liberalism and rationalism, yet there are reasons why several of his followers drifted to fascism. His dream of a Jewish homeland was not in any way eschatological, but rather had developed out of a reasoned analysis of antiSemitism as a social, political and economic phenomenon. He was committed to establishing a state that occupied both sides of the Jordan River, but emphasized that it could only be a nation when it became populated by a Jewish majority, and could thus function as a democracy. "I am just the opposite (of a fascist): an instinctive hater of all kinds of Polizei Staat utterly skeptical of the value of discipline and power and punishment, etc. down to a planned economy," he wrote. At a speech to a Society of 
History Lovers in Warsaw, he said, "I belong to that old fashioned school who still believe that in every civilized community there must be some respect of man for man, class for class, and race for race." ${ }^{\prime 15}$

But as Walter Laquer has observed, "The fact that Jews were often the victims of fascism did not necessarily make them immune to fascist influences. Revisionism believed in strength - in a sinful world only the strong were likely to get what was due to them. This manifested itself in the ideology of Betar, particularly in the cult of militarism with all its antics - the parades, the stress on uniforms, banners, insignia. To a certain extent all political movements of the 1920s and 1930s were influenced by the Zeitgeist. This all too often led to moral relativism, to deriding democracy, to aggression and brutality, and belief in an omnipotent, omniscient leader." Indeed, by the time Hecht came into contact with Revisionism, it was a broad umbrella for individuals and groups, many of whom held reactionary beliefs wholly inconsistent with those of the movement's liberal, pro-British founder. ${ }^{16}$

As a propagandist during the 1940s, Hecht had started out appealing to Americans to buy war bonds, fight for freedom and support Jewish rescue, but by 1947 he was generating agitprop on behalf of renegades whom he proudly acknowledged as "terrorists" and "gangsters." He had started as partner of Peter Bergson, the champion of the great and lonely humanitarian cause of rescue, but ended up touring the country with the mobster Mickey Cohen to raise money and arms for Menachem Begin, the Irgun leader who was described by a British police chief as "a ruthless thug who made Al Capone look like a novice. ${ }^{17}$ If one takes into account Hecht's previous odyssey from the self-hatred of A Jew in Love to the self-pride of "My Tribe is Called Israel," his 
dramatic reversals might even seem a mark of consistency. Yet alternatively, such apparent contradictions may not be contradictions at all, but rather different expressions of a romanticist philosophy that never changed.

Considered within the context of the competing ideologies that emerged in response to the Age of Enlightenment, much of what seems elusive, inconsistent, and even bizarre about both Hecht and the Revisionists begins to make sense. As Jeremy Ben-Ami noted, the narrow right-vs.-left terms of today's politics are unhelpful for analysis, because they frame contemporary debates and not the more fundamental disputes that were at stake in the ' 30 s and '40s and afterwards. ${ }^{18}$ In The Years of Extermination: Nazi Germany and the Jews, 1939-1945, Saul Friedlander argues:

The history we are dealing with is an integral part of the "age of ideology" and, more precisely and decisively, of its late phase: the crisis of liberalism in continental Europe. Between the late nineteenth century and the end of World War II, liberal society was attacked from the left by revolutionary socialism.... and by a revolutionary right that, on the morrow of World War I, turned into fascism in Italy and elsewhere, and into Nazism in Germany. Throughout Europe the Jews were identified with liberalism and often with the revolutionary brand of socialism. In that sense antiliberal and antisocialist (or anticommunism) ideologies, those of the revolutionary right in all its guises, targeted the Jews as representatives of the worldviews they fought... ${ }^{19}$

It would not be a major stretch to argue that "the crisis of liberalism" precipitated its collapse, for while the great liberal powers, America and Britain, emerged victorious, their prosecution of the war - from the White Paper to carpet bombings and Hiroshimawas hardly a resounding affirmation of liberal principles. Moreover, within the new era of the Cold War, the very character of these nations had forever changed.

Zionism was simultaneously an outgrowth of the Enlightenment and an indictment of its failures. Herzl and Jabotinsky had both been journalists, fiction writers 
and dramatists like Hecht, the type of modern, cosmopolitan Europeans who had proliferated during the nineteenth century thanks to the emancipation of Jewry. They both envisioned a state that would serve as a model of their liberal ideals, and their religiouslike devotion to this secular dream was itself characteristic of the post-Enlightenment age. But at the same time, the whole idea of Zionism proceeded from an acknowledgement that reason had not proven to be an antidote for man's primordial prejudices and hatreds. To the contrary, rationalism had made anti-Semitism all the more virulent: Darwinism led to race hatred based upon beliefs of superior and inferior bloodlines, while the Final Solution would represent a nightmare scenario of modern technocracy and technology, with all of their awesome efficiency and force, bent to the will of man's barbarity. ${ }^{20}$

At the Tenth Zionist Congress in 1911, Max Nordau had predicted that millions of European Jews would one day be massacred as a result of emerging political forces. When pogroms slaughtered thousands at the Polish-Russian border, in 1920 he had first proposed the idea of a mass evacuation of 600,000 Jews within a few months, anticipating that as many as a third would be lost in such a desperate gambit, but that many more would be saved. Jabotinsky's Revisionist movement took up Nordau's catastrophic Zionism, emphasizing the darker side of Zionism, the side that maintained a deep skepticism of the Enlightenment, while the Weizmann-Ben-Gurion mainstream, which envisioned a Jewish utopia, represented Zionism's liberal idealism. ${ }^{21}$

In 1952, the great philosopher and political theorist Isaiah Berlin delivered a series of talks about six thinkers who were prominent just before and after the French Revolution. In his lecture about the quintessential reactionary Joseph de Maistre, Berlin 
said, "Although Maistre may have spoken the language of the past, the content of what he had to say is the absolute substance of anti-democratic talk of our day." Berlin argued that while there were some significant differences that divided eighteenth century philosophers, there were certain beliefs they shared in common. Chief among these was "the belief that men were by nature, if not good, at any rate not bad, potentially benevolent, and that each man was the best expert on his own interests and his own values..." Maistre, on the other hand, had been forever scarred by witnessing the bloody spectacle of the Reign of Terror, which he blamed on the dangerous delusions of his day. Determined to destroy these beliefs, he "defended the importance of mystery, of darkness, almost of ignorance, and above all irrationality, as the basis of social and political life." As for the goodness of man, Maistre wrote:

There are insects of prey, reptiles of prey, birds of prey, fishes of prey, quadrupeds of prey. There is no instant of time when one creature is not being devoured by another. Over all these...man is placed, and his destructive hand spares nothing that lives.

Man kills to obtain food and kills to clothe himself. He kills to adorn himself and kills in order to attack. He kills in order to defend himself and he kills in order to instruct himself. He kills to amuse himself and he kills in order to kill. Proud and terrible king, he wants everything and nothing can resist him. ${ }^{22}$

Arguably the grim, anti-liberal view of mankind that the Revisionists had in common with Hecht gave them a unique perspective, a different way of seeing the world that enabled many of them to understand what was happening in Germany, to see the future of Nazism even before the Nazis could see it for themselves, and to prepare, however inadequately, for the impending catastrophe. This might explain not only why at one stage of events, the Revisionists seem to have possessed much greater clarity about the future - almost a kind of "second sight" - and perhaps to have held the moral high 
ground, but also why at a later stage, in choosing "terrorism" over diplomacy to achieve their ends, they appeared to many at the time and ever since as amoral thugs.

Calling for evacuation, in 1937 Jabotinsky had begged his fellow Jews to heed his warnings. "Jabotinsky," Hecht later wrote, "soldier, hero, and prophet of Jewish doom, had offended Zionism for some years now by riding, riding, like some despairing Paul Revere, through Eastern Europe, warning the poverty laden Jewish communities that they were squatting on a dynamite dump." Jabotinsky had likened European Jews to villagers at the foot of a volcano that was about to erupt. He wrote editors of a Jewish newspaper in Warsaw: "I regret that you do not see the dark clouds that are gathering over the heads of the Jews of Europe." Bergsonite Sam Merlin explained to Hecht that most Jews had refused to listen because they, like most people in general, honored respectability more than genius, courage, or anything else. Instead, they sided with the eminent Zionist leader Chaim Weizmann, who focused on selectivity. ${ }^{23}$

Merlin himself later wrote that the Jews had suffered from "three fatal weaknesses": "they lacked to an astounding degree a sense and an understanding of the political and social realities around them"; possessed a misguided faith in "patience to weather the storm"; and placed too much trust in established leaders, like Roosevelt and Churchill. On this last point, Zionist historians who were not Bergson partisans have agreed: Melvin Urofsky and Henry Feingold both argued that Stephen Wise and other like-minded Jews "labored under the terrible misapprehension... that somewhere in the world...existed 'a spirit of civilization whose moral concern could be mobilized to save the Jews." ${ }^{24}$ 
Yet there is troubling evidence that, to some degree, everybody had at least some inkling of what was about to happen, including American Jews and even the American public. But then why would Weizmann, the liberal idealist, coldly write off some four million Jews as early as 1936, and leave James G. McDonald, the future U.S. ambassador to Israel, "appalled but not surprised at his ruthless analysis," while the ostensibly cynical Revisionists desperately pursued rescue? Here again, the Bergsonites had an explanation. According to Alex Rafaeli, the Jews shared with their leadership a "ghetto mentality," a resigned acceptance of their own impotence and victimhood. As he explained in his memoir, "In the U.S. we fought against narrow minds, who saw the Jews as pariahs and small traders incapable of any kind of heroic effort, but the problem was that the Jews themselves felt inferior. They were scared to demand help for European Jews and were frightened to fight against anti-Semitic politicians, primarily in the State Department." ${ }^{25}$

Various currents of the nineteenth century backlash against the Enlightenment revived the medieval mythic ideals of strength, gallantry and valor. In Zionism, Max Nordau introduced "Muscular Judaism" as early as the Second Congress of 1898, an idea that resonated because it supported the goal of Jewish nationalism as a rebirth of body and spirit. The muskeljuden ("muscle Jew"), or the "new Jew," broke free from the antiSemitic stereotype of the scrawny, weak and inferior Jew. Jabotinsky had embraced this as a guiding principle ever since World War I, when he sought to form a Jewish Legion that would fight with the Allies. He was described by Weizmann in his memoirs as a man whose honorable qualities were "overlaid with a certain touch of the rather theatrically chivalresque, a certain queer and irrelevant knightliness, which was not at all Jewish." ${ }^{26}$ 
Hecht's own views had a distinctly American cast, having developed out of his experience as a Chicago crime reporter. He became enamored with the idea of the "tough Jew," and thus was rather pleased when he and the Irgun were branded as gangsters. He saw all politics as criminal — the events of the war only deepened this conviction-but the stakes had become too high for him to remain the "hear-all, see-all, do-nothing Newspaper Ned" who had once stood by and watched German troops gun down two thousand people at Moabit Prison. If his efforts to fund and arm the Jews of Palestine would call for a partnership with a real Jewish gangster like Mickey Cohen, that seemed only fitting.

The Jews of Europe and Palestine had long found themselves caught in a predicament similar to that of the tragic protagonists of Hecht's Notorious (1946) and Kiss of Death (1947), which helped usher in the postwar genre of film noir. Cast as criminals and trapped in a shadowy underworld, surrounded by predators in a dark jungle in which no one was who they appeared to be and everybody wanted to do them in one way or another, they nevertheless needed deals to survive. Since the days when Theodor Herzl had negotiated with Interior Minister Vyacheslav von Plevhe, the arch butcher of czarist Russia, Zionist leaders had often felt forced into devil's bargains. Weizmann, on the other hand, had always objected in principle: "Antisemites are incapable of aiding in the creation of a Jewish homeland; their attitude forbids them to do anything that might really help the Jewish people. Pogroms, yes; repressions, yes; emigration, yes; but nothing that might be conducive to the freedom of the Jews." ${ }^{27}$

Yet for Hecht, engagement in politics was itself a devil's bargain. He took the attitude that all cooperation, with President Roosevelt or the British, for example, 
depended not on genuine trust and shared values, but on mutual interests. As the hoodlum Nick Bianco says when he agrees to squeal for the assistant district attorney in Kiss of Death, "Your side of the fence is just as dirty as mine." The public itself was no more trustworthy: Hecht's propaganda reflected the view that in a world in which rational discussion was impossible, benevolent manipulation of the masses was the next best thing - the same "science of democracy" strategy, incidentally, that the U.S. Office of War Information adopted from Harold Lasswell and his colleagues in academia. As for the ethics of war, in fairness Palestine often erupted into bloody mayhem and the Jewish community, known as the Yishuv, had to fight for its life, but while Hecht like Begin talked a good deal about scruples and careful moral choices, the actual record of the Irgun tells a different story. Mickey Cohen would one day recall that he became "so goddamn excited" when he discovered that "these guys actually fight like racket guys.,"28

Hecht's rhetoric about politics is framed in language about law and authority that seems to draw directly from his experience with crime in Chicago. It is instructive that in Child, he introduces his own 110-page account of his career with the Bergson Group with an analogy to the criminal courts system. He notes that in many of the trials he observed, the accused would begin with the same answer: "Well, your honor, I was just walking down the street, minding my own business, when..."

"It is as a Jewish John Doe under indictment as one of the Palestinian 'Terrorists' who proudly called themselves the Irgun Zvai Leumi, that I now speak up," Hecht wrote. "All other witnesses have had their say—-the Jewish Zionists, Hebrew statesmen, authors and journalists and the British Empire. I offer my evidence neither as Jew nor 
propagandist but as an honest writer who was walking down the street one day when he bumped into history.",29 


\section{JEWISH KNIGHTS: THE BERGSON GROUP}

At the end of 1935 a group of Zionist activists, members of Beitar, the Revisionist youth movement, traveled to various Jewish communities in Europe to raise money and solicit support. Nothing about this was extraordinary; Zionist activists often took part in such missions...But something about that particular group of Beitarists was unique, for it left a great impression on the different Jewish communities it visited: Its members rode in on motorcycles and dressed in leather jackets.

\section{The Jewish Radical Right: Revisionist Zionism and Its Ideological Legacy, by Eran Kaplan $^{30}$}

Hecht disliked causes and had scant interest in Peter Bergson's story of a radical Zionist offshoot when the two first met in 1941. Inspired by Hecht's "My Tribe is Called Israel" column, the blonde, mustachioed twenty-five-year-old with a voice that tended to squeak when excited had telegrammed Hecht on August 28: "Thanks for giving in Sundays PM magnificent expression to the pride and spiritual heroism which for centuries accumulated in the soul of the genuine and conscious Jew. By creation of a Jewish army we intend to transform this heroic spirit into heroic deeds." Intrigued, Hecht agreed to meet Bergson at the 21 Club in midtown Manhattan, but by the time they were ordering a third round of drinks, he was running out of patience with talk of a leader named Jabotinsky and dreams of a Jewish Renaissance. He was outraged and disgusted by the failure of American Jews to speak out against the massacre in Europe, he explained, but had no interest in Zionist fundraising. His companion, however, just stared back with a knowing smile — as if Bergson was privy to something that Hecht didn't know about himself. ${ }^{31}$

Over the next few weeks Hecht became friends with the six delegates of the Irgun who would be known as the Bergson Group. Since arriving in 1939, their efforts to raise 
money for smuggling Jews out of Europe had been a crash course in American culture, and in the divisive politics of American Jewry. At first they had spoken only basic English—Arieh Ben-Eliezer and Alexander Rafaeli could speak none at all. From the start they had a few dedicated supporters, among them the journalists John and Frances Gunther, book-and-magazine publisher William Ziff, and editor and author Harry Louis Selden. But as they traveled to small meetings around the country, the American Zionist organizations sabotaged their efforts at every turn. Rabbi Stephen Wise and his colleagues, who since the early '30s had labeled Revisionism "a species of fascism," now denounced their fundraising as illegitimate and unscrupulous. "My pessimism told me that we had already lost the battle," recalled Ben-Ami. "Yet somehow I continued to function, performing to the best of my ability, hoping against hope that some Jews could still be saved. Our small remaining group in the United States did its utmost to raise funds for Ha'apalah, but we always came up short.",32

The delegation would soon find itself the Irgun's “cutoff battalion.” Bergson had been the last to appear in America, disembarking from the SS Scythia in July 1940 just three months after the arrival of Jabotinsky himself, who had come to campaign for a Jewish army. Then in August Jabotinsky unexpectedly died, which left Bergson in sole command of an uncertain mission in a vast, unfamiliar country. Since the outbreak of war illegal immigration had grown increasingly impossible, and with the death of Irgun commander David Raziel in May 1941, their parent organization in Palestine fell into disarray. Hecht recalled in Child that when he started meeting with the Bergsonites, who were by now shifting to focus on Jabotinsky's plan for a Jewish army, they lacked money for food and were quietly going hungry. ${ }^{33}$ 
Hecht found little poetry in their speech and in their clunky title for themselves, The Committee for a Jewish Army of Stateless and Palestinian Jews. But there was eloquence in their silent determination. "They sat solemn with energies, like a group of knights dedicated to the rescue of a maiden in distress," he wrote. "Their sense of reality was as deep as their idealism." He told his new friends that Zionist politics aside, their idea of a Jewish army appealed to him: "I'd like to help do something to bring respect back to the name of the Jew." 34

But Hecht insisted they make plain their army was not intended for American Jews, for otherwise their campaign would not only call into question Jewish patriotism, it would also play into the hands of the isolationists, who were warning Americans against allowing themselves to be dragged into "a Jewish war. ${ }^{, 35}$ As someone already volunteering with the interventionist Fight for Freedom Committee, Hecht saw himself as a Jew but also, by necessity, as an American committed to integration: the specific circumstances of the moment highlighted the need for unity, as well as the dangers of stoking racial divisiveness. Thus a paradox emerged that was to characterize his propaganda throughout the war years: the particularism of his newly discovered Jewish pride pushed beyond the boundaries of what was considered acceptable by the American Jews of the era, and yet he himself also appreciated the need for inclusion. That many Americans found the formulation of ethnicity in his propaganda acceptable is evident both in the turnout for the Bergon Group's events and in the fact that he produced remarkably similar content for the U.S. government, right through to the end of the war.

In a radio address during that summer of 1941, the isolationist North Dakota Senator Gerald Nye charged that Hollywood was infested with a dangerous "fifth 
column" of war-mongering foreigners. A month later, Nye appeared as the first witness when the Senate Subcommittee on Interstate Commerce opened hearings on Moving Picture Screen and Radio Propaganda, setting out to investigate foreign infiltration of the mass media industry, just as the House Committee on Un-American Activities would probe communist infiltration soon after the war. "Many people seem to assume that our Jewish citizenry would willingly have our country and its sons taken into this foreign war," Nye said at the very start of his testimony. "If anti-Semitism exists in America, the Jews have themselves to blame." 36

The interventionists responded one month later with Fun to be Free, a HechtMacArthur pageant at Madison Square Garden that called for the nation to unite in defeating a threat to the principles that all Americans believed in. On October 5 about seventeen thousand participated in the event, just over half as many as had attended the previous spring's isolationist rally sponsored by the America First Committee, featuring Charles Lindbergh and socialist leader Norman Thomas. Fun to be Free's chairman, former Republican presidential candidate Wendell Willkie, referred to the recent speeches of Lindbergh, Nye and others, declaring, "our opponents were resorting to one of the basest arguments, to divide the United States on the basis of race and religion." In the program guide, journalist Dorothy Thompson denounced the Senate hearings as a Star Chamber inquisition, "the greatest Nazi propaganda stunt ever pulled off in the United States," intended to intimidate Americans into silence. "This fight, therefore, is our fight," she continued. "It is the fight of every human being who believes in freedom of speech, habeas corpus, intellectual integrity, and freedom from intimidation."37 
Hecht, MacArthur and their longtime producer Billy Rose were responsible for the "fun" of Fun to be Free, the patriotic ballyhoo, and thanks in large part to Rose, there was no shortage of it. "I really fear for the fate of the country..." Hecht wrote his wife days before the performance, "because we may hurl an awful pail of lard at this recordsmashing pageant gate." 38 The African-American performer Bill "Bojangles" Robinson tap-danced on Hitler's coffin in his flashy gold 242nal pants and ermine, Eddie Cantor appeared in a hoop skirt, and Ethel Merman unsuccessfully tried to lift a five-year-old boy in a sailor suit to help her sing "What Say, Let's Be Buddies." Other stars included Jack Benny, Betty Grable and George Jessel.

"In addition to comedy, terror and oratory, the rally had considerable emotional appeal," enthused a New York Times reviewer. Following the variety show came the pageant written by Hecht and MacArthur, which celebrated contributions to freedom and the nation by great Americans from Patrick Henry to Roosevelt. The speeches then faded into a wail of air raid sirens, as radio announcers barked reports of enemy planes over Laredo, Texas, Los Angeles and San Francisco, while an air armada approached New York. The lights went dark, searchlights crisscrossed the balconies and vast ceiling, and thousands of parachutists dropped from above, adding the "terror" portion of the evening. The invaders, however, turned out to be tiny cardboard figures. "It is fun to be free," the New York Herald proclaimed. "(The show) expresses the native gusto of American life and the characters epitomize America's love of freedom and disposition to fight if necessary."39

After the attack on Pearl Harbor two months later, Hecht hailed America's entry into the war with a poem published in $P M$, "Uncle Sam Stands Up." Days later he left for 
Washington D.C., where all the officials "cling to me like I was a literary Joe Louis," he wrote Rose. "My reputation as sort of an instantaneous writer seems larger in Washington than it was even in Hollywood." Over the next several years, he would produce propaganda for the Office of War Information, Treasury Bond drives, Hollywood Victory Committee and State Department. He wrote one pageant for the Red Cross and another as a salute to American labor, patriotic speeches for celebrities like Paul Muni and Frank Sinatra, a comedy for G.I.s to perform, and a poem and radio play for the war bond campaigns. He also recruited fellow writers, including Clifford Odets, Lillian Helman, Maxwell Anderson and George S. Kaufman to write short training films for the public, like one on how to respond to an air-raid attack. ${ }^{40}$

From the time he became an interventionist, Hecht's newfound patriotism represented a shift, but not a fundamental change in worldview. "I had been no partisan of democracy in my earlier years," he confessed in Child. "Its sins had seemed to me more prominent than its virtues. But now that it was the potential enemy of the German Police State I was its uncarping disciple. Thus, oddly, in addition to becoming a Jew in 1939 I became also an American — and remained one." He may have remained one, but he nevertheless also remained, at heart, a romanticist. What his American and Jewish propaganda shared in common was a fascination with chivalry and its code-with the warrior's oath to protect the innocent and defenseless, and a dedication to valor, gallantry and honor. As Gil Troy described it, Hecht's patriotic propaganda was "a curious amalgam of sentiment and cynicism, myth and mysticism." ${ }^{41}$

A Tribute to Gallantry, for example, paid homage to both the civilian victims of the Axis and the Allied soldiers willing to make the ultimate sacrifice to protect them. In 
the fall of 1943, performances of this macabre pageant launched the New York War Fund Drive at the Waldorf-Astoria Hotel and at the Garden, where it featured a cast of three hundred. The idea was simple but effective. The play is set at a gate in "a corner of the sky," where a gatekeeper beckons the dead. They gather and tell their tales - children bombed while playing cards in the British town of Coventry, others while celebrating a confirmation in Luxembourg, dancing in Warsaw, and attending a wedding party in Rotterdam, Holland. Each is at one moment full of life and motion, and in the next, with a sudden crash of the orchestra, frozen in a tableau of death. All have been bombed, shot or starved: "the killing off of innocent populations has been the new military weapon introduced into war by the Germans and the Japanese," explains a narrator. An old Jew carrying a broken Torah approaches with a child who clings to his coat. They are among three million, they tell the gatekeeper, slaughtered in lime kilns, in gas chambers, and in front of guns.

These victims are joined by Allied soldiers fallen in battle. The gatekeeper promises that once they pass through the gate all their suffering will be forgotten, but the people quietly insist that they will remain and wait, and the soldiers stand with them. By now a great tide of the dead has formed, and the gatekeeper turns to the audience: "They ask for the sound of victory. They ask that you pour out your energy and your gold, your talent and your valor — as they have poured out their blood."42

Miracle on the Pullman, a radio play broadcast over the Blue Network on November 19, 1944, honored the grace of fallen heroes. It begins with "the human hodge-podge that makes up the U.S.A...taking a ride for itself" — heading out on a train from Grand Central Station. The passengers order pillows and highballs, argue politics 
and play rummy, losing themselves in the petty preoccupations of their comfortable existence. Ordinary mortals, they cannot hear in the high-pitched train whistle the voice of an angel, nor that of another accompanying them: the ghost of a G.I. named Joe, who has joined the journey that he had dreamed would one day bring him home. While the passengers snooze and grumble, Joe stares out in wonder at the Hudson River and the land he left behind. Then he begins to weep. They won't remember us, he says. The angel-whistle tries to reassure him: "You're crazy, Joe, to talk like that." No, says Joe, just listen to them. 'They don't even look out of the window at the towns goin' by. They don't give a whoop for anything but themselves. Just sit around, very bored with the war, and squawk about their dime a dozen troubles, and how business ain't so good." What do they care about the soldiers, right now in the dark, being blown apart or burned to cinders on the battlefield? "They're dead from the neck up. And they didn't die in any tanks or bombers. They died from sitting in easy chairs."

Then a pretty young woman hears the mournful sound of the whistle, and says, "It's funny. I keep thinking about_-over there." Her mind is on someone she said goodbye to, but not just on him. She is thinking about all of them, fighting in the war. A farmer says pardon me, do you know what today is? Why, it's "the day they're opening the War Loan Drive, Number Six. The government's goin' to raise money again — to fight with!" Soon the whole carload is holding an impromptu rally. Urged to give a speech, the young woman says that as she looks out the window she sees the face of a soldier she knew, and if they will all look out their windows, they will see faces, too. A rummy player volunteers ten grand, and as others up the ante, the sum jumps from one to 
two million. Joe stares, slack-jawed. "I told you they'd hear you, Joe," says the whistle, "I told you..."43

For its part, the Bergson Group's propaganda for a Jewish army, and indeed the Revisionist idealization of the muskeljuden, drew from the rich lore of Hebrew history, and from recent legend as well. Jabotinsky's great literary effort had been his 1926 novel Samson, a somewhat radical retelling of Samson and Delilah in which Samson is depicted as a political rather than a religious figure. The Revisionists summoned the names of the great ancient rebels: the fierce army of Simon bar Kochba that had fought the Roman empire, as well as the Maccabees, whose defeat of the Seleucid king Antiochus is celebrated each year at Chanukah. There were also heroes from the pioneering days of Palestine: Yosef Trumpeldor, a leader of the Jewish Legion who died in defense of the Tel Hai settlement, and Yehiel Michal Halperin, "the Jewish Don Quixote" famous for stepping into the lion's cage at the Jaffa Circus to disprove Arab claims of Jewish cowardice. $^{44}$

Betar was both an acronym for "alliance (brit) Yosef Trumpeldor" and the name of the city that was the stronghold of the Bar-Kochba revolt. One of the basic principles of the youth group was Hadar, a Hebrew word that, as Jabotinsky explained, has no direct translation into other languages but embodies several different concepts: "outward beauty, dignity, self-esteem, politeness, faithfulness..." While Betar's critics often associated its emphasis on discipline and military strength with fascism, Jabotinsky pointed to progressive, democratic leaders like Garibaldi and Abraham Lincoln. ${ }^{45}$

Hecht translated the case for a Jewish army to his fellow Americans in "Champion in Chains," an October 1942 article for Esquire. He explained that he was 
like many American Jews of late, "a little startled to find themselves Jewish." One day they had felt themselves fully integrated, far away from their Semitism, and then it was if they had woken up the next morning to a new discovery. It had not happened to everyone at the same time, Hecht explained, and for some of the most comfortable and respectable it still had not happened at all. But now "the red glare of a new era of Jew persecution" greeted them and returned them to their mostly forgotten identity. Hitler, "for reasons too mystic to determine," had been busy at work for years restoring the consciousness of Judaism.

Yet "the discovery that I was a Jew did not set me to lighting any Friday night candles nor did it alter by a phrase any of my attitudes toward life," he wrote. "These are American attitudes, born in America, nurtured in American schools and developed through service in American journalism, literature, drama and the movies."

As he had in $A$ Book of Miracles and his columns for $P M$, he expressed the helplessness, rage and shame that American Jews felt in witnessing the rise of Nazism. Every time they saw the word Jew in the black ink of newsprint, they were reminded of the nightmare into which the world had plunged. "That nightmare has been a butchering block for millions of defenseless people," he wrote. "It has also been a miasma in which the faraway American Jew, however 'emancipated,' however 'assimilated,' has found it hard to breathe." Yet now there was an answer to that nightmare: "He stands in Palestine - the warrior Jew — the descendant of Saul's ancient legions. You've seen him in the prize rings of America often-Benny Leonard, Sid Terris, Rube Goldstein, Battling Levinsky, Barney Ross, Maxie Baer and a horde of others - pugs all, with good jaws, strong hearts and brave fists." 
There were some 200,000 Jews of military age in the Middle East who were eager to serve, Hecht continued, and if any doubted their courage or abilities, they could look to the record of the November 1941 siege of Tobruk. Thousands of Palestinian Jews had fought with the British in defense of that strategic town and its harbor. And indeed when the garrison commander called for volunteers to carry supplies along a heavily bombarded road, so many had come forward and run the gauntlet with such grit that their fellow Irish, Scotch and Australian soldiers gratefully dubbed it "The Road to Zion." Still, Hecht noted that although the Scotts were permitted to wear their kilts, the Irish their shamrocks and the Australians their native hats, the Jews were forbidden to wear the Star of David.

And finally, there was the heroic example of David Raziel. In May 1941, the British landed the Irgun commander and a squad of his fighters at Habaniyah, an airfield near Baghdad. According to Nicholas Hammond, a British university lecturer sent to Palestine to train Jewish fighters in explosives, their mission had been to penetrate the capital disguised as Arabs, blow up oil installations, and perhaps even kidnap the Axisallied Palestinian nationalist leader, Grand Mufti Haj Amin al-Husseini. On their way to Baghdad, however, Raziel had been killed by a bomb from a lone German aircraft, and the mission was scrapped. Perhaps relying on an account by Bergson supporter Pierre Van Paassen, Hecht reported that before Raziel was killed, his team had accomplished its mission of ambushing 150 German mechanics en route to blow up oil wells that would otherwise go to the British. "There are 200,000 Raziels in Zion today," Hecht declared. ${ }^{46}$ 


\title{
2. 'CHAMPION IN CHAINS'
}

If you think that there is no other way than for Mr. Begin to offer you weapons-you are committing suicide. If there is no longer conscience in the world - there is the Vistula River...

\author{
Vladimir Jabotinsky, debating \\ Menachem Begin, September $1938^{47}$
}

For the land and freedom and government are not given to the weak and are not ever purchased - they have always been conquered by bloodshed and the sword.

Avraham Stern, in "Principles and Conclusions," July 29, $1939^{48}$

Meyer Levin, a Chicago novelist and one-time feature writer for the Daily News who had gotten his start with an endorsement from Hecht, was in New York making documentary films for the Office of War Information when he first met Bergson. At the behest of a colleague, he joined the young Palestinian for lunch, and then agreed to attend a small meeting at Frances Gunther's apartment where supporters were arranging a pageant for Madison Square Garden. Levin had a perspective different from most of Bergson's new American friends, having lived in Palestine during the '20s on a kibbutz, where he had become a deeply committed Labor Zionist. As he recalled acidly in his 1950 memoir In Search, he did not like what he now saw:

Bergson proved to be a tense little man, almost excessively well controlled. As the luncheon wore on, I began to realize I was in the company of a fanatic.

I couldn't put my finger on anything wrong. His plan for a Jewish army was sound, I felt.

...But as Bergson suggested future plans, I realized that he pursued the technique of drawing people in through a project on which there could be little disagreement, and then pushing them into more doubtful territory. His further plans included a Jewish state embracing TransJordan, to be acquired by force if necessary, and there were undertones, suggestions of methods that I felt inadmissible. ${ }^{49}$ 
Levin could not have known, but Bergson's edgy demeanor, like the squeak in his voice, were signs that for him the bloodletting in Europe was intensely personal. Born Hillel Kook in Lithuania in 1915 to a line of eminent scholars and leading rabbis, Kook and his family were among the hundreds of thousands forced to flee when the Russians had ordered their expulsion. The Kooks attempted to find shelter in the Ukraine, but arrived just in time for one of the bloodiest waves of pogroms in history, when four rival armies traversed the battle-scarred landscape, all of them targeting the Jews. During one raid that occurred when Kook was still a small child, his brother was shot multiple times in the chest while he and his mother and sisters hid in a courtyard cellar. "When they emerged, they found Nahum at death's door and the streets of the town literally flowing with blood," explained biographer Louis Rapoport. "The experience was indelibly branded into Kook's soul: His earliest memories were of Jews being shot, or cut down with swords or axes.. 50

As Hecht observed, the Bergson Group believed in action, not words, but therein lay the paradox of their U.S. mission. As the ideological offspring of Jabotinsky, inured to the violence of Palestine and Europe, they represented a new "maximalist wing" of the party united in a conviction that the time for speeches had passed. It had been the young Betar firebrand Menachem Begin who, in a famous September 1938 debate with his mentor, had "best expressed the increasingly feverish spirit of the Betar ranks in the face of the growing Nazi threat." Zionism, Begin announced, had reached a third stage of evolution. There had been "practical Zionism" and then "political Zionism," but now the time had come for "military Zionism"- - the time to fight. ${ }^{51}$ 
In America, however, where Revisionism had never really found traction, the "cutoff battalion" was starting from scratch. Hecht had been justified in describing the Bergsonites as "Mad Hatters," for in 1941 these six young men who did not even have enough money to feed themselves sought to build an army, rescue an entire race from annihilation, and create a new nation in hostile territory. As if such goals were not farfetched enough, to accomplish all of this they would first have to overcome the vehement opposition of the very people best positioned to stop them-Stephen Wise and the American Zionist establishment. Clearly they had faith in Theodor Herzl's dictum: "If you will it, it is no dream. ${ }^{, 52}$

To make any progress they would need to punch far above their weight, but this had always been both the challenge confronting Zionism and the nature of its genius. Zionist leaders had, like Hecht, possessed a talent for theatrics, for that was the only means by which representatives of a scattered and powerless minority could pursue their goals. Stagecraft had been in evidence ever since Herzl had insisted upon formal tails, white ties, and a dignified venue for the First Zionist Congress of 1897; his idea had been to convey "the atmosphere of a State," where the attending delegates would "feel that they were its National Assembly." The Balfour Declaration, the great diplomatic coup that represented the first real achievement of Zionism and indeed a turning point in world history, was arguably accomplished through a similar sleight of hand. Israeli historian Tom Segev contends that Chaim Weizmann had managed to secure sponsorship for a Jewish national home in Palestine by capitalizing on a paranoid, anti-Semitic notion held by the British ruling class: that the Jews wielded a mystic power over the world, that they "turned the wheels of history." 53 
Jabotinsky, a talented essayist and captivating speaker from Odessa who became active in Zionist politics as early as 1902, put particular stock in the optics of dignity and power. In successfully lobbying for a Jewish Legion deployed in the Middle East during World War I, he had sought a show of strength that would earn the Jews respect and status. And indeed, since competing Zionist factions possessed no actual land or power that they could fight over, when Jabotinsky established his Revisionist movement in 1923, he could offer nothing more substantive than an alternative strategy for diplomacy_a "maximalist" approach to negotiations with the British over the fate of Palestine, as opposed to the "minimalism" of Weizmann. ${ }^{54}$

But the disputes over tactics between Jabotinsky and the leadership of the World Zionist Organization represented something more than a clash of egos, competition for power and prestige, and different tastes in rhetoric and symbolism. They reflected a fundamental ideological divide that would harden over time. In this regard, one of the most telling disagreements was over whether to negotiate with anti-Semitic, antidemocratic actors. Since the days of Herzl, Weizmann and others had seen such dealings as both futile and morally indefensible, while Jabotinsky viewed them as realpolitik, often justifiable as the only possible means of saving lives. Beyond competing philosophies of political pragmatism, however, there were basic principles at issue. Jabotinsky was himself a liberal, but as someone relatively sanguine about capitalism and imperialism, he was simply not as averse to right-wing, even fascist regimes as were more liberal colleagues like Weizmann or socialists like Ben-Gurion.

As the stakes in Jewish lives increased over the years, these disagreements grew deeper and more bitter. Herzl had been roundly attacked for negotiating with the 
notorious czarist von Plehve, who in return for vague promises of support for the Zionists, wanted them to collaborate with the czar by undermining Jewish revolutionaries. Jabotinsky had been Herzl's lone defender at the time. A heated controversy over another devil's bargain ultimately forced Jabotinsky's resignation from the WZO Executive in 1923: namely, his talks with Simon Petilura, one of the military leaders whose troops terrorized the Ukraine during Kook's boyhood, killing thousands of Jews in pogroms between 1917 and 1920. Jabotinsky faced scathing criticism at the Twelfth Zionist Congress in 1921, to which he had retorted dramatically from the rostrum, "In working for Palestine I would even ally myself with the Devil.",55

Now no longer a leader in the WZO, Jabotinsky set out to build the Revisionist movement, intended as a return to the Herzlian principles from which the mainstream had strayed. In a November 1923 article for the Russian-language exile magazine, Rasswyet, he challenged Weizmann's strategy in Palestine by offering one that was diametrically opposed to it. Weizmann had summed up his gradualist approach with the old Lovers of Zion adage, "One more dunam, a few more trees, one more cow, one more goat, two more houses in Hadera." He believed that by purchasing land from the Arabs while maintaining cooperation with the British, the Jews could minimize resistance and achieve steady progress towards an undefined "national home." Jabotinsky countered that Weizmann grossly underestimated the resolve of the Arabs, dismissing them as a rabble that could be bribed into forgetting their own dream of sovereignty. Only if Arab nationalists were confronted with an "iron wall" of will and might, of either Jewish or British bayonets, could they be expected to make major concessions. Since Britain needed a Jewish state as a reliable beachhead for their empire, the Zionists must openly 
declare their intention of establishing a nation on both sides of the Jordan, and then demand the full protection of British arms. ${ }^{56}$

Jabotinsky's new movement grew steadily as the rise of Arab violence and corresponding British retreat from the pledges of the Balfour Declaration fed discontent with Weizmann. By 1935, when the Revisionists seceded from the WZO and founded the New Zionist Organization, they claimed a membership of 713,000, though this figure was undoubtedly exaggerated. But now, with a new generation coming of age, the party took on a life of its own, and Jabotinsky's overall authority eroded as the ranks swelled, factions developed and new, charismatic leaders emerged. Thousands had joined his Poland-based youth group Betar, drawn to its Nordau-muskeljuden romance with myths of strength, discipline and militarism. Reflecting the radicalism of the era, they increasingly challenged Jabotinsky's more liberal inclinations, particularly his continued preference for diplomacy over armed struggle and reluctance to turn against Britain. "Revisionist ideology was reminiscent of the European radical right and was accompanied by violence, especially between 1930 and 1938, when Mussolini's racial legislation finally induced Revisionism to discard its pro-Italian orientation,” observed Stern Gang chronicler Joseph Heller. ${ }^{57}$

Spearheading the initial confrontation with Jabotinsky and influencing those that followed was Abba Achimeir, a journalist, historian and one of the leaders of a group of renegade activists called Brit ha-Biryonim, which took its name from a sect of daggerweilding Hebrew zealots who had rebelled against the Roman Empire. By 1928, Achimeir had become disillusioned with socialist Zionism and turned instead to embrace the new nationalist movement in Italy, writing a series of eight articles for the daily Doar 
Hayom titled "From the Notebook of a Fascist." In 1955 he argued in his defense that these had been the incipient days of fascism, when even Winston Churchill had admired Mussolini. And indeed, Italian fascism was not a fundamentally racist ideology: when Hitler first assumed power, Mussolini was an outspoken and harsh critic of Nazi antiSemitism.

But from the summer of 1932 to late March 1933 Achimeir even praised Hitler, referencing "the glorious names" of nationalist movements, such as "Ataturk, Mussolini, Pilsudski, de Valera, Hitler.” Jabotinsky, who had limited control over what young Revisionists said and did in Palestine after he was permanently barred from the country in late 1929, had generally encouraged Achimeir, but incensed by what he now read, declared that this acolyte would be expelled from the party if Achimier wrote one more favorable line about Nazism. The increasingly extreme rhetoric reflected the rising tensions between the Revisionists and Laborites in Palestine, which had led to violent clashes, and culminated with the murder in June 1933 of a senior Zionist official, Chaim Arlosoroff. The very day he was killed, the Revisionist paper under Achimier's editorship had published what many read as a public threat against Arlosoroff's life. ${ }^{58}$

Achimier was charged with conspiracy and brought to trial along with two other Revisionists. They were acquitted of the killing, but Achimeir was still sentenced to jail for leading a terrorist group. Rage erupted against the Revisionists, who were from then on branded as fascists and Hitlerites, and against Jabotinsky in particular. "The Arlosoroff affair was to inject further poison into the two wings of Zionism for some time, " Heller observed. "Indeed, both sides perceived it as part of a world struggle 
between right and left." The enmity was so deep that recriminations about the murder persisted into the 1980s. ${ }^{59}$

Meanwhile, the early 1930s also saw the emergence of the force that was to become the Irgun. Dissatisfied with the socialist-oriented Jewish militia, the Haganah, Jerusalem commander Avraham Tehomi formed the breakaway unit Haganah Bet in April 1931. About half of the new group was recruited from Betar, and from the start Tehomi appealed to Jabotinsky to be its senior commander. As a clandestine, underground outfit, it hardly fit Jabotinsky's ideal of a Jewish Legion and he initially demurred, but realizing that it offered a means of retaining influence over the movement he had started, he accepted leadership in $1936 .{ }^{60}$

In creating Haganah Bet, Tehomi brought along a clique of young nationalists from Jersualem—Kook and two Hebrew University students, David Raziel and Avraham Stern. They were among the many who often clashed with a left-leaning faculty that included Judah Magnes and Martin Buber. "The leaders were almost exclusively young intellectuals who had grown up in the Polish revolutionary traditions," wrote author and journalist Arthur Koestler, an early Irgun supporter. "This created the peculiar ideological climate of the Irgun - a mixture of that quixotic patriotism and romantic chivalry which characterized Polish student revolutionaries, with the archaic ferocity of the Bible and the Book of the Maccabees." ${ }^{, 61}$

When the Arab Revolt erupted in 1936, the young commanders decided to fight fire with fire, and it was their resolve to employ violence that transformed Haganah Bet into the Irgun. The storm of Arab rage-largely in reaction to the great surge of Jewish immigration precipitated by Hitler's rise to power-would claim some six thousand lives 
from the outbreak of unrest that April to its subsidence three years later, with the passage of the British White Paper. Throughout those years, the Haganah maintained the policy of Havlagah, or "restraint," refusing to retaliate against the Arab attacks. Many of Haganah Bet's fighters, however, argued that restraint communicated weakness, while the Arabs achieved concessions through battle. Tehomi chose to side with the Haganah, and led about half the force in a return to the fold. The roughly fifteen hundred fighters who remained became the Irgun, with Raziel, Stern and Kook assuming leadership. ${ }^{62}$

Jabotinsky vacillated, for he knew that if he were to altogether oppose the Irgun's policy of retaliation he would lose all influence, and yet he objected to the increasingly indiscriminate nature of the attacks, such as terrorist bombings of populated areas that killed women and children. "I can't see much heroism and public good in shooting from the rear an Arab peasant on a donkey, carrying vegetables for sale to Tel Aviv," he told a meeting of the leaders in July 1937. Indeed, during the same years that the Irgun was virtually alone in rescuing lives through illegal immigration, it was also tossing bombs into Arab coffeehouses and marketplaces and shooting up busses. These attacks peaked in mid-summer 1938: according to contemporaneous newspaper accounts, on July 6, a milk-can bomb in the Arab market in Haifa claimed 21 lives and left more than 60 injured; on July 15, an electric mine in the old city of Jerusalem killed ten and wounded 29; on July 26 , another bomb in the Haifa market massacred 45 civilians and wounded about 60; and then on August 26, an explosion in Jaffa killed 24 and wounded 35. By their own counts, the Irgun claimed to have slaughtered 150 people in July alone, and 130 between the passage of the White Paper in late May 1939 and the outbreak of war in early September. ${ }^{63}$ 
These attacks, to be fair, were hardly occurring in a vacuum; Palestine was sinking ever deeper into a bloody morass. Each day brought a new spate of "disorders and disruption - telephones cut, bridges damaged, trains derailed, convoys ambushed and fighting in the hills," recalled one Mandate policeman. The British responded with often brutal raids on Arab villages, martial law, collective punishment, and torture. From 1936 through 1940, they demolished some two thousand homes, and in the two years following November 1937 carried out 112 executions, averaging one per week. Much of the overall violence, though, was in fact Arabs targeting other Arabs, either for collaborating or for failing to sufficiently support the insurrection. As a result of the rising toll on Jews, by 1939 the Haganah itself buckled on self-restraint. Caving into pressure from the ranks, Ben-Gurion allowed reprisals through a Special Operations Unit. Other Zionists joined the Special Night Squads, a secret army of vengeance formed by British intelligence officer Orde Charles Wingate. Completing the circle of violence, internecine warfare also resumed between the Haganah and the Irgun. ${ }^{64}$

Meanwhile in Europe, the Revisionists forged devil's bargains that yielded arms and training for their new, maximalist fighting force. Jabotinsky and Jeremiah Halperin had set the precedent in November 1934, when they established a naval academy in fascist Italy's port city of Civitavecchia with Il Duce's personal approval. Although the Betar leaders ordered their cadets to maintain a distance from the locals, the trainees nevertheless openly expressed support for Mussolini's regime and his war in Ethiopia, marching with Italian soldiers in parade and collecting scraps for munitions. ${ }^{65}$

Jabotinsky was also able to forge an alliance in Poland. Since the Polish citizenry blamed the Jews for the poor national economy, and the government, like the German 
Reich at this stage, was eager to expel them, Polish officials adopted a pro-Zionist policy. As the American Office of Strategic Services noted in a 1945 report, "The authorities were interested in exploiting the anti-democratic Revisionist party against the democratic Jewish opposition, which fought for equal rights of the Jewish minority."

British immigration restrictions and Labor Zionism's non-cooperation made Jabotinsky's hoped-for partnership on his mass evacuation scheme untenable, but the Poles were happy to provide arms to the Zionist underground in Palestine. According to the recollections of Irgunists, the government stocked a warehouse in Warsaw with 20,000 rifles and light and heavy automatic weapons, including 200 Hotchkiss heavy machine guns. But not more than a few hundred of these ever made it to Palestine before Germany's invasion in September 1939 made further smuggling impossible.

Far more fruitful was the Polish army's four-to-six-week training program for the Irgun conducted during the spring. While only about twenty-five men received training, they would form the core of officers who would later lead the revolt against the British. In addition to being trained in conventional warfare, they were schooled by veterans of Poland's pre-World War I underground army of liberation in "terrorist bombings, conspiracy, secret communications, partisan warfare, and underground planning," according to Irgunist Yaakov Eliav. “...Sabotage was taught scientifically."67 Avraham Stern had arranged the course, and since he scorned Jabotinsky's wavering on restraint and sympathies for England, it's likely that the father of Revisionism was not even aware of the arrangement. Based on the success of this partnership, Stern would later attempt to forge an alliance with the Axis-first with Italy 
in the fall of 1940, and twice more with the Nazis, late in 1940 and then in December 1941, just weeks before the Wannsee Conference.

While Jabotinsky found his authority over Revisionism challenged from the outside by the Irgun, another challenge arose from within. By 1938, Stern had infiltrated Betar with secret "cells," which were focused not on politics and ideology but on paramilitary training. The young head of Betar's Polish branch, Menachem Begin, articulated the new militancy in a famous debate with Jabotinsky at Betar's third world convention in September. He rose to amend the Betar oath, proposing to change, "I shall not raise my arm except in self-defense," by adding the clause "... and for the conquest of my homeland." World conscience, he argued, was nowhere in evidence and the League of Nations was about to dissolve. England had ruled in favor of the Arabs because the Arabs had national ambitions and were willing to fight, while only a fraction of the Jewish people was fighting. Echoing Stern, he declared: "We want to fight— to die or to triumph!" While Stern had openly defied Jabotinsky, it would later be Begin who reinterpreted the late founder's ideas and thus usurped him, seizing control of both his movement and his legacy. ${ }^{68}$

To resolve the question of Jabotinsky's authority, the Irgun leaders convened with the Revisionists for a meeting in Paris in February 1939, one of the results of which was to dispatch Ben-Ami and others to the United States. Raziel and Kook attended, but Stern stayed away, and a month later convened a press conference where he issued a bellicose warning to the British and Arabs. Despite the fact that the "Paris agreement" reasserted Jabotinsky's authority, the aged father nevertheless would fall increasingly out of touch. By the spring Stern was publicly deriding him, lumping him in with the Jewish Agency, 
the WZO's official administrative body in Palestine. Both kowtowed to England, Stern asserted, and both clung to naïve delusions about the power of world opinion and the League of Nations. Instead, Stern believed in force, "always decisive in the lives of conquerors and freedom fighters... For the land and freedom are not given the weak and are not ever purchased - they have always been conquered by bloodshed and the sword." 69

With the publication of White Paper on May 17, the Irgun announced that "blood and the sword" would decide the outcome in Palestine, and it launched a full-blown rebellion against Britain, blowing up the Palestine Broadcasting Service the same day. For the first time Irgunists assassinated a policeman, Arieh Polanski, on May 23. Six days later, Yaakov Eliav put his newly acquired terrorism skills to use, preparing a timed explosive that tailor and Irgun fighter Matzliach Nimrodi sewed into a jacket and then wore into Jerusalem's Rex movie theater, where he left it. "I was man-bomb, like the Arabs who go on suicide missions," Nimrodi later recalled to an Israeli journalist. The explosion killed five Arabs and wounded 18. The British responded by clapping Raziel in jail, but the campaign continued, with bombings of phone booths, post offices and coffee houses throughout the Mandate. On August 26, an explosion killed Ralph Cairns, head of the Jewish Department of the Palestine Police, and another officer, Ronald Barker, in retaliation for torturing Irgun members. Two days later a British raid netted the entire Irgun command, including Stern. ${ }^{70}$

The invasion of Poland and start of the war on September 1, however, would dramatically change the calculus of conflict, both for the British and the Revisionists. Jabotinsky immediately declared his allegiance to Britain, and Raziel did the same in a 
September $5^{\text {th }}$ letter to the commanding officer of the British army in Palestine. He then signed an agreement with inspector-general of police Alan Saunders promising that the Irgun would cease attacks on the British, furnish the Mandate with intelligence and assist in operations in the Middle East and the Balkans. For their part, the English promised to fund the Irgun, release their imprisoned fighters, and allot them a quarter of the immigration certificates. On October 24, 1939, Raziel was delivered from Sarafend Prison to the King David Hotel, shackled hand and foot: Hecht's "champion in chains.",71 


\section{CAMPAIGN FOR A JEWISH ARMY}

My father loved him. The collaboration with Ben Hecht was an incredible collaboration. They together produced amazing - amazing things. They revolutionized political campaigning and lobbying.

Rebecca Kook, daughter of Hillel Kook/Peter Bergson, and senior lecturer of politics and government at Ben-Gurion University of the Negev $^{72}$

Fight for the Right to Fight!

Newspaper advertisement for a Jewish Army ${ }^{73}$

On January 5, 1942, a full-page New York Times advertisement that announced "Jews Fight for the Right to Fight" marked the beginnings of the Bergson Group's first full-fledged publicity blitz. Over the next three years, the delegation would publish more than ninety different advertisements in at least forty newspapers in fifteen cities. Many featured dramatic headlines written by Hecht, with evocative, intricate caricatures drawn by the artist Arthur Szyk in the style of illuminated medieval manuscripts and miniature paintings. The use of advertisements for both publicity and fund-raising was one of many tactics deployed by the group, which also included propaganda leafleting, radio broadcasts, fund-raising dinners, petitions, and relentless, door-to-door lobbying in Washington, D.C. According to Hecht, collectively these reflected Bergson's "theory of a hundred guns": "It meant that he would gather cohorts wherever he might find them and shoot in all directions, so that when the day of victory came, no one, not even he, would know which gun had fired the decisive bullet." Bergson thus made his mark as a public 
relations maestro who understood the power of media and American public opinion and knew how to capitalize upon it. $^{74}$

The advertisement that appeared that January ran with 133 signaturesendorsements from three U.S. senators and 14 Congressmen, 11 rabbis, five clergymen, and numerous authors, journalists and entertainers - reflecting a basic Bergson strategy. "Putting their hard-won knowledge of the rules for molding American public opinion to use, Kook and delegation members eventually thrashed out a game plan," explained historian Judith Tydor Baumel, "first, convince a qualitative majority of the justice of your cause and the masses will follow suit." The delegation picked many of its first sponsors out of Who's Who in America, mailing out a hundred copies of a memorandum that called for a force of Palestinian and stateless Jews to fight alongside the American, British and other Allied armies, "legally and according to American foreign policy" for "survival of the Jewish people and the preservation of democracy." Those who wrote back to offer their support were then listed on the next circular, which went out to another hundred influential people, and the process was repeated until hundreds of luminaries of many different stripes had joined the rolls. ${ }^{75}$

For the mainstream Zionists, there was nothing controversial about the Jewish army proposition itself; it had in fact been at the forefront of their agenda since as early as 1938. A Jewish fighting force was seen not only as a means of pursuing vengeance against the Nazis but also of empowering the Yishuv and of protecting the community against Arab uprisings and invasions, which were increasingly regarded as an existential threat. But in a meeting with Zionist leaders on a visit to the United States in 1941, BenGurion had urged the leaders to shut out the Revisionists, and they had sabotaged 
Jabotinsky when he succeeded in obtaining the support of British ambassador Lord Lothian. The Jewish army issue was to become emblematic of the toxic rancor in Jewish affairs, revealing not only the rising antagonism towards the Revisionists in America, but also the widening rift between Ben-Gurion and Weizmann. While the British did ultimately establish a Jewish Brigade in 1944, scholars have argued that had the Zionists been able to overcome their differences, they could have closed the gap between England's formal adoption of the plan in October 1940 and its realization four years later. $^{76}$

Bergson was able to undercut the establishment's efforts at interference by putting gentiles into leading positions on the Committee for a Jewish Army, as well as his subsequent committees. “The secret was simple," explained Jabotinsky's son Eri, who was one of the six members of the Bergson Group. "The Committee for a Jewish Army was a non-sectarian, non-partisan, American organization. It was not a Jewish organisation. The principle was that we, a group of anonymous Palestinians, approached the American public with a request to help us in our enterprise. We didn't pose as the representatives of any movement or any party. We were just representing an idea and asking those who were in accord with our arguments to give us the support of their name. .77

Over the ensuing years, as the needs of the moment kept changing and Bergson's objectives shifted accordingly, the young Palestinian announced a new committee for each new mission. Hecht found it clumsy to label the entities "committees" and thought that creating so many different titles for essentially the same core of people only sowed confusion. But there was good reason for the obfuscation: It kept the focus on each 
respective cause while allowing the delegation to shed the name of Revisionism, which carried such baggage. This use of aliases was consistent with Kook's adoption of his pseudonym Peter Bergson, which he had done to insulate his eminent uncle, chief rabbi of Palestine Abraham Isaac ha-Kohen Kook, from association with illegal immigration and other Irgun activities. ${ }^{78}$

The group soon recruited an extraordinary roster of advocates. In addition to the Gunthers, Van Paassen and P.M. columnist Max Lerner, signatories included Lowell Thomas, Dorothy Parker, Upton Sinclair, I.F. Stone, Sinclair Lewis, Langston Hughes and Paul Robeson. Support reached across the cultural spectrum: On the one hand, the ads ran for free in the blue-collar Hearst scandal sheets that by now had lost much of their old rakish swagger, but still yowled just as loudly as they had in the days of the Chicago Herald-Examiner. Yet on the other hand, the group was championed by $P M$, the highbrow, maverick New York daily where staffers included the likes of Hecht as a daily columnist and Dr. Seuss as chief editorial cartoonist. While Hearst and the bombastic Walter Winchell wrote columns trumpeting Bergson's efforts, so too did the erudite theologian Reinhold Niebuhr. ${ }^{79}$

Prominent Americans in the media and in Washington were impressed by the selfconfident appeal, not for pity, but for a chance to prove Jewish resilience and strength. In referring to what he called "the Cause," Hecht wrote friend and newfound partner on the committee David O. Selznick: "I went into it for the same reason I think that you did. I felt that the Jews have been trying to arouse all kinds of emotions in the world - pity, compassion, horror, guilt, -- and that it would do all of us a lot of good if they could, for a change, inspire some other kind of emotions, such as a home run or a successful battle 
inspires in the Americano. I felt that Jews like ourselves who are a little stronger than most owed it to throw not only a few dimes to the dolor of the Jew but to give him a lift with our strength, to add our voices to his battle cry rather than his moans." ${ }^{\prime 80}$

Among the committee's supporters were second- and third-generation assimilated Jews such as Hecht and Lerner, the actor Eddie Cantor and Alfred Streslin, an advertising magnate Hecht recruited who provided an initial infusion of $\$ 5,000$. They tended to be attracted both to the image of "the new Jew" and to what Baumel refers to as the Revisionist's "demand orientation," of defining one's rights and then staking claim to them, as opposed to "the passive request orientation then current among other contemporary Jewish organizations." Their aggressive rhetoric was virtually unheard of, not only in discussions of the Jewish Problem, but also in American discourse about the status of minorities in general. Though on Hecht's advice, the committee downplayed its aspirations of statehood, the maximalist Revisionist poet Uriel Helperin perhaps expressed the spirit best when he had announced back in 1938, "Our very right to the country is our own, and the essence of our power is our own power." $" 81$

Despite Hecht's admonition to keep Zionism out of the equation, the appeal for national liberation nevertheless gained traction in Congress, where the issue of a Jewish army was raised twenty-four times during 1942. The Bergson Group reached out to other nationalist groups - the Irish, Yugoslav, Czech, Polish, Korean, Chinese and Free French — and found particularly strong support from the Chicago Czech community and the New York Irish. Congressman Will Rogers Jr., who was part Native American, became an increasingly passionate champion of Jewish rescue, lobbying the Roosevelt administration for an agency to be established. Another leading advocate was 
Representative Andrew Somers, the Brooklyn son of an Irish militant, who compared Britain's policy in Palestine to its handling of Ireland before independence. But their political support only took the Bergsonites so far: Somers' proposal in February for a congressional resolution, the most significant legislative initiative to be pushed on behalf of the cause, remained bottled up in the Foreign Affairs Committee, blocked by its chairman Sol Bloom, a representative of New York who was a Zionist. ${ }^{82}$

While the Bergson Group was successful in recruiting assimilated Jews as supporters, it had far more trouble with those closest at hand. In Hollywood, where Hecht's wife Rose and committee member Miriam Heyman prepared a fundraiser for a thousand guests at the Twentieth Century Fox commissary, Hecht realized that he needed a co-sponsor for the event, as his name alone would not carry enough weight. Bergson assumed that another sponsor would be easy to find, since his prize author was connected with the twenty most powerful Jews of the film industry. But Hecht knew otherwise, recalling that just two years earlier, Louis B. Mayer had served his family's celebrated chicken soup to Nazi editors at a luncheon decorated with swastikas. Even good friend David Selznick at first refused to help, on the grounds that he was an American and not a Jew. He finally agreed when Hecht won a bet that if they called any three friends of Selznick's choosing and asked whether he was an American or a Jew, all would identify him as a Jew. ${ }^{83}$

All the careful planning for the evening went awry when Lt. Col. John Patterson, the legendary lion hunter and former Jewish Legion commander, managed to simultaneously bore and offend the diners with a diatribe about British anti-Semitism. As some stormed out while others shouted in protest, gossip columnist Hedda Hopper saved 
the day by calling above the din with a pledge. Several guests joined in, but of the $\$ 130,000$ promised, only $\$ 9,000$ was paid. Hecht later remarked that that this first propaganda venture "was a fine success—if you care to overlook its failure." Harry Warner and British film director Victor Saville denounced their hosts to the FBI, which forced Hecht to spend two hours the next day with investigators. Bergson was especially disappointed; the Irgun command had expected to raise millions, as they knew the moguls could have given it easily. Instead, the affair turned out to be another lesson learned. "I don't have to tell you that the only cause such Jews want to hear about are causes which will conceal from them and from the world any hint of their Jewishness," Hecht wrote Selznick. The proceeds, at least, would pay for office rent, a mimeograph machine and letterhead. ${ }^{84}$

The British War Office finally did announce the formation of a Jewish Brigade nearly two years later, on September 20,1944. This force of 5,500 finally saw action only weeks before the end of the war, but afterwards its soldiers played a major role in helping survivors emigrate to Palestine. One veteran was Dov Gruner, who was to become the Irgun's most celebrated martyr in their armed struggle against the British Mandate. ${ }^{85}$

While there is little evidence that the Committee for a Jewish Army succeeded in directly influencing the War Office's decision to establish the brigade, the CJA could nevertheless claim credit for a far more enduring, if less concrete, achievement. As Bergson explained, "Until that time Jewish matters appeared on the next to last page of the newspaper. We placed them on the American public agenda, providing momentum for their movement from the dead pages to the news section and even to the front pages. 
For the first time in the history of the American public, Jewish affairs took up an entire page of the New York Times." ${ }^{, 86}$

Hecht and the committee had shattered an enforced silence in the public sphere. There was an element of truth to the Nazi canard that "the Jews control the U.S. media" - though hardly as part of the worldwide conspiracy that Hitler imagined — and American isolationists had struck preemptively to muzzle them. Charles Lindbergh, Senator Nye and others had stoked fears of a Jewish plot to manipulate the masses, while Joseph Kennedy had played on the reluctance of assimilated movie and publishing executives to draw attention to themselves as outsiders. Many of the most talented and successful Jewish writers Hecht knew were likewise reluctant to speak out, as were leading representatives of the American Jewish community, who were moreover under explicit instructions from State Department and White House officials not to portray the conflict as "a Jewish war."

To the extent that, as the Bergsonites believed, the collective silence reflected the subconscious self-hatred of diaspora Jewry, the true achievement of the committee lay not in meeting its specific goal, but rather in bringing "respect back to the name of the Jew," as Hecht later put it. He and the Bergson Group pulled the legitimate concerns and aspirations of the Jewish people out of the shadows and into the light, making it the explicit, prominent topic in American public discourse that it has been ever since. In the process, they raised more than a quarter of a million dollars and drew fifty thousand supporters over the eighteen months of the CJA's existence. "In the public relations sphere it was unique on the American scene: militant, but espousing a patriotic aim that was difficult to oppose," noted Baumel, "loud and bombastic, but incorporating these 
qualities into the American ethos of freedom and minority rights in a way that answered the human, and particularly American need for sensationalism. ... Hillel Kook filled the vacuum between the distressing reports from Europe and what was seen as contemporary American Jewish organizational impotence. Accordingly, Kook's group enjoyed a positive public image: it had plans, proposals, and noisy protests in comparison to the low-key protests whispered by the Jewish establishment until 1943."87 


\section{4. 'A CHALLENGE TO THE SOUL OF MEN'}

There were probably those who didn't join (our cause) that we didn't know about because it was known that we were a radical group. If we were radicals we would have thrown bombs. God knows if there was ever a justification to throw bombs, these were the years. We didn't even think about it, because we were not radical. We were humanists.

\section{Peter Bergson ${ }^{88}$}

In the early winter of 1943, Hayim Greenberg, editor of the Jewish Frontier, handed Hecht a stack of reports while they lunched together at a kosher restaurant. Obtained via Switzerland from Nazi-occupied Europe, some were accounts from eyewitnesses, others from sources in the underground. In clipped, factual sentences they described five thousand Jews crammed into freight cars lined with tons of quicklime, rolling to destinations where their partially decomposed corpses were pulled out and tossed into pits; five hundred men, women and children marched naked into an incinerator; twenty thousand mowed down in a field, target practice for Luftwaffe gunners. At a time when knowledge of the six Nazi killing centers had not yet come to light, Hecht began to wonder why the Germans were herding all their victims to Poland. Then he realized that the killing of millions would have to be tightly organized, to keep the pile-up of the dead from getting out of control.

Hecht told Greenberg that he planned to use the material for an article describing Germany as a nation of murderers. His companion protested: To brand all Germans killers would be to exhibit the same blanket hatred that the Nazis had for the Jews. "It will be bad for the Jews," the editor said, "if you make the Jews seem as cruel and unthinking as those whom you are trying to attack." 
Greenberg's thoughtfulness and lack of bitterness in the face of such inhumanity was moving. Hecht thanked him for the help and advice, but in parting thought: "His way was not my way. I was unable to answer his philosophical words. My head was full of faraway screams. ${ }^{199}$

Weeks earlier, on November 25, 1942, Bergson had learned that the Nazis had slain two million Jews and were carrying out a plan of complete extermination. The article in the Washington Post was three inches long and buried on page six. Rabbi Stephen Wise had delivered the news the previous day at a press conference, announcing that it had been confirmed by the State Department. Accordingly, Bergson ran straight to the office of Assistant Secretary of State Adolf Berle, where eventually he was granted a few minutes audience between appointments. Years later, he recalled the exchange: "I said, 'What are you going to do about it?' And he says, 'What can we do about it?' And I said, 'Surely you don't say the United States is going to do nothing? I am one individual here, a foreigner, and I know I am going to do something."

But doing something would turn out to be an extraordinary challenge. The Roosevelt administration maintained that the best and only way to help the Jews was to defeat Hitler as quickly as possible. An effort at rescue would mean a significant shift in Allied war policy, which would require public pressure. Such pressure, however, could only proceed from awareness, yet the public had not even begun to absorb a truth so dark it was hard to fathom and tested the limits of credulity: that a modern, civilized world power was systematically eradicating an entire race. Worse, the American press had bungled the story, while the American government was actively suppressing it. Once again, the Committee for a Jewish Army would have to shatter a wall of silence. Its 
urgent mission to inform and galvanize the public would thus involve Hecht in the most significant public relations coup of his life-his 1943 Holocaust pageant, We Will Never Die. To succeed, he would have to heed Greenberg's advice: Americans were determined to crush Hitler, but a call for rescue would require something more than an appeal to their hatred of Germany. It would have to inspire their humanity.

Precious time had already been lost. In August, the State Department had at first attempted to block Wise from receiving a report of the Final Solution from Gerhart Riegner, a representative of the World Jewish Congress in Switzerland. Then Undersecretary of State Sumner Welles had asked Wise to keep the information under wraps until it could be corroborated. More than three months passed before Welles finally confirmed the facts, and Wise has been harshly criticized for the delay. "How was he not driven mad by this secret?" wrote Auschwitz survivor Elie Wiesel. "How could other Jewish leaders pledge silence? How is it that they did not cry out in despair?" But defying a State Department request would have meant alienating the one U.S. agency empowered to help with rescue, and Wise needed "official confirmation" in the first place. 91

It may be a measure of just how unimaginable the genocide was in the fall of 1942 that, at least according to Bergson and his chief lieutenants, even he and Samuel Merlin had at first refused to believe the initial stories. News of extermination had in fact been leaking into the mainstream media since the spring, when American journalists held in Germany since Pearl Harbor had returned with accounts of mass killings. In June, American newspapers had treated with skepticism a report of systematic annihilation because it came from the Jewish socialist organization of Poland, the Bund. Riegner's report had come from a German industrialist with access to classified Nazi files, but since 
Wise would be presenting the new information as chairman of the World Jewish Congress, he could expect no better attention. ${ }^{92}$

In the event, the press buried the story despite Welles' confirmation, and the government offered no support. Wise was pressured by R. Borden Reams, specialist on Jewish affairs for the European Division, to "avoid any implications" that the State Department had been his source, and officials were evasive when reached by reporters. When Jewish organizations had held a mass meeting at Madison Square Garden in July, Roosevelt had sent a message predicting that the Nazis would not succeed in "exterminating their victims any more than they will succeed in enslaving mankind." In August he had warned that the United States and the "United Nations" would hold the perpetrators responsible for their crimes, thus echoing a vow that both he and Churchill had made at the Garden. But though Roosevelt held two press conferences a week, he did not mention the Riegner report to the general public after Wise's press conference and was not asked. The Office of War Information likewise refused to publicize the news in early December. Weeks later, Hecht wrote a newspaper advertisement criticizing the silence titled "Ballad of the Doomed Jews of Europe," but Judge Joseph Proskauer of the American Jewish Committee convinced Bergson not to publish it. ${ }^{93}$

As Hecht later explained,

1942 went by, with startling news of the rounding up of the Jews of Paris by the Nazis. It was suppressed by the newspapers. The Polish Government-in-Exile found ways to signal its death toll to the world. Seven hundred thousand Jews had already been "resettled" (in Valhalla) since the German occupation of 1939. The news remained buried in the Black Books of Poland mysteriously delivered to my door. The Germans held the Wannsee Conference drawing up the blueprint of their "Final Solution." The Berlin papers proclaimed the completion of their plans. ... The American newspapers did not pick up these stories from their sources. ${ }^{94}$ 
"Hang and burn but be quiet, Jews!" Hecht had written in his ballad, "The world is busy with other news." 95 This failure to inform the public of the Final Solution amounted to a lapse in journalism fundamentals. The papers treated the Riegner report as if it was an unimportant development in the old story of Jewish persecution by the Nazis. Though the estimates of the dead during that latter half of 1942 were staggeringly high, such claims made by Jewish sources were given far less prominence than casualty figures pouring in from Stalingrad and the tallies of U.S. losses during this first year of war, at El Alamein, the Battle of Midway, and Guadalcanal. Over ten million Americans were under arms, and everywhere the war had been going badly.

Moreover, the Final Solution failed to register with reporters and editors because the concept made so little sense: Why in the midst of this ferocious contest of arms would the Germans be so intent on eradicating a minority population of non-combatants? What could possibly be gained? Newspapers offered various explanations — that the deaths were due to the privations of war, that those who died were serving in work battalions, that the Nazis were trying to deal with a potentially troublesome element. Lost amidst all of the data and theories was that a genocide was unfolding across Europe, setting a horrific new precedent in modern war. There was, as Deborah Lipstadt put it, a "chasm that existed between information and knowledge." 96 When it came to one of the biggest stories of the twentieth century, the American media had - to use the journalistic termburied the lead.

Hecht had no tolerance for such obliviousness. "Our writers fill their columns daily with intrepid denunciations and exposures of tweedledum-tweedledee political confusion in the world," he wrote in February. "But of this overthrow of the basic 
concept of life, of this plunge into the ways of savagery, of this great backward step into massacre, they speak almost not at all." Years later, in writing about another blunder of the press - their obliviousness of Zionist "perfidy" during the war-he was slightly more understanding: "I have no criticism of these or any other newspapermen. I was once one of them. I remember my own addleheadedness, blindness toward truth, deafness for its words. My sins were not purposeful. I did not draw my pay as a philosopher or seer. My duties were to report the obvious, to echo the loudest and most important voices. Since these were always the voices of virtue and authority, I was their nimble press agent." ${ }^{\prime 97}$

Yet another obstacle confronting the Bergson committee was the attitude of two Jewish publishers of major newspapers: one more thread, similar to that of the Jewish Hollywood moguls, in the tragic tale of American media and the Holocaust. While New York Times publisher Arthur Hays Sulzberger refused to treat the extermination of Jews as a major story, Washington Post owner Eugene Meyer staunchly objected to any special effort at rescue and became a fierce opponent of Bergson and his followers. In early October 1944 the Post would run a series of articles attacking the group as illegitimate and unscrupulous. The paper admitted error ten days after the first story appeared, publishing a lengthy editorial that retracted most of the allegations and providing Bergson page-one space to present his side. But when U.S. Solicitor General Fowler Harper had sent a personal letter to Meyer objecting to the stories as vicious slander, the publisher replied that the group's demand for rescue constituted "harassment" of a president who was focused on winning the war. Meyer added that he did not believe "it is necessary for any pressure group, however well meaning, to devote its time and money to the business of 'molding American opinion' on this subject." 
Had it not been for Hecht, news of the Final Solution would also have been virtually absent from mainstream American magazines. While The New Republic and The Nation issued loud protests in December, these were liberal publications with relatively small readerships. Time, Newsweek and Life limited their attention to a brief mention of a UN statement of condemnation, relegated to the back pages. Hecht's "The Extermination of the Jews," which drew from Greenberg's reports and announced that six million would die, appeared in American Mercury in February, while a condensed version appeared in Reader's Digest that same month under the headline, "Remember Us." The articles constituted the only substantive coverage to appear in mass-circulation magazines. ${ }^{99}$

Ben-Ami later recalled that during the fall there had been heated debates about whether to pull back on the Jewish army campaign and concentrate instead on rescue. But when Wise had made his announcement, the committee shifted course. Twelve days later, on the first anniversary of Pearl Harbor, it published "A Proclamation on the Moral Rights of the Stateless and Palestinian Jews," a full-page advertisement in the New York Times that publicized the extermination and drew a link to the committee's proposal for a fighting force. Van Paassen's text was accompanied by 1,500 signatures and an illustration by Szyk showing a Jewish soldier, brandishing a machine gun, rising above a heap of shackled and bleeding victims. On February 8, the committee made the call for rescue explicit with the headline, "ACTION_NOT PITY CAN SAVE MILLIONS NOW!"100

Newspaper advertisements were a start, but the feeling was that something on a much grander scale would be needed to pierce the silence. At a strategy meeting in January, Hecht struck on the idea of staging a historical pageant - a form of theater 
devoted to civic purpose that had been popular with Americans, and American Jews in particular, since the late nineteenth century. In recent years, the flamboyant Zionist impresario Meyer Weisgal had set the standard for spectacle, first with The Romance of a People, his 1933 Chicago extravaganza involving some 6,000 actors, singers and dancers. The Eternal Road, a 1937 follow-up effort produced in response to the rise of Nazism, had featured 245 actors and 1,772 costume changes, all operating on a five-tiered stage with a choir six stories above the ground, twenty-six miles of electrical cable and $\$ 60,000$ worth of lighting. To enlarge the space of the New York Opera House, the contractors had "- - like Moses — hit rock and then water," flooding the theater and bringing the already chaotic rehearsals to a standstill. ${ }^{101}$

Hecht used his Hollywood connections to create a Cecil B. DeMille-like cast-ofthousands aesthetic that would top even this. The ninety-minute performance, produced by Billy Rose, directed by Moss Hart and scored by Kurt Weill, was a journey from biblical to modern times featuring somber but striking stagecraft on an immense scale. The cast of nearly five hundred included as its narrators two stars of the early gangster movies, Scarface's Paul Muni and Little Caesar's Edward G. Robinson, as well as Claude Rains, Frank Sinatra and some three-dozen other major and upcoming celebrities. Along with two hundred rabbis and Yeshiva students, a choir of fifty cantors and an equal number of players from the NBC Symphony Orchestra, they performed in front of two forty-foot tablets inscribed with the Ten Commandments and, suspended above, a glowing Star of David. "The aesthetic principle of the spectacle was this: more is more," noted the cultural historian Stephen Whitfield. ${ }^{102}$ 
The purpose was both to stir the conscience of American Jews and raise public pressure for rescue, but We Will Never Die also represented a return of fire in the war of propaganda. The Nazis had their own tradition and mastery of public mythmaking through spectacle. The Nuremberg Rallies, held from 1933 to 1938, had drawn a cast of hundreds of thousands from all parts of Germany and featured sound and lighting effects, martial music and elaborate presentations of flags and standards. At these and other events, Hitler and Minister of Propaganda Joseph Goebbels declared "world Jewry" the archenemy of Germany. ${ }^{103}$

While planning the pageant, Hecht thought he saw another opportunity to raise public awareness when he was invited to join thirty famous writers for dinner at the apartment of his friend George Kaufman, the playwright and New York Times drama critic. "All had written hit plays or successful novels," he later recounted. "Put their names together and you had the box-office flower of American culture. In addition to success, wit and influence, they had in common the fact that they were all Jews." Together, "they could command the press of the world." With the consent of Kaufman's wife Beatrice, Hecht addressed the guests as they sat for coffee in the living room. If we all spoke out against this slaughter, he argued, we might make a difference. He was able to recruit Moss Hart and Kurt Weill, but otherwise, his speech was met with a stony silence. One by one, the guests got up to leave. "I'm sorry it turned out like this," Beatrice said. "But I didn't expect anything much different. You asked them to throw away the most valuable thing they own—-the fact that they are Americans."

Because Hecht did not completely grasp Hitler's logic, he could not have fully appreciated the challenge that his own panorama of Jewish history would soon offer to 
the narrative of hate broadcast by the Nazis. He had told Kaufman's guests that he "felt certain that if we banded together and let loose our talents and our moral passion that we might halt the massacre...Consider what would happen to the Germans if they were to hear that their crime was sickening to the world! If a roar of horror swept the civilized earth and echoed into the land that was once Goethe's and Beethoven's!"105

This argument might have held true if Hitler's grip on power had been far less secure, as it had been in the early ' 30 s, when he was struggling with the Depression and Jewish activists had organized an anti-Nazi boycott. But now a loud cry of protest could have no such effect, not only because the armies of a newly ascendant Germany were sweeping across Europe, but also for reasons that, at least in the longer run, gave Hecht's pageant resonance. For although Hitler and his inner circle imposed a strict silence about the details of extermination, the Nazis were not so much denying the Final Solution as weaving their own story, presenting their assault on world Jewry as an integral front in Germany's broader battle. Indeed, after the invasion of the Soviet Union, it became "a means of rallying the German people to continue fighting," observed historian Richard Evans. ${ }^{106}$

On February 24, Hitler repeated for the sixth time his chilling "prophecy" to the Reichstag of January 1939, when he had warned that should international Jewry plunge the nations yet again into world war, the Jews of Europe would be annihilated. Like other conspiracy theorists, the Fuhrer believed he had uncovered the hidden truth behind world events: that the Jew, master of mimicry and deception, wizard of finance and media, was the unseen puppet master controlling Roosevelt, Churchill and Stalin. Since the summer of 1941, Hitler and Goebbels had spoken of extermination bluntly and often, but as a war 
of defense against an archenemy that was bent upon global domination. This paranoid fantasy, in which the Nazis viewed themselves as saviors to the world, was the Weltanschauung that Saul Friedlander has referred to as "redemptive anti-Semitism"the driving force behind the Holocaust. ${ }^{107}$

In vivid contrast, We Will Never Die would make the case for rescue by presenting the Nazi genocide as an assault on humanity itself:

First narrator: There were many civilizations already in the world; many heroes and philosophers had already entered history. But in the record of man's rise out of the fogs of savagery, there was still one page empty. It was on this page that the little tribe of shepherds and farmers beyond the Jordan wrote their creed - the creed that was destined to change the soul of man.

They wrote that the soul of man had not come from the beast, but been given him by God. They wrote that above all the greeds and lusts in the human soul stood goodness, righteousness and justice. They wrote that the destiny of man called him to serve this mighty creed, to serve it above all the other powers on earth. Writing thus on the empty page, this little tribe put down the words of a battlecry that has never ended, and of a dream that has alone survived all the debacles of history...

Second narrator: Today in the dark lands of Europe, the Germans are threatening to destroy the creed written by Abraham, and that now belongs to the whole world. ${ }^{108}$

The pageant thus spun a narrative that would live on in collective memory, portraying the Jewish triumphs of genius and saga of persecution and survival as a universal history. Once again, Hecht embraced paradox: He did not abandon the themes of strength and gallantry trumpeted in the Jewish army campaign, but rather, in three acts, presented the Jew respectively as symbol of world conscience, as its heroic warriordefender, and as martyr. "Our delegation came back to Nyack several times... watching in fascination as Hecht's abstract ideas gradually materialized," remembered Ben-Ami. "Hecht immersed himself in research, delving into Jewish history and lore with a 
vengeance, as if to punish himself for all the years during which he had ignored his heritage. $" 109$

While rehearsals were underway in mid-February, the New York Times reported that the Romanian government had offered to transfer 70,000 Jews from concentration camps in the Transnistria region to any place of refuge that the Allies chose, in return for the cost of transportation. Hecht seized on the news to unleash fury at British and American inaction, with an ad three days later that announced, "FOR SALE TO HUMANITY: 70,000 JEWS, Guaranteed Human Beings at $\$ 50$ a Piece.” The ransom, which was not the first to be demanded by an Axis country and would not be the last, was in fact higher—scholars have cited figures of between $\$ 350$ and $\$ 1300$ per refugee. Moreover the offer had been made by shadowy intermediaries, the Romanian government had made no guarantees, and the Nazis were opposed to any Jewish emigration to Palestine. In any case, the Allies balked. The British Foreign Office expressed deep skepticism that the proposal was genuine, dismissing it as Nazi blackmail. Welles concurred: "The probable actual source is the German propaganda machine which is always ready to use the miseries of the people of occupied Europe in order to attempt to create confusion and doubt within the United Nations." 110

Along with the oft-cited concern that Axis spies could be slipped in among refugees, the threat of Nazi propaganda had by now become a familiar argument against aid to the Jews: It had served to justify the White Paper as well as its strict enforcement, which cast shiploads of desperate Jewish refugees back to sea. When Samuel Merlin announced Hecht's pageant within weeks of the Romanian flap, the State Department's Near East specialist Wallace Murray urged his superiors to block the event in order to 
prevent its exploitation by the enemy. "Since European Jews were not universally popular," observed historian Richard Breitman, "and since Nazi propaganda featured alleged ties between international Jewry and the Allies, Washington saw little to be gained militarily or politically in assisting the most prominent victims of nazi persecution. ...Western humanitarian values were unable to prevail over the anti-semites and pragmatists who stressed the risks of giving evidence to support German charges. To a remarkable degree, Adolf Hitler had succeeded in devaluing the lives of European Jews in the eyes of the rest of the world." In other words, Hitler was writing the script. As Hecht's narrator would lament in We Will Never Die: "It is the cheapness of his death that gives the Jew... a bad name."111

The furious reaction of American Jews to Hecht's latest newspaper ad — not at their government, but at him—offered yet another vivid display of a characteristic fractiousness. Weeks earlier Hecht had tried, and failed, to gain the support of nearly three-dozen Jewish organizations for the pageant. Meeting with leaders at the Algonquin Hotel, he had read aloud from his script, moving many to tears, but as soon as he had finished and invited a response, old grudges between his guests boiled to the surface. "Within five minutes a free-for-all, bitter as a Kentucky feud, was in full swing," he recalled in Child. He retreated in disgust to his bedroom, where the antagonists stepped in one by one to bid farewell and wish him luck. This squabbling was an old trouble, they explained apologetically. ${ }^{112}$

To his dismay, the pageant "unleashed a new Jewish battle cry... 'Down with Ben Hecht."' In cities across the nation, he became a target along with rest of Bergson's Committee for a Jewish Army, which was denounced as a Revisionist front with no roots 
in the American Jewish community, no mandate, and no claim to legitimacy. For the thousands of Jews who belonged to the World Zionist Organization or the American and World Jewish Congresses, the basis for complaint was that they elected their leaders, whereas the Revisionists had eschewed the democratic process since seceding from the WZO in 1933. This issue was paramount to Rabbi Wise, Ben-Gurion, Weizmann and their supporters, because it was through elections that such organizations embodied the liberal-democratic principles of modern Jewry. "In whose name do you dare to speak and whom do you represent?" Wise had demanded of Bergson. He and his fellow Irgunists were viewed as irresponsible renegades whose cheap, inflammatory publicity stunts risked scuttling any real chance at rescue. Their efforts to conceal their Revisionist roots only made them seem shadier, as they appeared to be cynically exploiting the cataclysm in Europe for power and financial gain.

The American Jewish Congress had long been planning an event at Madison Square Garden, but it had been postponed several times. Under Wise's leadership, the American Zionist Emergency Council had been exhorting its members to challenge the Bergsonites on the local level since early in the year, and his decision in mid-February to hold the "Stop Hitler Now" rally eight days before We Will Never Die's premiere was likely intended as a preemptive attack against the pageant. The Committee for a Jewish Army tried to bridge a truce, suggesting that the two groups combine forces. Hecht submitted his script for objections and Bergson even offered to drop the committee's name from the billing. But the overture was rejected, and Wise, who according to Hecht had made clear his disapproval of the script, unsuccessfully tried to persuade Gov. Thomas Dewey to postpone an official "Day of Mourning" until after the premiere. The 
furor that ensued over the show's tour became its own spectacle, and seemed to display a sad irony: The Nazis were slaughtering Jews for organizing a worldwide conspiracy, yet American Jews could not even cooperate on an appeal for rescue. "How could Jews," Hecht asked, "under a load of hate in the world, find time to hate each other?"113

Wise's tactics in New York, however, did little to dampen public enthusiasm. When 50,000 people came to buy tickets after the premiere had already sold out, the committee hastily organized a second, late-night show on March 9. Both performances drew crowds of twenty thousand - a record attendance for the Garden. Loudspeakers accommodated the overflow crowd outside, and the radio carried the broadcast. Weill's mournful overture, based on the Kol Nidre, cut through the chilly darkness to greet the throngs, punctuated by blasts of a shofar and then lilted by cantor and choir. Between the two giant tablets, an actor playing a rabbi emerged. Almighty God, he intoned, "We are here to say our prayers for the two million who have been killed in Europe, because they bear the name of your first children — the Jews." He quoted the prophet Habakkuk: "They shall never die though they were slaughtered with no weapon in their hand."

Muni and Robinson appeared downstage at right- and left-center podiums, across a platform that was likely about sixty feet wide. As they began to speak, the tablets filled with clouds, flames and shadows. "Roll Call," the first of the pageant's three original parts, offered a recitation of 119 Jews who had made historic contributions to the arts, sciences, philosophy and politics. As the names were announced, actors in black robes entered carrying candles, while behind them, the great faces from across the centuries appeared half visible on the tablets. "Jews in the War," the loudest and most colorful segment, honored those fighting for the eighteen Allied nations, naming the enlisted and 
the fallen with invocations of Bar Kochba and Barney Ross. The point it emphasized was that the Jews had no homeland of their own to fight for. ${ }^{115}$ The wrenching final episode, "Remember Us," culled from the tragic vignettes Hecht had used in his Reader's Digest article. As twenty girls dressed in white emerged from between the tablets, a voice offstage spoke for them:

The Germans took a hundred and six of us and brought us to a hotel. They gave us perfumes and white robes to put on. They told us that at nightfall they would take us to a brothel and that we were to serve the Germans there. We waited all day. We anointed ourselves with the perfumes and put on the white robes. And when the sun was setting we knelt and prayed and each of us poisoned herself and died. The Germans came but none of us went to the brothel. There were many other thousands like us. Remember us.

The doomed girls were the last to join scores of actors who had now filled the stage, representing the two million dead. They stood in the shadows, encircling a brightly lit peace table where three Nazis sat beside representatives of the Allied nations. The narrators now reappeared to bring the performance to conclusion. If the Germans fulfill their promise to deliver another four million corpses by Christmas, they explained, there will be no Jews left to sit at this table of judgment. "The massacre of two million Jews is not a Jewish situation," said the narrator. "It is a problem that belongs to humanity. It is a challenge to the soul of man."116

We Will Never Die played to packed houses in Philadelphia, Boston and Chicago, with a finale at the Hollywood Bowl in Los Angeles, garnering an estimated total attendance of over one hundred thousand. John Garfield, Burgess Meredith and Yiddish actor Jacob Ben-Ami performed as the narrators, and the California performance included a fourth scene, "The Battle of the Warsaw Ghetto." It must have been written after the 
Chicago show in early May, when the three-week-long uprising was finally smashed and the handful of survivors was shipped off to camps.

The Washington performance on April 12 was attended by Eleanor Roosevelt, six Supreme Court justices, Cabinet officers, some three hundred members of Congress, top military officials, and a large portion of the foreign diplomatic corps. In her "My Day" column, the First Lady extolled We Will Never Die as "one of the most impressive and moving pageants I have ever seen. No one who heard each group come forward and give the story of what happened to it at the hands of the ruthless German military, will ever forget those haunting words: 'Remember Us." Yet despite this strong endorsement, the column gingerly avoided any mention of the need for an Allied rescue policy. ${ }^{117}$

Her husband remained similarly silent. Billy Rose had asked Roosevelt for a supportive statement to read before the premiere, and Hecht recalled being asked to submit several versions of a brief statement that the president might read. "I toiled all night," Hecht later wrote, "determined to put whatever I had of talent, experience as a newspaperman and writer, and my soul's deep vengeance at the service of my brother Jews." But some time after dropping off the pages with presidential aide David Niles, a secretary came out with an answer. "'He said No,' said the secretary and, as in a Chekhov play, burst into tears." 118

The pageant succeeded in drawing considerable media coverage, but this in turn mobilized the resistance of various Jewish groups. In smaller communities like Buffalo, Niagara Falls, Baltimore and Gary, Indiana, letter and telephone campaigns vilified the Bergson Group and put local sponsors under pressure. The committee's approach of funding the tour through advance ticket sales became untenable. The result, noted one 
pundit for the Jewish Review \& Observer, was that "the most powerful single weapon yet produced to awaken the conscience of America" was stopped cold. ${ }^{119}$

Nevertheless, the committee's bold endeavor was not completely fruitless. Hecht exaggerated when he later claimed "the news and pictures of the pageant in the press were the first American newspaper reports on the Jewish massacre in Europe," but the sustained attention the show brought to the issue did help to prod change. While in December the New York Times had grieved that nothing could be done for the Jews, a March $3^{\text {rd }}$ editorial suggested the United States "set a good example" for humanity by loosening its immigration laws. Times columnist Anne O'Hare McCormick appealed to Christians to do their utmost for rescue, asserting that the Jew is the "symbol of what this war is all about." The same day, the New York Herald Tribune publicized the pageant with an editorial headlined "They Will Never Die." Though the paper had not yet pressed for action, it would do so shortly, as would the New York Post, The New York Sun, The Nation and others. Meanwhile, a New York Times reporter asked Welles at a March $3^{\text {rd }}$ press conference what plans the government had in mind "in the light of the mass meeting" held two days earlier. The State Department responded by attempting to show how concerned it had been all along, flourishing a note sent to the British on February 25 that suggested a conference on "the refugee problem."120

It soon became clear, however, that despite the glimmers of hope early that spring, the Allies were not going to budge on rescue. In his autobiography, Hecht recalled walking down Fifth Avenue with Weill late one night when the tour was over. "Actually, all we have done is make a lot of Jews cry," Weill had said, "which is not a unique accomplishment." ${ }^{, 21}$ 
The shift in public opinion that March may well have given Roosevelt a crucial push to establish the War Refugee Board, a decision he made nine months later that saved an estimated 200,000 lives. ${ }^{122}$ But it would perhaps be too much to argue that Hecht's grand burst of propaganda had succeeded in sparking change and altering history. In contest against the Nazis, the pageant had never stood a chance; measuring its impact against that of Nazi pageantry, for example, would hardly be fair, since Hitler commanded armies and the Gestapo as well as the vast resources of the Orwellian Ministry of Popular Enlightenment and Propaganda. The Fuhrer could orchestrate events as well as publicity, applying persuasion hand-in-glove with mass coercion. With blitzkriegs, deportations and massacres, the Nazis choreographed the fate of whole populations just as Albert Speer had choreographed the crowds at Nuremberg. Goebbels' ministry laid the groundwork for planned offensives, or seized on developments to weave narratives of its choosing.

Even so, such power had its limits. Hitler could achieve nothing unless public sentiment was already in his favor, which is why Goebbels stressed that the ability to control Haltung — observable behavior - required long-term investment in Stimmungsentiment, morale. Although there continues to be debate about the overall effectiveness of the Reich's propaganda, historians broadly agree about its success in stoking racial animosity. The trilogy of infamous films that included The Eternal Jew (1941), for instance, was able to exploit the deep-seated Stimmung of European anti-Semitism to trigger the Haltung of spontaneous pogroms, which erupted concurrent to the ones orchestrated by the regime. ${ }^{123}$ 
"I knew now that rhetoric was no better than tears for my 'Jewish Problem'- the rescue of the word Jew from the garbage can in which the Germans had dumped it," Hecht later wrote. "...I saw that propaganda was incapable of altering anything around it. It might incubate in time, it might mold the future. But it could only confuse the present or irritate it." This was essentially the same conclusion reached at the time by Yale psychologist Carl Hovland, Columbia's Paul Lazarsfeld and a clique of fellow communication scholars, who were researching media effects for the U.S. Army's Information and Education Division. Their evidence, gathered through newly refined empirical methods, would give rise to a new, post-war skepticism about propaganda's power. $^{124}$

Such research, however, did not purport to measure the effect of propaganda upon policymakers, who may have already been convinced of its power or-as more often appears to have been the case-found the threat of enemy propaganda to be convenient cover for their own agendas. Regardless of propaganda's actual potency, it became a significant factor, one way or another, in the fate of hundreds of thousands of Jews offered for ransom by the Axis after 1941. Their deaths were the consequence of what one historian has called "a fatal convergence of preferences: both the Allied governments and Adolf Hitler preferred the extermination of European Jews to any large-scale release of them into Allied hands."

Perhaps We Will Never Die is best understood as a valiant effort by a small tribe of hopelessly outmatched underdogs. But while the case can be made that it was largely responsible for the War Refugee Board, what, if anything else, did it accomplish? 
However tempting it is to argue that the pageant set a mold for a postwar Jewish identity, when the war ended, We Will Never Die quickly faded from public consciousness.

Nevertheless, its challenge to the ugly anti-Semitism of the Nazis at the time was itself significant. In the darkest hour of Jewish history, at a moment when American Jewry was helpless, fragmented and bitterly divided, Hecht drew from the past to popularize an affirmative narrative of his people for the generation that lived through the war. Most importantly, We Will Never Die was the first prominent effort to construct collective memory in response to the Holocaust — an event that in recent decades has been as central to Jewish self-image as it has been controversial. As the first of such efforts, Hecht's portrayal arguably represents an archetype, and so it's worth noting that he presented the Jew not only as a target of persecution, but also as voice and defender of world conscience.

Hecht had made an earnest appeal to humanity. This had been Hayim Greenberg's way, and Hecht had tried it, but as he later said, this was not his way. As the months passed and millions more died while his efforts continued in vain, he increasingly came to regard Allied inaction as criminal. By the time military victory had been achieved, the Nazis had met their goal of slaughtering another four million, effectively erasing the Jewish population of Europe. Hecht's frustration had by then simmered into bitterness, and soon thereafter, boiled into rage. 


\section{5. 'ONE OF THE GREATEST CRIMES IN HISTORY'}

Historically, no massacre was ever so unexpected, no act of cruelty ever so great that it violated the professions of a civilization... But surely there was never so much self-deception about our essential goodness or our dream of 'social security," so little philosophic (or moral) searching of the lies our hopes build on our lack of community, as there is today. ... Something has already been done, by us the bystanders and not just the Nazi killers-which can never be undone, except as we seek to understand it and to grow human again (or expectant or merely wise) through it.
Alfred Kazin, responding to the suicide of Shmuel Ziegelboim, "In Every Voice, In Every Ban," The New Republic, Jan. 10, $1944^{126}$

The first half of 1943 was a turning point in the war in more ways than one, a time of optimism as well as of fatalism. The German surrender at Stalingrad on February 2 ended five grinding months of attrition that decimated Hitler's entire Sixth Army and forced what would be an irreversible retreat along the Eastern Front. By summer, Allied troops had taken Sicily and were poised to attack the Italian mainland, while rolling, thousand-plane U.S. and British bomb raids burned Germany's industrial cities to cinders. It was becoming clear that the defeat of the Thousand Year Reich was only a matter of time, but increasingly, the total liquidation of European Jewry also seemed inevitable. ${ }^{127}$ With each passing week, the Allies grew more confident of victory while Jews plunged deeper into despair.

As We Will Never Die toured the nation, delivering its warning that the situation represented "a challenge to the soul of men," Hecht continued to hammer home the message, firing off opinion columns in early March to the Christian Science Monitor, the Los Angeles Times and elsewhere. In "Jewish Situation Less Complex" he observed that 
in solving the Jewish "problem" of Europe, Hitler had created a much bigger problem for the world:

To date, humanity has done almost nothing. Its indignation has been small. It has raised no sustained official voice. It has shuddered and taken matters for granted.... In fact, the German massacre of $2,000,000$ human beings without guns or sticks with which to defend themselves has been possible only because humanity has stuck its skull into a fog. Its nerve endings are apparently dead. ... We who have stood by silently at the overthrow of basic human reason and sensibilities have been honorary members of the German posse. ... Hitler is a back number-a sort of Typhus Mary ... The germs we are combatting are those of spiritual corruption that have burrowed deep into the soul of man. There aren't many Nazis in New York today. But there are a myriad of numb people with hearts deader than doornails. These are the new Jewish situation. ${ }^{128}$

Even many who did not agree with Hecht nevertheless saw the awful events of 1943 as a challenge to the soul of American Jewry. Discourse among Jews had always been rife with storm and stress, but 1943 set a new standard, and though Hecht and his cohort had vowed not to attack their own people, they found themselves the target of increasingly aggressive opposition. Few American Jews had been prepared for the dire choices they would face as a community, choices that would redefine the way they saw themselves and deeply alter their culture and politics. The year was as transformative as it was painful. By its end, with Allied victory all but assured and attention turning to what the world would be like after the war, American Jews had embraced the dream of a homeland as never before. But the fate of their fellow Jews in Europe had by now been sealed; whatever had been done could not be undone, and questions about responsibility would not go away.

In Britain, where public reaction to the Riegner report had been swifter and stronger than in the United States, officials had pressed for a conference on refugees 
since early winter. With American sentiment stirred by Hecht's pageant and by a series of rallies organized in March, the Allies announced they would convene a meeting to address the crisis within weeks. From the start, however, signs were not auspicious. The choice of Bermuda as a venue meant that wartime restrictions would prevent Jewish groups and journalists from attending. The State Department set ground rules to ensure that special attention to the plight of Jews would be strictly forbidden, as would any talk of using the United States as a haven. Moreover, the conference, which was to begin April 19 and last two weeks, would have no authority to make decisions; its purpose was to be purely exploratory. ${ }^{129}$

In the end, the participants suggested that an Intergovernmental Committee on Refugees, dormant since the Evian Conference of 1938, should be reactivated, but it soon became clear that this was a maneuver by the State Department and British Foreign Office to sideline rescue proposals. "Young Congressman Will Rogers Jr., one of the CoChairman bagged by Peter Bergson, ... tried to track the commission down," Hecht later recalled. "He quizzed Undersecretary of State Breckinridge Long about it. Alas, the Commission had no office in the United States, and, in England - no address." While the conferees also recommended establishing camps in North Africa to admit three thousand people, overall, the experts and officials reaffirmed that the problem of refugees would best be solved by speedy victory in the war. The Jewish representative Sol Bloom, one of two delegates from Congress, argued briefly that the Allies should try to broker deals for the release of Jews, but British and U.S. officials staunchly opposed any negotiations with the enemy. American papers gave cursory attention to the news of these proceedings 
provided by five wire service reporters, the only press allowed to attend. The official conference report was made classified. ${ }^{130}$

Seen as a display of utter indifference, the Bermuda conference crushed hopes of rescue. Its timing had coincided with the Warsaw Ghetto Uprising, which broke out on the day the conference began. Two days later, a secret Polish transmitter that started to report the battle cut off after four sentences. Its final words: "Save us." Then on May 12 in London, leader of the Polish Bund Shmuel Ziegelboim committed suicide to protest Allied callousness. In one of his final letters, he wrote that while responsibility for massacring the entire population of Poland lay in the first instance with the perpetrators, indirectly it is also fell on the whole of humanity, including the citizens and governments of the Allied nations, "which thus far have made no effort toward concrete action for the purpose of curtailing this crime. By the passive observation of the murder of defenseless millions and of the maltreatment of children, women, and old men, these countries have become the criminals' accomplices." 131

Hecht later remarked that between precedence given to the war effort, concerns about floods of refugees, fears of spies and an Arab uprising and the like, the governments had offered a "deadly alphabet of reasons" for doing nothing in particular to save six million people. While Rabbi Wise denounced Bermuda as "sad and sordid," and the Jewish press took umbrage after Bloom relayed that he was satisfied with its results, once again it was Bergson's Committee for a Jewish Army that kicked up the most dust. Its advertisement at the outset of the meeting called on "the Gentlemen at Bermuda" to take "ACTION—not "exploratory words." Another at the conclusion charged: "To 5,000,000 Jews in the Nazi Death-Trap, Bermuda was a 'Cruel Mockery.",132 
This blunt attack sparked outrage on Capitol Hill. Incensed that Bergson had used his name on the vituperative ad without his knowledge or approval, Senator Harry Truman promptly quit the CJA. Senator Scott Lucas of Illinois, who had been the other Congressional delegate at Bermuda along with Bloom, took the message personally. On the floor of the Senate he lashed out, emphasizing that Bergson was "not even a citizen of this country." Suspicions that the Irgunists were a group of foreign subversives had already been mounting and would prompt extensive FBI investigations over the coming years, as well as significant efforts to deport Bergson. Weeks before Lucas started raising questions, J. Edgar Hoover had submitted a memorandum to the Justice Department that identified Hecht and the CJA as Communists involved in political and financial racketeering. The memo cited as its source an executive from the American Jewish Congress, which suggests that Rabbi Wise had been the informant. True to form, Hecht relished the notoriety. "We were creating a new school of Jews in the U.S.," he later wrote, "one which refused to believe blindly in the virtues of their enemies in Democracy’s clothing.",133

Facing this impasse with officialdom and having exhausted — at least temporarily_his enthusiasm for newspaper advertisements, speeches and pageants, Hecht did not abandon propaganda but instead shifted gears. He spent the next several months writing Guide for the Bedevilled, a discursive but "stinging philippic" on antiSemitism intended to both spread a message and, through its sales, raise additional funds for Bergson's committees. 'I wanted to publish 'Guide' the moment I saw it, just on principle, and then very much more after I read it for its fire and power as literature," wrote Maxwell Perkins in January $1944 .^{134}$ 
Yet though Perkins, the legendary editor of Hemingway, Fitzgerald and Wolfe, assured Hecht that publisher Charles Scribner himself "was greatly taken" by the book, the firm printed such a paltry first run in March and allotted so little for promotion that Rose Hecht later surmised there had been interference by "Rabbi Wise, et al." The Bergsonites were nevertheless determined to make the book a success: Hecht financed additional advertising with his own royalties while the committee contributed several thousand dollars more. Within weeks, Guide had reached the top of the non-fiction bestseller list, and by September had sold 27,795 copies. Billy Rose, nicknamed the "pintsized Barnum" and "Midget Maestro" of Broadway by a generally genial press, had taken the reins of publicity and matched dollar for dollar the money raised, so that more than $\$ 100,000$ poured into Bergson's coffers. ${ }^{135}$

By way of preface, Hecht argued that the American goons and loons who hated Jews were less harmful than insidious racists full of false talk about tolerance and high ideals. One such, he suggested, was "a woman more famous than intelligent" who in discussing anti-Semitism with him over lunch, unconsciously revealed her desire to shift the blame for the murder of millions from the Germans to the Jewish victims themselves - "not all the blame, but enough to remove murder as a political issue." What is it about you Jews, she demanded of Hecht, that makes you so unpopular? "The picture came to me," he recalled, "of an angry policeman badgering a corpse for explanations of the crime committed against it." As she flung about humanitarian phrases, pacing across an elegant library stocked with the noblest works of modern civilization, he realized she represented a sickness spreading like the common cold: the quiet acquiescence of highminded, respectable people everywhere. Upon departing he resolved to write a book that 
would contain what little he knew of the Jews and the great deal he knew of their enemies. Many books had been written about the Jews, he said, but the anti-Semite - now here was a far more obscure and elusive topic. ${ }^{136}$

His title was a wry reference to Guide for the Perplexed, the oblique and mystical exegesis on Jewish law by the $12^{\text {th }}$ century rabbi Maimonides, exalted by many as the great visionary masterpiece of the Middle Ages and condemned by others as heresy. Hecht warned that his "guide" would be an exercise in thinking out loud. Investigating "twenty-eight hundred years of unreason," would undoubtedly lead down countless blind alleys and into many thickets of contradictions. At times, continuity would seem altogether absent. "I may seem to be running backward," he wrote, "or to have stopped moving entirely, or to have vanished with a squeak down a rat hole." Such confusion, he predicted, will make excellent fodder for critics. ${ }^{137}$

About this he was not wrong. "It may very well be that what we need is a good lusty sense of outrage implemented by a vocabulary that could easily burn the paint off a fire truck passing on the next block," observed Norman MacDonald of the Boston Herald. But though MacDonald and others gave Hecht high marks for his saucy, entertaining prose, and the Jewish papers - which viewed the book as a kind of mea culpa for A Jew in Love - were virtually unanimous in their praise, critics were less impressed by the quality of Hecht's analysis, and Guide did nothing to dispel his image as a lowbrow Hollywood hack. In one of the few reviews that was unequivocally negative, Selig Greenberg of the Providence Journal wrote: "Mr. Hecht, who is known for his smart-aleck cynicism, here dons the mantle of the prophet crying in the wilderness. The unwonted attire fits the repentant cynic poorly, and his peroration is a 
hodge podge of vitriolic polemics against anti-Semitism, of autobiography and rambling philosophizing often bordering closely on the hysterical."138

Greenberg's remarks anticipated the reputation Hecht garnered over the succeeding years, as his rhetoric grew more vitriolic, for radicalism full of sound and fury and little substance, a reputation that would ultimately doom Guide for the Bedevilled to obscurity. This disdain was to become particularly prevalent among the set of mostly Jewish critics later known as the New York Intellectuals, who had achieved great cultural and political influence by the early ' 50 s. Somewhat typical of their antagonism was Louis Berg's slashing review of Hecht's memoir for the October 1954 issue of Commentary, "Brat of the Century," which described the author as "a word-slinger rather than stylist, master of invective rather than wit, poetaster rather than poet, crackpot philosopher and calculating crackpot, romantic cynic and cruel sentimentalist, third-rate Mencken and fifth-rate Rochefoucauld."139

For detractors such as these, well-versed in the intellectual discourse of their day, little of what Hecht was saying in 1943 was new, and that which was new seemed either half-baked, or offensive, or more than a bit of both. Several respected thinkers had already been warning for more than a decade that the Nazis' attack on Jews represented a threat to modern civilization. Among them had been none other than Rabbi Stephen Wise, who as far back as 1934, while Hecht was still stewing in the self-hatred of $A$ Jew in Love, had written: "The Jew has been a light to the nations, yet he is doomed to darkness. ... The truth is that Hitlerism is the business of humanity. The truth is inevitably borne upon us who have come to see certain things: ... what we have cherished as the values and standards of civilization are being broken down (and) ... the racial fanaticism 
of the Hitler Reich may be a most immediate and deadly peril to us Jews, but it is no less truly a threat and a danger to all races and to all nations." 140

What was new in Guide for the Bedevilled was something rooted in a Chicago reporter's cynical view of the human psyche and dark fascination with criminal psychology. As the most complete expression of Hecht's worldview during the 1940s, it remains important, not only in ways that reflected contemporaneous and future responses to Nazism, but also to the degree that his propaganda drew the contours of American postwar debates about Israel, and international politics and war more generally.

What liberals like Wise saw as a mortal threat to civilization, Hecht regarded as symptomatic of mankind's psychopathology. To make the point, he turned in the first instance to one of the lead architects of the Enlightenment. "Jew hatred was the odd hobby of this Prince of Reason—Voltaire," Hecht observed, "just as a master detective might practice murder on the side." How could such a friend of man, such a champion of rational behavior, tolerance and justice, have harbored such swaggering and irrational hatred? "Where, in God's name," Hecht posited, "was his reason?" The answer, he argued, involved a basic truth about reason that Voltaire never recognized, a point that could be no better illustrated than by Voltaire's own bigotry. ${ }^{141}$

The great French philosopher had failed to understand what Shakespeare and other poets and storytellers of the ages had always known: that man's thinking can never be divorced from his passions_-from his loves, jealousies, and hatreds. Voltaire's assertion, for example, that "prejudice is opinion without judgment," revealed not only his own confusion, but that which has bedeviled much of the world ever since. "This statement says that our souls can be purged of evil by the attentions of a schoolmaster," 
Hecht asserted. "It says that we are evil because we have not been exposed to enlightenment. It says that our passions can be arranged into... order by the application of external logic — knowledge. It says that error exists because truth has not been offered in exchange. It says that the prejudices which fling us into stupid, silly or barbarous behaviors are no more than an absence of judgment."142

Back in the era of The Front Page, Hecht had raised similar arguments against the notion of journalistic objectivity, the belief that a reporter need only cast aside personal feelings and biases in order to attain a higher truth. Such thinking represents an ignorance, Hecht maintained, not only of what literature has to teach, but of psychology as well. And without psychology there is no more insight and understanding "than there is history without bloodshed." Voltaire himself had proved that anti-Semitism "can thrive as virulently in the most acute and enlightened mind as it can in the darkened thought of fools."

Hecht did not altogether discount the link between reason and tolerance, but he suggested "true prejudice is an inner unreason as necessary to us as our outer reasonableness." As the externalization of our own weaknesses and sore points, it fulfills a deep need. Projecting blame for our shortcomings upon an invented enemy allows us to excuse and even flatter ourselves. Prejudice empowers us, gives us absolution; "it is our ruse for disliking others rather than ourselves"; it enables us to imagine that we can impose order on forces that would otherwise be out of our control. "It is into this dark place that the word Jew has fallen," Hecht concluded. "It has become a word, not of historical or religious meaning, but a symbol of obsessions - one of the mystic forces by which men are able to outwit their own insufficiencies."143 
By the same logic, the crime of murdering Jews holds special allure. In visits to the Cook County Jail as a young reporter, Hecht had met many a killer driven by a profound dissatisfaction with his lot in life, by a feeling of defeat that burned deep in the gut like an ulcer. The typical anti-Semite was much the same. "His need is to be lawless," Hecht explained, "to break the laws of logic, sanity, and good behavior, behind which he is hemmed in, bogged down and mousey." Through the act of homicide he shatters these manacles, and in that moment of bloodletting, feels free and empowered, "as happy as a felon who has broken jail." But unlike other criminals, such as the thief or gangster, the butcher of Jews need not forfeit social status to experience the thrill of the outlaw. He can remain a respectable citizen. "Anti-Semitism is the one crime for which there is neither a court of law nor bar of human judgment," Hecht asserted. "It is, therefore, the most popular of crimes." ${ }^{144}$

To explain Nazism, he simply attributed this pathology to the whole of Germany, a view reinforced by his own experience there as a foreign correspondent during the grim days of 1919. He had at first found Germans to be polite and cultured, he recalled, but the sight of two thousand men, women and children cut down by machine gunfire in Moabit Prison opened his eyes to "a layer of barbarity in the German soul," a "talent for cruelty" upon which they would soon build an empire. Germans were "pig-eyed," "fat-necked," "backward" and slavish, gnawed at by an age-old inferiority complex that had finally turned them into depraved killers. He suggested that upon their defeat in the war, they should be fenced in and declawed, kept in a kind of "Nazi zoo" where they could be studied as criminals for whatever they might teach about abnormal psychology. ${ }^{145}$ 
It was this tirade against the Germans, which carried on for forty pages, that most baffled and repelled the critics. How could an author first announce his book as an attack on prejudice, and then exhibit such grotesque prejudice himself? True, he made room for exceptions, noting two Germans who were his heroes - the liberal crusader Hugo Haase and painter George Grosz - and likewise discussed a self-hating Jew whose antiSemitism had been as virulent as Voltaire's. He had also warned from the start that he would "blunder into contradictions that a child of four (let alone a critic) will be able to spot in a twinkling." Perhaps he was only illustrating that he was as human as anyone else, and therefore just as governed by unreason. All such considerations, however, hardly mollified the reviewers. Elmer Rice judged the book "A Pitchfork with Prongs at Both Ends." Harold Rosenberg wrote that in Hecht's sweeping condemnation of mankind and of Germany, he solved the murder not by apprehending the perpetrator but by "locking up everybody in the neighborhood."146

Hecht boasted that he was first and last a journalist, not a scholar. ("There are too few mariners and too many geographers.") But though his barrage against Germans may have been crude and intemperate, the question of the average citizen's culpability would endure as a core debate about the Holocaust. Even the great humanitarian Stephen Wise would write: "No crimes of the men, who later were hanged as criminal war-makers, seemed terrible enough to disturb the...conscience of the German people... as long as there seemed the faintest hope of winning the war. The penitence that comes after defeat is not penitence." A half century later, historian Daniel Goldhagen reignited the dispute with Hitler's Willing Executioners, a publishing phenomenon that created extraordinary commotion in Germany just as the nation was adjusting to reunification. ${ }^{147}$ 
Guide for the Bedevilled was in fact packed with theories that would be examined and hotly contested for decades. Hecht's explanation for Nazism as mass psychosis may have seemed simplistic, phrased as it was in his customary journalese, but it essentially conveyed the premise of Erich Fromm's pioneering 1941 book of political psychology, Escape from Freedom. And decades before Americans had heard of Adolf Eichmann, Hecht offered his own take on Hannah Arendt's "banality of evil," imagining "the little German burgher at his desk, receiving reports of another seven thousand Jews run over by lorries (this money-saving device was thought up by a German general in Romania)... and entering (the reports) in a book as fastidiously as any accountant." Like Arendt, Hecht argued that evil need not be committed by raving monsters like Hitler, that it was more often perpetrated, with devastating effect, by ordinary, imbecilic little burghers like Eichmann. He added that it was precisely their ordinariness and imbecility that made them dangerous. ${ }^{148}$

But most important, in terms of Hecht's own subsequent turn towards militancy, was his emphasis on the criminality of the Final Solution, which anticipated the rhetoric that would thereafter come to the fore on matters of war and peace —of "international law," the "laws of war," "war crimes," and "crimes against humanity." He predicted that once peace had been declared the Allies and Germans would fondly embrace each other like exhausted boxers at the end of a match, and all would be forgiven. His prophecy proved mostly correct: Only a small percentage of the top Nazi war criminals were ever prosecuted, and as recently declassified documents have verified, the CIA recruited some as spies against the communists while keeping quiet about the whereabouts of others, including Eichmann. ${ }^{149}$ 
The events of the summer of 1943, which Hecht spent writing Guide for the Bedevilled, affirmed his darkest thoughts about the world, except for a major development in his personal life that flew in the face of his cynicism: the birth, on July $30^{\text {th }}$, of his daughter Jenny. Three days later he wrote a poem to her that became the epigraph for his book.

...What a difference appears to all the world when I look on my daughter, newly born.

Where is the world gone that has lost her face?...

The Bergson Group, meanwhile, spent the early part of the summer organizing the Emergency Conference to Save the Jewish People, a six-day affair attended by fifteen hundred participants that convened on July 20 at New York's Commodore Hotel. The American Jewish Congress and other organizations charged that the conference's goal of formulating a rescue program was redundant: At the March 1 rally, on the eve of Bermuda and again in June, they had presented versions of a plan that called for negotiations with the Axis, liberalization of immigration laws, establishment of safe havens, and other measures that were beginning to gain broad support. The recommendations of the Emergency Conference were indeed similar to the ones presented early in the spring but, along with the proposal in June, differed in one respect: They called for reprisals and punishments against Nazi war criminals. ${ }^{150}$

Moreover, the conference served to keep the issue of rescue in the headlines, and conveyed a pointed message. "We wanted to challenge the 'Let's win the war first' notion," Alexander Rafaeli recalled in his memoir, "as well as the impotence of the Jewish establishment, busily involved in a 'love affair' with the American president." Three major resolutions were to emerge from the proceedings: first, that the annihilation 
of Europe's Jews should be considered a separate problem from the general concern about refugees; second, that rescuing four million Jews need not interfere with the war effort; and third, that the Allies should create an independent agency devoted to the purpose. $^{151}$

Now re-branding themselves as the Emergency Committee to Save the Jews of Europe, the Bergsonites were beginning to criticize Roosevelt directly. They were nevertheless surprised by the politically partisan response to their call for a conference, a response that, in any case, far exceeded expectations. "When we approach an honest man, if he is a Republican, he will accept our offer and join us," observed Eri Jabotinsky in an early July report. "If he is a New Dealer, however, he will be sympathetic, but as for joining us and lending us his support, he will first ask 'somebody in Washington,' with the result that we will receive from him a beautiful letter expressing his sentiments and his regrets at not being able to participate because of a sudden trip to the West Coast."152

When Max Lerner, who served as co-chair of the event, telegraphed Secretary Hull and Roosevelt for an endorsement, he received a curt reply that the State Department was already doing all that it could. Stung by this rebuke from a president he had staunchly supported, Lerner published a July 22 editorial in PM provocatively headlined, "What About the Jews, FDR?" Once again the Bergson Group fared little better with the First Lady, who declined her invitation to the conference. She encouraged the effort to develop a plan, but expressed skepticism that anything more could be done.

Since she nevertheless offered to help in any way that she could, Bergson followed up in mid-August with a request for an encouraging message to be broadcast to the Jews of Europe by the Office of War Information. In a brief statement she extended 
her sympathies and expressed hope that the Jewish people would continue to fight for their existence, but repeated that the best way for America to save lives was by winning the war as quickly as possible. Bergson had also asked her to hand the president a copy of the conference's findings and recommendations. Days later Roosevelt returned the document to Eleanor's assistant with a note that said, "I do not think this needs any answer at this time. FDR."153

Hecht later wrote that he had remained an ardent admirer of Roosevelt, like millions of American Jews, even though Bergson had admonished that the president held a pact with the British to keep the Jews locked away in Europe and therefore out of Palestine. Hecht still stayed loyal, despite the government's lack of support for his pageant, its refusal to negotiate over the fate of the Romanian Jews, and its foot-dragging in general. Nevertheless, he recalled that he had never felt much affinity for the New Dealers, with their fine but empty talk about the woes of the Common Man, lynchings of Negroes in the South, and other conditions that never seemed to change:

On the whole, I fear I was a churlish Liberal, to whom all political leaders of all persuasions seemed no better than gadget peddlers with their foot in the door, whining the sale of their wares. With the politician, the foot stays longer, the whine is louder and the wares on sale more worthless - himself.

Such 'Liberals' as myself are apt to be uncomfortable with a friend in power. We prefer an enemy on the throne - an arrogant creature who despises the rights of man, or some paranoid knight of unreason. ${ }^{154}$

Attacking Roosevelt ran the risk of alienating the many American Jews who were so famously devoted to the president, who voted for him in greater proportions than any other ethnic or religious group in the United States. The former governor of New York had surrounded himself with Jewish advisors and political allies; testaments to the close bond that Jews felt with the president were legion, from the well-circulated slur about his 
"Jew Deal" to an account of how he was greeted like Moses when campaigning in Brooklyn. Republican Judge Jonah J. Goldstein summed up the sentiment, lamenting that his co-religionists lived in three velten (worlds): die velt (this world), yene velt (the next world) and Roosevelt. But now that time was running out in Europe, Bergson became convinced the man most responsible for Allied inaction had to be confronted. When the tensions mounted in the fall, Hecht would eventually jump — with a loud splash—into the fray. ${ }^{155}$

The escalation began in August and September, when the committee intensified its lobbying and ad blitz, with headlines proclaiming that Europe's Jews were still "caught between hammer of the enemy's brutality and the anvil of democracy's indifference." Among the most caustic was Hecht's "Ballad of the Doomed Jews of Europe," which had been withheld in late 1942 at Judge Proskauer's request. ${ }^{156}$ At the same time the group partnered with two ultra-Orthodox organizations, Agudath Israel of America and the Union of Orthodox Rabbis, to organize a demonstration in Washington.

On October 6, five hundred rabbis chanting from the book of Psalms marched to Capitol Hill, where they read a petition for rescue to Vice President Henry Wallace and twenty members of Congress. Although coverage of the event was disappointing, it offered another display of Bergson's talent for publicity. The striking photo published in Time showed the rabbis with their beards and long black coats, staring tear-streaked to the sky in front of Wallace, who "squirmed through a diplomatically minimum answer" to their appeal. From there the rabbis proceeded to the Lincoln Memorial to pray for America's soldiers and a speedy victory, and then on to the White House. Despite the fact that the Emergency Committee had tried for weeks to obtain an appointment with the 
president, Bergson and four leading rabbis were met by his secretary, Marvin McIntyre. Speechwriter and aide Samuel Rosenman had advised that the group behind the petition did not represent "the most thoughtful elements in Jewry," so Roosevelt instead went off to Bolling Field to dedicate Liberator bombers for a Yugoslavian combat unit. "From the president's perspective," noted Richard Brietman in FDR and the Jews, "Bergson and his allies gave Jewish issues undue publicity and detached Jewish concerns from broader Allied priorities and principles." ${ }^{2157}$

For Hecht, the breaking point came weeks later, with the October $30^{\text {th }}$ "Statement on Atrocities" the president signed with Churchill and Stalin at the Moscow Conference. The declaration vowed punishment for the mass executions in Axis-occupied countries, but though it cited the slaughter of "Polish officers," "French, Dutch, Belgian or Norwegian hostages" and "Cretan peasants," it made no mention of the Jews. This especially rankled the Bergsonites, and Hecht in particular, given their emphasis on genocide as a war crime. ${ }^{158}$

Three days after the statement appeared, Hecht blasted Roosevelt with an advertisement that consisted of a fable, "My Uncle Abraham Reports..." The tale, which appeared above a reprint of the declaration, told of a ghost of a Jewish uncle killed by the Nazis, elected by two million fellow ghosts - the "Jewish underground"- to be their World Delegate at Allied conferences. Upon return from the Moscow meeting, Abraham tells his people that they were not named among the Nazi victims the three powers promised to avenge. When a "Ghost from the Lime Kilns of Warsaw" asks why this was so, Abraham cannot say. "We were not allowed by the Germans to stay alive," he replies. "We are not allowed by the Four Freedoms to be dead." Abraham then leaves for the 
White House to sit on a windowsill two feet from Roosevelt and await justice, but he has left his pencil and notepad at home. ${ }^{159}$

To the great satisfaction of the Emergency Committee, Roosevelt left no doubt that he had felt the blow. Eleanor told Bergson that her husband was very upset by the ad, which he had described as a strike below the belt. Bergson's reply kept faith with a key Hecht maxim: Never apologize. According to Hecht, the president's financial advisor Bernard Baruch telephoned two days after the ad appeared to ask for a halt to such broadsides. Baruch alluded to an important statement Roosevelt was planning to make on a trip to the Middle East, which raised Hecht's hopes for a call to open the ports of Palestine, or something similarly momentous. Bergson, Merlin and Ben-Ami were skeptical, but Hecht insisted that the criticism stop immediately. Nothing materialized, however, when FDR traveled to Cairo and Tehran in late November, and for Hecht the amnesty ended when the president returned from a trip to the region in March 1945 singing praises of Saudi Prince Ibn Saud, a vehement anti-Semite and anti-Zionist. ${ }^{160}$

While to Hecht, Roosevelt was just another duplicitous politician, an alternative view is that, like Abraham Lincoln, he was a man of vision who faced a staggering array of challenges, who had need of all of his considerable charm and political acumen to manage the competing interests and imperatives of war. In late July, the president had reconfirmed his prior promises to mete out justice on behalf of the Jews, when Wise had asked him to threaten reprisals against Nazi satellites such as Romania and Hungary if they continued to cooperate with Germany. "I intend again, on suitable occasions, to revert publicly on this subject, as I am sure the heads of other United Nations Governments will also do," he had advised. ${ }^{161}$ 
As for Roosevelt's record on Zionism, in May 1942 he had reaffirmed his longstanding support for a Jewish National Home, and then in a bid to outdo the Republicans in the 1944 election, ran on a platform that called for a free and independent commonwealth and "unrestricted Jewish immigration and colonization." Yet all along he had been approving drafts of anti-Zionist statements from the State Department, and after re-election gushed to Congress about his meeting with the Saudi prince, no doubt with America's oil interests and alliance to Great Britain in mind. "Over the course of more than a decade as president," Breitman notes, "Roosevelt sounded at times like a Zionist, at times like a skeptic about Palestine's capacity to absorb new settlers, and at times, when speaking to anti-Semites, like an anti-Semite himself." Nevertheless, Brietman contends, FDR's policies did the Jews more good than his dissembling and evasions did harm. ${ }^{162}$

"My Uncle Abraham" hit the newspapers at a crucial time, days before congressmen introduced bi-partisan rescue resolutions in the House and Senate on behalf of the Emergency Committee, and just as the conflict between the Bergsonites and "the Jewish establishment" was coming to a head. Since Bermuda, the Zionists and nonZionists had shifted away from rescue while stepping up their attacks on the Bergson Group, a course of action that has been a focus of speculation and heated debate ever since. By autumn the Bergsonites were facing the united opposition of the American Jewish Conference, an umbrella organization of more than thirty Jewish groups originally formed in late August when they had gathered to develop a postwar plan for world Jewry.

Rescue had been at the bottom of the agenda in August, which was why the two orthodox groups had abstained and joined with Bergson, but the summit turned out to be 
a watershed event for American Zionism. It exceeded the expectations of Rabbi Wise and other Zionist leaders who, in the hopes that it might foster a sense of fellowship that would eventually unify support for the Zionist program, had decided not to rush things by pushing a controversial resolution that called for a Jewish commonwealth. This miscalculation gave Wise's chief rival, Rabbi Hillel Silver, an opening to deliver an impassioned and defiant call for statehood. When Silver declared that Jewish homelessness was "the principal source of our millennial tragedy" and had led directly to the Nazi catastrophe, he brought participants to their feet, releasing the floodgates of pent-up frustration and anguish that had been building all year. Though the speech marked the start of a nasty contest for power between Wise and Silver for leadership of the American Zionist Emergency Council, the movement had been energized as never before. $^{163}$

This new coalition now mobilized to lift the blockade on Palestine, even as it opposed Bergson's resolutions in Congress. The Emergency Committee was deliberately trying to stay focused on the urgent need for rescue and keep the messy politics of Palestine out of the equation. When the Zionists demanded that the rescue resolution include a call to end the White Paper, Bergson was incredulous: "If you were inside a burning house, would you want the people outside to scream 'save them,' or to scream 'save them by taking them to the Waldorf-Astoria?","164

The resolution was sailing through the Senate, but in the House the loyal Zionist Congressman Sol Bloom held it up in hearings at the end of November. During the ensuing weeks of contentious testimony, Congressmen previously unfamiliar with Jewish factionalism were bewildered by all the sniping. One asked whether he was attending a 
hearing or an investigation; others questioned the advisability of linking the Palestine issue with "the present and immediate necessity of rescuing the Jews." According to resolution sponsor Guy Gillette, a fellow Senate committee member remarked: "I wish these damned Jews could make up their minds what they want. I could not get inside the committee room without being buttonholed out here in the corridor by representatives who said that the Jewish people of America did not want passage of this resolution."165

The American Jewish Conference's opposition culminated in a scathing attack on Hecht and the Bergsonites just before Congressional recess at the end of the year, and weeks before the Senate was expected to vote overwhelmingly in favor of the resolution. Taking aim once again at Hecht's "Guaranteed Human Beings at $\$ 50$ a Piece" ad, their December 29 press release recited the usual allegations of fraud and declared that Bergson's resolutions had been introduced in "complete disregard of the rescue program which is actively pressed in Washington by representative Jewish agencies.” Months later, Zionist leader Nahum Goldmann again demanded the government either draft Bergson or kick him out of the country, describing his efforts as "a gigantic hoax" perpetrated on well-meaning Americans that "had not resulted in the rescue of a single Jew or in the saving of a single Jewish life." At the same meeting with a State Department official, Goldmann relayed that Rabbi Wise regarded Bergson "as equally great an enemy of the Jews as Hitler."

The extraordinary circumstance of Jewish organizations uniting in late 1943 to defeat a rescue proposal has been explained in various ways. Historian David Wyman noted the Zionists reasoned they would only have one chance to introduce legislation on Palestine, an opportunity that would be squandered by these resolutions. Wise and his 
allies understood that time was of the essence, that the fluid conditions of the immediate postwar period would afford their best shot at Jewish statehood. Certainly another key factor was a paralyzing despair that gripped American Jews, especially after Bermuda. Yet historians sympathetic with the Zionists have argued their actions reflected a tough, realistic assessment of tragic circumstances. They recognized that the hour for wholesale rescue of Jews from the Nazi vice had passed, if indeed it had ever existed. What was needed now was a steely focus on the days to come, on securing the future survival of Jewry by ensuring that such a catastrophe could never occur again. ${ }^{167}$

In Wise's case in particular, such reasoning becomes more understandable when viewed within the broader context of efforts at rescue that spanned more than a decade with ever-dwindling success, which preceded Hecht's efforts but ironically bore many parallels to them. Biographer Melvin Urofsky called Wise "a voice in the wilderness" during the 1930s, and indeed no American had warned more loudly and consistently about Hitler. Though the rabbi never claimed to have foreseen the full horror that would one day unfold, he cautioned as early as December 1931 that Hitler's threats against the Jews must be taken seriously, while other Americans were dismissing the man as a ridiculous kook. In 1943 Hecht would theorize, incorrectly, that the Nazis might heed an outcry from abroad, but it had been true in the months after the Fuhrer first became chancellor in 1933, when Wise had led the American Jewish Congress in organizing a massive rally at Madison Square Garden. Together with the American Federation of Labor, the Congress staged "The Case of Civilization Against Hitlerism" in front of 20,000 “jurors." 168 
Just as Hecht would be a maverick, Wise had declared that "the time for caution and prudence has passed," breaking from the Congress' sister defense organizations, the American Jewish Committee and B'nai Brith. These two groups represented a large portion of the Jewish community Wise called the "Sh-Sh Jews," who blanched at such loud protest and called instead for quiet, behind-the-scenes appeals to the State Department. During the mid-'30s, he crusaded for an anti-Nazi boycott and worked to establish the World Jewish Congress, envisioned not only to protect Jews but also to represent their highest ideals. In both campaigns, he fought the opposition of those he referred to as the American Shtadlonim, or "court Jews," who lacked the mettle to face the crisis of Nazism squarely. ${ }^{169}$

But from the 1940s onward it was Wise who would be branded "a pitiful Shtadlan" by Hecht, the Bergsonites and later critics, for what they saw as blind obeisance to Roosevelt. Wise's detractors have pointed to the letter to the president that he sent a week after publicizing the Reigner report. "Dear Boss:" he had begun, "I do not wish to add an atom to the awful burden which you are bearing with magic and, as I believe, inspired strength at this point..." Even Urofsky, whose reverential biography of Wise is titled A Voice That Spoke for Justice, concluded: "His faith in the goodwill of Franklin Roosevelt was not only ill-founded, but would prove disastrous." And: "If there is one charge that can be sustained against Wise and the others, it is that they placed their trust in Franklin Roosevelt."

There were many differences that divided the Jewish establishment and the Bergsonites - the dispute over the Palestine issue being only the latest to be thrown into the mix — but clearly a key fault line was how to interact with the president at a time 
when national unity and patriotism were at such a premium. By late 1943, FDR had become the nexus for all points of conflict: Who had the right to speak for the Jews, whether Hecht's polemics were hurting or helping chances for rescue, and who could best lead the advance of Jewish statehood. Most significant, however, the dispute over Roosevelt represented a clash of ideologies.

"It's not a matter of what the Zionists believe," Hecht remembered Samuel Merlin explaining. “...Stephen Wise will not tolerate any other Jewish organization working for Palestine and stealing honors and publicity from him.” While Wise refuted this charge in the autobiography he completed just before his death, his disavowal is not wholly convincing: None of the Jewish leaders could have achieved their positions without highly competitive, egoistic natures. Debating Wise's character and motivation, however, distracts from the core issue: the very real and passionate battle over ideas that makes what would otherwise be just a tragic story of Jewish infighting so important to modern history. For just as the Jews loved Roosevelt, as Hecht observed, "chiefly as the symbol of a new American obsession called 'liberalism,"' Wise-a leading fighter for social justice who co-founded both the National Association for the Advancement of Colored People and the American Civil Liberties Union in 1920 - personified the liberalism of American Jews. ${ }^{171}$

Ever since Hecht had started writing for $P M$, he had inveighed against a so-called enlightened worldview shared by many of his fellow Jews that left them paralyzed and uncomprehending prey as the Nazi snake coiled itself around Europe. In 1942, Bergsonite Reinhold Niebuhr argued that some American Jews had refused to face the crisis because they dreaded recognizing "that the solutions provided by the liberal Jewish world have 
failed to reach the depths of the problem." These assertions suggest a judgment that later became a commonplace: that American Jewish leaders had been psychically unprepared for such an explosion of vicious hatred, and for a catastrophe of such magnitude to spread so quickly. The fact that it was occurring not in "backwards" Tsarist Russia but in "cultured" modern Germany had made it all the more difficult to accept. As Roosevelt said in 1938, "I myself could scarcely believe that such things could occur in a twentieth century civilization." 172

The inadequacy of the liberal response was arguably evident in Wise's misplaced faith throughout the ' $30 \mathrm{~s}$ in a world conscience that could be mobilized to save the Jews, in his ambivalence, as a committed pacifist, to American military intervention until as late as October $1941,{ }^{173}$ and perhaps also in his failure, as someone so engaged, to see where Nazism had been headed. It was arguably reflected in what would later seem sluggish, misguided, or even callous about the course pursued by American Jewry during the war. It was a difference in consciousness between those accustomed to the comforts and safety of the United States and the militant young Irgunists who grew up in Europe during the 1930s. Like Hecht, the latter group saw all of liberal democracy, from the president on down, as criminally responsible for refusing to aid the Jews or even offer them safe harbor. They regarded Wise, the rest of the Shtadlonim of the Jewish establishment and their followers as dupes who clung to respectability, rendered impotent by a fatalistic "ghetto mentality."

Yet Wise did not deny the failure of liberalism. In his memoir, he pointed to the Shtadlonim of the American Jewish Committee and other "self-appointed protectors of Jewish life," unwilling "to face facts and deal with them aright." Such cowardice, he 
explained, was "the very saddening confession of the failure of so-called liberalism as the solvent or panacea of human ills." He readily acknowledged this failure in pointing to the anti-Semitism of the State Department and the British. ${ }^{174}$

But in his view, liberalism was not a matter of ideology, or of choice. "Jews never were...liberals by expediency," he argued. "They understood, as we continue to understand, that Jews... have no place or future in an illiberal world." Through the years of genocide and afterwards, his refusal to abandon liberal principles took the form of his staunch loyalty to Roosevelt. ${ }^{175}$

By the same logic, Wise viewed Revisionism as "a stark surrender to the rightfulness of fascism." He saw the evidence of the Revisionist movement's undemocratic nature in its 1933 decision to secede from the representative body for Jewish statehood, the World Zionist Organization; in Betar's militarism and in the Irgun's use of violence; and, most recently, in the Bergsonites' irresponsible, inflammatory publicity campaign. "They were little more than hoodlums in his eyes," observed Robert Silverberg, "and the fact that they were dedicated hoodlums, pledged to the same sacred cause he served, did not matter."176

This clash of ideologies did not simply play out between Jewish leaders. It was waged over kitchen tables, at dinner parties, restaurants and reception halls, in conference rooms and on sidewalks outside theaters-everywhere that American Jews gathered. A fellow Bergsonite would later reminisce in a letter to Hecht: "Do you remember the back room of the Penthouse Club and the meetings at homes where the little pip-squeak socalled business tycoons of the ready-to-wear industry proclaimed their loyalty to our Allies the British, whose only intent was to avoid donations to our Cause? And how 
refreshing it was when you told them point by point the ugly truth of their cowardice and evasions? I remember very well kicking the ass out of one meeting of some 'American patriot' and his silly son.” According to pro-Bergson chronicler Louis Rapoport, the questions Hecht and the Emergency Committee raised about loyalty and patriotism touched a nerve for progressives like Wise, who found it difficult to concede any contributions the group might have made to the cause of rescue. The animosity of the Zionists, Rapoport suggested, revealed "a basic uncertainty about their Jewishness in American life, their simultaneous pursuit of Zionist and assimilationist goals." ${ }^{177}$

The Zionists and the Bergsonites were unaware of it, but tensions over rescue had been building for months within the Roosevelt administration. The dispute erupted at the end of 1943 in a dramatic confrontation that, on the one hand, seemed to affirm Hecht's worst suspicions about the criminality of government, and on the other, at last produced the policy changes that he and the Emergency Committee had been seeking.

In April, Wise had finally been able to obtain a two-page message from World Jewish Congress representative Gerhart Riegner that had been blocked by the State Department, outlining a plan to smuggle Jewish children out of France and Romania with assets that would be frozen in Swiss bank accounts until the end of the war. Despite approvals over the summer from Treasury and the president himself, officials in the State Department and Britain scuttled Riegner's initiative by holding up the transfer of funds for the rest of the year. The obstructionism continued until Treasury Secretary Henry Morgenthau wrote to Secretary of State Hull, noting with alarm that three and a half months passed since Treasury had signed off on "the relatively simple matter of getting 
our Minister in Switzerland to issue a license." When the British were finally candid about their objections in mid-December, American ambassador John Winant reported that the Foreign Office was "concerned with the difficulties of disposing of any considerable number of Jews should they be rescued from enemy occupied territory." Here, at last, was the truth: British and State Department officials had feared that a rescue plan would in fact succeed.

Stunned by the statement from London, Morgenthau's staffers appealed to him to take action. Randolph Paul, one of four attorneys on the staff most engaged in the issue, said: “I don't know how we can blame the Germans for killing them when we are doing this. The law calls it para-delicto, of equal guilt..." The secretary later characterized the statement as "a Satanic combination of British chill and diplomatic double-talk; cold and correct, and adding up to a sentence of death." But he knew that he had to tread carefully. The administration's opponents, he explained, would go after him not as secretary, but because "I have done something for the Jews because I am a Jew." Before approaching the president, he would have to at least try to confer with Secretary of State Hull and his staff, who were now expecting fallout from Winant's blunt telegram and were hastily backpedaling. ${ }^{178}$

Most nervous among them was Assistant Secretary of State Breckinridge Long, portrayed in many histories of the American response to the Holocaust as an arch villain, the major impediment to Jewish immigration and rescue initiatives. A blue-blooded nativist who served as chief policymaker on all matters concerning European refugees, Long began in the summer of 1940 to institute a maze of restrictions on visa applications that slowed the flow of immigrants to a trickle, even as thousands clamored for asylum. 
By mid-December 1943, however, he was already in hot water over his testimony to the House committee on Bergson's rescue resolution. Among the gross inaccuracies and misleading claims now leaking out from his closed-door session, most damaging was his implication that 580,000 Jewish refugees had been admitted to the United States since Hitler took power in 1933, an exaggeration of 250 percent. Moreover, the 165,756 Jews who had immigrated represented only a tenth of those who could legally have been admitted under even the normal quotas. ${ }^{179}$

Meanwhile, the Treasury attorneys were unearthing proof that for a year now, the State Department had been suppressing all the news it received about extermination. A key piece of evidence, the first news that officials had ordered blocked, turned out to be an urgent cable from Riegner sent in January 1943, which reported that the Germans were killing six thousand Jews a day in Poland, and that 70,000 Romanian Jews who remained alive — half of the original population—were in imminent peril. ${ }^{180}$

Over the Christmas holiday of 1943, Josiah E. DuBois, Jr. prepared an 18-page document that he titled "Report to the Secretary on the Acquiescence of this Government in the Murder of the Jews." He detailed the charges that Long had used the visa application process to shut the door on refugees and then had misrepresented the record in his testimony before the House; that he and other State Department officials had not only failed to attempt to rescue the Jews or to cooperate with private groups, but had instead used "government machinery" to prevent such efforts; and that the State Department had also tried to block the flow of information about extermination, engaging afterwards in deception to conceal their guilt. "One of the greatest crimes in history, the slaughter of the Jewish people in Europe, is continuing unabated," DuBois wrote. 
“...Unless remedial steps of a drastic nature are taken, and taken immediately, I am certain...that this government will have to share for all time responsibility for this extermination." ${ }^{, 181}$ When DuBois gave the report to Morgenthau, he said that if the president did not act, he would resign and take his findings to the press.

Morgenthau toned down DuBois' inflammatory title, replacing it with "Personal Report to the President," but retained the assertions that the State Department had earned a reputation for anti-Semitism, and that exposure of its conduct would set off a scandal. On January 16,1944 , the secretary and two of the attorneys brought it to the president, who asked for an oral summary. Morgenthau added that if Roosevelt did not move ahead with rescue plans, Congress might beat him to the punch by passing Bergson's resolution. The president, however, was well apprised of the political situation and needed little persuasion. He suggested some minor changes and then agreed to sign an executive order after a discussion that lasted only twenty minutes. On January 22 , two days before the Senate was scheduled to vote on the rescue resolution, FDR created the War Refugee Board with Treasury attorney John Pehle as executive director. ${ }^{182}$

Hecht saw the liberalism of the "Sensitive Souls" who supported Roosevelt as a kind of moral palsy, "more often an illness than a point of view. It is to goodness what brutality is to strength." Its cravenness seemed apparent to him in the impotency of American Jewry and in Roosevelt's empty promises. Worse, liberal rhetoric often seemed to be camouflage for anti-Semitism, just as it had been for Voltaire in the days when he had spoken so eloquently of reason and tolerance. Hecht had seen it in the talk of the 
chillingly genteel lady whom he met for lunch, and in the statements from the "striped pants boys" of the beloved president's own administration.

In middle age, Hecht rediscovered the righteous wrath he had vented in youth. Like the Hebrew prophets who had attacked those who should know better-the people of the Covenant- - he and Bodenheim had once taken aim at the bohemians and intellectuals of the Jazz Age. Now he chastised the Allies, the liberals and, indirectly but no less pointedly, the Zionists.

The debates of 1943 have since been rehashed for seventy years, as history has become ideology. After liberal opinion started to turn against Israel in the 1970s, Hecht was championed as the original unapologetic hawk of American Jewry, the first to have called out that emperor Roosevelt wasn't wearing any clothes. Yet in Hecht's own view, he never ceased to be a liberal, albeit a churlish one, who had yearned to believe in the president but found him to be just another politician.

For a while, the furious quarreling over the Holocaust seemed to blur the old distinctions between right and left, thanks in part to a historian who in later years emerged as Hecht and Bergson's most formidable critic, Lucy Dawidowicz, a neoconservative contributor to Commentary whose positions were as mercurial as they were polemical. ${ }^{183}$ Since the 1990 s, the original ideological dividing lines have reasserted themselves, particularly as Dawidowicz and others who lived through the turmoil of those years have passed away. All along, however, the arguments over the actual historical record have remained the same. They can be boiled down to three major points of contention: the feasibility of rescue prior to 1944 , the achievements of the War Refugee Board, and the effectiveness of Hecht and the Emergency Committee. 
For Dawidowicz, Roosevelt's failings were dwarfed by his achievements in overcoming first the economic collapse of the United States and then the threat to civilization from National Socialism. "No president before or after him ever had to confront responsibilities of such urgency and gravity," she wrote, "whose range and complexity, domestic and foreign, often put them beyond one man's capacity to resolve and, impinging as they did upon one another, beyond any man's capacity to reconcile." Like other interlocutors who followed, Dawidowicz characterized historians critical of FDR and the Allies, like David Wyman, as Holocaust "revisionists" prone to pedantic moralizing, unable to grasp the realities and challenges of the war. ${ }^{184}$

Scholars more sympathetic to Roosevelt concede that he might have done more to rein in Breckinridge Long and the State Department, but argue that there was little he could have done to overcome the anti-immigrant sentiment of the American public and a significant bloc in Congress, particularly after the mid-term elections of 1942. On Palestine, the president was constrained by deep disagreements with the British over war strategy, the military imperative of protecting Middle East oil reserves, the recent record of Arab unrest, and potential impacts of Nazi radio broadcasts to the Arab world. Even such a seemingly specious worry as the one that Axis spies might slip among populations of Jewish refugees may not have been entirely unfounded, at a time when authorities deemed it necessary to warn the public that "loose lips sink ships." Moregenthau reminded the president that only three Jews admitted during the war had raised security concerns, ${ }^{185}$ but who really knew how much of a risk tens or hundreds of thousands of new arrivals from Europe could pose? 
As for the criticism of mainstream American Jewry, Dawidowicz served up blistering attacks against what she saw as not only grossly unfair and untrue, but as a perversion of history that essentially blamed the victims. In her view, rescuing a significant number of those caught in Hitler's vice had never been possible, but Jewish organizations had nevertheless pushed all they could for a plan to convince the Reich, its allies and satellites to allow Jews to emigrate to safe havens. "In effect, they proposed that the Allies beg Hitler to let the Jews go by appealing to his moral sense," she wrote. "They did not have a single bargaining chip to put on the negotiating table. That proposal, conceived in hopelessness and helplessness, was as naïve politically as it was unrealizable logistically.",186

Regarding the release of 70,000 Jews from Transnistria, it was never clear that the Romanian government had actually made the offer or that Hitler would have allowed it. But even if the offer had been real, how would Stalin have reacted to ransom paid to the Romanians at a time when their troops were fighting alongside the Germans at Stalingrad? (The Allies would again face this dilemma towards the end of the war, with Eichmann's so-called "blood-for-trucks” offer for Hungarian Jews.) Yet Hecht and latter day second-guessers such as Wyman faulted the Allies for not seeing what might have happened if the Americans and British had pursued the matter more forcefully. "In Yiddish,” Dawidowicz scoffed, "we would say to this: 'If grandma had wheels she'd be a streetcar.'"187

Wyman concluded that the success of the War Refugee Board in saving 220,000 lives suggests that many thousand more could have been rescued if the American government had been willing to act fourteen months sooner, when reports of the Final 
Solution were first confirmed. William D. Rubinstein disputes this, contending in The Myth of Rescue that the refugee board saved 20,000 at the most, and could not have saved more because Allied forces could not reach the victims until 1944. Underlying such disagreements, however, is the question of whether it matters if "only" hundreds or thousands more could have been rescued. Forty-one years after Riegner sent his famous cable, he weighed in on the verbal crossfire: "Let me say, nobody did enough. In such a situation, nobody does enough." 188

Finally, the Dawidowicz camp argues Hecht and the Bergsonites' publicity did little to influence Roosevelt's decision to establish the War Refugee Board, and that ever since then, the Bergsonites and their advocates have made exaggerated claims to a place in history they don't deserve. But the assessment of Morgenthau and his team, as well as a document in the Hecht archive, suggest otherwise. Morgenthau credited the Emergency Committee resolutions with pushing the president to act, according to records of a March 1944 meeting with DuBois and Pehle. When DuBois praised Morgenthau for the outcome, the secretary responded: "I had something to do with it granted, but the tide was running with me. ... I think that six months before I couldn't have done it." He added, "I am just wondering who the crowd is that got the thing this far." Pehle replied that it was the Bergson Group. ${ }^{189}$

While Jewish organizations were incensed that Hecht's newspaper attacks endangered their efforts at quiet diplomacy with the administration, Hecht and Billy Rose may have succeeded in exerting influence through a back channel—Bernard Baruch, Rose's close friend and mentor. Eight days after Roosevelt signed the executive order, Rose wrote to Hecht: "Our tall white haired charmer has evidently gotten part of his job 
done with the boss. He called me from Washington at the crack of dawn a couple of days before the announcement appeared about the boss's appointment of a Refugee Commission. I have since discussed it with him and the story of how this came about I wouldn't care to entrust to a letter. He is definitely of the belief that something will happen and happen quickly - that this is not merely Bermuda lipservice. ... He's very insistent that his name never be mentioned in connection with any work he may have done for this cause, because he's afraid it will reduce his effectiveness in the future. I am not under-rating the great contribution made by Peter's organization. I think it helped out plenty but I wouldn't be surprised that our friendship with the old boy helped bring this to a head. ${ }^{\prime 190}$

Pehle's record of the meeting with Roosevelt, included in the Morgenthau Diaries, says the president agreed to the executive order right then and there, so were Baruch or Rose merely flattering themselves? Would Roosevelt have signed the order that January had it not been for the Bergson Group? And how many people really were saved as a result? Could Roosevelt have rescued many thousands more by intervening with the State Department, or by using the bully pulpit to change immigration policy, or by taking a firm stand with the British? Was a deal on the Romanian Jews, or any subsequent offer, ever viable? How many could have been rescued if America had acted sooner, and does its foot-dragging indeed amount to a colossal moral failure? There are limits to what can be gleaned from the historical evidence, and it may not be possible to ever resolve such questions.

Dawidowicz asserted that while historians can and must make moral judgments, history should be studied on the basis of what it is, not on what it ought to have been. 
"We study the history of the murder of European Jews," she wrote in conclusion, "not just to mourn and commemorate them, but to try to understand the past and, if possible, to learn from it." ${ }^{191}$ What is clear is that by 1943, Hitler's carnage had concentrated many minds on a fundamental disagreement — on a clash between two worldviews that would be a key legacy of the war. Both sides understood Nazism as a challenge to civilization, even to "the soul of man." Hecht, when at his most extreme, adopted the position of maximalists like Avraham Stern, espousing the view that National Socialism had exposed an ugly truth, that the great liberal democracies of Churchill and Roosevelt were essentially frauds based on a disingenuous, unreal optimism about human nature. Rabbi Wise and those who shared his views, on the other hand, held that such thinking represented a surrender to fascism.

Ultimately, the conflict came down to the issue of legitimacy, whether it was who had the right to speak for the Jews or who could arbitrate the rule of law. To the American Zionists, Bergson and the Irgunists were nothing more than hooligans, exploiting the Holocaust to perpetrate an egregious hustle. To Hecht and the Bergsonites, the Allied governments had aided and abetted the greatest crime in history. From now on, Hecht would be the mouthpiece for a new American Zionist militancy, engaging the Allies in a war of words about gangsterism, terrorism and the law while blood spilled in Palestine.

\section{BLOOD AND FIRE}

For hundreds of years, you have been whipping 'natives' in your colonies... You will not whip Jews in their Homeland. And if British Authorities whip them-British officers will be whipped publicly in return.

The Irgun newspaper Herut, December $1946^{192}$ 
If our dreams of Zionism are to end in the smoke of the assassin's pistol and our labors for the future are to produce a new set of gangsters worthy of Nazi Germany, then many like myself will have to reconsider the position we have maintained so consistently and so long in the past.

\section{Winston Churchill, November $1944^{193}$}

In blood and fire Judea fell

In blood and fire Judea will rise

Ha-Biryonim ("The Hooligans") by Yaakov Cahan, 1903; Betar Youth theme, battle cry of the Stern Gang ${ }^{194}$

By late 1943 Hecht was sure the Nazis would indeed fulfill their promise to exterminate all of Europe's Jews, if not by Christmas, then certainly before the Allies could end the war. Feeling dismal and defeated, he had no stomach for yet another lost cause when Bergson and Merlin approached him about their next fabulously quixotic quest — ousting the British and establishing a Jewish state in Palestine. Hecht told them that he would sing no songs of heroes or martyrs; if his two friends wanted to trumpet a Semitic George Washington or Nathan Hale, they could find someone else to blow the horn. "There are no such characters in Nyack," he told them. Besides, what would be the point when almost all of the world's Jews, including the Zionists, "are on their knees to the British? All of them trying to whimper a nation into existence!"

He soon overcame the feeling that "there would remain a small, private area of defeat in me called the Jew," however, deciding that if his fellow underdogs were determined to fight, he could hardly turn his back on them. Stopping by the midtown offices of Bergson's American League for a Free Palestine in early February 1944, he 
saw "the most glowing-faced and busiest Jews I had ever seen" churning out their biweekly magazine, The Answer, organizing, fomenting a nationalist movement.

Menachem Begin, as the new commander of the Irgun, had just declared war on the British, and while Hecht was at first unimpressed by unrest in Palestine that seemed no more serious than the daily crime in New York, the attacks quickly grew more frequent and ferocious. "News of every gun (the Irgun) fired, every barrel of dynamite it exploded, of every railroad train it tipped over was brought to me in secret communiqués, some of them hidden in cigarette packages," Hecht wrote in Child. "I never read news with a more pounding heart. I had had no interest in Palestine ever becoming a homeland for Jews. Now I had, suddenly, interest in little else."195

Critics would find Hecht's breathless enthusiasm for bombings and shootings grotesque, but his activism had started with a call for a Jewish army, and a pledge to "bring respect back to the name of the Jew." Now he saw a chance to finish what he had started. As for his old reluctance to sully himself in the messy politics of Palestine, he had come too far for such misgivings; this was no longer just "politics" to him. Like many American Jews, he had not in the past found the arguments and flag-waving for a Jewish homeland compelling, but the experience of the war had changed everything. It had made the logic of Zionism real to him.

From early 1944 onward, Hecht served as propagandist for the Irgun, providing the angry battle cries for the revolt. "Ben Hecht wielded his pen like a drawn sword," proclaimed Begin in 1983, as Israel's prime minister. “...He helped shape public opinion, and by doing so, created a defensive shield of public support around the fighters in the field."196 
Hecht's advocacy of armed resistance against Britain, which was radical from the start while the war on Germany was still far from over, would lead him to shift orbits from the moderate Bergson to the militant Begin, and then finally, in the pursuit of money and weapons, to the wise guy Mickey Cohen. Hecht felt that Roosevelt and the British leaders made the political criminals of old Chicago seem quaint by comparison. Whether Hinky Dink or Mayor "Big Bill” Thompson had had blood on their hands, this new breed of rogues certainly had far more of it. If the British were going to denounce the Irgun and Stern Gang as gangsters and terrorists, Hecht would embrace these epithets as badges of honor.

Bergson, on the other hand, never really appeared to be the happy warrior, and ultimately tension arose between the two friends over how much of the money Hecht raised should pay for arms versus publicity and diplomacy. Hecht agreed with Begin that America was a sideshow compared to the real battle being waged in Palestine. In his memoirs, Hecht never intimates that, at least at one point, he grew impatient with Bergson, but the draft of an unsent letter of resignation stored among his papers makes clear that by September 1947, he was getting fed up. Angrily declaring that he no longer wished to finance "foolish Bergsonian high-dee-ho" he demanded that at least half the cash already in the till go to the Irgun. ${ }^{197}$

Whether or not bankrolling armed struggle had originally been the plan in dispatching a delegation to the United States, the Irgun was in disarray for years after the death of its commander David Raziel in 1941. Bergson later said that he insisted his organization in America keep its nose clean, especially while the Emergency Committee was carrying on its rescue work, and the FBI never uncovered any evidence of support 
for the Irgun, despite investigations that spanned from the war years until 1950. Nevertheless, the Bergsonites were able to provide some level of support all along, starting early in the fall of 1943, when the original "cutoff battalion" dispatched Arieh Ben-Eliezer to help revive the Irgun, find a new commander, and get things back on track. While the Emergency Committee had been pressing its rescue resolutions in Congress, Ben-Eliezer was in Palestine recruiting Begin, the former leader of Poland's Betar who had arrived in the Middle East with the Polish army-in-exile. ${ }^{198}$

The Bergsonites waited until they were confident of concrete achievements on rescue before announcing their campaign for the liberation of Palestine. Using funds from A Guide for the Bedevilled, they purchased the former Iranian embassy in Washington, D.C. for $\$ 63,000$ and renamed it the "Hebrew Embassy." In May 1944, they held a press conference in the thirty-room, unfurnished mansion to unveil the Hebrew Committee for National Liberation. Five days later they announced a separate committee that Hecht would co-chair, the American League for a Free Palestine, which had actually been organized months earlier, shortly before he had visited the ALFP's midtown offices. ${ }^{199}$

The press conference on Washington's “Embassy Row” was a typical Bergson flourish, but his sophisticated strategy for the Hebrew nation campaign proved a fiasco. His plan had been to dispense with the demon of "dual loyalty" by drawing a distinction between Americans of Jewish faith, and those he called "Hebrews"- the Palestinian Jews and the stateless Jews of Europe who wished to become members of a new Hebrew state. While "Jewish" was a word that described a person's religion, Bergson explained, "Hebrew" would describe a nationality. However farsighted this may have been in anticipating the distinction, later taken for granted, between Israeli and non-Israeli Jews, 
in trying to cater to the sensitivities of American Jews, he apparently revealed how little he understood them. His error may have been in trying to address uncomfortable questions of ethnic difference in a straightforward manner, at a time when many American Jews preferred to gloss over the subject, or avoid it altogether.

Once again, American Zionists heaped on the derision. To the former Jabotinsky confidant Meir Grossman, the Hebrew Committee was "a bunch of clowns"; to Labor Zionist leader Marie Syrkin, they were "charlatans." In the Washington Post, Dr. Israel Goldstein described the initiative as "buffoonery" and "comic opera drollery...four or five irresponsible young men who have assumed the role of Don Quixote and Pancho setting forth singlehandedly" to resurrect a Hebrew nation. The American Zionist Emergency Council told the press the committee was "made up of a half dozen adventurers" representing "an insignificantly small, pistol-packing group of extremists who are claiming credit for the recent terror outrages.” The Revisionist New Zionist Organization itself dismissed the differentiation between Jews and Hebrews as "false and historically groundless." Begin did not approve, and even members of Bergson's core group, including both Ben-Ami and Rafaeli, never liked the idea. Most importantly, the concept found no traction with the American Jewish public, which seemed to find it alien and confusing. ${ }^{200}$

Hecht gave his full support nevertheless, perhaps because he had a special place in his heart for ideas that managed to alienate and offend just about everyone. In a message to congratulate the founding of the HCNL, he wrote:

Zionism as a political force is as dead as the projects of Montezuma. ... The Jewish cause has been too long under the domination of Stephen Wise and his fellow Jewish fossils. What the Jews need most is a high wind to blow these ossified politicos out of 
their places. They are the dust that has gathered over a lost cause. I hope that out of the storm you raise will come the young and noble leadership that Hebrews of Europe deserve. ${ }^{201}$

Representative Richard P. Gale put the note in the Congressional Record, along with others sent in support of the committee. As a result, Hecht's disparaging comments about Wise and the Zionists drew fire in Jewish newspapers. While he may not have expected the message to become public, he could not have been surprised. After so many attacks against him and the Bergsonites, he may no longer have felt so obligated to hold his tongue against fellow Jews.

Courtroom trials of four Stern Gang members that summer proved the ideal forum for challenging Britain's legal authority in Palestine, and provided Hecht his first opportunity to put the case for armed rebellion before the American public. Though he had signed on with the Irgun, he served as propagandist for the fighters of the late Avraham Stern for the rest of the year, unrestrained by the qualms Bergson and Raziel had harbored about the breakaway group. Hecht said little about the Stern Gang in his autobiography, but explained: "If I discontinue reference here to the Sternists and write now only of the Irgun, it was not because there was anything less deserving about the Sternists. They were as valorous and nobly inspired a group of human beings as I have ever met in history."202

In mid-July he acted in the role of press agent for them, writing letters that protested the death sentence of "Palestinian freedom fighter" Matityahu Shmuelevitz to Eleanor Roosevelt, Henry Luce, Eugene Meyer, Hearst, Sulzberger, and a dozen other editors and publishers. The trials, and Shmuelevitz's impending execution in particular, gave an outfit desperately short on resources a chance to explain itself to fellow Jews and 
to the world, paid for courtesy of his Majesty's government. Israel Eldad, who became spiritual leader after Stern's demise, characterized the trials as: "The first declaration on an official, public platform that the British regime was a foreign and illegal regime."203

As Hecht later explained: "American and Jewish newspapers alike chronicled the Irgun's deeds of valor as the scurvy antics of hoodlums and gangsters. ... The British propagandists hardly needed to bestir themselves." But it had been the tactics and ideology of the Stern Gang, also known as Lehi, that helped earn the rebels of Palestine notoriety as "gangsters." Refusing to break off their attacks against British policemen and soldiers at the start of the war, the Sternists had snatched up Irgun dumps, and turned to bank robbery and allegedly to extortion to finance their campaign of targeted killings. After a September 1940 "expropriation” of $£ 4,400$ from the Anglo-Palestine Bank was quickly used up, they scavenged for cash, guns, materiel and an underground printing press. $^{204}$

By early 1942, the Sternists were pariahs within the Yishuv, with few Jews willing to hide them and plenty ready to turn them in. A heist that January spiraled into disaster when tellers at the Histadrut Bank refused to hand over money and the gang opened fire, killing two Jewish employees. Even more shocking had been Stern's announcement over the radio that he was pursuing the ultimate Devil's Bargain: a pact with Hitler. He believed Rommel would be victorious in the Middle East and that the desire to make Europe "Jew free" put the interests of Nazism in line with Zionism. Championing his scheme as a "revolutionary twist" on the teachings of Jabotinsky, he sent an emissary to meet with a German official in Beirut in late 1940, and another to Syria in December 1941. With news of these missions beginning to spread, the enmity of 
fellow Jews reached new heights after the Histadrut Bank killings, and a month later police finally hunted him down and shot him dead, allegedly in cold blood. By mid-May the rest of his fighters were either in custody or deep underground. ${ }^{205}$

When the gang rose from the ashes two years later, Hecht was on hand to petition for its captured gunmen and write a play about the most spectacular outrage of its bloody career. Soon after twenty Sternists had tunneled their way out of the Latrun detention camp on October 31, 1943, they had resumed operations under new leadership.

"Desperate beyond measure, on the far edge of history, despised by their opponents (and) denied by their own," as one chronicler described them, they sought to capitalize on the momentum of the trials that summer of 1944 with an operation that would change history: the assassination of Lord Walter Moyne, Britain's resident minister for the Middle East. "What was important to us was that he symbolized the British empire in Cairo," reflected Lehi leader Nathan Yellin-Mor. On November 6, two Lehi gunmen fatally wounded Moyne and his driver just outside of his residence. ${ }^{206}$

Hecht fired his opening volley of militant propaganda at Winston Churchill in December 1944, after the prime minister threatened that all Jews would be made to pay for Moyne's death. As the New York Times reported: "Churchill Warns Jews to Oust Gangs. ... He implied that his own support and that of many others might be withdrawn from the Zionist cause if the gangsterism, which he compared with that of Nazism, were not eliminated from Palestine." ${ }^{207}$ Weizmann and the Jewish Agency vowed immediate action and indeed the Haganah had for weeks been planning a crackdown, later to be called the "hunting season," or saison, not on Lehi, but on the larger, recently reemerged Irgun. 
"In Tel Aviv the Socialist Jews led by Ben-Gurion, the Zionists and the Jewish Agency-ites, all scampered eagerly to the British headquarters," Hecht later wrote in Child, "to protest their own innocence, and to prove it by betraying Irgun hiding places to British Intelligence.” Mass abductions and brutal interrogations in Haganah safe houses that involved beatings, cigarette burns, broken fingers and false executions yielded names turned over to the British, effectively crippling Menachem Begin's operations for months. But unbeknownst to the Zionists, the die had already been cast: Thirty-five years later, historian and British member of Parliament Nicholas Bethell uncovered evidence that Moyne's assassination had prompted Churchill to abandon plans for an independent Jewish state along lines that Weizmann had proposed just two weeks earlier. ${ }^{208}$

The central joke of Hecht's A Jewish Fairy Tale, which premiered at Carnegie Hall on December 4, was Churchill's description of himself as loyal friend to the Jews and "constant architect of their future." As a rabbi from Yonkers protested in a letter to the Times: "We think of the word 'architect' in the expression 'architect of the future of Jews' as spelled with a capital 'A.",,209

Hecht performed as narrator, introducing the play as a fairy tale about a people who had been fond of fairy tales ever since they had heard the one about "a wondrous God who loved them above all His other children.” The story features Tevya, Sholem Aleichem's comic-tragic, Job-like dairyman from the bygone world of the Jewish shetl, in his most familiar role: quibbling with God as if he were kidding with an old friend. This time, however, there was a twist, one that suggested the misfortunes of Aleichem's day were nothing compared to those of $1944 .^{210}$ 
The action opens with Tevya riding a cloud to the Pearly Gates after his body has been cast in a lime pit with other Jews from Lublin. Upon arrival in heaven, he is surprised to find that God is smoking a cigar and wears a yachting cap. The Old Man is angry because an Englishman has been killed. Tevya isn't sure he knows the gentleman. "Is his name Itzikle? Lezerel? Jozefle? There were lots of fine people killed - all from different lands." The name is Lord Moyne, thunders God. "Lord Moisha," says Tevya, trying to catch on. He is confused: Why should God be upset about this death when so many others have died? "So much excitement over one Englishman in heaven, I didn't expect to find," he complains. Exasperated, the Almighty turns to have these objections stricken from the Book of Fate, which curiously bears the title 10 Downing Street. "How have you rewarded my tireless friendship - my dream of Zionism?" sayeth the Lord. "By producing a new set of gangsters worthy of Nazi Germany...I find it necessary to the architecture of the Jewish future that all Jews must be punished for what these three Jews have done."211

God orders Tevya back to inform Europe's Jews that they must now wait another hundred years and pray in their synagogues for "the two percent of the Holy Land which I graciously allotted." Never mind the bellyaching that there may be no Jews left to tell, nor synagogues in which to pray. When Tevya floats towards the smoking graveyard of the continent, he glimpses Palestine for a moment, which has a large sign rising up from the soil: "Jews Keep Out - by Order of Their Tireless Friend Winston Churchill." In conclusion, Hecht inserts a version of the customary legal disclaimer: "Any resemblance between the character in our story called God and the true God who presides over the heavens, is purely coincidental." He promises to someday return with another story that 
has a proper fairy tale ending, one in which the Jews have a homeland of their own and the Jewish soul "has been given back its good name.",212

Ostensibly, A Jewish Fairy Tale satirized Churchill's arrogance and unfairness towards innocent Jews, while affording Hecht the pleasure of playing the heretic once again. Yet by putting his own P.R. spin on the events of the day, Hecht served Moyne's assassins as well. His cigar-smoking, finger-wagging God informed the audience that Moyne, "as Secretary of State for the Colonies," in 1942, had "pronounced Jewish immigration into Palestine...to be a disastrous mistake.” In Boston, Philadelphia and other major cities, the play thus helped publicize the Stern Gang's deed, while subtly casting what had played in the press as a horrific act of terrorism in a sympathetic light. $^{213}$

Hecht upbraided the British again soon thereafter, in late February 1945, for arresting Eri Jabotinsky, son of the Revisionist founder, while he was doing rescue work for the Emergency Committee in Turkey. In an open letter to Britain's ambassador in Washington, Hecht explained that Jabotinsky had recently brought news to light that British officials had persuaded the Turks to block the passage of Jewish refugees to Palestine. Jabotinsky had thereby done "a great service to England—at least that part of England which is fighting so valiantly for the sacred rights of man." Now he was in a British concentration camp. "The thousands of Hebrews who have been whisked out of sight without trial or voice to repine behind English barbed wire are as much symbols of British moral collapse as they are of Jewish travail,” Hecht charged. “...Whisking people off to concentration camps and stuffing gags in their mouths at the same time isn't cricket.",214 
While Hecht was butting heads with the English, he was at the same time producing propaganda for the Allies with a portly Brit who could have passed for Churchill's twin: Alfred Hitchcock. Their collaborations for Hollywood were arguably Hecht's greatest achievements, surpassing even his work with MacArthur and Hawks. The two had spent March and April 1944 writing Spellbound, and while Hitchcock completed the principal photography in August, they had sketched out a treatment for Notorious. Days after they started on the script in early December, they were tapped by the State Department and OWI to sell the public on Roosevelt's postwar plans for peace and security, which was remarkable, given Hecht's burning contempt for the administration. $^{215}$

While the Department wanted a six- or seven-minute film that wove a speech by Secretary of State Edward Stettinius Jr. together with newsreel footage, "Hitchcock and Hecht preferred to dramatize the need for a world-security organization," explains Hitchcock biographer Patrick Mcgilligan. After a December 17 brainstorming session before a group of Department officials, the pair traveled to Washington the day after Christmas and stayed up most of the night hashing out a script. They pitched presenting "the proposed international organization in dramatic form," according to a Stettinius memo, "by projecting into the future and telling the story of its operations in stopping an unnamed potential aggressor in the year 1960." Their apocalyptic vision, however, alarmed what Hecht called a "vacuous wagonload of politicos ... not a group of men to stir fear in anyone's heart." Department officials feared the pair was running roughshod over sensitive policy concerns, such as the need to build postwar alliances with former enemies. $^{216}$ 
Hecht felt little pride in the resulting 15-minute short titled Watchtower Over Tomorrow, for which he "finally put some scraps of information together" and "larded them with rhetoric and war episodes." Directing credit went to John Cromwell and Harold F. Kress. By April he had also written a radio script for ABC's Blue Network, Watch Tower For Tomorrow, narrated by Edward G. Robinson, in preparation for the conference in San Francisco to draft the United Nations charter. While the radio program aired during the opening ceremony on April 25, it is unclear whether the film was ever publicly exhibited. ${ }^{217}$

Both combined stark, prescient warnings about future threats with explanations of how a new regime of international law would protect against them. At a time when the "atomic bomb" appeared to be the stuff of scientific speculation, science fiction, and wartime propaganda less credible than Goebbels' promise of a "freeze bomb" for the V-3 rocket program, a voice told radio listeners: "You know what will happen in the next war? They'll press a button and blow up whole cities...in one smack.” The film opens with a space-age cannon, launching a warhead into orbit. "Death from the sky," says John Nesbitt in voice over, "from a bomb fired by an enemy thousands of miles away." Robinson intones that this evening, San Francisco "will become the scene of an international assembly dedicated to the purpose of outlawing war." Doubting Thomases will say "you can't change the face of nations and the soul of man ... No? Why not?" Has anybody figured out how they are going to do it? Asks an average Joe. "I don't know," replies his buddy Sam. "Going to argue, I guess, and lay down some new laws." 218 The first goal is "to set up a police and justice system to stop and punish the outlaw nations before they can start a war," explains Commander Harold Stassen, the 
American delegate. The film explains that the effort all started back with the international Court of Arbitration in the Hague, followed by the World Court. "This time, thank God, ... the indifference of 1920 is gone," Nesbitt remarks. At Dumbarton Oaks in Washington, Roosevelt's "Four Policemen"- the Soviet Union, China, England and America—recently drafted the new plan for future security. ${ }^{219}$

"Sounds okay," says a gum-chewing working stiff on the subway, played by Lionel Stander. "But what happens if some nation won't play ball?" Tense music rises as a future Hitler appears on screen, standing defiant before the UN. Nesbitt explains that in such a situation, the Security Council, led by its four permanent members, will act to isolate the rogue nation and, if necessary, summon an international force. "I get it!" says Stander. "What happens is like when there's trouble in the neighborhood. Somebody calls the cops, and the riot squad comes and takes care of things before the riot gets started!" We live in a Global Village now, Stassen said, in effect: "The people of the world have found that the earth has grown very small ... Science has shrunk the earth and brought every neighbor elbow to elbow."220

As soon as Hecht had finished these chores to help ensure the success of the conference, he plotted propaganda to sabotage it. In mid-February, Roosevelt had met with the Saudi king, and returned to tell Congress on March 2: "I learned more about that whole problem — the Moslem problem, the Jewish problem—-by talking with Ibn Saud for five minutes than I could have learned in the exchange of two or three dozen letters." On April 2, Hecht expressed his disgust in a letter to Rose as he prepared to leave for San Francisco. "I am writing today to learn if I am to be barred by the State Dept. from the 
conference," he said. "I sit sketching out the Jewish 'pageant' I am going to write. As I sketch it, I can understand anything the govt. might do to bar me."221

Call the Next Case would portray FDR "brought to trial before the bar of history for his crime on the Jewish question." The scene would be a courtroom with a jury of twelve Jews, sitting motionless and white-faced like corpses, representing the millions whom the president could have saved. Here, too, Hecht was framing the issues in terms of "the law," but while a vaunted body in San Francisco might sanction a new legal code and court for the world, he suggested, this was only the law of man and nations. There was a higher authority — "the bar of history" - to which even the great architect of the UN would be held to account. "There has been war before," he wrote Rose,

but never an extermination of people on such a scale. I am sure history will see Roosevelt and Churchill as workers in the Hitler butcher shop. I see them as representatives of the smallness of the human soul - as part of that decayed pedagogical rubble that piles up in the aging human mind. Both men added together haven't the simple and logical understanding of humanity that you would find in a shepherd boy or a chimney sweep. They can only play politics - as if that sort of playing was a superior thing to life and truth. ${ }^{222}$

The goal of Hecht's "grandiose propaganda stroke" would be to "explode the Jewish issue in the face of the entire world." His play pronouncing Roosevelt guilty of crimes against humanity would appear just blocks from the conference, and run as long as the sessions went on. The symbolism was crucial: the context would make the performance not just an indictment of one man, but of his whole grand vision for a postwar world. "I grinned at the thought of the State Department attending its opening," Hecht wrote. His cynicism echoed Begin's disdain for world conscience and the League of Nations, back when he had debated Jabotinsky in $1938 .{ }^{223}$ 
This time, the power of Hecht's propaganda would not be put to the test. He was writing Call the Next Case on April 12, less than two weeks before the opening session, when news came over the radio that Roosevelt had died. Hecht recalled a national outpouring of grief not seen since the death of Lincoln, one that left him awestruck, and while his own heart remained cold to this "man with the gift for making himself unreasonably loved," he tossed the play into the trash. Left unsaid was that if he had staged the pageant while the president's body was still barely cold, he could expect riots in the streets, and a backlash that would irreparably damage the cause in Palestine. The music chosen to open the conference, he accurately remembered, was "Lover, Come Back to Me." Staring at the world leaders in the Opera House on April 25, he "knew the show would be a flop. The leading man was missing, the crooning lieutenant in the white pants who gets the girls, for whom the script had been written, had left the cast."224

In its first major role on the world stage, the UN would be called upon to determine the fate of Jewish aspirations in Palestine. Hecht never explained why he agreed to write publicity for an institution that he apparently held in such low regardwhether he did it out of a sense of fellowship with Hitchcock, or because it was simply good business to lend a hand, or some combination of both. In the final days that spring of the war with Germany, newspapers and magazines were filled with images of the now liberated concentration camps, and whatever humanistic idealism once infused Hecht's efforts for rescue had since given way to extreme bitterness. Yet when it came to propaganda, he could be ideologically multilingual. The seemingly glaring contradictions in his propaganda about the UN offer yet another indication of a characteristic ambivalence that found its truest expression in art. 
Notorious was adapted from a 1921 Saturday Evening Post short story, but it was really more based on tales Hitchcock gleaned from friends involved in wartime espionage. It starred Cary Grant as T.R. Devlin, an American FBI agent who recruits Alicia Huberman, the daughter of a Nazi, to spy on her late father's associates. A party girl with an untidy past, Alicia is played by Ingrid Bergman, who as Pauline Kael noted, "is literally ravishing in what is probably her sexiest performance." Devlin falls for her, but his mission is to persuade her to "worm her way into a nest of Nazi spies" by going to bed with one of them. He is forced to choose duty over love. Soon she reports: "You can add Sebastian's name to my list of playmates."225

Hitch and Hecht packed their film with details that reflected the seaminess and duplicities involved in a conflict that, ironically, Americans would remember as "the good war," which had possessed a moral clarity they would afterwards long for in world affairs. Among the wartime particulars that make the film an intriguing historical document, most famous is the MacGuffin, or "pretext for the plot," as Hitchcock explained the term: the uranium ore, which the Nazi conspirators have stashed in wine bottles. The atomic bomb was Top Secret in 1944, and nobody but the experts knew uranium was the key ingredient, but Hitchcock later said that he and Hecht became confident they were on to something once they saw the jitters their questions about atom bombs aroused in Dr. Robert A. Milikan, a Nobel-Prize-Winning physicist at the California Institute of Technology. A detail less remarked upon is their prophetic depiction of Nazi war criminals granted asylum in South America. Ensconced in uranium-rich Brazil, the plotters continue to serve with impunity as executives of IG Farben, the notorious cartel that patented Zyklon B and, as investigations at the time 
revealed, had tentacles extending deep into American conglomerates. ${ }^{226}$ Discussing this spy thriller as Hecht's contribution to a new film genre, Leonard Maltin observed:

It is far from coincidental that what we now think of as film noir started to take root during World War II, and flourished in the years after the war. There were a lot of people who had gone overseas and came back changed men, not as bright eyed, optimistic, and openhearted as they once were. And all that is expressed in film noir-that suddenly Hollywood is not focusing on the sun-splashed streets of any town U.S.A., but instead on the dark alleys and the nighttime and the shadows, and the shadowy figures who populate the urban landscape. ${ }^{227}$

Hecht may have been inclined to embrace paradox, but the end of the war simplified several issues. The occupation of Palestine and White Paper policy continued, while the major reason for Jews to remain loyal to Britain was erased with the defeat of Nazi Germany. Moreover, no one could continue to argue that helping the Jews hindered some broader effort for the greater good of the war effort. To the contrary, the price that had been paid for not helping the Jews was now conspicuously in evidence. In the new politics of the postwar era, Hecht became a zealous partisan with a renewed interest in propaganda. Soon he discovered its potential as a weapon of war, and a tool for arming and equipping his side for battle. 


\section{ONLY THUS}

Probably Hecht thought he was echoing the brutal warriors and prophets of the early days of our people. But the return to our people is not intended to be an atavism. It is not a return to the sometimes primitive morality of our forefathers, whose bloodthirsty battle-cries belonged to the state of society in their time.

$$
\text { Meyer Levin, In Search } \text { S28 }^{28}
$$

If someone makes a law against humanity —who is the law breaker?

$$
\begin{aligned}
& \text { Tevya, in Ben Hecht's } \\
& \text { A Flag is Born }
\end{aligned}
$$

Hecht had taken a brief hiatus from screenwriting while there had been a Jewish emergency in Europe, but now that the war was over, he divided his energies between volunteering for the cause and "beating my way back to solvency" by earning a paycheck in Hollywood. During the latter half of 1945, he was mostly consumed with writing and directing Specter of the Rose, a murder mystery set in the world of ballet. Like The Scoundrel but not nearly as well received, it featured Lionel Stander as a thinly disguised Bodenheim who spat invective while dragging around a tattered sheaf of poems. ${ }^{230}$

Hecht also turned to Hollywood once again for contributions, hosting another dinner in August that was attended by more than four hundred guests, including producers Goldwyn, Zanuck, Selznick, Harry Warner and Walter Wagner, and celebrities Edward G. Robinson and Frank Sinatra. Weeks later, newspapers reported that Burgess Meredith and his wife Paulette Goddard were heading to Palestine to star in a movie Hecht would write about "the heroism of the Jewish self-defense Corps in war times." Nothing came of this, but the pace and intensity of his propaganda efforts resumed over the next couple of years. Of the roughly one dozen Hollywood scripts he worked on simultaneously in the mid- to late-'40s, most successful were two well-received 
collaborations on noir, Kiss of Death and Ride the Pink Horse, and his script doctoring on Selznick's Duel in the Sun. ${ }^{231}$

Hecht began to feel reinvigorated, not only because he had shifted from a futile campaign for rescue to an ultimately successful one for liberation, but also because he had new ideas about the usefulness of propaganda, and a new confidence in the "product" he was selling. Previously, he recalled in Child: "I had come to feel that propaganda was even less than water writing. It was writing traced on the air with a finger." But now:

I knew it was also something else. Propaganda with deeds behind it could echo valor and victory - and raise funds for larger triumphs. It could sustain warriors like a medicine and bewilder their enemy like a plague of locusts. It could confuse the enemy's home front, particularly a British home front as susceptible to phrases as to bombs.

Our Second Front was no longer an impotent yell into a barrel. Propaganda in behalf of dead Jews had been like advertising minus a commodity. In behalf of live men in whose hands flashed the first steel since Bar Kochba, it was a hell-raising medium. It could sell deeds to the world as lustily as it sold automobiles and hair lotions. ${ }^{232}$

Bergson, however, controlled the money, and he had different priorities. The committee adopted a three-point program dubbed "the three Rs": Repatriation of Holocaust survivors, Resistance to British occupation, and Recognition of the Hebrew Republic of Palestine. Bergson made clear that he wanted to focus first on "illegal immigration," smuggling the Displaced Persons now languishing in the liberated concentration camps through the British blockade. ${ }^{233}$

As ALFP co-chair, Hecht readily agreed, but soon encountered frustrating obstacles. Talk of financial irregularities and a welter of federal investigations took its toll on the League's credibility. To shore up public trust, on April 13, 1946, he announced a Repatriation Supervisory Board, with prominent individuals such as Louis 
Bromfield and Representative Will Rogers guaranteeing that every dollar donated would go exclusively to immigration. A full-page Times ad on April 17 that proclaimed: "Give Us the Money...We'll Get Them There!" was followed by one in the New York Post on the $29^{\text {th }}$ that touted "the underground railroad to Palestine." The Zionist mainstream charged that Hecht was an "innocent dupe of a high pressure salesmanship campaign" who was falsely claiming credit for the work of the Jewish Agency. And indeed, the Zionists could legitimately claim to be moving thousands of refugees, while the ALFP and HCLN never fully made good on their promises. ${ }^{234}$

Meanwhile, Menachem Begin was becoming increasingly frustrated by the lack of support that the Irgun was receiving from America. Far more concerned at this stage with action on the ground than with diplomacy and public relations, he did not share Bergson's eagerness to establish a provisional government, which he felt would only bolster the impression that the "fascist" Revisionists were jockeying for power. $\mathrm{He}$ complained about the insufficient funding at an October 1945 meeting in Palestine with Yitshaq Ben-Ami, who found that he could not disagree. "I myself felt that our United States delegation was developing an over-emphasis on the political and symbolic aspects of the struggle," Ben-Ami recounted in his memoir, Years of Wrath, Days of Glory, “ironically tilting backwards towards Jabotinsky's old political Zionism when the time for it was past." ${ }^{235}$

Fortunes had changed for the Irgun in the fall. During the preceding months of the brutally enforced "Season," the Jewish Agency had turned over the names of more than a thousand Irgun and Lehi fighters, which ultimately reduced Begin's organization to attacking telegraph poles after its initial, sustained burst of fury in 1944. But the rebels 
had refused to buckle, and their refusal to retaliate against fellow Jews—which Begin described as the real Havlagah, or self-restraint—-began to earn the grudging respect of the left-leaning Yishuv. By the spring of 1945, the crackdown had become unpopular in the neighborhoods and with the Hebrew press. When Britain's new Labour government proved unwilling to lift the White Paper even after the war was over, and deflected President Harry Truman's call in September for the admission of 100,000 DPs with a call for an Anglo-American Committee of Inquiry, the Jewish Agency could not deny that full-hearted cooperation had been fruitless. The Season altogether collapsed, and reversing course, the Haganah agreed to a pact of united resistance with the Irgun and Lehi. The ferocious coordinated attacks of the Tenuat Hameri campaign, as it was called, began a spiral into violence that would far surpass that of the 1930s, eventually developing into a three-way, all-out war with no front lines. ${ }^{236}$

The Haganah's participation in resistance ignited fresh debate in American newspapers about the Jewish "gangsters" of Palestine. When reporter Gene Currivan identified them as "an underground gangster group" in the New York Times, one reader wrote in to register his protest. "Underground it is - the British administration's utter lawlessness is responsible for that," he said, "but it is not a gangster group. If expediting the landing and entry of the so-called 'illegal' immigrants into their national home $\ldots$ is a manifestation of gangsterism, the word obviously needs a new definition." In The Nation, the esteemed journalist I.F. Stone fired back: "The Haganah are no more gangsters than were the men of Concord and Lexington." He added that they had "nothing to do with irresponsible terrorist groups like the Irgun and the Stern Gang." But in June, The Answer contributor George Nathan Horwitt likewise compared the Irgun's female recruits 
to Molly Pitcher, after Currivan described them as a "rare breed of teen-age 'gun molls,' who are far more vicious and blood-thirsty than anything the United States ever had in real life or on the screen.",237

Hecht followed the news in Palestine with the relish of a boy reading adventure stories. "No more sizzling battles were ever fought against towering odds," he later reminisced. "...Lion-of-Judea-Begin conducted the war in the guise of a bearded rabbinical scholar..." The Irgun unleashed a Reign of Terror that would distinguish them as one of the fathers of modern guerilla warfare. They destroyed more than twenty RAF bombers and Spitfires, demolished over a dozen railroad bridges and crippled the Mandate's train system, laid mines that blasted apart armored trucks, reduced government immigration offices and barracks to rubble, and launched relentless assaults on police stations. Together with Lehi, they raided banks, warehouses, arms depots and a diamond polishing plant, thus raking in the $£ 2,000$ to $£ 3,000$ required to sustain operations and propaganda efforts each month. A combined Jewish underground of about three thousand pinned down 80,000 British troops as well as thousands of policemen, who cordoned city streets with concertina wire and gun nests and retreated behind their fortifications. When the British did emerge, they did so en masse to conduct massive, nationwide dragnets. These culminated in late June with Operation Agatha, a round up of more than a thousand Jews, including senior members of the Jewish Agency. ${ }^{238}$

In response, the Irgun took British officers hostage and demanded prisoner exchanges, so that each detention and prosecution of a fighter became an opportunity to publicly challenge the legitimacy of British authority. "Even more important than military operations, the Irgun exploited the trials of their arrested members," observed 
historian J. Bowyer Bell. "In June and July the high command devised leveraged tactics to force the British one more step back in public humiliation. From the beginning the Irgun always considered the courts and prisons as their battlegrounds. The courtroom was a public forum, the prison yard a base for confrontation and escape.”239

Hecht defended the Irgun at the climax of this violence- a massive bombing of British army and civil authority headquarters at the King David Hotel that went horribly awry. As was their practice before every bombing, the Irgun had given warning to minimize the death toll, but either they botched the timing or their phone calls were ignored. The July $22^{\text {nd }}$ blast killed ninety-one people and wounded about forty-five, many of them civilians. It shattered the fragile Tenuat Hameri alliance, and might have had a disastrous impact on public support had it not been for Gen. Sir Evelyn Barker's vow to punish the Jews "in a way that the race dislikes as much as any by striking at their pockets." This eclipsed whatever furor Hecht's comments would otherwise have raised, appearing as they did in a Times story headlined "Leading U.S. Jews Denounce Violence." While spokesmen for the American Jewish Committee and AZEC lined up to condemn the Irgunists as cruel terrorist fanatics, Hecht declared: "The hand which writes British policy in Palestine is directly responsible ... Remember this hotel is the nerve center of a regime which uses concentration camps, suppression, terror and torture, which shoots unarmed civilians, and exiles and imprisons without trial.,240

Hecht recognized that, like early 1943, this was another turning point in history. In April, the final report of the Anglo-American Committee had recommended Palestine be handed over to a United Nations trusteeship, which could in turn lead to an independent Jewish state under a negotiated Partition plan. The Haganah's withdrawal 
from the Tenuat Hameri campaign after the bombing presented the Jewish people with a clear choice between two potential paths to statehood: armed struggle on the one hand, or civil disobedience and diplomacy on the other. In recommitting to the latter course, the Ben-Gurion camp signaled it would keep faith with Britain, America and the United Nations, and with the liberal ideals they purported to represent. The militants, on the other hand, presented themselves as the true democrats, since the British were blocking Hebrew rights to self-determination and freedom. The motto of the ALFP was: "It is 1776 in Palestine." Hanging in the balance was not only the fate of Europe's "Displaced Persons" and the very survival of the Yishuv, but also the future character of a Jewish state and its position in the world. ${ }^{241}$

After Billy Rose suggested another spectacle on the order of We Will Never Die, Hecht spent the early summer of 1946 writing one that would not only draw support for a Jewish homeland, but also make the case for armed resistance. A Flag is Born would be another historical pageant, but instead of featuring a "cast of thousands," it would cast a spotlight on three Holocaust survivors adrift in Europe and searching for the Promised Land — an especially troubling sight to American audiences in 1946. A vehicle of unvarnished, unapologetic propaganda, the play was crafted by Hecht in partnership with some of the great talents of the Yiddish theater to hit a nerve with Jewish Americans, and it did. Director Luther Adler and his half-sister Celia, the lead actress, were children of the legendary Jacob P. Adler, who helped establish Yiddish theater in New York City. Celia and Paul Muni played Zelda and Tevya, now rendered as pale apparitions of the once "salty and hilarious folk" who had appeared in Sholem Aleichem's fiction. The doomed couple personified the hapless "ghetto mentality" of the Jewish Agency, yet 
paradoxically, also conveyed Hecht's reverence for the world of his parents and grandparents, now lost forever. "All the Tevyas whose souls and sayings, whose bizarre and tender antics Sholem Aleichem immortalized in the richest Yiddish prose ever written — were massacred," Hecht wrote in an essay for the Times that July. "And all the quaint and heartwarming villages in which the Jews of Europe lived are no longer on the map. 242

The true star of the show, however, was a disciple of Celia and director Luther Adler's sister Stella, an eccentric but magnetic twenty-two-year-old actor named Marlon Brando. Stella Adler, the worldly celebrity and drama coach, had groomed Brando's extraordinary natural talent, adopting this corn-fed boy from Omaha as a member of her own family and introducing him to much of what he now knew of art and culture. ${ }^{243}$ The young David who appeared onstage as a result cut a striking figure with his muscular body and stunning good looks: as looked at from one angle, the kind of tousle-headed American youth who had recently beaten Hitler; as seen from another, "the New Jew" of Palestine.

Brando had already played in three Broadway shows, but his role in Flag was the first that he was truly excited about. Although Maxwell Anderson's Truckline Café, which had opened at the end of February, had been a flop, Brando's performance had generated considerable buzz, which only increased when he rebuffed the best efforts of MGM and other studios to get him under contract. Brando was eager to do serious work, and talk of Hecht's new pageant had enthralled Manhattan's progressive community. "I wanted to act in the play because of what we were beginning to learn about the true nature of the killing of the Jews," he later recalled, "and because of the empathy I felt for 
the Adlers and other Jews who had become my friends and teachers and who told me of their dreams for a Jewish state.” The all-star cast agreed to work for the Actor's Equity minimum; technicians gave their services for free and the set was built at cost. Hecht and composer Kurt Weill donated their royalties. ${ }^{244}$

As rehearsals got underway in August at a West Fifty-Fourth Street studio just above Al \& Dick's Restaurant, Muni heard the rumors about this crazy Brando kid who carried around mice and let them run all over the stage. Luther, who soon became uncomfortable with Brando's tendency to mumble, discussed his and Muni's concerns with Hecht, and suggested they find a safer bet. "Good actors bore me," Hecht replied. "I'm curious to know what this guy Brando is going to do. He intrigues me." Nevertheless, Hecht finally got so fed up that one afternoon he threw down a challenge by acting out a scene himself. Either this provocation or Luther's direction did the trick. "Marlon uncorked," the director recalled. "Muni suddenly thought he had a tiger by the tail. Brando was incredible: flash, violence, electricity. ... Celia's eyes became soup bowls. Muni turned scarlet. His lips began to tremble; then he got kind of foolish grin of approval on his face." A Flag is Born preceded A Streetcar Named Desire as Brando's first sensational performance, thus launching the ascent of a cultural icon. ${ }^{245}$

Many postwar American works argued that the Jewish survivors in Europe needed a haven in Palestine, ${ }^{246}$ but $A$ Flag is Born challenged the idea that the Jews must ask Britain or the United Nations for the permission to build one. Opening at the Alvin Theater on September 5, the curtain rose to reveal Tevya and Zelda staggering blindly somewhere in a continent that "echoes with the tumult and wail of a rebirth," but is for Jews a realm where the dead hold dominion over the living. "Does one open a shop under 
the gallows where one's father was hanged?" asks the narrator. "Does one return to picnic near the lime pit where one's children were slain? Europe is a gallows and a lime pit...There are dead people under every road of Europe — dead Jews." Since the Jews have no rights or representatives recognized by any world court, they "can address nothing more official than the world's heart and conscience," explains a brief prologue to the published script. "Are there such things?" The answer, Hecht's play suggested, was no. ${ }^{247}$

Having managed to survive Treblinka, Tevya and Zelda wander like ghosts, stopping to rest in what appears to be a park, but turns out, fittingly, to be a Jewish graveyard. There they stumble upon eighteen-year-old David, another survivor of Treblinka, stirring from sleep. When Tevya hails the boy's appearance as an answer to their prayers, David mocks his piety, pointing out that God didn't save anyone's sons or daughters in the death camps. The war has seared scorn deep into young David's soul, but he too dreams of the homeland, and vows to run the British blockade: "There are three things that British fences can't keep out of Palestine—rain, the wind, and a Jew..." He tells of a vision of a nearby bridge to Palestine that has just appeared to him in his sleep. $^{248}$

Tevya can't see the bridge, but he is soon overcome by visions of his own-of the Hebrew kings Saul, David and Solomon. He can no more counsel the angry, suicidal young man than he can provide food and a warm bed to his dying wife, so he appeals to Solomon for guidance. What can we do about a world full of enemies, he asks, who bar us from the one place that offers refuge, our Holy Land? If the world is your enemy, 
replies the great sage, then you must go to the world, and be not afraid: "In you, Tevya, is the tongue of greatness, the tongue that fashioned the eternal words of justice."249

Tevya appears before the Council of the Mighty, a caricature of the United Nations Security Council, where he immediately faces objections. When an English statesman charges that the Jews "have taken up arms against British law and order," Tevya retorts: "If somebody makes a law against humanity — who is the law breaker?" Allowed at last to say his piece, he pours the last of his strength into a soaring plea for a homeland. The delegates cheer and to his great elation, concede that he has convinced them. But when they announce another commission to study the issue, he reaches out pleadingly to this empty promise, and the vision fades. "Look at him!" David spits. "Holding out his heart like a beggar's cap! To whom, Tevya? To the hyenas in the night?"250

Tevya has awakened to find Zelda lying motionless at his feet. Overcome by grief, he collapses beside her as the Angel of Death casts its shadow upon them. Tevya urges David to continue on, but the young man is now spiraling into despair as well. Just as David raises a knife to kill himself, a light shines and a voice calls out his name. The envisioned bridge appears, and upon it, the fighters of the Haganah, Irgun and Lehi, beckon him to join. That bridge is in your heart, they tell him; it is a bridge of youth and courage. "Saul and the Maccabees live again in Palestine," says a soldier . “...We promise you an end to pleading and proverbs. The manhood the world took from us roars again in Palestine." David takes Tevya's talis, affixes a blue star from his pocket upon it, and holding this flag aloft, runs to the bridge. ${ }^{251}$ 
New York Times critic Brooks Atkinson praised Muni for one of the great performances of his career, but it was Brando's fiery, accusatory speech about the silence of American Jews that ignited an uproar. "The whole audience sort of rose up, en masse," recalled friend Jack Bittner. It was "like an electric shock that 'just cut through you with true emotion." At some performances, as he started to yell "When the six million were being burned and buried alive in the lime pits, where were you?" Jewish girls got out of their seats and screamed from the aisles, convulsing in anguish and guilt. One woman was so overcome by emotion that she shouted back at him, "Where were you?" "At the time there was a great deal of soul-searching within the Jewish community," Brando explained in 1994. When a close friend had asked how he managed to connect on such a personal level, he answered: "I was thinking about the police beating up on Negroes around Times Square." 252

Louis Kronenberger griped in $P M$ about "speeches that are too long, writing that is too purple" and New Yorker reviewer Wolcott Gibbs found Hecht's script to be "a combination of dubious poetry and political oversimplification.” Yet despite mixed reviews, the public response was overwhelming. The League extended the original fourweek run to three months, switching to different Broadway theaters for 120 performances, with some shows sold out six weeks in advance. When the cast received a standing ovation on opening night, Luther Adler called out: "If your cheers mean anything, give now before you walk out of the lobby." A member of the production made an appeal after each performance, and the donations exceeded box office revenues. Flag went on to play packed houses in Boston, Philadelphia, Detroit and Los Angeles. In Chicago, it ran for over a month. The play was banned in England, Canada and Palestine, 
but a tour of South America started in the summer of 1947, and refugees performed it in Hebrew at a British interment camp in Cyprus. At the end of the opening season, Luther Alder replaced Muni, and afterwards Jacob Ben-Ami took the role of Tevya. Brando was eventually replaced by Sidney Lumet, who later gained acclaim as the director of such films as Dog Day Afternoon and Serpico. ${ }^{253}$

There could be little doubt that Hecht's message was heard by the powers that be. The Times reported that members of the United Nations were invited to the premiere, "and there were more than a few of them," who "must have been under the impression that one scene in particular was laid at their doorsteps in Nassau County, in fact right into the chamber of the Security Council." When Whitehall lodged objections with the State Department, Hecht responded: "Britain may be able to patrol the Mediterranean, but she cannot patrol Broadway." The Washington D.C. performances were diverted to protest racial discrimination at the city's theaters, so the League hired a special train to transport dozens of officials, including foreign diplomats and some eighteen U.S. senators, to the opening night in Baltimore. ${ }^{254}$

The mainstream Zionists mounted as vehement a protest as they had against $W e$ Will Never Die. Most contentious were the performances in Philadelphia, where the January $27^{\text {th }}$ premiere for a two-week engagement coincided with a Zionist meeting at the Benjamin Franklin Hotel. Local branches and Zionist youth movements organized large street rallies and formed a picket in front of the Erlanger Theater, holding placards that read: "Do not attend this play!", "Watch your pockets!", and "Do not contribute as the money is being wasted!” A physician named Dr. Bernard Kahn who participated in the conference said that at least a dozen people accosted him in the hotel, appealing for him 
to not attend the play. He went anyway, saw the pickets, and later conveyed his shock to a local Zionist leader at what met the eyes of many non-Jews that night. "What an impression on them to watch the disgraceful display of disunion among the Jews!" he wrote. "I can hardly express myself adequately the bad taste and disgust I felt...and still do, at this nasty affair perpetuated in the name of the Zionist Organization of America." As for the show itself: "I have benefited more spiritually by this play than by all the Zionist meetings I have ever attended."255

Many critics of the play were appalled by what they saw as salesmanship for terrorism and gangsterism. Remarking that Flag "overflows with sincere crusading fervor," Life observed: "At the end it demands actual physical aid to the Palestine underground." Jewish Agency representative Eliahu Epstein voiced concern that crowds left "the theater excited and impatient with everything that is not based on Irish methods of national struggle." An Americans for Haganah "Sound Truck Project" in Jewish neighborhoods denounced the Irgun and its U.S. publicity campaign, while Zionist youth groups published ads in December 1946 alleging that the money raised by the ALFP would be used by "traitors" to buy " molotov cocktails, machine guns and home-made flame-throwers to blast the walls of a Labor clubhouse' or rubber hoses with which to beat youths who were reluctant to join the Stern Group.",256

Perhaps the most incisive retort to the play was an open letter to Eleanor Roosevelt from Judah L. Magnes, the dovish chancellor of Hebrew University of Jerusalem, criticizing her endorsement of it. Noting that Flag "makes an open appeal...for terrorist groups," and talked of speaking "to the English in a new language, the language of guns," Magnes lamented: "This is, indeed: a new Jewish voice, a voice 
which is opposed to the whole tradition of the Jewish religion.... It is but a reflection... of the militarism that has seized hold upon the greater part of mankind, and unhappily also part of the Jewish people." A staunch believer in a one-state solution for Arabs and Jews, Magnes decried Hecht's description of the Arabs as "a British lie wearing a tarbush," in one of the few references that the script made to them. Finally, he objected to an ALFP flyer that asserted the League's goal was to build a democratic state, with Arabs and Jews sharing the land as equal partners based on the principles of the Four Freedoms and Atlantic Charter. "It is a profound distortion of the truth to say that those responsible for this play want this," Magnes said. "What they want is a Jewish State, dominated by Jews." A truly democratic state, he explained, would be dominated by the Arabs, since they were in the great majority, and in a democracy, the majority rules. ${ }^{257}$

Magnes had insinuated that Hecht was peddling fascism, but the playwright clearly saw himself as a humanist who championed the Rights of Man, or "human rights," as they were being called in the new parlance of the postwar era. Hecht had moved the Washington, D.C. performances of Flag to Baltimore because he had joined with thirty-two other well-known dramatists to take a stand against racial discrimination. Upon learning that the Maryland Theater restricted blacks to the balcony, which the racists had named "nigger heaven," the League confronted the management hours before the opening curtain. Pointing out that a dust-up would draw particular attention since it happened to be the anniversary of Lincoln's birthday, the Bergsonites warned of an angry NAACP picket line, and threatened to test the theater's policy by having prominent invitees accompany African-Americans as their guests. The management relented, and 
the attendance of ten to twelve black men and women that night scored an important victory for the desegregation of Baltimore venues. "I am proud that it was my play which terminated one of the most disgraceful practices of our country's history," Hecht crowed to the press. ${ }^{258}$

When the London Evening Standard expressed alarm that 44,800 people "have already flocked...to see the most virulently anti-British play ever staged in the United States," Hecht replied: "I didn't know that backing the rights of people to live peacefully in their own land constituted being anti-British." He added that he expected Britons to like the play, since it protested "concentration camps, book burning and murder." Quentin Reynolds, the famous war correspondent who played the narrator, said that to label Hecht "anti-British" was to dismiss the "great work he did...for Britain's cause long before Pearl Harbor."259

Indeed, promotional materials for Flag were reminiscent of Fun to be Free and Hecht's wartime propaganda, and packed with the same patriotic ballyhoo. Touting him as the "Tom Paine" or "Jefferson" of Hebrew liberation, pamphlets distributed at theaters declared: "This is not a Palestinian front or a Hebrew or Jewish front, it is an American front." Democracy is a "cause that is never won but must always be fought for." The play drove home the message with a vignette from the Book of Samuel, in which Tevya sees the Hebrews of Jabesh-Gilead awaiting the orders of the great King Saul as they face siege by Nahash, ruler of the Amonites. A famous feature of the tale-the Amonite threat to gouge out the right eye of every Hebrew — suggests that liberty is as dear as an eye, but Hecht also related the more literal explanation provided by the Jewish historian Josephus: A warrior needs his right eye to see, since his left is hidden behind his shield. The old 
men of the village implore Saul to surrender, but he commands them to fight or face death by his own hand. "My kingdom is not a matter of flocks and houses and the earnings of careful men," says the great monarch. "It is a matter of the spirit.,"260

Despite the exhortations of Jeffersonian liberalism in the pamphlets and ads for the play, this was the same jingoistic bombast about gallantry that Hecht had provided for the Allies, and it smacked of the same romanticist sensibility. As Stephen Whitfield noted: "The political signature is easy to identify, since he wished to honor what the reactionary publicist Maurice Barrès called la terre et les morts ('the earth and the dead')." Magnes had pointed out the contradictions in Hecht's pageant, which was not the only work of a pro-Irgun writer that was either denounced for its hypocrisy or celebrated for its nuance, depending upon the commentator's point of view. In fact, $\mathrm{New}$ York Times critic Richard Watts. Jr. contrasted the complexity of Arthur Koestler's novel Thieves in the Night, which hit the bookstores while Flag was on Broadway, with the "simple, primitive, black-and-white propaganda" of Hecht's script. "In the end, though, Koestler is as partisan as Hecht," Watts added, "for all the Hamlet-like qualities he allows his protagonist or the germ of patriotism he permits an occasional Arab or the taciturn decency he concedes to a rare British official." ${ }^{261}$

Marlon Brando had believed that he was acting as a militant progressive, just as he would in the 1970s when he supported the American Indian Movement at Wounded Knee, but later in life he had second thoughts about the work he had done for the Irgun. After acting in the play, he had toured as "a kind of traveling salesman" for the cause, speaking at screenings of an eighteen-minute film, Last Night We Attacked. "That people fresh out of Bergen-Belsen, Dachau and Auschwitz should be stopped on the open sea by 
British warships and interned again behind barbed wire on Cyprus was enraging," Brando recalled in his 1994 memoir. "I did not know then that Jewish terrorists were indiscriminately killing Arabs and making refugees out of them on their own land.... Now I understand much more about the complexity of the situation than I did then." ${ }^{262}$ Receipts for the ALFP totaled $\$ 742,000$ in 1946 , overwhelmingly from the ticket sales for A Flag is Born and attendant publicity. How these funds were disbursed remains murky, since support for illegal immigration and the Irgun had to be provided through clandestine methods. Bergson remained in charge of coordinating all efforts, and since he and the rest of the Palestinian Jews of the HCNL were registered as foreign agents, any assistance they gave to Begin's fighters would be in violation of federal regulations. The FBI wiretapped the group's phones and offices, opened mail, dug through trash, raided offices, and maintained a paid informant, continuing the investigations for years after the state of Israel was established and the group had disbanded. As more than a thousand pages of internal reports released under the Freedom of Information Act reveal, the bureau never uncovered evidence of illegal activity, but according to Bergsonite activist Baruch Rabinowitz the group was able to maintain support all along while eluding the $\mathrm{FBI}^{263}$

In A Child of the Century, Hecht proudly recalls watching in awe as Americans gave "millions" to purchase arms and medical supplies for the Irgun, but this whitewashes the tensions that arose over how much of the money raised actually went to that purpose, and the questions that remain about what happened to the rest. In later years, Bergson always maintained that he had opposed direct financing of the Irgun. BenAmi quotes "a scathing letter" from Begin in his memoir from July 10, 1947, which 
complains of receiving "not even a farthing for the battle." Ben-Ami concurred: "All along, not securing sufficient funds had been our greatest failure." Beyond the personal testimony, certain facts are indisputable: Bergson was ousted as chairman of his own Hebrew Committee of National Liberation in December 1947—he euphemistically took "a leave of absence" - and was replaced by Merlin, who agreed to follow Irgun directives. Begin never spoke directly of his conflicts with Bergson, but he barely acknowledges any contributions by the U.S. group in his memoir, The Revolt. ${ }^{264}$

Very little of the money seems to have gone to repatriation efforts, either. Funds from the pageant purchased the Abril, an eight-hundred-ton yacht that set sail for France as the SS Ben Hecht on December 27, 1946. The ALFP told the New York Times that it had transferred roughly $\$ 300,000$ to a repatriation fund in Europe, while a spokesman for the Maritime Commission reported that the Abril had been bought for $\$ 36,100$. But the European fund evidently did not yield much in the way of results: During the postwar years, Mossad ships transported about 70,000 refugees to Palestine, including some 30,000 on nine vessels purchased in America. By contrast, the six hundred refugees aboard the SS Ben Hecht appear to have been the sum total for the Bergson Group. (In any case, the British intercepted all ten American ships, and the refugees were sent to interment camps, mostly in Cyprus.) $)^{265}$

So if neither arms nor repatriation can account for a significant portion of the hundreds of thousands that Hecht raised, where did the rest of the funds go? By all accounts, money not reinvested in America went to establishing a provisional Hebrew government in France, and to launching a similar publicity campaign there. Using the methods that had proven so effective in United States, Bergson started La Riposte, a 
French version of his magazine The Answer, and sought non-partisan appeal, recruiting leftist intellectuals like Jean-Paul Sartre and Simone de Beavoir as well as leaders on the extreme right. ${ }^{266}$

A strong believer in the power of media and diplomacy, Bergson appears to have pursued a grand strategy: through gaining recognition for his government-in-exile from France, one of Britain's chief rivals, he could acquire immense quantities of arms, enough to dwarf the dribble of American contraband that Begin kept pestering him for. He intimated as much in a letter to Hecht about how he intended to use the windfall from the pageant. "If all this will give us the strength and the means to establish the Provisional government, we are bound to succeed in turning the present tide of defeat, after which the tortuous road to freedom becomes a glorious highway," he wrote in early October 1946. “...I know now and I will know then that it was 'The Flag' which provided the Archimedes point and which gave us the lever with which to lift this heavy ballast." 267

Begin, with his perspective from the front lines, grasped the logic of Bergson's strategy all too well, and also understood the dangers. Ben-Ami recalled that when he first relayed the plan for a provisional government during a meeting in Palestine, the Irgun chief became extremely tense. Chopping his hands in the air for emphasis, Begin warned of "a bloody civil war," and later repeated this warning in his 1947 letter: "To rush with such a decisive political step will be to destroy that edifice before it is built." A year later, one of the most tragic episodes of Israel's early history proved that both leaders had been right in their own way. ${ }^{268}$ 
Bergson always adamantly denied that a scheme to overthrow Israel's newly born government was in the works on June 11, 1948, when an Irgun crew set sail from the southern coast of France in a ship called the Altalena. But documents from a 1949 French Defense Ministry inquiry reveal that French senior negotiators, at least, believed a coup was imminent when Bergson convinced them to ship enough weapons and equipment to supply an entire army. Deputy Chief of Staff Major General Henri Coudraux, who was put in charge of the operation, stated that there had been "a secret agreement concluded with the Irgun, promising advantages to France if it seized power." In a 2010 study, Israeli historian Meir Zamir suggests that Ben-Gurion's envoys in France got wind of the agreement, which is why, on June 22, 1948, he commanded the Israeli Defense Forces to fire on the ship when it landed in Tel Aviv, killing sixteen Irgunists. Among the dead was Avraham Stavsky, who had been one of the leaders in smuggling refugees during the late '30s and a personal hero to Hecht. Stavsky had turned his back to the beach when the firing started, Hecht recalled in Child, and upon learning about the Altalena affair, Hecht, too, forever turned his back on the Jewish state. ${ }^{269}$

Whether or not Bergson had been pursuing a grand strategy to gather arms all along, Hecht's papers reveal that he was not made aware of it, and had gradually become alienated from his friend. By 1947, as mainstream Zionists and Bergsonites alike began turning to members of the underworld in a scramble to acquire arms, explosives, tanks, planes and ships wherever they could find them, Hecht forged a partnership with the most powerful Jewish gangster of the day: Mickey Cohen. Hecht was in effect now freelancing, going his own way in a departure from the Bergson Group. An angry letter that he drafted shortly after he joined forces with Cohen explains his own politics and 
priorities at the time. The letter, addressed "Dear Sam"— presumably Merlin—was written after a September performance at Carnegie Hall of The Terrorist, a salute to the recently martyred Irgun fighter Dov Gruner, which Begin had urged Hecht to write. In a fit of pique after waiting up most of the night for a call or wire that never came, Hecht wrote: "This indifference to me and self-obsession of the League served to wake me up to a number of things that have been on my mind for some time. Here they are."270

He objected to the group's continued efforts to outdo the Haganah's repatriation efforts, which he called "absurd and against all propaganda sense. ... The Exodus story can't be topped by a few five-and-ten-cent gestures by the League." He also protested the continued complaints and attacks against the Partition Plan, which was headed for a vote in the UN General Assembly. "The Partition is obviously wrong. But to attack the UN is a thousand times more wrong," he said. "England is the enemy. The UN is a half-fraud." Britain would happily underwrite the League's complaints, because it would provide them an excuse to throw out the whole proposal. "My main point about the League's activities is this - I do not want to further its present policy and expenditures," he continued. "I think all it has done up to two months ago excellent. It was necessary to stir and stir and churn up public emotion - to inspire the Haganah and Zionists to further and bolder action. This the League did." 271

But now it was frittering away money uselessly on its provisional government adventure and efforts to compete with the larger organization's repatriation efforts. He noted that of the $\$ 750,000$ raised by the League in 1946 , only $\$ 35,000$ went to the Irgun. This year, 50 percent of the earnings should go to the fighters, instead of less than 5 percent. "I have no wish to finance French junkets and foolish Bergsonian high-dee-ho 
with my efforts. ... I have no wish to battle the League- It is only that I wish to withdraw myself from sustaining its (to me) childish and extravagant futility." Although according to his wife Rose, Hecht never sent the letter, and his cooperation with the group continued, but by then Bergson was exiting the scene. ${ }^{272}$

Only Thus had been the motto of the resistance, and debate would rage for decades over which course had been more effective in ousting the British—-the armed struggle of the Irgun and Lehi, or the determined civil disobedience and statecraft of the Jewish Agency. The insurgency came to a climax in the spring and summer of 1947, with the Irgun's spectacular Acre Prison jailbreak and its hanging of two British sergeants, amidst a continuing torrent of raids and bombings. That same summer, the mythic saga of the Haganah's refugee ship Exodus riveted world attention and, at least in popular memory, provided the decisive push for Partition when the General Assembly voted on November 29.

In his 1961 book Perfidy, Hecht wrote that while on a visit to New York at the end of the '40s, Winston Churchill met Billy Rose at the home of Bernard Baruch, and spoke to him about the recent tumult. "If you were interested in the establishment of an Israeli nation, you were with the right people," Churchill said. "It was the Irgun that made the English quit Palestine.” After careful research of archival documents, Israeli historian Aviva Halamish concluded that the Exodus did not play the pivotal role at Lake Success it has been assigned in popular memory. Yet as she witnessed the Intifada of Palestinian Arabs in 1987, she gained a new respect for the restraint that Ben-Gurion's side had exercised decades earlier: "I learned to value even more the illegal immigration as a unique method chosen by the Jewish national liberation movement—Zionism—in its 
struggle for independence. Not personal or blind terror, nor acts of violence involving physical attacks on the enemy and casualties on the part of the strugglers, but a calculated blend of political and diplomatic activity and a struggle which took advantage of the weakness of the strong and the power of the weak." 273

It ultimately may have been the combination of Ben-Gurion's tactics and armed resistance that achieved success for the Jews. Regardless, out of the catastrophe of the Holocaust and the ensuing fight for statehood, two distinct perspectives emerged that have defined arguments about Israel ever since. 


\section{CONCLUSION}

The catastrophe wrought by National Socialism suggested that Hecht had been right to reject the rosy view of man and human progress so fundamental to liberalism. Mankind had proven not only flawed, but murderous. Like Erich Fromm, Hecht understood Nazism as a case of mass psychopathy, while in his view, the great governments "of the people," built upon the humanistic ideals of the Enlightenment, had been exposed as frauds. At best, Churchill and Roosevelt had responded to the challenge of Hitler by fighting not for ideals, but for narrowly defined national interests, even though that had meant forsaking an entire population targeted for annihilation. Hecht had not only predicted the genocide four years before the first news of it arrived, he had painted a chillingly vivid panorama of what the world could expect. He had cried out for rescue early and often, and had kept on doing so, even when those cries fell upon deaf ears. History seemed to have proven him right; his so-called "cynicism" had in fact been realism — even, somehow, a truer humanism. Still, while there could be little confusion about what Hecht did not believe, the question remained: What did he believe in?

Jewish Frontier managing editor Ben Halpern offered an answer in a lecture to fellow Labor Zionists of the Pioneer Women's Organization, weeks after Hecht's 'Letter to the Terrorists of Palestine" appeared in newspapers. Halpern, a Harvard Ph.D. and deeply engaged Zionist activist, explained Hecht, the Bergson Group and Irgun as an “irresponsible, undisciplined opposition" that sought to undermine the Jewish Agency's strategy for statehood and usurp its power. Noting that the Irgunists and Sternists had ambitions to conquer not just Palestine but all of Transjordan and had vowed to resist Partition, Halpern warned that the militants were prepared to defy the will of the Jewish 
majority, by force if necessary. "This is terrorism—-terrorism directed against the Jewish community as much as against the British government," he declared. The campaign of violence, he said, went beyond the notorious bombings of British installations: The aim was to rule the Yishuv through intimidation. Citing a recent news article in which the Stern Gang had claimed "expropriations" accounted for twenty percent of its financing, he charged:

Whatever the percentage is, they engage in bank robberies and rob businesses in Palestine and they engage in extortions. They threaten people with bombing their business or beating them up if they don't kick in the required sum.

They terrorize the Jewish community in many other ways. They seize taxi cabs and hold drivers prisoners so they can use them in their raids. They terrorize Jewish schoolteachers to force the children in classes to post their bills, to put up their billboards, their posters. They flog young boys for various reasons - sometimes because they have been members of the Stern Group and decided they don't want to be any longer. And cases have been known where they killed young boys in public streets. ${ }^{274}$

Building upon this picture of a gangster rampage, Halpern characterized the Irgun's kidnapping of British officers as vendettas, intended to instigate a cycle of reprisal that would derail the political process. He argued that a letter from Hecht to a British newspaper which called Britons "the nicest enemies the Jews ever had" amounted to an open invitation to a "game of war." Such a cavalier attitude towards the violence, which Halpern called "Ben Hechtism," put the lives of Jews in peril, he said, because if the British army so chose it could obliterate the entire Yishuv. ${ }^{275}$ Halpern's thrust was to explain who the radicals were and what they represented. "These people are fascists," he concluded, "and don't be surprised that there are idealists among them - they are fanatics, devoted to an ideal or ideology, among all fascist groups. As in all fascist groups they are not choosey about their methods. They use lies, use murder, use extortion, they use 
sympathy of the Jewish community in cases of provocation given by the British." He then offered a definition for this label that he had given them: "Fascism in itself is a system for gaining power without any other objectives.... This is all a means to gain power; a sheer power drive." In other words, Hecht's charged rhetoric, theatrics and contradictions could be understood as pure nihilism, a belief in nothing. Hecht was a huckster for a group of racketeers, who valued nothing, understood nothing except the tactics of grabbing money and power. ${ }^{276}$

Was Hecht a fascist? The explanation Halpern had offered for fascism was common in his day, but by the 1960s, scholars began to challenge the contention that it was indeed an ideology devoid of content. On the one hand, fascism had been a political movement that had emerged in Italy in 1919 and came to the fore when Mussolini took power in 1922. On the other, after the Second World War the term become the epithet hurled at anyone whom people - mostly on the left—didn't like, the unanswerable, capping insult to any argument. "While in our political vocabulary there are not many terms that have enjoyed such a considerable vogue as the word fascism, there are equally not many concepts in contemporary political terminology so notoriously blurred and imprecise," wrote Israeli political scientist Ze'ev Sternhell in 1976, expressing the view of his peers. Much of the confusion stemmed from the fact that the original Italian fascists had never clearly delineated their core principles in the first place. ${ }^{277}$

In more recent years, scholars have offered explanations that built upon the spadework of identifying the characteristics common to the various fascist movements. One early point of agreement was that Italian fascism could be easily distinguished from National Socialism, since the latter was rooted in a virulent racism, a war against the 
Jews that was even more defining than opposition to Marxism. Another was that fascism should be understood as something more than a set of negatives, a consensus that emerged largely in response to one the great first works about fascism by the German philosopher and historian Ernst Nolte. Nolte had argued that fascism was the great "anti" ideology: anti-liberal, anti-Marxist, anti-bourgeois, in short, a rejection of everything modern. ${ }^{278}$

Had Hecht heard the more recent explanations of fascism, he might have been reluctant to admit the degree to which they seem to evoke ideas he had professed since his days as a young rebel. In The Birth of Fascist Ideology: From Cultural Rebellion to Political Revolution, Sternhell, for instance, describes an early twentieth century cultural and intellectual movement that started as "a rejection of the heritage of the Enlightenment and French Revolution.” In seeking to synthesize "an organic, tribal nationalism," it "wished to rectify the most disastrous consequences of modernization," namely pervasive alienation in a new urban, industrialized world, the dehumanization of the individual in an increasingly fragmented society. Sternhell could just as well have been discussing Hecht's commentary on Voltaire when he observed that many writers of the era "constantly attacked the critical spirit and its products, opposing them to instinct, intuitive and irrational sentiment, emotion and enthusiasm - those deep impulses which determine human behavior and which constitute the reality and truth of things as well as their beauty.",279

One such progenitor of fascism was Barrés, who believed that "in order to ensure the welfare of the nation, one had to turn to the people and exalt the primitive force, vigor and vitality that emanated from the people, uncontaminated by the rationalist and 
individualist virus. ${ }^{, 280}$ For the most part, this suggested Hecht's cheerleading for the tough "New Jew." He was certainly fond of tribes, having been as loyal to the Irgun and to the Jews as he had been in the past to journalists, artists, and pirates. But Hecht was neither the kind of nationalist nor anti-individualist that Sternhell goes on to discuss, and the analysis offers nothing that would explain or account for Hecht's campaign for rescue. Hecht was as much a liberal as was Jabotinsky, and his advocacy for individual and minority human rights had been in no way insincere.

However unsatisfying Halpern's explanation of fascism might be for later generations of scholars, he had been on to something in suggesting that Hecht and the Revisionists were defined by an absence of belief. It was, after all, a deep and abiding faith in the democratic process - in the face of so much evidence to the contrary - that kept the Ben-Gurion camp from violently resisting British policy, and underpinned their policy of restraint, or Havlagah. By the same token, it was the Irgun's rejection of Havlagah that resulted in the slaughter of civilians, in their reprisals against the Arab Revolt, their bombing of the King David Hotel, and their killing of over one hundred Arabs in the village of Deir Yassin in 1948.

The marketplace bombings of the 1930s had been loudly condemned, Ben-Ami recalled in his memoir, but something had to be done to stop the Arabs from smuggling weapons in on vegetable trucks while Mandate policemen looked the other way. Irgunists involved in the King David Hotel explosion swore that they had given sufficient warnings; the British had simply chosen to ignore them. As for Deir Yassin, Irgun and Stern Gang veterans always described what happened as a ferocious house-to-house battle to clear a village that had been a staging ground for Arab attacks during the siege 
of Jerusalem. Women and children were killed because the fighters had been forced to toss grenades into each home. But in the aftermath, Haganah and British commanders circulated allegations of a massacre, mass rapes and prisoners paraded through the streets of Jerusalem, while lurid accounts of atrocities broadcast in Arabic were remembered as having sparked the wave of panicked flight that created the Palestinian refugee crisis. Many of the most damning reports about Deir Yassin have not held up to scrutiny, but the episode seared the infamy of the Irgun and Stern Gang into collective memory. ${ }^{281}$

Latter-day defenders point out that the Jewish militants were allegedly committing these crimes during years when Jews were being persecuted, hunted, and exterminated by the millions. Who has the right to judge the measures of people fighting for their lives during such desperate times? No one, however, has condemned the militants more harshly than their Jewish contemporaries did at the time. And regardless of the justifications they came up with for each individual incident, by the time that the rumors were spreading about Deir Yassin, the Irgun and Stern Gang had established a record of civilian casualties clearly distinguishable from that of the Haganah. It would forever be part of their legacy to the Jewish state. ${ }^{282}$

Hecht never expressed any regrets, but for the rest of his life, he brooded over the choices he had made. After the British Cinematograph Exhibitor's Association announced a boycott of Hecht's films in October 1948, he shifted from screenwriting to introspective autobiography. The book that he started about Mickey Cohen in the late 1950s turned out to be less biography than self-reflective inquiry into questions from the previous decade that still preoccupied him. Cohen's odyssey from pint-sized Boyle Heights boxer with the Star of David stitched into his trunks, from "that wild, hot-headed 
Jew kid with the lean face and Indian hair-do" to King of the Sunset Strip resonated as myth as well as farce, and Hecht could not resist finding ways to link the gangster's ongoing war against law, order and respectability with yesteryear's Jewish rebellion in Palestine. ${ }^{283}$ As Hecht delved deeper into the story - until Cohen double-crossed him by peddling it to others - his drafts and correspondence betray an uncertainty about whether he had been serving as proud troubadour of the "tough Jew," or friend of the devil. Perhaps he was both.

\footnotetext{
${ }^{1}$ Deborah E. Lipstadt, Beyond Belief: The American Press and the Coming of the Holocaust, 1933-1945, 1st Free Press pbk ed. (New York: Free Press, 1993), 98-111. The Nazis still had no plan for the Jews... Saul Friedländer, The Years of Extermination: Nazi Germany and the Jews, 1939-1945, 1st ed. (New York, NY: Harper Collins Publishers, 2007), 31, 187-188, 189, 237. The evolution and timing of the Nazis' extermination policy will be discussed in detail.

${ }^{2}$ Lipstadt, Beyond Belief, 103, 105, citing Saturday Evening Post, April 22, 1939, 104; and Press Conferences of Roosevelt, vol. XII, 227-229.

${ }^{3}$ Ibid, 101-102. Saul Friedländer, Nazi Germany and the Jews. Volume I, The years of persecution, 1933-1939 (New York, NY: HarperCollins, 1997), 284-285.

4 "We Are Wanderers," Time 32, no. 23, December 5, 1938, 19-20. Lipstadt, Beyond Belief, 107111, citing Christian Science Monitor, November 15, 1938, 1.

${ }^{5}$ Hecht, "The Little Candle," in A Book of Miracles, 25. On the efficiency of the Final Solution, see endnote \#20.

${ }^{6}$ Ibid.

${ }^{7}$ Walter Laqueur, A History of Zionism, 523-527; Nicholas Bethell, The Palestine Triangle: The Struggle Between the British, the Jews and the Arabs, 1935-48 (London: A. Deutsch, 1979), 5968.

8 "A more evil, foolish and short-sighted policy could not be imagined..." Tom Segev, One Palestine, Complete: Jews and Arabs Under the British Mandate, 1st Owl Books ed. (New York: Owl Books, 2001), 440, citing David Ben-Gurion, Memoirs, vol. VI (in Hebrew) (Tel Aviv: Am Oved, 1971), 200ff. “. .. a death sentence..." and "... a darkness all around us..." Walter Laqueur, A History of Zionism, 527, 532-533, citing Chaim Weizmann, Trial and Error (New York: Harper, 1949), 410, and the annals of the World Zionist Congress (Eton Hakongress), August 24, 1939. The Central Zionist Archives are located in Jerusalem. http://www.zionistarchives.org.il/en/Pages/ Default.aspx

${ }^{9}$ Tom Segev, One Palestine, Complete, 450, 461. On "selectivity," see Segev, 393-396, Walter Laqueur, A History of Zionism, 281, 318, 326-327, 332-333, 351-353. Edwin Black provides a concise explanation and some additional sources, in The Transfer Agreement: The Dramatic Story of the Pact Between the Third Reich and Jewish Palestine (Cambridge, Mass: Brookline Books, 1999), 142. See also endnote \#12.

${ }^{10}$ The mainstream Zionists denounced as fascists... Judith Tydor Baumel-Schwartz, The "Bergson Boys" and the Origins of Contemporary Zionist Militancy, 1st ed. (Syracuse, N.Y: Syracuse University Press, 2005), 13, 75-76. In 1936, Vladimir Jabotinsky had proposed a plan to "evacuate" a million and a half Jews... S. Klinger, Vladimir Jabotinsky, The Ten Year Plan for
} 
Palestine: A Brief Outline (London, New Zionist Press, 1938), cited in Walter Laqueur, A History of Zionism, 371. A year later, the Irgun dispatched Yitshaq Ben-Ami... Yitshaq Ben-Ami, Years of Wrath, Days of Glory: Memoirs from the Irgun, 1st ed. (New York: R. Speller, 1982), 122-130, 141-144, 157-158. Ben-Ami's activities are summarized in Baumel, The "Bergson Boys," 5-7. The World Zionist Organization only managed to smuggle 6,200... Yitshaq Ben-Ami, Years of Wrath, Days of Glory, 321. See also Yehuda Bauer, American Jewry and the Holocaust: The American Jewish Joint Distribution Committee, 1939-1945 (Detroit: Wayne State University Press, 1981), 130, citing records from the JDC Archives in New York, File \#42, "Palestine Emigration-Immigration, 1938-47, B. Kahn Memorandum, Nov. 29, 1939." According to Bauer, out of a total of 17,240 immigrants smuggled into the country illegally up until the war started in September 1939, "The Revisionists" claimed to have brought 9,460. Of that 17,240 total, 11,370 were seized by the British, which means that only 5,861 made it through. Ben-Ami, however, is clearly referring to a broader time frame than Bauer is. Baumel noted that documents in the Jabotinsky Archive in Tel Aviv and elsewhere substantiate Ben-Ami's narrative of his activities. In 2011, the memoir of fellow delegation member Samuel Merlin was posthumously published, and offers a brief but vivid account of Ben-Ami's rescue of 2,400 refugees marooned on the icy Danube River. Samuel Merlin and David S. Wyman Institute for Holocaust Studies, Millions of Jews to Rescue: A Bergson Group Leader's Account of the Campaign to Save Jews from the Holocaust (Washington, D.C.: the David S. Wyman institute for Holocaust Studies, 2011), 29-30. ${ }^{11}$ The British mere deducted an estimated number... Tom Segev, One Palestine, Complete, 459. The official Nazi policy was to expel Jews from Europe... Saul Friedländer, The Years of Extermination, 31, 188. While the Irgunists coordinated their activities with none other than Adolf Eichmann...Y Yitshaq Ben-Ami, Years of Wrath, Days of Glory, 147, 152-153, 158, 184, 274. 256-259. "When you soup with the devil..." Years of Wrath, 209.

${ }^{12}$ On shutting the doors and Henry Montor's letter... Baumel, The "Bergson Boys," 28, 74-75, citing Henry Montor to Rabbi Baruch Rabbinowitz, December 11, 1940, The American Friends of the League for a Free Palestine, 11, Jabotinsky Archives, Jabotinsky Institute in Israel. On Montor's pamphlet... Yitshaq Ben-Ami, Years of Wrath, Days of Glory, 321. Henry Montor, active in Zionism since his adolescence, served with the United Palestine Appeal from 1930 until 1950, as executive vice president after 1939. According to the Encyclopedia Judaica: "Although Montor was an ardent Zionist, the prevailing Zionist aim at the time was for 'selective' immigration to build a Jewish state, not the rescue of Jewish refugees. Therefore in 1940 Montor...refused to intervene for a shipload of Jewish refugees stranded on the Danube. He wrote a letter to a rabbi in Maryland stating that 'Palestine cannot be flooded with ... old people or with undesirables.' He circulated thousands of copies of the letter, which asked Jews not to support illegal immigration to Palestine." See "Montor, Henry," in the Jewish Virtual Library. http://www.jewishvirtuallibrary.org/jsource/ judaica/ejud_0002_0014_0_14152.html See also Samuel Merlin, Millions of Jews to Rescue, 30-31.

${ }^{13}$ Irving Howe, "American Jews and the Holocaust," letters column, Commentary, September 1983. http://www.commentarymagazine.com/article/american-jews-and-the-holocaust/ See also Lucy Dawidowicz, "Indicting American Jews," Commentary, June 1983.

${ }^{14}$ Jeremy Ben-Ami, Afterward in Millions of Jews to Rescue, 195-199.

${ }^{15}$ A humanist whose ideas were rooted in liberalism and rationalism... Walter Laqueur, A History of Zionism, 379. A Jewish democracy, with a majority on both sides of the Jordan... A History of Zionism, 347. "I am just the opposite (of a fascist)..." A History of Zionism, 382. "I belong to that old fashioned school..." Laurence Weinbaum, A Marriage of Convenience: The New Zionist Organization and the Polish Government 1936-1939 (Boulder : New York: East European Monographs ; Distributed by Columbia University Press, 1993), 21. 
${ }^{16}$ Walter Laqueur, A History of Zionism, 381. By the time Hecht came into contact with Revisionism, it was a broad umbrella for individuals and groups... Joseph Heller, The Stern Gang: Ideology, Politics and Terror, 1940-1949 (London: Routledge, 2004).

${ }^{17}$ These are in fact Tom Segev's words for the way Haifa police chief Raymond Cafferata described Menachem Begin in an unpublished autobiography, although Cafferata may indeed have drawn the comparison to Capone - a high-profile figure in his day. Tom Segev, One Palestine, Complete, 475.

${ }^{18}$ Jeremy Ben-Ami, Afterward in Millions of Jews to Rescue, 196-197.

${ }^{19}$ Saul Friedländer, The Years of Extermination, xvii.

${ }^{20}$ Historians have discussed and debated the alleged efficiency of the Final Solution, and the Reich as a modern, technocratic state gone mad, since Raul Hilberg published his 1961 classic, The Destruction of European Jews. As David Wyman explained in "Managing the Death Machine," upon the release of a new edition of Hilberg's book in 1985: "Early chapters define and analyze the 'destruction process' (definition of who the Jews are, expropriation of their property, concentration of the victims and then their annihilation) and the 'machinery of destruction." Christopher Browning noted: "It was not the chaos, anarchy, and internal competition of the Nazi regime that radicalized Jewish policy in Hilberg's view, but rather the 'fusion' of its four hierarchies into a single machinery of destruction that operated according to the inevitable logic of the destruction process. 'Consonance' and 'synchronization,' not chaos and internal competition--an 'inherent pattern,' not improvisation--hold center stage in Hilberg' s view." The "functionalist" school of Holocaust historians, on the other hand, would later argue that the extermination developed in an unplanned and haphazard way, and that "the Nazi regime was an inefficient machine out of control." But "for Hilberg it was a machine that was all too efficient and in control of both itself and its victims." Raul Hilberg, The Destruction of the European Jews (New York: Harper \& Row, 1961). David Wyman, "Managing the Death Machine," New York Times, August 11, 1985. Christopher R. Browning, "The Revised Hilberg" Simon Wiesenthal Annual, vol. 3 (1986): 294. http://motlc.wiesenthal.com/site/pp.asp?c=gvKVLcMVIuG\&b=395051

${ }^{21}$ Edwin Black, The Transfer Agreement, 76-77; Walter Laqueur, A History of Zionism, 371.

${ }^{22}$ Isaiah Berlin, "Maistre," in Freedom and Its Betrayal: Six Enemies of Human Liberty (Princeton, N.J. : Chichester: Princeton University Press, 2002), 132-138.

${ }^{23}$ Hecht, "Preface to Shylock," p.4, in "Shylock, My Brother," Works, 1908-1983, Box 23, Folder 635, BHNL. Walter Laqueur, A History of Zionism, 372. Hecht, Child of the Century, 531532.

${ }^{24}$ Samuel Merlin, Millions of Jews to Rescue, 3-5. Jabotinsky's foresight should not, however, be exaggerated: He envisioned evacuation over a ten-year period and did not foresee the coming war.

${ }^{25}$ Laurence Weinbaum, A Marriage of Convenience, 239, citing James G. McDonald, My Mission in Israel, 1948-1951 (New York: Simon and Schuster, 1951), 251. Alex Rafaeli, Dream and Action: The Story of My Life (Jerusalem, Israel: A. Rafaeli, 1993).

${ }^{26}$ Todd Samuel Presner, Muscular Judaism: The Jewish Body and the Politics of Regeneration, Routledge Jewish Studies Series (London; New York: Routledge, 2007), 1-2. Walter Laqueur, $A$ History of Zionism, 378-379, citing Chaim Weizmann, Trial and Error, 63.

${ }^{27}$ Walter Laqueur, A History of Zionism, 125-126, citing Chaim Weizmann, Trial and Error, 82.

${ }^{28}$ Ben Hecht, Charles Lederer, Eleazar Lipsky, Philip Dunne, Kiss of Death, starring Victor Mature and Richard Widmark, directed by Henry Hathaway (Los Angeles: $20^{\text {th }}$ Century Fox, 1947), DVD. Stanley J. Baran, Mass Communication Theory: Foundations, Ferment, and Future, 6th ed. (Boston, MA: Wadsworth Cengage Learning, 2012), 94. Mickey Cohen, In My Own

Words, 91.

${ }^{29}$ Hecht, Child of the Century, 515-516. 
${ }^{30}$ Eran Kaplan, The Jewish Radical Right: Revisionist Zionism and Its Ideological Legacy, Studies on Israel (Madison, Wis: University of Wisconsin Press, 2005), xi.

${ }^{31}$ Ibid, 516-517; Peter Bergson to Ben Hecht, August 28, 1941, Incoming Correspondence, 19141979, Box 55, Folder 1069b, BHNL. For Bergson's account of their first encounter, see David S. Wyman, A Race Against Death: Peter Bergson, America, and the Holocaust (New York: New Press : Distributed by W.W. Norton \& Co, 2002), 89-90. Of Hecht's version, Bergson said: "It is all true except that we were hungry - physically hungry. That was also true, but not on that day. You know, a writer fuses these things."

${ }^{32}$ Alexander Rafaeli, Dream and Action, 89-92, 93-99, 109-112; Yitshaq Ben-Ami, Years of Wrath, Days of Glory, 213-223, 238, 318-320; Samuel Merlin, Millions of Jews to Rescue, 23-31. Introduction by Rafael Medoff and David Wyman's interviews with Peter Bergson in A Race Against Death, 19-20, 59; Baumel, The "Bergson Boys," 7-17, 28, 34-35, 38-43, 48-49, 51-52, 75-77; Rafael Medoff, Militant Zionism in America: The Rise and Impact of the Jabotinsky Movement in the United States, 1926-1948 (Tuscaloosa: University of Alabama Press, 2002), 3344. The original organization was called the American Friends of a Jewish Palestine.

${ }^{33}$ Bergson used the expression "cutoff battalion" frequently in interviews archived at the Oral History Division, Institute for Contemporary Jewry, Hebrew University, Jerusalem, 55 (b), cited in Baumel, The "Bergson Boys," 2, 284. On Jabotinsky's death, the campaign for a Jewish army, and Bergson's leadership, The "Bergson Boys," 46-47, 62-68, 82-87; Rafael Medoff, Militant Zionism, 45, 63, 65, 70-71; Yitshaq Ben-Ami, Years of Wrath, Days of Glory, 241-244, 249-250; Samuel Merlin, Millions of Jews to Rescue, 42-43. Quietly going hungry... Hecht, Child of the Century, 516; Interview with Peter Bergson, A Race Against Death, 89-90; Baumel, The "Bergson Boys," 49.

${ }^{34}$ Hecht, Child of the Century, 522, 523, 535, 536.

${ }^{35}$ Ibid, 536.

${ }^{36}$ J. Hoberman and Jeffrey Shandler, Entertaining America, 64-65.

${ }^{37}$ Souvenir program in "Fun to Be Free, 1941, 1944," Publicity, 1920-1979, Box 79, Folder 2396, BHNL. The previous spring's America First rally... Robert Skloot, "We Will Never Die: Success and Failure of a Holocaust Pageant," Theatre Journal 37, no. 2 (May, 1985): 173.

${ }^{38}$ Ben to Rose, undated, "Hecht, Ben - to Rose, 1940-1941" in Family Correspondence, 19151976, Box 73, Folder, 2255, BHNL.

39 "Freedom Rally Thrills 17,000," New York Times, October 8, 1941, 1, 7.

${ }^{40}$ Ben to Rose, December 12, 1941, "Hecht, Ben - to Rose, 1940-1941" in Family Correspondence, 1915-1976, Box 73, Folder, 2255, BHNL. Freedom Rally Thrills 17,000," New York Times, October 8, 1941, 1, 7. Over the next several years, he would produce propaganda for... In Incoming Correspondence, 1914-1979, see "American Red Cross, 1943," Box 55, Folder 1029; "Hollywood Victory Committee, 1942," Box 58, Folder 1339; "United States Treasury Department, 1944-1945," Box 63, Folder 1716; "United States War Department, 1942-1945," Box 63, Folder 1717. In Works, 1908-1983, see "Pageant of American Labor," Box 11, Folder 320, Box 17 Folder 436 and Oversized Box 54, 1942, BHNL. See also Troy, From Literary Gadfly, 53 and p. 144, endnote \#23.

${ }^{41}$ Hecht, Child of the Century, 518. Gil Troy, From Literary Gadfly, 54.

${ }^{42}$ Hecht, A Tribute to Gallantry, in The Best One-Act Plays of 1943 (New York: Dodd, Mead, 1944), 41-56. "War Fund Spectacle to Be Held Tonight," New York Times, November 15, 1943.

${ }^{43}$ Hecht, Miracle on the Pullman, in "Works -Miracle on the Pullman, 1945, 1972," in Works, 1908-1983, Box 89, Folder 2583, BHNL.

${ }^{44}$ On Samson and Delilah, see Lenni Brenner, The Iron Wall, 79-82. On Halperin, see Rafael Medoff, Militant Zionism, 48-49. Jabotinsky made far less use of the ancient Hebrew warriors than did the younger "maximalist" Revisionists who took charge of the movement in Palestine once Jabotinsky was barred from the country - the "historian-propagandist" Abba Achimier, 
"messianic prophet-poet" Uri Zvi Greenberg, and "right-radical journalist" Yehoshua Heshel Yeivin. Avraham Stern and Israel Eldad would soon thereafter take up this imagery and mythmaking. Israel Eldad, The First Tithe (Tel Aviv: Jabotinsky Institute in Israel, 2008), 2730ff; Joseph Heller, The Stern Gang, 4-5, 11-20, 15, 39, 93-94; Walter Laqueur, A History of Zionism, 361-365. For a quick summary of who the Maccabees, the Sicarri, the Biryonim and Simon Bar-Kochba originally were and why diaspora Jews lionized the Maccabees but essentially buried the memory of the second rebellion, see Reuven Firestone, "Holy War in Modern Judaism? 'Mitzvah War' and the Problem of the 'Three Vows," in Journal of the American Academy of Religion 74, no. 4 (2006): 957-958. Heller offers a cogent analysis of these myths and the Holocaust in Israeli collective memory, and critiques their treatment by the "new historians," in "Alternative narratives and collective memories: Israel's New Historians and the use of historical context," Middle Eastern Studies 42, no. 4 (July 2006): 571-586. On their use for publicity by the Bergson Group, see for example Judith Baumel, The "Bergson Boys," 202; and Baumel, "Right-Wing ideologies among American Jews: The seductive myth of power in crisis," Nationalism and Ethnic Politics 4, no. 4 (1998): 90-91. See also "Establishing Authority: The Memorialization of Jabotinsky and the Burial of Bar Kochba Bones in Israel Under the Likud," by Myron Aronoff, in Aronoff, ed. The Frailty of Authority, Political Anthropology, v. 5 (New Brunswick: Transaction Books, 1986), 105-130.

${ }^{45}$ Walter Laqueur, A History of Zionism, 360-361, 380; Eran Kaplan, The Jewish Radical Right, 24-27.

${ }^{46}$ Hecht, "Champion in Chains," Esquire, October 1942, 36, 168-169. On training the Jews of Palestine and the mission in Iraq, see Nicholas Bethell, The Palestine Triangle, 101-106, 134135. Pierre Van Paassen's account of David Raziel's mission in Iraq appears in That day alone, (New York, The Dial Press, 1941), 330-334. "Jewish Heroism at Tobruk Reported; Zionist Flag Ordered Removed,” Jewish Telegraphic Agency, December 7, 1941.

http://www.jta.org/1941/12/07/archive/ jewish-heroism-at-tobruk-reported-zionist-flag-orderedremoved According to Yaacov Tarazi, one of three men Raziel led on the mission, the oil-field plan had been aborted upon their arrival at Habaniya and they were enroute to conduct reconnaissance on Iraqi defenses in Pluga when their car was hit by a bomb from a lone German scout plane. J. Bowyer Bell, Terror Out of Zion: Irgun Zvai Leumi, LEHI, and the Palestine Underground, 1929-1949 (New York: St. Martin's Press, 1977), 55-56, citing Daniel Levin, David Raziel: The Man and His Times (Doctor of Hebrew Letters Diss., Yeshiva University, 1969), 312.

${ }^{47}$ Joseph Heller, The Stern Gang, 41. A lengthy excerpt from this speech appears in Colin Shindler, The Triumph of Military Zionism (New York: I.B. Tauris, 2006), 207-208.

${ }^{48}$ Joseph Heller, The Stern Gang, Politics, 53.

${ }^{49}$ Meyer Levin, In Search, An Autobiography (New York: Horizon Press, 1950), 302-310. Levin is most famous as an early discoverer and champion of Anne Frank's diary, whose later effort to bring it to the stage embroiled him in a bitter battle. His autobiography is scathingly critical of Hecht, who had once been his idol and had given him his first break. As a young man, Levin had brought an early attempt at a short story collection straight to a small office on Clark Street, where Hecht and Bodenheim were producing the Chicago Literary Times. Hecht had responded with a testimonial that won Levin a job as picture chaser at the Chicago Daily News. By the time "Ben Hecht had moved to New York, ... I became the star feature reporter, feeling like the inheritor of an oversize mantle." Ibid, 23-26.

${ }^{50}$ Louis Rapoport, Shake Heaven and Earth,13-17.

51 "... the increasingly feverish spirit of the Betar ranks..." Lenni Brenner, The Iron Wall, 104.

Joseph Heller, The Stern Gang, 40-41. Walter Laqueur, A History of Zionism, 164,

52 “...Mad Hatters..." Hecht, Child of the Century, 535. 
${ }^{53}$ Ben Halpern. "Herzl's Historic Gift: The Sense of Sovereignty," in Theodor Herzl, Herzl Year Book, vol. 3 (New York: Herzl Press, 1960), 27-34. Walter Laqueur, A History of Zionism, 104. Tom Segev, One Palestine, Complete, 5, 33, 40, 48, 50.

${ }^{54}$ Joseph Heller, The Stern Gang, 2; Walter Laqueur, 346, 352, 495.

${ }^{55}$ Lenni Brenner, The Iron Wall, 13-17, 63-71; Walter Laqueur, 344; Edwin Black, The Transfer Agreement, 77.

${ }^{56}$ Lenni Brenner, The Iron Wall, 72-78, citing Vladimir Jabotinsky, "O Zheleznoi Stene," Rasswyet, November 4, 1923, 2-4. Walter Laqueur, A History of Zionism, 495.

${ }^{57}$ Joseph Heller, The Stern Gang, 4-7.

${ }^{58}$ Tom Segev, "Words That Can't Be Retracted," Haaretz, April 20, 2012.

http://www.haaretz.com/ weekend/the-makings-of-history/words-that-can-t-be-retracted1.425541

${ }^{59}$ Joseph Heller, The Stern Gang, 21-22; Lenni Brenner, The Iron Wall, 91-96. As prime minister in 1982, Menachem Begin appointed a former supreme court justice to conduct an official inquiry into the crime, but the investigation was inconclusive. David B. Green, "This Day in Jewish History/The Murder of Chaim Arlosoroff," Haaretz, June 16, 2013.

$\mathrm{http} / /$ www.haaretz.com/news/features/this-day-in-jewish-history/.premium-1.530046

${ }^{60}$ Joseph Heller, The Stern Gang, 22-23, 30-32; Walter Laqueur, A History of Zionism, 374.

${ }^{61}$ Louis Rapoport, Shake Heaven and Earth, 19-23. Arthur Koestler, Promise and fulfillment: Palestine 1917-1949 (London: Macmillan, 1949), 91.

${ }^{62}$ Joseph Heller, The Stern Gang, 23, 31, 41; Lenni Brenner, The Iron Wall, 99-100. Louis Rapoport, Shake Heaven and Earth, 28-29. Kook was involved in setting up a retaliation unit upon the split in 1937. But physically he was slight and lacked Raziel and Stern's charisma as a military leader. He was soon sent on a military mission — dispatched to Poland to serve as a contact with Jabotinsky.

${ }^{63}$ Jabotinsky vacillated... Joseph Heller, The Stern Gang, 30-32, 34-35, 37-40. "I can't see much heroism and public good in shooting from the rear..." Lenni Brenner, The Iron Wall, 100. "Terror Strikes Haifa-23 Dead and 79 Wounded," Palestine Post, July 7, 1, 2; "Tension in Haifa as Death Toll Grows to 27," July 8, 1938 1, 2; "General Calm in Haifa/Arab Death Roll Now 53 From Monday's Bomb," July 8, 2; “Ten Arabs Killed in Old City, Jerusalem/29 Others Wounded/Men, Women and Children in Panic; Market in Shambles," July 17, 1, 2; "After the Bombs," editorial, July 17, 8; "Hundred Arab Casualties in Haifa Bomb Explosion/Early Morning Outrage in Arab Melon Market in Kingsway; Curfew Imposed," July 26, 1; "The Haifa Disaster," editorial, July 26, 6; "Palestinian Situation Again Before House/Outrages in Haifa, Tel Aviv," July 28, 1, 3; "59 Arab Causalties in Jaffa Explosion/Bomb in Vegetable Market," August 28,1 . By their own counts, the Irgun claimed to have slaughtered 150 in July alone... Joseph Heller, The Stern Gang, 40. And 130 between the passage of the White Paper... Tom Segev, One Palestine, Complete, 441.

${ }^{64}$ Nicholas Bethell, The Palestine Triangle, 35-36, 52-55, 68; Tom Segev, One Palestine, Complete, 382-387, 398-400, 417-426.

${ }^{65}$ Erin Kaplan, The Jewish Radical Right, 155-158.

${ }^{66}$ On Jabotisnky's attempts to broker an evacuation plan with Polish government, see chapters 46 and 8 of Laurence Weinbaum, A Marriage of Convenience. "The authorities were interested in exploiting the anti-democratic Revisionist party..." A Marriage of Convenience, 235.

${ }^{67}$ Ibid, 139-140, 145-152.

${ }^{68}$ Stern had arranged the course... ibid, 130-131, 134-136, 150; Joseph Heller, The Stern Gang, 45-46. The young head of Betar's Polish branch, Menachem Begin, articulated the new militancy... Lenni Brenner, The Iron Wall, 104; Joseph Heller, The Stern Gang, 7, 40-41.

${ }^{69}$ Judith Tydor Baumel, 8, 20; Joseph Heller, The Stern Gang, 41-45, 51-53-55. 
${ }^{70}$ J. Bowyer Bell, Terror Out of Zion, 49, 54-55; Joseph Heller, The Stern Gang, 49, 54-59. "I was a man-bomb..." Nadav Man, "Germany in Pictures - Part V," Ynetnews.com, November 5, 2010. http://www.ynetnews.com/articles/0,7340,L-3971931,00.html

${ }^{71}$ Joseph Heller, The Stern Gang, 61-62; J. Bowyer Bell, Terror Out of Zion, 52.

${ }^{72}$ Richard Trank and Marvin Hier, Against the Tide (Los Angeles: Moriah Films, the Jack \& Pearl Resnick Division of the Simon Wiesenthal Center, 2009), DVD.

73 “JEWS FIGHT FOR THE RIGHT TO FIGHT,” New York Times January 5, 1942.

${ }^{74}$ Peter Kook, interviewed in Richard Trank and Marvin Hier, Against the Tide; David S. Wyman and Rafael Medoff, A Race Against Death, 23. "The Bergson Group, America, and the Holocaust: A Previously Unpublished Interview with Hillel Kook / Peter Bergson, ” American Jewish History 89, no. 1 (2001) Endnote \#9. http://muse.jhu.edu/journals/american_ jewish_history/v089/89.1wyman.html Hecht, Child of the Century, 540.

${ }^{75}$ Judith Tydor Baumel, The "Bergson Boys, "87-88. Baumel explains: "Putting their hard-won knowledge of the rules for molding American public opinion to use, Kook and delegation members eventually thrashed out a game plan: first convince a qualified minority of the justice of your cause and the masses will follow suit." This illustrated the group's media savviness. Two years later, pioneering media scholar Paul Lazarsfeld would introduce "two-step flow theory," the notion that the public embraces ideas only after they are first championed by an elite group of "opinion leaders."

${ }^{76}$ Ibid, 85-86. Rafael Medoff, Militant Zionism, 75.

${ }^{77}$ Judith Tydor Baumel, The "Bergson Boys," 88.

${ }^{78}$ Rafael Medoff, Militant Zionism, 70-71.

79 Jeremy Ben-Ami, Afterword in Millions of Jews to Rescue, 196-197; Judith Tydor Baumel, The "Bergson Boys," 88, 148; Louis Rapoport, Shake Heaven and Earth, 49, 57-58; Rafael Medoff, Militant Zionism, 71-72, 112; David Wyman and Rafael Medoff, A Race Against Death, 124. Dr. Seuss' editorial cartoons for $P M$ can be found on the UC San Diego Special Collections and Archives web page, "Dr. Seuss Went to War," at http://libraries.ucsd.edu/speccoll/dswenttowar/

${ }^{80}$ Ben Hecht to David Selznick, undated, three pages, in Selznick, David O., 1951-1964," Outgoing Correspondence, 1913-1977, BHNL.

${ }^{81}$ Judith Tydor Baumel, The "Bergson Boys," 97. Joseph Heller, The Stern Gang, 36.

${ }^{82}$ Louis Rapoport, Shake Heaven and Earth, 57; Judith Tydor Baumel, The "Bergson Boys, " 91 , 98, 105-105.

${ }^{83}$ Hecht, Child of the Century, 537, 539-540. Louis B. Mayer's luncheon with Nazi editors... Ben Urwand, The Collaboration, 198-200; Gil Troy, From Literary Gadfly, 69.

${ }^{84}$ Hecht, Child of the Century, 541-544; Gil Troy, From Literary Gadfly, 69.

${ }^{85}$ Judith Tydor Baumel, The "Bergson Boys," 133; David Wyman and Rafael Medoff, A Race Against Death, 31.

${ }^{86}$ Judith Tydor Baumel, The "Bergson Boys," 130, 132-134.

${ }^{87}$ Ibid, 132, 135.

${ }^{88}$ Richard Trank and Marvin Hier, Against the Tide.

${ }^{89}$ Hecht, "The Goodness of a Jew, in Child of the Century, 548-550.

${ }^{90}$ Richard Trank and Marvin Hier, Against the Tide. Washington Post, November 25, 1942, 6. Some major dailies ran the story of Wise's announcement on their front pages, but most put in on an inside page. See Deborah Lipstadt, Beyond Belief, 181.

${ }^{91}$ David S. Wyman, The Abandonment of the Jews: America and the Holocaust, 1941-1945, 1st pbk. ed. (New York: Pantheon Books, 1985), 42-45, 46-51. But defying the State Department request would have meant alienating... The Abandonment of the Jews, 54. ...official confirmation..." ibid, and see also Chapter 8, "Official Confirmation," in Deborah Lipstadt, Beyond Belief, 159-196. “...shaken heaven and earth..." Eli Wiesel, Dimensions in American 
Judaism (Spring 1968), 11.” On the source of Riegner's information, See Louis Rapoport, Shake Heaven and Earth, 235, endnote \#44.

${ }^{92}$ Bergson and Merlin had at first refused to believe the official stories... Interview with Peter Bergson in David Wyman and Rafael Medoff, A Race Against Death, 58; Yitshaq Ben-Ami, Years of Wrath, Days of Glory, 281. News of extermination had been leaking into the mainstream media since spring... Deborah Lipstadt, Beyond Belief, 159-176. Although the Jewish press had been filled with stories of a systemic extermination for weeks, Bergson said of Wise's announcement: "My first thought was disbelief. I hoped it was not true." According to Ben-Ami: "We became embroiled in a heated debate, some of us inadvertently repeating the arguments that Dr. Schiper had given to David Wdowinski in the Warsaw Ghetto: 'Germany will not dare kill millions of civilians because world opinion would not stand for it. Besides, it is physically impossible to organize mass killings on such a scale."”

${ }^{93}$ David Wyman, Abandonment of the Jews, 62, 65 77-78; Deborah Lipstadt, Beyond Belief, 183, 185-186, 251-242. Roosevelt's pronouncements in July and August... Richard Breitman, FDR and the Jews (Cambridge, Massachusetts: The Belknap Press of Harvard University Press, 2013),198, 223. Joseph Proskauer of the American Jewish Committee convinced Bergson not to publish it... Interview with Bergson in David Wyman and Rafael Medoff, A Race Against Death, 65-67.

${ }^{94}$ Hecht, "Preface to Shylock," 10, BHNL

${ }^{95}$ Hecht, "Ballad of the Doomed Jews of Europe," advertisement, New York Times, September $14,1943,12$. The committee did run the ad nearly a year later.

${ }^{96}$ Deborah Lipstadt, "Rationalizing the Deportations" in Chapter 8 of Beyond Belief, 176-180.

97 "A Letter from Ben Hecht," PM, February 22, 1943. This editorial was reprinted numerous times, including as an editorial headlined "Jewish Situation Less Complex," Los Angeles Times, March 11, 1943, 4. Ben Hecht, Perfidy / Ben Hecht (New York: Messner, 1961), 65.

${ }^{98}$ Laurel Leff, Buried by the Times: The Holocaust and America's Most Important Newspaper (Cambridge, UK ; New York: Cambridge University Press, 2005). Deborah Lipstadt, Beyond Belief, 228. Leff argues that because of Sulzberger's personal beliefs of what it meant to be Jewish - he regarded Judaism as a religion, not a peoplehood - "the Times never acknowledged that the mass murder of Jews because they were Jews was something its readers needed to know." See pp. 13-16.

${ }^{99}$ David Wyman, Abandonment of the Jews, 63. Hecht, "The Extermination of the Jews," American Mercury, February 1943, 194-199. http://www.unz.org/Pub/AmMercury-1943feb00194 Hecht, "Remember Us!" Reader's Digest, February 1943, 107-110.

${ }^{100}$ Yitzhaq Ben-Ami, Years of Wrath, Days of Glory, 281. Pierre Van Paassen, "A Proclamation on the Moral Rights of the Stateless and Palestinian Jews," advertisement, New York Times, December 7, 1942, 14. Action-Not Pity Can Save Millions Now!" advertisement, New York Times, February 8, 1943, 8.

${ }^{101}$ At a strategy meeting in January... Yitshaq Ben-Ami, Years of Wrath, Days of Glory, 284285. A form of theater devoted to civic purpose that had been popular with Americans, and with Jewish Americans in particular... Arthur Aryeh Goren, "Pageants of Sorrow, Celebration and Protest: The Public Culture of American Jews," Literary Strategies: Jewish Texts and Contexts (1996): 202, 206-207. Stephen J. Whitfield, "The Politics of Pageantry," American Jewish History 84, no. 3 (1996): 221-234. Ben-Ami, the only one of the Bergsonites who appears to have spoken to when the idea for a pageant was hatched, said it happened on a January day when he and two friends with links to theater, Stella Joelson and Saul Collins, visited Hecht out in Nyack. Also, Samuel Merlin wrote that Hecht invited some thirty Jewish leaders to discuss the pageant on January 26. Samuel Merlin, "American Jews and the Holocaust," letters column, Commentary, September 1983. http://www.commentarymagazine.com/article/american-jews-and-the-holocaust The timing makes sense, because the pageant was performed early in March. 
${ }^{102}$ Cast of nearly five hundred... "We Will Never Die Given in Washington," New York Times, April 13, 1943. The cast included... Hecht, Child of the Century, 558-563; Robert Skloot, "Success and Failure of a Holocaust Pageant," 172, 175; Stephen Whitfield, "The Politics of Pageantry," 240. "The aesthetic principle of the spectacle...: "The Politics of Pageantry," 240241.

${ }^{103}$ Garth Jowett and author., Propaganda \& Persuasion / Jowett, Garth. ; Propaganda and Persuasion, fifth ed. (Thousand Oaks, Calif.: SAGE, 2012), 247-248. Hilmar Hoffmann, The Triumph of Propaganda: Film and National Socialism, 1933-1945 (Providence: Berghahn Books, 1996), 151, 176. The use that Hitler and Goebbels made of rallies to promote their anti-Semitic agenda is described in depth in Jeffrey Herf, The Jewish Enemy: Nazi Propaganda During World War II and the Holocaust (Cambridge, Mass: The Belknap Press of Harvard University Press, 2006).

${ }^{104}$ Hecht, "A Search for Trumpets," in Child of the Century, 550-553.

${ }^{105}$ Ibid, 551.

${ }^{106}$ Not only because the armies of a newly ascendant Germany were sweeping across Europe...Aristotle A. Kallis, Nazi Propaganda and the Second World War (New York: Palgrave Macmillan, 2005), 67-68, 76, 82; Richard J. Evans, The Third Reich at War, 1939-1945 (London; New York: Allen Lane, 2008), 281; Jeffrey Herf, The Enemy Within, 264-265 and throughout. Hecht and Menachem Begin were Holocaust "functionalists" of their day, each offering a variation on that theory. For Hecht, the idea that that Hitler was not some all-powerful leader carrying a grand plan to its inevitable conclusion offered hope that a public outcry might halt the killings. For Begin, the idea that the Nazis had conducted experiments to test the world's indifference to the murder of Jews would help justify the Irgun's Revolt. See Menachem Begin, "We Fight, Therefore We Are," in The Revolt (London: W. H. Allen, 1951), 26-28.

${ }^{107}$ On February 24, Hitler had repeated and since the summer of 1941... Richard Evans, "Launching Genocide," in The Third Reich at War, 245-247, 254-255, 263, 268, 280. Like other conspiracy theorists... Jeffrey Herf, The Jewish Enemy, 264-265. "Redemptive anti-Semitism..." Saul Friedländer, The Years of Extermination, xviii-xix; Aristotle Kallis, Nazi Propaganda and the Second World War, 84.

${ }^{108}$ Hecht, We Will Never Die, 4-5, in “We Will Never Die, 1943,” Works, 1908-1983, Box 31, Folder 795, BHNL. Audio of the Hollywood Bowl performance can be found at: https://archive.org/ details/WeWillNeverDieBenHechtKurtWeill

${ }^{109}$ Yitshaq Ben-Ami, Years of Wrath, Days of Glory, 285.

${ }^{110}$ C.L. Sulzberger, "Romania Proposes Transfer of Jews," New York Times, February 13, 1943. Hecht, "For Sale to Humanity 70,000 Jews," New York Times, February 16, 1943, 11. . David Wyman, Abandonment of the Jews, 82-84; Robert Darst, "Guaranteed Human Beings for Sale: The Collaborative Relocation of Jews from Axis Europe, 1933-1945," Journal of Human Rights 1, no. 2 (June 2002): 207-230. ( Ephraim Ophir, "Was the Transnistria Rescue Plan Achievable?" Holocaust and Genocide Studies 6, no. 1 (1991): 1-16.

${ }^{111}$ Richard Breitman, "The Allied War Effort and the Jews, 1942-1943," Journal of Contemporary History 20, no. 1 (January 1985): 146, 152. Hecht, We Will Never Die, 5 BHNL.

${ }^{112}$ Hecht, "The Hatfields and the McCohens," in A Child of the Century, 553-557. Samuel Merlin wrote that this took place on January 26. Samuel Merlin, "American Jews and the Holocaust," letters column, Commentary, September 1983. http://www.commentarymagazine.com/article/ american-jews-and-the-holocaust

113 Judith Tydor Baumel, The "Bergson Boys," 120-122; David Wyman, Abandonment of the Jews, 89-91; Robert Skloot, "Success and Failure of a Holocaust Pageant," 173-174. Hecht, Child of the Century, 557, 563. 
${ }^{114}$ Robert Skloot, "Success and Failure of a Holocaust Pageant," 174; Deborah Lipstadt, Beyond Belief, 200-201; David Wyman, Beyond Belief, 90-91. Stephen Whitfield, "The Politics of Pageantry," 241; Hecht, We Will Never Die, 2, BHNL.

${ }^{115}$ Hecht, We Will Never Die, 6-19, BHNL; Robert Skloot, "Success and Failure of a Holocaust Pageant," 176-177.

${ }^{116}$ Hecht, We Will Never Die, 19-27.

${ }^{117}$ David Wyman, Abandonment of the Jews, 91-92; Robert Skloot, "Success and Failure of a Holocaust Pageant," 171-173.

${ }^{118}$ Hecht, "Preface to Shylock," 21. The White House had in fact been queasy about refusing Billy Rose's request altogether. It had ordered the OWI to formulate a response, and was handed a bland statement condemning totalitarian brutality that mentioned neither Jews nor extermination. Even this, however, proved to be too strong for senior aides David Niles and Stephen Early, so the administration sent no message at all. David Wyman, Abandonment of the Jews, 92.

${ }^{119}$ David Wyman, Abandonment of the Jews, citing Taslitt in the Jewish News and Observer, April 23, 1943.

${ }^{120}$ Hecht, We Will Never Die, 576 Stephen Whitfield, “The Politics of Pageantry," 242-243; Deborah Lipstady, Beyond Belief, 201-202, citing New York Times, March 3, 1943, 22, March 4, 1943; New York Herald Tribune, March 3, 1943, 18, March 4, 1943, sec. II, 3; New York Sun, March 3, 1943; The Nation, March 13, 1943, 366-367; New York Post, March 6, 1943, 21.

${ }^{121}$ Hecht, Child of the Century, 576.

122 David Wyman, Abandonment of the Jews, xiv, 285-287 328329.

${ }^{123}$ Aristotle Kallis, Nazi Propaganda and the Second World War, 4-5, 74. On the trilogy of antiSemitic films... Hilmar Hoffmann, The Triumph of Propaganda, 173, 175, 176.

${ }^{124}$ Hecht, Child of the Century, 587. Stanley Baran and Dennis K. David, Mass Communication Theory, sixth ed., 139, 149-151.

${ }^{125}$ Robert Darst, "Guaranteed Human Beings for Sale," 207.

${ }^{126}$ Alfred Kazin, "In Every Voice, In Every Ban,” The New Republic, Jan. 10, 1944, 45.

${ }^{127}$ See "Germany in Flames," "The Long Retreat" and "'Hell Has Broken Out,"” in Richard Evans, The Third Reich at War, 419-420, 441-467, 479-483. David Wyman, Abandonment of the Jews, 120-123; Judith Tydor Baumel, The "Bergson Boys," 136-137.

128 "Jewish Situation Less Complex," Los Angeles Times, March 11, 1943.

${ }^{129}$ David Wyman, Abandonment of the Jews, 108-110, 113; Judith Tydor Baumel, The "Bergson Boys," 137.

${ }^{130}$ David Wyman Abandonment of the Jews, 116-119; Judith Tydor Baumel, The "Bergson Boys," 137-138; Richard Breitman, FDR and the Jews, 224. Hecht, "Preface to Shylock," 12, BHNL. Breckinridge Long was actually an assistant secretary of state, in charge of the visa division.

${ }^{131}$ David Wyman, Abandonment of the Jews, 122-123.

${ }^{132}$ Hecht, "Preface to Shylock," 14. David Wyman, Abandonment of the Jews, 120. David Wyman and Rafael Medoff, A Race Against Death, 37.

${ }_{133}$ Judith Tydor Baumel, The "Bergson Boys," 139. Louis Rapoport, Shake Heaven and Earth, 78. Yitshaq Ben-Ami, Years of Wrath, Days of Glory, 324-325. Rafael Medoff, Militant Zionism, 188-193; Medoff, "When the U.S. Government Spied on American Jews," on Wymaninstitute.org. http://wymaninstitute.org/articles/2006-1-gov-spied.php David Wyman, Abandonment of the Jews, 149. Hecht, A Child of the Century, 578.

134 "Hecht Flays Anti-Semites in His Stinging Philippic," Chicago Tribune, March 16, 1944. Maxwell Perkins to Hecht in "Perkins, Maxwell, (Charles Scriber's Sons), 1944, Incoming Correspondence, 1914-1977, Box 61, Folder 1533, BHNL. 
${ }^{135}$ Billy Rose to Hecht, letters and telegrams, March 25, 1944; April 17; May 9; May 16; June 3; June 27; letter from Whitney Darrow of Charles Scribner's Sons to Billy Rose, May 17; notes from Rose Caylor Hecht on letter from June 27, in "Rose, Billy, 1943-1956," in Incoming Correspondence, 1914-1917, Box 61, Folder 1586, BHNL. See also Gil Troy, From Literary Gadfly to Political Activist, 86. "pint-sized Barnum" and "Midget Maestro" were common nicknames for Rose in the press. See for example United Press International, "Eleanor Files Suit Against Billy Rose," The Wilmington News (Wilmington, N.C.), November 20, 1951, 20; International News Service, "Price of Whoopee to Skyrocket," Palm Beach Daily News, March $18,1944,6$.

${ }^{136}$ Hecht $A$ Guide for the Bedevilled, 1-7, 12-13.

${ }^{137}$ Ibid, 11.

${ }^{138}$ Norman MacDonald, "Hecht Makes Case for Jews," Boston Herald, March 30, 1944. Selig Greenberg, "Nazi Concatenation," Providence Journal April 30, 1944.

${ }^{139}$ Louis Berg, "Brat of the Century," Commentary, October 1954.

http://www.commentarymagazine.com/article/a-child-of-the-century-by-ben-hecht/

${ }^{140}$ Stephen Wise, “The War Upon World Jewry," in Pierre Van Paassen, Nazism: an assault on civilization, Wise, James Waterman,; 1901 - ; joint ed. (New York, H. Smith and R. Haas, 1934), 220.

${ }^{141}$ Hecht, Guide for the Bedevilled, 20, 24.

${ }^{142}$ Ibid, 27-29.

${ }^{143}$ Ibid, 29-31.

${ }^{144}$ Ibid, 36-37.

${ }^{145}$ Ibid, 71-75, 126, 150, 156.

${ }^{146}$ Ibid, 11, 32-35, 73-75, 224-235. Elmer Rice, “A Prong at Both Ends," Saturday Review of Literature, March 25, 1944, 5-6, 20-21. Harold Rosenberg, "The Possessed," Contemporary Jewish Record, June 1944, 309-311.

${ }^{147}$ Hecht, Guide for the Bedevilled, 157. Stephen S. Wise, Challenging Years: The Autobiography of Stephen Wise (New York: Putnam, 1949), 293-294. Daniel Jonah Goldhagen, Hitler's Willing Executioners: Ordinary Germans and the Holocaust, 1st ed (New York: Alfred A. Knopf, 1996).

${ }^{148}$ Erich Fromm, Escape from Freedom (New York: Rinehart, 1941). Hannah Arendt, Eichmann in Jerusalem: a Report on the Banality of Evil, Rev. and enlarged ed (Gloucester, Ma: Peter Smith, 1986). Hecht, Guide for the Bedevilled, 149-150.

${ }^{149}$ Hecht, Guide for the Bedevilled, 43. Sam Roberts, "Declassified Papers Show U.S. Recruited Ex-Nazis," New York Times, December 11, 2010.

${ }^{150}$ Judith Tydor Baumel, The "Bergson Boys," 142, 148-149; David Wyman, The Abandonment of the Jews, 87-89, 144.

${ }^{151}$ Alex Rafaeli, Dream and Action, 104. Judith Tydor Baumel, The "Bergson Boys," 146-147. 152 Judith Tydor Baumel, The "Bergson Boys," 144.

${ }^{153}$ Ibid, 148; David Wyman, Abandonment of the Jews, 145-148. Max Lerner, "What about the Jews, FDR?" PM, July 22, 1943, 2.

${ }^{154}$ Hecht, Child of the Century, 572-573.

155 "The "Jew Deal..." David Wyman, The Abandonment of the Jews, 15n, 107. Greeted like Moses... Michael Benson, Harry S. Truman and the Founding of Israel (Westport, Conn: Praeger Publishers, 1997), 21. Die Velt, Yene Velt and Roosevelt... Gil Troy, From Literary Gadfly to Political Activist, 78.

${ }^{156}$ David Wyman, The Abandonment of the Jews, 147. Hecht, "Ballad of the Doomed Jews of Europe," advertisement, New York Times, September 14, 1943, 12.

157 "Rabbis Present Plea to Wallace," New York Times, October 7, 1943; "U.S at War: Oil and the Rabbis," Time, October 18, 1943, 21. See also Richard Brietman, FDR and the Jews, 229-231. 
158 "Texts of Three-Power Conference Documents," New York Times, November 2, 1943.

${ }^{159}$ Hecht, "My Uncle Abraham Reports..." New York Times, November 5, 1943, 14.

160 Interview with Peter Bergson in David Wyman and Rafael Medoff, A Race Against Death, 139. Judith Tydor Baumel, The "Bergson Boys," 153. Hecht, A Child of the Century, 574-575, 580-582. Baumel quotes Kook from another interview on his response to her: "You know, Madam, I sometimes wonder where I find the strength to sit here with you and talk reasonably about these matters. If I were now to take two pistols and shoot you and anyone else who stood in my way and burst into the president's office and shoot him, it would not be overreacting. ... How ...can the president say that in a situation where five thousand people are being murdered daily... and we are simply trying to shout "Help us"...that we are doing too much, how is it even possible to do too much?"

${ }^{161}$ Richard Breitman, FDR and the Jews, 227.

162 Ibid, 253-260.

${ }^{163}$ David Wyman, Abandonment of the Jews, 160-164.

${ }^{164}$ Interview with Peter Bergson in Against the Tide.

${ }^{165}$ Louis Rapoport, Shake Heaven and Earth, 128-138.

166 "Relief Unit Scored by Jewish Group," New York Times, December 31, 1943. Nahum

Goldmann... "Memorandum of conversation of E.M. Wilson, State Department, Near Eastern

Division, with Nahum Goldman et al, May 19, 1944, regarding Peter Bergson," National

Archives, State Department, 867N.01/2374, reprinted in the Appendix to David Wyman and

Rafael Medoff, A Race Against Death, 229-232.

${ }^{167}$ David Wyman, Abandonment of the Jews, 160, 173.

168 "A Voice in the Wilderness, Chapter 18, in Melvin I. Urofsky, A Voice That Spoke for Justice: The Life and Times of Stephen S. Wise, SUNY Series in Modern Jewish History (Albany: State University of New York Press, 1982) 261, 262. Richard Breitman, FDR and the Jews, 78. Edwin Black, The Transfer Agreement, 33-46

${ }^{169}$ Melvin Urofsky, A Voice That Spoke Justice, 264-266,

${ }^{170}$ David Wyman, Abandonment of the Jews, 71-72. Melvin Urofsky, A Voice That Spoke Justice, 315.

${ }^{171}$ Hecht, Child of the Century, 547, 571. Melvin Urofsky, A Voice That Spoke Justice, 331.

${ }^{172}$ Reinhold Niebuhr, "Jews After the War," Part I, The Nation, February 21, 1942, 214.

${ }^{173}$ Melvin Urofsky, A Voice That Spoke Justice, 309-11.

${ }^{174}$ Stephen Wise, Challenging Years, 311-312.

${ }^{175}$ Ibid.

176 Judith Tydor Baumel, The "Bergson Boys," 168.

${ }^{177}$ Undated letter to Hecht from Herbert Bentley, in "Bentley, Herbert, n.d.," Incoming Correspondence, 1914-1977, Box 55, Folder 1069, BHNL.

${ }^{178}$ Arthur D. Morse, While Six Million Died; a Chronicle of American Apathy (New York: Random House, 1968), 73-99; David Wyman, Abandonment of the Jews, 178-184.

${ }^{179}$ Breckinridge Long characterized... See for example ibid, 190-191; Long's words are voiced by an actor with a Southern drawl in Richard Trank and Marvin Hier, Against the Tide. Influence on immigration... Leibush Lehrer, president of the Yiddish Scientific Institute, "Refugee Figures Questioned," letter to the editor, New York Times, December 27, 1943. Lehrer's analysis is recited in Arthur D. Morse, While Six Million Died, 94.

${ }^{180}$ Arthur D. Morse, While Six Million Died, 45; David Wyman, Abandonment of the Jews, 8081.

${ }^{181}$ Josiah DuBois, "Report to the Secretary on the acquiescence of this government in the murder of the Jews," initialed by Randolph Paul, January 13, 1944, Morgenthau Diaries, Book 693, 212 229, reprinted in the Appendix of David Wyman and Rafael Medoff, A Race Against Death, 187201. 
${ }^{182}$ Richard Breitman, FDR and the Jews, 234-235.

${ }^{183}$ Lucy Dawidowicz, "Indicting American Jews," Commentary, June 1983. Dawidowicz was a brilliant and incisive writer, but in the midst of her polemics she often contradicted herself in ways she never satisfactorily addressed. For example, she originally had championed the Bergson Group, before attacking them in print years later. When confronted about this by her major target, Samuel Merlin, she responded that her views had changed after she had learned more of the facts. What had changed her mind was learning of the crucial role Oscar Cox, general counsel of the Foreign Economic Administration, had played in creating the War Refugee Board. Cox was indeed instrumental, but that takes nothing away from the entirely different role played by the Bergsonites. The argument makes so little sense that it seems more like a tactical dodge, a deliberate use of obscurantism to throw people off her trail. Another such example is that she condemned the State Department as blatantly anti-Semitic, but nevertheless defended Roosevelt against Wyman's Abandonment of the Jews. While there have been critics of Roosevelt, "Until now, no one has charged the United States and its people with complicity with the murder of the Jews." But that's exactly what Roosevelt's own people did, in an official document, as well as others such as Ziegelboim. See the letter from Samuel Merlin and her reply in "American Jews and the Holocaust," Commentary, September 1983, and "Could America Have Rescued Europe's Jews?" in Lucy S. Dawidowicz, What Is the Use of Jewish History?: Essays, 1st ed. (New York: Schocken Books, 1992), 159-160.

${ }^{184}$ Lucy Dawidowicz, "Could America Have Rescue Europe's Jews?" in What is the Use of Jewish History?, 163.

${ }^{185}$ Richard Breitman, FDR and the Jews, 235.

${ }^{186}$ Lucy Dawidowicz, "Could America Have Rescue Europe's Jews?" in What is the Use of Jewish History?, 166.

${ }^{187}$ Ibid, 167.

${ }^{188}$ W. D. Rubinstein, The Myth of Rescue: Why the Democracies Could Not Have Saved More Jews from the Nazis (London; New York: Routledge, 1997). Forty-one years after Riegner sent his famous cable... Saul S. Friedman, "Saving the Jews: Franklin D. Roosevelt and the Holocaust," The Free Library, September 1, 2007. http://www.thefreelibrary.com/Saving the Jews: Franklin D. Roosevelt and the Holocaust.-a0180029229

${ }^{189}$ Louis Rapoport, Shake Heaven and Earth, 152-153, citing The Morgenthau Diaries, March 8, 1944, Container 707, 220-221.

${ }^{190}$ Billy Rose to Ben Hecht, January 30, 1944, in "Incoming Correspondence, 1914-1979," Box 61, Folder 1586, BHNL. Bernard Baruch, Billy Rose's mentor...Polly Rose Gottlieb, The Nine Lives of Billy Rose (New York: Crown Publishers, 1968), 212-213.

${ }^{191}$ Lucy Dawidowicz, “Could America Have Rescue Europe's Jews?” in What is the Use of Jewish History?, 176-177.

192 J. Bowyer Bell, Terror Out of Zion, 184.

${ }^{193}$ Clifton Daniel, "Churchill Warns Jews to Oust Gangs," New York Times, November 18, 1944.

${ }^{194}$ Monty Noam Penkower, "The Kishinev Pogrom: A Turning Point in Jewish History," Modern Judaism 24, no. 3 (2004): 207.

${ }^{195}$ Hecht, Child of the Century, 590-594.

${ }^{196}$ Menachem Begin to Hecht biographer William MacAdams, January 5, 1983, Folder No. 373, MacAdams Collection, BHNL.

${ }^{197}$ Letter from Hecht to Samuel Merlin, early fall 1947, "Tamir, Shmuel (Sam) and Ruth, 19551972," Incoming Correspondence, 1914-1979, Box 63, Folder 1692, BHNL. This letter appears to be misfiled. For one thing, it is outgoing correspondence from Hecht. For another, the "Sam" he is addressing is clearly Samuel Merlin, who was acting head of the Bergson Group at the time, though Rose Caylor Hecht has written "Tamir?" on it. Tamir was an active Irgunist and later the 
attorney who defended Malchiel Greenwald in the "Kastner trial," and worked with Hecht on Perfidy.

198 David Wyman, Abandonment of the Jews, 149; Judith Tydor Baumel, The "Bergson Boys," 175. Interview with Peter Bergson in A Race Against Death, 123. Militant Zionism, 188-193; Medoff, "When the U.S. Government Spied on American Jews," on Wymaninstitute.org. http://wymaninstitute.org/articles/2006-1-gov-spied.php The actual involvement of the group in arms smuggling is discussed in Chapter VII, Only Thus.

${ }^{199}$ Frederick R. Barkley, "New Group Sets Up a Hebrew Nation,” New York Times, May 19, 1944; Judith Tydor Baumel, The "Bergson Boys, 201.

${ }^{200}$ Meir Grossman, Congress Weekly, May 26, 1944; Marie Syrkin, "Liberation by Double Talk," Congress Weekly, August 11, 1944, 2-8; Dr. Israel Goldstein, Washington Post, May 19, 1944; B. Netanyahu, "The Fiasco of the Hebrew Committee," Zionews Magazine, July 1944, 13, cited by Louis Rapoport, Shake Heaven and Earth, 167; and Gil Troy, From Literary Gadfly to Political Activist, 93, drawing on files in the Palestine Statehood Committee archive at Yale University; Barkley, "New Group Sets Up a Hebrew Nation," New York Times, May 19, 1944. Begin did not approve... Yitshaq Ben-Ami, Years of Wrath, Days of Glory, 355-356. Interview with Alex Rafaeli in Judith Tydor Baumel, The "Bergson Boys," 204

${ }^{201}$ Extension of Remarks, Rep. Richard P. Gale submitting Answer magazine, June 15, 1944, No. 79-90: A3436-37 (1944).

${ }^{202}$ Hecht, Child of the Century, 594.

${ }^{203}$ Gil Troy, From Literary Gadfly to Political Activist, 95, citing the Ben Hecht file, Series I, Palestine Statehood Committee Papers, Israel Eldad, The First Tithe, 155.

${ }^{204}$ Hecht, Child of the Century, 597. J. Bowyer Bell, Terror Out of Zion, 65-66, 69; Joseph Heller, The Stern Gang, 89-90.

${ }^{205}$ J. Bowyer Bell, Terror Out of Zion, 270-273; Joseph Heller, The Stern Gang, 62, 68, 79, 8589, 91-91, 96-97. "Gangsters Must Be Found and Punished," Palestine Post, January 25, 1942, 3. "Abraham Stern Wanted: Jewish Community Will Fight Terror," Palestine Post, January 27, 1942, 3; "Police to Offer L.P. 3,000 As Rewards," Palestine Post, January 27, 1942, 3. "Leader of Stern Gang Shot Dead," Palestine Post, February 13, 1942, 3.

${ }^{206}$ J. Bowyer Bell, Terror Out of Zion, 84-85; Nicholas Bethell, The Palestine Triangle, 181-182. ${ }^{207}$ Clifton Daniel, "Churchill Warns Jews to Oust Gangs," New York Times, November 18, 1944.

${ }^{208}$ Hecht, Child of the Century, 596; J. Bowyer Bell, Terror Out of Zion, 132-134; Tom Segev, "Hunting Season, chapter 21, in One Palestine, Complete, 451-458. Nicholas Bethell, The Palestine Triangle, 184-186. Anthony Howard, "Duplicity and Prejudice," a review of $A$ Palestine Triangle, New York Times, May 19, 1944. Hecht and his cohort considered partition to be scraps from Britain's table anyway, and would hardly have been much surprised, or impressed, that Churchill was considering the offer.

${ }^{209}$ Jeremiah J. Berman, "Churchill Speech Protested," letter to the editor, New York Times, November 23, 1944.

${ }^{210}$ Hecht, A Jewish Fairy Tale, 1, in Series III, Subject File for Hecht, Palestine Statehood Committee Papers, Miller Nichols Library, University of Missouri-Kansas City. Hecht performed as narrator... "A Jewish Fairy Tale at Carnegie Hall Tonight," New York Post, December 4, 1944, 22. Available through FultonHistory.com, a New York State historical newspaper site.

${ }^{211}$ Hecht, A Jewish Fairy Tale, 1-6, 7, 9 ,12.

${ }^{212}$ Ibid, 13, 16, 17.

${ }^{213}$ Ibid, 10, Gil Troy, From Literary Gadfly to Political Activist, 96.

${ }^{214}$ Extension of Remarks, letter from Hecht to the Earl of Halifax, February 26, 1945, entered into the Congressional Record by Representative Andrew L. Somers, No. 79-91:A950-51 (1945).

${ }^{215}$ Patrick McGilligan, Alfred Hitchcock: a Life in Darkness and Light, 1st ed. (New York: Regan Books, 2003), 253, 366, 368. 
${ }^{216}$ Ibid, 368-369; Hecht, A Child of the Century, 583.

${ }^{217}$ Hecht, A Child of the Century, 583; Watch Tower for Tomorrow, radio script, Works, 19081983, Box 31, Folder 792, BHNL; Watchtower Over Tomorrow, directed by John Cromwell and Hartold F. Kress (Washington, D.C.: U.S. Office of War Information, 1945). "On Your Radio Dial," San Bernadino County Sun, April 25, 1945, 11. The film is available online at vimeo.com: http://vimeo.com/63510160 Indicative of his lack of pride in the film, Hecht gets the title wrong in his autobiography, calling it The World of Tomorrow.

${ }^{218}$ Hecht, Watch Tower for Tomorrow, 3, 6, 18; Watchtower Over Tomorrow.

${ }^{219}$ Hecht, Watch Tower for Tomorrow, 6, 18; Watchtower Over Tomorrow.

${ }^{220}$ Hecht, Watch Tower for Tomorrow, 13; Watchtower Over Tomorrow.

${ }^{221}$ Hecht to Rose, April 2, 1945, in "Hecht, Ben - to Rose, 1943-1949," Family Correspondence, 1915-1976, Box 73, Folder 2257, BHNL. Thomas W. Lippmann, "The Day FDR Met Saudi Arabia's Ibn Saud," The Link 38, no. 2 (April-May, 2005): 9. On the website for Americans for Middle East Understanding, Inc. http://www.ameu.org/getattachment/51ee4866-95c1-4603-b0dde16d2d49fcbc/The-Day-FDR-Met-Saudi-Arabia-Ibn-Saud.aspx

${ }^{222}$ Hecht to Rose, April 2, 1945, in "Hecht, Ben - to Rose, 1943-1949," Family Correspondence, 1915-1976, Box 73, Folder 2257, BHNL.

${ }^{223}$ Hecht, $A$ Child of the Century, 583.

${ }^{224}$ Ibid, 583-584. Irvine Douglas, "San Francisco Conference Opens with Short Session," Sydney Morning Herald, April 27, 1945, 1.

${ }^{225}$ Patrick McGilligan, Alfred Hitchcock: a Life in Darkness and Light, 366. Pauline Kael, 5001 Nights at the Movies (New York: H. Holt, 1991), 536. RKO Radio Pictures et al., Notorious, videorecording (1946, Criterion Collection: Home Vision Entertainment, 2001), DVD.

${ }^{226}$ François Truffaut, Hitchcock, Rev. ed., 1st Touchstone ed. (New York: Simon \& Schuster, 1985), 168-169. See also "Part 19, "Notorious through to a discussion about success," on Interview: Alfred Hitchcock and Francois Truffaut, August 1962, the complete audio recordings, available at the Alfred Hitchcock wiki:

http://www.hitchcockwiki.com/wiki/Interview:_Alfred_Hitchcock_and

Fran\%C3\%A7ois_Truffaut_(Aug/1962)\#Audio On IG Farben and Zyklon B, see Antony C. Sutton, Wall Street and the Rise of Hitler (Seal Beach, Calif: '76 Press, 1976).

${ }^{227}$ David O'Dell, Ben Hecht - The Shakespeare of Hollywood, from The Adventures of Young Indiana Jones Documentaries (Marin County: Lucasfilm, 2007), DVD set.

${ }^{228}$ Meyer Levin, In Search, 306-307.

${ }^{229}$ Hecht, A Flag is Born, 20, in "Flag is Born, A, 1946," Works, 1908-1983, Box 9, Folder 271, BHNL.

${ }^{230}$ Hecht to Peter Bergson, n.d. fall 1946, in "Bergson, Peter, 1951-1964," Outgoing Correspondence, 1931-1977, Box 66, Folder 1823, BHNL. Hecht, Specter of the Rose (Los Angeles: Republic, 1946), VHS. William MacAdams, Man Behind the Legend, 239-240.

${ }^{231}$ Gil Troy, Man Behind the Legend, 97-98. Phineas Biron, "Strictly Confidential," column, Jewish Western Bulletin, September 7, 1945. http://www.multiculturalcanada.ca/node/364286 William MacAdams, The Man Behind the Legend, 242-248.

${ }^{232}$ Hecht, A Child of the Century, 605-606.

${ }^{233}$ Hecht, Shake Heaven and Earth, 204-205; Gil Troy, From Literary Gadfly to Political Activist, 98.

234 "Hecht Claims Disputed," New York Times, April 16, 1946; Clifton Daniels, "Seizures Lift Costs in Smuggling Jews," New York Times, April 15, 1946; "Britain is Trying to Suppress This American Action," advertisement, New York Evening Post, August 28, 37.

${ }^{235}$ Yitshaq Ben-Ami, Years of Wrath, Days of Glory, 357-358.

${ }^{236}$ Ibid, 353. J. Bowyer Bell, Terror Out of Zion, 133, 136, 137-144; Tom Segev, One Palestine, Complete, 471-472. 
${ }^{237}$ Gene Currivan, "3 Terrorists Bands in Palestine Cited," New York Times, December 31, 1945; J.H. Nuemann, "Work of the Haganah Described, New York Times, letter to the editor, January 4, 1946; I.F. Stone, "Patriots or Gangsters?" The Nation, January 12, 1946; Nathan George Horwitt, "Gun-Moll Journalism," The Answer, June 1946, 17, in "Israel - The Answer, April 1943-July 2, 1948," Subject Files, 1919-1981, Box 77, Folder 2345, BHNL.

${ }^{238}$ Hecht, Perfidy, 27-28; Menachem Begin, The Revolt, 93-94; J. Bowyer Bell, Terror Out of Zion, 150-167.

${ }^{239}$ J. Bowyer Bell, Terror Out of Zion, 163.

${ }^{240}$ Ibid, 169-173; Nicholas Bethell, The Palestine Triangle, 257-268. "Leading U.S. Jews Denounce Violence," New York Times, July 25, 1946.

${ }^{241}$ The final report of the Anglo-American Committee... Nicholas Bethell, The Palestine Triangle, 235-236. The end of the Tenuat Hameri agreement... J. Bowyer Bell, Terror Out of Zion, 173-174. It's 1776 in Palestine... Yitshaq Ben-Ami, Years of Wrath, Days of Glory, 384.

${ }^{242}$ Luther, Celia and Jacob Adler... Stephen Whitfield, "The Politics of Pageantry," 247. "... salty and hilarious folk..." Hecht, "Tales of Capering, Rueful Laughter," New York Times, July 7, 1946, 100.

${ }^{243}$ Peter Manso, Brando (London: Weidenfeld and Nicolson, 1994) 100-180 passim.

${ }^{244}$ On Brando's rise and working for the equity minimum... Manso, Brando, 176-177, 180-182. Mrlon Brando, Brando: Songs My Mother Taught Me, 1st ed. (New York: Random House, 1994), 105.Gil Troy, From Literary Gadfly to Political Activist, 100.

${ }^{245}$ Jerome Lawrence, Actor, the Life and Times of Paul Muni (New York: Putnam, 1974), 291292. Peter Manso, Brando, 183-184.

${ }^{246}$ See Hasia R. Diner and ebrary, Inc, We Remember with Reverence and Love American Jews and the Myth of Silence After the Holocaust, 1945-1962 (New York: New York University Press, 2009), 266-321.

${ }^{247}$ Hecht, A Flag is Born, prologue and 1-5.

${ }^{248}$ Ibid, 5-7.

${ }^{249}$ Ibid, 7-17.

${ }^{250}$ Ibid, $17-24$.

${ }^{251}$ Ibid, 24-26.

${ }^{252}$ Brooks Atkinson, "The Play," New York Times, Sept. 7, 1946, 10; Rafael Medoff, Militant Zionism, 155; Peter Manso, Brando, 185.

${ }^{253}$ Quoted in Stephen Whitfield, The Politics of Pageantry, 247. Gil Troy, From Literary Gadfly to Political Activist, 104. Atay Citron, "Staging Hecht's Pageant-Drama: A Flag is Born," in Staging the Holocaust: The Shoah in Drama and Performance, Cambridge Studies in Modern Theatre (Cambridge ; New York: Cambridge University Press, 1998), 90.

254 "UN Men Feel at Home at New Hecht Play," New York Times, September 6, 1946. Quote in Gil Troy, From Literary Gadfly to Political Activist, 100, quoting an undated copy of an article in The Answer.

${ }^{255}$ Atay Citron, "Staging Hecht's Pageant-Drama," 91.

256 “A Flag is Born," Life, September 30, 1946; Eliahu Epstein quoted in Troy, 103. Rafael Medoff, Militant Zionism, 195-196.

${ }^{257}$ Judah Magnes, “Magnes Says Play Supports Terror,” New York Times, December 3, 1946, 41.

${ }^{258}$ Rafael Medoff, Militant Zionism, 159-160.

${ }^{259}$ Gil Troy, From Literary Gadfly to Political Activist, 104-105.

${ }^{260}$ Ibid, 109.

${ }^{261}$ Stephen Whitfield, "Politics of Pageantry," 245. Richard Watts Jr. "Koestler's Novel of Zionism," November 3, 1946, 158.

${ }^{262}$ Marlon Brando, Songs My Mother Taught Me 109-111. 
${ }^{263}$ Jessie Zel Lurie, "Confusion Worse Confounded," Congress Weekly, February 7, 1947, 10. Rafael Medoff, Militant Zionism, 188-193; Medoff, "When the U.S. Government Spied on American Jews."

${ }^{264}$ Hecht, A Child of the Century, 609. Interview with Peter Bergson in A Race Against Death, 123. Yitshaq Ben-Ami, Years of Wrath, Days of Glory, 424-425. Judith Tydor Baumel, The

"Bergson Boys," 237-238. Louis Rapoport, Shake Heaven and Earth, 205-206. Menachem Begin, The Revolt, 63. Of Bergson's eventual departure from the group, Baumel notes: "Money matters continued to be an unfailing source for disagreements and harsh disputes between the Irgun and members of the Hebrew committee.

${ }^{265}$ George Horne, “Mystery Ship Seen as Exiles' Haven,” New York Times, January 18, 1947. Aviva Halamish, The Exodus Affair: Holocaust Survivors and the Struggle for Palestine, 1st ed (Syracuse, N.Y: Syracuse University Press, 1998),16. Rafael Medoff uses the same figures in Militant Zionism, 196.

${ }^{266}$ Yitshaq Ben-Ami, Years of Wrath, Days of Glory, 395; Judith Tydor Baumel, The "Bergson Boys," 224.

${ }^{267}$ Peter Bergson to Hecht, October 10, 1946, in “Bergson, Peter, 1941-1952, 1962” Incoming Correspondence, 1914-1979, Box 55, Folder 1069b, BHNL.

${ }^{268}$ Yitshaq Ben-Ami, Years of Wrath, Days of Glory, 356, 424.

${ }^{269}$ Meir Zamir, "'Bid' for the Altalena: France's Covert Action in the 1948 War in Palestine," Middle Eastern Studies 46, no. 1, 17-58. Hecht, Child of the Century, 621-625.

${ }^{270}$ Letter from Hecht to Samuel Merlin, early fall 1947, 1, "Tamir, Shmuel (Sam) and Ruth, 1955-1972," Incoming Correspondence, 1914-1979, Box 63, Folder 1692, BHNL. See also endnote 197 above.

${ }^{271}$ Ibid, 2.

${ }^{272}$ Ibid, 2-3.

${ }^{273}$ Hecht, Perfidy, 40. Aviva Halamish, The Exodus Affair, 16.

${ }^{274}$ Mark A Raider, “' Irresponsible, Undisciplined Opposition': Ben Halpern on the Bergson Group and Jewish Terrorism in Pre-State Palestine," American Jewish History 92, no. 3 (2004): $322,326,327-328$.

${ }^{275}$ Ibid, 330, 335-336.

${ }^{276}$ Ibid, 341, 358.

${ }^{277}$ Started in Italy in $1922 \ldots$ Stanley G. Payne, Fascism, Comparison and Definition (Madison: University of Wisconsin Press, 1980), 3-4. Ze'ev Sternhell, Chapter 9, "Fascist Ideology," in Fascism: a Reader's Guide: Analyses, Interpretations, Bibliography (Berkeley: University of California Press, 1978), 315.

${ }^{278}$ Zeev Sternhell, The Birth of Fascist Ideology: From Cultural Rebellion to Political Revolution (Princeton, N.J: Princeton University Press, 1994), 4-5. Stanley Payne, Comparison and Definition, 1-6.

${ }^{279}$ Ze'ev Sternhell, The Birth of Fascist Ideology, 6, 10

${ }^{280}$ Ibid, 10.

${ }^{281}$ Yitshaq Ben-Ami, Years of Wrath, Days of Glory, 231. Menachem Begin, The Revolt, 164.

${ }^{282}$ Yoav Gelber, Appendix II, "Propaganda as History: What Really Happened at Deir Yassin? in Palestine, 1948: War, Escape and the Emergence of the Palestinian Refugee Problem (Brighton; Portland, OR: Sussex Academic Press, 2001), 307-390.

${ }^{283}$ Hecht, “The Incomplete Life of Mickey Cohen," Scanlan's Monthy, March 1970, 72. 


\section{Part IV: Mickey Cohen, L.A.'s Al Capone}


Mickey Cohen was wary at first when a man appeared at his headquarters in Hollywood one day and asked for help in arming the Jews of Palestine.

"He tells me especially about the Irgun and the type of war they're fighting against the British and the type of guys they are and all this," Cohen remembered. "And I got high on him. But you know when you're kinky, your mind runs kinky."

Still, the visitor's claim to represent the screenwriter Ben Hecht had impressed business manager Mike Howard, and urged to take the request seriously, Cohen accepted an invitation to see Hecht face-to-face and find out what this was all about. ${ }^{1}$ At Hecht's home down the coast in Oceanside, California, Howard initially did the talking, explaining that his boss wanted to make sure the appeal was on the level. Cohen had just been sold a phony bronze plaque from Palestine for two hundred dollars by a Chicago grifter posing as a Jewish patriot. "As soon as Mr. Cohen's friends catch this thief," Howard went on, "they will break his head. In the meantime, we would like to be of some help to the Jewish situation - if we can be assured we are not going to be trimmed. So Mr. Cohen would be obliged if you told him what's with the Jews who are fighting in Palestine. Mr. Cohen is sorry for the dead Jews in Europe but is not interested in helping them.",2

Despite their leeriness, Hecht could be reasonably confident about winning his guests over, for he was well familiar with the gangster code. He knew Cohen professed a deep sense of duty to his people, like Meyer Lansky, whose East-Coast "Combination" had ordered Cohen back home to assist fellow Jew Benjamin "Bugsy" Siegel a decade earlier, and like Siegel himself, for whom the young gunman had served as chief enforcer, bodyguard and apprentice. All had received the same street corner schooling in 
youth, which for Cohen had been on the West Coast version of the Lower East Side, Boyle Heights. In such neighborhoods throughout the country, the rules were the same, for the Italians, Irish and everyone else: Don't show weakness. When someone shoves you, shove back. Be loyal to your blood—your family and your kind, the ones you can count on in a fight. And last but not least, a blow against one is a blow against all. For Jews, this creed dated back to the early twentieth century, when Samuel "Nails" Morton had organized a defense group to fight off Polish gangs marauding Chicago's "Jewtown" along Maxwell Street. On New York's East Side, Big Jack Zelig had defended his community against Italian toughs seeking to rob businesses and lure Jewish girls into prostitution. "It was not simply an aspect of protecting one's turf against rivals," observed Jewish mob historian Robert Rockaway, "but a deeper commitment to the safety of one's people."3

As Hecht likely knew, Jewish mobsters had waged war against the Nazis in their own way since the days when Hitler first took power, often through personal campaigns that revealed much about a gangster's character. Cohen boasted that during a short stint in the L.A. county jail, he was delighted to find himself sharing a holding cell with two well-known Nazi numbskulls, radio propagandist Robert Noble and Ellis O. Jones, codirector of Friends of Progress. Seizing the opportunity, Cohen bashed their heads together, then left them climbing the bars and screaming for the guards while he calmly returned to reading his newspaper. FBI records show Cohen was indeed serving time for bookmaking when the pair was arrested for libel in April 1942, a charge for which they received five-year sentences. They later faced federal prosecution, along with twenty-six other Nazi sympathizers, in the "Great Sedition Trial of 1944." 
Whatever personal satisfaction Cohen may have gained from the alleged thumping, it hardly could have added much to the measures already undertaken by state and federal law enforcement against conspirators who turned out to be far more effective at stirring debates about civil liberties than they were at threatening national security. Still, word of the assault brought Cohen requests from the Writer's Guild to deal with harassment they were getting from Nazi sympathizers, and from a judge who wanted a German Bund meeting busted up. "So we went over there and grabbed everything in sight — all their bullshit signs — and smacked the shit out of them," said Cohen, hardly a civil libertarian himself. "Don't forget we had to fight the coppers too, because a lot of the coppers were Nazis themselves in those days."

Siegel's most legendary exploit was memorable not only for its signature razzledazzle, but also for the intriguing possibility that he could have changed the course of human history. According to a dishy 1967 biography by mob reporter Dean Jennings, who also wrote a Saturday Evening Post series that would seal the fate of Hecht's unpublished manuscript on Cohen, Bugsy traveled to Italy in 1938 as "Sir Bart" Siegel, a baronet from an old English line, to pursue a get-rich-quick scheme with his paramour, a real Italian countess named Dorothy di Frasso. The lovers planned to sell Mussolini a powerful new explosive compound called Atomite, but their demonstration flopped. This angered Il Duce, who in addition to demanding the full return of his $\$ 40,000$ advance, expropriated the countess' Villa Madama, and added insult by installing two unwelcome guests: Herr Joseph Goebbels and Hermann Goering. ${ }^{6}$

The Nazis' arrival forced their "hostess" and her boyfriend from the main house into living quarters in the stable. Siegel, who was familiar with Goebbels, became 
"apoplectic every time he saw the German rolling up the Villa driveway in his bulletproof Mercedes." Further incensed that the countess would allow the propaganda minister and "that fat bastard Goering" into the stable for a social call, Siegel let slip that he planned to kill them-hardly an idle threat, considering the source. But when she begged him to consider the consequences, self-interest won out over homicidal impulse- he had, after all, originally come to sell munitions to a Nazi ally—and he promptly dropped the idea. $^{7}$

By contrast, Lansky's well-documented private wars had both more serious impacts, and deeper implications. After German U-boats had sunk 272 merchant ships within six months of America's entry into the war, in 1942 he brokered and oversaw a pact between U.S. Naval Intelligence and an incarcerated Charles "Lucky" Luciano. In exchange for commutation of his sentence, Luciano issued orders from jail for the Mafia to clear out infiltrators along New York's waterfront and keep vigilance over the nearby restaurants, hotels, bars and brothels, where loose lips could sink ships. When a U-boat delivered eight Nazi saboteurs to American shores in June 1942, the underworld got a fix on the Long Island landing point for four of them, and traced their paths to New York City. Luciano's contacts also furnished topographical details for the July 1943 Allied invasion of Sicily, and divulged the secret location of the Italian Naval Command, which in turn yielded an intelligence bonanza. ${ }^{8}$

Lansky was thus not referring to razzle dazzle when he later told a trio of Israeli biographers: "I want to make my situation clear. The reason I cooperated was because of strong personal convictions. I wanted the Nazis beaten. I made this my number one 
priority even before the United States got into the war. I was a Jew and I felt for those Jews in Europe who were suffering. They were my brothers."

Then, having paused for thought, he added: "I've never got used to the idea of being called a criminal, and I'd like to tell you how and when this label was first put on me."9

After Hitler took power, he explained, the rise of Nazi sympathizers in America alarmed Jewish leaders, including the most respected of all, Rabbi Stephen Wise. The rabbi sent Lansky a message urging him to do something about this dangerous trend. In 1935, Republican New York judge Nathan Perlman also asked him "to take action" against meetings of the American German Bund. Flattered to be of sevice, Lansky refused the judge's offer of money and legal assistance, but did request one thing: insulation from criticism in the Jewish press. Perlman promised to try, and Lansky got his campaign underway. ${ }^{10}$

Long forgotten now, the ensuing clashes of the Bundists and Jews in New York and New Jersey flared up for more than a year on a surprising scale. Estimates of the Bund's national strength vary, from a Justice Department figure of 8,500 at its peak in 1938 to a tally of 22,000 reported after a six-month investigation by the Chicago Daily Times in 1937. The Bund published newspapers, ran a network of Hitler Youth summer camps, and held a Madison Square Garden rally in February 1939 attended by some 22,000. To beat back this rising tide, Lansky brought in Siegel and other members of the Brooklyn hit squad, Murder Incorporated, at the same time that he was quietly approached by Jews of various ages and occupations. "We taught them how to use their fists and handle themselves in fights, and we didn't behave like gents," Lansky said. ${ }^{11}$ 
Since he had begrudgingly promised Judge Perlman not to kill anyone, his wrecking crew broke Nazi arms, legs and ribs with practiced efficiency. While some Bund leaders and brash anti-Semites earned themselves special treatment, "the main point was just to teach them that Jews couldn't be kicked around." At first Lansky understood Perlman and Rabbi Wise to be pleased with the results. But as the clashes grew more intense, so did the publicity. In April 1938, the New York Herald Tribune reported a bloody three-way melee at the uptown Yorkville Casino between several hundred Brownshirts, a crowd of Jews, and some seventy-five policemen. ${ }^{12}$

To Lansky's surprise, condemnations rang forth from the Yiddish Morgen Journal of New York and other Jewish newspapers. The judge had failed to keep his word. "When they reported our anti-Bund activities they referred to us as 'the Jewish gangsters," he recalled bitterly. "...In fact the Jewish newspapers were the first to call us the 'mob of Lansky and Bugsy Siegel.' This was the first time I was ever publicly mentioned as a gangster." Soon the label stuck with the mainstream newspapers and radio, and when Lansky tried to protest, he could hardly argue with the reply: His own people were already describing him that way. ${ }^{13}$

Rabbi Wise and other leaders now decried the violence. "They wanted the Nazis taken care of but were afraid to do the job themselves," Lansky complained to Jewish mob historian Robert Rockaway. "I did it for them. And when it was over they called me a gangster." To his Israeli biographers, he allowed that there were groups who became known as Murder Incorporated and by other sensational titles. "Of course there were criminals, but I had nothing to do with that kind of criminal violence," he insisted. "But as the years went on, people confused the issues." ${ }^{.14}$ 
To a similar protestation of innocence from Mickey Cohen, Hecht once conceded, "It's a point." After all, in the post-war years, Hecht had aided the Irgun and Stern Gang by challenging the status-quo distinctions between lawmaker and lawbreaker. In this he had merely been following the playbook: Everyone engaged in the armed struggle against British rule, from former law student Begin and scholarly Lehi sage Israel Eldad to the average fighter on the street, understood the rebellion in such terms. Moreover, Hecht and the Bergson Group had charged the U.S. government and Allies with aiding and abetting "one of the greatest crimes in history." They had issued some of the earliest and most strident calls for holding German authorities accountable as "war criminals," going so far as to urge the use of chemical weapons in reprisal for the Nazi war crime of gassing Jewish civilians. ${ }^{15}$

But although Hecht was an expert at "simple, primitive, black-and-white propaganda," he was at heart a Hamlet type, a writer whose inclination to mix up villains with heroes had made him the bane of Hollywood censors since the days of Scarface, who had often left even those closest to him wondering whether he held any true convictions at all. For a man so adept at twisting tropes and themes, who had made a career out of embracing various points of view, the propaganda wars of the 1940s had put certain intriguing perplexities into focus. He began to realize that he had always accepted the same "relaxing bed-time story" as the rest of society. "How cozy to imagine still that the law-breakers are our greatest danger, and not the law-makers," he wrote, in the introduction to his Cohen biography. ${ }^{16}$

During the latter half of the 1950s, the Cohen project became Hecht's means of addressing questions that had lingered for more than a decade. If society did indeed have 
it wrong, then where should the lines be drawn between law and lawlessness? Where did the true differences lie between the cop and the criminal, between the civilized and the savage, between good and evil? What was the difference anymore, in a world full of governments and corporations far more powerful and rapacious than any "crime syndicate," in a world where poison gas, firebombs, atom bombs, even the Irgun's "terrorist" bombs, had become necessary to protect the innocent?

The 1940s had been a long journey for Hecht, from studiously apolitical Hollywood writer to volunteer propagandist to militant who had partnered with an outlaw in arming a guerilla underground. Now he wanted to retrace his steps. "My friend, Mr. Cohen, one-time underworld potentate who has cajoled me into being his official biographer, is likely to gnash his teeth off and on as his reads, for I am loud with data only vaguely related to him," Hecht wrote. "And though I shall write fully about this erstwhile industrious law-breaker, he shall be missing from many of my pages. In his place will be musings and recollections he has unwittingly aroused in me. For Mickey is as much a point of view as a character (italics added)." 17

Turning biography into autobiography was nothing new for Hecht. Beginning with Guide for the Bedevilled, he had been writing books that wove together facts and discussion of his purported subject with personal tales that sometimes took him far astray. Early in Hecht's 1957 book about Charles MacArthur he dropped the pretense that he was writing a biography, describing it instead as "a letter about a friend who has died." Though he had tried to capture MacArthur's spirit, Charlie ended up revealing far more about the author than about the dearly departed. Hecht had also attempted to summon the late Bodenheim's spirit the following year, in 1958, with his off-Broadway play 
Winkelberg, but used his own words for the poet's speech and verse. In an article for the New York Times, he explained that his friend's words were "a bit too fragile for public ken.” This outraged some old-time Greenwich Villagers who felt a loyalty to Bodenheim, who picketed the performances. ${ }^{18}$

Hecht's editor at Doubleday Margaret Cousins recalled fondly: "When I knew him he found it absolutely necessary to devote his time to telling the world about his friends and what had happened to them, and the only way he could do it was to write." In writing of them, he transformed each friend into an archetype - Charlie, the comedian who laughed in the face of tragedy; Bodie, the tormented, uncompromising poet; and finally Mickey, the outlaw, the "tough Jew." As one old friend after another now passed away in the 1950s, each became, "in a sense, a collaborator in the myth of Hecht's own past," explained his biographer Doug Fetherling. ${ }^{19}$

Though Rose Hecht had always been a supportive wife and even at times Hecht's collaborator, the book on Cohen rankled her. She shared her concerns with her sister, the respected psychiatrist Minna Emch, who in early July 1958 wrote a letter that posed a question to her brother-in-law: Just whose idea had it been to write this book? Was this something Hecht had felt compelled to do...or was it possible that he was subtly being used? This gave him pause, for it had already begun to dawn on him that inevitably the book would become not just an investigation of ideas, but of Mickey Cohen.

Provisionally titled The Soul of a Gunman, the choices he now faced about how to present Cohen's story were forcing him to arrive at a judgment about the man. ${ }^{20}$ 
To anyone sifting through Hecht's later works for his final word about the Holocaust and Israel, a far more obvious candidate would be Perfidy, his non-fictional, 281-page indictment of his old Jewish Agency rivals published three years before his death. In vivid, quick-cutting scenes that read like a movie script, it recounts the Kastner trial of 1954, which was the new nation's most dramatic confrontation with the demons of the Holocaust until Adolf Eichmann's trial in 1961. Rudolf Kastner had been a senior official in the Mapai Party's government who stood accused by self-published journalist Malchiel Greenwald of having collaborated with the Nazis. Greenwald's mimeographed pamphlets would likely have gone unnoticed, but when Israel's Attorney General sued for libel on Kastner's behalf, a talented 31-year-old attorney and former Irgun commander named Shmuel Tamir pierced Kastner's lies on the witness stand, unleashing a torrent of disclosures that were as shocking to Israelis as they were painful.

Debate over the case continues, but the agreed-upon facts are these: With Germany's resources stretched thin by the spring of 1944, the SS sought to deport Hungary's 800,000 Jews to Auschwitz without igniting another Warsaw Ghetto Uprising. The best way to make sure the Jews went quietly was to keep them ignorant about where they were headed. Eichman and other officers therefore made an offer to Kastner, the defacto leader of the Aid and Rescue Committee for the Jewish Agency in Budapest. The Nazis agreed to release some 1,685 Jews to Switzerland, including Kastner's family and friends, leading Zionists, and 150 wealthy Jews who helped pay for the passage of others. In exchange, Kastner either agreed to remain silent or, according to witnesses, used the trust and authority of his position to deceive the rest of the population into believing they were being resettled instead of heading to their deaths. 
Kastner allegedly helped the Germans transport 440,000 Jews to the gas chambers in less than two months - one of the most efficient operations of the Final Solution. During the trial, proof emerged that after the war, he had offered testimony at Nuremberg that allowed the infamous SS Colonel Kurt Becher to escape prosecution as a war criminal. In June 1955, Judge Bejamin Halevi ruled that Kastner had indeed "sold his soul to the devil," and exonerated Greenwald on all counts. The judgment precipitated the resignation of Moshe Sharett, who had served as prime minister during Ben-Gurion's temporary absence from politics, causing the collapse of the Mapai government. Two and a half years later, Israel's Supreme Court overturned all counts except the allegation that Kastner had testified for Becher, but by then, Kastner had been assassinated by three veterans of Lehi. $^{21}$

Perfidy had a horrific story to tell, but one that adds little insight into Hecht's views or the debates of the 1940s. As with other controversies over the devil's bargains offered by the Nazis, there are, once again, limits to what the historical evidence can reveal. Hecht presented Kastner as "a remarkable monster," while others have challenged the facts, interpreted them differently, and unearthed new ones to portray him as a tragic dupe whose human weakness was brutally exploited, or even as a Jewish Oskar Schindler whose negotiations actually saved over 20,000 , as many as were possible under the circumstances. Either Kastner testified for Becher in exchange for the Jewish ransom, or he did it to recover the money for Israel and then kept mum, as was his patriotic duty. ${ }^{22}$ Hecht also related the "blood for trucks" offer made to Kastner's associate Joel Brand, and accused Weizmann, Ben-Gurion and Sharett of perfidy for refusing the deal. In other words, Kastner was evil for accepting one devil's offer, while the Zionist 
leadership was evil for rejecting another. Hecht had nothing to say about how the Soviet allies might have reacted to a donation of 10,000 trucks and other goods to their enemy along the Eastern Front, while some 8.7 million Red Army soldiers fell in battle. On the other hand, a recent account from one of Kastner's assassins suggests that his murder may have been a Mapai cover-up. ${ }^{23}$

One trouble with these controversies is that one never knows what piece of the puzzle might be missing, what new fragment of evidence could suddenly turn the heroes of a tale into villains, or vice-versa. Historical evidence does matter, particularly in regard to the Holocaust, but so do ideas and principles. In the end, even if Hecht had been right about Kastner, what, from all of this, has been learned?

Hecht's book about Cohen, on the other hand, is revealing in part because by finding out more about the gangster, the author had to delve deeper into his own assertions, namely the myth of the "tough Jew" that he had offered to the American public. As he admitted, the book was at least as much autobiography as it was biography, and confronting the realities of his mobster-collaborator turned out to be a test of his own ideas and character as well. Having agreed to split the profits with Cohen 50-50, he had embarked upon a project that revealed itself to be his own devil's bargain, and indeed, it was one of the truest tests he ever faced, precisely because he never saw it coming... 


\section{2. 'SOME KIND OF STRENGTH'}

In his eyes we Israelis had been molded by blood, violence, and a struggle for survival and power in the sands of the Middle East. Meyer perceived his background on New York's Lower East Side as similar, though in a different setting. He felt a kinship with me that transcended generations, cultures and continents.

Uri Dan's introduction to Meyer Lansky: Mogul to the Mob ${ }^{24}$

Interviewer: Mr. Hecht, do you think that murder is ever justified? Hecht: I think valor is always justified.

Interview with a British newsman Circa May $1947^{25}$

By the spring of 1947 Hecht was long past making appeals to world conscience, and in the face of increasingly shrill vilification, no longer felt obliged to hold his tongue against his Jewish detractors. "I had been promoted from a wanton, publicity-seeking racketeer to a Fascist out to plunge the surviving Jews into a blood bath," he later recalled. He answered his critics in April, with a speech at a Hotel Astor banquet for the crew of the refugee ship, the SS Ben Hecht. There had until recently been "fifty-seven varieties of Palestinian strategists, Zionist Palaverers, and Hebrew disputants," he told the dinner guests. "Today there are only two Jewish parties left in the field - the Terrorists and the Terrified." By this he meant that Jews faced a stark choice in the Middle East: They could either inflict terror, or be the victims of it. ${ }^{26}$

Two weeks later his "Letter to the Terrorists of Palestine," alienated even some close friends, including actor Edward G. Robinson, who had been one of his staunchest allies on the Emergency Committee. "His comments about his delight at the death of every English soldier sickened me," Robinson wrote in a memoir. "I thought him, at the 
very least, irrational. I never acknowledged him again.” Even among the Bergson's delegation, his chief deputy Samuel Merlin was disturbed by the tone and opposed publishing the ad. Bergson did not see a problem, though he later felt it should not have been run because it was "bad propaganda." 27

Responding to furious protests from the British government, the president demanded an end to incitement. "Despite the fact that he is president," Hecht remarked blandly, "Mr. Truman is still entitled to his opinion.” American newspapers roundly condemned him as a war-mongering extremist, including his old employer the Chicago Daily News, which scolded: "This white-hot inspiration to hatred is a sad disservice both to the cause of Zionism and to the hopes of world peace. Mr. Hecht in effect joins Hitler in preaching that the issue cannot be resolved peacefully." The New York Herald Tribune warned that in all probability "more terror will produce only more bitter and violent reactions everywhere and that the fugitive chance of a reasonable settlement will in the end be lost." In a letters column filled entirely with denunciations, reader William A. Kirk expressed disbelief that the Herald Tribune would dare to run a full-page ad "to aid and abet crime and violence" against "a nation friendly to the United States." Others cautioned that the sympathy of Americans would soon evaporate if the Jews carried on this way. ${ }^{28}$

Jewish groups rushed to distance themselves from Hecht's claim that American Jews — except, he had stipulated, the rich and respectable—-had "a holiday in their hearts" when British blood was spilled. "Terrorism is hostile to Jewish religion and tradition," explained the American Jewish Committee. Another Herald Tribune reader pointed out that "to call the activities of the extremists Zionist policy is simply to confuse two 
entirely opposite views and principles." While the British Daily Mail opined that Hecht had encouraged anti-Semitism, the Palestine Post complained that Lord Beaverbrook's Mail and Daily Express were using Hecht to tar Zionism with one brush and vent their own anti-Semitic rage. ${ }^{29}$

Among the lone voices speaking out in his defense were columnists Walter Winchell, who relished jousting with the British journalists, and Leonard Lyons. Daily News reader J.M. Winnetka wrote that while people accused Hecht of hurting rather than helping the Zionist cause: "I see no evidence that anyone is helping the Jews but themselves. A national home for the Jews is not only desirable from a symbolic point of view, it is an immediate necessity." Marion Kuhn argued in the Herald Tribune: "The admission of 100,000 displaced persons is a matter which transcends all considerations of politics and power. These people have been through hell on earth. They have waited for eight tortured years. Is there to be no end to the waiting?" ${ }^{30}$

Hecht had packed his letter with references to freedom fighters and 1776, but all that liberal contemporaries like Robinson heard was a bizarre and disturbing call for more bloodshed. Amid such an uproar over Hecht's holiday in his heart, one could be forgiven for either altogether missing or dismissing the point he was trying to make: that among the parties in Palestine, the Irgun were in fact the true champions of liberal-humanist ideals. In his view, they were defending the Rights of Man not only as the vanguard of a national liberation movement, but also as the front line in a war for survival. He saw nothing fascist or anti-democratic in their pessimism about Britain's good faith, the moral authority of the UN, or for that matter, the existence of world conscience; that was 
merely clear-eyed recognition of the realities borne out by the war and the situation in Palestine.

"For however stupid and wry-headed the world may seem when studied from headline to headline," he had said at the Astor, "there is one flag it flies that has never been lowered. This is the flag of moral justice and human rights." On the other hand, the battle cry of "the loquacious Zionists and Tweedledum Knights of the Jewish Agency""Whatever happens, let us stay in the good graces of our enemy" - "seemed a peculiar technique for a revolution." 31

This myopia and cowardice, he asserted, was the real threat to the aspirations of the Jews, and to all human aspiration. "There will always be Jews who imagine that if they are seen crawling on their bellies among their enemies they will be mistaken for non-Jews or at least for high-class Jews," he admonished. "I'm thinking of a white Christmas named Arthur Sulzberger, owner of the New York Times. Mr. Sulzberger's stomach-tour among Anglo-Saxons is not a new spectacle in Jewish history. It is one of the few authentic bases for anti-Semitism. Looking on the immemorial Sulzbergers the anti-Semite says, 'If a Jew is so ashamed of his cause and his people, what a shameful cause and people they must be. ${ }^{,, 32}$

The return of the nineteen crewmen honored that evening, most of them American, represented another coup for the Bergson Group. The American League for a Free Palestine had sent the Ben Hecht on a kind of Trojan-horse mission, expecting that the arrest and imprisonment of U.S. citizens would embarrass England. It did. After intercepting the ship on March 8, 1947, British destroyers transported the six hundred refugees to an internment camp in Cyprus and the crew to Acre Prison, where many Irgun 
and Lehi fighters were jailed. Poised for action, the League rallied the American public with a flurry of ads and press releases, the mother of one crewman launched a grass-roots campaign, and the League's members in Congress demanded the crew's release. "The British can capture ships to their hearts' content," Hecht proclaimed, "but there are many more where they came from." One advertisement noted: "The British in Palestine are democratic with respect to prisons - they'll jail anyone; Hebrews, Arabs-AND NOW AMERICANS...The only 'law' in Palestine is British might.” After the House of Representatives condemned the seizure, the British released the crew, and they arrived home to a cheering crowd at City Hill on April 17. ${ }^{33}$

Bergson had left for Paris months earlier, in in late 1946, to establish a provisional government, while in America, the League's activists had shifted focus from repatriation to armed struggle. Hecht underwent surgery for peritonitis in mid-June 1947, and again in July. He was still recovering at Roosevelt Hospital in New York when he was asked to compose another appeal for funds. Members of the committee smoked and paced around his highly flammable oxygen tent as he wrote on the back of his x-ray chart, penning a paean to Irgun fighters hanged by the British, as Dov Gruner and three others had been on April 16. "Requiem for Three" vowed that their deaths would be answered by "the roar of guns, motors and bombs." Three weeks later, Begin cabled to suggest a play about Gruner, and offer praise for showing a "readiness to take the stones hurled at you from all sides. ${ }^{34}$

By September 1947, Hecht's The Terrorist appeared at Carnegie Hall. Set on the morning of Gruner's hanging, it opens with Tevya once again, this time accompanied by 
Judah Halevy, the twelfth century poet, philosopher and proto-Zionist. The two angels stand above the fighter as he awaits his execution.

Halevy: ... It is his good name the English hang — so that he shall seem a criminal instead of a Hebrew soldier who fought to free his homeland of an invader.

Tevya: To hang a soldier - this is against the law! And the Englishthey are in Palestine against the law. The whole thing is against the law, Reb Halevy!

Halevy: Nothing that is done to Jews is against the law-if it is done by a nation. A nation can only commit a crime against another nation. And the Jew, however numerous he be, is forever outside the law, because he belongs nowhere. ${ }^{35}$

Hecht had returned to the same questions raised in A Flag is Born about who were the lawmakers and the lawbreakers, this time within the context of the armed revolt. A Scottish sergeant calls Gruner a traitor upon learning that he is a fellow British army war veteran who had also fought at Alamein. Gruner replies that he still serves the same cause, the struggle against tyranny. "A fine cause it is," the sergeant scoffs, "when your own Jewish people call ye a lawbreaker and a terrorist!" My people have lived like an unwelcome guest for so long, Gruner says, that they don't know how to fight for themselves. When guards arrive to march him to the scaffold, Gruner asks if he will die in prison garb. "Gangsters and hoodlums are not entitled to military dress," an officer spits back. Gruner points out that he was arrested in military uniform. In reality, he had been disguised as either a British policeman or an Arab prisoner in a raid on a police armory, but that would muddle Hecht's point: A prisoner of war cannot be executed under the Geneva Conventions, but a criminal has no such rights. ${ }^{36}$

When the guards start to beat their condemned prisoner for refusing an order to stand, the Scottish sergeant has heard and seen enough. A furious officer barks at him to remember his duty as he rushes to Gruner's defense, but he has been roused by a more 
personal sense of duty. "I'm a Scotchman, not an Englishman!" he yells. "I'm a man! And as a man I ask ye to stop what you're doin'!"37

The final scene at the gallows echoes the macabre tableaus of Hecht's wartime pageants, and their sometimes-overwrought symbolism. In chorus, ghostly victims tell Gruner they have dreamed that one day he would come, to stand up for them all. $\mathrm{He}$ drops into the noose as the lights go out. When they turn on again, Gruner is gone, and the flag of Israel hangs from the rope. ${ }^{38}$

In Palestine, Gruner's execution had ignited a chain of reprisals that brought the revolt to a fever pitch, and it may have been a direct appeal from Begin that prompted Hecht to approach Mickey Cohen. On June 10, Irgun chief Begin had sent "a scathing letter" to the Hebrew Committee, furious that thousands had been spent on the Ben Hecht while fighters were dying in the field. Despite some optimism for cooperation in March 1947, the high command had lost patience with Bergson. All along, Hecht had maintained direct contact with the Irgun. "Around me in Nyack the Palestinian underground crackled constantly," he later wrote. "Russian and British spies pattered through the house and eavesdropped at the swimming pool where the Irgun captains were wont to gather for disputation." Hecht was discharged from the hospital on June $24^{\text {th }}$ and had to undergo a second surgery three weeks later. ${ }^{39}$ By all accounts, he first met Cohen at Oceanside late that summer. Twenty years later, the gangster recalled the encounter:

Ben had somebody else with him from Israel, from the Irgun. This guy got me so goddamn excited. He started telling me how these guys actually fight like racket guys would. They didn't ask for quarter and they gave no quarter. And I got pretty well enthused with them. And then I could see and sense that's what Ben wanted me to do. ${ }^{40}$ 
Yitshaq Ben-Ami later explained that the Irgun had always drawn support from lower-income and first-generation American Jews, but the spectacular Acre Prison jailbreak after Gruner's death and execution of British soldiers that summer of '47 captured the attention of another subgroup: the Jewish mob. Decades later, Cohen had vivid memories of the events: I started to have relationships with Irgun members back in Israel. They got to understand me better and I got to understand them better, and this was when the English hung those three Jewish kids.

I had pretty near got blowed up with the Irgun about this. I even had a beef with Ben Hecht. I told him and the Irgun, "Lookit, everything from this part of the country is going to stop cold if you don't get hold of some top English officers and hang them up in the same public square. If you don't, that's going to be the end of my involvement with it."

And they done it. They hung some British officers right in the middle of the goddamn public square. ${ }^{41}$

Ben-Ami acknowledged Cohen's contributions, but said another key figure was "Uncle Joe" a cockney and dabbler in sentimental poetry who was particularly disturbed by his native land's conduct. Uncle Joe set up meetings in New York, Chicago, Detroit and Los Angeles where Hecht and other Irgun representatives spoke. A lunch in Detroit attended by 25 people, for example, raised $\$ 30,000$. “The respectable Jews did very little to help," wrote Ben-Ami, reciting Hecht's refrain. "The 'Jewish rejects' did come across - as did the Jewish-speaking ones from the Lower East Side of New York and the Jewish ghettoes in Philadelphia, Boston and Chicago." Altogether, "the Jewish underworld" gave about $\$ 120,000$, most of which went to outfitting and arming the Altalena, he said, though some was transferred to an account in Switzerland. ${ }^{42}$

The Yishuv was outnumbered and desperate for weapons by late fall, when Palestine erupted into a chaotic civil war. Arab gunmen fired the opening rounds in an 
attack on two Jewish buses near Petah Tikva on November 30, a day after the UN General Assembly passed the partition resolution. Within days, it was obvious the clashes were escalating into a full-scale conflict, despite the continued presence of British troops. Thousands of foreign fighters poured in to reinforce militias from the 800 Arab villages: hundreds of Muslim Brotherhood volunteers, and the relatively well-equipped Arab Liberation Army, a force of between 4,000 and 7,000. What was more ominous, from the Jewish perspective, were the armies of Egypt, Syria, Transjordan, Iraq, Lebanon and Saudi Arabia that stood waiting on the sidelines, poised to attack with air forces, tanks and modern artillery as soon as the British left in mid-May.

"We need war material and the means to make war," Samuel Merlin wrote Hecht from Palestine on December 30, 1947. “...Precisely now we face a war of life or death. Expressis verbis: life or death.” Between the Haganah's core strike force, the Palmach, and the fighters of Irgun and Lehi, the Jews had 7,000 troops at most. In theory, the Haganah could also call up its militia of 35,000 . But there were not nearly enough guns for half of them. ${ }^{43}$

"I guess (Ben) thought I was some kind of strength," Cohen said, "that could help certain people." Cohen said the mob smuggled weapons along the East-Coast waterfront, describing a role that would have been an easy transition from its cooperation with Naval Intelligence during the war, as Lansky himself also claimed, if not corroborated. Overseeing operations were Albert Anastasia, acting chief of the Combination's killing machine, Murder Incorporated, and Charlie "the Jew" Yanowsky. "Charlie had the docks in New Jersey," Cohen explained, "and Albert had them in New York." Their web of control over longshoreman unions, stevedore firms, police and politicians had been spun 
long back in the days of Prohibition. Another important player on the docks was Newark's Longy Zwillman, whose "Minutemen" had also fought the Nazi Bund in the 1930s. "We knew he not only ran the rackets, he elected mayors and governors," recalled journalist and New Jersey native Sidney Zion. "We knew he was running guns to the Irgun when they were fighting the Arabs with matzo balls. ... I knew plenty of guys in Newark who were saved by him from anti-Semitic hoods." ${ }^{44}$

The mob tracked and sabotaged shipments going to the Arabs, ensured security over crates delivered to the docks for the Jews, and stole U.S. military surplus arriving on ships. "I had access to all that stuff on the docks," Cohen said. "Some of the stuff and equipment like machine guns that we got back to Israel had never got a chance to be used in the Second World War. They weren't even put together. They were still in the cases, in the straw, in the oil and everything. We shipped them right over." Many Irish longshoremen had gained expertise in arms and explosives fighting the British, and felt solidarity with the Jews. Cohen said he convinced a New Jersey dockworker named "Chopsie" to join the fight in Palestine. ${ }^{45}$

Contraband came in regularly from local Revisionists like Abraham and Sylvia Zweibon, who had been gathering arms for the Irgun since late 1945. The Zweibons received a steady stream of packages, mostly from army veterans, at their floor-covering store in Brooklyn. Donations of guns and materiel piled so high that the couple ran out of space even after opening a second store nearby, and soon filled up the basement of their upstate vacation home. Lower East Side funeral home owner Lawrence Schwartz drove a hearse with weapons-filled coffins to warehouses around the city, and then on to Marine Terminal in Hoboken, New Jersey (Yanowsky's turf) or Bush Terminal in Brooklyn. "I 
watched with awe as they rose out of their stores and work shops and came to our side," Hecht recalled. "Jewish clerks and salesladies, garage workers, plasterers, elevator boys, Yeshiva students, policemen, garment worker, prize fighters, housewives, Jewish sailors and soldiers still in their uniforms, Jews from night clubs, tenements, farm lands, synagogues and even penthouses came boldly to the Irgun banner." ${ }^{46}$

Cohen said he organized League fundraisers in Boston, Philadelphia, Miami and elsewhere, which seems consistent with Ben-Ami's account. A group of his fellow Jewish mobsters in St. Louis agreed to host a dinner if former world champion boxer Barney Ross would give the keynote speech. The event raised over $\$ 100,000$, according to an unpublished memoir by old-guard Revisionist Rabbi Baruch Rabinowitz. Another League activist named Paul Gropman remembered Cohen's muscle at an ALFP meeting in Los Angeles. "You can always spot these guys," he said. "They keep their right hand in their pocket if they're right-handed, because that's where the gun is. ... He sent these guys there, I think there were two of them, and he probably said, 'Hey, I don't want the meeting disrupted.' It was a Jewish meeting. These guys weren't Jews, or they didn't look like Jews to me. These guys were hoods. What the hell were they doing at this Jewish nationalism meeting?"

With Cohen and Barney Ross as League advocates, Hecht's activism continued through May $14^{\text {th }}$, 1948, when Ben-Gurion declared Israel's independence. The day before, Hecht staged a final pageant at Madison Square Garden, The End of Silence, drawing a crowd of 20,000 with yet another a roster of celebrities: Sid Ceasar, Hazel Scott, Dean Martin and Jerry Lewis, among others. It was in part a benefit for the George Washington Legion, Barney Ross' force of American volunteers seeking to fight in Israel 
just as the Abraham Lincoln Brigade had once fought in Spain. Ross, a two-division boxing title-holder and Marine Corps war hero wounded at Guadalcanal, had recruited 2,500 volunteers by the end of March, but the United States government had refused to issue them passports. In April and again on May 12, he and over 400 recruits marched on Washington to protest the travel prohibition. ${ }^{48}$

Given Slapsy Maxie's namesake, the swanky Wilshire Boulevard nightclub was an apt locale for Cohen's major May $24^{\text {th }}$ fundraiser. Maxie Rosenbloom was another world champion Jewish boxer, who had earned the nickname "Slapsy" because of his unique style of offense - open-handed cuffs thrown in lightning flurries. An actor in more than sixty films, including Hecht's Nothing Sacred, he played either the punch-drunk boxer or 'the comic tough guy, the B-movie gangster, saying 'dese,' 'dem' and 'dose' in his heavy New York accent." 49

Hecht's account of that evening in $A$ Child of the Century has become iconic, a romantic folktale about the Jewish mob giving salute to Israel that has been quoted and recounted in countless books, articles and academic papers. But Hecht's story may be misleading in certain particulars. There were indeed plenty of "lawless and semi-lawless characters" present, but the crowd of 1,500 also included so many high officials that the scene might have reminded Hecht of aldermen Hinky Dink and Bathhouse John's Gangster Balls in Chicago's First Ward back in the days of his youth. One guest struck by the mix of personalities was Lt. Rudy Wellpott, head of the Vice Squad—later "Administrative Vice"-for the Los Angeles Police Department. "It was interesting to notice who some of the people were that were present," he told a prosecutor at a 1949 grand jury investigation. "There were some judges, Assemblymen, Congressmen, some 
people from your office." Then again, Wellpott could have been lying: He was already under indictment for bribery and perjury, in a scandal orchestrated by Cohen that would soon turn Los Angeles upside down. ${ }^{50}$

Although Hecht's erroneous reference in his memoir to a recent hospital stay and Ben-Ami's account would seem to place the event around the late summer of 1947, club owner Charles DeVore dated the event to May 1948 when he testified at Cohen's tax trial three years later. A strong piece of evidence corroborates DeVore: The text of Hecht's speech stored among his papers clearly suggests that time frame. Charles, the official owner of the club along with his brothers $\mathrm{Al}$ and Sy, recalled being so inspired by the speech that when Cohen was about to pay the club $\$ 5,000$ cash for the event, Charles asked the gangster to keep half as a donation. ${ }^{51}$

Hecht had told the crowd that he had come on behalf of Menachem Begin. "He asks that I do what I can to arouse among the Jews who are not fighting in the Holy Land, the knowledge that without them the Holy Land will be lost. ... 'We are fighting against great odds,' the Irgun commander says. 'The enemy outnumbers us and is better equipped. His resources are unlimited. Great Britain is supplying him with its millions, its munitions and its manpower. We have only ourselves." Hecht invoked the memory of the Warsaw Ghetto Uprising, when thirty thousand Jews with junkyard scrap for weapons, "outnumbered as in a nightmare," had held out against the German Wehrmacht for twenty days. The Allies hadn't provided arms or any other support, he said, because of Britain's "shabby little plan to steal Palestine for themselves." Now, with money from American loans, Britain was pouring arms and expertise into Transjordan's Arab Legion and the other Arab armies, hoping to install a puppet regime. "A champion stands in Palestine," 
Hecht concluded. "He will not surrender. But he calls on us. He needs us. If he loses, he will lose because we did not put a gun in his hand."52

Decades later, in early 1981, a shocking tale aired on 60 Minutes about what happened to over $\$ 750,000$ raised that evening. Cleveland mobster-turned-informant Jimmy "the Weasel" Fratianno repeated for Mike Wallace the allegations he had made in his newly released biography, The Last Mafioso: Cohen had scammed the money, Fratianno claimed, by handing it to a trusted "rabbi," and then planting a Los Angeles Herald-Examiner article about a ship loaded with arms for Israel that sank somewhere at sea. "He's tapping his finger against the newspaper," Fratianno said in the book, "and looking at me with his hound-dog eyes, not a fucking expression on his face, and he keeps repeating, 'Oh, terrible, terrible. What a tragedy.'",53

Immediately after the 60 Minutes episode aired, Ben-Ami had tried to correct the record, providing his account of Uncle Joe, the Irgun's mysterious guide in the American underworld, and the fundraisers held for the Irgun by the mob. Cohen's event at the nightclub, Ben-Ami wrote, had raised only $\$ 50,000-\$ 60,000$, and the money was given to Hecht, who passed it directly to representatives of the League and the Irgun. Fratianno's figures of $\$ 750,000$ and up were "sheer fantasy," and none of the money was stolen. BenAmi also had an explanation for the origins of the tale about the alleged Herald-Examiner article: After the Altalena was shelled, he said, Cohen's enemies had circulated the story that the ship never existed and it was all a con. ${ }^{54}$

The mob's intrigue with the Irgun had a fitting coda in June 1948. Weeks after the Slapsy Maxie's benefit, Ben-Ami had phoned fellow Bergsonite Alex Rafaeli in Europe and asked him to fly to Palermo on a mysterious, unspecified mission. Escorted upon 
arrival to the Las Palmas Hotel, Rafaeli had cooled his heels for two days before finally being summoned to the dining room, where he was met by a pale, haggard-looking Lucky Luciano. The mafia don had been released from prison, but deported, in exchange for his aid to Naval Intelligence. Now he wanted to return to America, and knew the Bergsonites were friendly with Henry Morgenthau. "If you can help get me back to America," he told Rafaeli, "I'll get you all the boats you need." Rafaeli said that he would pass on the proposal as soon as he returned to Rome. By the time he had arrived in the Italian capital, however, various arms pipelines were flowing to Israel, and there was no need for Luciano's fishing boats. ${ }^{55}$

It is impossible to know how important the underworld's assistance was to the Jewish state - an issue that remains shrouded in controversy. During the critical early months of the civil war, the only large arms shipments came from Europe, particularly from Czechoslovakia. Deliveries that finally arrived on March 31 and April 2, 1948, totaling 4,700 rifles, 240 medium machine guns and 5 million rounds, reached Palestine just in time for the Haganah to break the siege on Jerusalem. By May, years of planning at last began to fall into place, and the Haganah's hauls of fighter planes, B-17 Flying Fortress heavy bombers, armor, jeeps, munitions and materiel dwarfed what the Irgun had been able to accrue. The story of how this was accomplished is told in Leonard Slater's 1970 book The Pledge, which downplays the notion that the mob played any meaningful role. ${ }^{56}$ But the exclusion of American Jewish gangsters from Israel's history may have parallels to Lansky's experience with Rabbi Stephen Wise in the 1930s: In the eyes of many supporters, the hand of organized crime would seem a terrible blight on the Jewish state, and in the eyes of its enemies, further evidence of Israel's illegitimacy. 
Many first-hand accounts openly acknowledge the role of the mob. Headquarters for the Haganah's vast smuggling scheme was the seedy Hotel Fourteen at 14 East $60^{\text {th }}$ Street, where chief operative Yehuda Arazi crafted deals and Teddy Kollek acted as "traffic cop," coordinating the flow of goods. Right downstairs was the glitzy Copacabana Club, essentially the East Coast counterpart of Slapsy Maxie's, the favorite haunt of the New York underworld. "In my business...we can't be too fussy about who we do business with," Slater quotes Arazi as saying, after he met with two hoods from Murder Incorporated. But none of Arazi's deals with the underworld amounted to anything, Slater maintains, because the offers were either fake or overpriced. Kollek, however, recounted in his memoir that his work touched on "liaisons with spies, mobsters, movie moguls, statesmen, bankers, professors, industrialists, and newspaper men; and no lack of illegalities, from petty to international." Reuven Dafni, another Haganah agent, said he accepted a total of $\$ 50,000$ in donations from Bugsy Siegel, and credited Miami gangster Sam Kay with providing the connection to the president of Panama - a major help, because it allowed the Jews to register ships under the Panamanian flag. ${ }^{57}$

Smuggling the goods through the ports became the responsibility of twenty-twoyear-old Elie Schalit, who set up an array of shell companies with the aid of New York attorney Nahum Bernstein. But given the thousands of tons of contraband that began to move to Israel over the summer and fall, it is hard to believe help from the mob on the waterfront was not necessary. If Naval Intelligence had to rely on the active assistance of the mob to secure U.S. shipping, wouldn't such assistance have been necessary to secure so much illegal shipping? According to Lansky, Arazi had summoned him to Hotel 
Fourteen and said: "I know the mafia, or whatever you want to call it, controls the Port of New York." When Arazi then asked Lansky to intercept a shipment going to the Arabs and divert it to Haifa, the cooperation with Joe Adonis, Anastasia and the longshoremen began. $^{58}$

Regardless of how important such aid turned out to be, everyone involved in the arms smuggling was an outlaw, in violation of the U.S. embargo act of December 5, 1947. "Here was an opportunity that happened maybe once in a lifetime, maybe not even once in a lifetime," said Al Robison, a textile manufacturer who was among the prominent U.S. Jewish businessmen backing the cause. "That we could be cloak-anddagger people, that we could live dangerously and feel highly virtuous about it." The government itself was looking the other way. When New York City police had received a tip from a building superintendent in April, they discovered hundreds of rifles and pistols in a loft on West $28^{\text {th }}$ Street. At a pre-trial hearing one month later, Judge Frederick Strong dismissed the case against two young men discovered at the scene, arguing that their mere presence in the loft did not prove they were in sole possession of the contraband. A New Jersey case stemming from an arrest in late November was similarly dismissed. Even the discovery of some 250 tons of TNT that crashed off a waterfront crane on a rainy January night, though it had been a serious setback for the Haganah, did not result in a single day of jail time. ${ }^{59}$

Disregard for the embargo act apparently reached all the way to the man who had signed it into law. "It was only God's will that Harry Truman was president," said Cohen. “He couldn't openly allow it to be known that he was okaying the stuff to be shipped back there or that stuff was being stolen from the ships that were coming back from the 
Second World War. But it was only with Truman looking the other way, or with his being in favor, that it was done." The embargo may have been a sop to the Arabs and a way of appeasing the many officials in his administration who strongly favored taking their side in the conflict. But senior adviser Clark Clifford had persuasively argued that the Arab states depended on the United States for 90 percent of their oil revenue - "their need of us is greater than our need of them." And while "the Jewish vote" and campaign finance must have been factors in Truman's decision-making, so were his personal friendships with Jews, as well as his sympathy for their plight. ${ }^{60}$

This rampant flouting of the law has, of course, led to some sore feelings. In the Journal of Palestine Studies, Ricky Dale-Calhoun noted derisively that oil magnate Rudolf Sonneborn and the seventeen businessmen who started to develop the smuggling plan with Ben-Gurion weeks before the end of World War II "took maximum advantage of a number of conditions." Among others, they seized on "corruption, malfeasance, and dereliction of duty on the part of local officials; connections with the American criminal underworld; and legal expertise to exploit the weaknesses and loopholes in U.S. law." As a result, he huffed: "Despite the heroic myth in which it has previously been cloaked, the Jewish Agency's U.S. arms procurement effort amounted to a highly effective criminal conspiracy."

In the final days of the American League Hecht ignited yet another controversy, one that exacted a personal toll. Amid continuing Israeli victories in the fall, UN mediator Count Folke Bernadotte had proposed a peace plan that would have given the Negev Desert to the Arabs and internationalized Jerusalem. When four members of Lehi assassinated Bernadotte on September 17, 1948, Hecht told the press he was "an ass not 
worthy of so fine a death." He added: "He was not sharp enough to be the villain of the piece. He was a professional cat's paw, hired to pull the chestnuts out of the fire for the British." Hecht, who still held to Jabotinsky's dream of a Greater Israel that spanned both sides of the Jordan River, argued that if Bernadotte's plan was adopted, "Israel would be reduced to a Miami Beach." Weeks later, the Council of Britain's Cinematograph Exhibitors Association announced its boycott of his films, citing Hecht's holiday-in-hisheart remark. Though the ban was finally lifted in 1952, as late as 1956 he was denied credit for The Iron Petticoat out of fear of losing the British market. ${ }^{62}$

More than a year of Zionist gun-running and Menachem Begin's transition from Irgun commander to political leader had done nothing to alter the rhetoric of previous days. When Begin visited America at the end of November, the American League wished him luck at a banquet in the Waldorf-Astoria that was also a farewell ceremony. Tonight, Hecht said, "we go back to smaller things. ... My interest in the land of Israel lies only in this deeper knowledge - that if Israel is beaten down, it will not be a nation alone that is beaten. ... It will be Truth and the unending cry of the human soul for freedom that will be conquered." ${ }^{63}$

Days later, Albert Einstein, Hannah Arendt and Sidney Hook were among the signatories of a letter in the New York Times that likened Begin's new Herut, or "Freedom Party" to "Nazi and Fascist Parties," formed, as it was, out of the terrorist Irgun. "Today they speak of freedom, democracy and anti-imperialism, whereas until recently they openly preached the doctrine of the Fascist state," the letter asserted. "It is in its actions that the terrorist party betrays its real character." As an example, the authors cited the massacre of 240 civilians in the peaceful village of Deir Yassin, which was "not 
a military objective" - allegations that would not prove to be entirely accurate. "The IZL and Stern groups inaugurated a reign of terror in the Palestine Jewish community," they continued. "Teachers were beaten up for speaking against them, adults were shot for not letting their children join them. By gangster methods, beatings, window-smashing, and wide-spread robberies, the terrorists intimidated the population and exacted a heavy tribute." 64

Hecht's career as an activist was over, but he would long remain rankled by what he saw as the hypocrisy of those who had labeled him a terrorist and gangster, of those who professed to speak in the name of law and order, of the distinctions they drew between lawmaker and lawbreaker. 


\section{CHAMPION IN CHAINS, REVISITED}

Organized gangsterism is returning - a new kind of gangsterism, combining the ruthlessness of the Prohibition Era with the scientific tactics and strategy used by the underground in World War II.

Movie trailer for

A Street With No Name, $1948^{65}$

Hecht once told a colleague about the day Mickey Cohen's bullet-proof limousine first pulled up to the house in Oceanside, California. Throughout the whole visit, the gangster and his two burly bodyguards never took their hats off.

“They acted like people I made up," Hecht said. ${ }^{66}$

Indeed, even the voluble author never quite articulated the uncanny degree to which his visitor was a composite of the characters he had known in youth and the ones who populated his own imagination. For decades, Hecht been spinning tales about them in prose, plays and movies, and finally, out this grist, into the myth of the "tough Jew" of his propaganda. In some ways, Cohen appeared a funhouse-mirror reflection of Chicago hoods like Nails Morton and the p.r.-savvy Al Capone, or Hecht's own Diamond Louie and Tony Camonte. A simian figure with pouty lips and a scar curling under one eye, standing five-foot-five in elevator shoes, "the Mick" resembled "the fifth banana in a Bfight picture...a dark cupid." His cream-colored and pastel suits draped a once sinewy pugilist's body, gone soft from pastries and ice cream. ${ }^{67}$

Yet Cohen was something other than a pug-faced, pint-sized parody who posed for magazine covers in front of his spectacular clothing closet and monogrammed doggie bed for Tuffy. Friends such as Hecht understood that his compulsive habit of washing his hands fifty to sixty times a day was simply germ phobia. Others in Hollywood found it 
eerily reminiscent of crazy Lady Macbeth's vain attempts to scrub out that damn spot, recalling the line from the great bard: "Will all great Neptune's ocean wash this blood clean from my hand?" ${ }^{68}$ And the Mickster was also something far more than comic relief: By the late 1940s, he had amassed a vast empire.

Groomed by Siegel and a debonair gambler known as Nick the Greek, he had graduated from a gun thug "going on the heavy"-pulling heists — to "a bookie's bookie," who ran a network of six-to-eight spots that offered under-the-table off-track betting, each raking in anywhere between $\$ 30$ and $\$ 150,000$ daily. He also opened exclusive gambling clubs that catered to the Hollywood elite. With these revenue streams, by 1945 he had expanded into protection, extortion, loan sharking, strikebreaking, slot and pinball machine concessions, and, though he denied it, prostitution and narcotics. "His finger in every pie, his hand in every wallet," noted biographer Tere Tereba, Cohen's dominion stretched across Southern California down to Mexico. It was rumored to reach up to San Francisco and as far out as Honolulu and Manila. ${ }^{69}$

Cohen was Tony Camonte on steroids, a Jewish Scarface for the Atomic Age, a "miniature colossus" equipped on a scale far beyond what Hecht and Hawks had imagined in their early talkie. Among the legitimate businesses that served as Cohen's fronts, headquarters was Michael's Exclusive Haberdashery at 8804 Sunset Boulevard, a veneer for what would become a fortress that put Camonte's steel shutters and bulletproof desk chair to shame. By the time of the Slapsy Maxie's affair, "any appearance he made in Hollywood was sure to draw gunfire," Hecht recalled. Beneath the walnutwalled showroom of imported gabardine suits, camelhair coats, finely woven shirts and 
smoking jackets, Cohen protected his private office with an electronically operated, triple layered mesh steel door, reinforced with wrought iron. As a final redoubt for the hoods who sometimes doubled as his clothing salesmen, he installed a secret chamber wired to observe the store and office, soundproofed and comfortably accoutered with a radio and fully stocked fridge. Around the corner was a chop shop where a Ford sedan could be rapidly rebuilt into a replica of an Los Angeles Police Department (LAPD) squad car. ${ }^{70}$

By the time his enemies launched their all-out onslaught of shotgun blasts, machine-gun strafings and bombings that the newspapers would call "The Battle of the Sunset Strip," Cohen had brought West an ethnic mix of some twenty "ex-convicts, muscle guys, bust-out gamblers and killers." In addition to his soon-to-be-deceased "right-hand" Hooky Rothman, "built like a bull," and "left-arm" Neddie Herbert, the weapons expert and court jester, there was Johnny Stompanato, a twenty-two-year-old ex-marine ladykiller reputedly charged with watching over the beautiful women Cohen used for blackmail. Soon they were joined by the lethally treacherous "Happy" Harold Meltzer, fresh from the East Coast where he was liked for the recent icepick murder of Charlie "the Jew" Yanowsky. ${ }^{71}$

Cohen's troops drove a fleet of Navy-blue Cadillacs with torpedo fins and shining chrome, bullet-proofed, souped up for speed and outfitted with secret weapons stashes, as well-suited for the Strip's poshest clubs as for boulevard firefights. The crew, decked out in Michael's exclusive finery, was undoubtedly one of the nattiest armies in history. "If he had a coat of arms," quipped bookmaker George Redston, "it probably would have shown $\$ 100$ bills rampant on a field of double-crosses. ${ }^{, 72}$ 
In one of a dozen assassination attempts, gunmen had opened fire from both sides of Cohen's street as he was pulling into his Brentwood home, forcing him to duck below window level and drive blindly backwards for two blocks. After that, he purchased a 4,400-pound Cadillac Fleetwood that could roll through the next fusillade on its Goodrich Silvertown Seal-o-Matic tires. It was armored in eight-inch thick high-carbon steel that could resist anything short of a direct hit from a bazooka, lined with bullet-proof fiberglass, and had inch-thick window glass with beveled windshield and slits to allow for outgoing fire. Unfortunately, once the $\$ 7,000$ worth of modifications had been made, a judge would only agree to issue a road permit if Cohen would tell who had permitted testing at the LAPD gun range. Cohen said he tried to sell the Caddie to Emperor Haile Selassie, Juan Peron, and a certain Latin American dictator who was indeed interested, but was wiped out before he could make the purchase. The car sat in storage for a long time before it was finally sold, for a pittance, to a car museum in Texas. ${ }^{73}$

The son of Russian immigrants from Kiev, Meyer Harris Cohen was born in Brownsville, Brooklyn in 1913. His devout, orthodox father Max "was in some kind of import business to do with Jewish fishes," who died when Mickey was only weeks old, leaving his mother Fannie with little money to raise her six children. In 1915, she brought Mickey and his sister out to Los Angeles and opened a small grocery in Boyle Heights, "the toughest and grittiest area of the city," Hecht noted. It was an immigrant district full of Italians, Jews, Mexicans and a dozen other ethnicities, like the slums of the East Coast, or Maxwell Street and the Near West Side in Chicago. ${ }^{74}$ 
During the years when Chicago's circulation wars were honing the deadly skills of young thugs in advance of Prohibition, little Mickey was learning to scrap and hustle as a newsboy on the West Coast. He was three when he first sat on a pile of newspapers and found that he could furtively swap copies of the Los Angeles Record for hot dogs and candy. "I was really looking to make a buck at a very early age," he told Hecht. As a boy he would sleep in the men's room of the Examiner, help city editor Jim Richardson sober up and, in return for the favor, be the first to grab a hot edition, "say the Dempsey-Firpo fight," as it rolled off the presses. "I hung around the Newsboys Club at Spring and Court streets, and during these days became rather adept at whipping other newsboys who challenged my rights to profitable corners," he related. ${ }^{75}$

Never much for school, he loitered in pool halls, ran numbers and bottles of whiskey, hired himself out for protection, and soon got into trouble with the authorities. He was nine when police found a still behind his brothers' drugstore, and after he hit an officer with a hot plate of food, was booked for bootlegging. One incident then followed another: He was nabbed stealing a crate of Abba-Zaba from a candy factory; kicked out of Hebrew school for flicking on and off the lights during an assembly and slapping a kid in the mouth; and caught trying to hold up a downtown movie theater with a baseball bat. "He took to burglary as a duckling takes to water," Hecht observed. "No Jewish morality, nor family decency touched his spirit.. ${ }^{, 76}$

He had done two spells in reform schools and was on probation when local boxing referee Abe Roth, volunteering as his Big Brother, helped channel all that aggression into the ring. At twelve, Cohen began to fight four-rounders across the city several nights a week, showing promise. A year later he won the flyweight title at the 
American Legion Newsboy's Championship. "I won the fight, but my real pleasure was putting money together," he said. "Of course, if there was any way to steal money, I'd steal it, too." His early victories inspired confidence that he could go pro, and so at fifteen with truant officers on his tail, Mickey hoboed out to Cleveland to see his brother Harry, who agreed to act as his manager. ${ }^{77}$

It was through boxing that Cohen first became acquainted with the underworld. A booming industrial hub, the city's proximity to Canada made it an important bootlegging link for the Combination controlled by Lansky, Luciano and Frank Costello. Locally, the powers that be were the Italian mafia of Murray Hill and Mayfield Road that Hecht referred to as "the Hill Mob." Soon to establish themselves were "the Cleveland Four," a quartet of Jewish rumrunners that included Lou Rothkopf, later to be a major player in Las Vegas, and former Detroit Purple Gang member Moe Dalitz. But when Cohen arrived in 1928 it was the Italians who ran the show, unlike in New York, where the groups were wedded in "a happy marriage of convenience" as NYPD investigator Ralph F. Salerno described it. "The Jews supply the moxie. The Italians take care of the muscle. And they split the money between them., ${ }^{, 78}$

Like others of his ilk, Cohen would shrug off the various names given to each gang; to him, they were simply the people. "It is a bashful synonym for the word society or the word government," Hecht explained. "The real gangster offers it almost mystic allegiance. Young Cohen was gangster from his toes up. No glimmerings of other codes disturbed him. He accepted the people, as a stray dog, destined for the dog pound, accepts a hearth studded with meat bones." 79 
His talents in the ring attracted such attention that within a year managers sent him to train at Mahattan's legendary Stillman's Gym on West Fifty Fourth Street, the nexus of the boxing universe and the Combination. Amid the crowds and smoke, the people sat ringside and conducted business. "The place is one of the centralizing institutions of the underworld," observed Alva Johnson in the New Yorker. "Rival lowlife factions meet here casually under a flag of truce, as the rival financial and social mobs fraternize at the opera." Cohen started to get to know Damon Runyon, the boxing reporter and great underworld chronicler who gave Slapsy Maxie his nickname, and met famous fight enthusiasts like Al Jolson. Cohen's managers introduced him around, promoted him, and lined up bouts for "the California Wildcat," the new featherweight with a white Star of David and monogram emblazoned on his blue satin trunks. ${ }^{80}$

As a writer who had so often eulogized fighters—-Jewish ones, in particularHecht must have been eager to learn about his friend's past career. Enthusiasm for the sport had prompted Hecht's brief return to journalism in the late 1920s, when he had covered a half dozen Madison Square Garden bouts for the Daily Telegraph, and written an essay about the Garden crowds for the New Yorker. Ten years later, a lyrical final column for 1001 Afternoons in New York began: "I saw Jack Dempsey knocked out of the ring at Atlantic City and come back to win./I saw Ben Jeby, knocked down three times, climb back on his feet and land a haymaker."${ }^{\prime 81}$

Hecht's rhapsodies about Jewish pugilists became a hallmark of his propaganda. In his letter to the terrorists, he recalled sitting ringside at the Max Schmelling-Max Baer fight with one of Hollywood's "respectable Jews," who had been unable to bear the sight of a German beating a Jew. For the first nine rounds, his companion had kept his head 
down, then cheered himself hoarse in the tenth, when Baer finally knocked Schmelling onto the canvas. Among the many who shared Hecht's enthusiasm, screenwriter Budd Schulberg, author of On the Waterfront, used to talk boxing with Cohen and regularly attended fights at Hollywood Legion Stadium. "I must confess we had a special kvell for the exploits of our Jewish boxers," he remarked. Immigrants of his father's generation like Adolf Zukor had boxed a dollar per round in back alleys in order to survive. American-born boys of his and Hecht's generation saw boxing, like show business, as a path to fame and fortune. A Jewish champion, Schulberg said, was "a repudiation of the stereotype of Jews being afraid to fight back." ${ }^{, 82}$

Cohen, however, was no champion like Barney Ross or Benny Leonard. "I fought with the best of them," he explained to Hecht. "I wasn't the worst. Neither was I the tops." He claimed to have a record of thirty-two main events, a figure he later doubled to seventy-nine, but one credible source suggests he had six wins and two losses when he went up against his first major competitor, Tommy Paul, who was forty-seven and six. The pummeling that Paul delivered shattered Cohen's confidence, and his dreams: "I began to see that I really didn't have it to be great in the ring. "After that, the young fighter lost nine of the next ten matches before quitting the game for good. ${ }^{83}$

Hecht might have considered casting Cohen as a heroic underdog — the Davidwith-a-slingshot type — but the young featherweight had not quite fit that mold either. The classic journeyman fighter of lore is a brawler who makes up in "heart" for what he lacks in skills and conditioning. He can't beat a champion, but he can give as good as he gets long enough to give the crowd its money's worth. But Tommy Paul had knocked Cohen bleeding and senseless two minutes into the first round, spinning him into a two-year 
losing streak. "A man who fought Baby Arizmendi may boast," Hecht ventured. In the end Cohen had indeed fought the Mexican champion, as well as the equally legendary Chalky Wright, but by these final fights he was out of shape and hadn't lasted three rounds. "Nowadays Mickey likes to reminisce about his record as a gladiator," wrote Jennings, who handed out the journalistic equivalent of the bashing Cohen got from Tommy Paul. "Actually he was a second-rater with a glass chin and was knocked out in most his bouts." 84

The stories that Cohen shared with Hecht revealed him to be a different sort of fighter altogether. "I must have been a real crazy punk," he confessed. "It's actually hard for me to believe."

For example, one night I'm fighting a pretty good man named Carpenter, and the fight was on the belly (the bout wasn't fixed). It's a very important fight for me because a lot of the people are at ringside. And I'm eager to make a good impression. So from the first bell I climb all over my opponent and punch the hell out of him. By the third round he's got glass eyes and his arms are hangin'. I belt him and knock him down. He gets up. I knock him down again. I keep knockin' him down five, six times in a row and he keeps getting' up every time. I finally get so upset by his not stayin' down that I jump in and start biting his ear off. So help me, I nearly got it bitten off before the referee can pry us apart. My opponent runs around hollerin' with a glove over his bloody ear. The referee hangs on me. "You got him dead," he says. "What do you want to do-eat him?",85

The ring had awarded Cohen years of sweat and dirt, lousy money, and disfiguring scars under his eyes as well as a broken nose. His true passion anyway had always been for crime, and during his rise and fall as the California Wildcat, he had meanwhile launched a career in armed robbery. With a black bandanna on his face and Tommy gun in his fists - or pistol, shotgun, whatever was handy-he and a crew of Italians "raised" establishments all over Cleveland, three to four times a week. "It made 
me equal to everybody," he said. "Even as small as I was, when I whipped out that big .38 it made me as big as a guy six foot ten." 86

He estimated that he pulled two hundred stickups, which would have made him a major contender even then, when the most notorious crime wave in American history was exploding in the nation's midsection. During 1933 and 1934, Bonnie and Clyde were swapping headlines with John Dillinger, Pretty Boy Floyd, Ma Barker and the BarkerKarpis Gang, Machine Gun Kelly, Baby Face Nelson, and dozens of other brigands. So adroit was Cohen that he never got arrested: Since his crew specialized in gambling joints, cafés and whorehouses, the hill mob caught up with him before the police did. Fortunately the old Italian bosses had developed a respect for the tough little "Jew boy," and soon reached an accommodation with him. He would act as their enforcer and could continue to freelance, as long as he did so out of their territory. ${ }^{87}$

Thus began Cohen's life in crime, though Hecht would quibble with such terminology. "Lawlessnes," he mused, "is the debatable word in Mickey’s early rise."

He broke laws, but they were laws of an alien civilization; a civilization he had avoided from his first waking days. What made him successful, actually, was keeping and enforcing the laws of the only world he knew, the underworld. In this world cut throats were prime ministers and robbers were nobility. Like any Horatio Alger hero, Mickey aspired to a chummy nod from his betters. And Mickey's betters were finely dressed ex-killers now pot-bellied and flashing with diamonds, who bribed high police officials and politicians and put the screws on the town. And who sat "at the round table" where decisions were made on head breakings and "put outs." ... Mickey carried out sentences against such undesirables. ${ }^{88}$

In 1934 Cohen's activities began to draw too much heat, and he was forced to "lam it" to Chicago. The mob stepped in to have an armed robbery charge reduced to embezzlement, and eventually dismissed, after he was fingered in a cafeteria heist 
planned with the proprietor. But a shoot-out during another stickup had resulted in the arrest of one his crew, and now investigators were closing in.

It was shortly after arriving in Chicago that he claimed to have met Capone at his headquarters. "I met him as a kid meets a hero," he told Hecht. "He ribbed me about some of my heists. But there was a piece of work I had done for him he kind of admired." FBI records indicate that the embezzlement charge in Cleveland was in 1934, three years after Capone went to prison, but Cohen clearly spent time in Chicago before then. $\mathrm{He}$ knew Capone's brothers Mattie and Ralph, whom he met through former boxer Machine Gun Jack McGurn. A senior figure in the Chicago Outfit, McGurn was suspected in the St. Valentine's Massacre and was assassinated on its seventh anniversary in $1936 .{ }^{89}$

Despite his respect for Capone, Cohen struck out on his own as he had in Cleveland, again creating friction with the mob. Unable to make do with a poker concession he had been allotted, he opened a "bust-out" in the Loop offering craps, a fast-money, highly volatile game that police and the outfit had agreed to keep out of the downtown business district. "Greasy Thumb" Jack Guzik, treasurer for the syndicate, flew in from Miami and called Cohen to a round table. Guzik ordered the game terminated, but Cohen ignored the decree. On a wintry night one week later, Cohen was standing on the sidewalk outside his joint when a burst of machine-gun fire sprayed from a passing car. He hit the deck on the slush-covered pavement, ruining his fine clothes, but even this stern warning failed to deter him. ${ }^{90}$

It was nevertheless becoming clear that that the hot-headed young punk had outstayed his welcome in Chicago. During a beef in a drug store soon thereafter, he cracked a particularly truculent bruiser in the skull with a sugar dispenser and then the 
butt of the man's own pistol "till his head popped open like a melon and he bled like a hydrant." There again was that terrible temper. "It's a funny thing — while I'm talking about all those things I can hardly believe they happened to me," he told Hecht more than twenty years later. "It's like they happened to somebody else - a close friend or something. No, I don't feel any remorse or anything like that about those things, because, as I said, they weren't things I did. I mean, me who's sittin' here talkin'."91

As before, his connections in the underworld - this time a Capone fixer-sorted the matter out with the police and courts. Cohen was then summoned to Cleveland, where Lou Rothkopf had a directive to pass along on behalf of the Italians, Lanksy — the whole Combination. They wanted him to join Siegel in Los Angeles and "like stand in for their end of the action. ${ }^{, 92}$

This was essentially a job opportunity offered by fellow Jews to a promising young boychick, though Cohen understood the Arnold Rothstein principle that mobsters, like rats, should be left free to scavenge for themselves. He recognized that Jews needed to stick together; the Italians had their power and organization, and "being Jews, Benny and me and even Meyer couldn't be a real part and parcel of that." However, he hadn't been told to put himself fully under Siegel's wing, and when he arrived home in L.A. in 1937, phoning up the senior mobster felt too much like reporting for work. ${ }^{93}$

"Actually we never even gave a fuck about Benny," he recalled. "We were just rooting, just taking off scores." He decided that Siegel could make the first overture, and raiding bookie joints and brothels by the dozen did eventually catch Siegel's attention. When he hit major bookmaker Morrie Orloff, he snatched $\$ 23,000$ that belonged to the reigning Sicilian in Los Angeles, Jack Dragna. After that, Siegel had the delicacy to send 
Champ Segal, a well-respected boxing manager who had known Mickey as a boy, to bring him in. ${ }^{94}$

At some point in the mid 1930s, Siegel had slipped into town unnoticed, having come West to establish the same kind of dominion he had built during the heyday of Prohibition back East. His grand scheme was to seize control of all the horse and dog tracks from Southern California down to Mexico, and take a cut of all gambling clubs, bookmaking operations and brothels. But initially he faced the resistance of the downtown syndicate, and while he built alliances and laid his plans, maintained a low profile - or, at least, as low a profile as someone like him could manage. Locally he was known as just "a wealthy sportsman," another flashy playboy hobnobbing with the rich and famous, until an unforeseen chain of events fortuitously wiped the field of the competition. $^{95}$

Depression-era Los Angeles was a testament to Hecht's cynicism about government and the law: a city controlled by a criminal cabal of elected officials, bosses and police. "You know, in Chicago the gangsters paid off the police but the gangsters did the job," said one prominent defense attorney. "In Los Angeles, the police were the gangsters." When a reform-minded cafeteria owner and a former cop teamed up to expose the high-level corruption, the chief of the LAPD intelligence squad tried to silence them — with bombs. But both of his attempts were badly botched, leaving a trail of evidence that implicated Police Chief James (“Two-Gun”) Davis and Mayor Frank Shaw. By the fall of 1938, LAPD Captain Earl Kynette had been convicted of attempted murder, Chief Davis had resigned, and Shaw was removed from office in an unprecedented recall 
election. The scandal, which swept the LAPD clean of its top ranks, foreshadowed another one ten years later that would be engineered by Cohen. ${ }^{96}$

Summoned to meet with Siegel, Mickey had jammed a huge $\$ 50$ Stetson hat onto his head, and "looking like a giant mushroom in motion," noted Jennings, trotted into the sweat room of the Hollywood YMCA. Siegel came out naked wrapped in a towel with a big smile on his face. "For Christ sake, Mickey thought, he's almost pretty. The eyes were baby blue beneath long dark lashes, the dark hair showed finger waves, and the mouth and chin were almost feminine." In the version recounted to Hecht, Siegel said, "You were supposed to contact me when you got here." Cohen shrugged it off: "I hadn't gotten around to it yet." Siegel noted the big score he had just made at Morrie Orloff's, and asked him to kick back the money he had taken from Dragna’s man. ${ }^{97}$

"I don't know what you're talking about," I says. He looks at me confused for a minute. Them Eastern guys are used to giving an order only once. Then he smiles. "You're a good boy," he says, "but you're a little crazy. I want you to kick back that money."

"I wouldn't kick back no money for my mother," I says. He looks at me cold and says, "You heard what I said." I says, "Go take a fuck for yourself." And walk out of that steam room before I start meltin'. 98

Cohen survived, and was even persuaded to return the money, after Siegel gently urged him to at least give back a stickpin he had taken, (“it was his family whoreloom.”) Thus began a decade long partnership and mentorship. Cohen served as strongman in the conquest of Los Angeles, and in return, Siegel made a mensch out of him. "I found Benny a person with brilliant intelligence — he would look right through you," Cohen told Hecht. "He commanded 1,000 percent respect and got it. Also he was tough. He came out the hard way—muscle work, heists, killings. 'You little son-of-a-bitch,' he said to me. 'You reflect my younger days.',"99 
Siegel more than just acted like guys Hecht made up. He was a ready-made American myth, a combination psychopath and starry-eyed dreamer possessed of that same "terrible innocence" as Tony Camonte. In the days of Prohibition, he would break someone's bones for $\$ 2$, or kill them for less than $\$ 50$. Running truckloads of bootleg liquor, Bugsy never hesitated when danger threatened, recalled Joseph "Doc" Stacher. "While we tried to figure out what the best move was, Bugsy was already shooting," Stacher said. "When it came to action there was no one better. I've seen him charge ten men single-handed and they would all turn and run. I never knew a man who had more guts." The newspapers had taken to calling Bugsy, a variation of "bugs" that was slang for crazy, a nickname Benjamin Siegel couldn't stand. "His rages were so pure and incandescent, so very much the essence of Benny, that people who knew him did not take offense at them," observed Lansky biographer Robert Lacey. ${ }^{100}$

But the man the FBI credited with thirty murders sealed his own doom when he sank some \$6 million of mob money into the Flamingo Hotel, a fabulous oasis on a lonely stretch of Clark County, Nevada that would one day be the Las Vegas strip. It had shimmered in the desert, beckoning the real-life Siegel just as the neon billboard flashing “THE WORLD IS YOURS” had beckoned Hecht's fictional Camonte. Others had come before him, but Siegel could rightly claim credit for dreaming Las Vegas into existence. By then, however, he was laid out in his $\$ 5,000$ bronze coffin lined with silk. ${ }^{101}$

Siegel paid his I handsomely to seize control over Los Angeles, which in a period of seven years, Cohen did. First to go was the gambling empire of Eddie Nealis. "Siegel was fixed on bringing Nealis to knees," Cohen told Hecht. "That Mexican son of a bitch thinks he's comin' in with me," said Siegel. "Keep on him." Cohen heisted Nealis' posh 
Clover Club — resulting in an embarrassing encounter with Betty Grable—wrecked five of his gambling joints, shot his tough Irish enforcer Jimmy Fox, and barked down his gun bulls with the Sheriff's Department. Finally Cohen chased Nealis himself out of town. ${ }^{102}$

But the key to money and power, as Siegel well knew, was the racing wire, the service essential to bookies because it provided the nationwide racing results, as well as crucial information on track conditions, jockeys and trainers. Since 1927 it had been the monopoly of the Nationwide News Service owned by Moses Annenberg, the very same man who, along with his brother Max, had headed the circulation department for Hearst during Chicago's newspaper wars. Also the owner of the Philadelphia Inquirer, the Miami Tribune and the Daily Racing Form, Annenberg employed the same brutal methods he had used in the early days to knock out nineteen competing wire services. "It was Annenberg's ruthless world that gave birth to Mickey Cohen," asserted Cohen biographer Tere Tereba. When Annenberg pleaded guilty to income tax evasion in 1939, control of the racing wire went to James Ragen, another veteran of the circulation wars, who renamed it Continental Press.

Siegel partnered with the Chicago Outfit to set up the competing Phoenix-based Trans-America Service. Since the 1,800 L.A. bookmakers had remained with Continental, he assigned Cohen to wrest control of them just as he had once fought for profitable corners as a newsboy. ${ }^{103}$ After Continental's West Coast representative Russell Brophy turned down a deal, Cohen and associate Joe Sica paid a visit to the competition's downtown headquarters. Marching past the receptionist, they tore out thirty phone lines, wrecked the office and beat Brophy into semi-consciousness. When Cohen was asked about the incident years later at the Kefauver Committee hearings, he denied that there 
had been any assault; it had just been an argument. A senator noted that Sica had been fined $\$ 200$ for hitting Brophy, while Cohen had been fined \$100. “Then I must have hit him less," he said. ${ }^{104}$

He had retreated to Phoenix for six months while Siegel fixed the charges, and upon return, managed bring five hundred bookmakers on board with Trans-America. $\mathrm{He}$ later said that he was learning to use diplomacy rather than fists to meet his ends, but Jennings noted: "There is no existing record that shows how many cracked skulls or how many unsolved murders were a direct result of Siegel's western war on Continental Press." Ragen survived a shotgun blast in June 1946, but succumbed at the hospital two months later from what was believed to be mercury poisoning. ${ }^{105}$

While waging the wire war during his work hours, Cohen meanwhile sought to settle down to a life of domestic tranquility. In October 1940 he married LaVonne Norma Weaver, a beautiful, auburn-haired, twenty-three-year-old shiksa whom he described as a dance instructor. Though seemingly as demure as a debutante, she actually had a record of her own for burglary and solicitation. They were married late at night in a chapel on Western Avenue, but the wedding almost didn't happen, because the minister tried to bar the couple's bulldog from attending, and Cohen refused to go through with the ceremony unless Tuffy could be present as a witness.

Like so many other young couples flocking to the suburbs during the postwar years, in 1947 the Cohens moved into their ranch-style home in the sleepy glen of Brentwood. Despite its modest outward appearance, Cohen had lavished tens of thousands on interior decoration and special modifications to accommodate his unique compulsions. A water-heating-system large enough for a hotel allowed him to shower 
several times a day. His cedar-paneled walk-in closet contained hundreds of tailor-made, perfectly pressed monogrammed suits, well over sixty handmade shoes, sixteen hundred pairs of socks and a breathtaking array of lotions, accessories and other clothing items. ${ }^{106}$

Hecht nevertheless understood Mickey as a primordial, primitive figure, a type that had remained unchanged throughout the eons, utterly uncorrupted by society. Paleontologists, he wrote, had read the tale of armed robbery and murder "in the fractured fossil skulls of a million years ago. Heisters who had just learned to walk upright entered the caves of Spain and 'raised' missing links cooking dragon meat in the hills of Java. Hunting, sex and robbery were the three original occupations of homo sapiens when his jaw still held the monkey outline. I have felt, listening to Mickey, that he was obviously a throwback." ${ }^{107}$

Because criminals were "a part of man's soul, not his institutions," they remained immune to the high-flown political "jabberwock" of the McCarthy era that seemed to be hurtling mankind towards apocalypse. "In all my talks with Mickey Cohen, the word innocence has always haunted me," Hecht mused in his handwritten notes. "No matter how many killings, heists and other acts of violence and lawlessness Mickey related to me as part of his career, I came away from each confab with a curious feeling that there was something innocent about the man." Given the nature of the times, Hecht often confessed a certain admiration. "How harmless these crooks seem alongside today's honorables who are staunchly determined to blow up our planet so that the ideals of freedom shall not perish," he wrote in Gaily Gaily. "Let us hope that the surviving insects will be smart enough to admire our recorded aspirations. This way, ants and glowworms, crawl up for a look at the highfalutin' print left behind by humanity."108 
It may seem unfair and unfounded to suggest that Hecht likened his Cro-Magnon gangster to the ancient Maccabee or follower of Bar Kochba, and by proxy, to the "new Jew" of Israel, or that he admired the latter for similar reasons. Certainly Hecht never drew a direct a connection, but the parallels were obvious, as critics of his propaganda would have acknowledged. "Probably Hecht thought he was echoing the brutal warriors and prophets of the early days of our people," Meyer Levin surmised at the end of the 1940s. "But the return to our homeland is not intended to be an atavism. It is not a return to the sometimes primitive morality of our forefathers, whose bloodthirsty battle-cries belonged to the state of society in their time." Hecht was happy to point to the criminality of the so-called lawmakers, but he never actually tried to draw distinctions between the Irgun and the actual "gangsters" they were accused of being. Apparently, he never deemed it necessary to justify himself or his cause, but his silence also reflects the fact that his romanticist worldview was less a conscious, clearly formulated philosophy than a part of who he was, an intuitive way of thinking. A creature of a certain milieu and era, he hadn't consulted a textbook to discover that Romanticism was defined as "the rejection of civilized corruption, and a desire to return to natural primitivism and escape the spiritual destruction of urban life." 109

Siegel was, in Cohen's own words, "trying to put some class in me, and trying to evolve me." Just as Hecht's Camonte had tried to train one thug as an administrative assistant and brought his fellow hoods to the theater, both Siegel and Cohen had scrambled to catch up with twentieth century civilization. They were hardly alone at this in Hollywood - the land of self-transformation, despite what Fitzgerald claimed about second acts in American life. "The studios maintained in-house finishing schools to teach 
contract actors grammar, elocution, the social graces, and novel skills, like fencing," noted Tereba. "The publicity departments fabricated new names and birth dates, as well as 'proper,' even 'aristocratic,' backgrounds for the human assets. From waitress to Wellesley girl, from grease monkey to gent, the film city was a phony world replete with glittering surfaces. As the gag went, the men who owned the film factories had gone directly from Poland to polo, and early on, were caught up in self-improvement frenzies. With private tutors, they smoothed out their accents, and learned to handle cutlery and speak a smattering of French.” 110

Cohen hired Los Angeles Mirror columnist Florabel Muir's husband Denny Morrison as a tutor to expand his vocabulary by teaching him a handful of "hundreddollar words" each. He collected a library of more than one thousand volumes, all selected by his interior decorator. When he agreed to lend Muir a copy of War and Peace only for a short while, she asked if he was actually planning to read it. "Not in a thousand years," he said. "I got a war and peace of my own to worry about. Why should I worry about Tolstoy's? I want it back 'cause it leaves a hole on the shelf when it's gone. It mathes the color of them other books."

He was taking after Siegel, who upon arrival in Los Angeles had enrolled his daughters in an elite girls' school, and signed them up for riding lessons at the upscale Dubrock Riding Academy. He smoked cigars, took the occasional snifter of brandy, and became a member of the exclusive Hillcrest Country Club. With the help Countess di Frasso and actor George Raft, who had starred opposite Muni in Scarface and in many other gangster pictures, Siegel had cultivated contacts among Hollywood's aristocrats and celebrities. But he had long found L.A., with its patchwork of jurisdictions, a 
frustrating place to operate, and after a degrading, petty arrest on a charge of bookmaking in May 1944, decided he was fed up. ${ }^{112}$

Following the mob's playbook of using its wartime largesse from a booming black market to expand into legitimate enterprises, Siegel looked to the wide-open territory of Las Vegas, where he soon became embroiled in entanglements that snowballed out of control. By 1946 he had led Lansky and other partners into investing in the brainchild of Hollywood Reporter founder Billy Wilkerson, the Flamingo Casino Resort. The entrepreneur had sought to duplicate the glamour and sophistication of his three nightclubs that had given rise to the Sunset Strip, but his vision had outstripped his resources. Now a majority partner, Siegel took charge of the construction and set a Christmas 1946 deadline, but his own grandiose vision of a luxury resort knew no limits. He demanded original designs, rare woods and the finest marble - the plumbing alone cost \$1 million — and fabulously expensive fixes to problems with the original layout and construction. To make matters worse, after he called FBI Direct J. Edgar Hoover a cocksucker the federal government shut down construction for weeks while it launched investigations into fraud, narcotics distribution, draft dodging and tax evasion. ${ }^{113}$

Siegel's dream became a nightmare as costs soared to $\$ 3$ million. Pushed to stick with the December deadline, his grand opening was an epic fiasco. None of the hotel rooms were finished; storms in L.A. grounded planes; the fountain didn't work; the lights went dark; and crooked croupiers and local gamblers took the casino's bank for tens of thousands. While Lansky and Frank Costello provided the money to finish the hotel, a panicked Siegel flew into his infamous rages. Rumors circulated that Virginia Hill, his 
equally volatile and violent new girlfriend, was siphoning the money into a Swiss bank account. $^{114}$

When Siegel demanded \$2 million from the Chicago Outfit to fold Trans-America now that Ragen's death had made it unnecessary, it was the final straw. The consensus among historians is that Luck Luciano ordered Siegel's death, with Lansky's at least tacit approval. Most believe that Mickey Cohen, who had the most to gain, was also on board. "To be honest with you, his getting knocked in was not a bad break for me," Cohen later confessed. On the early morning of June 21,1947 , a gunman rested a .30-caliber army carbine into a notch of the garden latticework outside Virginia Hill's Beverly Hills mansion. Siegel was sitting on the living room couch. As if in final insult, the first shot blew out one of those famous baby-blue eyes, sending his right eyeball crashing into the tile floor of the dining room fifteen feet away. The second shot smashed in his left eye, shattering his nose and slicing through a vertebrae in the back of his neck. Another seven shots went wild. Florabel Muir's column described the pervading perfume of nightblooming jasmine that hung in the air when she came upon the bloody scene. The Herald-Express's front page photo showed Siegel's body on a slab at the morgue, his big toe sticking out from a sheet, a tag dangling from it that misspelled his name. ${ }^{115}$

While Siegel had been spiraling to his death, Cohen took care of the remaining few who openly challenged his reign. After Hooky Rothman unceremoniously booted Joe Shaman out of the La Brea Club casino, Shaman's six-foot, 250-pound brother Max came to settle the score. Having enjoyed a reputation as a tough guy back in the old Boyle Heights neighborhood, Max burst into Cohen's bookmaking headquarters, a dilapidated "paint store" on Beverly Boulevard. Cohen "banged him out," as he later recalled, and 
though police suspected the gun found on Shaman was a plant, they lacked the evidence to prosecute. ${ }^{116}$

Next to go, in 1946, were Bennie “the Meatball” Gamson and George Levinson, two Chicago hoods who had teamed up with local gambler Paulie Gibbons to knock the gangster off his perch. Following the fatal shooting of Gibbons at his Beverly Hills apartment, a drunken bum showed up at the funeral with a box and card that read "To my pal." The mortician gingerly lifted the lid, revealing a pile of horse manure. Five months later, Levinson and the round-faced Meatball were riddled with bullets at their hotelroom hideout. Cohen meanwhile dispatched with long-time nemesis Jimmy Utley, who had recently "put on a heat campaign," using his police connections. Dressed casually in Hawaiian shirts, Cohen and an accomplice had entered Lucey’s Restaurant, the fashionable lunch spot that Utley owned, pistol-whipped him in front of dozens of studio executives, directors and stars, tipped their hats to the crowd and waltzed out, traipsing a trail of blood behind them. ${ }^{117}$

By the time Cohen and Hecht were becoming friends in the summer of 1947, Siegel was in his grave and Los Angeles had a new king of the underworld. But Cohen found that his only reward was to become the biggest target of other mobsters and the police. Hecht recalled all-night rides with the moody crime lord and his bodyguard, Neddie Herbert, along the Pacific Coast. "These were hard times for Mickey, and there was practically no diversion open to him," Hecht wrote. “... They tossed bombs into his Westwood home, killed several of his cronies, including his invaluable barrister, and eventually blew 'Neddie' Herbert's headfull of jokes off and sent most of Mickey's entourage into their caskets."118 
"They" turned out to be Jack Dragna, who was secretly using "Happy" Harold Meltzer and Jimmy Fratianno to infiltrate Cohen's gang. Two and a half months after the Slapsy Maxie's dinner, “the Weasel” set up a hit at Michael's Haberdashery, signaling Dragna's gunmen as he left the store. But Fratianno had made the mistake of forgetting Cohen's obsession with germs and shook his hand upon departure, which put the lucky mob boss in the bathroom minutes later, when shotgun blasts claimed Hooky Rothman. "It sounded like a war broke out," Cohen told the press, which inspired them to dub these incidents "the Sunset Strip Wars."119

Herbert fell in the sixth assassination attempt on July 20, 1949, when Cohen and a phalanx of policemen and mobsters came under a barrage of fire as it exited Sherry's nightclub at 4 a.m. Bullets also struck a young woman and Special Agent Harry Cooper, assigned as police protection by California's attorney general. Florabel Muir was caught by a ricochet bullet in the fanny. Wounded in the shoulder and barking commands, Cohen dragged the massive Special Agent Cooper into the back of a sedan that sped from the scene. After Herbert's funeral, Rabbi Baruch Rabinowitz told the newspapers, "I considered him a good boy," and recalled that he had been eager to help the underground in Palestine. ${ }^{120}$

Dragna's war came to a spectacular conclusion on February 9, 1950, when twenty-eight sticks of dynamite detonated under Cohen's home, blowing out windows throughout the neighborhood and sending shockwaves felt at a police station three miles away. Miraculously, Mickey, LaVonne and even Tuffy escaped unscathed, because the bomb had been tossed into a crawl space directly beneath Cohen's gargantuan cementencased vault. The safe deflected the force of the explosion, which tore off the front of 
the house and blasted a crater twenty feet wide, six-feet deep. Police and the press arrived to find Cohen staring in disbelief at his destroyed wardrobe. ${ }^{121}$

Angered by all the attention, the East-Coast bosses pressured Dragna to cease and desist, but Cohen's extraordinary luck had nevertheless run out. On June 20, 1951, he was convicted of three counts of income tax evasion and one count of making a false statement to the Internal Revenue Service. While he sat in county jail awaiting his sentence, reporters had asked what he thought about comparisons people were now making to Al Capone. "That's the silliest thing in the world," he scoffed. "Me and Capone? Bfff!” Three weeks after his conviction, Judge Ben Harrison sentenced him to five years imprisonment and charged him with nearly $\$ 300,000$ in fines, court costs and unpaid debts to the government. ${ }^{122}$

"I am full of hair-raising information told me by an ex-underworld kingpin named Mickey Cohen," Hecht would begin his tale years later. "How he shot, slugged, gouged and swindled his way from rags to riches. How he preyed on society as a stick-up man and crooked gambler, how he corrupted its guardians and strutted for a time in the nation's headlines. In addition to facts, I have a knowledge of this disorderly man that may be a deep one. I know him as well as I know Macbeth or the blonde Borgia." ${ }^{2123}$

Cohen's story would present Hecht with one last gangster epic for his final years. Hecht also could, and did, plumb the depths of his memories for tales of the underworld, but here was a fresh story packed with all manner of myths and themes in which he was so well versed, which could uniquely combine ideas that had percolated over a lifetime. The question remained: What would he make of it all? And there was one other unique element to the project: Mickey Cohen was a man Hecht counted as a friend. 


\section{THE OLD NEW JOURNALIST}

Memory is the worst of playwrights. Its ghosts have no time sense. They intermingle, overlap, pop up in the wrong places at the wrong time. And they even tell lies. But I welcome their mendacity and disorder without criticism. It is not easy to remember oneself.

$$
\text { Ben Hecht, Gaily Gaily }{ }^{124}
$$

Hecht could empathize with his many old friends and colleagues in Hollywood who found themselves out of work when blacklisting became policy, though he did not suffer so cruel a fate. "The cold war blew like an icy wind across the country to the Pacific Coast," remarked screenwriter John Howard Lawson, one of the so-called Hollywood Ten who were fired for refusing to testify before the House Committee of UnAmerican Activities. Hecht was no communist, but after the British announced their boycott of his films, he returned West for "a chill Christmas week - there were no jobs or parties for me. The movie moguls, most of them Jews for whose pockets I had netted over a hundred million dollars in profits with my scenarios, were even nervous of answering my hellos, let alone hiring me.” His circumstances were, nevertheless, not nearly as dire as for those listed as subversives in the infamous Red Channels pamphlet. The fact that at one point he used the name of his chauffeur, Lester Barstow, as a pseudonym after the studios agreed to hire him for half his usual fee, suggests that he was struggling to maintain a comfortable lifestyle with Rose and their daughter Jenny-a large household staff, homes in Nyack and Oceanside, and an apartment in Manhattan. ${ }^{125}$ Whether or not the British boycott encouraged Hecht to return to prose late in life, this final phase was the like the third act to one of his better scripts: In hindsight it would seem inevitable. He spent five years writing his massive autobiography $A$ Child of the 
Century, completing the 950-page manuscript in July 1953. In the meantime, he continued to earn a paycheck churning out screen work at his usual pace, and expanded into the new medium of television. In the fall of 1958, he hosted a weeknight television talk show on Manhattan's WABC-TV, inheriting Mike Wallace's production staff after the future 60 Minutes star interviewed Mickey Cohen and the LAPD sued the network for libel. Though The Mike Wallace Interview departed from prime time, Hecht kept the pot boiling on local television. In addition to his caustic and colorful "Bedtime Stories" delivered each night, he jousted over the merits of Hollywood with native son Budd Schulberg; swapped murder and gangster stories with crime photographer Weegee; sifted through the political dirt with columnist Drew Pearson; compared notes on writing, rebellion and bohemianism with Jack Kerouac; and, in what proved to be a final straw for the station management, questioned Salvador Dali about a newly invented form of sex. ${ }^{126}$

Yet in the conclusion to Child, Hecht wrote that he inhabited a world full of ghosts. His parents were long dead, as were the indomitable Tante Chasha and his old newspaper buddies, Sherman Duffy and Wallace Smith. Herman Mankiewicz had just passed away and Max Bodenheim would soon be murdered in the Bowery. Even some who were still alive, like his first daughter Teddy now residing in Brazil and the alcoholic Charles MacArthur, seemed more like wispy spirits than fellow living souls. Keenly aware of his own mortality, Hecht's thoughts were now more focused than ever on his literary legacy. ${ }^{127}$

One of his last great films was Where the Sidewalk Ends (1950), director Otto Preminger's expressionistic noir thriller about a cop who becomes a killer. Haunted by his late father's criminality, Mark Dixon is a hard-bitten, brutal detective so obsessively 
driven to pin a murder on his dad's former crony, Tommy Scalise, that he goes too far interrogating a suspect. In trying to cover up the man's death by framing Scalise, Dixon spirals deeper into his own abyss. Mixing up cops and criminals, Hecht was once again in his element, a setting critic Boris Trbic describes as "a doleful metropolis of crime and violence; a city with no limits, no values and absolutely no rules, inhabited by a series of disillusioned and insecure loners who are casualties of urban decline and decay."128

He script-doctored other films that became classics, such as Preminger's Angel Face and The Man with the Golden Arm, and Hitchcock's Strangers on a Train. He also authored a few gems, such as Miracle in the Rain, an adaptation of his 1943 novella that has endured as a popular wartime romance. The posthumously produced Seven Faces of Dr. Lao is an astonishing, charmingly childlike comedy about an ancient Chinese fakir who brings a magical circus to a dusty town out West. Dr. Lao's troupe of chimerical creatures - an abominable snowman, Merlin the magician, Medusa, and climactically, a Godzilla-like sea serpent — appear differently to each visitor of the circus tent, and help set things right in a struggle between a crusading reporter and a corrupt local boss. While these two films could not appear more dissimilar on the surface, they both center around Hecht's signature character, a puckish young newspaperman, and offer a retort to his cynicism that suggests a hidden continuity to his work. One hears, in Hecht's distinctive dialogue, a man carrying on a debate with himself.

As for the rest of his Hollywood output, such as Trapeze, another circus film, or Dino de Laurentiis' Ulysses, a few were solid pieces of entertainment never meant to stand the test of time, but the principal characteristic they shared in common was mediocrity. "He didn't take the whole thing seriously," said Hugh Gray, one of his co- 
writers from those years. “...He was obviously good in the old tough style, the old Chicago newspaperman. He had a marvelous storytelling ability and was incredibly bright. I felt what he made of himself was a hack, a hack of genius." ${ }^{129}$

For a man newly motivated to treat screenwriting as a means to a monetary end, the emphasis was on hack. Some movies were simply rehashes or adaptations of old work, like Living It Up, a Dean Martin-Jerry Lewis vehicle that combined Nothing Sacred and Hazel Flagg, the Broadway musical based on the same material. The Fiend Who Walked the West was a Western-horror remake of Kiss of Death that starred Robert Evans as "the kooky killer," trying his best to match Richard Widmark's famous performance as the psychotic Tommy Udo. Some films fell flat, like Monkey Business, an attempted return to the screwball comedy, and Actors and Sin, Hecht's third and final effort at directing after Astoria, which combined two short films adapted from satires of the film industry, Actor's Blood and Concerning a Woman of Sin. Others movies held promise, but either Hecht failed to come through with a great script, as was the case with his collaboration with Howard Hawks and Charles Lederer on The Thing (from Outer Space), or the studio botched it up, which is what happened when a producer tossed out Hecht's story for Love Happy, a vehicle for his good friend Harpo that was the final Marx Brothers movie and one of the first speaking roles for Marilyn Monroe. ${ }^{130}$

The most tragic casualty of Hollywood sausage-making was Hecht's James Bond movie Casino Royale, a project that had reawakened his old passion and, with the near completion of a final, polished version just two days before his death, may have been one of the finest scripts he ever produced. The successive drafts of Hecht's screenplay now collecting dust in his archive "are a master-class in thriller writing, from the man who 
arguably perfected the form with Notorious," opined British spy novelist Jeremy Duns. "Hecht made vice central to the plot, with (the villain) Le Chiffre actively controlling a network of brothels and beautiful women who he is using to blackmail powerful people around the world. Just as the theme of Fleming's Goldfinger is avarice and power, the theme of Hecht's Casino Royale is sex and sin. It's an idea that seems obvious in hindsight, and Hecht used it both to raise the stakes of Fleming's plot and to deepen the story's emotional resonance."131

By 1964 the first two Bond films, Dr. No and From Russia With Love, had already been produced, though certain trademarks_-"Vodka Martini, shaken not stirred," and "Bond. James Bond."-were not yet in the mix. Hecht sketched characters wellsuited to the mold of the emerging franchise, such as a ravishing Eurasian drug-addicted madam named Lili Wing and her lesbian girlfriend Georgie, who keeps a black pussycat perched on her shoulder. The sinister wife of the colonel, Madam Chiffre, has a face torn apart by bullet wounds and rasps "metallically through a tube inserted in her ripped out larynx." She may be a classic Bond villain but the spectacle of corruption envisioned in the pre-title sequence is classic Hecht: CIA buddy Felix Lieter seizing senior United Nations diplomats lured into honey traps by gorgeous call girls. "Many of the scenes are darkly comic, and some of the sexual antics are politically incorrect even for the Sixties," Duns observed, "with references to politicians being attracted to children and a car chase through Hamburg's red light district ending with Bond drenched in mud disguised as a lesbian wrestler."132

Of the five drafts stored among Hecht's papers, the earliest from 1957 hews closely to the novel with one significant exception: the hero is not Bond but Lucky 
Fortunato, "a rich, wisecracking American gangster who is an expert poker player." Perhaps because the draft is otherwise so faithful to the book, or because an article in Time mentions Hecht "had three bashes" at it, Duns surmised that Hecht was not the author of the Fortunato version, that the draft was sent to him as a starting point by producer Charles Feldman. But Duns was not considering the script within the broader context of Hecht's published and unpublished material; if he had, he would have factored in Hecht's preoccupation with the gangster, a character who was arguably as much a signature of his work as his Huck-Finn-like reporter. ${ }^{133}$

Hecht enjoyed all criminals and, while the gangster was a favorite, he devoted attention to various types - wild outlaws like Teddy Webb and Tommy O'Connor; pretty murderesses like Roxie Hart (based on the real-life Beulah Annan); and cunning psychopaths like Henry Spencer. Starting with Guide for the Bedevilled, Hecht spun tales from his crime reporting days in A Child of the Century, Charlie and Gaily Gaily. He regularly published shorter pieces of memoir and fiction with titles like "Rehearsal for Murder," and “A Jackpot of Corpses" in Ellery Queen's Mystery Magazine and Playboy. Right up until his final days, he reworked drafts of a Runyonesque musical about the bootlegging wars between the Irish and Italians, with his old friend Deannie O'Banion as hero and Capone as villain, to which he gave several possible titles: Chicago, Chicago Days, Chicago Nights, Underworld and Angel in the Underworld. ${ }^{134}$

In January 1964 Hecht wrote Feldman to update him on "our blissful Casino Royale," adding that he "never had more fun writing a movie." His exuberance is particularly striking in contrast to the discontent he had expressed for years about writing for Hollywood, a measure of how little enthusiasm he'd had for work that otherwise only 
fed his insecurities. At some point in the 1950s, Hecht complained that he was now writing scripts for television, "the most completely infantile type of entertainment invented since the creation of the rattle." But there was nothing to be done. "I have never quite mastered the trick in books or theater of being both admired and 'bought,"' he wrote his sister-in-law. “...I was never meant to divert people and the fact that I have for thirty or forty years been tenaciously trying to do so is proof of my soft character and too vague ambition. I was never the gardener of my estate but always the handyman pushing wheelbarrows hither and yon."

Tellingly, Casino Royale would suffer a cruel fate after he died: The project fell apart in negotiations with Albert Broccoli and Harry Saltzman, the producers who owned the rest of the Ian Fleming properties, when Feldman demanded a bigger cut than they were willing to accept. The James Bond spoof that Feldman eventually brought to the screen in 1967 was an abysmal, incoherent mess. As for what could have been, Duns' verdict is that "all the pages in Hecht's papers are gripping, but the material from April 1964 is phenomenal. ... It has all the excitement and glamour you would expect from a Bond film but is more suspenseful, and the violence is brutal rather than cartoonish. ... Casino Royale might even have been regarded as not just a classic Bond film, but as a classic thriller." Hecht, however, had long understood that he could not control what became of such work - that was the nature of the Hollywood beast. And with movies, who really remembers the writer anyway? ${ }^{136}$

Clearly Child of the Century was a determined effort to leave something substantial behind. Taking his title from Alfred de Musset's La Confession d'un enfant du siècle, he drew on his experiences to write "inside history," offering an extraordinary 
window into his era. Biographer Doug Fetherling noted: "Hecht was truly, as he said, a child of the century: a member of that generation born close to 1900 and the first to come of age with the big-time gangster, the automobile, the world war, the skyscraper and the interior monologue. ... In its depiction of one person's progress across the landscape of his time, it falls within the tradition of the best American autobiography that stretches from Benjamin Franklin through Henry Adams to Emma Goldman."137 Like his historical pageants, it featured a giant cast of characters rendered in short, deft anecdotes, from Louis Brandeis to Groucho Marx, both Roosevelts and dozens of the great writers, artists and celebrities of his day. A final 115- page section that describes his partnership with the Bergson Group and Irgun also made the book a powerful follow-through to his propaganda work. Historians ever since have found it difficult to write against the grain of Hecht's compelling narrative, to the great consternation of his political foes.

As for the book's critical reception, Hecht could hardly count on support from the great arbiters of literary taste of the day, the "New York Intellectuals," particularly since he had launched a preemptive strike against them. In recalling New York City's wild, fin de siècle party during the 1920 s, he contrasted the old smart set with the current clique. Today's elite New Yorker "is as tame as a white mouse, and as given to running in circles. He is not a New Yorker unless you wish to insult him. He is a Citizen of the World with a grown-up soul. ...With his second helping of ghoulash, my New Yorker takes up the problem of India. His small talk seldom embraces less than a continent.” When the writers he was referring to, such as Irving Howe and Leslie Fiedler, thereafter acknowledged Hecht at all, it was with scorn, mostly as an example of the self-hating Jew that he had represented as author of A Jew in Love. ${ }^{138}$ 
Nevertheless, Partisan Review darling Saul Bellow proclaimed the book's importance in the New York Times. "Among the pussycats who write of social issues today," Bellow wrote, "he roars like an old-fashioned lion.” Though Bellow hadn't picked up a copy of Hecht's early novels or the Broken Necks collection in twenty years, he still remembered the stories, the characters and even some of the odd phrases, "the scribble of rooftops across the sky," "the greedy little half-dead." As a fellow Chicagoan and recent recipient of the National Book Award for The Adventures of Auggie March, Bellow graciously acknowledged the debt he owed Hecht and the other writers of the Renaissance: "What was marvelous was that people should have conceived of dignifying what we saw about us by writing of it, and that the gloom of Halstead Street, the dismal sights of the Back of the Yards and the speech of immigrants should be the materials of art." Four years later, Jack Kerouac would similarly tip his hat to Hecht as a guest on The Ben Hecht Show. Unlike the friendly reception that Kerouac received from his host on the program, most others who interviewed him about On the Road had been hostile. ${ }^{139}$

A Child of the Century opened the floodgates in Hecht, unleashing a current that would flow into his later books, and the influence it would have on his Mickey Cohen biography is particularly significant within the context of the day. Arguably, there were two major trends emerging in postwar literature that would move in opposite directions. One, sparked in backlash to the 1930s social realism of writers like John Dos Passos and James T. Farrell, eschewed a broader social and political landscape to focus on inner lives. In the brooding and paranoid atmosphere of the McCarthy era, the fiction of J.D. Salinger and Jewish writers such as Bellow and Bernard Malamud, "set out on a course of self-examination,” noted Mark Shechner, “...thrown back on its own resources, it 
became more introspective and more literary." Starting in the 1940s, this became identifiable as the literature of "alienation," a catchall explanatory term for something that drew literary intellectuals like a magnetic force. ${ }^{140}$

The second trend was literary journalism, a resurgence of an old tradition kept alive after the war by Norman Mailer and John Hersey, and by New Yorker writers A.J. Liebling, Lillian Ross and Joseph Mitchell in the 1950s. After the phenomenal success of Truman Capote's "nonfiction novel" In Cold Blood in 1965, the "New Journalism" of the Baby Boom Generation exploded with a wave of new talent—Tom Wolfe, Hunter S. Thompson, Joan Didion, Jimmy Breslin, Gay Talese, Michael Herr and others. ${ }^{141}$ A year before Hecht's death, the University of Chicago Press acknowledged his place in literature with what amounted to a backhanded compliment that made the occasion far more bitter than sweet. The press had issued a new edition of Erik Dorn as part of its Chicago Renaissance series without giving Hecht the opportunity to preview Nelson Algren's rather unusual introduction, which contained disparaging remarks about the author and the novel. Furious, Hecht refused the invitation to the publication party. "I have no hankering to pose in your local festivities as a literary patsy," he wired. ${ }^{142}$

Algren's introduction was itself a backhanded compliment. He credited Dorn as an alienation novel produced decades ahead of its time, while at the same time suggesting that this was a dubious achievement. Since the book was the portrait of an empty, nihilistic "organization man," the whole enterprise was essentially a farce. "For no American yet has written a novel this good yet this bad," he asserted. "This is the one serious work of literature we have that by the same token stands a literary hoax." Ultimately Algren didn't commend the book or the author: "For the value that is derived 
from the novel today is not within the novel itself, but from the curiously prophetic shadow that a book, written a half century ago, now casts across our own strange times." When Hecht retorted that this criticism displayed "a Beverly Hillbilly kind of intellectuality," Algren's comments were more unequivocally damning. "He hasn't done anything since Erik Dorn," Algren said. "He's made one or two good movies and some awful bad ones. ... He won't take responsibility for his own talent." ${ }^{\text {143 }}$

Since this assessment echoed the criticisms that had been leveled against Hecht for many years, it became the conventional wisdom at the end of his life. Even his book editor at Doubleday, Margaret Cousins, who said she adored him, wrote ten years later: “Actually, I don't think he ever lived up to the brilliant promise forecast by his first book — the novel Erik Dorn —when he was hailed by critics as a Daniel-Come-toJudgment, because he was more interested in living than in writing. Writing was his sometime mistress, but he was married to life." Hecht certainly had a reputation as a bon vivant, but this seems a curious conclusion to draw about so remarkably prolific an author. $^{144}$

If Hecht can be credited as a pioneer of the alienation novel, then with greater hindsight, it is likewise appropriate to acknowledge him as a forefather of New Journalism, a contribution that he made, simultaneously, in the early 1920s. Literary journalism had existed long before Hecht's time, and had been a proud Chicago tradition during the late-nineteenth-century heyday of George Ade, Finley Peter Dunne, Eugene Field and the Whitechapel Club. But the four hundred sketches of Hecht's "One Thousand and One Afternoons" column revived this tradition and introduced it into the modern newspaper, reflecting the new crosscurrents shaping journalism: a rising 
skepticism about journalistic objectivity even as the American Society of Newspaper Editors codified objectivity as a professional standard. Fusing the factual data gathered by legmen with his own subjective impressions, psychological insights and storytelling, Hecht forged a hybrid that Tom Wolfe would one day proclaim as a new literary form in his seminal 1973 anthology of Baby-Boom journalists. ${ }^{145}$

The worst that can be said of Dorn and Hecht's collected columns is that the prose was fitful and the stories lacked emotional depth; neither book added up to anything substantial enough to endure as a classic. This, however, had more to do with relative youth and immaturity of the author than with discipline, craftsmanship or storytelling talent. A lifetime of experience separated this author from the author of the cycle of books that started with $A$ Child of the Century, a man who was mellower and significantly wiser. As the stories of Gaily Gaily demonstrate, the older Hecht possessed a command over narrative and a steady, natural rhythm that made his work more accessible. Fetherling noted one striking aspect of Child "is the verve with which Hecht invokes the environments of his past, as though he had never left them, while at the same time analysing and appraising them. The two actions are not distinct but take place simultaneously, giving the whole book an unusual quality of detached exuberance."146

Hecht had returned to prose, but with the minor exception of The Sensualists, he no longer tried to write novels. Instead, his books proceeded from where he had started as a journalist and columnist. Writing in the 1970s, Fetherling had argued: "Hecht the Memoirist was the kind of writer their detractors accuse the present New Journalists of being. He shifted focus away from a careful analysis of the facts toward an impressionistic truth supported by a mesh of tiny detail. Much of the detail was certainly 
as he remembered it, but some was included because it sounded plausible. None of it was researched.",147

The Mickey Cohen project was the closest Hecht would come to a return to journalism, the one book—with the exception of his ghost-written 1954 "autobiography" of Marilyn Monroe - that wasn’t populated by ghosts. A large excerpt finally appeared in the March 1970 premiere issue of Scanlan's, a groundbreaking monthly that showcased aggressive investigative reporting and slashing cultural criticism, launched by the maverick former Ramparts editor Warren Hinckle and Sidney Zion, a New York Times alum. ${ }^{148}$ A latter-day Hecht champion, Zion provided an introduction to Hecht's piece that hailed his work for the Irgun and explained Cohen's role in the fight for a Jewish state. "Writing this tale, I am aware that it may sound a little crazy to a lot of people," Zion added. "What was a gangster doing helping Israel? ... And the Irgun. Weren't they a bunch of right-wing Jewish terrorists?"

The untold truth is that scores of Jewish outlaws were busy running guns around Mr. Truman's blockade while their liveried cousins shook their heads in shame or sat in those Frank Lloyd Wright temples rooting for the English.

Those who had supped with Jewish mobsters will hardly be surprised by this. ... Thus, the old Meyer Lansky mob on the Lower East Side of Manhattan was actively hustling guns for Palestine. And in Jersey City Harold (Kayo) Konigsberg, then breaking into the head breaking business, performed extraordinary tasks for the Irgun. ${ }^{149}$

Scanlan's made the connection between the old journalist and the New Journalists more than just theoretical. The magazine was "going to start Hecht's literary renaissance," Zion told the New York Times, when asked about the Cohen excerpt. "Some kids read it and thought it was beautiful," he added. "There's closing the generation gap for you." "The Unfinished Life Of Mickey Cohen" ran alongside a feature by a rising 
new talent named Hunter S. Thompson, who despite his success with Hell's Angels, was still too much of a handful for the mainstream glossies. Thompson's profile of Olympic ski champion Jean-Claude Killy had first been commissioned by Playboy, which recoiled in horror when he turned in an eleven-thousand-word exposé savaging the celebrity athlete as a mindless shill for Chevrolet. After Scanlan's published the piece alongside Hecht's, the editors provided the opening he had been waiting for. As a follow-up for their June issue, they teamed Thompson with a macabre British cartoonist named Ralph Steadman and sent the pair off to do their worst. The resulting story that surfaced out of an alcohol-poisoned delirium, "The Kentucky Derby is Decadent and Depraved," immediately gained Thompson notoriety for a first-person style "so outrageous it needed its own name": Gonzo Journalism. ${ }^{150}$

News of Hecht's book had first come to light as Cohen was hitting the peak of national celebrity, over a year after his October 1955 release from McNeil Island Federal Penitentiary. As the gangster had told the Kefauver committee, he drew headlines every time he spit on the sidewalk, and this new development was treated with maximum fanfare. “Mickey Cohen's bizarre quest for publicity is easily understood when you hear that Ben Hecht is writing his biography—with a view toward the big movie money," Walter Winchell announced on May 31, 1957. Weeks earlier, the LA Times had reported that since the previous summer, United Artists had been considering a movie to be written by Hecht titled The Mickey Cohen Story or The Poison Has Left Me, but no decision had yet been reached. Cohen's delivery of a 150-page manuscript at Oceanside two months after Winchell's announcement also garnered national attention. "He must 
have done it himself," Hecht told the press. "No one but Mickey uses words that way. It's a gold mine of facts-I haven't seen so many facts since I was a newspaper reporter."151

But Hecht had reservations from the start, which he mulled over months later as he waited for Cohen to emerge from the shower- - his third of the day —at the Del Capri, an exclusive residential motel in Westwood. One the one hand, "it could be a fine shoot'em-up story, with important sociological overtones,” Hecht mused. “...Mickey leads me into an understanding of my time, and not a jolly one." But though Hecht was often nostalgic about his newspaper days, he had no desire to go "hopping around for data" like a cub reporter. Another source of concern was the ex-convict's new claim of being a changed man. He had identified himself as a florist, no less, the proprietor of Michael's Tropical Plants operating out of a greenhouse on South Vermont Avenue, which actually sold plastic fakes. Having closed that, he would soon be opening the wholesome Carousel ice cream parlor. "I lost the crazy heat in my head," the new and improved Michael Mickey Cohen told Hecht, "even though I seen enough dirty crooked double-crosses to keep me mad for a hundred years." For the sake of the book, Hecht certainly hoped the new Mickey wasn't real: “Who wants to hear about a toothless tiger?" Then again, perhaps Mickey hadn't reformed permanently, which might make for a fabulous twist ending. ${ }^{152}$

"How to handle my biographic dynamite?" Hecht wondered. His years as a newspaperman had taught him all too well the have-your-cake-and-eat-it-too approach to this kind of story. "You hold your subject up to scorn while titillating the reader with the details of his sadism, lechery and horrid misdeeds. ... You identified your gangster as a vicious, rat-blooded character unworthy of human consideration, and then went on to 
consider every fascinating quirk of his being." It would be the safest approach, but Hecht couldn't summon any moral indignation about underworld criminals. "Unlike historical or political figures, they break laws on only a small scale," he reasoned. "They do not betray trusts, bankrupt widows and orphans, or invent hydrogen bombs - and drop them."153

On the other hand, Hecht had no desire to be like the mob shysters he had watched tug a jury's heartstrings with sob stories about "extenuating circumstances"beloved wife and a hungry child to feed, a rough upbringing on the wrong side of the tracks. "I have an unquestionable record as an honest man," Hecht wrote. “... Having written many books as an honest man, I do not suddenly want to seem to be the mouthpiece of a criminal. And, perhaps, to have always been that.",154

Cohen at last emerged from the bathroom at the Del Capri, naked except for green silk socks and maroon garters, covered from head-to-toe in a layer of talcum powder. Donning a fedora, he looked like one of those street performers who pose as a frozen statue, or a snowman. Hecht watched in confusion as the pudgy mobster raced about, caroming from one wall of the tiny bedroom to the next. All Hecht could figure was that Cohen was trying to shake the off powder. Mad as this may seem, "it is no lunacy," Hecht wrote. "It is Mickey caught up in a mood so deep, tossed around on memories so violent, high diving into daydreams so vivid, that he has not the slightest awareness of darting around for an hour in a darkening room—naked and with a hat on." ${ }^{155}$ Cohen was an unknown quantity - a Jack-in-the-Box that the old crime reporter did not completely understand. 
Nor was Hecht even sure of his own point of view. "A thing baffles me which may well be baffling the reader," he confessed. "It is - what do I think of Mickey? And what do I feel about him and his infatuation with violence and lawlessness?" Other than "outlandish fellows like the Marquis de Sade," it was typical in such matters for a writer to adopt the traditional view of society. And if Hecht was not altogether in sympathy with the law-abiding public, then what alternative did he offer? ${ }^{156}$

Six years later, Nelson Algren would conclude his contentious introduction to Hecht's first novel by observing: "It wasn't splendor that was lacking in Hecht, it wasn't gas he ran out of, and it surely wasn't brass. It was belief. For he came, too young, to a time when, like Dorn, he had to ask himself, 'What the hell am I talking about?' And heard no answer at all."157 


\section{5. 'AS PURE AS THE DRIVEN SNOW'}

Crime, vice and corruption in California had a special flavor-exotic, overripe, and a little sickening. The rackets there, like the state itself, were big and colorful.

$$
\text { Senator Estes Kefauver }{ }^{158}
$$

I'd say, "Lookit, I got my own way to live, I got my own ways of doing things. I live out in California, I live in Hollywood, where ya open up a goddamn burger stand and they make a big premiere out of it."

$$
\text { Mickey Cohen, In My Own Words }{ }^{159}
$$

By the late 1950s there were two popular theories to explain Mickey Cohen's unusual relationship with the press. One might be called the Frankenstein theory, the notion that Cohen was a monster created by the newspapers who had broken loose from the castle and now rampaged across the countryside. It remained to be seen whether the press, like the good doctor-creator of the story, were the only ones who could destroy the creature they had jolted to life; perhaps they had lost control of him, or perhaps they secretly had no desire to stop him because he continued to serve their dark ends. "Today I ask myself, 'Why do we put up with him?'” said J. Edward Murray, managing editor of the Los Angeles Mirror in 1958. "The man is a pipsqueak and a myth. But he's the only approach the town has to an underworld figure. This town is lined up for a hoodlum headline figure, and Mickey has done a snowjob on the local columnists."

A decade earlier Cohen had been the answer to a newspaper publisher's prayers. Los Angeles had five major dailies, each printing several editions, and their circulations dropped precipitously, like movie attendance, with the advent of television. There were already four million TV sets in American households, with another eight million about to 
hit market. Cohen was a constant source of good copy and a jukebox of quotes. Despite his claim to having gone on the straight-and-narrow after his release from prison-which was itself a rich source of stories - the press still found him as full of intrigue as ever, "running around like the rabbit at the dog track." In 1958, "New York Confidential" columnist Lee Mortimer announced, "Top hoods telling Mickey (The Louse) Cohen that if he doesn't shut his trap and keep out of the papers, he'll get one more story—on the obit page." But apparently Cohen could not help himself. Whether the papers flattered or attacked him seemed to make no difference; whenever a reporter reached out, he was always available. ${ }^{161}$

Alternatively, there was the vampire theory, the suggestion that Cohen was a nightclubbing Count Dracula feeding on the lifeblood of the city while he summoned columnists and reporters to do his bidding like a bevy of entranced pale brides. "It was easy for Mickey to seduce me. The truth is I fell for him hard," confessed New York Post reporter $\mathrm{Al}$ Aronowitz. "He was a showman. Oh, I know he killed people and he was a Yiddish momser and he was just plain no good ... But mostly I liked Mickey because he was fun." Aronowitz added: "Mickey had the inside dope on everybody in Hollywood simply because one of his sidelines was blackmail...he was one of my best 'sources.' The whole time I knew Mickey, I could feel the subtle way in which he manipulated me. It was as if I could feel his hands on my shoulders, gently but firmly steering me exactly where he wanted me to go." 162

The former newsboy had pushed ink since at least as far back as 1931, when as an eighteen-year-old flyweight he used to phone up the "Cleveland Chatter" columnist for Ring magazine. When police shook him down at one point in 1958, they found a little 
black book full of unlisted numbers for powerful politicians, prize fighters, newspapermen and Hollywood celebrities. In his fateful four-part exposé for the Saturday Evening Post, Dean Jennings observed that at one time, Cohen purchased "newspapermen and cops the way rich playboys buy girls who will be thrown away when they are no longer amusing." He kept half a dozen journalists on his payroll. ${ }^{163}$

"The swath Mickey Cohen cut through Los Angeles is strewn with blood and rubble," Jennings wrote. "For irony in a city where drama is a bread-and-butter commodity, nothing can eclipse the fact that Mickey got as much or more fan mail than many movie stars, or that today wide-eyed teen-age girls cluster around him for autographs. At one night-club opening I attended with Mickey, a dozen screen personalities were virtually ignored, but there was a line of people at our table, waiting for Mickey’s signature." 164

As underworld kingpin, Cohen aggressively burnished his public image while currying favor with police and city officials. Weeks before each Thanksgiving and Christmas, he later recalled, precinct captains would give him lists of poor families he would provide with baskets containing turkeys, hams and chickens, and other necessities for a decent holiday. He and his crew would also bundle toys and clothing for the children. He estimated that they delivered three hundred packages each year. "I didn't do these things with the thought of maybe these people are going to sit on juries, although that could happen," he said. "It did have its rewards, though, in that a lot of people had a good word for you 'cause maybe somebody's brother or cousin will say, 'Geez, I'm going to be on the Mickey Cohen jury." 
Cohen had other purposes for publicity that were less savory. He invested in Hollywood Nite Life, a subscription-only magazine startup distributed to studio chiefs and top producers that dished out the latest tattle on Hollywood celebrities. The magazine's "salesmen" would approach stars and millionaires to suggest that they could either purchase advertisements or find themselves featured in an upcoming issue. Decades later, Cohen denied any direct involvement, but according to grand jury testimony in the summer of 1949, he ran a sex-and-shakedown ring that kept the magazine in business, using prostitutes often procured by Stompanato and wild parties that were recorded. Among the seven beautiful young women named in the inquiry were blonde starlet Lila Leeds and dancer Vicki Evans, who in September 1948 had been nabbed with Robert Mitchum at a marijuana party in Leeds' hillside cottage. In addition to that scandal, which nearly derailed Mitchum's career, even Cohen's friends Frank Sinatra and Judy Garland had been targeted. ${ }^{166}$ In the 1950 s, Mortimer referenced these schemes in describing an operation that bears a striking resemblance to the sinister plot hatched by Hecht's James Bond villain Colonel Chiffre:

The Stompanato-Mickey Cohen blackmail angles (first revealed here) will explode into a new and bigger page one story involving dozens of Hollywood, Broadway and political figures who have been paying off in fear for years. The ring is operated out of Chicago by the Fischetti-Capone mob and the glamour boy and gal affiliates employ gigolos of the Stompanato type, babes and homos, while sleazy, slimy little hoods such as Cohen are the front men who do the dirty. ${ }^{167}$

Cohen was hardly the only Los Angeles hustler who discovered the potential of newly developing wiretap technology. Columnist Florabel Muir noted with alarm what was fast becoming a growth industry. "Should a man of importance make the mistake of talking too freely to his light o' love over the phone," she observed, "he's libel to find a 
gent at the back door with a recording and demands for a payoff." ${ }^{\text {"168 }}$ Among those most eager to employ the devices were the police, who found them a powerful new investigative tool. Their surveillance of Cohen was what had led to his acquaintance with wiretaps in the first place.

Cohen had been bugged by the LAPD's so-called Gangster Squad, but electronic eavesdropping was not their only trick. Once he became "the man with the juice," as Jennings, put it, he had fought a war on two fronts: one against underworld rivals trying to kill him, and the other against the police, who had made him Public Enemy Number One. After the brutal slayings of "the Meatball" and Levinson in the fall of 1946, Chief Clemence B. Horrall decided that the times now called for desperate measures. In October Lieutenant William Burns offered eighteen hulking, hand-picked men a chance to join a new detail. The unit would be supplied with two rusted old Fords and a Secret Service Fund for informants, and the work would be strictly off-the-books. Assignments would be chosen by Chief Horrall personally. The officers would make no arrests. In conclusion to his briefing, Burns had hoisted a Tommy gun and told his recruits, "You'll be working with these." 169

Sergeant Jack O'Mara and seven fellow officers who also signed on carried their Tommies in violin cases as they rousted hoods, taking out-of-towners for long rides up Mulholland Drive and into the Hollywood Hills. There they would treat the tourists to a view of the sparkling city lights that stretched for miles, once colorfully described as “jewels on the breast of the harlot." O’Mara would explain that this wasn't Cleveland or Detroit or New York, this was L.A., where hoods weren't tolerated. As the boys dangled 
a gentleman above the dizzying heights, O'Mara would ask if he felt a sneeze coming on. ${ }^{170}$

Reorganized and expanded into the intelligence division under Horrall's more sophisticated and technocratic successors, the unit would eventually prove invaluable to a young and ambitious Senate investigator named Robert F. Kennedy when he turned his focus to organized crime in the late 1950s. But despite the macho bravado of the original squad, it had little to show for results during its first few years. It succeeded in planting a bug in Cohen's new home, but a federal grand jury could find nothing of use in the nineteen wax recordings and miles of tape. When excerpts were leaked to the San Francisco Chronicle in August 1949, the public was treated to cryptic murmurings, along with a domestic quarrel in which Mickey told LaVonne to go to hell while kissing his pet cockatiel. After Toughie tore up the flowerbed, Cohen could be heard moaning, "How could you do this?" again and again. ${ }^{171}$

Aware by late 1948 that he was under surveillance, Cohen asked private detective Barney Ruditsky to recommend a wiretap expert, and was subsequently put in touch with Jim Vaus, an amateur electronics buff and master tinkerer. As fortune would have it, Vaus also did jobs for the LAPD, and had no qualms playing for both teams. Dazzled by Cohen's opulence and eager to impress his new boss, Vaus also had valuable intelligence to share. He had been tapping the lines of L.A.'s most famous madam, the so-called "Queen Bee of Hollywood" Brenda Allen, when she had put in a call to the unlisted number for the Hollywood Vice Squad. Allen, it turned out, was the girlfriend of Sergeant Elmer Jackson, the right-hand-man of Lieutenant Rudy Wellpott, the head of Vice and a major Cohen beneficiary. The information would come in handy months later, 
when "Happy" Harold Meltzer, who already had twenty-six items on his rap sheet, went to trial for possession of an unlicensed gun. ${ }^{172}$

In the interim, a dramatic scandal burned an image in the public consciousness of Cohen as a Jekyll-and-Hyde character, after one of his goodwill efforts spun out of control. LAPD Captain Harry Lorenson, chief investigator for the police commission, had asked him to do something about Alfred Pearson, a radio repairmen in the West Adams neighborhood who was a notorious rip-off artist. The police had received hundreds of complaints about Pearson over the years, and he had been charged with assaulting several customers. Residents were now in a furor over the case of Mrs. Elsie Phillips, a sixtythree-year-old widow who had refused to pay her $\$ 8.91$ repair bill. Pearson had taken her to court, won a judgment of $\$ 81$, and then purchased her home at auction for $\$ 26.50$ when she was forced to sell it to satisfy the ruling. He was now rubbing salt in her wounds by charging \$10 a month in rent. Cohen asked why somebody didn’t "just pay the goddamn radio bill," but it was too late for that. Lorenson explained that the neighbors were planning to hold a demonstration outside Pearson's Sky Pilot Radio Shop, and the captain wanted Cohen to show up and teach the man a lesson. The police, Lorenson promised, would steer clear.

On March 19, 1949, Cohen stood alongside some five hundred cheering picketers while his thugs gave the repairman a savage beating inside the store. As the hoods rushed from the scene, however, they pulled an illegal U-turn, drawing the notice of two rookie officers who hadn't gotten the memo to leave the men alone. With the police in pursuit, pistols, tire irons and a riding crop went flying out the window. As soon as Cohen heard of the arrests he was able to get the men released from the Wilshire Division station, but 
by then his luck had already gone from bad to worse. An amateur photographer had snapped photos of the arrest and brought the prints to the Los Angeles Times, where a reporter recognized the men as members of Cohen's gang. ${ }^{173}$

Within two days, Police Chief Horrall was being asked to explain why Mickey Cohen's wrecking crew had been released without charges while Pearson was en route to the hospital with broken bones and a fractured skull. "The story smelled up Los Angeles like a broken sewer," Jennings noted. After the men turned themselves in, Cohen unwittingly provided the final touch to the story himself. "I'm as pure as the driven snow," he had blurted out. A cartoon lampooned the mobster as Snow White looking on while his goons, the Seven Dwarfs, busted Pearson's head. The image crystalized the incident, which would thereafter be remembered as "the Affair of Snow White and the Seven Dwarfs." ${ }^{174}$

The fallout had not even begun when Meltzer went on trial weeks later. In an opening statement on May 5, attorney Sam Rummel promised to prove Meltzer's charge was part of an eighteen-month shakedown by Lieutenant Rudy Wellpott and Sergeant Elmer Jackson. The victim had been Mickey Cohen, who had lavished expensive gifts on the officers' girlfriends and picked up their tabs at the House of Murphy, the Brown Derby, Dave's Blue Room, Slapsy Maxie's and other pricey establishments. Meltzer's charge had finally been brought, Rummel said, because Cohen had refused to contribute $\$ 10,000$ to $\$ 20,000$ to what the Wellpott and Jackson claimed was a campaign fund for the reelection of Mayor Bowron. Why hadn't they arrested Cohen himself? "The did not want to kill the goose they hoped would lay the golden egg." For two days Rummel presented witnesses to substantiate his claims. Even the officers themselves did not 
altogether deny them, although the mayor's campaign fund manager did testify that no one except his committee members was authorized to collect or solicit for money.

Then on May 7, Rummel dropped another bombshell. The defense promised to produce recordings that would prove Sergeant Jackson had been carrying on an affair and an illicit business arrangement with Hollywood madam Brenda Allen, and other tapes that would further substantiate the defense's claims that Cohen had been the victim of extortion. "When the jury hears these," Cohen said, "it will blow the case right out of court." A mistrial was hastily declared, while rumors circulated that it had been stalled to protect the mayor, up for reelection on May 31. Bowron won by a thin majority but by mid-June 1949, a county grand jury impaneled each year to investigate municipal misconduct had subpoenaed Allen and others caught up in the scandal. The thirty-sixyear-old redhead with a slight Southern accent complained that in addition to paying protection money, she was forced to let cops in for free to her parties, where these freeloaders would snatch the nuts off her pecan pie. With yet more revelations of corruption generating shrill headlines and a vicious sex murderer still on the loose nearly two years after the notorious Black Dahlia murder, Chief Horrall announced his retirement on June 28. By the end of summer, the grand jury had indicted him, Assistant Chief Joseph Reed, Wellpott and Jackson for perjury. Cohen could now boast that he had taken down the top brass of the LAPD. ${ }^{175}$

The cure, however, proved worse than the disease, as the two men who succeeded Chief Horrall had served as commanders in World War II and literally treated the war on crime as the opening skirmish of World War III. As interim chief, Mayor Bowron appointed retired Marine Major General William Worton, who sought to give the now 
tarnished force "the esprit of a good combat unit." He instituted aggressive inspections, which he often conducted himself, and made the police academy even more like Quantico than it had been before. The force itself already had a military pedigree: 90 percent of the 1,400 officers who had joined after the war were veterans. Worton had a strong appreciation for good intelligence, having worked undercover in Shanghai for Naval Intelligence during the 1930s, and he reorganized the Gangster Squad into an elite investigative team that targeted organized crime. ${ }^{176}$

The following summer the police commission appointed Worton's permanent replacement, Police Chief William H. Parker, who was every bit the spit-and-polish type as his predecessor, and would soon rival FBI Director J. Edgar Hoover as a national leader in the war on crime. At a time when two thousand firefighters fanned out across Los Angeles to distribute 600,000 copies of a booklet titled Survival Under Atomic Attack, Parker presented the police as the front line in a global battle against godless communism. Announcing a coordinated effort by three-dozen law enforcement agencies to crack down on criminal syndicates, he explained, "It is now clear that Russia is hoping we will destroy ourselves as a nation through our own avarice, greed, and corruption in government." At presentations to civic groups throughout the city, he evoked images of the great fallen empires of Egypt, Babylon, Greece and Rome, rotted at the core by decadence and hedonism, as he waved a big pointer stick and slapped charts showing the rise in criminal activity. This was war, and American society was under attack from within. "This is a case of a lawless criminal army warring against society itself," he said “...The most dangerous criminals are professionals— - people who refuse to work 
productively or legitimately, people who sneer at those who do and refer to them as 'suckers' and 'chumps.”

For years, writers like Hecht had been scripting Noir films with crooked cops and glamorous criminals, offering a jaundiced view of sunny Los Angeles as a place of murky shadows, mired in corruption. In restoring the LAPD's image, Chief Parker had a powerful new ally who provided an antidote to all of that: Jack Webb, creator and lead of the popular new television series Dragnet. Formerly a radio actor who had starred as the world-weary private eye in Pat Novak for Hire, Webb had been inspired by his role in the 1948 feature He Walked By Night, which was based on a real case of a burglar-turnedcop-killer. When Detective Sergeant Marty Wynn, the film's LAPD technical advisor, suggested the department would be willing to share its case files, Webb initially created the series as a radio program. Critics were impressed by the show's gritty, understated style and Webb's zeal for accuracy, as well as by Webb himself as the strictly allbusiness police sergeant, Joe Friday. Encouraged by the show's popularity and strong reviews, NBC launched the television series on Sunday, December 16, 1951. As the picture of an LAPD sergeant's badge filled the screen, a narrator spoke the trademark opener: "Ladies and gentlemen, the story you are about to see is true. The names have been changed to protect the innocent." The Hollywood Reporter predicted, "This series is going to do more to raise the rest of the country's opinion of Los Angeles than any other show of any kind." 177

But just as Dragnet was completing its first fourteen-episode run at the end of March, the city experienced "a serious case of cognitive dissonance." The local newspapers revealed that on Christmas Eve an angry mob of some fifty officers, drunk on 
holiday booze, had viciously beaten seven young men, five of them Latinos, in Central Booking. Accounts of the brutality along with photos of crushed noses, black eyes and bruised backs filled the news pages in what the press was calling "Bloody Christmas." Equally as disturbing was that Parker's new Internal Affairs division had whitewashed its investigation, concluding that the men had suffered no abuse in custody whatsoever. ${ }^{178}$

From the days when the notorious "bum brigade" had beaten back Dust Bowl Oakies to mad bomber Captain Kynette to Brenda Allen and "Bloody Christmas," all the spit and polish and Jack Webbs in the world could not wipe the stain off the LAPD by the 1950s, any more than Cohen's incessant washing could remove the blood from his hands. It was fitting that the department's new headquarters, leaky and cramped from the day it opened in 1955 and later dubbed the Parker Center, was nicknamed "the Glass House" by prisoners ... an innocent reference to its glassy architectural style, no doubt. ${ }^{179}$

Chief Parker, nevertheless, was able to survive the scandal, and undaunted, continued to capitalize on Dragnet as a tool for public relations. After the California Supreme Court issued ruling in 1955 that illegally obtained wiretaps were not admissible in court, Parker was livid. In response, the department treated Dragnet to a case file for a feature film involving a juicy gangland murder. When the police hit a wall because the key evidence, a wiretap recording, is thrown out at the trial, a liberal, ACLU-type female juror makes the argument. "How do we know that all you policemen wouldn't be running around listening to our conversations?" she says. "We would if you talked murder," responds Friday, in his gruff, customary deadpan. ${ }^{180}$

Right up until Cohen was shipped off to the penitentiary in 1952, he had also been trying to rehabilitate his public image. City editor Jim Richardson of Hearst's Examiner, 
the old friend from the Boyle Heights days, was disturbed by the way Mickey had been portrayed in the Snow White affair and offered some advice. In the summer of 1949, Cohen appeared in the paper embracing Mrs. Elsie Phillips, announcing that he was going to buy back her home and pay for its repair. Hearst himself was eighty-six-yearsold by then, but he still knew a good story when he saw one. "This is a very kind and wonderful thing he did," Hearst told Richardson. "I don't want you to refer to him as a hoodlum any more. A man who does a thing like this isn't a hoodlum. You can call him a gambler, but I wish you'd see that he gets a fair break."

Hearst had his eye on another rising star in Los Angeles in late 1949, the blueeyed, lantern-jawed, trumpet-voiced Reverend Billy Graham. The old publishing tycoon had a two-word command for his editors: "Puff Graham." Hearst also said his newspapers were going to use Cohen to promote Graham's career, at least according to Cohen. "He didn’t ask me can we use you?" Cohen recalled. "He told me." The little gambler didn't mind. One of Graham's newest disciples was Jim Vaus, who was now born again and swearing off crime, and in late 1949 Vaus took Graham to meet the Cohens at their home in Brentwood, where Mickey and LaVonne served their guest hot chocolate and cookies. Hearst, with his infallible instinct for good publicity, had been on to something: The odd partnership would prove advantageous to both men. ${ }^{181}$

Like Hecht, Graham would prove crucial to the second phase of Cohen's career as a celebrity gangster, which was initially marked by a flurry of national headlines in May 1957, a year and a half after his release from prison. Just over a month after the LA Times had first reported Hecht's book-and-movie project, Cohen appeared with the reverend before a crowd of 17,500 at Madison Square Garden. Though Cohen related that he had 
at first been angry about Graham's efforts to convert him to Christianity, he later understood the preacher was simply trying to offer him something he that he believed was good, like a steak sandwich or a piece of chocolate cake. "I said, 'Listen, we've had an understanding that we're friends, but that it wouldn't get into no religion bullshit or anything like that," Cohen claimed. "Now I may not be considered by a lot of people as being a good Jew, but I was born a Jew. And that's it." Regardless of what Graham had been led to believe, he may have been surprised when Cohen appeared at the Garden with a big gold mezuzah on his watch chain. The gangster smiled and waved to the crowd, but said nothing about Jesus or anything else.

The really big news from the same weekend in New York, however, was Cohen's appearance as one of the first guests on The Mike Wallace Interview. The newsman had made a name for himself with his local New York television program Night Beat, where he had demonstrated a hard-hitting interview style that often trapped guests in a corner. The writer Paul Lieberman recently compared him to "a coiled snake, poised to lunge forward and strike." During a pre-interview, Cohen had warned that his motivation for being on the show was "to attack the cops," but neither writer-research Al Ramrus nor his superiors had recognized the red flag. ${ }^{182}$

Perhaps because he was used to interrogations by the police and crossexaminations on the witness stand, Cohen did not flinch at his host's toughest questions. "You have made book, you have bootlegged," Wallace said. "Most important of all you've broken one of the commandments-you've killed, Mickey. How can you be proud of not dealing in prostitution and narcotics when you've killed at least one man, or how many more? How many more, Mickey?" Cohen snapped back: "I have killed no 
man that in the first place didn't deserve killing." When Wallace then asked, "By whose standards?" Cohen responded, "By the standards of our way of life. And I actually, in all of these killings — in all of what you would call killings — I had no alternative. It was either my life or their life."

The interview proceeded further into uncharted territory for 1950 s television as Wallace asked his guest, "without naming names," to discuss his bribery of police officials. Without realizing it, he had just handed Cohen the opportunity he had been waiting for. "I have a police chief in Los Angeles who happens to be a sadistic degenerate," Cohen ranted. “... I'm going to give him much to bring a libel suit against me. ... This man here is as dishonest politically as the worst thief that accepts money for payoffs ... He is a known alcoholic. He's been disgusting. He's an old degenerate. In other words, he's a sadistic degenerate of the worst type." Cohen had similarly choice words for Captain James Hamilton, head of the intelligence division, which he called "the Stupidity Squad."183

Chief Parker and Captain Hamilton were not appeased by ABC's formal apology the next day, nor by a televised retraction from the company's vice president a week later. Wallace had invited Parker to appear on the show, but the chief said he had no intention of debating a mobster. Cohen, who was already deep in debt to the federal government and legally possessed no assets, was immune to a libel suit, and declared that he would not take back a word. Tutored by his attorneys, he furnished a remarkable little lecture of civil rights. "Parker in my opinion shares the purview of Alexander Hamilton: 'the people are the great beast,"” Cohen intoned. “...Obviously Parker has a hatred of constitutional guarantees." $\mathrm{ABC}$, on the other hand, had to pay out $\$ 45,975.09$ to the 
chief and $\$ 22,978.55$ to Hamilton. The damage was so great that by the fall of 1958 , Wallace had to return to local television. His producer Ted Yates and production staff were by then teamed with a guest from the previous February, who had made such an impression that Yates had pitched WABC-TV for a show of his own: Ben Hecht. ${ }^{184}$

As Winchell had suggested, Cohen's courtship of the media put him in a position to expect "the big movie money" from his collaboration with Hecht—or at least to convince others that he had a blockbuster on his hands. Hecht, for his part, regarded Cohen's publicity-seeking as typical of a local and saw nothing calculated about it:

The scramble for publicity is a norm in Hollywood. Movie people hire press agents as freely as they do cooks and diverse lawyers. Brides of a month telephone gossip columnists with news of their pregnancy. Famous screen lovers notify the city desks of their change of bedrooms. Studio tycoons hurry the news of their gas pains and day dreams to the waiting editors. And does any story break of scandalous events, participants - contrary to journalists' experience elsewhere in the world - besiege reporters and clamor for flashlight cameras, like children loose in a cookie shop. ${ }^{185}$

Cohen had never exactly been a media maestro, but since the early days of his wiretaps and blackmail ring, there had been more to his relationship with the press than Hecht realized. In the late 1950s, it yielded him a bonanza-for a while. Then his maneuverings not only wrecked his partnership with Hecht, they proved to be his undoing as well. 


\section{TIME OUT FOR PSYCHOLOGY}

A horsefly on the rump of humanity.

Television reporter George Puntam's description of Mickey Cohen ${ }^{186}$

The underworld is not a geographic area. Its trail runs thru slums, fine hotels, swank residences and office buildings - cafés, theaters and the sanctums of government.

...The corruption of government - the bribing of its large and little factotums - is the perquisite of what Mickey calls "the higher echelon" of society. ... Railroad, oil and manufacturing empires have been built in the Republic with the aid of canny bribery.

Ben Hecht, notes for the Mickey Cohen biography ${ }^{187}$

Hecht may have resolved to write his book "without skittering about like a cub reporter," but he trailed Cohen on several occasions in 1957 and '58, capturing his companion's expressions and eccentricities with the keen eye he had always possessed as a journalist. After the gangster had performed his bizarre talcum-powder dance, Hecht witnessed him finish preening with more fussiness than a debutante preparing for a coming-out party. Cohen's vast wardrobe from Brentwood was long gone now, but Hecht duly noted the " 30 pressed and spotless suits crowded in the closet," along with " 25 Chinese, Japanese and Persian robes of silk" and " 35 pairs of glistening shoes" lined up neatly on the floor. ${ }^{188}$

Finally, the pair climbed into Cohen's newest customized Cadillac and headed out to the modest Hollywood bungalow of Fred Sica, one of the only bodyguards to have survived the 1940s. Sica had prepared a gourmet meal, and greeted them at the door in a dainty apron. Eight fellow guests were already at the table. As storytelling was a favorite 
pastime in the underworld, each was eager to play Scheherazade, and they spun tales about many of Hecht's favorite characters from old Chicago, such as Teddy Webb, Blackie Weed and Tommy O'Connor. He also heard about more recent legends, such as The Soldier, an ingenious con man who once collapsed in Reno from heart palpitations and then proceeded to scam his doctor. After dinner the hoods retired to the parlor, where their favorite movie, Robin Hood, hushed them into reverent silence. Hecht assured them that Errol Flynn was just as fine a drinker and fighter in real life. ${ }^{189}$

Aboard a chartered boat on a March 1958 fishing trip in La Paz, Mexico, Chicago mob attorney George Bieber provided the two friends a lesson on the ancient history of organized crime. In the time of the pharaohs, he said, as many as a hundred thousand slaves would die from whippings or hernias while building the pyramids—-giant tombs for the rulers and their vast riches. After a pyramid was completed, hundreds of architects and artists who knew the secret location of the burial vaults would be poisoned or stabbed. Yet when archeologists later uncovered the ruins, they discovered the storerooms had all been picked clean by heisters, who had schemed in cahoots with the royal members of the pharaoh's court. This, Bieber explained, was the beginning of organized crime.

"If you was to ask me," Cohen remarked, "those monarchs stabbing and poisoning all those characters and putting all that wealth out of circulation were worse than the heisters."

“It's a point," Hecht agreed. ${ }^{190}$

Once Cohen's line hooked a marlin, all eyes were fixed on the crime lord locked in a mighty, thirty-minute tug-of-war with "the marine locomotive" off their stern. "His 
chin is tucked down," Hecht noted. "His left eye has become bloodshot. And he is addressing the lunging, thrashing, whooping marlin in a soft, lethal sort of voice. 'You dirty punk bastard, who d'ya think you are. I'll tear your goddam head off. Come on, you sonofabitch, or I'll jump in the water and pull your lousy fins off ya.",191

Cohen brought Hecht's mind back to the days of Prohibition, and to himself as a young reporter. He reflected that he had covered crime like it was sports, without a thought for what it all meant. In the years leading up to the Volstead Act, he had witnessed a brash, noisy nation in throes of late adolescence. His was an odd perspective - a nostalgia for the First Ward bosses and their gangster balls and blacklegs and ballot stuffers. "The pioneers were trying on their first frock coats and silk hats," he reminisced. "Ex-hobos and horse thieves and Ragged Dicks from city slums were in command of the million new factory chimneys. And the workers, without unions to guide them, were happily throwing bricks through windows and clubbing bosses on the street corners. I remember these Americans, despite the injustice, graft and filthy poverty, as a people childishly in love with themselves and the wonders of their democracy.", ${ }^{192}$

All that had disappeared. Americans now were as obsessed with violence as ever, but they were the living dead, wandering shopping malls and gazing glassy-eyed at the cowboys, Indians, cops and robbers darting across their television screens like dim traces of memories not quite theirs any longer. "Crime ... has become the only easy escape from the stupidity of laws, religions, economic problems, etc." Hecht jotted in fragmentary notes. "It has become the last adventure open to the daring - taking the place of exploration and conquest. ... Gangsterism is the only anarchic element left-it has taken the place of the arts in the U.S. Mass media—movies, radio, television—have 
hurried the process of regimenting the American mind and lowering it into docility. Lawlessness becomes more and more the only outlet for any social rebellion in the land." 193

Hecht admired the heisters over the pharaoh-politicians because at least the criminals were honest by comparison. In pursuing their own ends, they risked their own lives, rather than letting others do the dying for them. Yet a heister too grows old, loses his sharp, primitive instincts and becomes "as full of nonsense as a Secretary of State." In Cohen's case, arriving in Capone's Chicago had changed him. Before that he knew all about hooligans on the fringes of society. "He did not know, however, that there were ten times as many crooks in the respectable seats of government," Hecht wrote. "It was this vision that was to guide him to power and fortune."194

Like their fellow Americans, the mob had grown up and grown old over the decades as well. Back when East Coast crooks like Joe Adonis and Waxey Gordon had been "running beer," Hecht argued, Capone had figured out how to turn crime into big business. The suburb of Cicero became "an empire unto itself," where the Capone mob installed its own stooge politicians and placed gunmen at all the polling places to ensure their elections. On one occasion, upset over some trivial matter of municipal policy, Capone had slugged the mayor Joseph Z. Klenha, knocking him down the steps of city hall while policemen stood by and watched. ${ }^{195}$

As these broader insights piled up, Hecht's book started to become something far more than just Mickey Cohen's biography. The notes and drafts suggest an ambitious epic, an effort to expound upon a whole philosophy. If Hecht was unable to do much legwork at his age, he could at least do the mental work to fit Cohen into some broader 
social and political context. He compiled research and wrote forty-two pithy essays on criminals and crime. Eschewing the old outlaw legends like Billy the Kid and Jesse James, he wrote profiles of a range of twentieth century crooks and killers, from Albert Anastasia to Charles Ponzi, from John Dillinger to "The Ladies of Crime.,"196

An entry headlined "The New Criminal" described the bosses who now possessed major holdings in a full spectrum of legitimate businesses, such as real estate and securities, while continuing to run the same old rackets in prostitution, narcotics, loansharking, strike-breaking, gambling and the rest. The existence of a national criminal cartel was famously exposed on November 17, 1957, when police stumbled upon a summit near Apalachin, a Western New York hamlet. An alert state trooper had become suspicious of scores of expensive cars with out-of-state plates arriving at the estate of Joseph "Joe the Barber" Barbara, a local beer and soft drink vendor. Police arrested sixty of the Mafia dons in attendance, with $\$ 300,000$ in loose change jingling in their pockets. ${ }^{197}$

The episode drew increased scrutiny upon Frank Costello, the "prime minister of the underworld," who was a close partner of Luciano and one of the chieftains of the Combination, or National Crime Syndicate, as it was also called. Hecht noted that Costello owned a thirteen-story office building on Wall Street, and two others in the same neighborhood. Here and in other passages, he was already implying by the late 1950 s that the entire financial industry was becoming a vast criminal empire. "Crime Pays" cited sixty-five financial interests of the delegates at Apalachin, including bakeries, law firms, textile manufacturers, food chains, consulting firms, power corporations, baseball clubs...the list went on. Initially, the rapid expansion into legitimacy had occurred after 
Prohibition and again after the war, when the mob took leases and concessions at the three major New York airports and bought into luxury hotels, such as the BeverlyWilshire in Los Angeles and New York's Waldorf-Astoria. But Hecht noted that the underworld had been buying up stocks and real estate since the days of Arnold Rothstein in the $1920 \mathrm{~s} .{ }^{198}$

Other essays questioned the lines drawn between criminals and respectable society. "We're All Crooks" listed numerous infractions that an average businessman might commit on a given day, such as fudging his taxes, bribing an elevator inspector, and accepting a kickback—in the form of a polite gift—for a client's contract. "Valentine for the Gunman" proposed a National Hall of Fame for crooks and killers, since crime was more popular in America than sports, "second only to our enthusiasm for saving the world.” The televised Kefauver Committee hearings had been highly successful entertainment, he remarked, exhibiting "a catch of gila monsters and boa constrictors never before held." The senator had spent $\$ 300,000$ on the investigation, "the cost of a Bmovie," and "about as effective."199

This new book of Hecht's quickly began to draw nearly as much heat—at least on a personal level — as had his rather more public propaganda for the Irgun. Early on, revenue agents and police detectives appeared with a warrant to search his house and seize his manuscript as an asset belonging to the U.S. government. Hecht said he hadn't started writing yet, but did not understand how his work could possibly be an asset before he'd had a chance to publish it. He'd had plenty of political opponents in the 1940s, but now his own friends were urging him to abandon the work and stay away from the 
gangster, which alienated him more from them than from Cohen. ${ }^{200}$ But what made the project uniquely prickly was that for the first time, his own wife was objecting.

By the summer of 1958, Rose had invited her sister, the well-published psychoanalyst Dr. Minna Emch, into the discussion. An undated letter suggests that at first, the three debated whether the book had been inspired by Hecht's work for the Jews. "When I came home last night Rose told me of your talk with her about me," he wrote Emch. "I was pleased and impressed by what you had to say, but had to shy away from your diagnosis of working the Jewish business out of my system. What neither you nor Rose appear to know is that my Jewish business was Rose. I contributed my logic, but Rose was the one who lived it emotionally and socially."201

Perhaps because Emch had no desire to argue with her brother-in-law, she ceded the point in her July $3^{\text {rd }}$ reply and returned to the question of what had originally motivated the book. An artist hardly needs a reason for his choice of subject, she acknowledged, and indeed any reason he offers will likely be a self-deception covering an unconscious motivation. In this case, however, she had the impression that the idea had not originated with Hecht at all, but with Mickey Cohen, and was rooted in the gangster's need to fill "his own central psychic emptiness." Again, she brought up their work together for the Jews:

When Ben originally came to him and talked to him about the Irgun, Ben not only appeared as the master-mind of a bigger revolution than any of Mickey's, but I feel that a psychic love affair of a very deep kind began - a one-sided love affair to be sure — but generated by Ben with his genius for making people breathe more deeply in his presence. On that occasion Ben enlarged Mickey's concept of the little "Jew Boy" identity he had once worn, and made possible through this tag a primitive identification with a "People" (not Mickey's bosses), and 
with himself(Ben). This Mickey obviously never let go of, for it is still his hoped-for ticket to an acceptable identity-via Ben. ${ }^{202}$

She argued, in effect, that Cohen was using Hecht to fill a vacuum inside himself, and in the process had encouraged Hecht to latch on just as tightly. "To me it makes sense that this man could kill as he did," she concluded. "For I have seen in the most swaggering of independent attitudes the utter despair and the mad violence that the threat of separation arouses in these swallowing ones." 203

Two days later Hecht wrote back, thanking her for her letter, which was "a big present." He agreed that Cohen wanted a new social existence, a new recognition and a status as something more than a hood. This in itself did not interest Hecht, but what did was something about their relationship that could prove elucidating, if he could ever put his finger on it.

The thing that started me to writing tells me much about this relationship. It was my old literary friend - anger. The Government Revenue Agents and Narcotics Detectives questioning me about Cohen got me angry. A Saturday Evening Post writer named Jennings talking to me for hours about the Cohen articles he was going to write made me angrier. Jennings and the Govt. Agents (and nearly all who have spoken to me about Mickey) spoke out of such a goony sense of virtue, decency and nobility of soul (their own, all) that an old friendiconoclastic me - was whistled out of his lair. I knew when I felt angry what my relation (in part) to my subject was. I have always questioned noisily the phony surfaces by which society binds itself to its own image. I have always been a sort of pencil-outlaw. I felt in Mickey a fresh (and happily cockeyed) point of view against society. Mickey is the strayed wild dog wanting to get back into to the kitchen warmththe Lucifer spaniel. Peering into the kitchen, he becomes a remarkable and comic study in righteousness. ... Mickey thus gives me a chance to attack the hypocrisies of society from a more primitive and gaudy point of view than psychologists (other than Dostoevsky) have usually taken. I am not sentimental about a gangster but my mind is pleased by the fact that a gangster can expose shams and stupidities with glaring light. I'll be frank. While seeming to present a vicious enemy of society (Mickey) it is my hope to present his brother-a vicious society. I am 
again poking around in my own plot-humanity debasing itself with pretenses and cowering pathetically behind its myths. Mickey, the criminal, is to me a small, half-clownish disturber of life alongside the cliché-maddened mindless idea-egomaniacs who are our political leaders (and there are no other leaders any more.) ${ }^{204}$

Hecht was in essence planning to do what he had done in much of his best workpresent a protagonist who was the least unsympathetic of all the characters in the story. As for the psychology of Cohen, Hecht had his own elegant theories, just as his sister-inlaw had hers. He likened the gangster to a gilgul, a Kabbalistic term for a soul in transition, central to a conception of reincarnation within Jewish mysticism. In one passage of his most complete manuscript, Hecht described the gangster as stuck in a kind of purgatory, unable to complete the spiritual journey of his reform. ${ }^{205}$

Rose, however, had a simpler explanation for the man: He was no damn good. Apparently the tension between husband and wife escalated over the matter, because in August, Minna wrote to her sister: 'I do hope the 'problems' settle down to something that will allow you to stay in California for the present if that is what you want." ${ }^{206}$ When Rose oversaw the archiving of her late husband's papers decades later, she inserted a typed, one-page record of her objections among his drafts: "Notes on what I think is a fallacy in Hecht's reasoning in the Mickey Cohen manuscript."

She conceded that various officials in government and officers in law enforcement were on the take. But it seemed a false logic to therefore label all politics as criminal, or everyone else who is "tarred by the same brush of being in politics." That, she said, "is a criminal's kind of reasoning, for purposes of self-justification."

But for an author to borrow this pattern when starting from the objective (vantage) of the criminal's psychology...makes the author seem dangerously infected by his character's point of view. I'll admit I 
think, as his wife, that it is unbecoming for Ben to rail at society like England's "angry young men," and when he says he was "always like that," I merely think it was less unbecoming in his youth, but not more sane.

In The Untouchables ... the author speaks of Al Capone's evil talent for corruption. It is corrupting to buy officers who should be enforcing the law or threaten citizens by amply demonstrated death threats to join criminal enterprises. And it doesn't follow as a corollary that the "corrupter" is an innocent, because other classes join in through fear or greed.

...It is necessary for Mickey Cohen to convince himself now when he is at bay that "society" has no good, kind people...It's Ben's attacking society from that vantage point that sticks in my craw. I don't say he shouldn't write about the Decline of Western Civilization. I just don't like Mickey Cohen as a Messiah.

What it amounts to in our present fight is that Ben and I are playing cops and robbers, with me naturally as cop. As a cop, I do abhor Mickey, and I know as papa's daughter what it might mean to a small legitimate businessman to become enmeshed, through fear, with a mob, as they did in Chicago. ${ }^{207}$

Rose was hardly alone in her judgment of Cohen. In 1959, Steve Stevens was a nineteen-year-old former Mouseketeer - a co-star of Annette Funicello — struggling to become an adult actor when he fell in with the gangster's entourage. Cohen, who was a fan of Stevens' juvenile delinquent roles on television, had reached out as if to a long-lost nephew. At first, the swirl of the kingpin's world had been intoxicating, with the shining Cadillacs and access to nightspots like Earl Warren's and the Brown Derby, places so exclusive Stevens had only misted up their windows in the past, where celebrities, beautiful women and obsequious attendants now hovered around him. ${ }^{208}$

But as Stevens recalled in his memoir King of the Sunset Strip, this seductive world soon turned ugly and dangerous. When Cohen overheard an insult from an adjacent table at the legendary Village Capri, he crashed a magnum bottle into the offending speaker's head, and then returned to his meal while his goons carried the limp victim and 
his screaming date outside. Having reestablished his reign over the underworld, Cohen demonstrated his power by shooting Jack "the Enforcer" Whalen dead in the middle of Rondelli's Restaurant that December. The place had been full, but not a single witness would testify against him. ${ }^{209}$

During the same period, Stevens landed a role in High School Caesar, a B-movie about a thug who runs protection rackets and cows the rest of his school into submission. Stevens played Cricket, the bully's sycophantic sidekick. When lead actor John Ashley described the main character as "a dyed-in-the-wool sociopath," Stevens asked what that meant. "He's a guy without a shred of conscience," said Ashley. "He's a user. He mistreats others who are close to him. He'll screw anybody, and yet while all his buddies know it, they still remain loyal to him, even as he gets them in deeper and deeper."

Stevens soon found himself Cohen's errand boy—a lowly but nevertheless treacherous occupation. Old friends began to avoid him. He witnessed the mobster beat one hood nearly to death, and after Stevens allegedly screwed up by getting arrested on a delivery, Cohen slugged and thrashed him into a bloody daze as well. "I couldn't admit, even to myself, that Mickey had done this—had beaten me," Stevens recalled. "Almost immediately I'd substituted his rationalization— that he'd done this 'for my own good,' so I'd 'pay attention'—for the blunt reality of his psychopathic behavior."210

Police were well acquainted with—and deeply frustrated by — Cohen's slipperiness. The LAPD continued to find him "a vexing enigma." The FBI decided he was useless as an informant: "These Agents report that Cohen has held back information, has been evasive, misleading, two-faced and ingratiating. Los Angeles suggests that Cohen may pretend to act as an informant simply to try to obtain information from the 
bureau." Another memo noted that he had been known to kill in the past and "can be considered armed and dangerous.",211

Hecht, who was an early lay expert on psychopaths and had been writing about them since the 1920 s, never seems to have entertained the notion that he was dealing with one. He evidently had forgotten what his old friend Sherman Duffy had advised about a killer they had encountered at the county jail, when Hecht had asked how people could seem so good and then appear to change so suddenly and dramatically. "You'll find that's easiest thing people can do," Duffy had said, "change into swine."212

Moreover, Hecht had a considerable reputation to uphold as the tough Chicago crime reporter who was nobody's fool. True, he had written many stories about himself as the naïve and gullible cub reporter who would swagger into a brothel "playing the drunkard and whoremonger with all the vocabulary at my command," only to spend the evening clutching the hand of some fallen girl, imploring her to reform. But that was the boy reporter. He also told stories of the seasoned, jaded veteran, who barely blinks at the sight of a workman being sawed in half by a locomotive. One reviewer called his memoir "a cry from the soul of an armored car.",213

There is no specific diagnosis for "psychopathy" in contemporary psychology, but it falls within the broader category of Antisocial Personality Disorder, "a pervasive pattern of disregard for, and violation of, the rights of others," from childhood onward. Qualified experts today use a Psychopathy Checklist developed by Canadian psychologist Robert D. Hare to determine a diagnosis based on twenty criteria, including: "glib and superficial charm"; "cunning and manipulativeness"; "pathological lying"; "parasitic lifestyle"; "callousness and lack of empathy" and "lack of remorse or guilt.", 214 
Essentially, a psychopath is an individual who finds him or herself at war with the world, driven by a bottled-up rage or, perhaps, a pure malevolence. Lacking the normal depth of feelings for others, with the possible rare exception of, say, a mother or child, psychopaths see everyone around them as things to be used and discarded.

The theory of psychopathy may be the closest mainstream science comes to acknowledging the existence of evil, and indeed has long been criticized as too dependent upon value judgments. In rebuttal, proponents of the theory like Dr. Hare point to a growing body of empirical evidence. In recent decades, tests seem to indicate that psychopaths possess a smaller amygdala - the portion of the brain that registers anxiety and fear-than the rest of the population. This has reinforced the long-held view that psychopaths can never "mend their ways," can never fundamentally change or redeem themselves, because they are biologically different, almost a different species than the rest of humanity. ${ }^{215}$

This also suggests profound socio-political implications: If psychopaths are indeed as fearless as they are ruthless, and if, as the theory maintains, they are cunning and manipulative and see the world in terms of winners and losers, than high concentrations of them can likely be found at senior levels of government and top posts in the corporate food chain. They are likely to hold a position of power, such as a general in the military... or a boss in the underworld. In The Psychopath Test, the journalist Jon Ronson wrote that he was reminded of "a story I once did about a conspiracy theorist named David Icke, who believed that the secret rulers of the world were giant, blooddrinking, child-sacrificing lizards who had shape-shifted into humans so they could perform their evil on an unsuspecting population. I suddenly realized how similar the two 
stories were except in this one the people who spoke of snakes in suits were eminent and utterly sane psychologists, respected around the world."216

Hecht had expressed, even argued, many similar ideas for years. He had long held to the Hobbesian view of man as fundamentally barbaric and murderous. In Guide for the Bedevilled, for example, he had in effect explained Nazism as mass psychopathy, likening the psyche of Hitler's faithful to the killers he had met on death row. He had told many tales of the extraordinary cunning with which some murderers could convince you of their innocence. Yet somehow, when it came to Mickey, there was a blind spot.

He had noticed that Cohen had a trick: "It is that always...there are two Mickey Cohens talking. I have learned to listen to both at the same time.” There was the wild young Mickey who ran around insensible as a beast, who could split a head like a melon, and there was the sensitive Mickey, who yearned to be a good, normal person- the one who served hot chocolate and cookies to Reverend Graham. Hecht cautioned himself not to lapse into sentimentality, for gangsters have a talent for arousing in writers "a fellow sense of lawlessness - safe enough at the typewriter, or, worst of all, evoking in them a sort of boozy paternalism." Yet Hecht nonetheless concluded that the real Mickey who sat beside him was the gilgul, the soul waiting at the gateway of normal, decent life, just to be let in. ${ }^{217}$

Though Hecht had assured his sister-in-law that he was not sentimental about gangsters, he nevertheless had concluded, "The odds are three to one that Mickey, if not stopped by a bullet, will wind up a Rotarian." And he sometimes forgot himself completely, launching into full-throated tributes to his remarkable little friend: "He paid off on the dot and to the nickel. He fixed fights and let his pals in on the take. He 
operated hideaway gambling rendezvous where the dice, wheels and cards were as on the level as any operator could afford to have them. One the side he beat up Nazi propagandists, staked bums to binges, never overlooked the birthday of a policeman's kid, paid medical for all wounded supporters and was good for a touch anybody who smiled and said, 'Hello, Mickey.",218

These reveries were interrupted by Rose, and at least as consequentially, by Dean Jennings. The Saturday Evening Post writer had also noticed there were two different Mickeys, but he drew far different conclusions about them. He noted that Cohen had summed the matter up himself, in responding to syndicated columnist George Sokolsky, one of his fiercest critics. "I will not deny that at one time in my life, I was a pretty fair replica of the devil," Cohen wrote. "But today I am Michael Cohen, and every day I have to wrestle with Mickey Cohen." Jennings felt the claim that the old villainous Mickey lay dead and buried somewhere was "not quite compatible with the facts."219

"There is nothing in this world that shouldn't be done for a friend," Cohen later told the journalist, "and there is nothing in this world that shouldn't be done to an enemy." While Jennings's mind ran through all the pistol-whippings and murders that had been tied to his subject over the years, he asked just what should be done to an enemy. A small, sinister smile rippled across the gangster's face, but then Cohen just shrugged and replied that he had learned in recent years to be more of a diplomat. Jennings looked around the apartment, at the stocks of soap for washing and bottles of colognes for clearing up bad odors. Everywhere he looked, he felt that he saw the evidence of "the turbulent conflicts between Michael Cohen, the gentleman-diplomat, 
and Mickey Cohen, hoodlum — he once admitted he has to struggle with this Jekyll-Hyde problem every day. ${ }^{220}$

In September 1958, one month after Minna Emch's last letter to Hecht, the appearance of the first installment of Jennings' Saturday Evening Post series somewhat settled the debate over Cohen's character. Hecht and Cohen had agreed to a fifty-fifty split on the biography, but Cohen had gone behind Hecht's back to do the series for the Post, with its three million subscribers. Jennings' stories themselves imparted further revelations of betrayal, revealing that Cohen had been going behind his friend's back for months, selling over $\$ 100,000$ in shares for a non-existent movie that Hecht was supposed to write. $^{221}$

The Saturday Evening Post billed the series as "a revealing clinical study of a shameful American paradox," and Jennings' main thrust was that Mickey Cohen had manipulated the press and public, turning his celebrity into a jackpot. Figures on how much money he had taken Reverend Billy Graham's supporters for have ranged, but according to W.J. Jones, a wealthy member of the reverend's board of directors, $\$ 18,000$ was the price tendered for Mickey Cohen's soul. Jim Vaus had personally kicked in an additional \$5,000. Naturally, the Graham camp was disappointed when Cohen had not come to Jesus, but as Cohen pointed out, they had profited from his big name - as had he. ${ }^{222}$ All of this, however, along with the appearance on The Mike Wallace Interview and the thousands of headlines, had been mere stepping stones to Cohen's big cash cow: Ben Hecht.

As Jennings pointed out, Cohen's effort arguably originated back in 1947, when the two had first partnered to raise money for the Irgun. Los Angeles businesswoman 
Ruth Fisher, who had invested $\$ 7,500$ in the movie, told the journalist: "I first heard about Mickey when I was on a trip to Israel, and I'm one of the few people who can see his good side.” A psychiatrist named Dr. Leonard Krause, as curious about Cohen's psychology as Hecht and Dr. Emch, had invested more than $\$ 25,000$. "I was very impressed by Mr. Cohen," he said. "He is a gentle and nice fellow." Underworld attorney Bieber had also dropped $\$ 25,000$, as did retired Nashville shoe manufacturer Max Feigenbaum, and a man in the appliance trade named David Krause. Smaller fish eager to get in on the action included jukebox dealer A.V. Stemler $(\$ 15,000)$ and a carhop, who was repaid $\$ 3,000$ out of the $\$ 10,000$ he loaned. ${ }^{223}$

Back in March, during the same month that the two friends had gone on their fishing trip, Cohen had approached IRS agent Guy McGowen with an offer. The U.S. government could get the first $\$ 50,000$ from the book and movie deal, Cohen suggested, and he would keep the second $\$ 50,000$. The feds could keep the rest of the money after that. The catch was that in the meantime, Cohen would have to maintain his lavish lifestyle as a necessary business expense. "I must keep up a front," he explained. "My only asset is the motion picture. If I lowered my living standards it would take away my reputation. If I was to make myself unknown I'd be out of the picture." To Jennings, he had added: "You can't expect Mickey Cohen to go around like a three-dollar-a-daybum." By late September Cohen was still pushing the movie, now appropriately titled Flim Flam. $^{224}$

And this, in the end, was Jennings point: Cohen had played everyone like a violin, and used the media - namely, the journalists — to do it. Casting aside any precedent that might have been set by Al Capone, Jennings asserted: "Mickey Cohen—and this is what 
makes him stand alone in organized crime-shrewdly and deliberately courted the press." Now that Cohen was free from jail, he and the publicity-mad city of Los Angeles were stuck together, "like two ends of a dumbbell."225

The series ended portentously with a quote from a revenue agent: "We have to move slowly...Don't think that the Government isn't on top of the whole thing." Whether or not the articles pushed the impending prosecution of Cohen along or, as has been suggested, sealed his fate, Jennings certainly helped all he could to deliver the longest sentence ever given for tax evasion: fifteen years, three years longer than what had been given to Al Capone. "Dean Jennings may as well have been a federal agent," said Post columnist Al Aronowitz, "because his testimony later helped send Mickey to Alcatraz." If Cohen was indeed a manipulative psychopath who had long used journalists for his own ends, he had met his match. "That cocksucker," said Mickey, in the biography that he finally did publish. "I really believed Dean Jennings was my friend.,226

The fiasco of the book and movie served as the central drama of Cohen's sensational, star-studded trial in 1961, which lasted forty-one days and included testimony from 194 witnesses. Hecht told the court that he had first learned from Jennings that Cohen was selling shares in a movie. "I couldn't believe anyone would be stupid enough to buy into a non-existent property," he testified. "I told Cohen what Jennings had told me. He didn't admit it or deny it, but I knew what the silence meant."227

An appeals court was equally amazed that Cohen had been able to acquire such large sums from such an extraordinary variety of people, rich and poor, famous and unknown. "The particular brand of magic that he used in obtaining these moneys does not 
always appear," the judgment said. "That there was fraud involved in many instances is plain." Perhaps it would have been unfair, but someone might have asked Hecht why he too had been stupid enough to invest so much—so many weeks or months of his life-in the same project as every other sucker. The answer would have been no different for him than for the others, for he had also been won over by Mickey's magic charms. He had described Cohen as "a small, half-clownish disturber of life" to his sister-in-law, but not only had he and the esteemed psychiatrist misread his 'dese, 'ems and 'dose buddy, he had underestimated him as well. ${ }^{228}$

Two explanations have been given for why Hecht dropped his own book after the Saturday Evening Post stories appeared. Rose told Sidney Zion that it was "partly because of a brilliant, questioning letter" that Ben received from Minna on her deathbed. The more popular explanation is that for legal or commercial reasons - it is never entirely clear which — the series rendered Hecht's story worthless, and the additional, obvious implication is that Cohen had violated the author's trust and friendship. But Hecht never seems to have affirmed either of these explanations - he continued to speak of the book as something he might want to finish, and remained friends with Mickey. ${ }^{229}$

Neither explanation gives any weight to the influence that Rose might have had, nor does it take into consideration two other factors that may have been importantHecht's pride, and the pall that the whole episode cast upon his prospective book. Jennings may have stopped short of openly deriding Hecht, but his narrative has Cohen playing all the reporters and media interests as pawns, leading up to his bamboozling of the biggest, most hardboiled reporter of them all. For the climax of the Post series, Jennings suggested that all of Cohen's publicity-making put the mobster in a position to 
turn the reputation of the tough old Chicago newsman and screenwriting legend into his own personal gold mine. Particularly after all the additional attention that Cohen's trial gave to his $\$ 100,000$ fundraising adventure, Hecht's attempt to use Mickey “as a fresh (and happily cockeyed) view against society" may not have played so well—especially since in the end it seemed that he was the one who had been used. Much of the reading public would likely see what his own wife had seen: an author "dangerously infected by his character's point of view."

What she had suggested, with her comments about England's angry young men, and about his views on corruption, was that her husband had been blinded by his own cynicism to what Cohen really was. Hecht was so caught up railing against his democratically elected government that he had let the wolf in through the front door. Yes, Hecht had always been like that, but it had never been sane. Back in the days of Erik Dorn, he had, in Algren's view, run out of belief. In the 1940s, his liberal critics had called this lack of belief fascism.

When he first set aside the Cohen biography in the fall of 1958, Hecht had plenty else to think about — his new television program was now on air, putting him in contact on a nightly basis with some of the most iconic figures of the era. The evening with legendary crime photographer Weegee was like a meeting of two long-lost brothers. Reminiscing about what had endeared him to Murder Incorporated, Weegee said: "I was a freelance photographer and I had one stiff a night. I could live, with blintzes, coffee, hot tea with lemon." He recalled that after Dutch Schultz was gunned down, he had disguised himself as a doctor- "I had more uniforms than Willie Sutton"- to snap photos of the 
corpse. The two old newspapermen discussed the perfect murder, women killers, more gangsters and, of course, Mickey Cohen.

W: Mickey Cohen? There you go name dropping again.

BH: I can't help it.

W: I tell you Mickey Cohen is the future of the murder business. Gangsters and so forth.

BH: Well I think he's the past. He's a very good boy now. He sells flowers.

W: Flowers? For funerals?

BH: No, for weddings.

W: All the gangster friends could get their flowers from him. They could open charge accounts. Hey, that's a new angle.

BH: Now Weegee, tell me, what was the most vicious murder you ever ran into?

W: One of the early ones of Murder Incorporated, they took a guy in a lot in Brownsville, they tied him up with wires and poured kerosene on him and set him on fire. The guy was alive, mind you. As he tried to free himself, he would just strangle himself more.

BH: Why did they do that? They must have been sore at him. ${ }^{230}$

The program also gave Hecht the opportunity to connect with the new wave of writers. The major disagreement that finally ended the show was WABC-TV's refusal to let Hecht interview Norman Mailer about his recently published essay, "The White Negro." The opening lines of Mailer's piece suggests the sweeping postwar context he would provide to explain a new, defining cultural figure - the hipster, and a new cultural divide between the worlds of the "hip" and the "straight": "Probably we will never be able to determine the psychic havoc of the concentration camps and the atom bomb upon the unconscious mind of almost everyone alive in these years." ${ }^{231}$

Like Hecht, Mailer argued that the criminal was the only true social rebel left in the land. But Mailer, taking his cue from a drift towards narcissism that he had observed in rebels of the postwar era, focused specifically on the notion of the hipster as 
psychopath. Unlike their predecessors from the 1930s, the new generation of rebels had no collectivist idealism, no socialist program to believe in. Mailer's essay explored this idea at length; he used the word psychopath forty-six times and quoted from Robert Lindner's book on the topic: "The psychopath is a rebel without a cause, an agitator without a slogan, a revolutionary without a program: in other words, his rebelliousness is aimed to achieve goals satisfactory to himself alone." ${ }^{232}$

Although the station management deprived Hecht of the chance to discuss these ideas with Mailer, Jack Kerouac's appearance allowed Hecht to compare notes with the leading representative of the Beat Generation. Hecht started with a line from Kerouac's 1950 debut novel The Town and the City: "Everyone feels like a Zombie, and somewhere at the ends of the night, the great magician, the great Dracula-figure of modern disintegration and madness...the Devil if you will... is running the whole thing." Hecht felt the passage expressed the way he had often felt about the world, but wasn't sure if their devils were the same. Kerouac, however, was coy. He said only that the words belonged to one of his characters, and did not reflect his own views at all. ${ }^{233}$

Their exchange was cordial, but Hecht struggled much of the time to find common ground with his mercurial guest. Finally, he asked: "What do you think about people who don't climb the mountain, don't have mysticism, people like me, on a treadmill, always trying to make a little money?" This elicited a surprising response. "No you lived a wonderful life," Kerouac said. "I could write a book about the way you lived —newspaperman, traveling around writing scripts, plays, everyone throwing roses at you." With that last phrase, Hecht wondered if maybe once again he was being derided as a sellout, but Kerouac assured him this wasn't the case. 
By 1964, his daughter Jenny was a twenty-one-year-old actress living on her own in Greenwich Village, a "wildly beautiful, stormy-looking blonde girl," as Doubleday editor Margaret Cousins remembered her. A member of the Living Theater, she would die less than a decade later of either a suicide or drug overdose. "Ben was devoted to Jennie and liked to go to her apartment and hang around with her young friends," recalled Cousins. "He dug kids — who were just beginning to revolt and demonstrate — and acquire various other habits. What I mean is that he was not old in his mind or attitudes, although he did not entirely approve of the way the world was going.",234

Meanwhile, Mickey Cohen's luck had finally run out. Having lost his appeals, he was sent to Alcatraz on May 15, 1962, but transferred to a federal penitentiary in Atlanta a month before Attorney General Robert F. Kennedy closed "the Rock" in March 1963. On August 14, fellow convict Burl Estes McDonald clubbed him with a three-foot iron pipe, splitting the back of his skull with a wound that was six-inches long by three-inches wide, driving fragments of bone into his brain. Cohen somehow survived with his mental facilities intact after a two-week coma, but was wheelchair-bound for the rest of his life. When he sued the U.S. government for $\$ 10$ million, prison authorities were hard-pressed to explain how Estes had managed to escape his own maximum-security facility, scale a fence and penetrate the building that housed the general population. Cohen was awarded a judgment of $\$ 110,000$, but the IRS immediately garnished the entire sum. ${ }^{235}$

"I received your most appreciated book tonight," he wrote Hecht on February 12, 1964, "and the few words that you wrote to me on the inside of the book was better and done more for me then all the medicine and treatment that the doctors could possibly prescribe." In March, he wrote at length of how much he and other prisoners had enjoyed 
reading Gaily Gaily. "The more I think of it the harder I can kick myself in the rear end for not staying with you and for not nudging you more to get our book to an end," he added. "I would of stayed out of here, and wouldn't have wound up a cripple for the rest of my life. But I guess that is the way the ball bounces."236

Hecht had written on March 17. "You are not in the only jail there is. There is another jail called 'old age' in which I am beginning to serve time," he wrote. A month later, on April 18, 1964, he collapsed from a heart attack in his dressing room. Rose found him lying on the ground and held him. She tried to keep him breathing, but the color drained from his face. Shortly after he passed, she went downstairs and sat with Jenny, who had just arrived home with friends. "Every once in a while I went back to the room where he lay in our great bed and I kept on talking to him and telling him how dear he was, still in broken Yiddish," Rose recalled. "Except for a lullaby I used to sing to Jenny I had never spoken of love in the mother tongue. I felt these words would reach his soul. I guess that is what it means to be a Jew."237

The funeral service at Temple Rodeph Sholom on West Eighty-Third Street was packed. Peter Bergson delivered a eulogy, as did Menachem Begin, who came with a delegation from Israel. "I kept thinking how it would all have amused Ben," said Cousins. "And I kept hoping that wherever he had got to, he would find the rest of them - that his friends were waiting for him somewhere, with booze and nefarious plans. Something that much alive couldn't just disappear."238

\footnotetext{
${ }^{1}$ Mickey Cohen, In My Own Words, 89-91.

${ }^{2}$ Hecht, $A$ Child of the Century, 610.

3 "The Combination..." Robert Lacey, Little Man: Meyer Lansky and the Gangster Life, 1st ed (Boston: Little, Brown, 1991), 10-11. Had ordered Cohen back home... Mickey Cohen, In My Own Words, 35. Samuel "Nails" Morton, "Big Jack" Zelig... Robert A. Rockaway, But He Was
} 
Good to His Mother: The Lives and Crimes of Jewish Gangsters (Jerusalem: Grefen, 2000), 220224. "It was not simply an aspect of protecting one's turf..." ibid, 221. See also Rose Keefe, "Big Jack Zelig, Lower East Side Gang Leader," on J-Grit.com, “The Internet Index of Tough Jews.” http://www.j-grit.com/big-jack-zelig-lower-east-side-gangster.php

${ }^{4}$ Mickey Cohen, In My Own Words, 67-68. Criminal record, anti-Racketeering FBI field office file, 92-106, October 8, 1960, on Meyer Harris Cohen, pp. 11-13 in FBI file 92-HQ-3156, Part One, 19-21. "Accused of Libel on Gen. M'Arthur," New York Times, April 1, 1942; "Noble, Jones Face 3 Sets of Charges," New York Times, April 2, 1942; "Sentenced for Roosevelt Libel," New York Times, May 20, 1942; Louis Nizer, "What to Do When a Judge Is Put Up Against the Wall," New York Times, April 5, 1970. Colin S. Hoffman, Conspiratorial Politics: The Friends of Progress and California's Radicals of the Right During World War Two (B.A. Thesis, University of California, Davis, 2004), 87.

${ }^{5}$ Mickey Cohen, In My Own Words, 68; Colin S. Hoffman, Conspiratorial Politics.

${ }^{6}$ Dean Southern Jennings, We Only Kill Each Other: The Life and Bad Times of Bugsy Siegel (Englewood Cliffs, N.J: Prentice-Hall, 1967), 74-76. Robert Lacey attributes Jennings' story to Siegel's friend George Raft, the movie actor. See Little Man, 112. Countess Dorothy di Frasso's niece was Mary "Mimi" Taylor, the model and actress with whom Hecht was carrying on an affair. Hecht and Siegel may therefore have been personally acquainted. Since they would have known each other through Hecht's mistress, it is unlikely that Hecht would have written of the connection. Mary Elizabeth Plummer, "Winsome Bachelor' Girls of U.S. Await Right Man," Associated Press wire story, The Bee (Danville, Va.), August 17, 1936, 2.

${ }^{7}$ Dean Jennings, We Only Kill Each Other, 77.

${ }^{8}$ Robert Lacey, Little Man, 114-127; Timothy Newark, Mafia Allies: The True Story of America's Secret Alliance with the Mob in World War II (St. Paul, Minn.: Zenith Press, 2007), 89-111, 152-154; Uri Dan, Dennis Eisenberg, and Eli Landau, Meyer Lansky: Mogul of the Mob (New York: Paddington Press, 1979), 186-223. Much about this alliance was documented in the Herlands Report of 1954 commissioned by New York Governor Thomas E. Dewey, who as a federal prosecutor had originally put Luciano away. Mogul of the Mob quotes Lansky at length on ferreting out Nazi spies from West Side hotels, restaurants in Yorkville, and a gay brothel near the Brooklyn Navy Yard. See pp. 195 and 199. Lansky's recollections were first published in Uri Dan's three-part series "Meyer Lansky Breaks His Silence" in Ma'ariv in July 1971. Questions have been raised about the veracity of Mogul of the Mob, but the Herlands Report corroborates at least some of these accounts. See for example Mafia Allies, p. 105. For doubts about Mogul of the Mob, see Robert Rockaway, "American Jews and Crime," American Studies International 38, no. 1 (February 2000): 29.

${ }^{9}$ Uri Landau et al, Mogul of the Mob, 184.

${ }^{10}$ Ibid, 184-185; Robert Rockaway, But He Was Good to His Mother, 228-229; Robert Lacy, Little Man, 113.

${ }^{11}$ Luther Huston, "Bund Activities Widespread/Evidence Taken by Dies Committee Throws Light On Garden Rally," New York Times, February 26, 1939. "Nazi Secrets in U.S. Told by Times Men," Chicago Daily Times, September 9, 1937. The Bund published newspapers... Timothy Newark, Mafia Allies, 271. “...And we didn't behave like gents.” Uri Dan et al, Mogul of the Mob, 185; Robert Rockaway, But He Was Good to His Mother, 229.

${ }^{12}$ Uri Dan et al, Mogul of the Mob, 185-186. "Seven Injured at Nazi Rally Here When Legionnaires Heckle Speaker," New York Times, April 21, 1938; Timothy Newark, Mafia Allies, 74-75, citing "Veterans Fight Nazis on Hitler's Birthday," New York Herald Tribune, April 21, $1938,1,7$.

${ }^{13}$ Uri Dan et al, Mogul of the Mob, 186.

${ }^{14}$ Ibid; Lansky interview with Robert Rockaway in But He Was Good to His Mother, 230-231. 
${ }^{15}$ Hecht, "The Incomplete Life of Mickey Cohen" in Scanlan's, 65. On challenging the distinction between lawmaker and lawbreaker, see for example Menachem Begin, The Revolt, 37, and Israel Eldad, The First Tithe, 155. Going so far as to urge the use of chemical weapons... Louis Rapoport, Shake Heaven and Earth, 91; Judith Tydor Baumel, The "Bergson Boys, " 149150, 213. Like Hecht and Bergson, Alex Rafaeli was also deeply concerned with the issue of war crimes. In his memoir Dream and Action he recounts that as an officer with the U.S. Army's Counter Intelligence Corps, he was responsible for the capture and indictment of Alfried Krupp, one of Germany's major munitions manufacturers. Krupp was convicted in 1948 of crimes against humanity for his participation in Germany's aggression, the plundering of occupied lands, and the barbaric treatment of concentration camp inmates, who were used for slave labor.

16 "Simple, primitive, black-and-white propaganda..." Richard Watts Jr., "Koestler's Novel of Zionism," November 3, 1946, 158. "Relaxing bed-time story..." Hecht, "The Incomplete Life of Mickey Cohen," 58.

${ }^{17}$ Hecht, "All Day He Fell," labeled "First Draft, February 6, 1959," p. 1, in "Cohen, Mickey, MS Draft, 1958-1959," Works, 1908-1983, Box 7, Folder 220, BHNL.

${ }^{18}$ Hecht, Charlie, 23. Hecht, "Lament for a Lost Bohemia," New York Times, January 12, 1958. Doug Fetherling, The Five Lives of Ben Hecht, 170-171.

${ }^{19}$ Letter from Margaret Cousins, Hecht's editor at Doubleday for Gaily Gaily, to Stephen Fuller, aka William MacAdams, February 4, 1976, p. 2 of 3, Folder 378, MacAdams Collection. Doug Fetherling, The Five Lives of Ben Hecht, 168.

${ }^{20}$ Letter to Hecht Minna Emch, postmarked July 3, 1958, "Emch, Minna to Ben, n.d., 19441958," in Family Correspondence, 1915-1976, Box 71, Folder 2223, BHNL. William MacAdams, The Man Behind the Legend, 270. MacAdams reports that Hecht signed with Henry Holt and Company in January 1958 to write Soul of a Gunman.

${ }^{21}$ Hecht, Perfidy, 44-208; Lucy Dawidowicz, "Ben Hecht's Perfidy," Books In Review, Commentary, March 1962, 260-264; Menachem Z. Rosensaft, "A ghost of the Holocaust who continues to haunt," On Faith, Washington Post, May 22, 2013. http://www.washingtonpost. com/blogs/on-faith/wp/2013/05/22/a-ghost-of-the-holocaust-who-continues-to-haunt/

${ }^{22}$ Hecht, Perfidy, 104. Menachem Z. Rosensaft, "A ghost of the Holocaust who continues to haunt." Ralph Blumenthal, "Once Reviled as Nazi Collaborator, Now a Savior," New York Times, October 21, 2009. Shoshana Barri, "The Question of Kastner's Testimonies on Behalf of Nazi War Criminals" Journal of Israeli History 18, no. 2-3 (1997): 139-165.

${ }^{23}$ Lucy Dawidowicz, "Ben Hecht's Perfidy," 262. Some 8.7 million Red Army soldiers fell... Soviet Casualties and Combat Losses in the Twentieth Century (London: Greenhill Books, 1997), 79. Other historians put the figure far higher. Hecht, Perfidy, 208-247. Ralph Blumenthal, "Once Reviled as Nazi Collaborator, Now a Savior," New York Times, October 21, 2009. http://www. nytimes.com/2009/10/22/nyregion/22survivors.html Gaylen Ross, Killing Kasztner (Brooklyn: GR Films, 2008). http://www.killingkasztner.com/

${ }^{24}$ Uri Dan et al, Mogul of the Mob, 10.

${ }^{25}$ David O'Delll, Ben Hecht - The Shakespeare of Hollywood, DVD.

${ }^{26}$ Hecht, "Speeches - [To the Crew of the SS Ben Hecht) - 1947," in Works, 1908-1983, Box 27, Folder 689, BHNL. "Men of 'Ben Hecht' Get Hero Welcome," New York Evening Post, April 14, 1947, 20.

${ }^{27}$ Hecht, "Letter to the Terrorists of Palestine," New York Herald Tribune, May 15, 1947, 17. Edward G. Robinson, All My Yesterdays; an Autobiography (New York: Hawthorn Books, 1973), 156. Louis Rapoport, Shake Heaven and Earth, 203.

28 "Halt in Palestine Agitation Here Requested by Truman," New York Times, June 6, 1947, 1. "Funds for Terror," Newsweek, June 16, 1947, 30, quoted in Gil Troy, From Literary Gadfly to Political Activist, 113. "Driving Backward," editorial, Chicago Daily News, May 21, 1947, 18. 
“The Latest Tragedy," editorial, New York Herald Tribune, May 20, 1947, 28. William A. Kirk, "Crime and Violence," and Alice E. Holden, "Sympathy Alienated," in "Ben Hecht's Letter on Palestine Terrorism Backfires," letters column, New York Herald Tribune, May 18, 1947, 7.

29 "Hecht Views Decried By 2 Jewish Groups," New York Times, June 5, 1947, 17. Mardoqued Salomon, M.D., "Zionist Aims and Ideals," letter to the editor, New York Herald Tribune, 28. C.V.R. Thompson, "For a year I've wanted to say this," editorial column, Daily Express, March 20, 1947, 2. George Lichteim, "Seeking an Easy Target," editorial, Daily Express, November 2, $1948,4$.

30 "Winchell calls us Brutish," Daily Express, May 23, 1947, 1. Leonard Lyons... Gil Troy, From Literary Gadfly to Political Activist, 112, 157, endnote \#54; Louis Rapoport, Shake Heaven and Earth, 203. J.M. Winnetka, "With Ben Hecht on Palestine," letters column, Chicago Daily News, May 24, 1947, 14. Marion Kuhn, "Why Irgun Fights," New York Herald Tribune, May 23, 1947, 24.

${ }^{31}$ Hecht, "Speeches - [To the Crew of the SS Ben Hecht) - 1947."

${ }^{32}$ Ibid.

33 "U.S. Zionists Fight Seizure of Vessel," New York Times, March 9, 1947; “U.S.-Manned Refugee Ship Siezed at Haifa with Crew," New York Times, March 10, 1947. A kind of Trojanhorse mission... Louis Rapoport interview with Hillel Kook, cited in Shake Heaven and Earth, 202. Rafael Medoff, Militant Zionism, 160-163. "Britannia Waives the Rules/British Jail

American Seamen in Palestine. Who is Breaking What Law?" advertisement, New York Evening Post, March 19, 1947, 40. "Men of 'Ben Hecht' Get Hero Welcome," New York Evening Post.

${ }^{34}$ Judith Tydor Baumel, The “Bergson Boys," 223. "Hecht Ill," Daily Express, June 14, 1947. Hecht, A Child of the Century, 615. Gil Troy, From Literary Gadfly to Political Activist, 115, quoting from Hecht, "Requiem for Three," PM, July 30, 1947. Menachem Begin to Hecht, Tammuz, 5707 (June-July, 1947), "Begin, Menachem, n.d.," Incoming Correspondence, 19141979, Box 55, Folder 1059, BHNL. Gruner had been hanged along with three others. Hecht's "Requiem for Three" was in response to the execution of three Irgunists on July 26.

${ }^{35}$ Hecht, The Terrorist, reprinted in The Answer, September 19, 1947, Section 2, 1-8, in "IsraelThe Answer, April 1943 - July 2, 1948," Subject Files, 1919-1981, Box 77, Folder 2345, BHNL.

${ }^{36}$ Ibid. "4 Dead in Police Raid on Ramat Gan," and "Official Communique," Palestine Post, April 25, 1946, 1.

${ }^{37}$ Hecht, The Terrorist, 4.

${ }^{38}$ Ibid, $4-8$.

${ }^{39}$ A chain of reprisals... The Irgun launched dozens of attacks over the next three months, but most notably there was the Acre Prison jailbreak on May 4, 1947, and the hanging of the British sergeants Clifford Martin and Mervyn Paice. See for example J. Bowyer Bell, Terror Out of Zion, 199-238. A "scathing letter"... Yitshaq Ben-Ami, Years of Wrath, Days of Glory, 424-425.

Hecht's discharge from the hospital in June and upcoming surgery in July were reported under "Sundry Gleanings," in Sam Zolotow, "Lee, Huston To Do a Play On the Circus," New York Times, June 23, 1947.

${ }^{40}$ Mickey Cohen, In My Own Words, 89=91; Hecht, A Child of the Century, 610-611.

${ }^{41}$ Yitshaq Ben-Ami, "Gangsters Contributed \$60,000 in Cash," Jewish Week and the American Examiner, 3. Mickey Cohen, In My Own Words, 91-92.

${ }^{42}$ Yitshaq Ben-Ami, "Gangsters Contributed \$60,000 in Cash."

${ }^{43}$ Benny Morris, "Lashing Back - Israel's 1947-1948 Civil War," Military History Quarterly (Spring 2009). http://www.historynet.com/lashing-back-israel-1947-1948-civil-war.htm Benny Morris, The Birth of the Palestinian Refugee Problem Revisited, 2nd ed. (Cambridge, UK ; New York: Cambridge University Press, 2004), 16-17, 36, endnote \#7. Howard Morley Sachar, A History of Israel: From the Rise of Zionism to Our Time, 3rd ed., rev. and updated (New York: 
Knopf, 2007), 299-300. Leonard Slater, The Pledge (New York: Simon and Schuster, 1970), 129, 132, 182-183, 208. Letter from Samuel Merlin to Hecht, December 30, 1947, "Merlin, Samuel (Sam), n.d., ca. 1938-1971," Incoming Correspondence, 1914-1979, Box 60, Folder 1472, BHNL. ${ }^{44}$ Mickey Cohen, In My Own Words, 89, 92. Uri Dan et al, Mogul of the Mob, 295-296; Robert Lacey, Little Man, 163. On Charley "the Jew" Yanowsky... Nathan Ward, Dark Harbor: The War for the New York Waterfront, 1st ed (New York: Farrar, Straus and Giroux, 2010), 169-171; James Terence Fisher, On the Irish Waterfront: The Crusader, the Movie, and the Soul of the Port of New York (Ithaca: Cornell University Press, 2009) 145-146; Ginger Adams Otis, "Inside New York's 'Waterfront' Mob," New York Post, June 20, 2010. Robert Rockaway, But He Was Good to His Mother, 231, 246-247. Ricky-Dale Calhoun, "Arming David: The Haganah's Illegal Arms Procurement Network in the United States, 1945-49," Journal of Palestine Studies 36, no. 4 (Summer 2007): 28. "We knew he was running guns..." Sidney Zion, "Luciano a Genius? No, My Jews,” Daily News, December 3, 1998. http://www.nydailynews.com/archives/opinions/ luciano-genius-jews-article-1.818998

${ }^{45}$ Uri Dan et al, Mogul of the Mob, 295-296; Robert Lacey, Little Man, 163. Mickey Cohen, In My Own Words, 92-93.

${ }^{46}$ Robert I. Friedman, The False Prophet: Rabbi Meir Kahane--from FBI Informantto Knesset Member, 1st ed (Brooklyn, N.Y: Lawrence Hill Books, 1990, 35-37). Rafael Medoff, Militant Zionism, 202-205. Hecht, A Child of the Century, 609.

${ }^{47}$ Mickey Cohen, In My Own Words, 92. Yitshaq Ben-Ami, "Gangsters Contributed $\$ 60,000$ in Cash." Paul Gropman interview with the author, August 2013. Rafael Medoff, "An Unorthodox Rabbi on Capitol Hill: The Legacy of Rabbi Baruch Rabinowitz," Jewish Action (Spring 2004). http://www.ou.org/publications/ja/5764/5764spr/PROFILE.PDF

48 "Come and Salute the Colors of Hebrew Freedom," advertisement, New York Evening Post, May 3, 13. "U.S. To Deny Visas in Palestine Clash," New York Times, March 31, 1948. Gil Troy, From Literary Gadfly to Political Activist, 117. See also Isaac Zaar, Rescue and Liberation: America's Part in the Birth of Israel (New York: Bloch Pub. Co, 1954) and Jeffrey Weiss and Craig Weiss, I Am My Brother's Keeper: American Volunteers in Israel's War for Independence 1947-1949 (Atglen, PA: Schiffer Military History, 1998).

49 Jeff Wheelwright, “How Punchy Was Slapsy Maxy?” Sports Illustrated, April 11, 1983. http://sportsillustrated.cnn.com/vault/article/magazine/MAG1120714/

${ }^{50}$ Hecht, "The Underworld Kicks In," in A Child of the Century, 611-613. "Wellpott Heard Phone Recordings of Own Voice, He Tells Grand Jury," Los Angeles Times, August 10, 1949, 2-3.

51 "Witness Tags Cohen as Debt Welsher," Los Angeles Times, June 8, 1951, 1, 4. "Speeches: [Delivered at Slapsie Maxie's - Financed by Mickey Cohen] ca. 1943 (sic)" in Works, 19081983, Box 27, Folder 683, BHNL. Patrick Goldstein, "Did Mickey Cohen really own Slapsy Maxie's nightclub?" The Big Picture blog, Los Angeles Times, December 1, 2011.

http://atimesblogs.latimes.com/movies/2011/12/a-hollywood-history-lesson-did-mickey-cohenreally-own-slapsy-maxies-nightclub-.html The May 24th, 1948 date is also reported in Dean Jennings' four-part, 1958 series on Cohen. See "Mickey Cohen: The Private Life of a Hood, Conclusion," The Saturday Evening Post, October 11, 1958, 118. Local history buffs have posted photos of the club, details about its remodeling by Don Loper, and information about clothier Sy DeVore. See for example the Southern California Architectural History and Tattered and Lost Ephemera blogs. http://socalarchhistory.blogspot.com/2011/01/william-krisel-and-georgealexanders.html and http://tatteredandlostephemera.blogspot.com/2013/02/san-francisconightclub-1944-slapsy.html An excellent, hard-to-find photo of the exterior can be found here: https://www.facebook.com/permalink.php?storyfbid=416910931710713\&id=117046218546

${ }^{52}$ Hecht, "Speeches: [Delivered at Slapsie Maxie's - Financed by Mickey Cohen] ca. 1943 (sic)," BHNL. 
${ }^{53}$ Jimmy Fratianno, interview by Mike Wallace, 60 Minutes, CBS, January 4, 1981. http://www. cbsnews.com/video/watch/?id=7405452n Ovid Demaris, The Last Mafioso: The Treacherous World of Jimmy Fratianno (New York: Times Books, 1981), . Fratianno and Demaris were slapped with a \$110-million defamation suit in April 1981 for the claim that a story about a sunken ship had been planted in the press at Cohen's request. Agnes Underwood, the now retired assistant managing editor of the Los Angeles Herald-Examiner whom Fratianno had named in his story, said she never even Mickey Cohen at the time, and complained that the mobster had smeared her lifelong reputation as a journalist. Fratianno then tried to sue Demaris, claiming that the words attributed to him in the book "were not (his) words or statements"- though this would do little to explain what he had told Wallace on television. A judge ultimately dismissed Underwood's libel case, concluding that the Fratianno's statement was mere opinion and could not be construed as fact. Myrna Oliver, "Retired Newspaper Editor Claims Book Defamed Her," Los Angeles Times, April 23, 1981, A9. Myrna Oliver, "Ex-Hit Man Takes Aim at Author," Los Angeles Times, November 25, 1981, A16. Myrna Oliver, "4 Dropped from \$110-Million Libel Suit," March 19, 1982, D3.

${ }^{54}$ Yitshaq Ben-Ami, "Gangsters Contributed \$60,000 in Cash," Jewish Week and the American Examiner, 3.

${ }_{55}$ Alex Rafaeli, Dream and Action, 160-162.

${ }^{56}$ Benny Morris, "Lashing Back - Israel's 1947-1948 Civil War," Military History Quarterly. Downplays the notion that the mob played any meaningful role... Leonard Slater, The Pledge, 133.

${ }^{57}$ Leonard Slater, The Pledge, 81-85, 127, 133, 196. Teddy Kollek, For Jerusalem: a Life, 1st American ed. (New York: Random House, 1978), 68-69. Robert Rockaway, But He Was Good to His Mother, 246-248. Uri Dan et al, Mogul of the Mob, 296. One clear sign of the connection between the Copacabana and Slapsy Maxie's was the entertainment: Jerry Lewis and Dean Martin were booked at the Copa within weeks of their performance in Hecht's pageant, and immediately before their long-running engagement at Slapsy Maxie's that launched their careers as Hollywood celebrities. See Jerry Lewis on performing at the Copacabana and Slapsy Maxie's: http://www.youtube.com/watch? $=6 \mathrm{~F} 2 \mathrm{wfBkErL0}$

${ }^{58}$ Leonard Slater, The Pledge, 63-65, 181-182. Uri Dan et al, Mogul of the Mob, 296.

59 “Arab Aides in U.N. Hail TNT Seizure," New York Times, January 10, 1948. Leonard Slater, The Pledge, 132, 171-172, 192, 321. Rafael Medoff, Militant Zionism, 207-209, 210-211.

${ }^{60}$ Mickey Cohen, In My Own Words, 92. Michael T. Benson, Harry S. Truman and the Founding of Israel (Westport, Conn: Praeger, 1997), 113. On Truman's sympathies and motivations, see also Michael Joseph Cohen, Truman and Israel (Berkeley: University of California Press, 1990).

${ }^{61}$ Ricky-Dale Calhoun, “Arming David," Journal of Palestine Studies, 31.

${ }^{62}$ C.V.R. Thompson, "Bernadotte Was an Ass, Hecht Says," Daily Express, September 25, 1948, 1. "Hecht's Films Under Ban," New York Times, October 14, 1948. Thomas F. Brady, "Britain Objects," New York Times, October 24, 1948. Letters to Hecht from Peter Bergson, "Bergson, Peter, 1941-1952, 1962," Incoming Correspondence, 1914-1979, Box 55, Folder 1069b, BHNL. Gil Troy, From Literary Gadfly to Political Activist, 118.

${ }^{63}$ Hecht, "Speeches: [Menachem Begin Welcome], n.d.," Works, 1908-1983, Box 27, Folder 687, BHNL. "Former Irgun Leader Sees Palestine Unity With Brotherhood Among Jews and Arabs," New York Times, November 30, 1948. “£12-A-Head Banquet Served With Hate,” Daily Express, November 30, 1948, 1.

${ }^{64}$ Hannah Arendt, Albert Einstein et al, "New Palestine Party/Visit of Menachen (sic) Begin and Aims of Political Movement Discussed," letter to the editor, New York Times, December 4, 1948, Books, 12. According to Benny Morris, between 110 and 120 villagers were killed at Deir Yassin. On the death toll, the motivation and orders for the operation against the village, and the 
reverberations, see Benny Morris, The Birth of the Palestine Refugee Problem, Revisited, 233240.

${ }^{65}$ Harry Kleiner, A Street With No Name, directed by William Keighley, starring Mark Stevens and Richard Widmark (Los Angeles: 20th Century Fox Film Corp., 1948). Trailer featured on Ben Hecht, Charles Lederer, Eleazar Lipsky and Philip Dunne, Kiss of Death, directed by Henry Hathaway, starring Richard Widmark and Victor Mature (Los Angeles: 20th Century Fox Film Corp., 1947), DVD.

${ }^{66}$ William MacAdams, The Man Behind the Legend, 270. Based on MacAdams interview with Frank Tashlin, the screenwriter who co-wrote Love Happy with Hecht.

${ }^{67}$ Estes Kefauver, Crime in America, 1st ed. (New York: Greenwood Press, 1968), 249. Tere Tereba, Mickey Cohen, 22. Hecht, "About Me, First," 19, "Cohen, Mickey, MS draft, 19581959," in Works, 1908-1983, box 7, folders 216, 219, BHNL. Hecht, "The Incomplete Life of Mickey Cohen," Scanlan's, 62.

${ }^{68}$ Paul Lieberman, Gangster Squad: Covert Cops, the Mob, and the Battle forLos Angeles, 1st ed (New York: Thomas Dunne Books/St. Martin's Griffin, 2012), 180, 202, 495. Dean Jennings, “The Private Life of a Hood, Part Two," The Saturday Evening Post, September 27, 1958, 110. Life published photos of him on numerous occasions, most famously a photo essay titled "Trouble in Los Angeles," Life, January 16, 1950, 75-85. Alas, the doggie bed photo is not included in the set Life has posted on the Interntet: http://life.time.com/crime/mickey-cohenphotos-of-a-legendary-los-angeles-mobster-1949/\#1

${ }^{69}$ Hecht, "Some Notes for Cohen Movie," 3-5; “About Me, First," folder 216, 9-10; "Cohen, Mickey, n.d., 1951-1976," in Subject Files, 1919-1981, Box 77, Folder 2341, BHNL. Mickey Cohen, "Own Story," unnumbered pages, in "(Other Writers) Cohen, Mickey - Mickey Cohen, Own Story, n.d.," Works, 1908-1983, Box 51, Folder 976, BHNL. Tere Tereba, Mickey Cohen, 65-69, 85. FBI file 62-HQ-89947, office memorandum to Mr. D.M. Ladd from A. Rose, "Michael 'Mickey' Cohen, information concerning," July 21, 1949, pp. 2-3.

70 “...miniature colossus...” Ted Prager and Larry Craft, Hoodlum (New York: Retail Distributors, 1959), 95. "Sure to draw gunfire..." Hecht, A Child of the Century, 611. On steel doors and secret compartments of Michael's Haberdashery... Mickey Cohen, "Own Story," unpaginated. Imported gabardine suits, camelhair coats, finely woven shirts and smoking jackets... Paul Lieberman, Gangster Squad, 93, 121; John Buntin, L.A. Noir: The Struggle for the Soul of America's Most Seductive City, 1st ed (New York: Harmony Books, 2009), 129. Around the corner was a chop shop... Tere Tereba, Mickey Cohen, 86.

${ }^{71}$ Hecht, "The Incomplete Life of Mickey Cohen," Scanlan's, 66, 72. Tere Tereba, Mickey Cohen, 86-88.

${ }^{72}$ A fleet of Cadillacs... Dean Jennings, "The Private Life of a Hood, Conclusion," 114; Ted Prager and Larry Craft, Hoodlums, 95-96; Tere Tereba, Mickey Cohen, 88-89. "If he had a coat of arms..." George Redston with Kendell F. Crossen, The Conspiracy of Death (Indianapolis: Bobbs-Merrill, 1965), 87.

${ }^{73}$ Mickey Cohen, "Own Story" unnumbered pages; Dean Jennings, "The Private Life of a Hood, Part Three," The Saturday Evening Post, October 4, 1958, 120; FBI file 62-HQ-89947, Office memo to FBI director from SAC, Los Angeles, October 30, 1950, 226-227.

${ }^{74}$ Mickey Cohen, "Own Story"; idem, In My Own Words, 2. Hecht, "The Incomplete Life of Mickey Cohen," Scanlan's, 60.

${ }^{75}$ Hecht, “About Me, First," 5, folder 219; “The Incomplete Life of Mickey Cohen," Scanlan's, 60; Florabel Muir, Headline Happy, 1st ed. (New York: Holt, 1950), 215-216. Mickey Cohen, In My Own Words, 6; idem, "Own Story."

${ }^{76}$ Hecht, "About Me, First," 5, folder 219; "The Incomplete Life of Mickey Cohen," Scanlan's, 60. Mickey Cohen, In My Own Words, 2-6. Trying to hold up a downtown movie theater... Tere 
Tereba, Mickey Cohen, 10-11, citing Jeffrey Feinman, Hollywood Confidential (Chicago: Playboy Press, 1976), 86.

${ }^{77}$ Hecht, “About Me, First," 5, folder 219; “The Incomplete Life of Mickey Cohen," Scanlan's, 60; Mickey Cohen, In My Own Words, 8, 64.

${ }^{78}$ Robert Rockaway, But He Was Good to His Mother, 44-47; Tere Tereba, Mickey Cohen, 14-16. Hecht, "About Me, First," folder 216, 7, 8; untitled manuscript, folder 217, 3; "The Incomplete Life of Mickey Cohen," Scanlan's, 60, 61. "The Jews supply the moxie..." Mickey Cohen, In My Own Words, opening epigraph.

${ }^{79}$ Hecht, "About Me, First," 37, Folder 216; “The Incomplete Life of Mickey Cohen," Scanlan's, 66.

${ }^{80}$ Mickey Cohen, In My Own Words, 11-14. John Buntin, L.A. Noir, 45, quoting Alva Johnston, "The Cauliflower King-I," The New Yorker, April 8, 1933, 24. Tere Tereba, Mickey Cohen, 15.

${ }^{81}$ Hecht, "The Philoolooloo Bird," The New Yorker, November 3, 1928. Hecht, "Testament of a Reporter," in 1001 Afternoons in New York, 367. William MacAdams, The Man Behind the Legend, citing Hecht, "The Rights That Failed," The Morning Telegraph, January 19, 1929. "The Money Lure," The Jewish Criterion, January 4, 1929, 42, reports that Hecht has been recruited by the Morning Telegraph to cover prize fights, and will join Ring Lardner on the payroll.

http://pjn.library.cmu.edu/books/CALL1/CRI_1929_073_009_01041929/vol0/part0/copy0/jpg/s $\mathrm{m} / 0042$-sm.jpg Hecht wrote that every morning at eight for twenty years he "punched the bag, did mat work and grunted lifting weights" under the eye of trainer Elmer Cole. See $A$ Child of the Century, 300.

${ }^{82}$ Hecht, "Letter to the Terrorists of Palestine," New York Herald Tribune, May 15, 1947, 17. Rob Edelman, "Boxing Writer Learned His Love of the Gloves as a Child," The Jewish Daily Forward, May 23, 2003. http://forward.com/articles/8860/boxing-writer-learned-his-love-of-thegloves-as-a/ The article reports that Budd Schulberg was about to be inducted into the Boxing Hall of Fame \& Museum on June 8, 2003.

${ }^{83}$ Hecht, "The Incomplete Life of Mickey Cohen," Scanlan's, 60. "I began to see that I really didn't have it..." Mickey Cohen, In My Own Words, 13-14. Cohen told Senator Estes Kefauver's committee investigating organized crime that he fought in thirty-two main events. See the full text of investigation of organized crime in interstate commerce, hearings before a Special Committee to Investigate Organized Crime in Interstate Commerce, United States Senate, Eightyfirst Congress, second session, pursuant to S. Res. 202. http://archive.org/stream/investigationofo 10unit/investigationofo10unit_djvu.txt Later he claimed to have fought seventy-nine bouts... John Hall, "The Old Fighter," Los Angeles Times, November 13, 1974, E3. One credible source... "Mickey Cohen," on BoxRec.com. http://boxrec.com/list_bouts.php?human_id=166332\&cat =boxer The record on the site appears to be relatively accurate and complete, consistent with what I could find reported in newspapers. One source of confusion is that there was a welterweight from Denver at the time who was also named Mickey Cohen - a far more successful boxer. "Decision Stuns California Boy," Cohen bout with Ollie Bartlett, Los Angeles Times, December 11, 1930. "Chalky Wright to Meet Cohan," Los Angeles Times, April 6, 1933. Associated Press, "Arizmendi Stops Cohen," Los Angeles Times, May 15, 1933, 11.

${ }^{84}$ Hecht, "About Me, First," 6, Folder 216; "The Incomplete Life of Mickey Cohen," Scanlan's, 60. Dean Jennings, "The Private Life of a Hood, Part One," The Saturday Evening Post, 86.

${ }^{84}$ Hecht, "About Me, First," 35, Folder 216; untitled manuscript, folder 217; "The Incomplete Life of Mickey Cohen," Scanlan's, 66.

${ }^{85}$ Hecht, "About Me, First," 35, Folder 216; untitled manuscript, folder 217; "The Incomplete Life of Mickey Cohen," Scanlan's, 66. 
${ }^{86}$ John Buntin, L.A. Noir, 45. Hecht, "The Incomplete Life of Mickey Cohen," Scanlan's, 61. "It made me equal to anybody..." Mickey Cohen, In My Own Words, 16.

${ }^{87}$ Two hundred heists in Cleveland... Hecht, "About Me, First," 8, folders 216, 219; "The Incomplete Life of Mickey Cohen," Scanlan's, 61. Bryan Burrough, Public Enemies: America's Greatest Crime Wave and the Birth of the FBI, 1933-34 (New York: Penguin Press, 2004), xi-xii, 16. Hecht noted: "There are hard luck heisters who walk into a sheriff's posse if they so much as make a pass at a candy store. And there are heisters who can blow up a safe at high noon without attracting attention." "About Me, First," 41, folder 216.

${ }^{88}$ Hecht, "About Me, First," 7, folder 219; "The Incomplete Life of Mickey Cohen," Scanlan's, 60-61.

${ }^{89}$ As a kid meets a hero, Hecht, "About Me, First," 61, folder 216; "The Incomplete Life of Mickey Cohen," Scanlan's, 73-74. Mattie and Ralph Capone and "Machine Gun" McGurn, “About Me, First," 54, folder 216; "The Incomplete Life of Mickey Cohen," Scanlan's, 71-72; Mickey Cohen, In My Own Words, 24-26. "'Machine Gun' McGurn is Slain in Chicago; Linked to St. Valentine's Day 'Massacre' of 1929," New York Times, February 15, 1936.

90 "About Me, First," 8, 60-61, folder 216; “The Incomplete Life of Mickey Cohen," Scanlan's, 73-74. Mickey Cohen, "Own Story."

91 "... his head popped like a melon..." Hecht, "About Me, First," 70, folder 216; untitled manuscript, 70, folder 217; "The Incomplete Life of Mickey Cohen," Scanlan's, 76; Mickey Cohen, "Own Story," 22-23. "It's a funny thing..." Hecht, untitled manuscript, 9, folder 217. In other drafts, Cohen is quoted as saying: "And now when I'm telling you these things it's like they happened to somebody else - a close friend or somebody. I feel ashamed over lots of them happening. Maybe it's just a way of coverin' up but, so help me - they didn't happen to me. And they never will." "About Me, First," 14, folders 216, 219.

${ }^{92}$ A Capone fixer... Hecht, untitled manuscript, 70, folder 217; “The Incomplete Life of Mickey Cohen," Scanlan's, 76. Mickey Cohen, In My Own Words, 34.

${ }^{93}$ The Arnold Rothstein principle... Robert Lacey, Little Man, 50, 60-61, 66. On Lansky, Rothkopf, Jewish fellowship, and phoning Siegel... Mickey Cohen, In My Own Words, 35-36. Cohen said: "If you want to know the truth about it, I didn't even want to go to work, and that's what being with Benny would be like."

${ }^{94}$ Hecht, untitled manuscript, 82-84, folder 217; "The Incomplete Life of Mickey Cohen," Scanlan's, 80; Mickey Cohen, In My Own Words, 36-38; Dean Jennings, We Only Kill Each Other, 69-71.

${ }^{95}$ A "sportsman"... FBI file 62-HQ-89947, office memorandum to Mr. D.M. Ladd from A. Rose, "Michael 'Mickey' Cohen, information concerning," July 21, 1949, p. 2; Dean Jennings, We Only Kill Each Other, 36, 38, 46, 243. On Siegel's plans... We Only Kill Each Other, 42-46, 80, 106107; Tere Tereba, Mickey Cohen, 33-35, 44-45.

${ }^{96}$ Paul Lieberman, Gangster Squad, 44-48; John Buntin, L.A. Noir, 70-76.

${ }^{97}$ Dean Jennings, We Only Kill Each Other, 70-73.

${ }^{98}$ Hecht, untitled manuscript, 83-84; “The Incomplete Life of Mickey Cohen," Scanlan's, 80.

99 "...family whoreloom..." Mickey Cohen, In My Own Words, 39. "I found Benny a person..." Hecht, "Mickey notes," 1, folder 216.

${ }^{100}$ Robert Rockaway, But He Was Good to His Mother, 22. Uri Dan et al, Mogul of the Mob, 5657. Robert Lacey, Little Man, 157.

${ }^{101}$ Henry M. Holden, FBI 100 Years: An Unofficial History (Minneapolis, Minn: Zenith Press, 2008), 76. Florabel Muir, Headline Happy, 189; Dean Jennings, We Only Kill Each Other, 176. Siegel's \$5,000 coffin... Paul Lieberman, Gangster Squad, 83; United Press International, "Brief Siegel Service Held," Tuscon Daly Citizen, June 27, 1947, 2.

${ }^{102}$ Hecht, "Mickey notes," 3, folder 216. 
${ }^{103}$ Dean Jennings, We Only Kill Each Other, 80. Paul Lieberman, Gangster Squad, 79, 184; John Buntin, L.A. Noir, 91-92, 115-116; Tere Tereba, Mickey Cohen, 63-64. See also Christopher Ogden, Legacy: A Biography of Moses and Walter Ogden Annenberg, 92-112ff and John Cooley, The Annenbergs.

${ }^{104}$ Hecht, "Mickey notes," 9, folder 216; Mickey Cohen, In My Own Words, 61-62; Tere Tereba, Mickey Cohen, 64. Transcript of the Kefauver committee to investigate organized crime. http://archive.org/stream/investigationofo10unit/investigationofo10unit_djvu.txt

${ }^{105}$ Dean Jennings, We Only Kill Each Other, 80. Drew Pearson, "Chicago Gangland Songbird Murdered for his 'Singing,"' Washington Merry-Go-Round column, The Morning Herald (Hagerston, Md.), October 26, 1963, 5. Tere Tereba, Mickey Cohen, 80.

${ }^{106}$ Mickey Cohen, "Own Words." Tere Tereba, Mickey Cohen, 51-52, 92, 133-134; Dean Jennings, "The Private Life of a Hood, Part Two," The Saturday Evening Post, 110.

${ }^{107}$ Hecht, untitled draft, 79, folder 217; "The Incomplete Life of Mickey Cohen," Scanlan's, 78.

${ }^{108}$ Political "jabberwock" and "... a part of man's soul..." Hecht, "Why I Write This Book," 1, 3; "The Incomplete Life of Mickey Cohen," Scanlan's, 58, 59. "No matter how many killings..." handwritten notes, folder 221. "How harmless these crooks seem..." Gaily Gaily, 87.

${ }^{109}$ Meyer Levin, In Search, 306-307. Literary Terms and Definitions," the website of Dr. L. Kip Wheeler. http://web.cn.edu/kwheeler/lit_terms_R.html

${ }^{110}$ Mickey Cohen, In My Own Words, $4 \overline{3}$. Dean Jennings, We Only Kill Each Other, 124. Tere Tereba, Mickey Cohen, 104.

${ }^{111}$ Florabel Muir, Headline Happy, 220.

112 Dean Jennings, We Only Kill Each Other, 38, 48, 124. After a degrading petty arrest... ibid, 142-143; Florabel Muir, Headline Happy, 193-195.

${ }^{113}$ Florabel Muir, Headline Happy, 188-190; Dean Jennings, We Only Kill Each Other, 148-152, 176; Robert Rockaway, But He Was Good to His Mother, 167-168; Tere Tereba, Mickey Cohen, 76-78.

${ }^{114}$ Dean Jennings, We Only Kill Each Other, 160-163, 180-181; Uri Dan et al, Mogul of the Mob, 153-154; Robert Rockaway, But He Was Good to His Mother, 168; Tere Tereba, Mickey Cohen, $78-79$.

${ }^{115}$ Letter to J. Edgar Hoover, FBI director from Los Angeles SAC R.B. Hood, July 1, 1947, pp. 3, 4, 7, FBI file 62-81518. http://vault.fbi.gov/Bugsy\%20Siegel\%20/Bugsy\%20Siegel\%20Part\% 2030\%20of\%2032 When Siegel demanded \$2 million from Trans-America... Dean Jennings, We Only Kill Each Other, 191-192; John Buntin, L.A. Noir, 116. The consensus among historians... See for example Tere Tereba, Mickey Cohen, 80. "To be honest, his getting knocked in..." Mickey Cohen, In My Own Words, 81. On the early morning of June 21, 1947... We Only Kill Each Other, 203-204. The pervading perfume of nightblooming jasmine, and the HeraldExpress... Florabel Muir, Headline Happy, 197-199; We Only Kill Each Other, 207.

${ }^{116}$ Mickey Cohen, "Own Story," 22; In My Own Words, 71-73.

${ }^{117}$ Mickey Cohen, In My Own Words, 51-52; Paul Lieberman, Gangster Squad, 55-58; John Buntin, L.A. Noir, 112-113; Tere Tereba, Mickey Cohen, 73-74.

${ }_{118}^{118}$ Hecht, A Child of the Century, 611.

119 "Mickey Cohen Associate Slain, Gang Warfare Revival Seen," Los Angeles Times, August 19, 1948, 1, 2. Paul Lieberman, Gangster Squad, 120-123; Tere Tereba, Mickey Cohen, 99, 172-175.

120 "Gang Guns Wound Cohen and 3 Aides," Los Angeles Times, July 20, 1949, 1. Florabel Muir, "I Get Shot At," Chapter 19 in Headline Happy, 202-210. "Cohen Fails to Fly East as Planned," Los Angeles Times, July 30, 1949, 1, 3.

${ }^{121}$ Tere Tereba, Mickey Cohen, 144-147; John Buntin, L.A. Noir, 152.

122 "Mickey Cohen's Splendor Fades Like Frayed Jail Garb He Wears," Los Angeles Times, June 22, 1951, 2. 
${ }^{123}$ Hecht, "Why I Write This Book," 1, folder 216; "The Incomplete Life of Mickey Cohen," Scanlan's, 58.

${ }^{124}$ Hecht, Gaily Gaily, 197.

${ }^{125}$ William MacAdams, The Man Behind the Legend, 255. Hecht, A Child of the Century, 607.

${ }^{126}$ William MacAdams, The Man Behind the Legend, 255, 260-261. Foreword by Mike Wallace and Introduction and Ben Hecht, Television Performer by Bret Primack in idem, adapt. and ed., The Ben Hecht Show: Impolitic Observations from the Freest Thinker of 1950s Television (Jefferson, N.C: McFarland, 1993), xi-xii, 1-4, 5-17, and throughout.

${ }^{127}$ Hecht, A Child of the Century, 631. Dough Fetherling, The Five Lives of Ben Hecht, 148.

${ }^{128}$ Boris Trbic, "Where the Sidewalk Ends," Senses of Cinema, no. 8 (July 2000). http://sensesofcinema.com/2000/cteq/sidewalk/

${ }^{129}$ William MacAdams, The Man Behind the Legend, 260.

${ }^{130}$ The "kooky killer"... Trailer for The Fiend Who Walked the West youtube.com. http://www.youtube.com/watch?v=6HpvhW8o0sQ Harry Brown, Ben Hecht et al, The Fiend Who Walked the West, directed by Gordon Douglas and starring Robert Evans (Los Angeles: $20^{\text {th }}$ Century Fox, 1958). On what happened to Love Happy, see William MacAdams, The Man Behind the Legend, 256-257.

${ }^{131}$ Jeremy Duns, "Casino Royale: discovering the lost script.” The Telegraph, March 2, 2011. http://www.telegraph.co.uk/culture/film/jamesbond/8345119/Casino-Royale-discovering-the-lostscript.html

${ }^{132}$ Ibid.

${ }^{133}$ Ibid.

${ }^{134}$ Hecht, "Rehearsal for Murder," Ellery Queen's Mystery Magazine, January 1955, 134-146; “A Jackpot of Corpses," Playboy, March 1961, 51, 132-133. "Chicago Days, 1959," title page, in Works, 1908-1983, Box 4, Folder 152, BHNL.

${ }^{135}$ Jeremy Duns, "Casino Royale." Hecht letter to Minna Emch, n.d., "Hecht, Ben - to Emch, Minna and Arnold (Noldi), n.d., 1953-1958," Box 71, Folder 2234, BHNL.

${ }^{136}$ Jeremy Duns, "Casino Royale."

${ }^{137}$ William MacAdams, The Man Behind the Legend, 255. Doug Fetherling, The Five Lives of Ben Hecht, 157.

${ }^{138}$ Hecht, A Child of the Century, 359. Edward Alexander, Irving Howe: Socialist, Critic, Jew, Jewish Literature and Culture (Bloomington: Indiana University Press, 1998), 53. Leslie A.

Fiedler, "The Jew in the American Novel," in The Collected Essays of Leslie Fiedler, Vol. 2 (New York: Stein and Day, 1971). Because of A Jew in Love, Howe characterizes Hecht as "the first to attack Jewish group existence from a standpoint close to fashionable Bohemian antiSemitism."

${ }^{139}$ Saul Bellow, "The 1,001 Afternoons of Ben Hecht," review of A Child of the Century, New York Times, June 13, 1954.

${ }^{140}$ Mark Shechner, After the Revolution, 16, 42.

${ }^{141}$ Marc Weingarten, The Gang That Wouldn't Write Straight: Wolfe, Thompson, Didion, and the New Journalism Revolution, 1st ed (New York: Crown Publishers, 2006), 1-34.

${ }^{142}$ Austin C. Wehrwein, "Hecht Attacks Algren Preface," New York Times, November 21, 1963.

${ }^{143}$ Ibid. Nelson Algren, "Erik Dorn: A Thousand and One Afternoons in Nada," introduction to Erik Dorn, x, xiii, xvii.

${ }^{144}$ Letter from Margaret Cousins, Hecht's editor at Doubleday for Gaily Gaily, to Stephen Fuller, aka William MacAdams, February 4, 1976, p. 2 of 3, Folder 378, MacAdams Collection.

${ }^{145}$ Preface in Tom Wolfe, The New Journalism, 1st ed. (New York: Harper \& Row, 1973). Tom Wolfe, "The Birth of 'The New Journalism'; Eyewitness Report," New York, February 14, 1972. http://nymag.com/news/media/47353/ 
${ }^{146}$ Doug Fetherling, The Five Lives of Ben Hecht, 157.

${ }^{147}$ Ibid, 167.

${ }^{148}$ Marc Weingarten, The Gang That Wouldn't Write Straight, 228.

${ }^{149}$ Sidney Zion, "On Ben Hecht," preface to “The Incomplete Life of Mickey Cohen," Scanlan's.

${ }^{150}$ Henry Raymont, "Scanlan's, a Monthly Magazine, Promises to 'Vilify' Institutions," New

York Times, February 25, 1970. Marc Weingarten, The Gang That Wouldn't Write Straight, 228-

235. Hunter S. Thompson, "The Kentucky Derby is Decadent and Depraved," Scanlan's, June

1970. Weingarten is quoting from a letter to Thompson from Bill Cardoso, who was editor of the

Boston Globe Sunday Magazine.

${ }^{151}$ Walter Winchell, On Broadway column, Humboldt Standard (Humboldt, Calif.), May 31, 1957, 4. "Bandsman With Welk Turns Cinema Villain," in Movieland Events column, Los Angeles Times, April 10, 1957. "Cohen Takes Manuscript to Author," Los Angeles Times, August 4, 1957, 34 .

${ }^{152}$ Hecht, "About Me, First," 1, 2, 13, folders 216, 219. United Press International, "One-Time Mobster Takes Up New Life In Greenhouse," Salina Journal (Salina, Kans.), July 30, 1956, 19.

${ }^{153}$ Hecht, "About Me, First," 3, folders 216, 219.

${ }^{154}$ Hecht, "Author Confessions," 2-3, folders, 216, 222.

${ }^{155}$ Hecht, "About Me, First," 18, folders 216, 219. Two informants advised the FBI "in the beginning of 1958 while he was residing at the Del Capri Hotel, that Cohen in his showers will 'air dry' himself rather than as he expressed it have a rough towel possibly injure his skin. (Redacted) advised from their personal observation this process of 'air drying' has Cohen has after a shower takes approximately 45 minutes." "Personal Habits and Peculiarities," antiRacketeering FBI field office file, 92-106, October 8, 1960, p. 252, in FBI file 92-HQ-3156, Part One, 249.

${ }^{156}$ Hecht, "Author Confessions," 1, folders 216, 222.

${ }^{157}$ Nelson Algren, "Erik Dorn: A Thousand and One Afternoons in Nada," introduction to Erik Dorn, xvii.

${ }^{158}$ Senator Estes Kefauver, Crime in America, 238.

${ }^{159}$ Mickey Cohen, In My Own Words, 82.

160 "Today I ask myself..." Dean Jennings, "The Private Life of a Hood, Conclusion," 115-116.

${ }^{161}$ Tere Tereba, Mickey Cohen, 100. "...running around like the rabbit at the dog track..." Dean Jennings, "The Private Life of a Hood, Part Three," 118. Lee Mortimer, Hollywood Confidential column, New York Mirror, August 4, 1958, 10, quoted in office memo from Mr. A.H. Belmont to Mr. W.C. Sullivan, August 13, 1958, p. 2, FBI file 62-HQ9947.

${ }^{162}$ Al Aronowitz, The Blacklisted Journalist website, Column Seven, section two, March 1, 1996. http://www.blacklistedjournalist.com/column7a.html

${ }^{163}$ Paul Lieberman, Gangster Squad, 319. Dean Jennings, "The Private Life of a Hood, Part One," 24, 91.

${ }^{164}$ Dean Jennings, "The Private Life of a Hood, Part One," 85.

${ }^{165}$ Mickey Cohen, "Own Story," unnumbered pages; In My Own Words, 102.

${ }^{166}$ Mickey Cohen, In My Own Words, 108-110. Tere Tereba, Mickey Cohen, 103-104, 134-135, 216.

${ }^{167}$ Lee Mortimer, New York Confidential column, New York Mirror, April 29, 1958, quoted in FBI field office file, 92-106, October 8, 1960, p. 99 in FBI file 92-HQ-3156, Part 1, 106.

${ }^{168}$ Quoted in Paul Lieberman, Gangster Squad, 125.

${ }^{169}$ Ibid, 2-4. "...the man with the juice...” Dean Jennings, “The Private Life of a Hood, Conclusion," 36.

${ }^{170}$ Paul Lieberman, Gangster Squad, 59-76, 210.

${ }^{171}$ John Buntin, L.A. Noir, 140, 201-203, 219-223. Tere Tereba, Mickey Cohen, 130-132. 
${ }^{172}$ Wellpott Heard Phone Recordings of Own Voice, He Tells Grand Jury," Los Angeles Times, August 10, 1949; Paul Lieberman, Gangster Squad, 2-3, 127-131; John Buntin, L.A. Noir, 123131; Tere Tereba, Mickey Cohen, 109-112.

173 "Man in Long Dispute With Tenant Beaten," Los Angeles Times, March 20, 1949; Mickey Cohen, In My Own Words, 94-100.

174 "Told to Forget It, Officers Testify," Los Angeles Times, March 22, 1949. Dean Jennings, "The Private Life of a Hood, Conclusion," 114. Tere Tereba, Mickey Cohen, 116, 118. United Press International, “'Snow White' Cohen Relents, Keeps Bail for Penitent Aide," Abilene Reporter (Abilene, Texas), August 31, 1949.

${ }^{175}$ Paul Lieberman, Gangster Squad, 127-132, 134-135; John Buntin, L.A. Noir, 131-135; Tere Tereba, Mickey Cohen, 122-125, 130, 148.

${ }^{176}$ John Buntin, L.A. Noir, 138, 141. Paul Lieberman, Gangster Squad, 150.

${ }^{177}$ Paul Lieberman, Gangster Squad, 276-281; John Buntin, L.A. Noir, 161-162, 183-185, 192.

${ }^{178}$ John Buntin, L.A. Noir, 179-181, 189.

${ }^{179}$ Bob Pool, "LAPD employees say goodbye to Parker Center," Los Angeles Times, October 30, 2009. Miles Corwin, Homicide Special: a Year with the LAPD's Elite Detectiveunit, 1st Owl

Books ed (New York: Henry Holt, 2004), 20.

${ }^{180}$ Paul Lieberman, Gangster Squad, 283-285; John Buntin, L.A. Noir, 207-209, 211-212.

${ }^{181}$ Mickey Cohen, In My Own Words, 100, 106, 107; Tere Tereba, Mickey Cohen, 118-119, 141.

${ }^{182}$ Mickey Cohen, In My Own Words, 107. Paul Lieberman, Gangster Squad, 320-321, 325, 330, 333.

${ }^{183}$ Paul Lieberman, Gangster Squad, 325-327.

${ }^{184}$ Ibid, 328-329; John Buntin, L.A. Noir, 234-238; Tere Tereba, Mickey Cohen, 202-203. Foreword by Mike Wallace and Introduction and Ben Hecht, Television Performer by Bret Primac, The Ben Hecht Show, xi-xii, 4, 5-7.

${ }^{185}$ Hecht, untitled manuscript, 74, folder 217; “The Incomplete Life of Mickey Cohen," Scanlan's, 77.

${ }^{186}$ George Redston, The Conspiracy of Death, 69.

${ }^{187}$ Hecht, "Mickey notes," handwritten and unnumbered, folder 226.

${ }^{188}$ Hecht, loose page of untitled draft, p. 18, folder 219. "About Me, First," 19, folders 216, 219; "The Incomplete Life of Mickey Cohen," Scanlan's, 62.

${ }^{189}$ Hecht, "About Me, First," 19-26, folder 216; 19-24, folder 219; "The Incomplete Life of Mickey Cohen," Scanlan's, 62-64.

190 "Cohen Departs for Mexico to Finish His Book," Los Angeles Times, March 13, 1958, 4. Hecht, "About Me, First," 33-34, folder 216; "The Incomplete Life of Mickey Cohen," Scanlan's, 65.

${ }^{191}$ Hecht, "About Me, First," 47, folder 216; “The Incomplete Life of Mickey Cohen," Scanlan's, 70 .

${ }^{192}$ Hecht, "About Me, First," 64-65, 66, folder 216, 217; “The Incomplete Life of Mickey Cohen," Scanlan's, 74-75.

${ }^{193}$ Hecht, "About Me, First, 65-68, folder 216, 217; “The Incomplete Life of Mickey Cohen," Scanlan's, 74-75. "Mickey Notes," 1, folder 226.

${ }^{194}$ Hecht, "About Me, First," 3-4, folders 216, 219. "... as full of nonsense as a Secretary of State..." "Why I Write This Book," 4, 216; "The Incomplete Life of Mickey Cohen," Scanlan's, 59. "He did not know, however, that there were ten times as many crooks..." "About Me, First," 49, folder 216; "The Incomplete Life of Mickey Cohen," Scanlan's, 70.

${ }^{195}$ Hecht, "Al Capone," unnumbered pages in "Cohen, Mickey - Research Notes on Crime and People, 1958-59," folder 229. Jonathan Eig, Get Capone: The Secret Plot That Captured America's Most Wanted Gangster, 28. 
${ }^{196}$ Hecht, Cohen, "Mickey - Research Notes on Crime and People, 1958-59," folders 228-229.

${ }^{197}$ Hecht, "The New Criminal," folder 228. John Buntin, L.A. Noir, 242-243; Paul Lieberman, Gangster Squad, 368-370.

${ }^{198}$ Hecht, "The New Criminal" and "Crime Pays," folder 228. Tere Tereba, Mickey Cohen, 73.

${ }^{199}$ Hecht, "We're All Crooks" and "Valentine for a Gunman," folder 228.

${ }^{200}$ Revenue agents... Hecht, "About Me, First," 21-22, folders 216, 219; "I Set the Stage," 4-5, folders 223, 224; Letter from Hecht to Minna Emch, July 5, 1958, "Hecht, Ben - to Emch, Minna and Arnold (Noldi), n.d., 1953-1958," Family Correspondence, 1915-1976, Box 71, Folder 2234. His own friends were urging him... "About Me, First," 2, folders 216, 219.

${ }^{201}$ Undated letter from Hecht to Minna Emch, folder 2234.

${ }^{202}$ Letter from Minna Emch to Hecht, July 3, 1958, folder 2223.

${ }^{203}$ Ibid.

${ }^{204}$ Letter from Hecht to Minna Emch, July 5, 1958, folder 2234.

${ }^{205}$ Hecht, "Night Club Gilgul" in "About Me, First," 68-72A, folder 216; "The Incomplete Life of Mickey Cohen," Scanlan's, 75-76.

${ }^{206}$ Letter from Minna Emch to Rose Hecht, August 13, 1958, folder 2228.

${ }^{207}$ Rose Hecht, "Notes on what I think is a fallacy in Hecht's reasoning in the Mickey Cohen manuscript" in "Cohen, Mickey, n.d., 1951-1976," Subject Files, 1919-1981, Box 77, 2341.

${ }^{208}$ Steve Stevens with Craig Lockwood, King of the Sunset Strip: Hangin' with Mickey Cohen and the Hollywood Mob (Nashville, Tenn.: Cumberland House, 2006).

${ }^{209}$ Steve Stevens with Craig Lockwood, King of the Sunset Strip, unpaginated Kindle edition. Walter Ames, "Locigno Indicted in Whalen Murder," Los Angeles Times, December 11, 1959, 2. On the Whalen murder and trial of Cohen associate Sam Locigno, see also Paul Lieberman, Gangster Squad, John Buntin, L.A. Noir, and Tere Tereba, Mickey Cohen.

${ }^{210}$ Steve Stevens with Craig Lockwood, King of the Sunset Strip, unpaginated Kindle edition.

${ }^{211}$ Office memo to Mr. Ladd from A. Rosen, April 24, 1951, FBI file 62-HQ-89947. "Personal Habits and Peculiarities," FBI field office file, 92-106, October 8, 1960, pp. 253-254 in FBI file 92-HQ-3156, 250-251.

${ }^{212}$ Hecht, A Child of the Century, 147.

${ }^{213}$ Ibid, 182. "In Rusty Armor," review of $A$ Child of the Century in Time, June 21, 1954.

214 "Antisocial Personality Disorder," in American Psychiatric Association and American

Psychiatric Association, Diagnostic and Statistical Manual of Mental Disorders: DSM-IV, 4th ed (Washington, DC: American Psychiatric Association, 1994), 645-650. The Hare Psychopathy Checklist Revised (PCL-R) can be found on the website for Encyclopedia of Mental Disorders. http://www.minddisorders.com/Flu-Inv/Hare-Psychopathy-Checklist.html\#ixzz2VY2BrSPx See also Robert Hare's caveats about the checklist on his own website, Without Conscience. http://www.hare.org/scales/pclr.html

${ }^{215}$ Jon Ronson, The Psychopath Test: a Journey through the Madness Industry (New York: Riverhead Books, 2011), 91-95, 109-117.

${ }^{216}$ Ibid, 137-138.

${ }^{217}$ Hecht, "About Me, First,” folder 216, 69-70; “The Incomplete Life of Mickey Cohen,” 76. Columnist Florabel Muir noted, "And so gradually with him, as with hundreds of others in trouble, I've come to assume a sort of mother-confessor role." Headline Happy, 219.

${ }^{218}$ Hecht, "About Me, First," 1, 11, folders 216, 219; "The Incomplete Life of Mickey Cohen," Scanlan's, 61.

${ }^{219}$ Dean Jennings, "The Private Life of a Hood, Part One," 25.

${ }^{220}$ Dean Jennings, "The Private Life of a Hood, Part Two," 110.

${ }^{221}$ Hecht and Cohen had agreed to a fifty-fifty split... United Press International, "Hecht Discovers Little Interest in Life of Cohen," The Terre Haute Star (Terre Haute, Ind.), May 18, 
1961, 33. Three million subscribers... Tere Tereba, Mickey Cohen, 238. Cohen had "sold" over $\$ 100,000$ in shares... Dean Jennings, "The Private Life of a Hood, Conclusion," 118.

222 "A revealing clinical study..." Dean Jennings, "The Private Life of a Hood, Part One," 23. According to W.J. Jones... in Jennings, Conclusion, 118.

${ }^{223}$ Ibid, 118; Tere Tereba, Mickey Cohen, 256-257.

${ }^{224}$ Cohen had approached IRS agent Guy McGowen... "I must keep up a front..." Paul

Lieberman, Gangster Squad, 355-356. "You can't expect Mickey Cohen..." Dean Jennings, "The Private Life of a Hood, Part One," 86. Flim Flam... FBI field office file, 92-106, October 8, 1960, on Meyer Harris Cohen, p. 237, in FBI file 92-HQ-3156, Part One, 234.

${ }^{225}$ Dean Jennings, "The Private Life of a Hood, Part One," 25, 85.

${ }^{226}$ Ibid, Conclusion, 118. Al Aronowitz, The Blacklisted Journalist, column seven. Mickey Cohen, In My Own Words, 116-117.

${ }^{227}$ United Press International, "Hecht Discovers Little Interest in Life of Cohen.” Tere Tereba, Mickey Cohen, 256.

228 "This particular brand of magic...” Paul Lieberman, Gangster Squad, 495. “... small, halfclownish disturber of life..." Letter from Hecht to Minna Emch, July 5, 1958.

${ }^{229}$ Both of these eplanations can, in fact, be rooted to "On Ben Hecht," Sidney Zion's preface to "The Incomplete Life of Mickey Cohen," in Scanlan's, 56-57.

${ }^{230}$ Bret Primack, "Weegee and Ben Hecht: The Crime Beat," in The Ben Hecht Show, 51-58.

231 "Ben Hecht, Television Performer," in ibid, 14-15. Norman Mailer, "The White Negro," in Advertisements for Myself (New York: Putnam, 1959), 338. Originally published in Dissent, Summer 1957.

${ }^{232}$ Norman Mailer, "The White Negro," 337-358.

${ }^{233}$ Jack Kerouac, The Town \& the City, Penguin Classics (London: Penguin, 2000), 370. Hecht's complete interview with Jack Kerouac can be found on Youtube, parts one and two:

$\mathrm{http}: / \mathrm{www}$. youtube.com/watch? $\mathrm{v}=\mathrm{uK} 39 \mathrm{vf4otrg}$ andhttp://www.youtube.com/watch? $\mathrm{v}=\mathrm{rcsUW}$ LBJlk

${ }^{234}$ Letter from Margaret Cousins, Hecht's editor at Doubleday for Gaily Gaily, to Stephen Fuller, aka William MacAdams, February 4, 1976, Folder 378, MacAdams Collection.

${ }^{235}$ Tere Tereba, Mickey Cohen, 258-259, 262-264, 266-267.

${ }^{236}$ Mickey Cohen letters to Hecht, February 12 March 22, 1964, "Cohen, Mickey (Michael), (a.k.a. Meyer Harris Cohen), 1955-1964,” Incoming Correspondence, 1914-1979, Box 56, Folder 1133, BHNL.

${ }^{237}$ Letter from Hecht to Mickey Cohen, March 17, 1964, "Cohen, Mickey, 1964," Outgoing Correspondence, 1931-1977, Box 66, Folder 1852, BHNL. William MacAdams, The Man Behind the Legend, 283.

${ }^{238}$ William MacAdams, The Man Behind the Legend, 284. Letter from Margaret Cousins, February 4, 1976. 
CONCLUSION 
People who spend their days delving into history tend to feel that society possesses a short memory. Crying in the Wilderness proceeded from the belief that the major dilemmas confronting the world today are, at root, no different from those facing the world in the 1940s, that we still wrestle with the same basic questions concerning what Hecht referred to as "the soul of man." The challenges of how to deal with man's inhumanity to man are not insurmountable; the questions of how best to protect the innocent, of what measures may be right or wrong, justifiable or unjustifiable, are not unanswerable. Yet too much of the time, Americans, Israelis and the rest of the world continue to rehash the same old arguments, covering the same old ground, rather than taking stock of the past and learning from it.

Crying in the Wilderness deals squarely with Hecht's concern over the soul of man. It is the story of how his grim view of human nature yielded a kind of prescient "second sight" at one moment in history—during the late 1930s and early "40s—yet ultimately became a blind cynicism that caused Hecht to lose his way. The idea is that by following his story, we can learn something that he himself failed to discover. Previous studies have focused either on Hecht's political activism or on his cultural legacy, but the effort here has been to integrate those two biographical threads by explaining his concern with human nature both as a writer and as an activist, a worldview that can be summed up by the term Romanticism. A political as well as cultural movement that first emerged in the early $19^{\text {th }}$ century but carried over into Hecht's time, Romanticism is the strand that ties together his journalism, prose, playwrighting, screenwriting, propaganda and memoirs. 
Biographies and analyses have frequently scratched at the surface of Hecht's Romanticism without getting at the substance of it. Gil Troy, for example, wrote in his 1982 thesis From Literary Gadfly to Political Activist: "Expressionism, Decadence, Symbolism, Dadaism, Radicalism, Bohemianism and the other 'isms' that shaped Hecht and his times were basically reactive. They negated what existed without offering alternatives. Many seemed to be motivated by some idyllic past rather than a visible future. In the absence of an affirmative vision they often degenerated into litanies of cynical, superficial and meaningless negation."1 What Troy does not acknowledge is that these "isms" of the early twentieth century — particularly Expressionism, Decadence and Symbolism — all owed a debt to Romanticism, a backlash against the Enlightenment characterized by reactiveness and a longing for an idyllic, pre-modern past. Whether or not a German Expressionist film or a Decadent novel lacked an "affirmative vision" or degenerated into meaningless cynicism, these works expressed a view of man and "progress" that was arguably more truthful than the liberal humanist alternative, which in the years leading up to and after the Great War, increasingly appeared Pollyannaish.

By the same token, biographer Doug Fetherling discusses "the Hechtian Man," the egoist anti-hero who appears in various guises, such as the Organization Man Erik Dorn in Hecht's first novel, the Capone-like gangster Tony Camonte in Scarface, the heartless Don-Juan publishing magnate Anthony Mallare in The Scoundrel, and the arrogant attorney Lee Gentry in Crime Without Passion. What Fetherling does not mention is that these are all twentieth century reworkings of the original anti-heroes of Romantic novels, such as the scholar Heinrich Faust of Goethe's Faust (1808), Dr. Victor Frankenstein of Mary Shelley's Frankenstein (1818), and fallen Archdeacon Claude Frollo of Victor 
Hugo's The Hunchback of Notre Dame (1831). The Romantic novelists, having inherited a post-feudal, secular world, presented tragic figures unmoored from the traditions and continuities of the past, driven mad by their own egoistic desires and ambitions, desperately seeking some substitute for the spiritual sustenance or salvation that was no longer attainable by them. In each case, the cause of a character's downfall is his own hubris, implying that a world in which God is absent is destined to be a world given over to mankind's vanity and arrogance.

Romanticism did not disappear after the early nineteenth century. It carried on, cloaked in different styles, like an aging gent whose wardrobe kept changing with the fashions of the times. Almost immediately, younger writers applied new approaches to Romantic themes. Edgar Allan Poe twisted them with satire and irony in his short tales published during the 1830s and '40s. Gustave Flaubert, a Victor Hugo disciple and the father of Realism who would later declare "No monsters and no heroes!" recast the egoist antihero as a tragic heroine in Madame Bovary (1856), just as Leo Tolstoy later would in Anna Karenina (1877), and Henry James would in Portrait of a Lady (1881). And as Lotte H. Eisner documents in The Haunted Screen, German Expressionist filmmakers were continuing this tradition of reworking the Romantic tale just as Hecht was making a name for himself as a young writer. ${ }^{2}$

At least two film scholars have written of The Front Page as a coy retelling of Faust. In Fast-Talking Dames, Maria DiBattista describes Cary Grant as "the dapper Mephistopheles," in the 1940 adaptation, His Girl Friday, and describes how director Howard Hawks drew out the darker side beneath Grant's charm. Neil Sinyard writes that Billy Wilder's 1974 version of The Front Page "brings the disquieting elements of the 
Johnson/Burns relationship right out into the open. Quite simply, Johnson's relationship with the demonic Burns (the name is significant) is seen as a Faustian struggle for a man's soul. Johnson must choose between the conciliating tenderness of his fiancée, or the malign promptings of his editor, which will lead to a dehumanising ruthlessness. ... Hildy and his girl do finally escape, but Burns' continuing hold over Hildy ('The son of a bitch stole my watch!') is, in this reading, really chilling." ${ }^{, 3}$ These brief discussions, howeverthough they acknowledge Hecht's debt to Romanticism—-tell us nothing of why it might be helpful to consider him as a Romanticist.

It is helpful for various reasons, but chiefly because it roots Hecht as a firstgeneration Jewish American and an American Jewish writer. As encapsulated in the ideas of "the secular priest" and "non serviam," Hecht and Bodenheim were among a group of Americans, Jews as well as gentiles, who embraced art as a religion and broke free of what Joyce's Stephen Dedalus sums up as "that in which I no longer believe...my home my fatherland and my church."

The embrace of art as a religion - the notion of the secular priest—is not only exemplary of the Romantic tradition, it is also exemplary of modern Jewish American culture. Just as many twentieth century American Jews threw themselves into the arts and showbusiness with religious zeal, others plunged into the utopian dreams of socialism or Zionism. When it comes to Jews in the popular arts, the most iconic figure is Jack Robin, protagonist of The Jazz Singer, who tells his father, a venerable cantor of the old neighborhood: "You're right papa. ... You did teach me to sing songs of prayer. ... But when I got out on the street with the other kids, I found myself singing the same songs they sang. And they're very much alike,-our songs—and the street songs. ... I just got 
them mixed, papa—See?" Author of The Jazz Singer Samson Raphaelson made clear that he saw Robin's break with faith and embrace of the secular as a descent into madness. While Hecht may never have descended into madness himself, Dorn, Camonte, Mallare and the rest of his egoist protagonists did, each after beginning to see themselves as God. ${ }^{5}$ Julian Levinson notes in his book on Jewish American writers: "Various critics, novelists and poets...read Judaism into Romaniticsm and vice versa.” Such writers include Lionel Trilling, in his essay "Wordsworth and the Rabbis" (1950), Harold Bloom in Shelly's Mythmaking (1959), and Saul Bellow in Herzog (1964), which follows the odyssey of Moses Herzog, a Jewish intellectual historian who specializes in Romanticism. In a section titled "Coda: Jewish Romanticism," Levinson argues that Trilling, Bellow, Bloom, Alfred Kazin and Allen Ginsberg all enact the drama of breaking with the old world and becoming lost in the new, but Jewish writers add a final chapter to the traditional Romantic story. After the rupture and fall comes the possibility, at least, of Return, the suggestion that wounds can be healed, that people can be made whole again. ${ }^{6}$ This is an echo of the Torah narrative, of a people returning after centuries of bondage in Egypt. It is also an echo of the twentieth century drama of the Jewish people's return to the Holy Land after the devastation of the Second World War. It is a journey—personal, political and artistic — that Hecht made himself.

Reading Hecht as a Romantic offers insights into what he was thinking and how he can be understood. It allows us to understand him as a writer who carried a coherent literary tradition from one era into the next, rather than as a hack who possessed many quirky, unrelated characteristics. As noted in Part I, these qualities included: "the rejection of civilized corruption, and a desire to return to natural primitivism and escape the 
spiritual destruction of urban life; ... a turning in upon the self and a heightened examination of human personality and its moods; ... a preoccupation with the genius, the hero, and the exceptional figure in general; $\ldots$ and a predilection for the exotic, the remote, the mysterious, the weird, the occult, the monstrous, the diseased, and even the satanic." In other words, qualities that were the exact inverse of those embraced by the liberal humanists, who believed in reason and democratic institutions, and maintained an optimistic view of human progress.

Hecht was a man with a deeply felt Romantic sensibility during a period when Romanticism still had a powerful hold on his society. Romanticism was the wellspring of his literary imagination, and it molded his whole cultural and political outlook, just as it molded the debates of his day. Romanticism explains how he managed to spin tales with such extraordinary speed: He could weave endless variations of its various tropes and themes just as Poe had done, and the Romantic tradition even served as an inspiration when he played against it, as he did with the naturalistic and impressionistic sketches of One Thousand and One Afternoons in Chicago.

By contrast, alternative characterizations of Hecht, such as of him as a cynic, offer little insight into the controversial figure that he would become. Larzer Ziff discussed "the twin defenses of cynicism and sentimentality" of Chicago reporters, but this was Ziff's effort to explain a style of journalism that was molded by social and economic forces at the dawn of the twentieth century. Essentially, journalists were expected to turn a blind eye to injustices they knew their papers would never report, while remaining open to the kind of heartwarming, human interest material that was a journalist's bread and butter. "Cynicism" may sum up Hecht as a newspaperman, and his dour view of human nature, 
but "sentimentality" explains little about a man who distrusted the mob but held great admiration for the individual, who placed such importance in friendship and proved to be a loyal friend to so many. Moreover, though Hecht has been called sentimental, as well as schmaltzy, this seems too dismissive of a man who wrote whimsical films about children and circuses like One in a Blue Moon or the more artistically successful The 7 Faces of Dr. Lao, the exuberantly idealistic Let Freedom Ring, or the unabashed wartime romance Miracle in the Rain, which many regard as a classic. ${ }^{8}$

Understanding Hecht as a Romanticist provides the crucial degree of nuance that makes his "churlish liberalism" and Zionist militancy comprehensible. With so much branding of Hecht and his allies as "terrorists," "gangsters" and "fascists," it is easy to overlook or misunderstand that most were, in fact, liberals at heart, and that their conflict with the mainstream Zionists essentially represented a debate within the liberal tradition. Histories of Zionism explain the movement within the context of the European Enlightenment: Referring to the old, cloistered world of European Jewry, Melvin Urofsky explains in American Zionism from Herzl to Holocaust: "The rationalist enlightenment of the eighteenth century and the nationalist movements of the nineteenth destroyed much of this stability and unleashed the forces that ultimately emerged as modern Zionism." Walter Laqueur discusses Romanticism in reference to the anti-Semitism that reared its head in Germany and elsewhere during the nineteenth century, but he also explains Romanticism as a guiding influence on Jabotinsky and the Revisionist movement. Recognizing Hecht as a Romanticist helps to place him within this political and historical context. It explains why immediately he felt such a deep identification with the 
Bergsonites, and why, in passages written many years apart, he continually refers to them as Jewish "knights."

Lastly, Romanticism helps to place Hecht within the context of the emergence of mass media and mass entertainment. Like the rest of their cohort, he and Max Bodenheim had embraced art with a religious-like zeal, seeking a path to some secular version of salvation just like the tragic figures in the Romantic novels. Yet while many of their contemporaries were similarly devoted to art, the pair's uniquely romanticist egoism set them apart, and made them more like the kind of artist-entertainers who would emerge later, in the postwar era. Both men — but Bodenheim in particular-were closely connected to an extraordinary number of the century's great writers, and the fact that Hecht and Bodenheim made a full-time profession out of ridiculing these literary giants (in the Chicago Literary Times) tells us much about the sense of mission that the two friends shared.

It is in their story that we see the tradition of the Hebrew prophets, of railing at the "chosen" for failing to hold their end of a holy covenant. Ultimately, the HechtBodenheim narrative of dreaming and idealism, rebellion and alienation, the story of their respective fates and of what Bodenheim would come to represent to Hecht, is the story of a confrontation between the artist and what Horkheimer would refer to as an emerging "culture industry." Hecht rebelled not simply against the movie industry, but also against Broadway producers (A Jew in Love), and book and newspaper publishers.

Hecht's Romanticism never was a creed, it was an anti-creed, and he would likely have been warier of Mickey Cohen had he not been so cynical about the American government, or about democratic ideals in general. Crying in the Wilderness offers a 
cautionary tale to people on both ends of the political spectrum. Liberals are advised to take notice of Rabbi Wise's failure to respond appropriately to the rise of Nazism. Conservatives can look at the trajectory of Hecht's thinking in his later years, and ask themselves where such an implacably grim view of mankind and political institutions ultimately leads.

Debates of recent years have covered whether torture can be justified as a means of tracking and catching terrorists; whether foreign "enemy combatants" have a right to trial, or can be snatched off a battlefield and incarcerated indefinitely in some offshore prison, or can be assassinated by a Hellfire missile shot from a drone, which may also claim the lives of innocent civilians. Discussions continue over what one commentator recently called "the over-worked dichotomy between America's strategic interests and its core values. ${ }^{10}$ Israel's critics continue to insist that its actions are in violation of international law, while supporters wonder where the nation's settlement policy is taking it. Stanley Fischer, a former governor of the Bank of Israel governor, recently told an audience at New York University: “The approach that we have to be strong, because if we're not strong we will be defeated, is absolutely correct but it is not the only the part of national strategy. The other part is the need to look for peace, and that part is not happening to the extent that it should."11

Today, as in Hecht's day, there are leaders who boldly assert liberal principles, who present a vision of the world as people want it to be, who deliver speeches and make symbolic gestures, laying down markers of hope. Meanwhile, these same leaders deal ruthlessly in secret with the world as it really is. Hecht might have called this lying, or 
typical political hypocrisy. But one might argue that people have a right to demand nothing less from those whom their society places in positions of responsibility. 
${ }^{1}$ Troy, From Literary Gadfly, 23-24.

${ }^{2}$ Edgar Allan Poe twisted them with satire and irony... See Introduction by G.R. Thompson to Edgar Allan Poe, Great Short Works of Edgar Allan Poe, A Perennial Classic (New York: Harper \& Row, 1970), 1-45. Gustave Flaubert, the father of realism... Bernard Doering, "Madame Bovary and Flaubert's Romanticism," College Literature 8, no. 1 (January 1, 1981): 1-11, doi:10.2307/25111355. "No monsters and no heroes!"... George Sand, The George Sand-Gustave Flaubert Letters (New York: Liveright, 1970), 349. Flaubert refers frequently and fondly to "father Hugo" in his letters. See for example in his letters to George Sand, pp. 303, 319. Lotte H. Eisner, The Haunted Screen: Expressionism in the German Cinema and the Influence of Max Reinhardt (Berkeley: University of California Press, 1969).

${ }^{3}$ Maria DiBattista, Fast-talking Dames (New Haven, CT: Yale University Press, 2001), 276, 296. Neil Sinyard, Filming Literature: The Art of Screen Adaptation (New York: St. Martin's Press, 1986), 166.

${ }^{4}$ James Joyce, A Portrait of the Artist as a Young Man, 247.

${ }^{5}$ Donald Weber, Haunted in the New World, 59. J. Hoberman and Jeffrey Shandler, Entertaining America, 77-78, 82.

${ }^{6}$ Julian Levinson, Exiles on Main Street, 168-170.

7 "a rejection of civilized corruption ..." "Literary Terms and Definitions," the website of Dr. L. Kip Wheeler, http://web.cn.edu/kwheeler/lit_terms_R.html; "a turning in upon the self..." Encyclopedia Britannica Online, s.v. "Romanticism," accessed October 1, 2013, http://www. britannica.com/EBchecked/topic/508675/Romanticism. See also Chris Baldick and Oxford University Press, The Oxford Dictionary of Literary Terms, 3rd ed, (Oxford ; New York: Oxford University Press, 2008), http://proxy.mul.missouri.edu:3443/views/ENTRY.html?entry=t56.e131 \&srn=1\&ssid=228167676\#FIRSTHIT; J. A. Cuddon, The Penguin Dictionary of Literary Terms and Literary Theory, 3rd ed (London: Penguin, 1992); The Routledge Dictionary of Literary Terms, (London; New York: Routledge, 2006).

${ }^{8}$ Larzer Ziff, The American 1890s; Life and Times of a Lost Generation (New York: Viking Press, 1968), 152. He has been called schmaltzy... Joseph Epstein, "The Great Hack Genius," Commentary (December 1990): 42.

${ }^{9}$ Melvin Urofsky, American Zionism from Herzl to the Holocaust, 8. Walter Laqueur, A History of Zionism, 21, 378-380, 381-382. In passages written many years apart, Hecht continually refers to them as Jewish "knights"... A Child of the Century, 522; Hecht, "Preface to Shylock," p. 9, in “Shylock, My Brother, 1964," Works, 1908-1983, Box 24, Folder 635, BHNL. Hecht was working on Shylock a decade after writing Child. Referring to the Irgun fighters who would appear at his door in Nyack, Hecht wrote in the Shylock preface: "And I began to see these men and their curious overcoats romantically; I saw at my door Princes and Knights, and uniforms bearing an invisible device strange to our day - the responsibility of the individual for what was happening elsewhere in the world."

10 "the over-worked dichotomy..." Anne Marie Slaughter, "Interests vs. Values? Misunderstanding Obama's Libya Strategy," The New York Review of Books, March 30, 2011.

${ }^{11}$ Quoted in Thomas L. Friedman, "Bibi and Barack, The Sequel," op-ed column, New York Times, December 3, 2013. 
Crying in the Wilderness Appendix: A survey of the scholarship and historical debates 
In the opening pages of his biography, Hecht made light of a regret that haunted him for much of his life. "I can understand the literary critic's shyness towards me," he famously quipped. "It is difficult to praise a novelist or a thinker who keeps popping up as the author of innumerable movie melodramas. It is like writing about the virtues of a preacher who keeps carelessly getting himself arrested in bordellos."

From the start, Hecht's literary reputation had been in dispute. As Fetherling explains, "At the time of his first New York success (on stage) he was already a light in Hollywood, and it is difficult today to understand the harmful effect that had on his standing as a literary man. The common notion, that he had sold his creative soul to Hollywood ... remained unchallenged until the 1960s, when his books were nearly all out of print and forgotten."2

He is still best remembered for The Front Page, the iconic newspaper farce that he wrote with fellow Chicago newspaper veteran Charles MacArthur. Since the sensation of its 1928 Broadway debut, it has spawned four movies and four television productions, a radio play and regular revivals on the stage. ${ }^{3}$ The Front Page remains cardinal to discussions of the reporter in popular culture; with its romantic portrayal of the reporter big city as rake and rebel, it fired the public imagination of Hecht's day just as Fear and Loathing in Las Vegas and All the President's Men would one day for a later generation. "The play has been called the Rosetta stone of journalism, the key to figuring out the hieroglyphics and high jinks of a strange craft," Robert Schmuhl recently noted. ${ }^{4}$ On the other hand, Hecht's considerable corpus of prose drifts father and farther into the misty past, as off the radar for literary scholars as for the public. 
Yet it would not be accurate to conclude that, aside from The Front Page, Ben Hecht has been forgotten, nor that he has become irrelevant. Since the early 1970s, scholars and critics have produced a steady stream of studies that highlight his importance in ways that reflect two major recent trends in American society. A first group of studies, contributions to the emerging field of film criticism in the 1970 s and ' 80 s that were concerned with his screenwriting, argued Hecht's enduring cultural significance. A second group examined Hecht from an entirely different perspective. These were political histories of the Holocaust that focused on the Bergon Group's campaign for the rescue of Europe's Jews, and their Zionist activities after the war.

Hecht's extraordinary energy, rich experiences and five careers - as journalist, novelist, screenwriter, propagandist and memoirist— present biographers with an embarrassment of riches, as well as a unique challenge. Jeffrey Brown Martin contends, "So much wit, so many anecdotes, so many lives are there in a single man that his spirit threatens to overwhelm any study of his work, reducing it to a discursive meander through a witty man's life." ${ }^{5}$ This dissertation does not attempt to capture "a life," but rather to understand Hecht's propaganda through biography; it uses his life and writings to explain the significance of this campaign and, conversely, uses the propaganda to argue the significance of his life and work. The approach of interweaving two narratives, one that explores a cultural dimension of the propaganda and another that explores a political dimension, acknowledges that two veins of scholarship have yielded equally important but distinct insights into it. 


\section{Cultural biographies: from screenwriter to propagandist}

Given the contempt for movies that Hecht shared with many of his contemporaries, he likely would have been dismayed, if not surprised, by the fact that for forty years after his death he would chiefly be remembered as a screenwriter. But this happened because, just as he passed away in 1964, he was materializing as a central figure in a debate that would establish a new respect for film criticism as well as for film. ${ }^{6}$

The debate between Andrew Sarris and Pauline Kael became an examinationwhat has been called an archeological excavation—of Hecht's era, the seminal years for movies with sound. Writing first for the small but influential Film Culture, and soon thereafter for the Village Voice in the early 1960s, Sarris advanced the French "auteur theory," the idea that "the director is king," the determining factor in the artistic success or failure of a film. Kael, a West Coast critic who found the theory more mystique than substance, retorted with a fourteen-page broadside in a 1963 issue of Film Quarterly. ${ }^{7}$

Ultimately, Kael expressed her own views in Raising Kane, her 1971 book about how Orson Welles robbed the glory for Citizen Kane from its true author/auteur: screenwriter Herman Mankiewicz. Raising Kane can be credited with the attention paid to Hecht the screenwriter over the succeeding years. It is Kael's narrative of the great migration of writers to Hollywood with the advent of sound, a tale she begins by relating Mankiewicz's legendary cable summoning Hecht West:

WILL YOU ACCEPT THREE HUNDRED DOLLARS PER WEEK TO WORK FOR PARAMOUNT PICTURES? ALL EXPENSES PAID. THE THREE HUNDRED IS PEANUTS, MILLIONS ARE TO BE GRABBED OUT HERE AND YOUR ONLY COMPETITION IS IDIOTS. DON'T LET THIS GET AROUND. 
What Kael admires in Hecht, whom she credits with writing half the entertaining films to come out of Hollywood, is his breeziness, his ability to savage shallow people, corrupt politics and a venal press with alacrity and glee, and without sanctimony. ${ }^{8}$

If Kael had cast doubt on the eminence of the auteur, Richard Corliss would go the extra step of presenting an alternative "Screenwriter's Theory," and use Hecht to make his point. "Ben Hecht was the Hollywood screenwriter," Corliss writes. "Nearly every fact of that talented and haunted breed—from the streetcorner wit and inexhaustible articulateness to the sense of compromise and feelings of artistic frustration - can be found in Hecht's dazzingly contradictory career."

Two years later, Canadian journalist Doug Fetherling produced the first book devoted to Hecht, and the first to discuss his propaganda. In his foreword, Fetherling explains that The Five Lives of Ben Hecht is not a biography, but "an attempt to sort out his reputation." Noting Hecht's standing had been a matter of dispute for decades, first over his literary merit, and then over his screenwriting, Fetherling argues that "in the course of such debate the true importance of Hecht had been lost sight of"- that he was a man who had cross-pollinated various cultural forms, and had done so with extraordinary wit and exuberance. In literature he had blended the sensibilities of the Decadents, Symbolists and Expressionists of Europe with a gritty American naturalism drawn from urban newspaper work. In film, he infused a new intelligence and sophistication into popular culture, "making it more inventive, meaningful and important than it was before he arrived." 10

Even those who had respected his prose had failed to appreciate the true nature of his genius. "They did feel that he published much too promiscuously even before he 
disgraced himself in their eyes by retiring to Hollywood," Fetherline writes. "Yet the truth is that his dexterity was based in an admirable adaptability and dedication to purpose. The fact that one man could write, near the start of his career, for Mother Earth, Emma Goldman's anarchist magazine, and later for the Marx Brothers, indicates a strength and not a weakness."11

Fetherling carries the argument of Hecht's versatility into a reading of his propaganda. From the start of Hecht's advocacy for the Jews of Europe in 1939, the situation was complex. On the one hand, Britain stood alone against the Nazis. On the other, the British protectorate over Palestine barred entry to the Jews attempting to flee Europe. Yet this was a situation that left Hecht "less ambivalent than ambidextrous." 12

Essentially, Fetherling sees Hecht's propaganda as having generated more heat than light. He admires Hecht's polemics, observing that Hecht's approach had been "to meet indifference with outrage, to retaliate with full force when attacked and, when in doubt, to attack anyway for good measure." He touts Hecht's ability to single-handedly launch a multi-pronged crusade, pulling out "every literary trick he knew in defense of world Jewry," from magazine articles and newspaper advertisements to speeches and grand-scale theatrical pageants starring Hollywood celebrities. ${ }^{13}$ He notes that Hecht early on saw himself as an American first and a Jew second, even as Hecht charged others with the same offense, but that this view would change in the aftermath of the war. And he points out that "in this case the mob was the Nazis rather than faceless Chicagoans, 'the greedy little half-dead' of the early stories and novels." But Fetherling merely dismisses Hecht's politics as contradictory and simplistic, and while he says that Hecht's help in bringing the state of Israel into being is "seldom doubted," one must question if "that good 
is outweighed by the harm he did in stirring up anti-Semitism and generally pitting Jew against Jew." 14

In fact, however, Hecht himself concluded in the end that his propaganda had been ineffective. And Fetherling's charge that Hecht was responsible for anti-Semitism is obtuse, while his suggestion that Hecht provoked division fails to acknowledge the deep and bitter schisms that had long existed within American Jewish culture and politics, which Hecht was in no way responsible for. Although Hecht did increasingly stray into the internecine fray in the name of the Bergson Group, the record shows that otherwise, the Group itself assiduously avoided retaliating against the sustained and vociferous attacks upon them by Rabbi Wise and the mainstream American Zionists. ${ }^{15}$

In 1985, Emerson College film scholar Jeffrey Brown Martin would publish Ben Hecht: Hollywood Screenwriter, based on the thesis he completed in 1978. In his chapter on Hecht's Zionism, he argues that with the war coming on just as Hecht was entering middle age, "his youth seemed to evaporate," and he dropped his cheery, mocking cynicism for an intense outrage at the butchery that was unfolding in Europe. Hecht's scripts during the 1940s suggest a turn towards earnestness, an embrace of political causes and the power of the press. A Jew in Love had revealed Hecht's deep ambivalence about his Jewish background in the 1930s, but in the "40s he developed a conception of Jewish identity that was peculiarly his own, and championed the Irgun's "fighting Jew." Hecht eventually "came to realize he had been wrong about propaganda and the moral outrage it induced," Brown Martin concludes, but he had "found his Judaism.".16

More insightful than the actual chapter on the propaganda itself, however, is the preceding one, where Brown Martin relates experiences that sent Hecht off on his 
trajectory. In perhaps the most incisive study to date on Hecht's storytelling, Brown Martin traces the twists and turns of Hechtian themes to explain why a journalist and storyteller would turn to propaganda. He describes Hecht and MacArthur's efforts to write, direct and produce four films in Astoria, Long Island with a million-dollar investment from Paramount Studios. Their first was Crime Without Passion (1934), an icy psychological investigation into the cruel Don Juan types that Hecht had encountered in New York City, which broods upon the Smart Set's contempt for the common man. The film portrays the downward spiral of Gentry, a murderous attorney, who in this scene quoted by Brown Martin, speaks to his secretary about the crowds far below his office window:

Gentry: Fascinating, those insects. The so-called human race. They don't look like porch climbers, murderers and wife beaters from here. To think those harmless-looking little doodlebugs were full of greed, and lust and all the seven deadly sins. You know I often wonder, Miss Keeley, why people go on living. Intelligent people, I mean.

Keeley: Shall I send out for some bicarbonate of soda. You haven't much time for moods this morning...

Gentry: I wish, Miss Keeley, that you'd stop referring to my philosophical flights as stomach aches.

While Gentry cheats the justice system, the Don Juans of Hecht's novel A Jew in Love (1931) and movie The Scoundrel (1935) are a literary publisher and stage producer respectively, who make mischief within the realm of culture. Ironically, however, Crime Without Passion and The Scoundrel were Hecht's earnest forays into independent filmmaking, and their commercial failure led to his own disillusionment about the "little people" whom his egoists disdain. "While he had not feared failure," Brown Martin explains, "he had not imagined that his tastes would find so little sympathy and it confirmed his estimation of the low intelligence of the American public." It was a feeling 
Hecht vented in Nothing Sacred (1937), his wicked comedy that targets the booboisie of the American heartland. ${ }^{17}$

In 1990, William MacAdams published The Man Behind the Legend, the only fulllength biography of Hecht and the last book to focus on his screenwriting. It is a problematic source, for it lacks footnotes and adequate sourcing, yet it is exhaustively researched. The author donated his collected books, documents, oral history recordings and other materials to Chicago's Newberry Library as a complement to the Hecht archive, and the finding aid runs forty-eight pages long.

The Man Behind the Legend relates anecdotes and quotes liberally from published and unpublished works to fill out the picture of Hecht's contempt for the movie industry, and dissatisfaction with being a screenwriter. MacAdams discusses how Hecht's booklength polemic against anti-Semitism, Guide for the Bedevilled, becomes a lengthy attack on the cowardice of Jewish studio executives for refusing to make movies about the Nazi extermination of their co-religionists. ${ }^{18}$ Thus Hecht draws an explicit connection between what he sees as Hollywood's lack of artistic integrity and the spinelessness of Hollywood's Jews.

"The movies are one of the bad habits that corrupted our century," Hecht wrote in Child. They are "an eruption of trash that has lamed the American mind and retarded Americans from becoming a cultured people." They have fed "naivete and buncombe in doses never before administered to any people. They have slapped into the American mind more human misinformation in one evening than the Dark Ages could muster in a decade." ${ }^{19}$ 
With this quote, New York Times critic Michiko Kakutani opens her mixed review of MacAdams's biography, in order to highlight a mystery that he fails to grapple with: "He points out that Hecht was always hungry to make money, but offers no further explanation for his continual eagerness to take on work he says he despised. The reader gets no insight into the emotional or psychological reasons that led Hecht to frantically overbook his schedule (he was frequently forced to write a film in a couple of afternoons, or farm it out to friends), no insight into how he was able to reconcile this furious commercial work with his vociferously proclaimed ambitions to be a serious literary artist. ${ }^{20}$

All the studies of Hecht's screenwriting deal at length with his disdain for Hollywood, and in the process many delve into the connections between this disdain and his turn towards propaganda. Yet Kakutani points out the one overarching mystery that none of them address: Why did Hecht continue to write for Hollywood, when he constantly complained that he hated it? Another question, also left unanswered, is what is the underlying relevance of the Jewish issues to the story of Hecht's experience in Hollywood? ${ }^{21}$ Without these key missing components, we are unable to see the whole picture, and thus can't fully grasp Hecht's significance to the history of film or, for that matter, to the history of mass media in the twentieth century. I argue that the narrative of Hecht's relationship with Bodenheim answers these two questions.

\section{Political biographies: Hecht and the Bergson Group in collective memory}

In 1999, University of Chicago historian Peter Novick published an influential polemic in which he voiced profound distaste for the prominence the Holocaust had come 
to assume, not in the consciousness of Europe, where the genocide had occurred, nor in Israel, but within America. The Holocaust in American Life argues that Americans suppressed their feelings about the catastrophe during the first twenty or so years after World War II, a phenomenon Novick attributes to America realigning with Germany and the Soviets replacing the Nazis as the enemy with the onset of the Cold War. But since the 1970s, the Holocaust has come to fill an "identity void" for American Jews, brought on by a decline in religious observance, a lack of shared, identifiable cultural traits, a rise in intermarriage, and decades of assimilation, "all of which threatened demographic catastrophe., ${ }^{22}$

As a result, Novick argues, the Holocaust surfaced as "the only common denominator of American Jewish identity," with victimhood becoming the defining aspect of Jewishness. This occurred amidst a general "decline in America of the integrationist ethos (which focused on what Americans have in common and what unites us) and its replacement by a particularist ethos (which stresses what differentiates and divides us)." In Novick's view, this "growth of victim culture" also marked a shift rightward, providing an ideological framework that mandated an uncritical view of Israel and a self-righteous, hardline attitude towards the Israeli-Palestinian conflict. ${ }^{23}$

With these complaints about misuse of the past, Novick suggests the issues at stake in another historiographical debate that has Hecht emerging as a key figure. The conceptualization of the Holocaust in contemporary American society, and its uses for that society, are an example of "collective memory," a term coined in the 1920s by the French sociologist Maurice Halbwachs, who was himself sent to his death at Buchenwald for protesting the arrest of his Jewish father-in-law. Unlike our sense of history, of the "past as 
a foreign country," our memory ignores the passage of time. Collective memory refers to some core eternal truth, usually tragic, that a group reads into a past kept alive through shared sentiment. $^{24}$

Novick's argument is premised on the view that over a period of thirty years, a spate of inaccurate, popular histories constructed a mythology of the Holocaust that has served as the basis for collective memory. Borrowing a phrase from Henry Feingold, he contends that this "comfortable morality tale that has passed for history" proffers a series of assertions about which there has been no scholarly consensus. Thousands, if not hundreds of thousands of Jewish lives could have been saved, these books declare, were it not for three factors: prevailing anti-Semitism in Britain and America that made it politically untenable to allow European Jews to immigrate in an escape from the Nazis; the blinkered moral turpitude of American Jewish leaders, most notably the Zionist leader Rabbi Stephen Wise, who failed as advocates for Jewish rescue; and most importantly, Allied wartime policy about which assessments vary, from an "abandonment of the Jews" in David Wyman's appraisal, to "bordering on complicity," in the view of Deborah Lipstadt. $^{25}$

Over the years, these histories devoted increasing attention to Ben Hecht and the Bergson Group, to the point where the story of their campaign for rescue has become a primary focus. This trend was anticipated by Frank W. Brecher, a forerunner to Novick, in a 1990 article for Holocaust and Genocide Studies:

There is a striking correlation between belief in the feasibility of mass rescue and strong support for "the Bergson Group," that element within the Jewish community in the United States which was most forceful in seeking to arouse the general public and the Congress to demand governmental action against the anti-Jewish atrocities in Europe. Conversely, the more an historian believed that mass rescue was, in the words of one of 
them, an "unachievable task," the less impressed he or she was with the efforts of the Bergsonites. $^{26}$

Whether or not one agrees with Novick's views on the Holocaust itself, it is hard to dispute that the linkage between the histories that offer this "comfortable morality tale" and American collective memory, as developments since the publication of The Holocaust in American Life strikingly affirm. It is a process that began with Arthur Morse's 1967 best-seller While Six Million Died, the first well-publicized condemnation of Allied apathy and indifference, and the first to chronicle the actions of the War Refugee Board, the rescue agency that President Roosevelt established in January 1944. By recounting the WRB's success at rescue, Morse emphasizes what might have been possible had the Allies acted sooner and with more genuine determination. ${ }^{27}$ The Politics of Rescue by Feingold, published in 1970, introduces the role that Hecht and the Bergson Group played in establishing the WRB, overcoming Roosevelt's ambivalence and the active resistance of the State Department, most notably Assistant Secretary of State Breckinridge Long. ${ }^{28}$

Sarah E. Peck and Monty Noam Penkower offered the first complete, detailed narratives of the Bergson Group's rescue campaign, in the Journal of Contemporary History (April 1980) and American Jewish History (March 1981) respectively. ${ }^{29}$ Peck relates the vilification and obstructionism the Bergsonites faced from Zionist and nonZionist American Jewish leaders. Penkower suggests that the Group achieved only "meager success in the face of the Holocaust," and that their true accomplishment lay in changing the way American Jews viewed themselves and their place in the world. Neither study addresses the Group's postwar activities.

In 1982, Gil Troy completed his remarkably precocious Bachelor of Arts thesis at Harvard, "Ben Hecht: From Literary Gadfly to Political Activist." As one of the only 
lengthy analyses of Hecht's campaign, and the only known one that investigates the propaganda through biography, it deals most directly with my concerns. Troy seeks to understand glaring contradictions that he originally came across in his research, and finds that while Hecht was called a communist and a fascist, an anti-Semite and a philo-Semite, such characterizations are unfair to the man and the causes he served. Furthermore, Hecht's contradictions are themselves not as stark and dramatic as they appear, but only seem that way because of the man's penchant for shock and provocation. ${ }^{30}$

Troy argues that in the early stages of the war, Hecht had hoped to appeal to the world's conscience, but by 1947 he had fallen back on Menckenian credo that a writer's primary duty lay in "stirring up the animals." In the end, Hecht capitulated to what Troy calls "extremism," and alienated many more people than he persuaded or inspired. But ultimately, Hecht is best appreciated as a critic and iconoclast, an idealist "who retreated into cynicism because he could not accept the compromises necessitated by reality." His was a muddled, "ad-hoc philosophy, in which past alliances or enmities were immaterial and the sole criterion was whether one was on the right side at the right time." ${ }^{, 31}$ It is hard to dispute these conclusions, but they often mistake Hecht's ambivalence for superficiality, and fail to adequately address the deeper questions raised by the Second World War that Hecht was struggling with. Also, perhaps because Troy was writing in the early 1980s, the study does not discuss how Hecht's inclinations anticipated cultural and political trends of the late twentieth century.

Troy eventually published a much-condensed version of it in the fall 2003 edition of the Journal of Ecumenical Studies. ${ }^{32}$ But ultimately, it was David Wyman's Abandonment of the Jews (1984) that drew public attention to the Bergson Group. In a 
review for The Journal of American History, Leonard Dinnerstein wrote that while Abandonment contained little new information beyond what had been disclosed by Morse, Feingold and Bernard Wasserstein's Britain and the Jews of Europe (1979), Wyman's research was "massive and deep," and Abandonment provided the most compelling account of the price paid for organized American Jewry's disunity and the obstructionism of the State and War departments. ${ }^{33}$ Wyman also went further than any of his predecessors in condemning the president. "Franklin Roosevelt's indifference to so momentous an historical event as the systematic annihilation of European Jewry emerges as the worst failure of his presidency" he states in his preface. ${ }^{34}$

Most significant, however, was Wyman's claim that the WRB was responsible for saving 200,000 lives. ${ }^{35}$ In his fierce critique of Wyman, Brecher calls this a "liberal claim," and disputes that it shows how many Jews could have been saved had the WRB been created prior to 1944. Most of the agency's work involved negotiations with breakaway actors within Nazi Germany or with Axis satellite nations, Brecher points out, and such deals were achievable only in the final chapter of the war, when command and control began to slip from Hitler's grip. ${ }^{36}$

Abandonment spawned a subliterature about the Bergson Group that is considerable in its own right. Brecher had targeted the book because it "represents the culmination of scholarship on the subject (of Allied indifference and apathy)" and Novick writes that it "achieved a certain canonical status," though he judges it to be "simply bad history." After its publication, Wyman spent the next sixteen years delivering some 425 public lectures in North America and Israel, and advising on the PBS American Experience documentary America and the Holocaust: Deceit and Indifference (1994). ${ }^{37}$ In 
2002, he and historian Rafael Medoff published A Race Against Death: Peter Bergson, America and the Holocaust, which combined interviews done with Bergson, chief lieutenant Samuel Merlin and other Bergson supporters.

Three years prior to Wyman and Medoff's collaboration, Jerusalem Post editor Louis Rapoport's biography of Bergson, Shake Heaven and Earth saw publication, having found a new audience thirteen years after Rapoport had completed it and eight years after the author's death. Rapoport's most important contributions are his explanations of the divisions within the Bergson Group, and between the Bergsonites and the Irgun. ${ }^{38}$

Although Hecht and Bergson maintained their close mutual affection, Rapoport relates that their differences grew pronounced as Hecht's aggressive, romantic admiration for the Irgun led to his "Letter to the Terrorists of Palestine." ${ }^{39}$ Their disagreements over American Jewish identity were perhaps most salient in the separate ways that they responded to the publisher of the New York Times, Arthur Hays Sulzberger, who was an outspoken assimilationist and anti-Zionist. In a meeting with Sulzberger, Bergson concurred when the media magnate offered the traditional American Reform view: that Judaism was strictly a religion, not a basis of peoplehood. Bergson was amenable to this idea because, as the war was coming to an end, he sought a way to promote the cause of a homeland for stateless and Palestinian Jews that would avoid American concerns about dual loyalty. However, Bergson overlooked the fact that Sulzberger's view of Judaism had shaped the New York Times editorial policy during the Holocaust, justifying the publisher's abdication of any journalistic responsibility to report the Nazi extermination of a Jewish people, which Sulzberger feared would brand the Times as a "Jewish newspaper." Hecht, on the other hand, during a speech at the Hotel Astor on April 21, 1947, launched into a 
tirade against "high-class Jews," singling out "a white Christmas named Arthur Sulzberger," whose actions "among the Anglo-Saxons is not a new spectacle in Jewish history. ${ }^{40}$

In 2002, the same year that saw publication of A Race Against Death, Medoff published his own narrative of the Bergson Group, Militant Zionism: The Rise and Impact of the Jabotinsky Movement in the United States, 1926-1948. This offered the first lengthy, published account of the Bergsonite's propaganda effort after the war. Medoff describes the dramatic tour of Hecht's Zionist 1946 pageant A Flag is Born, relating the emotional outpouring it invoked from American Jewish audiences still struggling to grasp the horror of the Nazi genocide, and Hecht's refusal to allow the play to be staged at a segregated theater in Baltimore. Militant Zionism also draws on FBI files, oral histories and other research to investigate Hecht's fundraising collaborations with Mickey Cohen, the boxer Barney Ross and other "tough Jews," as well as various arms smuggling operations for the Irgun. ${ }^{41}$

As the record makes clear, Wyman did more than inspire Rapoport and Medoff and draw scholarly attention to the Bergson story; he also solidified its place in American collective memory. In 2003, Medoff founded the David S. Wyman Institute for Holocaust Studies, a non-profit dedicated to educating the public about the Holocaust. The institute "focuses on the abandonment of Europe's Jews during the Nazi era, the efforts to promote rescue, and the moral and historical lessons of those experiences." ${ }^{, 42}$

For Medoff, this has meant a continued focus on the Bergsonites. Of the roughly 120 listed participants of the institute, many are family members and allies of the original group who remain highly influential in politics and culture. ${ }^{43}$ The Washington D.C.-based 
organization, in fact, seems based on the Bergson model: the names of Congressmen, scholars and famous writers fill its rosters and these individuals volunteer for campaigns, just as they once did for Bergson's committees. And in echo of Bergson activism, Medoff stirs publicity and organizes petitions. A signature achievement was his five-year effort to convince the United States Holocaust Memorial Museum to change its permanent exhibit to acknowledge the Bergson Group, which they did in July $2007 .^{44}$

The issue is significant because museums and memorials are crucial to the construction of collective memory. Novick argues that while Americans Jews had participated in an unofficial boycott of German-made goods during the 1950s, these "around the kitchen table" feelings are altogether less salient and enduring than feelings that become officially enshrined. Situated on the National Mall, the Holocaust museum stands as "the principal address for American Jewry," and acknowledgment of the alleged failure of the United States to protect the Jews of Europe served as a principal justification for establishing this American Holocaust museum in the first place. ${ }^{45}$

The purpose of this study is not to weigh in with another assessment on how America met moral responsibilities during the Holocaust. Still, it is worth addressing a couple of key points of dispute, in order to make clear my own premises, and explain how my work fits within this context. One underlying question for historians, which pertains both to the policy towards Jewish refugees and to action or inaction on rescue, has been what was known and understood by Americans, and at what time. This is particularly pertinent to our understanding of Hecht, who initially became involved with Bergson because he wanted to publicize the Nazi persecution of the Jews. But the broader inquiry of what was understood and when really represents a bundle of more specific, difficult 
questions, most importantly: What was known by ordinary Americans, versus those in higher places? And what was known before early 1942, by which time the Nazis had embarked upon their plan of total annihilation known as "the Final Solution," versus what was known afterwards?

In her careful study of how five hundred American newspapers covered the escalation of Nazi persecution, Deborah Lipstadt offers a tempered judgment of why the press originally buried the story, from the time of Hitler's rise to power in 1933 to the early stages of the war. She cites anti-Semitism as one factor among many, along with deep skepticism engendered by the false atrocity stories that had proliferated as propaganda during World War I, and Nazi censorship and intimidation. ${ }^{46}$ Novick, likewise, concedes that Nativism and anti-Semitism were factors, along with another important one: the desire of assimilationist Jews powerful in the newspaper and movie industries not to seem preoccupied with the fate of their co-religionists, and not to appear to be trying to draw America into "a Jewish war." (Novick nevertheless also presents the latter concern as a legitimate strategic consideration for the Office of War Information.) Ultimately, however, he argues that the Jews at first weren't really the big story: "The point should be underlined, from early 1933 to late 1942 ... Jews were, quite reasonably, seen as among but by no means the singled-out victims of the Nazi regime."47

In 2005, Laurel Leff took direct issue with this assertion in her scathing indictment of how the New York Times, under Sulzberger's leadership, deliberately downplayed the story. She argues that the careful reader of the Times would have been aware of what was happening to the Jews at the time these things were occurring: the proliferation of antiSemitic laws in German allied countries, the deaths from disease and starvation of 
hundreds of thousands in the ghettoes and labor camps in Eastern and Western Europe, the mass killings in the Soviet Union and, as the war progressed, mass gassings in Auschwitz, Treblinka and Maidanek. "The Times also indicated that these were not isolated incidents, but part of Germany's attempt to find a solution to Europe's 'Jewish problem,' which from 1942 on was the Final Solution." Quoting from a letter of a Times correspondent, she counters Novick's claim that journalists at the time doubted the veracity of these reports. ${ }^{48}$

While "surface currents" might have pushed journalists to conclude that the campaign against the Jews was neither "distinct" nor "particularly salient," as Novick puts it, there were certainly strong undercurrents of information pushing journalists in the contrary direction. "The acknowledgment that one interpretive framework—perceiving the mass murder of Jews as a minor part of a worldwide conflagration—-dominated Americans' contemporaneous knowledge of the Holocaust should be the start of the inquiry, not its end," she contends. ${ }^{49}$

In regard to the Final Solution, it has become a commonplace for historians to emphasize that the notion of a Jewish genocide was so far outside the bounds of experience and rationality that it was Beyond Belief, as the title phrase of Lipstadt's book suggests. People did not know, this argument runs, could not have known, because they simply could not comprehend. Yet Lipstadt is no less unsparing than Leff in her ultimate conclusion that "dispassion, if not indifference" was the chief reason why the American press failed to report the Final Solution. After all, journalists such as Dorothy Thompson, William Shirer, Arthur Koestler, I.F. Stone and Max Lerner offer a striking comparison: "They were able to surmount the obstacles posed by the World War I atrocity stories, absence of impartial witnesses, German obfuscation, and the unprecedented nature of the 
tragedy. They had no more information than the rest of their colleagues. In fact, some of them depended on reports in other major dailies for their information.... They not only believed what was being reported but refused to accept it as inevitable." 50

On the charged question of what was known and not known, twin perils confront the historian. On the one hand, there looms the cardinal sin of presentism, of judging the people of the past with the benefit of hindsight. On the other hand, soft-peddling this question can paper over what the the Holocaust tells us about the darker side of human nature. It is worth keeping in mind what a young fictional German character has to say about his own country's efforts to come to grips with its crime, in the recent film adaptation of Bernhard Schlink's The Reader:

There is something disgusting about this.... Do you know how many camps there were in Europe? People go on about how much did everyone know: 'Who knew? What did they know?'

Everyone knew! Our parents, our teachers - that isn't the question! The question is how could you let this happen? knew. ${ }^{5}$

... Thousands. That's how many there were, thousands of camps. Everyone

In his autobiography, Hecht relates confrontations that he had with fellow Jews who held executive positions in the film industry, and with others who had written hit plays and successful novels. These Jews, he writes, "could command the press of the world." According to his account, they failed to join his effort to publicize the Nazi slaughter because they feared identifying themselves as Jews, and in so doing, forfeiting their identity as Americans. ${ }^{52}$ Hecht's recollection of these debates, written in the early 1950s, raises the question of whether he is guilty of reading history backwards. Did any of these individuals, including himself, really understand the situation as clearly as he says 
they did, and were they all simply guilty of a kind of foolishness or cowardice? Did he see things differently than they did? And if so, what did he understand, and why was he able to see what others could or would not? By seeking the answers to these questions, which can be found in the primary documents of those years, and particularly in Hecht's own writings and correspondences, this study hopes to build upon an understanding of the times that has been developed by Lipstadt and Leff.

As the German student suggests, beyond the questions of what was known and when is the matter of what could have been done. Over the years, skeptics like Novick and Brecher persistently cast doubt on the feasibility of rescue. Novick argues that the mainstream American Zionists were correct in their tough-minded decision to essentially give Europe's Jews up for dead and to focus instead towards the future, on the winnable cause of Jewish statehood. ${ }^{53}$ Brecher emphasizes the argument, put forth at the time by representatives of the American and British governments and since then by many others as well, that unrealistic rescue efforts amounted to nothing more than a distraction from the most efficient way to stop the killing, which was to defeat the Nazis in the war. ${ }^{54}$

The arguments about what could have been done most notably revolve around the ransom offers for Jews by Axis elements in Romania and Hungary, as well as around what might have been achieved by bombing Auschwitz. In the end, these debates tend to degenerate into a hashing of arcane details and speculations about conditions during wartime, subjects about which our knowledge will inevitably remain murky and consensus will likely be impossible to achieve. ${ }^{55}$

Regardless of conjecture about the potentialities of rescue, the fact remains that the record of obstructionism, indifference and, at times, overt anti-Semitism within the 
American federal bureaucracy is as substantial as it is disturbing. The record of the disunity within the American Jewish "community," while it was hardly a shocking new development at the time, is equally undeniable and disheartening. Given this context, the extraordinary efforts of Hecht and the small, outmatched group of activists led by Peter Bergson deserve our remembrance and respect.

It is the legacy of the Bergson Group that has been at issue, and arguments over the feasibility of rescue have masked an ideological clash perpetuated ever since Hecht, Bergson and their cohorts first appeared on the political scene. ${ }^{56}$ This is why Novick, in his polemic, devotes most of his attention to the Holocaust's place in contemporary American society. Brecher accuses Wyman of marshaling the facts of history to press an agenda of staunch support for Israel. Adding emphasis, he chastises Wyman for neglecting to discuss that what made Bergson, the "nuisance diplomat," an unacceptable partner to mainstream, organized American Jewry was he represented the Irgun-

an outcast political element which embraced: (i) a set of political beliefs and organizational practices that many considered fascistic and (ii) a terrorist course of action in Palestine which, aside from doubts about its efficacy and inclusion of America's military ally, Britain, among its targets, was simply not supported by a broad sector of the Jewish community. In a word, what we are dealing with here is nothing less than the conflict over the very nature of the Jewish national movement, a conflict so fundamental that it would actually lead to a violent clash of arms in June 1948 in Palestine among the Palestinian Jews themselves, even as they were in the midst of a war of survival and independence. .... Whether justifiably or not American Jews saw their only chance to obtain essential cooperation from the United States government, not in the confrontational tactics of the Group, but in the spirit of positive interaction and persuasion which had traditionally borne fruit for Jewry in the Western world.

With this curious suggestion that, up until the eve of European genocide, the Jewish "spirit of interaction and persuasion had traditionally borne fruit in the Western world," Brecher tips the hand of his own ideological bias. ${ }^{57}$ 
It is not the purpose of this dissertation to enlist with one side or the other in this decades-long argument. Rather, my aim is to illuminate the fundamental questions that the debate has raised all along, but has been too partisan to address. On the issue of whether the Allied governments, the media, and American Jewish leaders were guilty of an historic moral failure, the preponderance of evidence clearly suggests that they were. Equally obvious, it seems, is that the Bergson Group's campaign for rescue was a ray of light that cut through the darkness of those days.

But while this is the stuff of compelling historical narrative, it is not the whole story. What the Wyman narrative shares with Novick's is a narrow ideological focus that underplays the more troubling complexities which are this history's true legacy. If we can agree that the Bergson Group's campaign for rescue was brave, even prophetic, we must also acknowledge what happened off in Palestine: the Irgun's policy of reprisal that targeted scores of Arab civilians during the Arab Revolt that began in 1936, the criminal negligence that claimed dozens of innocent lives in the 1946 bombing of the King David Hotel, and the massacre of between 100 and 120 Arab villagers at Deir Yassin. ${ }^{58}$ This prompts the question: what kind of philosophical system made it to possible to achieve such moral clarity on the one hand, and on the other, to countenance such shocking violations of what, in a post-World War II world, we now call "human rights"? An intellectual history that probes this question might focus on Bergson himself, or on the Irgun's leader Menachem Begin. But this study, as a media history, focuses instead on the American journalist and screenwriter who arrived at this perspective through his own, uniquely American experience, and then introduced it into our public sphere. 
Penkower's original study of the Bergson Group is distinct from the others discussed here, because it does not posit that greater Jewish unity or more determined Allied rescue efforts would have made much of a difference. Nor does it argue that the group's political lobbying or Bergson and Hecht's mastery of publicity achieved much in the end. Instead, Penkower concludes:

The separatists wrought their greatest transformation on the American Jewish community. Until their arrival, the outbreak of World War II checked the protest movements in which Jews had been engaged during the 1930s, such as the anti-Nazi boycott or demonstrations against Britain's Palestine policy. Assimilated Jews feared taking any steps which might raise the question of dual loyalty and strengthen antiSemitism. The Jewish establishment, relying on the good will of Roosevelt and Churchill, was also restrained and the Zionist leadership in particular did what it could to check the Bergsonites' growth. But American Jewry at large could not but be aroused by the independent, aggressive effort of the young Palestinians. Their guiding principle of directly attacking the criminal, rather than defending the victim, attracted estranged souls like Ben Hecht or non-aligned intellectuals like Max Lerner, who insisted that Jews should "no longer be the anvil of history but its hammer." ${ }^{59}$

In Child of the Century, Hecht writes that in 1939, "I became a Jew and looked on the world with Jewish eyes. The German mass murder of the Jews, recently begun, had brought my Jewishness to the surface." In this sense, Hecht became the prototype of the American Jew, discussed by Novick, whose identity was forged by the Holocaust. Hecht quickly adds that the German police state inspired in him a newfound love of democracy and, "Thus, oddly, in addition to becoming a Jew in 1939 I also became an Americanand remained one. ${ }^{60}$ But here we must take issue with the last part of his statement. For at the beginning of the war, Hecht was focused on the Allied effort, and pointedly disavowed any interest in the cause of Zionism. But by the time he was living through the bitter aftermath of the Holocaust, he had evolved into a champion of what he and his comrades 
called "the fighting Jew," the lead propagandist and fundraiser for that faction of Zionist "terrorists" known as the Irgun, and an outspoken advocate of attacks against America's ally, Britain. Although he wrapped his communiques in jingoistic rhetoric about the American Revolution, he was hardly shy about raising questions of loyalty, and about presenting himself as a Jew first and an American second.

So much of Novick's rhetoric about the Holocaust in collective memory can easily be flipped on its head. The idea that the Holocaust has produced a "victim culture" has as a direct corollary the proposition that it produced a fighting culture exemplified by the Israeli Sabra and the Israel Defense Forces. Novick argued that because the conditions imposed by the Nazis were so extreme, the Holocaust really has no "lessons" to teach us ... though one must wonder why, if we can learn nothing from such a seminal event, we should study history at all. ${ }^{61}$ Lawrence Langer, alternatively, quotes Herman Melville"To produce a mighty book, you must choose a mighty theme"—and suggests that for artists and writers, the Holocaust is "the White Whale of our time." Holocaust art "is a necessary art, ever more necessary as that event recedes in time and new generations struggle to comprehend why a civilized country in the midst of the twentieth century coolly decided to murder all of Europe's Jews." ${ }^{62}$

The Holocaust in American Life traces the evolution of the catastrophe in the public's consciousness over sixty years, citing what Novick regards as turning points: the Adolf Eichmann trial in 1961 and Hannah Arendt's controversial essays about it for the New Yorker; the Arab-Israeli wars of 1967 and 1973; the NBC mini-series The Holocaust (1978); Steven Spielberg's Schindler's List; and the opening of the Holocaust Museum. In his review for The Journal of American History, Severin Hochberg argues that at least as 
important was the specifically American experience; for Americans in the late '70s and '80s, the bitter ordeal of the Vietnam War gave America's "good war" a special significance. Such currents in the culture "have little to do with Jews, Jewish leaders, the media, or 'competitive victimization.' The issues ordinary Americans see and respond to in those events are clearly American preoccupations: abuse of governmental power, racism, the extent of responsibility for one's neighbor, above all the embodiment of Adolf Hitler as Absolute Evil. Those themes have powerful resonance in American history."63 Instead of tracing conceptualizations of the Holocaust that evolved over the decades following the war, this dissertation takes 1910 as a starting point, and follows currents in thought that shaped American responses to the breaking news and immediate aftershocks of the catastrophe. In Hecht, we see a hardboiled Chicago crime reporter reinventing himself as a voice of wrath during the rise of Nazism. At the same time, we see a first-generation Jewish American coming to terms with identity and making a mark on American culture and politics in the process. As historian David Brion Davis has suggested: "By showing how cultural tensions and contradictions may be internalized, struggled with and resolved within actual individuals, biography offers the most promising key to the synthesis of culture and history.",64

\section{Hecht's propaganda in political and intellectual history}

To put the debate over the Hecht-Bergson publicity campaign into a broader context, the proposition that it changed the course of history suggests a Great Man or “whiggish" narrative, a favorite target for media scholars ever since James Carey’s 1974

critique, "The Problem of Journalism History." 65 Richard Evans has observed that the 
world wars reinforced traditional "kings and battles" accounts of the past. ${ }^{66}$ But has Hecht's campaign earned him a place as a gallant knight in the pantheon of history?

Carey faults this whole interpretive frame, not so much for being wrong as for being dull, narrow and exhausted. Opening up another line of attack, Michael Schudson has warned that media historians commonly ascribe too much importance to the role media have played in events. ${ }^{67}$ Although I do not maintain that Hecht's propaganda achieved the rescue of thousands, I do contend that it offers a window into the beliefs people held at the time in the extraordinary power of mass communication. This in turn explains the very real and lasting power media held, and the nature of its impact.

Schudson's point reflects a modern approach in social science, pioneered by Paul Lazarsfeld and Carl Hovland, which casts aside a "Magic Bullet Theory" of direct media control and instead focuses on quantifying "limited effects." ${ }^{68}$ In contemporary discussions, the Magic Bullet Theory refers to a notion said to be prevalent before and during the war, that mass media possesses the power to inject messages into people's heads just as a syringe can pump liquid straight into a brain. ${ }^{69}$ Historian J. Michael Sproule argues that this theory was invented after 1940 and doesn't accurately reflect the thinking during the two decades leading up to the war. It tells us more about the postwar researchers, a breed of utilitarians more interested in the mechanics and processes of short-term media effects than in concerns about manipulation. Their "Magic Bullet myth" is a straw man that was invented to bury a competitive field of discourse, which has thus obscured an important story of how people once understood propaganda. ${ }^{70}$

In the 1920 s there was broad consensus among scholars and popular writers alike that the massive propaganda effort of World War I had been remarkably effective. Three 
of the most enduring responses were Walter Lippmann's Public Opinion (1922), Edward Bernays's Propaganda (1928) and Harold Lasswell's Propaganda Technique of the World War (1927). Of these three, Lasswell is the one directly connected to the propaganda of the Second World War.

Contrary to the idea of media as hypodermic needle, his ideas were premised on skepticism that media messaging could function according to the stimulus-response model of John B. Watson's behaviorism. He believed that even crude forms of propaganda could be effective with a vulnerable population subjected to trauma-for example, Germans wracked by the Depression — but he did not maintain that simple media stimuli would have much effect. Instead, he thought that the only way to produce reliably effective propaganda was through a careful, strategic plan involving the gradual development of narratives - or myths, and symbols, like the swastika. He called these master or collective symbols. $^{71}$

Lasswell's content analysis of Axis propaganda for the Library of Congress, funded by the Rockefeller Foundation, was initially helpful to the American war effort. But by 1943, the more methodologically acute and innovative social science of Lazarsfeld, Hovland and others was proving more useful. By then, Lasswell's ideas were also under ideological attack. $^{72}$

But while Lasswell's work would soon be buried in the competition for status and funding, with the result that in the postwar years, "propaganda" would altogether cease to exist as a field of research, his studies are nonetheless invaluable as primary documents of intellectual history. They help us understand what is perniciously misleading about the Magic Bullet myth. The image of the hypodermic needle evokes the awe with which 
political elites, in particular, must have greeted the birth of radio, newsreels and talking pictures. However, their experience of the Great War had made them wise to what historian Jack Roth later observed, that the conflict had represented "the first modern effort at systematic, nationwide manipulation of collective passions." ${ }^{, 73}$ Canny power brokers did not necessarily believe that media could change attitudes but rather, as Roth suggests, it could inflame and redirect collective passions that were already there.

Through his study of Nazi propaganda, Lasswell suggested that such manipulation could be achieved through the use of master symbols. The results, like the swastika and the crowds at Nuremberg's Zeppelin Field offering their Sieg Heil, still burn in our consciousness. In this war of propaganda, Hecht struck back by casting his own ideas into images drawn from master symbols. ${ }^{74}$ There is corollary here with the ideas about mythology that concern media historians when they discuss Maurice Hallwbach's idea of collective memory. What this suggests is that the propagandists of the era very deliberately loaded their symbols with content, and it is therefore important to unpack this imagery, which still holds such power over us, and investigate the provenance of their ideas. That way, the true reasoning and broader implications of the rhetoric surrounding Jewish identity and the politics of Israel become more apparent. We may find that some ideas have strange bedfellows; hence my suggestion that some rhetoric about Israel that today we associate with the political right can be traced, through Hecht, to a reporter's experience in gangland Chicago and to Hollywood gangster movies. ${ }^{75}$ If we view the same old tropes with fresh eyes and a clearer sense of perspective, the ideas and principles that deserve to endure will reassert themselves, and those things that are truly the domain of the past can be left where they belong. 


\section{Hecht's propaganda in social and cultural history}

Hecht did not claim that his propaganda had achieved anything. In Child he relates that after the tour of We Will Never Die, composer Kurt Weill lamented: “Actually, all we have done is make a lot of Jews cry, which is not a unique accomplishment.” Describing himself as "just an honest writer who was walking down the street one day when he bumped into history," Hecht knows this autobiography is not the memoir of a Great Man and does not offer it as such; he merely promises a story worth reading. He concedes that he is neither rich nor famous nor even, as discussed, much respected as a writer. So as he himself suggests, we may want to file Hecht's story among "little people" biographies, a chronicle of someone who, because of his rich and varied experience, gives us an extraordinary window into the past. A writer, he once explained, "has an historic duty to exhibit himself as an artifact of individualism."76

Kael and Corliss, his early champions in film criticism, were on to this idea of the writer as artifact when they presented him as the iconic Hollywood writer who had come West with the advent of sound. Kael's Raising Kane is an early example of a socialcultural mass media history that treats Hecht as representative of a famous literary migration, a quest for better pay and new opportunities in an era of dramatic technological, economic and cultural change. Corliss argued that Hecht "was the Hollywood screenwriter," representative of this "talented and haunted breed" with his "sense of compromise and feelings of artistic frustration."77 But a more complete understanding requires seeing him within a broader historical and cultural context, as media worker, artist, rebel and American Jew. 
Those who have taken the longer view of Hecht's life see his Hollywood encounter as but one chapter in a story of a child of the century who came of age as a star of the modern era's avant garde and died just as the baby boomers were coming into their own. Hecht's biographers in the '70s and '80s aptly understood him within the history of 20th century American cultural rebellion, an area of scholarship that was just beginning to emerge when the biographies of Hecht were published and which has since flourished.

With the passage of years, hindsight has allowed some scholarly consensus to emerge about the 20th century American cultural rebel. Now that we can see Hecht within the bigger picture, his significance becomes salient: Among the moderns, Hecht was unique in presaging the broad cultural shift over later decades that Novick had pointed to: the move from an integrationist to a particularist ethos. Novick is clearly referring to a changing view of ethnic identity, but as he and others point out, this also pertains to politics becoming less about "us" and more about "me"; in other words, the political turned increasingly personal.

These changing characteristics - particularism, the political fusing with the personal-were a major part of the trouble postwar cultural rebels faced when they, like Hecht in the Hollywood of 1930s, struggled to maintain their integrity while producing mass media entertainment. That is because the imperatives of self that came to shape their rebel ideology can easily become confused, by artist and audience alike, with selfcenterdness and self-indulgence. Furthermore, as Todd Gitlin has observed, the line between rebellion and showmanship in America has itself become blurry: "Popular culture absorbs oppositional ideology, adapts it...domesticates it; at the same time, popular culture is a realm for the expression of forms of resistance and oppositional ideology." 78 
Among the histories of cultural rebellion, a seminal work, and an important source in biographies of Hecht, is Henry F. May's The End of American Innocence. May writes that from 1910 to 1920, an avant-garde of bohemian artists, intellectuals and activists attacked fundamental Victorian notions of culture, social order and basic morality. At root this was an epistemological battle, with "the moderns" challenging what was knowable or unknowable, and even questioning the very existence of truth. But the matter directly at issue was Anglo Saxon hegemony, the old order, and the principles that upheld it. ${ }^{79}$

To understand the significance of the furor sparked by Hecht's propaganda, one must appreciate that it was the Zionists who invented America's shorthand for ethnicity in the first place, by popularizing the terms "Melting Pot" and "pluralism." Israel Zangwill, the author of the 1908 hit play The Melting Pot, was a British Jew of Russian extraction who founded the Jewish Territorial Organization, a Zionist faction that advocated a Jewish homeland on whatever land could be acquired, whether in Palestine or not. The Melting Pot's message that immigrants should shed their ancestral ties to "be formed into a new people of freedom" in the Melting Pot of America resonated with Teddy Roosevelt because of the president's own opposition to hyphenated Americans. ${ }^{80}$ But in a two-part article for The Nation in 1915, philosophy professor and Zionist Horace Kallen offered, in the way of rebuttal, an anti-assimilationist theory that would come to be known as "cultural pluralism."

Kallen posits a paradox: he argues that ethnic groups - as we call them now; they were called "races" then—are intrinsically different from one another and must remain so. But in their apartness, they can nevertheless cohere together into a more perfect whole. There is no way to erase differences rooted in ethnicity, Kallen writes, for, "Men may 
change their clothes, their politics, their wives, their religions, their philosophies, to a greater or lesser extent: they cannot change their grandfathers." Difference, however, does not disqualify opportunities for co-existence; to the contrary. America can become like a symphony, performed by an orchestra in which "every type of instrument has its specific timbre and tonality." ${ }^{81}$

Kallen articulated his theory at a critical time for Jewish nationalism, when the European leadership of the World Zionist Organization, fractured and immobilized by the outbreak of the Great War, turned to America to carry the torch. As newly appointed president of the Federation of American Zionists, Louis Brandeis employed Kallen's cultural pluralism to attack the "dual loyalty" charge that stoked anxieties and undermined enthusiasm for Zionism among American Jews. Brandeis, a prominent attorney, close confidant of President Woodrow Wilson and rising star in American politics, asserted that Zionism was "the Pilgrim inspiration and impulse over again," and, that "multiple loyalties are objectionable only if they are inconsistent." An American could also be loyal to his or her family, lodge, city or state, he argued. It was the deeper commitment to justice and democracy that mattered. ${ }^{82}$

To put Hecht's militant Zionist propaganda within this context, it appears that each new paradigm of ethnicity that the Zionists offered defined itself by breaking the promises of the previous one. Those who had supported the Melting Pot ideal countered Nativist restrictionism by promising that immigrants would shed their old ties to become true Americans. Then the cultural pluralists argued that immigrants and their descendants must in fact hold fast to those old ties, but that these new citizens would become all the more loyal to America because of them. Finally, in his "letter," Hecht does away with promises 
of loyalty altogether, arguing instead that the Jews must fight for their life, liberty and pursuit of happiness just as America's founding fathers had once fought against the British for these same rights.

Hecht's "letter" in fact signals the steady failure and disillusionment with collectivist aspirations that histories of American cultural rebellion relate. His relevance as "an artifact of individualism" stems from the fact that, unlike so many of his peers, he was not attracted to socialism or collectivist ideologies in general, which is why his own prewar attitudes are so predictive of the postwar era, when people became thoroughly disillusioned with such dreams. More recent works, like Christine Stansell's American Moderns and Leerom Medovoi's Rebels: Youth and the Cold War Origins of Identity, have contributed to our understanding of this evolution in three respects: they link changing conceptions of ethnicity with the broader shift from shared to self-oriented ideals; they show this shift in mainstream (Anglo Saxon) culture, both high and low; and they search for the linguistic and epistemological origins of "identity" contained in the phrase "identity politics." 83

Studies of American Jewish culture have described the same trajectory. In The New York Intellectuals, Alan Wald relates the history of a group of writers formed around the Menorah Journal, who originally embraced cultural pluralism in the 1920 s only to abandon it for the more universalist ideals of communism and then Trotskyism in the 1930s. ${ }^{84}$ Mark Shechner's After the Revolution, which focuses on postwar Jewish writers, argues that the collapse of socialism after Stalin's purges and show trials had a more profound impact upon on many of them than the revelations about Hitler's concentration camps. Their disillusionment propelled them towards a more personal, insular politics, the 
politics of self-liberation. ${ }^{85}$ In Entertaining America, J. Hoberman observes that by the time Hecht died, Roth's fiction and Hollywood movies were portraying a "Jewish bad boy," in whom "self-hatred merged with self-absorption, narcissism seemed indistinguishable from personal liberation, and alienation was a function of identity." 86 However, the issue of how the individual relates to the broader society doesn't help us define Hecht's propaganda as the expression of a committed cultural rebel, and as a conception of Jewish identity. The premise of this study is that Hecht's relationship with two Jewish rebels, the gangster Mickey Cohen and the poet Max Bodenheim, provide this key. Hecht made clear that he was contesting the image of the Jew as victim and supplicant, so on one level, Cohen offers a straightforward model: He is the living image of the tough Jew, the Zionist Muskeljuden that Max Nordau had originally called for in 1898, and that Vladimir Jabotinsky and Menachem Begin later championed. Alternatively, we can look to the conception of Judaism that Kallen and Brandeis advanced, the idea of a people of the covenant on a quest for their Promised Land, whose "pilgrim spirit" had brought them to America just as it had once brought the Puritans. This argument emphasized, as Kallen put it, that the more a Jew "becomes a free man and an American, the more he becomes all the more a Jew." ${ }^{\prime 87}$ If we are to understand Hecht as a critic and not a reactionary, we may consider whether he shared this notion, and whether he was consciously taking prominent Jews and the liberal Americans in Roosevelt's camp to task, just as the Hebrew prophets had once focused their ire on God's Chosen People. But do these descriptions fully explain Hecht's marked interest in a man who, as he well understood, was a thuggish, sociopathic killer with a taste for Hollywood flair? And how are we to understand the Jew as Max Bodenheim, a failed, shattered modernist poet? 
Mirroring the debates in media history, scholars have weighed the merits of interpretive analysis versus social history in discussions of how to define Jewishness. ${ }^{88}$ In an effort to integrate the insights of both history and the cultural criticism, I suggest four motifs that typify the Jewish American cultural rebel. When we consider them, a kind of narrative emerges, a series of succeeding images like the pictures in a flip book. These are: (1) the secular priest; (2) non serviam; (3) alienation and madness; and (4) return and rebirth.

\footnotetext{
${ }^{1}$ Hecht, Child, 2.

${ }^{2}$ Fetherling, Five Lives, 16-17.

${ }^{3}$ Wikipedia, s.v. "The Front Page," last updated November 25, 2010, http://en.wikipedia.org/wiki/The Front Page.

${ }^{4}$ Robert Schmuhl, “The Front Page Turns 75," Poynter.org, August 6, 2003, http://www.poynter.org/ uncategorized/14410/the-front-page-turns-75/.

${ }^{5}$ Brown Martin, Hollywood Screenwriter, 4.

${ }^{6}$ Raymond J Haberski, It's Only a Movie!: Films and Critics in American Culture (Lexington, Ky: University Press of Kentucky, 2001), 123-124. Haberski writes that critics Andrew Sarris and Pauline Kael would "move quite a bit beyond their predecessors in popularizing the notion of movies as art."

${ }^{7}$ Brown Martin, Hollywood Screenwriter, xi; Fetherling, Five Lives, 17; Haberski, “Andrew Sarris, Pauline Kael, and the Duel for the Soul of Criticism," in Only a Movie!, 122-143; David Kipen, "Auterism's Great Snow Job," on the San Francisco Chronicle's Web site, SFGate.com, 22 April, 2001, http://articles.sfgate.com/2001-04-22/living/17595246_1_auteur-theory-auteuristandrew-sarris. Hecht was not just at the center of an argument about movies as art: Haberski explains how the Kael-Sarris exchanges became deeply intertwined with broader debates over the merits of popular culture, which reflected changes well underway by the mid-1960s, as the old divisions between "highbrow" and "lowbrow" blurred. Dwight MacDonald, taking aim at Sarris, jumped into the fray, with his arguments about Masscult and Midcult; Sarris, for his part, incorporated Susan Sontag's advocacy for the democratization of art in her essays "Against Interpretation" and "One Culture and the New Sensibility."

${ }^{8}$ Pauline Kael, ; See also Kael's reviews in Kiss Kiss Bang Bang, 1st ed. (Boston: Little, Brown, 1968), 33, 59, 319-320; Her reviews in 5001 Nights at the Movies of the rest of Hecht's most successful screenwriting efforts are also informative and insightful (New York: Henry Holt, 1991), 310-311, 335, 399, 629, 657, 758, 796.

${ }^{9}$ Richard Corliss, Talking Pictures: Screenwriters in the American Cinema, 1927-1973 (Woodstock, N.Y: Overlook Press, 1974), 5. The introduction to Talking Pictures is titled "Notes on a Screenwriter's Theory, 1973"- - echoing the title for Sarris' Film Culture essay, "Notes on the Auteur Theory in 1962," and follows a guest introduction by Sarris himself. Just as Sarris' 1968
} 
The American Cinema is a taxonomy of great directors, Corliss' book is a critical survey of screenwriters, with Hecht topping the list.

${ }^{10}$ Fetherling, Five Lives, 1, 17, 191.

${ }^{11}$ Ibid, 186.

${ }^{12}$ Ibid, 124-125.

${ }^{13}$ Ibid, 126

${ }^{14}$ Fetherling quotes Hecht as saying, during the campaign for a Jewish army, that he "would be glad to see a nation of Jews under a Jewish flag," but "could no more feel myself a part of it than any other country beyond the USA." Of this, the biographer notes, "He was, in that instance, treating himself as an American first and a Jew second - the same order of priorities for which he attacked other American Jews." Ibid, 129, 131, 136.

${ }^{15}$ On the Bergson Group's policy and record of restraint, see Rapoport, Shake Heaven and Earth, 161; In Literary Gadfly, Troy argues that in 1947, Hecht abandoned restraint, and let the fur fly. See 107-109, 119-120.

16 "'My Tribe is Israel': World War II and the Irgun" chapter in Brown Martin, Hollywood Screenwriter, 141-160.

17 "Writer-Directors: The Scoundrel and Crime Without Passion" chapter in Ibid, 109-140.

${ }^{18}$ Digging deep into Hecht's published and unpublished writings and other sources, MacAdams offers humorous and vivid illustrations of Hecht's contempt for Hollywood, and how this inspired his propaganda campaign. William MacAdams, Ben Hecht: The Man Behind the Legend (New York: Scribner, 1990), 167-250.

${ }^{19}$ Hecht, Child, 468.

${ }^{20}$ Michiko Kakutani, "He Spoke of Art, but Made His Money in Movies," New York Times, 20 March 1990, Books of The Times.

${ }^{21}$ An elegantly written essay that delves into this question, though it doesn't adequately answer it, is Joseph Epstein's “The Great Hack Genius." Written upon the release of MacAdam's book, the essay is mainly focused on what biographical study, "with its propensity for digging up hallowed ground," will reveal of Hecht's character, and whether it would have been better for Hecht to remain a legend. Epstein concludes that while Hecht wasted his talents as a writer, he was a fascinating, extraordinary human being. Joseph Epstein, "The Great Hack Genius," Commentary, December 1990, 40-48.

${ }^{22}$ Peter Novick, The Holocaust in American Life (Boston: Houghton Mifflin, 1999), 1-2, 7. For his arguments about the role of the Cold War, see his chapter titled "That is the Past, and We Must Deal with the Facts Today," 85-102.

${ }^{23}$ Ibid, 6-8, 10.

${ }^{24}$ Ibid, 3-5; and Maurice Halbwachs, On Collective Memory (Chicago: University of Chicago Press, 1992). Mass communication scholars have emphasized the media's role in the process of collective memory, arguing that people with the power of the press have an easier time having their voices heard, deciding what is said, and determining what is archived. Barbie Zelizer observed how the media "established themselves as authoritative spokespersons" for the Kennedy assassination. Michael Schudson has argued that newspapers are "the most representative carrier and construer and creator" of public consciousness. See also Janice Hume and Noah Arceneaux, "Public Memory, Cultural Legacy, and Press Coverage of the Juneteenth Revival," Journalism History 34, No. 3 (Fall 2008), 156-157; and Hume, "Press, Published History, Regional Lore: Shaping the Public Memory of a Revolutionary War Heroine," Journalism History 30, No. 4 (Winter 2005), 201. Barbie Zelizer, Covering the Body: The Kennedy Assassination, the Media, and the Shaping of Collective Memory (Chicago: University of Chicago Press, 1992). Michael Schudson, Watergate in American Memory: How We Remember, Forget, and Reconstruct the Past (New York: BasicBooks, 1992), 33. 
${ }^{25}$ Ibid, 47-49.

${ }^{26}$ Frank W. Brecher, "'The Western Allies and the Holocaust': David Wyman and the Historiography of America's Response to the Holocaust: Counter-Considerations," Holocaust and Genocide Studies 5, No. 4 (1990), 425.

${ }^{27}$ Arthur D Morse, While Six Million Died; a Chronicle of American Apathy (New York: Random House, 1968).

28 “Access: Http://catdir.loc.gov/catdir/toc/fy0714/41021015.html," n.d..

${ }^{29}$ Penkower, "In Dramatic Dissent”; Sarah E. Peck, "The Campaign for an American Response to the Holocaust, 1943-1945," Journal of Contemporary History 15, No. 2 (April 1980), 367-400. Penkower also published "Believe the Unbelievable!" in Midstream XXVII, No. 4 (April 1981), 31-37. Pre-dating these two entries, Melvin Urofsky summarized the wartime and post-war efforts of Hecht and Bergson Group, in We Are One!: American Jewry and Israel, 1st ed. (Garden City, N.Y: Anchor Press, 1978), 75-81, 97-98, 150-152.

${ }^{30}$ Troy, "From Literary Gadfly," i, 121.

${ }^{31}$ Ibid, 92, 123-124, 128-129. Troy takes the point about "stirring up the animals" from Fetherling, in Five Lives, 126, 136.

${ }^{32}$ Gil Troy, "From Literary Gadfly to Political Activist: The Political Transformation of Ben Hecht," Journal of Ecumenical Studies 40, no. 4 (Fall2003 2003): 431-449, doi:Article

${ }^{33}$ Leonard Dinnerstein, review in The Journal of American History 72, No. 1 (June, 1985), 186187.

${ }^{34}$ Wyman, Abandonment, xv.

${ }^{35}$ Ibid, 285 and n129 on pages 405-406. Wyman offers detailed breakdowns to explain his total.

${ }^{36}$ Brecher, "Western Allies," 431.

37 "Note by David Wyman on the Origin and Structure of the Book," in A Race Against Death, xv.

${ }^{38}$ In fact, as a result of these tensions, Bergson was deposed as the leader of his own group in December 1947. Rapoport, Shake Heaven and Earth, 28, 42-43, 199, 201, 205-206, 208.

${ }^{39}$ Samuel Merlin particularly disapproved of Hecht's letter and opposed its publication. Ibid, 203.

${ }^{40}$ Hecht, "Speeches - [To the Crew of the SS Ben Hecht $)$ - 1947," in Works, 1908-1983, Box 27, Folder 689, BHNL.

${ }^{41}$ Medoff, Militant Zionism, 151, 154-156.

42 “About the Wyman Institute," on the David S. Wyman Institute Web site, accessed October 5 , 2010, http://www.wymaninstitute.org/about/. Rafael Medoff responded to my email inquiry on October 5 that he had established the institute in 2003.

${ }^{43}$ Members of the institute's committees include Yitshaq Ben-Ami's son Jeremy, now executive director of the Jewish lobbying group J Street; Professor Benzion Netanyahu, father of current Israeli prime minister Benjamin Netanyahu; Bergson's wife Nili and their daughter Rebecca Kook, a political science professor at Ben Gurion University; Henry Morgenthau III, an author and television producer and son of FDR's Secretary of the Treasury; and Stella Adler's daughter Ellen, executive chair of the Stella Adler Studio of Acting. Ibid.

${ }^{44}$ Etgar Lefkovits, "US Holocaust Museum to include information about Bergson Group," The Jerusalem Post, 1 August, 2007, News section, 7; and "US Holocaust Museum launches exhibit on Bergson rescue group," 16 July, 2008, News section, 9.

${ }^{45}$ Novick, Holocaust, 11, 48, 98.

${ }^{46}$ Deborah E Lipstadt, Beyond Belief: The American Press and the Coming of the Holocaust, 1933-1945 (New York: Free Press, 1986), 4-5, 8-9, 18-24, 248.

${ }^{47}$ Novick, Holocaust, 21, 27-29, from his chapter on the American public's knowledge about the Holocaust while it was happening, "We Knew in a General Way," 19-29.

${ }^{48}$ Laurel Leff, Buried by the Times: The Holocaust and America's Most Important Newspaper (Cambridge, UK: Cambridge University Press, 2005), 3, 7. 
${ }^{49} \mathrm{Ibid}, 8$.

${ }^{50}$ Lipstadt, Beyond Belief, 275-276.

${ }^{51}$ The Reader, directed by Stephen Daldry, DVD (The Weinstein Company, 2009). This dialogue does not appear in the novel.

${ }^{52}$ Hecht, Child, 550-553.

${ }^{53}$ Novick, Holocaust, 45.

${ }^{54}$ Brecher, "Western Allies," 428.

${ }^{55}$ For instance, Novick cites a study which concludes that the offer in the fall of 1942 to release some seventy thousand Romanian Jews for fifty dollars per life, publicized by Hecht in newspaper advertisements, was never real. Novick also dismisses Adolf Eichmann's proposal to trade a million Hungarian Jews for ten thousand trucks, along with quantities of tea, coffee, cocoa and soap, as directly contrary to war aims, because the trucks were to be used against the Soviets on the Eastern Front and would thus have created a wedge between the Allies. Other studies, however, have argued that the callous failure of the Allies to pursue these negotiations in earnest, a refusal justified in distinctly ugly, bigoted language by the British Foreign Office, proved at least as crippling to their outcomes as the factors that Novick cites. Novick, Holocaust, 52-43, citing Ephraim Ophir, "Was the Transnistria Rescue Plan Achievable?" Holocaust and Genocide Studies 6, No. 1 (1991), 1-16, and Richard Breitman Shlomo Aronson, "The End of the Final Solution? Nazi Plans to Ransom Jews in 1944," Central European History 25 (1992), 177-203. For the alternative view, see Robert Darst, "Guaranteed Human Beings for Sale: the collaborative relocation of Jews from Axis Europe, 1933-45," Journal of Human Rights 1, No. 2 (June 2002), 223.

${ }^{56}$ Indeed, this feud over the history was white hot long before Novick's book was published. For a glimpse at the ad hominem vehemence with which arguments were pressed, see for example the letters column in the September 1983 issue of Commentary, in response to Lucy Dawidowicz's article, "Indicting American Jews," accessed December 6, 2010, https://www.commentarymagazine.com/ viewarticle.cfm/american-jews-and-the-holocaust-13470?page=all.

${ }^{57}$ Brecher, "Western Allies," 425-426, 432, 434.

${ }^{58}$ On the Irgun's targeting of Arab civilians during the Arab Revolt, see Brenner, The Iron Wall, 100; Segev, One Palestine, Complete, 385, 441. The King David Hotel bombing killed 91 people, most of whom were hotel staff, clerks for the British, or members of the public. Nicholas Bethell offers a careful account of it in The Palestine Triangle: The Struggle for the Holy Land, 1935-48 (New York: Putnam, 1979), 257-267. On Deir Yassin, see Benny Morris, The Birth of the Palestinian Refugee Problem, 1947-1949 (Cambridge [England]: Cambridge University Press, 1987), 237-238.

${ }^{59}$ Penkower, "In Dramatic Dissent," 307.

${ }^{60}$ Hecht, Child, 517-518.

${ }^{61}$ Novick, Holocaust, 12-13.

${ }^{62}$ Lawrence L. Langer, "The Americanization of the Holocaust on Stage and Screen," in From Hester Street to Hollywood: The Jewish-American Stage and Screen (Bloomington: Indiana University Press, 1983), 227-228.

${ }^{63}$ Severin Hochberg, review in The Journal of American History 87, No. 3 (December 2000), 1099-1101.

${ }^{64}$ David Brion Davis, "Some Recent Directions in Cultural History," American Historical Review 73 (Feb., 1968), 705.

${ }^{65}$ James W. Carey, "The Problem of Journalism History," Journalism History 1, (Spring 1974), 25, 27; also in James Carey: A Reader, ed. by Eve Stryker Munson and Catherine A. Warren (Minneapolis: University of Minnesota Press, 1997). For assessments of the impact of this essay, 
see David Paul Nord, “A Plea for Journalism History," Journalism History 15, No. 1 (Spring 1988), 9-10; Nord, "James Carey and Journalism History: A Remembrance," Journalism History 32, No. 3 (Fall 2006), 122-123; introduction and conclusion sections of Jean Folkerts, "American Journalism History: A Bibliographic Essay," American Studies International 29, No. 2 (October 1991). 4; and Barbie Zelizer, "History and Journalism," chapter in Taking Journalism Seriously: News and the Academy (Thousand Oaks, Calif.: Sage, 2004), 86-87.

${ }^{66}$ Richard J Evans, In Defense of History, American ed. (New York: W.W. Norton, 1999), 139140.

${ }^{67}$ Michael Schudson, "Toward a Troubleshooting Manual for Journalism History," Journalism \& Mass Communication Quarterly, 74, No. 3 (Autumn 1997), 463-476. See also Zelizer on Schudson in "History and Journalism," 87.

${ }^{68}$ Elihu Katz, "On Conceptualizing Media Effects" Studies in Communication 1 (1980), pages 120-122, 124-125; Stanley J Baran, Mass Communication Theory: Foundations, Ferment, and Future, 5th ed. (Belmont, CA: Thompson Wadsworth, 2009), 128-163; Elihu Katz and Columbia University, Personal Influence; the Part Played by People in the Flow of Mass Communications (Glencoe, Ill: Free Press, 1955); Carl Iver Hovland, Experiments on Mass Communication (Princeton, Princeton University Press, 1949).

${ }^{69}$ See for example Shirley Biagi's textbook for undergraduates Media/Impact: An Introduction to Mass Media, 8th ed. (Australia: Wadsworth Pub, 2007), 245. For an overview of how researchers have attempted to grapple with the deeper questions of media power, see Katz, "On Conceptualizing Media Effects," 119-141.

${ }^{70}$ J. Michael Sproule, "Progressive Critics and the Mass Communication Myth," Critical Studies in Mass Communication 6, No. 3 (September 1989), 225-246. Baran, Mass Communication Theory, xxi, 80-83, 92-93, 128-163.

${ }^{71}$ For a concise summary of Lasswell's ideas on propaganda, see Baran, 81-83; Harold Lasswell, The Theory of Political Propaganda," American Political Science Review 21 (1927), 627-631; Lasswell, "The Strategy of Revolutionary and War Propaganda," Public Opinion and WorldPolitics [Lectures on the Harris Foundation 1933], ed. Quincy Wright (Chicago: University of Chicago Press, 1933), 185-221; Lasswell, Propaganda Technique in the World War [by] Harold D. Lasswell (London: K. Paul, Trench, Trubner \& Co., Ltd, 1927).

${ }^{72}$ Sproule, "Progressive Critics."

${ }^{73}$ World War I, a Turning Point in Modern History; Essays Inthe Significance of the War (New York: Knopf, 1967), 109.

${ }^{74}$ In discussing this, I will incorporate scholarship on Hecht's pageants, namely Stephen J. Whitfield's "The Politics of Pageantry, 1936-1946," American Jewish History 84, No. 3 (1996), 221-251, Atay Citron's "Pageantry and theatre in the service of Jewish nationalism in the United States, 1933-1946" (Ph.D. diss., New York University, 1989) and Robert Skloot, We will never die : the success and failure of a Holocaust pageant ([Baltimore MD: Johns Hopkins University, 1985).

${ }^{75}$ Perry Miller introduced his classic study of intellectual history, Errand into the Wilderness, by explaining the "inner logic" of his research: "The beginning I sought was inevitably-being rooted in the seventeenth century - theological. This was not a fact of my choosing: had the origin been purely economic or imperial, I should have been no less committed to reporting." By this reasoning, in seeking the ideological origins of an American posture towards Israel through a study of the Hecht-Bergson propaganda campaign, it makes sense to investigate the modern, secular culture of early twentieth century America. Perry Miller, Errand into the Wilderness (Belknap Press, 1956), ix.

${ }^{76}$ Hecht, Child, 4-5, 516, 576; "Works," "Disenchanted Diary: Toasts to Disaster" Box 8, Folders 241-243, BHNL. 
${ }^{77}$ See Kael, Raising Kane, 9-10; Corliss, Talking Pictures, 5.

${ }^{78}$ Todd Gitlin, "Prime Time Ideology: The Hegemonic Process in Television Entertainment," in Television: The Critical View, 3rd ed. (New York: Oxford University Press, 1982), 452.

${ }^{79}$ Henry Farnham May, The End of American Innocence; a Study of the First Years of Our Own Time, 1912-1917, 1st ed. (New York: Knopf, 1959).

${ }^{80}$ Israel Zangwill, The Melting-Pot, Drama in Four Acts. (New York, Macmillan, 1909); Stephen J Whitfield, In Search of American Jewish Culture (Hanover, NH: University Press of New England [for] Brandeis University Press, 1999), 72-73.

${ }^{81}$ Horace M. Kallen, "Democracy Versus the Melting-Pot," The Nation, 25 February 1915.

${ }^{82}$ Urofsky, American Zionism, 127-129 citing Louis Brandeis, Menorah Journal 1 (January 1915), 4; Maccabean 23 (July 1915), 34; Boston American (July 4, 1915); and the pamphlet, The Jewish Problem, and How to Solve It (New York, 1915), 12.

${ }^{83}$ Christine Stansell, American Moderns: Bohemian New York and the Creation of a New Century, 1st ed. (New York: Metropolitan Books, 2000); Gangster Film Reader.

${ }^{84}$ Alan M Wald, The New York Intellectuals: The Rise and Decline of the Anti-Stalinist Left from the 1930s to the 1980s (Chapel Hill: University of North Carolina Press, 1987)

${ }^{85}$ Shechner, After the Revolution

${ }^{86}$ Entertaining America: Jews, Movies, and Broadcasting (New York: Jewish Museum, under the auspices of the Jewish Theological Seminary of America, 2003), 221.

${ }^{87}$ Kallen, "Democracy Versus the Melting Pot."

${ }^{88}$ See for example in Whitfield, In Search of American Jewish Culture, 1-31; and Levinson, Exiles on Main Street, 1-11. 


\section{SELECTED BIBLIOGRAPHY}

Allen, Frederick Lewis. Only Yesterday: An Informal History of the 1920's. 1st Perennial classics ed. New York: Perennial Classics, 2000.

Alexander, Edward. Irving Howe: Socialist, Critic, Jew. Jewish Literature and Culture. Bloomington: Indiana University Press, 1998.

American Psychiatric Association, and American Psychiatric Association. Diagnostic and Statistical Manual of Mental Disorders: DSM-IV. 4th ed. Washington, DC: American Psychiatric Association, 1994.

Anderson, Margaret C. My Thirty Years' War; an Autobiography. Westport, Conn: Greenwood Press, 1971.

Anderson, Sherwood. Letters of Sherwood Anderson. 1st ed., reprinted. New York: Kraus Reprint Co, 1969.

Brace and Company, 1942.

Andrews, Wayne. Battle for Chicago. New York: Harcourt, 1946.

Antheil, George. Bad Boy of Music. Garden City, N.Y: Doubleday, Doran \& Company, inc, 1945.

Aranoff, Myron J., ed.The Frailty of Authority. Political Anthropology (New Brunswick, N.J.) v. 5. New Brunswick (U.S.A.): Transaction Books, 1986.

Arendt, Hannah. Eichmann in Jerusalem: a Report on the Banality of Evil. Rev. and enlarged ed. Gloucester, Ma: Peter Smith, 1986.

Avrich, Paul. The Haymarket Tragedy. Princeton, N.J: Princeton University Press, 1984.

Baldick, Chris, and Oxford University Press. The Oxford Dictionary of Literary Terms. 3rd ed. Oxford Paperback Reference. Oxford; New York: Oxford University Press, 2008. http://proxy.mul.missouri.edu/login?url=http://www.oxfordreference.com /view/10.1093/acref/9780199208272.001.0001/acref-9780199208272.

Baran, Stanley J. Mass Communication Theory: Foundations, Ferment, and Future. 2nd ed. Australia ; Belmont, CA: Wadsworth, 2000.

- Mass Communication Theory: Foundations, Ferment, and Future. 6th ed. Wadsworth Series in Mass Communication and Journalism. Boston, MA: Wadsworth Cengage Learning, 2012. 
Barri, Shoshana. "The Question of Kastner's Testimonies on Behalf of Nazi War Criminals." Journal of Israeli History 18, no. 2-3 (1997): 139-165.

Bauer, Yehuda. American Jewry and the Holocaust: The American Jewish Joint Distribution Committee, 1939-1945. Jerusalem : Detroit: The Institute of Contemporary Jewry, Hebrew University; Wayne State University Press, 1981.

Baumel-Schwartz, Judith Tydor. The "Bergson Boys" and the Origins of Contemporary Zionist Militancy. 1st ed. Modern Jewish History. Syracuse, N.Y: Syracuse University Press, 2005.

Begin, Menachem. The Revolt. London: W. H. Allen, 1951.

Bekken, Jon. "Crumbs from the Publishers' Golden Tables: the plight of the Chicago newsboy," Media History 6, No. 1, (2000), 45-57.

Benson, Michael T. Harry S. Truman and the Founding of Israel. Westport, Conn: Praeger, 1997.

Berlin, Isaiah. Freedom and Its Betrayal: Six Enemies of Human Liberty. Princeton, N.J. : Chichester: Princeton University Press, 2002.

Bell, J. Bowyer. Terror Out of Zion: Irgun Zvai Leumi, LEHI, and the Palestine Underground, 1929-1949. New York: St. Martin's Press, 1977.

Ben-Ami, Yitshaq. Years of Wrath, Days of Glory: Memoirs from the Irgun. 1st ed. New York, N.Y: R. Speller, 1982.

Bercovitch, Sacvan. The American Jeremiad. Madison: University of Wisconsin Press, 1978.

Bethell, Nicholas. The Palestine Triangle: The Struggle Between the British, the Jews and the Arabs, 1935-48. London: A. Deutsch, 1979.

Bilek, Arthur J. The First Vice Lord: Big Jim Colosimo and the Ladies of the Levee. Cumberland House Publishing, 2008.

Blacher Cohen, Sarah, ed. From Hester Street to Hollywood: The JewishAmerican Stage and Screen. Bloomington: Indiana University Press, 1983.

Black, Edwin. The Transfer Agreement: The Dramatic Story of the Pact Between the Third Reich and Jewish Palestine. Cambridge, Mass: Brookline Books, 1999. 
Bodenheim, Maxwell. Duke Herring. New York: H. Liveright, inc, 1931.

—. Blackguard. Chicago: Covici-McGee, 1923.

1954.

—. My Life and Loves in Greenwich Village. New York: Bridgehead Books,

—. Slow Vision. New York: The Macaulay Company, 1934.

Boettiger, John. Jake Lingle; or, Chicago on the Spot. New York: E.P. Dutton \& Co., Inc, 1931.

Bogdanovich, Peter, and Museum of Modern Art (New York, N.Y.). The Cinema of Howard Hawks. New York: Film Library of the Museum of Modern Art, 1962.

Boggs, Tom. Millionaire Playboy: a Delirious and True Extravaganza of Inheriting a Fortune and Squandering It. New York: The Vanguard Press, 1933.

Borgwardt, Elizabeth. A New Deal for the World: America's Vision for Human Rights. Cambridge, Mass: Belknap Press of Harvard University Press, 2005.

Brando, Marlon. Brando: Songs My Mother Taught Me. 1st ed. New York: Random House, 1994.

Brecher, Frank W. “"The Western Allies and the Holocaust': David Wyman and the Historiography of America's Response to the Holocaust: Counter-Considerations," Holocaust and Genocide Studies 5, No. 4 (1990), 423-446.

Breitman, Richard. FDR and the Jews. Cambridge, Massachusetts: The Belknap Press of Harvard University Press, 2013.

Brenner, Lenni. The Iron Wall: Zionist Revisionism from Jabotinsky to Shamir. London : Totowa, N.J: Zed ; Biblio Distribution Center, 1984.

Buntin, John. L.A. Noir: The Struggle for the Soul of America's Most Seductive City. 1st ed. New York: Harmony Books, 2009.

Richard Breitman Shlomo Aronson, "The End of the Final Solution? Nazi Plans to Ransom Jews in 1944," Central European History 25 (1992), 177-203.

Burrough, Bryan. Public Enemies: America's Greatest Crime Wave and the Birth of the FBI, 1933-34. New York: Penguin Press, 2004.

Butcher, Fanny. Many Lives--One Love. 1st ed. New York: Harper \& Row, 1972.

Carey, James W. "The Problem of Journalism History," Journalism History 1, (Spring 1974), 2-5, 27.

- James Carey: A Reader, ed. by Eve Stryker Munson and Catherine A. Warren (Minneapolis: University of Minnesota Press, 1997). 
Clarens, Carlos. Crime Movies: From Griffith to The Godfather and Beyond. 1st ed. New York: Norton, 1980.

Chipman, Bruce L. Into America's Dream-dump: a Postmodern Study of the Hollywood Novel. Lanham, Md: University Press of America, 1999.

Chisholm, Robert B. Handbook on the Prophets: Isaiah, Jeremiah, Lamentations, Ezekiel, Daniel, Minor Prophets. Pbk. ed. Grand Rapids, Mich: Baker Academic, 2009.

Churchill, Allen. The Improper Bohemians: a Re-creation of Greenwich Village in Its Heyday. 1st ed. New York: Dutton, 1959.

Cohen, Michael Joseph. Truman and Israel. Berkeley: University of California Press, 1990.

Cohen, Michael Mickey. Mickey Cohen, in My Own Words: The Underworld Autobiography of Michael Mickey Cohen, as Told to John Peer Nugent. Englewood Cliffs, N.J: Prentice-Hall, 1975.

Cooney, John. The Annenbergs. New York: Simon and Schuster, 1982.

Corliss, Richard. Talking Pictures: Screenwriters in the American Cinema, 19271973. Woodstock, N.Y: Overlook Press, 1974.

Corwin, Miles. Homicide Special: a Year with the LAPD's Elite Detective Unit. 1st Owl Books ed. New York: Henry Holt, 2004.

Coser, Lewis A. Men of Ideas; a Sociologist's View. New York: Free Press, 1965.

Crane, Hart. The Letters of Hart Crane, 1916-1932. New York: Hermitage House, 1952.

Cruse, Harold. The Crisis of the Negro Intellectual. New York: Morrow, 1967.

Cuddon, J. A. The Penguin Dictionary of Literary Terms and Literary Theory. 3rd ed. London: Penguin, 1992.

Daldry, Stephen. The Reader. DVD. The Weinstein Company, 2009.

Dardis, Tom. Some Time in the Sun. New York: Scribner, 1976.

David Brion Davis, "Some Recent Directions in Cultural History," American Historical Review 73 (Feb., 1968), 696-707.

Davis, Susan O'Connor. Chicago's Historic Hyde Park. Chicago: University of Chicago Press, 2013. 
Dawidowicz, Lucy S. The War Against the Jews, 1933-1945. 10th anniversary ed. [Ardmore, Pa.] : New York: Seth Press ; Distributed by Free Press, 1986.

. What Is the Use of Jewish History?: Essays. 1st ed. New York: Schocken Books, 1992.

Deem, James M. Kristallnacht: The Nazi Terror That Began the Holocaust. The Holocaust through Primary Sources. Berkeley Heights, NJ: Enslow Publishers, 2012.

Demaris, Ovid. The Last Mafioso: The Treacherous World of Jimmy Fratianno. New York: Times Books, 1981.

Dewey Johns, Elizabeth. Chicago's Papers and the News. Unpublished Ph.D. dissertation, University of Chicago, 1942. 2001.

DiBattista, Maria. Fast-talking Dames. New Haven, CT: Yale University Press,

Diner, Hasia R. We Remember with Reverence and Love American Jews and the Myth of Silence after the Holocaust, 1945-1962. New York: New York University Press, 2009.

Dinnerstein, Leonard. Review of David Wyman's Abandonment of the Jews in The Journal of American History 72, No. 1 (June, 1985), 186-187.

Doering, Bernard. "Madame Bovary and Flaubert's Romanticism." College Literature 8, no. 1 (January 1, 1981): 1-11. doi:10.2307/25111355.

Doherty, Eddie. Gall and Honey; the Story of a Newspaperman. New York: Sheed \& Ward, 1941.

Dornfeld, A. A. Behind the Front Page: The Story of the City News Bureau of Chicago. Chicago, Ill: Academy Chicago, 1983.

Dreiser, Theodore, and Theodore Dreiser. Newspaper Days. 7th ed. First published as A Book About Myself v.2. New York: H. Liveright, 1922.

Duffey, Bernard I. The Chicago Renaissance in American Letters. 2d ed. East Lansing: Michigan State University Press, 1956.

Duncan, Hugh Dalziel. The Rise of Chicago as a Literary Center from 1885 to 1920; a Sociological Essay in American Culture. Totowa, N. J: Bedminster Press, 1964.

Eig, Jonathan. Get Capone: The Secret Plot That Captured America's Most Wanted Gangster. 1st Simon \& Schuster hardcover ed. New York: Simon \& Schuster, 2010. 
Eisenberg, Dennis. Meyer Lansky: Mogul of the Mob. New York: Paddington Press : distributed Grosset \& Dunlap, 1979.

Ehrlich, Matthew C. Journalism in the Movies. History of Communication. Urbana: University of Illinois Press, 2004.

Eisner, Lotte H. The Haunted Screen: Expressionism in the German Cinema and the Influence of Max Reinhardt. Berkeley: University of California Press, 1969.

Eliot, T. S. The Letters of T.S. Eliot. Rev. ed. New Haven: Yale University Press, 2011.

—. The Letters of T.S. Eliot. New Haven: Yale University Press, 2011.

Encyclopaedia Judaica. 2nd ed. Detroit: Macmillan Reference USA in association with theKeter Pub. House, 2007.

Encyclopedia of White Power: a Sourcebook on the Radical Racist Right. Walnut Creek, CA: AltaMira Press, 2000.

Encyclopedia of World Biography. 2nd ed. Farmington Hills: Cengage Gale, 2011. http://ezproxy.umsl.edu/login?url=http://find.galegroup.com/gvrl/infomark.do? type $=$ aboutBook\&prodId $=$ GVRL\&eisbn $=9781414462790 \&$ userGroupName $=$ morenetum sl\&version $=1.0$.

Epstein, Joseph. "The Great Hack Genius," Commentary, December 1990, 40-48. " "Sorting Out Ben Hecht." Chicago Tribune. Accessed October 13, 2013. http://articles.chicagotribune.com/2002-03-31/entertainment/0203290370_1_ben-hechtjoseph-epstein-carl-sandburg.

Evans, Richard J. The Coming of the Third Reich. 1st American ed. New York: The Penguin Press, 2004.

—. The Third Reich at War, 1939-1945. London; New York: Allen Lane, 2008.

—. In Defense of History. American ed. New York: W.W. Norton, 1999.

Fanon, Frantz. The Wretched of the Earth / Frantz Fannon; Translated from the French by Richard Philcox ; Introductions by Jean-Paul Sartre and Homi K. Bhabha. New York: Grove Press, 2004.

Fedler, Fred et al, Reporting for the Media. 8th ed. New York: Oxford University Press, 2005.

Feingold, Henry L. The Politics of Rescue; the Roosevelt Administration and the Holocaust, 1938-1945. New Brunswick, N.J: Rutgers University Press, 1970.

. Zion in America: The Jewish Experience from Colonial Times to the Present. New York: Hippocrene Books, 1974. 
Fiedler, Leslie A. The Collected Essays of Leslie Fiedler. New York: Stein and Day, 1971.

Feinman, Jeffrey. Hollywood Confidential. Chicago: Playboy Press, 1976.

Fetherling, George. The Five Lives of Ben Hecht. Toronto: Lester and Orpen, 1977.

Fisher, James Terence. On the Irish Waterfront: The Crusader, the Movie, and the Soul of the Port of New York. Cushwa Center Studies of Catholicism in Twentiethcentury America. Ithaca: Cornell University Press, 2009.

Folkerts, Jean. "American journalism history: A bibliographic essay," American Studies International 29, no. 2 (October 1991).

Fowler, Gene. Skyline; a Reporter's Reminiscence of the 1920s. New York: Viking Press, 1961.

Freeman, David. A Hollywood Education: Tales of Movie Dreams and Easy Money. New York: Putnam, 1986.

Friede, Donald. The Mechanical Angel, His Adventures and Enterprises in the Glittering 1920's. 1st ed. New York: A.A. Knopf, 1948.

Friedländer, Saul. Nazi Germany and the Jews. Volume I, The Years of Persecution, 1933-1939. New York, NY: HarperCollins, 1997.

- The Years of Extermination: Nazi Germany and the Jews, 1939-1945. 1st ed. New York, NY: Harper Collins Publishers, 2007.

Friedman, Robert I. The False Prophet: Rabbi Meir Kahane--from FBI Informant to Knesset Member. 1st ed. Brooklyn, N.Y: Lawrence Hill Books, 1990.

Fromm, Erich. Escape from Freedom. New York: Rinehart, 1941.

Silver, Alain, ed. Gangster Film Reader. Pompton Plains, N.J: Limelight Editions, 2007.

Gelb, Arthur. O’Neill. 1st ed. New York: Harper, 1962.

Gelber, Yoav. Palestine, 1948: War, Escape and the Emergence of the Palestinian Refugee Problem. Brighton; Portland, OR: Sussex Academic Press, 2001.

Greenwald, Richard A. The Triangle Fire, the Protocols of Peace, and Industrial Democracy in Progressive Era New York. Philadelphia: Temple University Press, 2005. 
Gilbert, Martin. Kristallnacht: Prelude to Destruction. 1st ed. New York: HarperCollins, 2006.

Goldhagen, Daniel Jonah. Hitler's Willing Executioners: Ordinary Germans and the Holocaust. 1st ed. New York: Alfred A. Knopf, 1996.

Goldman, Emma. Living My Life. New York: Dover Publications, 1970.

- Nowhere at Home: Letters from Exile of Emma Goldman and Alexander Berkman. New York: Schocken Books, 1975.

Goren, Arthur Aryeh. "Pageants of Sorrow, Celebration and Protest: The Public Culture of American Jews." Literary Strategies: Jewish Texts and Contexts (1996): 202.

Gottlieb, Polly Rose. The Nine Lives of Billy Rose. New York: Crown Publishers, 1968.

Haberski, Raymond J. It's Only a Movie!: Films and Critics in American Culture. Lexington, Ky: University Press of Kentucky, 2001.

Hagemann, E.R. "Scarface: The Art of Hollywood, Not 'The Shame of a Nation'." The Journal of Popular Culture 18, no. 1 (June 1, 1984): 30-42.

doi:10.1111/j.0022-3840.1984.1801_30.x.

Halamish, Aviva. The Exodus Affair: Holocaust Survivors and the Struggle for Palestine. 1st ed. Syracuse, N.Y: Syracuse University Press, 1998.

Handbook of Communication Science. Beverly Hills: Sage publications, 1987.

Hansen, Harry. Midwest Portraits: a Book of Memories and Friendships. New York: Harcourt, Brace and company, 1923.

Harris, Jed. A Dance on the High Wire: Recollections of a Time and a Temperament. New York: Crown Publishers, 1979.

Hecht, Ben. A Book of Miracles. New York: Viking, 1937. 1927.

-A Thousand and One Afternoons in Chicago. New York: Covici Friede,

—. A Jew in Love. New York: Covici, Friede, 1931.

- A Tribute to Gallantry, The Best One-Act Plays of 1943. New York:

Dodd, Mead, 1944.

- Actor's Blood. New York: Covici, Friede, 1936.

. Charlie: The Improbable Life and Times of Charles MacArthur. 1st ed.

New York: Harper, 1957.

—. Count Bruga. New York: Boni \& Liveright, 1926.

- Erik Dorn, a Novel. Chicago in Fiction. Chicago: University of Chicago

Press, 1963. 
-. Fantazius Mallare: a Mysterious Oath. Chicago: Covici-McGee, 1922.

—. Gaily, Gaily. Garden City, New York: Doubleday, 1963.

-I Hate Actors! New York: Crown publishers, 1944.

- Letters from Bohemia. Garden City, New York: Doubleday, 1964.

- Perfidy. New York: Messner, 1961.

- The Champion from Far Away. New York: Covici, Friede, 1931.

. The Front Page. New York: Covici-Friede, 1928.

. The Front Page: From Theater to Reality. The Art of Theater Series. Hanover, NH: Smith \& Kraus, 2002.

-. To Quito and Back. New York: Covici, Friede, 1937.

-. Underworld: An Original Story of Chicago. [Chicago?: Hecht, 1927.

Heller, Joseph. The Stern Gang: Ideology, Politics and Terror, 1940-1949. London: Routledge, 2006.

Hemingway, Ernest. A Moveable Feast: The Restored Edition. 1st Scribner hardcover ed. New York, NY: Scribner, 2009.

Herf, Jeffrey. The Jewish Enemy: Nazi Propaganda During World War II and the Holocaust. Cambridge, Mass: The Belknap Press of Harvard University Press, 2006.

Herzl, Theodor. Herzl Year Book. New York: Herzl Press, 1958.

Hier, Marvin, (Author of screenplay), Simon Wiesenthal Center, and Moriah Films. Against the Tide. Trank, Richard (Author of Screenplay); (Producer); (Director). [United States]: Moriah Films, 2008.

Higham, John. Send These to Me: Immigrants in Urban America. Rev. ed. Baltimore: Johns Hopkins University Press, 1984.

Hilberg, Raul. The Destruction of the European Jews. Harper Torchbooks, TB 1959. New York: Harper \& Row, 1961.

Hillier, Jim, and Peter Wollen, eds. Howard Hawks: American Artist. British Film Institute, 1997.

Hoberman, J., and Jeffrey Shandler. Entertaining America: Jews, Movies, and Broadcasting. New York: Jewish Museum, under the auspices of the Jewish Theological Seminary of America, 2003.

Hochberg, Severin. Review of Peter Novick's Holocaust in American Life in The Journal of American History 87, No. 3 (December 2000), 1099-1101.

Hoffmann, Hilmar. The Triumph of Propaganda: Film and National Socialism, 1933-1945. Providence: Berghahn Books, 1996. 
Holden, Henry M. FBI 100 Years: An Unofficial History. Minneapolis, Minn: Zenith Press, 2008.

Horkheimer, Max. Dialectic of Enlightenment: Philosophical Fragments. Cultural Memory in the Present. Stanford, Calif: Stanford University Press, 2002.

Hovland, Carl Iver. Experiments on Mass Communication. Princeton, Princeton University Press, 1949.

Howe, Irving. Sherwood Anderson. American Men of Letters Series. Stanford, CA: Stanford University Press, 1968.

Janice Hume and Noah Arceneaux, "Public Memory, Cultural Legacy, and Press Coverage of the Juneteenth Revival," Journalism History 34, No. 3 (Fall 2008), 155-162. - Hume, "Press, Published History, Regional Lore: Shaping the Public Memory of a Revolutionary War Heroine," Journalism History 30, No. 4 (Winter 2005), 200-209.

Jabotinsky, Vladimir and Klinger, S. The Ten-Year Plan for Palestine, a Brief Outline. Jabotinsky, Vladimir,; 1880-1940. London, New Zionist Press, 1938.

Jennings, Dean Southern. We Only Kill Each Other: The Life and Bad Times of Bugsy Siegel. Englewood Cliffs, N.J: Prentice-Hall, 1967.

Jerome, Fred. Einstein on Israel and Zionism: His Provocative Ideas About the Middle East. 1st ed. New York: St. Martin's Press, 2009.

Johnston, Alva. The Legendary Mizners. 1st pbk. ed. New York: Farrar, Straus \& Giroux, 1986.

Jowett, Garth. Propaganda \& Persuasion. Thousand Oaks, Calif.: SAGE, 2012.

Joyce, James. A Portrait of the Artist as a Young Man. Centennial ed. New York: Viking Press, 1982.

Kallen, Horace M. "Democracy Versus the Melting-Pot," The Nation, 25 February 1915.

Kael, Pauline. 5001 Nights at the Movies. New ed. New York: Henry Holt, 1991. . Kiss Kiss Bang Bang. 1st ed. Boston: Little, Brown, 1968.

- The Citizen Kane Book: Raising Kane. 1st ed. Boston: Little, Brown, 1971.

Kakutani,Michiko. "He Spoke of Art, but Made His Money in Movies," New York Times, 20 March 1990. 
Kallis, Aristotle A. Nazi Propaganda and the Second World War. Houndmills, Basingstoke, Hampshire ; New York: PalgraveMacmillan, 2005.

Kammen, Michael G. American Culture, American Tastes: Social Change and The 20th Century. 1st ed. New York: Alfred A. Knopf : Distributed by Random House, 1999.

Kaplan, Eran. The Jewish Radical Right: Revisionist Zionism and Its Ideological Legacy. Studies on Israel. Madison, Wis: University of Wisconsin Press, 2005.

Katz, Elihu, and Paul Lazarsfeld. Personal Influence; the Part Played by People in the Flow of Mass Communications. Glencoe, Ill: Free Press, 1955. (1980), 119-139.

Kazin, Alfred. "In Every Voice, In Every Ban," The New Republic, 10 January 1944, 44-46. . On Native Grounds: An Interpretation of Modern American Prose Literature. New York: Harcourt, Brace \& World, 1942.

Keefe, Rose. Guns and Roses: The Untold Story of Dean O'Banion, Chicago's Big Shot before Al Capone. Nashville, Tenn.: Cumberland House, 2003.

Kefauver, Estes, and United States. Crime in America. 1st ed. New York: Greenwood Press, 1968.

Kerouac, Jack. The Town \& the City. Penguin Classics. London: Penguin, 2000.

Klatt, Wayne. Chicago Journalism: a History. Jefferson, N.C: McFarland \& Co, 2009.

Koestler, Arthur. Promise and Fulfillment: Palestine 1917-1949. London: Macmillan, 1949.

Koszarski, Richard. Hollywood on the Hudson Film And Television in New York from Griffith to Sarnoff. New Brunswick, N.J: Rutgers University Press, 2008.

Kollek, Teddy. For Jerusalem: a Life. 1st American ed. New York: Random House, 1978.

Kotynek, Roy. American Cultural Rebels: Avant-garde and Bohemian Artists, Writers and Musicians from the 1850s through the 1960s. Jefferson, N.C: McFarland \& Co, 2008.

Kramer, Dale. Chicago Renaissance; the Literary Life in the Midwest, 1900-1930. 1st ed. New York: Appleton-Century, 1966. 
Kreymborg, Alfred. Troubadour, an American Autobiography. American Century Series, S-22. New York: Sagamore Press, 1957.

Lacey, Robert. Little Man: Meyer Lansky and the Gangster Life. 1st ed. Boston: Little, Brown, 1991.

Langner, Lawrence. The Magic Curtain: The Story of a Life in Two Fields, Theatre and Invention, by the Founder of the Theatre Guild. 1st ed. New York: Dutton, 1951. 1972.

Laqueur, Walter. A History of Zionism. New York: Holt, Rinehart and Winston, ed., Fascism: a Reader's Guide: Analyses, Interpretations, Bibliography. Berkeley: University of California Press, 1978.

Lasch, Christopher. The Culture of Narcissism: American Life in an Age of Diminishing Expectations. 1st ed. New York: Norton, 1978.

Lasswell, Harold Dwight. Propaganda Technique in the World War [by] Harold D. Lasswell. London: K. Paul, Trench, Trubner \& Co., Ltd, 1927. . "The Theory of Political Propaganda," American Political Science Review 21 (1927), 627-631; ."The Strategy of Revolutionary and War Propaganda," Public Opinion and World-Politics [Lectures on the Harris Foundation 1933], ed. Quincy Wright (Chicago: University of Chicago Press, 1933), 185-221.

Lawrence, Jerome. Actor, the Life and Times of Paul Muni. New York: Putnam, 1974.

Leff, Laurel. Buried by the Times: The Holocaust and America's Most Important Newspaper. Cambridge, UK: Cambridge University Press, 2005.

Lefkovits,Etgar. "US Holocaust Museum to include information about Bergson Group," The Jerusalem Post, 1 August, 2007, News section, 7.

_. "US Holocaust Museum launches exhibit on Bergson rescue group," The Jerusalem Post, 16 July, 2008, News section, 9.

Lesy, Michael. Murder City: The Bloody History of Chicago in the Twenties. 1st ed. New York: W.W. Norton \& Co, 2007.

Levin, Meyer. In Search, an Autobiography. New York: Horizon Press, 1950.

Levine, Charles. Propaganda techniques of the Bergson group, 1939-48, 1974. 
Levinson, Julian. Exiles on Main Street: Jewish American Writers and American Literary Culture. Jewish Literature and Culture. Bloomington: Indiana University Press, 2008.

Lieberman, Paul. Gangster Squad: Covert Cops, the Mob, and the Battle for Los Angeles. 1st ed. New York: Thomas Dunne Books/St. Martin’s Griffin, 2012. 1922.

Lippmann, Walter. Public Opinion. New York: Harcourt, Brace and Company,

—. The Phantom Public. New York: Harcourt, Brace, 1925.

Lipstadt, Deborah E. Beyond Belief: The American Press and the Coming of the Holocaust, 1933-1945. New York: Free Press, 1986.

Longstreet, Stephen. Chicago, 1860-1919. New York: McKay, 1973.

Luhan, Mabel Dodge. Intimate Memories. New York: Harcourt, Brace and company, 1933.

. Movers and Shakers: Volume Three of Intimate Memories / Luhan, Mabel Dodge,; 1879-1962. ; Intimate Memories,; V.3. New York: Harcourt, 1936.

- Intimate Memories: The Autobiography of Mabel Dodge Luhan. 1st ed. Albuquerque: University of New Mexico Press, 1999.

Lundberg, Ferdinand. Imperial Hearst ; a Social Biography. The Modern Library of the World's Best Books. New York: The Modern Library, 1936.

MacAdams, William. Ben Hecht: The Man Behind the Legend. New York: Scribner, 1990.

Mackay, Constance D'Arcy. The Little Theatre in the United States. New York: H. Holt and Company, 1917.

Mailer, Norman. Advertisements for Myself. New York: Putnam, 1959.

—. Marilyn, a Biography. New York: Grosset \& Dunlap, 1973.

Mangione, Jerre. The Dream and the Deal: The Federal Writers' Project, 19351943. 1st ed. Boston, [Mass.]: Little, Brown, 1972.

Manso, Peter. Brando. London: Weidenfeld and Nicolson, 1994.

Martin, Jeffrey Brown. Ben Hecht, Hollywood Screenwriter. Ann Arbor, Mich: UMI Research Press, 1985.

Mast, Gerald. A Short History of the Movies. 9th ed. New York: Pearson/Longman, 2006. 
May, Henry Farnham. The End of American Innocence; a Study of the First Yearsof Our Own Time, 1912-1917. 1st ed. New York: Knopf, 1959.

Mayer, Martin. Making News. 1st ed. Garden City, N.Y: Doubleday, 1987.

McCarthy, Todd. Howard Hawks: The Grey Fox of Hollywood. 1st ed. New York: Grove Press, 1997.

McDonald, James G. My Mission in Israel, 1948-1951. New York: Simon and Schuster, 1951.

McGilligan, Patrick. Alfred Hitchcock: a Life in Darkness and Light. 1st ed. New York: Regan Books, 2003.

McPhaul, John J. Deadlines \& Monkeyshines: The Fabled World of Chicago Journalism. Englewood Cliffs, N.J: Prentice-Hall, 1962.

Medoff, Rafael. Militant Zionism in America: The Rise and Impact of the Jabotinsky Movement in the United States, 1926-1948. Tuscaloosa: University of Alabama Press, 2002.

Medovoi, Leerom. Rebels: Youth and the Cold War Origins of Identity. Durham: Duke University Press, 2005.

Mencken, H. L. My Life as Author and Editor. 1st ed. New York: Knopf, 1993.

- Notes on Democracy. New York: Knopf, 1926.

Mendes-Flohr, Paul R. Divided Passions: Jewish Intellectuals and the Experience of Modernity. Culture of Jewish Modernity. Detroit: Wayne State University Press, 1991.

Merlin, Samuel, and David S. Wyman Institute for Holocaust Studies. Millions of Jews to Rescue: a Bergson Group Leader's Account of the Campaign to Save Jews from the Holocaust. Washington, D.C.: the David S. Wyman institute for Holocaust Studies, 2011.

Miller, David. The Blackwell Encyclopaedia of Political Thought. Blackwell reference;. Oxford, UK ; New York, NY, USA: B. Blackwell, 1987.

Miller, Perry. Errand into the Wilderness. Cambridge, Mass.: Belknap Press of Harvard University Press, 1984.

Milton, Joyce. The Yellow Kids: Foreign Correspondents in the Heyday Ofyellow Journalism. 1st ed. New York: Harper \& Row, 1989.

Mindich, David T. Z. Just the Facts: How “Objectivity” Came to Define American Journalism. New York: New York University Press, 1998. 
Moore, Jack B. Maxwell Bodenheim. Twayne's United States authors series TUSAS 156. New York: Twayne Publishers, 1970.

Moore, William T. Dateline Chicago: a Veteran Newsman Recalls Its Heyday. 1st ed. New York: Taplinger Pub. Co, 1973.

Morris, Benny. The Birth of the Palestinian Refugee Problem, 1947-1949. Cambridge [England]: Cambridge University Press, 1987.

Morse, Arthur D. While Six Million Died; a Chronicle of American Apathy. New York: Random House, 1968.

Munby, Jonathan. Public Enemies, Public Heroes: Screening the Gangster from Little Caesar to Touch of Evil. Chicago: University of Chicago Press, 1999.

Muir, Florabel. Headline Happy. 1st ed. New York: Holt, 1950.

Murray, George. The Madhouse on Madison Street. Chicago: Follett Pub. Co, 1965.

Nasaw, David. The Patriarch: The Remarkable Life and Turbulent Times of Joseph P. Kennedy. New York: Penguin Press, 2012.

Nash, Jay Robert. The Great Pictorial History of World Crime. Wilmette, IL: History, Inc, 2004.

Niebuhr, Reinhold. "Jews After the War," The Nation, 21 February 1942, 214$216,253-255$.

Newark, Timothy. Mafia Allies: The True Story of America's Secret Alliance with the Mob in World War II. St. Paul, Minn.: Zenith Press, 2007.

NetLibrary, Inc. King James Bible. 2nd ed. Champaign, Ill: Project Gutenberg.

Nord,David Paul. “A Plea for Journalism History," Journalism History 15, No. 1 (Spring 1988), 8-15.

. "James Carey and Journalism History: A Remembrance," Journalism History 32, No. 3 (Fall 2006), 122-127.

Novick, Peter. The Holocaust in American Life. Boston: Houghton Mifflin, 1999.

Nussbaum, Martha Craven. Upheavals of Thought: The Intelligence of Emotions. Cambridge, UK ; New York: Cambridge University Press, 2001. 
Oxford English Dictionary Online, Oxford University Press, http://proxy.mul.missouri. edu:2585/view/.

Ogden, Chris. Legacy: a Biography of Moses and Walter Annenberg. 1st ed. Boston: Little, Brown, 1999.

Ophir, Ephraim, "Was the Transnistria Rescue Plan Achievable?" Holocaust and Genocide Studies 6, No. 1 (1991), 1-16

Pells, Richard H. Radical Visions and American Dreams: Culture and Social Thought in the Depression Years. Middletown, Conn: Wesleyan University Press, 1984.

Penkower, Monty Noam. "In Dramatic Dissent: The Bergson Boys," American Jewish History LXX, No. 3 (March 1981), 281-309. 37. "Believe the Unbelievable!" Midstream XXVII, No. 4 (April 1981), 31-

Parry, Albert. Garrets and Pretenders: a History of Bohemianism in America. New York: Covici, Friede, 1933.

Payne, Stanley G. Fascism, Comparison and Definition. Madison: University of Wisconsin Press, 1980.

Perry, Douglas. The Girls of Murder City: Fame, Lust, and the Beautiful Killers Who Inspired Chicago. New York: Viking, 2010.

Poe, Edgar Allan. Great Short Works of Edgar Allan Poe. A Perennial Classic. New York: Harper \& Row, 1970.

Pound, Ezra. The Letters of Ezra Pound, 1907-1941. 1st ed. New York: Harcourt, Brace, 1950.

Prager, Ted and Craft, Larry. Hoodlums: New York. New York: Retail Distributors, 1959.

Presner, Todd Samuel. Muscular Judaism: The Jewish Body and the Politics of Regeneration. Routledge Jewish Studies Series. London; New York: Routledge, 2007.

Primack, Bret, ed. and Hecht, Ben. The Ben Hecht Show: Impolitic Observations from the Freest Thinker of 1950s Television. Jefferson, N.C: McFarland, 1993.

Raider, Mark A. "Irresponsible, Undisciplined Opposition: Ben Halpern on the Bergson Group and Jewish Terrorism in Pre-State Palestine," American Jewish History 92, No. 3 (September 2004), 313-360. 
Rapoport, Louis. Shake Heaven \& Earth: Peter Bergson and the Struggle to Rescue the Jews of Europe. Jerusalem ; New York: Gefen Pub. House, 1999.

Rafaeli, Alex. Dream and Action: The Story of My Life. Jerusalem, Israel: A. Rafaeli, 1993.

Ravitz, Abe C. "Ballyhoo, Gargoyles, \& Firecrackers: Ben Hecht's Aesthetic Calliope." The Journal of Popular Culture 1, no. 1 (June 1, 1967): 37-51. doi:10.1111/j.0022-3840.1967.0101_37.x.

Redston, George. The Conspiracy of Death. Indianapolis: Bobbs-Merrill, 1965.

Rhodes, Chip. Politics, Desire, and the Hollywood Novel. Iowa City: University of Iowa Press, 2008.

Rideout, Walter B. Sherwood Anderson a Writer in America. Madison: University of Wisconsin Press, 2006.

Riverside Film Productions, WNET (Television station : New York, N.Y.), FirstRun Features (Firm), and National Endowment for the Humanities. Arguing the World. Videorecording. First Run Features, 2006.

RKO Radio Pictures, Vanguard Films (Los Angeles, Calif.), Home Vision Entertainment (Firm), and Criterion Collection (Firm). Notorious. Videorecording. Criterion Collection : Home Vision Entertainment, 2001.

Robinson, Edward G. All My Yesterdays; an Autobiography. New York: Hawthorn Books, 1973.

Rockaway, Robert A. But He Was Good to His Mother: The Lives and Crimes of Jewish Gangsters. Jerusalem ; New York: Gefen Pub. House, 2000.

Rollyson, Carl E. Biography, a User's Guide. Chicago: Ivan R. Dee, 2008.

Ronson, Jon. The Psychopath Test: a Journey through the Madness Industry. New York: Riverhead Books, 2011.

Rosemont, Franklin. The Rise \& Fall of the Dil Pickle: Jazz-age Chicago's Wildest \& Most Outrageously Creative Hobohemian Nightspot. Bughouse Square. Chicago: Charles H. Kerr Pub, 2004.

Rosenbaum, Ron. The Secret Parts of Fortune: Three Decades of Intense Investigations and Edgy Enthusiasms. 1st ed. New York: Random House, 2000.

Rosow, Eugene. Born to Lose: The Gangster Film in America. New York: Oxford University Press, 1978. 
Roth, Jack J., ed. World War I, a Turning Point in Modern History; Essays In the Significance of the War. New York: Knopf, 1967.

Rubinstein, W. D. The Myth of Rescue: Why the Democracies Could Not Have Saved More Jews from the Nazis. London; New York: Routledge, 1997.

Rudnick, Lois Palken, and NetLibrary, Inc. Mabel Dodge Luhan New Woman, New Worlds. 1st ed. Albuquerque: University of New Mexico Press, 1984.

Ruth, David E. Inventing the Public Enemy: The Gangster in American Culture, 1918-1934. Chicago: University of Chicago Press, 1996.

Sachar, Howard Morley. A History of Israel: From the Rise of Zionism to Our Time. 3rd ed., rev. and updated. New York: Knopf, 2007. 1970.

Sand, George. The George Sand-Gustave Flaubert Letters. New York: Liveright,

Sandburg, Carl. Chicago Poems. New York: H. Holt and Company, 1916.

Sayers, Michael. The Plot Against the Peace; a Warning to the Nation! New York: Dial press, 1945.

Schoenfeld,Joe. "Seventeen Thousand Turn Out at 'Fun to be Free," Variety 8 October, 1941, 2, 16.

Schudson, Michael. Discovering the News: a Social History of American Newspapers. New York: Basic Books, 1978. - Toward a Troubleshooting Manual for Journalism History," Journalism \& Mass Communication Quarterly, 74, No. 3 (Autumn 1997), 463-476.

Schumbacher, Claude, ed. Staging the Holocaust: The Shoah in Drama and Performance. Cambridge studies in modern theatre. Cambridge: Cambridge University Press, 1998.

See, Carolyn Penelope. The Hollywood Novel: An Historical and Critical Study. Ann Arbor: University Microfilms, 1976.

Segev, Tom. One Palestine, Complete: Jews and Arabs Under the British Mandate. 1st ed. New York: Metropolitan Books, 2000.

Seldes, Gilbert. "The Daemonic in the American Theatre." The Dial (September 1923), 303-308.

The Seven Lively Arts. New York: Harper \& brothers, 1924. 
Shechner, Mark. After the Revolution: Studies in the Contemporary JewishAmerican Imagination. Bloomington: Indiana University Press, 1987.

Sherman, Stuart Pratt. Critical Woodcuts. New York, London: C. Scribner's Sons, 1926.

Shindler, Colin, and ebrary, Inc. The Triumph of Military Zionism. London; New York: I.B. Tauris, 2006.

Simmel, Georg. Sociology of Georg Simmel. S.1.: The Free Press, 1950.

Sims, Norman Howard. The Chicago Style of Journalism. PhD dissertation, University of Illinois at Urbana-Champaign, 1979.

Sinclair, Upton. The Brass Check: A Study of American Journalism. University of Illinois Press, 2002.

Sinyard, Neil. Filming Literature: The Art of Screen Adaptation. New York: St. Martin's Press, 1986.

Skloot, Robert. "We will never die : the Success and Failure of a Holocaust pageant," Theatre Journal 37, no. 2 (May 1985): 167-180.

Slater, Leonard. The Pledge. New York: Simon and Schuster, 1970.

Soviet Casualties and Combat Losses in the Twentieth Century. London : Mechanicsburg, Pa: Greenhill Books ; Stackpole Books, 1997.

Spinney, Robert G. City of Big Shoulders: a History of Chicago. DeKalb: Northern Illinois University Press, 2000.

Sproule, J. Michael. "Progressive Propaganda Critics and the Magic Bullet Myth." Critical Studies in Mass Communication 6, no. 3 (September 1, 1989): 225-246. doi:10.1080/15295038909366750.

Stansell, Christine. American Moderns: Bohemian New York and the Creation of a New Century. 1st ed. New York: Metropolitan Books, 2000.

Starrett, Vincent. Born in a Bookshop: Chapters from the Chicago Renascence. 1st ed. Norman: University of Oklahoma Press, 1965.

Steffens, Lincoln, and University of Missouri-Columbia. The Autobiography of Lincoln Steffens. New York: Harcourt, Brace and Company, 1931. 
Sternhell, Zeev. The Birth of Fascist Ideology: From Cultural Rebellion to Political Revolution. Princeton, N.J: Princeton University Press, 1994.

Stevens, Steve and Lockwood, Craig. King of the Sunset Strip: Hangin' with Mickey Cohen and the Hollywood Mob. Nashville, Tenn.: Cumberland House, 2006.

Strausbaugh, John. The Village: 400 Years of Beats and Bohemians, Radicals and Rogues: a History of Greenwich Village. New York, NY: Ecco, an imprint of HarperCollinsPublishers, 2013.

Sullivan, Edward Dean. Chicago Surrenders. New York: The Vanguard Press, 1930.

- Rattling the Cup on Chicago Crime. Freeport, N.Y: Books for Libraries Press, 1971.

Sutton, Antony C. Wall Street and the Rise of Hitler. Seal Beach, Calif: '76 Press, 1976.

Swanberg, W. A. Citizen Hearst, a Biography of William Randolph Hearst. New York: Scribner, 1961.

Teachout, Terry. The Skeptic: A Life of H.L. Mencken. 1st ed. New York: HarperCollins, 2002.

Television: The Critical View. 3rd ed. New York: Oxford University Press, 1982.

Tereba, Tere. Mickey Cohen: The Life and Crimes of L.A. 's Notorious Mobster. Toronto, Ont: ECW Press, 2012.

The Cambridge Companion to Dewey. Cambridge ; New York: Cambridge University Press, 2010.

The Routledge Dictionary of Literary Terms. Routledge Dictionaries. London; New York: Routledge, 2006.

Thompson, Dorothy. "Do Israeli Ties Conflict with U.S. Citizenship?: America Demands a Single Loyalty," Commentary, March 1950, 210-219.

Troy, Gil. Ben Hecht : From Literary Gadfly to Political Activist, Bachelor of Arts thesis for Harvard University, 1982.

_. "From Literary Gadfly to Political Activist: The Political Transformation of Ben Hecht." Journal of Ecumenical Studies 40, no. 4 (Fall2003 2003): 431-449.

Troy, William. “The Story of the Little Magazines.” Bookman 70 (1930): 657. 
Truffaut, François. Hitchcock. Rev. ed., 1st Touchstone ed. New York: Simon \& Schuster, 1985.

Urofsky, Melvin I. American Zionism from Herzl to the Holocaust. 1st ed. Garden City, N.Y: Anchor Press, 1975.

- A Voice That Spoke for Justice: The Life and Times of Stephen S. Wise. SUNY Series in Modern Jewish History. Albany: State University of New York Press, 1982.

Van Paassen, Pierre. Nazism: An Assault on Civilization, Wise, James Waterman, joint ed. New York, H. Smith and R. Haas, 1934.

Vorse, Mary Heaton. A Footnote to Folly: Reminiscences of Mary Heaton Vorse. Signal Lives. New York: Arno Press, 1980.

Wald, Alan M. The New York Intellectuals: The Rise and Decline of the antiStalinist Left from the 1930s to the 1980s. Chapel Hill: University of North Carolina Press, 1987.

Ward, Nathan. Dark Harbor: The War for the New York Waterfront. 1st ed. New York: Farrar, Straus and Giroux, 2010.

Warshow, Robert. The Immediate Experience; Movies, Comics, Theatre \& Otheraspects of Popular Culture. New York: Atheneum, 1971.

Watson, Bruce. Bread and Roses: Mills, Migrants, and the Struggle for the American Dream. New York: Viking, 2005.

Weber, Donald. Haunted in the New World: Jewish American Culture from Cahan to The Goldbergs. Jewish Literature and Culture. Bloomington: Indiana University Press, 2005.

Wendt, Lloyd. Lords of the Levee; the Story of Bathhouse John and Hinky Dink. 1st ed. Indianapolis, New York: Bobbs-Merrill Company, 1943.

Weinbaum, Laurence. A Marriage of Convenience: The New Zionist Organization and the Polish Government 1936-1939. Boulder : New York: East European Monographs ; Distributed by Columbia University Press, 1993.

Weingarten, Marc. The Gang That Wouldn't Write Straight: Wolfe, Thompson, Didion, and the New Journalism Revolution. 1st ed. New York: Crown Publishers, 2006.

Weiss, Jeffrey. I Am My Brother's Keeper: American Volunteers in Israel's War for Independence 1947-1949. Atglen, PA: Schiffer Military History, 1998. 
Wetzsteon, Ross. Republic of Dreams: Greenwich Village: The American Bohemia, 1910-1960. New York: Simon \& Schuster, 2002.

Weizmann, Chaim. Trial and Error. New York: Harper, 1949.

Whitfield, Stephen J. In Search of American Jewish Culture. Hanover, NH: University Press of New England [for] Brandeis University Press, 1999.

_."The Politics of Pageantry, 1936-1946," American Jewish History 84, No. 3 (1996), 221-251.

Williams, William Carlos. Imaginations. New York: New Directions Pub. Corp, 1971.

The Selected Letters of William Carlos Williams. New York: New Directions Pub. Corp., 1984.

Wilson, Edmund. Classics and Commercials: a Literary Chronicle of the Forties. New York: Vintage Books, 1950.

Wise, Stephen S. Challenging Years: The Autobiography of Stephen Wise. New York: Putnam, 1949.

Wolfe, Tom. The New Journalism. 1st ed. New York: Harper \& Row, 1973.

Wyman, David S. The Abandonment of the Jews: America and the Holocaust, 1941-1945. 1st ed. New York: Pantheon Books, 1984.

- A Race Against Death: Peter Bergson, America, and the Holocaust. New York: New Press : Distributed by W.W. Norton \& Co, 2002.

- "The Bergson Group, America, and the Holocaust: A Previously Unpublished Interview with Hillel Kook / Peter Bergson," American Jewish History, 89.1 (2001), 3-34.

Zaar, Isaac. Rescue and Liberation: America's Part in the Birth of Israel. New York: Bloch Pub. Co, 1954. 1909.

Zangwill, Israel. The Melting-Pot, Drama in Four Acts. New York, Macmillan,

Zelizer, Barbie, "History and Journalism," chapter in Taking Journalism Seriously: News and the Academy. Thousand Oaks, Calif.: Sage, 2004, 80-110.

Ziff, Larzer. The American 1890s; Life and Times of a Lost Generation. New York: Viking Press, 1968. 
Julien Gorbach grew up in the Boston metropolitan area and majored in literature as an undergraduate at Sarah Lawrence College in Bronxville, New York, where he graduated in January 1993. It was his love for writing and storytelling that led to a career in journalism.

He earned a Master's degree from New York University's Graduate School of Journalism in 1998, and worked for the next six years at daily and weekly newspapers in the Southwest and the Gulf Coast. For the Roswell Daily Record in New Mexico, he covered drive-by shootings, while writing an investigative series on murders that remained unsolved because gangs had intimidated witnesses into silence. For the Daily Advertiser in Lafayette, Louisiana, and the Free Press in Key Largo, Florida, he covered local culture, crime and politics, as well as environmental issues, with particular attention to marine pollution and offshore drilling.

In 2005, he became an adjunct instructor at the University of Louisiana at Lafayette, where he taught writing, literature, editing, convergence and media studies courses. Throughout those years, he also freelanced for the Boston Phoenix, Time Out New York, the San Francisco Review of Books, the San Francisco Bay Guardian and the New Orleans Gambit, and covered Hurricane Katrina for the Boston Globe.

In 2007 he enrolled in the doctoral program at the University of MissouriColumbia School of Journalism. In completing his coursework over the next three years, he studied for a visiting semester with the Center for Middle Eastern Studies at the 
University of Chicago, and took classes over the summers at Harvard University. In

2011, he returned to faculty of the University of Louisiana at Lafayette as a Visiting Lecturer of New Media. 